\title{
ESTUDO DOS EFEITOS DOS TRATAMENTOS FÍSICO- MECÂNICOS NA HIDRÓLISE DA CELULOSE DO BAGAÇO DE CANA-DE-AÇÚCAR
}

Tese apresentada ao Instituto de Química de São Carlos da Universidade de São Paulo como parte dos requisitos para a obtenção do título de doutor em química.

Área de concentração: Química Orgânica e Biológica

Orientador: Antonio Aprigio da Silva Curvelo

São Carlos 


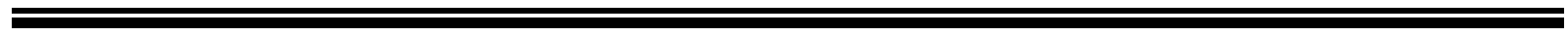




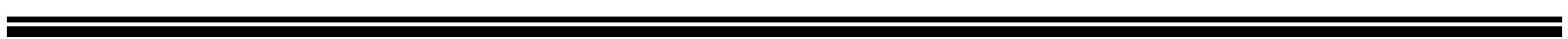

"Les temps sont durs pour les rêveurs." 


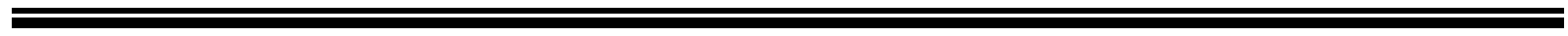




\section{AGRADECIMENTOS}

Primeiramente, agradeço a Deus e meus mentores espirituais, que me acompanharam, me protegeram, me deram forças e sabedoria para que eu caminhasse até aqui.

Agradeço imensamente aos maiores amores da minha vida, meus pais Elaine e Dario, por todo amor, compreensão, ensinamentos, por criarem todas as oportunidades do mundo e por sempre me receberem de braços abertos em nosso ninho! Esse trabalho é por vocês!

À minha irmã Isabella, por ser minha companheira em todas as jornadas que percorri, e por ser essa pessoa linda, forte e poética a qual tenho muito orgulho de ter como base.

À minha "mãe" científica Maria Teresa, por me dar tantas oportunidades, por me orientar e guiar, e por acreditar em mim até quando eu mesma não achava que era capaz. Tenho muito orgulho de ter trabalhado e convivido com você.

Ao professor Aprigio pela orientação, valiosos ensinamentos, por toda paciência e compreensão, e por ser um exemplo de pesquisador e professor ao qual devemos nos espelhar.

Aos professores Naceur Belgacem e Julien Bras, por me recepcionarem em seu laboratório na França e me permitirem vivenciar este grande crescimento científico.

Ao Victor, por ter entrado em minha vida talvez em uma das fases mais difíceis e mesmo assim ter conseguido trazer tanto amor e leveza. Obrigada por me fazer ter vontade de continuar!

A todos os amigos que passaram pelo grupo de Físico-química orgânica do IQSC ao longo destes anos, que sempre me receberam com carinho e contribuíram não só para o meu crescimento profissional, mas também pessoal: Marcelo, Lisias, Glauco, Bárbara, Fernanda, Luiza, Luiz Ramos e Luisão.

A todos os amigos que passaram pelo CTBE ao longo dos anos que estive lá, que foram minha segunda família e fizeram este tempo ser leve, divertido e proveitoso: Leiluana, Camila, Karen, Renan, Fernanda, Lívia, Silvane, Cristiane, Érica, Simone, Pedro, Tatiane, Edilaine, Daniele, Gislaine, Viviane, Angélica, Kiane, Caio, André, Rogério, Adriano. Nunca me esquecerei de vocês.

À professora Sarita Rabelo pelo auxílio em laboratório e pelos muitos ensinamentos.

Ao pesquisador Carlos Driemeier pelo auxílio com análises e pelas importantes contribuições científicas a este trabalho.

Aos meus anjinhos de quatro patas, Dani e Aquiles, que foram meus companheiros e me deram o maior amor desinteressado que já pude sentir.

Por fim, agradeço a todos que em algum momento passaram pelo meu caminho ao longo desta jornada, que me fizeram evoluir espiritualmente e ter vontade de ser cada dia uma pessoa melhor para o próximo. 


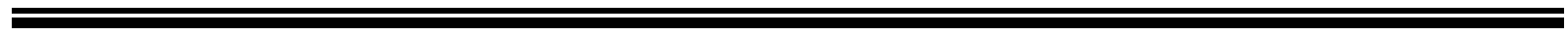




\section{RESUMO}

SANTUCCI, Beatriz Stangherlin. Estudo dos efeitos dos tratamentos físico-mecânicos na hidrólise da celulose do bagaço de cana-de-açúcar. 2018. 350f. Tese (Doutorado) Instituto de Química de São Carlos, Universidade de São Paulo, São Carlos, 2018.

Com o intuito de elucidar os efeitos das propriedades físicas e morfológicas na efetividade da sacarificação enzimática das fibras de bagaço de cana-de-açúcar, este trabalho propõe o uso de diferentes métodos de processamento físico-químicos e -mecânicos para a modificação da estrutura da parede celular. Os tratamento físico-mecânicos, através de fenômenos de fibrilação e delaminação, promovem a abertura estrutural das fibras e aumentam a acessibilidade das enzimas hidrolíticas aos polissacarídeos, porém sem modificar a composição química do material. Para uma compreensão abrangente da ação dos métodos físico-mecânicos propostos nas características estruturais, as fibras de bagaço foram previamente tratadas por métodos físico-químicos - hidrotérmico e organossolve - de modo a obter cinco materiais de diferentes composições químicas. O estudo dos tratamentos físicomecânicos foi realizado empregando-se equipamentos de diferentes configurações, cujos modos de ação e consequente impacto nas fibras diferem entre si, sendo estes dois tipos de refino - refinador de discos Bauer e moinho Jokro, e um tipo de moagem - moinho criogênico. A variável do refino em moinho Jokro foi o tempo de tratamento, enquanto as variáveis do processamento em refinador de discos foi o tempo de refino e a distância entre os discos. Já as condições da moagem criogênica foram definidas de modo a obter amostras homogêneas do ponto de vista macroscópico. As modificações provocadas na estrutura das fibras foram determinadas a partir das análises das áreas superficiais externa (dimensões das fibras) e interna (porosidade da parede celular), além da organização cristalina das fibrilas celulósicas. Primeiramente, estudou-se de modo detalhado os efeitos dos métodos mecânicos nas propriedades estruturais das amostras de bagaço, interpretando-se como os efeitos primários do refino evoluem de acordo com a severidade e o tipo tratamento empregado a partir das caracterizações dos efeitos secundários. Posteriormente, confrontaram-se os resultados obtidos nas análises físicas e morfológicas com o rendimento de açúcares obtido na hidrólise enzimática. Os resultados permitiram constatar que, enquanto o moinho Jokro promoveu um grande aumento no rendimento de glicose obtido por culminar, 
simultaneamente, no aumento da estrutura capilar pela intensa fibrilação interna, e da área superficial externa tanto pela formação de elementos finos quanto pela redução das dimensões das fibras por corte, o refinador de discos Bauer levou a uma melhoria menos pronunciada na hidrolisabilidade por resultar no aumento da porosidade, porém sem expressivos corte e fibrilação externa das fibras. Diferentemente, a moagem criogênica promoveu apenas a drástica e heterogênea redução das dimensões das fibras, enquanto não permitiu mudanças significativas na digestibilidade das amostras. Por fim, os valores dos parâmetros estruturais determinados foram analisados pelo método estatístico de componentes principais (PCA) visando quantificar por qual fator cada uma destas características influencia na extensão da hidrólise da celulose do bagaço. A PCA permitiu visualizar que os fatores relacionados à superfície interna da parede celular, como a área de poros acessíveis e a dimensão lateral do cristalito de celulose, são os principais aspectos que regem o rendimento de sacarificação da biomassa lignocelulósica. Os resultados deste estudo permitiram assim a proposta de um modelo de predição do comportamento de hidrólise das amostras de bagaço.

Palavras-chave: Bagaço. Pré-tratamento. Refino. Hidrotérmico. Organossolve. Ultraestrutura. Sacarificação Enzimática. 


\begin{abstract}
SANTUCCI, Beatriz Stangherlin. Study of the effects of physico-mechanical treatments on sugarcane bagasse cellulose hydrolysis. 2018. 350f. Tese (Doutorado) - Instituto de Química de São Carlos, Universidade de São Paulo, São Carlos, 2018.
\end{abstract}

In order to elucidate the effects of the physical and morphological properties on the effectiveness of enzymatic saccharification of sugarcane bagasse fibers, this work proposes different methods of physico-chemical and -mechanical processing to modify the cell wall structure. Through fibrillation and delamination phenomena, physico-mechanical treatments promote the structural opening of the fibers and increase the accessibility of hydrolytic enzymes to polysaccharides, but without modifications on the chemical composition of the processed material. For a thorough comprehension about the action of the proposed physicomechanical methods on the structural characteristics, the bagasse fibers were previously treated by physico-chemical methods - hydrothermal and organosolv - to obtain five materials with different chemical composition. The study of the physico-mechanical treatments was performed by equipment with different configuration, which operating modes and consequent impact on the fibers differ from each other. The equipment were two types of refiner - Bauer discs refiner and Jokro mill - and one type of mill - cryogenic mill. The refining variable considered for the Jokro mill was the refining time, while the processing variables for the disc refiner were the refining time and the discs gap. Concerning the cryogenic mill, the operation conditions were defined to achieve macroscopic homogeneous samples. Modifications on the fibers structure were assessed by analysis of the external and internal surfaces (fibers dimension and the cell wall porosity, respectively), as well as the crystalline organization of the cellulosic fibrils. Firstly, it was performed a thorough study concerning the effects of the mechanical methods in the structural properties of the bagasse samples. In this study, it was interpreted how the primary effects of refining evolve according to severity and type of treatment from the characterization of the secondary effects. Then, the results acquired in the physical and morphological analysis were confronted with the glucose yield obtained in the enzymatic hydrolysis. The results showed that the Jokro mill promoted a great increase in the glucose yield by culminating, simultaneously, in the increase of the capillary structure by the intense internal fibrillation, and of the external surface area both by the formation of fines as 
by the reduction of the dimensions of fibers by cutting. In turns, the Bauer discs refiner leaded to a lower improvement of the bagasse pulps hydrolysability, which was a consequence of the increased porosity, but without expressive cut and external fibrillation of the fibers. In a different way, the cryogenic milling promoted just a drastic and heterogeneous reduction of the fibers dimensions, without any significant change in the digestibility of the samples. Finally, the determined values of the structural parameters were analyzed by the statistical method of the principal component analysis (PCA), aiming to quantify by which factor each one of these characteristics influences in the extent of hydrolysis of bagasse cellulose. The PCA showed that the factors related to the internal surface of the cell wall, such as the accessible pore area and the lateral dimension of the cellulose crystallite, are the main aspects that govern the saccharification yield of the lignocellulosic biomass. The results of this study allowed the proposal of a empiric prediction model of the hydrolysis behavior of the bagasse samples.

Keywords: Bagasse. Pretreatment. Refining. Hydrothermal. Organosolv. Ultrastructure. Enzymatic Saccharification. 


\section{LISTA DE FIGURAS}

Figura 1. Histórico de produção energética no Brasil por fonte (1970-2014).

Figura 2. Estrutura anatômica do colmo da cana-de-açúcar (variedade CB 45-3): corte transversal do entrenó mostrando (A) os feixes vasculares e as células do tecido parenquimático, e (B) detalhe das células vasculares circundadas por fibras esclerenquimáticas.

Figura 3. Estrutura molecular da celulose. 37

Figura 4. Seções transversais de (A) um cristal de celulose e (B) um agregado cristalino, onde os retângulos pretos representam as cadeias celulósicas e os círculos cinza representam polissacarídeos não cristalinos (hemiceluloses e celulose). 38

Figura 5. Estrutura dos açúcares componentes das hemiceluloses. 39

Figura 6. Possível estrutura molecular de xilana em gramíneas

Figura 7. Fórmula estrutural das unidades precursoras da lignina.

Figura 8. Principais estruturas identificadas nas ligninas do capim elefante: $A=$ estruturas $\beta$ $\mathrm{O}-4^{\prime} ; \quad \mathrm{B}=$ fenilcumaranas formadas pelo acoplamento $\beta-5^{\prime} ; \mathrm{C}=$ resinóis formados pelo acoplamento $\beta$ - $\beta$ '; $\mathrm{D}=$ espirodienonas formadas pelo acoplamento $\beta-1$ '; $\mathrm{PCA}=$ unidades de p-cumarato; FA = unidade de ferulato; I/I' = terminações dos álcoois p-hidroxicinamílicos; $\mathrm{H}$ $=$ unidades $\mathrm{p}$-hidroxifenila; $\mathrm{G}=$ unidades guaiacila; $\mathrm{S}=$ unidades siringila.

Figura 9. Possível esquema dos diferentes níveis hierárquicos da nanoestrutura dos materiais lignocelulósicos.

Figura 10. Parede celular da cana-de-açúcar, mostrando (A) as diferentes camadas $(\mathrm{ML}=$ lamela média, $\mathrm{PCW}=$ parede primária, $\mathrm{SCW}=$ parede secundária); e (B) detalhe da diferenciação das subcamadas secundárias.

Figura 11. Arquitetura da parede celular das células vegetais. 47

Figura 12. Possíveis rotas dentro de uma biorrefinaria da cana-de-açúcar. 50

Figura 13. Representação da composição modular de uma enzima O-glicosil hidrolase 57 
Figura 14. Ilustração dos mecanismos de inibição exercidos pela lignina na atividade enzimática durante a hidrólise da celulose: as fibrilas celulósicas estão representadas em vermelho, as moléculas de lignina em azul e as enzimas TrCel7 A em verde (CBM em verde mais claro e $\mathrm{CD}$ mais escuro).

Figura 15. Curva típica da conversão da celulose por tempo de reação de hidrólise enzimática.

Figura 16. Mecanismo de hidrólise ácido-catalisada das ligações glicosídicas dos polissacarídeos. 108

Figura 17. Reações de formação do furfural, do HMF e outros produtos de degradação a partir dos monossacarídeos formados em meio ácido. 109

Figura 18. Mecanismo de solvólise das ligações $\alpha-\mathrm{O}-4$ das ligninas via formação de sistemas carbônio-oxônio. 118

Figura 19. Exemplo de reações de condensação entre fragmentos de lignina em meio ácido.

Figura 20. Representação da ação de um refinador nas fibras lignocelulósicas.

Figura 21. Efeitos primários do refino nas fibras lignocelulósicas.

Figura 22. Comparação entre (A) uma fibra não refinada e (B) uma fibra refinada, mostrando a fibrilação externa com formação de finos.

Figura 23. Ilustração da fibrilação interna de uma fibra, que provoca (A) o inchamento e (B) a delaminação das camadas internas da parede celular. 126

Figura 24. Ilustração da ação de corte das fibras pelo refino.

Figura 25. (A) fotos de refinadores de discos e (B) ilustração indicando suas partes constituintes.

Figura 26. Esquema de funionamento de um refinador de discos.

Figura 27. Partes constituintes dos refinadores laboratorials (A) tipo PFI e (B) tipo Jokro. 133

Figura 28. Fluxograma do desenvolvimento experimental deste projeto de tese. 
Figura 29. (A) Foto e (B) desenho das partes constituintes do moinho tipo Jokro. 160

Figura 30. Fotos (A) do refinador de discos Bauer utilizado e (B) seus discos constituintes.

Figura 31. (A) Foto e (B) esquema de um moinho criogênico. 165

Figura 32. Esquema do equipamento para a determinação do grau de refino SchöpperRiegler. 168

Figura 33. Reação para a quantificação espectrofotométrica de açúcares redutores, baseada na conversão do ácido 3,5-dinitrosalicílico em seu análogo reduzido. 185

Figura 34. Valores das solubilizações totais (massa) e de cada um dos macrocomponentes da parede celular após o pré-tratamento das fibras de bagaço de cana-de-açúcar em diferentes condições. 196

Figura 35. Variação do grau Schöpper-Riegler $\left({ }^{\circ} S R\right)$ com (A) o tempo de refino em moinho Jokro, (B) o tempo de refino em refinador Bauer e (C) a moagem criogênica, para os cinco

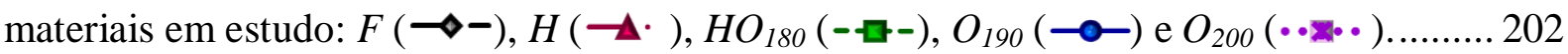

Figura 36. Curvas de distribuição do volume incremental de partículas analisadas (\%) em função do diâmetro da partícula $(\mu \mathrm{m})$ de acordo com o tempo de refino em moinho Jokro para as amostras (A) $F$, (B) $H$, (C) $H O_{180}$, e (D) $O_{190}$.

Figura 37. Curvas de distribuição do volume incremental de partículas analisadas (\%) em função do diâmetro da partícula $(\mu \mathrm{m})$ de acordo com o tempo de refino em refinador Bauer para as amostras (A) $H_{180}$ e (B) $O_{190}$, (C) de acordo com o refino em moinho Jokro e em refinador Bauer para a amostra $O_{200}$, e (D) de acordo com o moagem criogênica para as amostras $F, H, H O_{180}$ e $O_{190}$.

Figura 38. Variação da área superficial específica externa (ASE $-\mathrm{m}^{2} / \mathrm{g}$ ) com (A) o tempo de refino em moinho Jokro, (B) o tempo de refino em refinador Bauer e (C) a moagem criogênica, para os cinco materiais em estudo: $F(\multimap-), H(-\boldsymbol{\Delta} \cdot), H O_{180}(-\nabla-), O_{190}(\multimap-)$ e $O_{200}(\bullet \cdot \cdot \cdots \cdot \bullet)$

Figura 39. Variação do comprimento médio ponderado (mm) das fibras com (A) o tempo de refino em moinho Jokro, (B) o tempo de refino em refinador Bauer e (C) a moagem criogênica, para os cinco materiais em estudo: $F(\multimap-), H\left(-\boldsymbol{\Delta}^{\cdot}\right), H O_{180}\left(-\boldsymbol{\nabla}^{-}\right), O_{190}(\multimap-)$ e $O_{200}(\bullet \cdot \cdot \cdot \bullet \cdot \bullet$ 
Figura 40. Variação do teor de finos (\%) com (A) o tempo de refino em moinho Jokro, (B) o tempo de refino em refinador Bauer e $(\mathrm{C})$ a moagem criogênica, para os cinco materiais em estudo: $F(\multimap-), H(\neg \cdot), H O_{180}(-\square-), O_{190}(\multimap-)$ e $O_{200}(\bullet \cdot m \cdot \bullet)$.

Figura 41. Variação da largura média $(\mu \mathrm{m})$ das fibras com $(\mathrm{A})$ o tempo de refino em moinho Jokro, (B) o tempo de refino em refinador Bauer e (C) a moagem criogênica, para os cinco

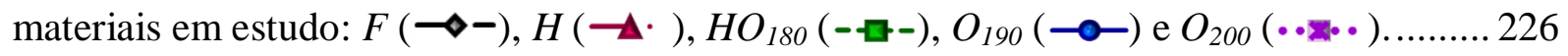

Figura 42. Variação da razão de aspecto com (A) o tempo de refino em moinho Jokro, (B) o tempo de refino em refinador Bauer e $(\mathrm{C})$ a moagem criogênica, para os cinco materiais em

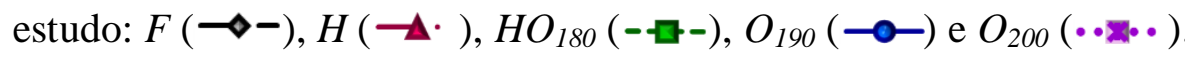

Figura 43. Variação da área superficial específica externa (ASE $-\mathrm{m}^{2} / \mathrm{g}$ ) com (A) o tempo de refino em moinho Jokro, (B) o tempo de refino em refinador Bauer e (C) a moagem

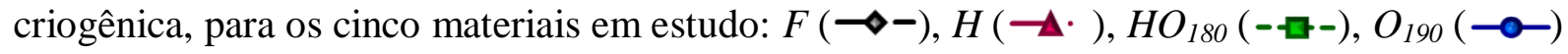
e $O_{200}(\cdot \bullet \cdot m \cdot \bullet)$

Figura 44. Variação da massa linear $(\mathrm{mg} / \mathrm{m})$ com (A) o tempo de refino em moinho Jokro, (B) o tempo de refino em refinador Bauer e $(\mathrm{C})$ a moagem criogênica, para os cinco materiais

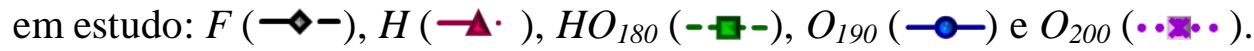
234

Figura 45. Imagens microscopia ótica obtidas para as fibras de polpa organossolve (A) não refinadas e processadas em (B) moinho Jokro, (C) refinador Bauer e (D) moinho criogênico.

Figura 46. Curvas de distribuição da área cumulativa de poros $\left(\mathrm{m}^{2} / \mathrm{g}\right)$ em função do diâmetro do poro de acordo com o tempo de refino em $M J$ para as amostras (A) $F$, (B) $H$, (C) $H O_{180}$, e (D) $O_{190}$

Figura 47. Curvas de distribuição da área cumulativa de poros $\left(\mathrm{m}^{2} / \mathrm{g}\right)$ em função do diâmetro do poro de acordo com o tempo de refino em $R D$ para as amostras (A) $H O_{180}$ e (B) $O_{190}$, (C) de acordo com o refino em $M J$ e em $R D$ para $O_{200}$, e (D) de acordo com $M C$ para $F, H, H O_{180}$ e $O_{190}$

Figura 48. Variação da área total de poros $\left(\mathrm{m}^{2} / \mathrm{g}\right)$ com (A) o tempo de refino em moinho Jokro, (B) o tempo de refino em refinador Bauer e (C) a moagem criogênica, para os cinco

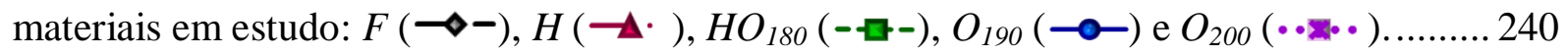

Figura 49. Variação da área de poros $\left(\mathrm{m}^{2} / \mathrm{g}\right)$ com diâmetros maiores ou iguais a $9,90 \mathrm{~nm}$ com (A) o tempo de refino em moinho Jokro, (B) o tempo de refino em refinador Bauer e (C) a moagem criogênica, para os cinco materiais em estudo: $F(\multimap-), H(\rightarrow \mathbf{\Delta} \cdot), H_{180}\left(-\nabla^{-}-\right)$, $O_{190}($ - 
Figura 50. Variação da dimensão lateral do cristalito de celulose (Å) na direção do plano $(200)_{\mathrm{m}}$ com (A) o tempo de refino em moinho Jokro, (B) o tempo de refino em refinador Bauer e (C) a moagem criogênica, para os cinco materiais em estudo: $F(\multimap-), H\left(\rightarrow \mathbf{\Delta}^{\cdot}\right)$,

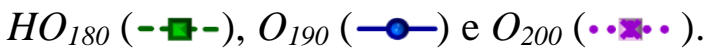

Figura 51. Variação da dimensão lateral do cristalito de celulose $(\AA)$ na direção dos planos $(110)_{\mathrm{m}}$ e (1-10) $)_{\mathrm{m}}$ com (A) o tempo de refino em moinho Jokro, (B) o tempo de refino em refinador Bauer e $(\mathrm{C})$ a moagem criogênica, para os cinco materiais em estudo: $F(\neg-), H$

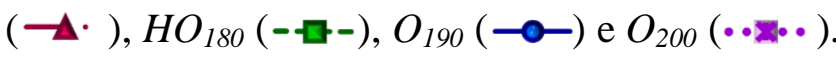

Figura 52. Variação da distância intermolecular $(\AA)$ ao longo do plano $(200)_{\mathrm{m}}$ no cristalito de celulose com (A) o tempo de refino em moinho Jokro, (B) o tempo de refino em refinador Bauer e (C) a moagem criogênica, para os cinco materiais em estudo: $F(\rightarrow-), H(-\mathbf{\Delta} \cdot)$, $H_{180}(--\square-), O_{190}(\multimap-)$ e $O_{200} \quad(\cdot \bullet \cdot m \cdot \bullet)$.

Figura 53. Variação da dimensão b $(\AA)$ da cela unitária monoclínica do polimorfo $\mathrm{I} \beta$ da celulose com (A) o tempo de refino em moinho Jokro, (B) o tempo de refino em refinador Bauer e (C) a moagem criogênica, para os cinco materiais em estudo: $F(\rightarrow-), H(\rightarrow \mathbf{\Delta} \cdot)$,

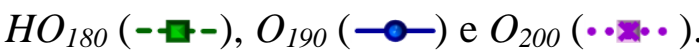

Figura 54. Variação do decréscimo da cristalinidade da celulose (\%) com (A) o tempo de refino em moinho Jokro, (B) o tempo de refino em refinador Bauer e (C) a moagem

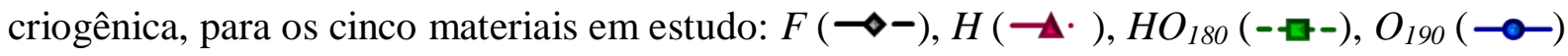
e $O_{200}(\cdot \bullet \cdot \cdots \cdot \bullet)$

Figura 55. Variação da dimensão lateral do cristalito de celulose $(\AA)$ na direção do plano $(200)_{\mathrm{m}}$ com o volume de poros $(\mathrm{cm} 3 / \mathrm{g})$ da parede celular para os diferentes materiais em estudo.

Figura 56. Variação do rendimento de xilose (\%) obtido após $72 \mathrm{~h}$ de hidrólise enzimática com o rendimento de glicose $(\%)$ para os diferentes materiais em estudo.

Figura 57. Variação do rendimento de glicose (\%) após $24 \mathrm{~h}$ de hidrólise enzimática com (A) o tempo de refino em moinho Jokro, (B) o tempo de refino em refinador Bauer e (C) a moagem criogênica, para os cinco materiais em estudo: $F(\neg-), H(-\vec{\Delta} \cdot), H O_{180}(-\boldsymbol{\nabla}-)$,

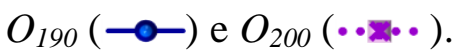

Figura 58. Variação do rendimento de glicose (\%) após 48h de hidrólise enzimática com (A) o tempo de refino em moinho Jokro, (B) o tempo de refino em refinador Bauer e (C) a moagem criogênica, para os cinco materiais em estudo: $F(\neg-), H(-\mathbf{\Delta} \cdot), H_{180}\left(-\mathbf{Z}^{-}\right)$,

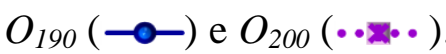


Figura 59. Variação do rendimento de glicose (\%) após 72h de hidrólise enzimática com (A) o tempo de refino em moinho Jokro, (B) o tempo de refino em refinador Bauer e (C) a moagem criogênica, para os cinco materiais em estudo: $F(\multimap-), H(-\mathbf{\Delta} \cdot), H_{180}(--\nabla-)$,

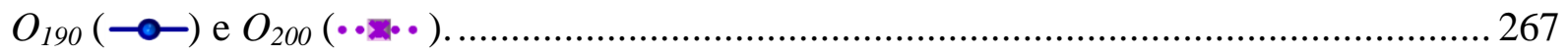

Figura 60. Variação do rendimento de glicose $(\%)$ obtido após $72 \mathrm{~h}$ de hidrólise enzimática com a área superficial específica externa (ASE $-\mathrm{m}^{2} / \mathrm{g}$ ) calculada por distribuição de tamanhos de partículas.

Figura 61. Variação do rendimento de glicose (\%) obtido após $72 \mathrm{~h}$ de hidrólise enzimática com a área superficial específica externa $\left(\mathrm{ASE}-\mathrm{m}^{2} / \mathrm{g}\right)$ calculada por MorFi. 277

Figura 62. Variação do rendimento de glicose (\%) obtido após $72 \mathrm{~h}$ de hidrólise enzimática com a área de poros $\left(\mathrm{m}^{2} / \mathrm{g}\right)$ com diâmetros maiores ou iguais a $9,90 \mathrm{~nm}$. 279

Figura 63. Variação do rendimento de glicose $(\%)$ obtido após $72 \mathrm{~h}$ de hidrólise enzimática com a dimensão lateral do cristalito de celulose $(\AA)$ na direção do plano $(200)_{\mathrm{m}}$

Figura 64. Variabilidade do sistema de amostras de bagaço estudado representada pelos parâmetros físicos e morfológicos: (A) influência (loadings) das variáveis originais nas componentes principais; (B) representação das amostras (scores) de acordo com as componentes principais $P C 1$ e $P C 2$. 287

Figura 65. Modelo de variação da digestibilidade enzimática das amostra de bagaço estudadas com os parâmetros estruturais que mais contam para a vairabilidade do sistema: (A) influência (loadings) das variáveis originais nas componentes principais; (B) correlação entre os valores de rendimento de glicose $(\%$ - $72 \mathrm{~h})$ mensurados e as representações das amostras (scores) de acordo com a componente principal PC1. 288 


\section{LISTA DE TABELAS}

Tabela 1. Características dos elementos constituintes do bagaço de cana-de-açúcar. 36

Tabela 2. Principais diferenças entre as hemiceluloses e a celulose. 40

Tabela 3. Relação entre os efeitos primários do refino e os efeitos secundários provocados nas fibras lignocelulósicas.

Tabela 4. Publicações acerca do uso de métodos de refino como pré-tratamento para o aumento da sacarificação enzimática do bagaço das lignoceluloses.

Tabela 5. Sequência de ajustes da aproximação entre os discos e tempos de retiradas de alíquotas aplicados nos ensaios de tratamento físico-mecânico em refinador de discos Bauer.

Tabela 6. Resumo das condições de processamento empregadas nos pré-tratamentos físicoquímicos e físico-mecânicos.... 169

Tabela 7. Composição química das amostras de bagaço de cana-de-açúcar em estudo 195

Tabela 8. Valores de rendimento de glicose (\%) obtidos após $24 \mathrm{~h}, 48 \mathrm{~h}$ e $72 \mathrm{~h}$ de hidrólise enzimática para as cinco as amostras de bagaço de cana-de-açúcar em estudo. 259

Tabela 9. Resultados da análise estatística de variância (ANOVA) aplicada ao modelo empírico proposto para predizer a conversão enzimática dos polissacarídeos do bagaço de cana-de-açúcar. 


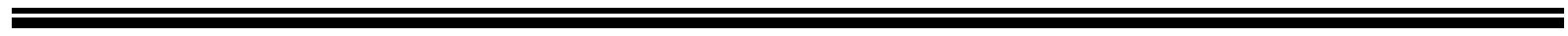




\section{SUMÁRIO}

CAPÍTULO 1. INTRODUÇÃO.

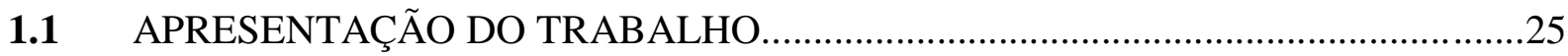

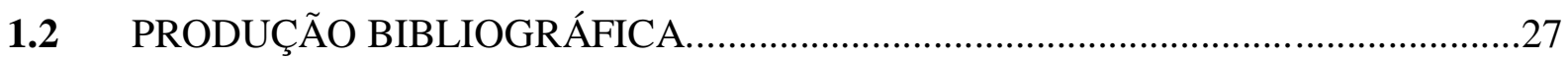

CAPÍTULO 2. MOTIVAÇÃO E ESTADO DA ARTE ........................................................29

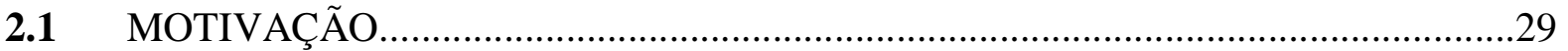

2.1.1 Biomassa para bioenergia: a necessidade sustentada pela oportunidade....................29

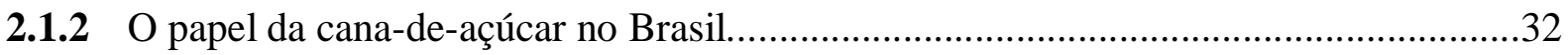

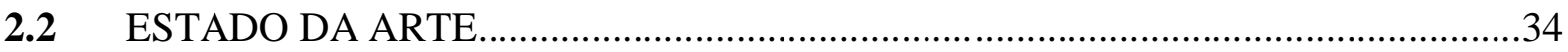

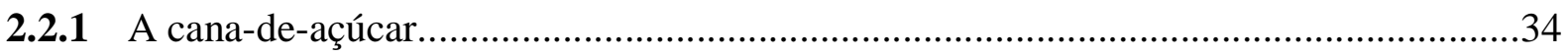

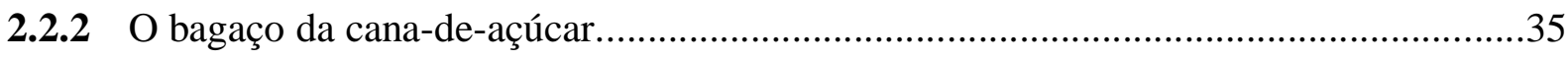

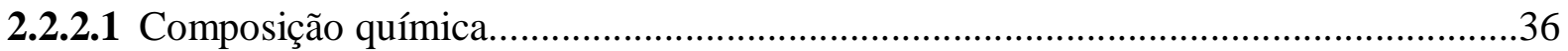

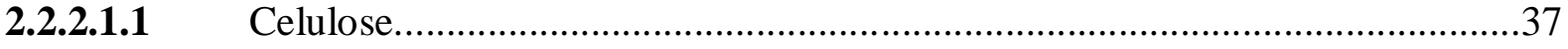

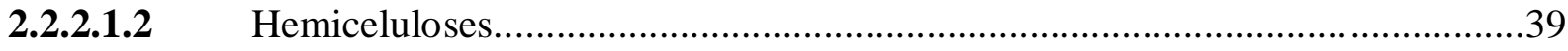

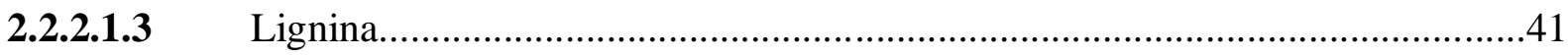

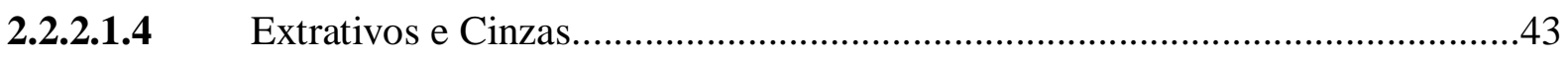

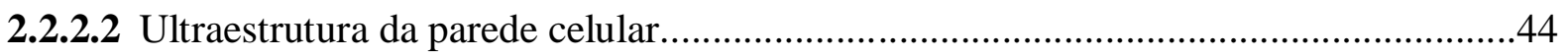

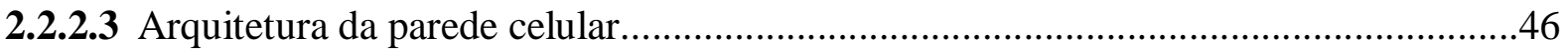

2.2.3 A biorrefinaria da cana-de-açúcar e os desafios do etanol celulósico...........................48

2.2.4 Hidrólise enzimática da biomassa lignocelulósica...................................................54

2.2.4.1 Hidrolases glicosídicas: características e classificações.............................................55 


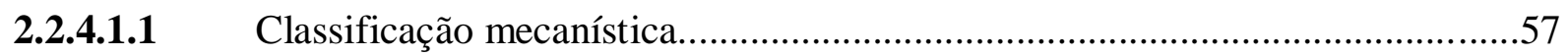

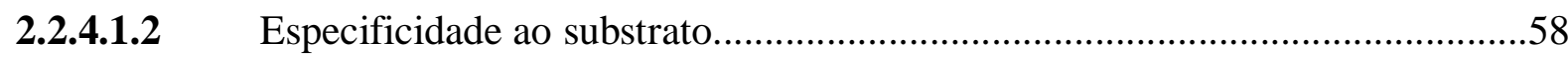

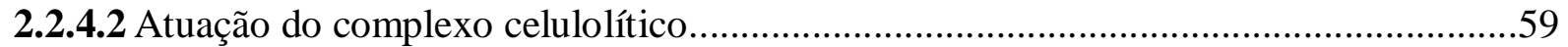

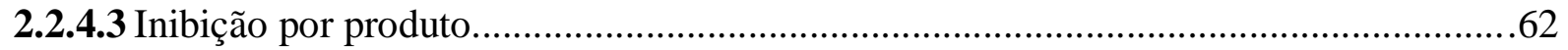

2.2.5 Fatores estruturais do substrato lignocelulósico que influenciam a efetividade da

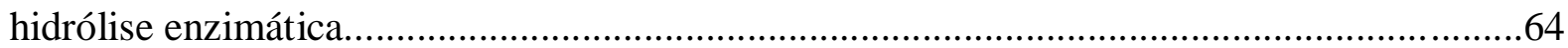

2.2.5.1 Área superficial específica...............................................................................66

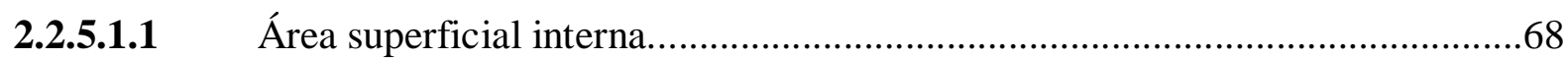

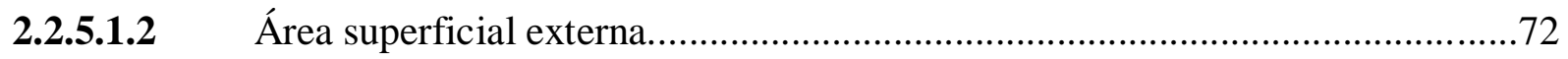

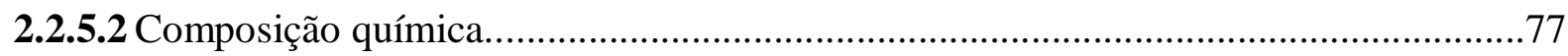

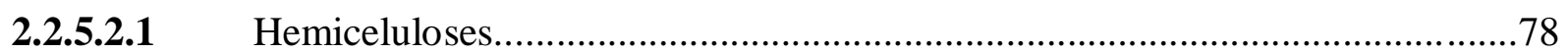

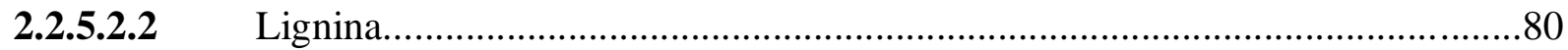

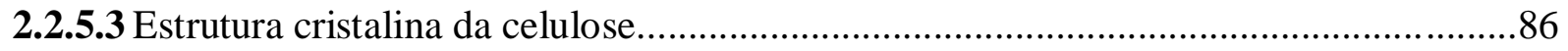

2.2.5.4 Comportamento cinético da hidrólise enzimática da celulose ....................................91

2.2.5.5 Modelagem matemática da digestão enzimática da celulose.....................................94

2.2.6 Pré-tratamentos aplicados às biomassas lignocelulósicas.........................................101

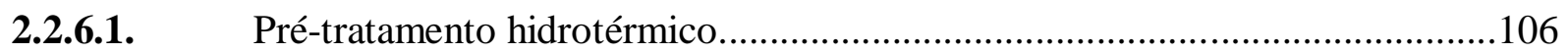

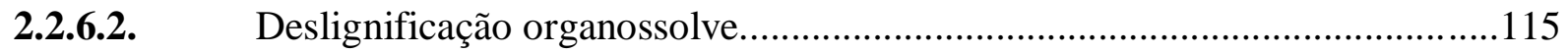

2.2.7 Processamento físico-mecânico da biomassa lignocelulósica.....................................121

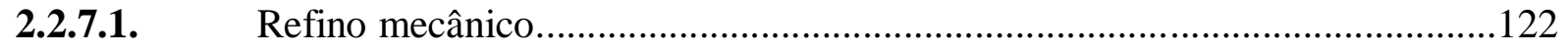

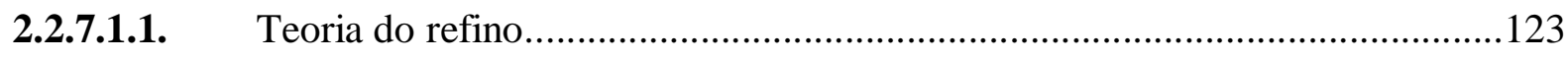


2.2.7.1.2. Efeitos do refino.

2.2.7.1.3. Fatores que influem no processo de refino................................................128

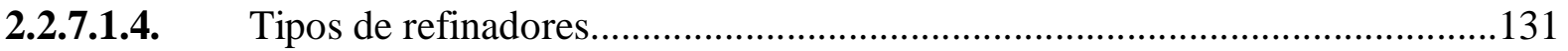

2.2.8. Influência dos métodos de refino na sacarificação de materiais lignocelulósicos......134

CAPÍtulO 3. OBJETIVOS

3.1. OBJETIVOS GERAIS

3.2. OBJETIVOS ESPECÍFICOS.

CAPÍTULO 4. MATERIAIS E MÉTODOS.

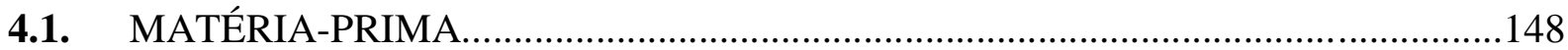

4.2. PRÉ-TRATAMENTOS FÍSICO-QUÍMICOS..................................................... 148

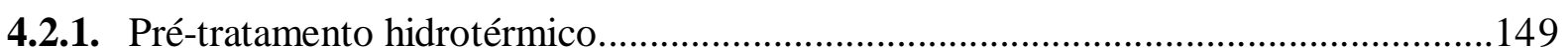

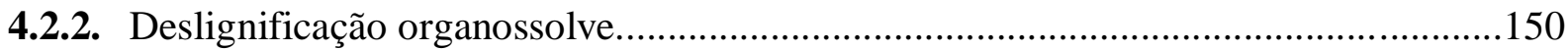

4.3. DETERMINAÇÃO DA COMPOSIÇÃO QUÍMICA DA BIOMASSA IN NATURA E

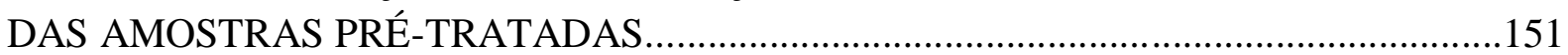

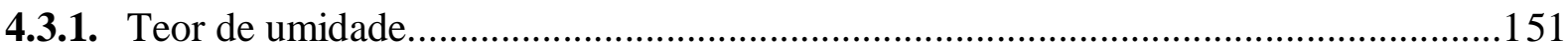

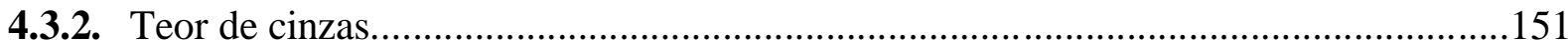

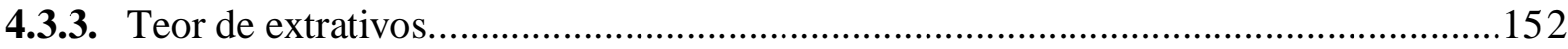

4.3.4. Teores de lignina total, carboidratos, ácidos orgânicos, furfural e HMF....................153

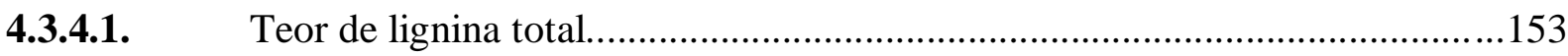

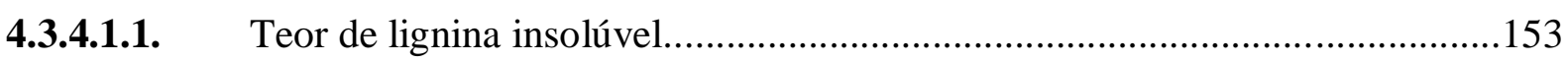

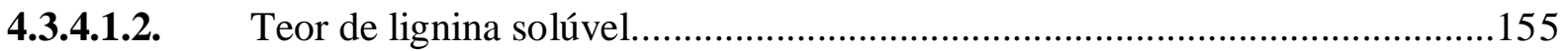

4.3.4.2. Teores de carboidratos, ácidos orgânicos, furfural e HMF.............................156 
4.4.1. Moinho centrífugo tipo Jokro.

4.4.2. Refinador de discos Bauer.

4.4.3. Moinho criogênico .165

4.4.4. Determinação do Grau de Refino Schöpper-Riegler.

4.5. CARACTERIZAÇÕES FÍSICAS E MORFOLÓGICAS. 170

4.5.1. Distribuição de tamanhos de partículas. 170

4.5.2. Análise morfológica das fibras. 173

4.5.3. Microscopia ótica 177

4.5.4. Termoporometria 177

4.5.5. Difração de raios-X. 181

4.6. SACARIFICAÇÃO ENZIMÁTICA DOS POLISSACARÍDEOS DA BIOMASSA LIGNOCELULÓSICA. 184

4.6.1. Determinação da atividade enzimática do complexo celulolítico. .184

4.6.2. Determinação da atividade enzimática do complexo b-glicosídico. 188

4.6.3. Reação de hidrólise enzimática aplicada às amostras de bagaço. 190

4.6.3.1. Determinação da concentração de açúcares nos hidrolisados enzimáticos.....191

4.7. ANÁLISE DE COMPONENTES PRINCIPAIS E CONSTRUÇÃO DO MODELO DE PREDIÇÃO DA CONVERSÃO ENZIMÁTICA DA CELULOSE.

CAPÍTULO 5. RESULTADOS E DISCUSSÃO.

5.1. CARACTERIZAÇÃO DA COMPOSIÇÃO QUÍMICA DAS AMOSTRAS DE BAGAÇO DE CANA-DE-AÇÚCAR IN NATURA É PRÉ-TRATADAS 
5.2. AVALIAÇÃO DOS TRATAMENTOS FÍSICO-MECÂNICOS APLICADOS ÀS AMOSTRAS DE BAGAÇO DE CANA-DE-AÇÚCAR.

5.3. EFEITOS DOS TRATAMENTOS FÍSICO-MECÂNICOS NAS PROPRIEDADES ESTRUTURAIS DAS AMOSTRAS DE BAGAÇO DE CANA-DE-AÇÚCAR..................209

5.3.1. Distribuição de tamanhos de partículas................................................................209

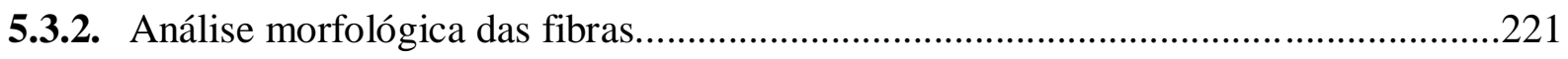

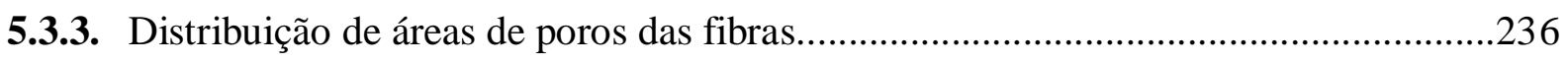

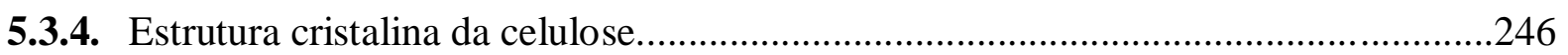

5.4. EFEITOS DAS PROPRIEDADES ESTRUTURAIS NA EFETIVIDADE DA SACARIFICAÇÃO ENZIMÁTICA DAS AMOSTRAS DE BAGAÇO..............................258

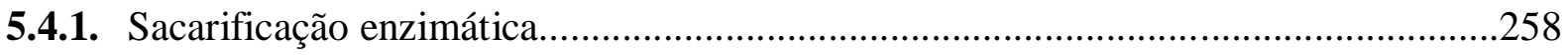

5.4.2. Avaliação dos efeitos das propriedades estruturais na sacarificação enzimática........274

5.4.3. Análise de componentes principais e construção do modelo de predição da conversão

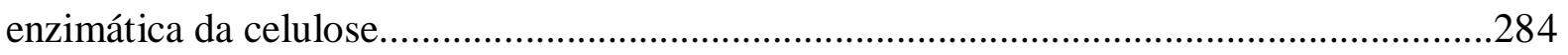

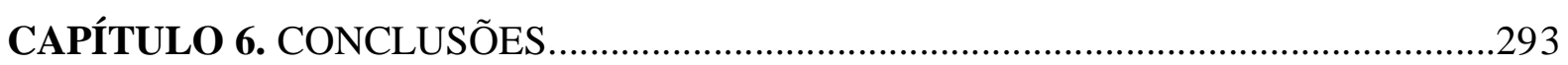

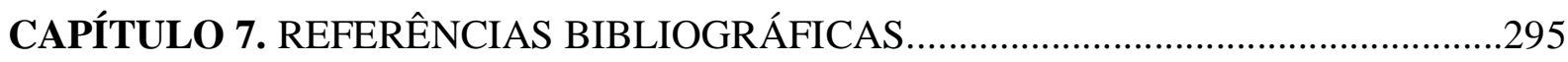

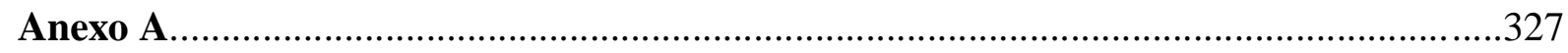

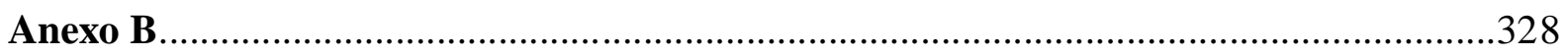

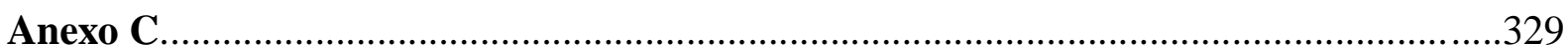

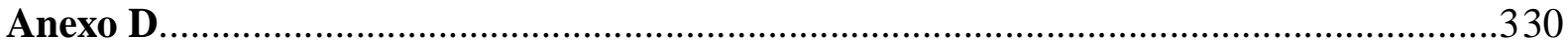

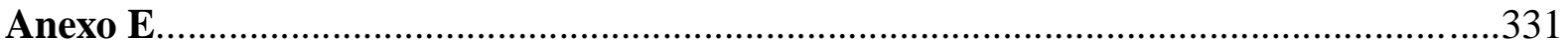

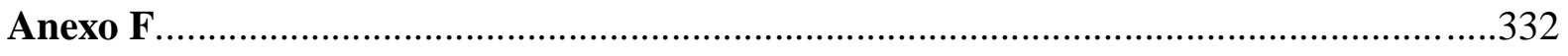

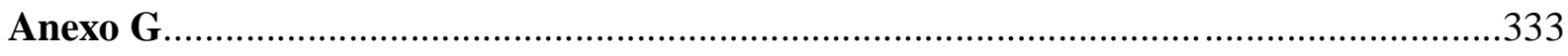


Anexo H.

Anexo I

.336

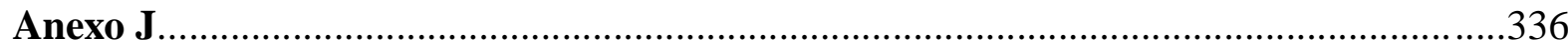

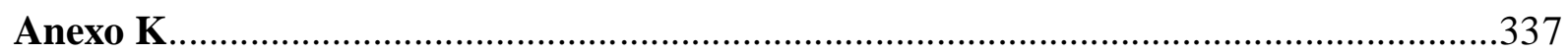

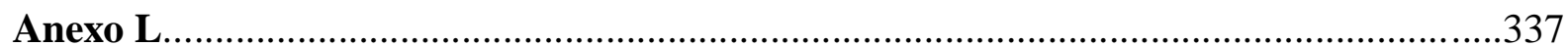

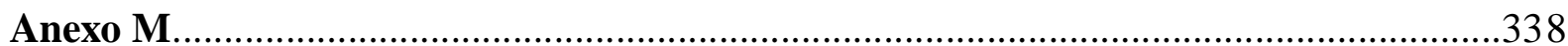

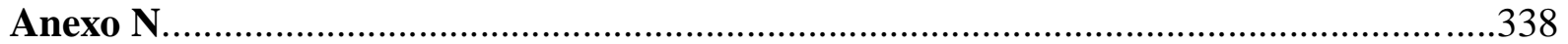

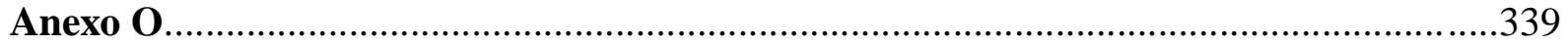

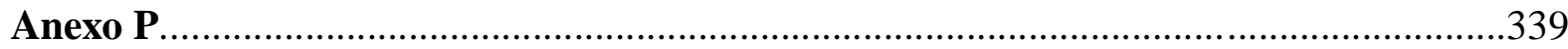

Anexo Q

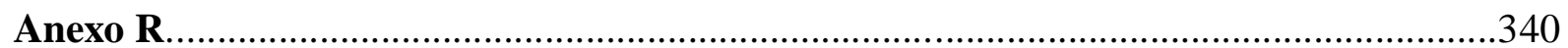

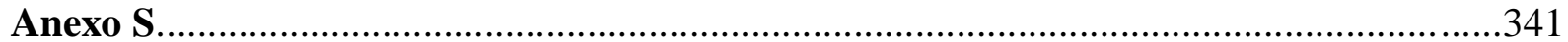

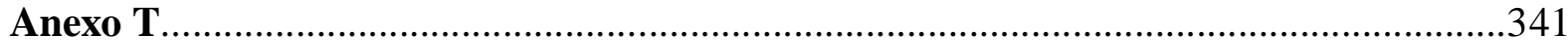

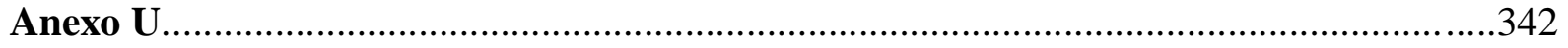




\section{CAPÍTULO 1. INTRODUÇÃO}

\subsection{APRESENTAÇÃO DO TRABALHO}

O bagaço de cana-de-açúcar é o maior excedente agroindustrial produzido no Brasil, fato que encoraja o seu uso como matéria-prima renovável para a produção de commodities, blocos químicos e novos materiais de alto valor agregado. Entretanto, a complexidade estrutural desta biomassa lignocelulósica dificulta o fracionamento dos componentes da parece celular, assim como restringe a acessibilidade dos agentes hidrolíticos aos polissacarídeos constituintes. Uma das dificuldades em interpretar a influência de cada um dos parâmetros estruturais das fibras lignocelulósicas na restrição da ação hidrolítica enzimática se dá pelo fato destes aspectos estarem inter-relacionados, além de que os métodos de processamento geralmente aplicados às biomassas alteram mais de uma propriedade ao mesmo tempo.

Este projeto de tese, em sua forma geral, esteve inserido no escopo de um projeto em colaboração com o Laboratório Nacional de Ciência e Tecnologia do Bioetanol (CTBE). O projeto como um todo envolveu diferentes etapas, descritas a seguir, que também foram executadas pela candidata ao título.

$\mathrm{Na}$ primeira etapa deste projeto realizou-se o estudo cinético da remoção dos componentes não celulósicos - hemiceluloses e lignina - das fibras de bagaço de cana-deaçúcar segundo três rotas de pré-tratamentos químicos: 1- hidrotérmico; 2- organossolve; 3hidrotérmico seguido de organossolve, realizados em diferentes temperaturas e tempos de reação. Tanto a fração sólida quanto a fração líquida foram caracterizadas quanto a sua composição química. Os resultados obtidos foram então utilizados para a obtenção dos parâmetros cinéticos e termodinâmicos de remoção destes componentes durante os métodos de processamento mencionados. A fração sólida obtida foi também submetida à hidrólise enzimática, obtendo-se um conjunto completo de dados que permitem inferir a influência da composição química das biomassas lignocelulósicas na susceptibilidade à sacarificação.

Os resultados obtidos nas análises de caracterização dos licores de pré-tratamento hidrotérmico, assim como os parâmetros cinéticos e termodinâmicos de remoção das hemiceluloses das fibras de bagaço, já estão publicados em revista científica da área, e até a data de depósito desta tese possuía 27 citações. A referência completa deste artigo encontra-se 
no item 1.2. Já os dados referentes às composições das frações sólidas obtidas no prétratamento hidrotérmico e nas duas rotas de deslignificação organossolve, assim como os resultados de hidrólise enzimática das amostras geradas, foram organizados em dois artigos e estão em fase de correção, sendo intitulados:

"Evaluation of hydrothermal pretreatment severity on sugarcane bagasse ultrastructure and cellulose digestibility."

- "An extensive comparison of organosolv, hydrothermal pretreatment and their combination for full exploitation of lignocellulosic components from sugarcane bagasse."

A partir dos dados de composição química e dos resultados de hidrólise enzimática obtidos na primeira etapa deste projeto, foi escolhida uma condição de cada uma das três rotas de pré-tratamentos físico-químicos estudadas. Estas amostras, além das fibras de bagaço in natura, foram então utilizadas no estudo de tratamentos físico-mecânicos.

Os processos estudados nesta segunda etapa do projeto compreenderam um método de refino mecânico de escala laboratorial, um método de refino de escala piloto, e um método de moagem criogênica. Dentro deste estudo, avaliaram-se de modo detalhado os efeitos das variáveis de cada um dos métodos físico-mecânicos nas propriedades estruturais da parede celular das fibras de bagaço. Ademais, confrontaram-se os dados numéricos das análises físicas e morfológicas realizadas com os rendimentos de glicose obtidos na hidrólise enzimática das amostras processadas. A análise estatística multivariada deste conjunto de dados permitiu a obtenção de um modelo empírico para a predição do comportamento das amostras de bagaço frente à sacarificação enzimática de acordo com suas características físicas e morfológicas.

$\mathrm{Na}$ terceira e última etapa do projeto, as polpas organossolve não-branqueadas, fibriladas nas maiores intensidades de cada um dos métodos de refino, foram aplicadas em um estudo de obtenção de nanofibrilas de celulose (NFCs) utilizando tratamento enzimático e sonicação de alta intensidade. As NFCs obtidas foram caracterizadas segundo algumas analises essenciais que indicaram o potencial de aplicabilidade das nanoestruturas com teores residuais de lignina em produtos de maiores valores agregados.

Esta etapa do projeto foi executada durante o estágio sanduíche no exterior no Laboratoire de Génie des Procédés Papetiers (LGP2) do Institut Polytechnique de Grenoble - Pagora, na cidade de Grenoble (França), entre o segundo semestre de 2014 e o primeiro semestre de 2015. Os resultados provindos deste estudo também já estão publicados em 
revista científica da área, e até a data de depósito desta tese possuía 10 citações. A referência completa deste artigo também se encontra no item 1.2.

Devido ao grande volume de resultados, optou-se por apresentar neste trabalho de tese apenas o bloco que representava a maior inovação e cujas interpretações eram mais desafiadoras, além de ainda não estar publicado em revista científica. Este se refere ao estudo completo dos efeitos dos tratamentos físico-mecânicos na hidrólise da celulose do bagaço de cana-de-açúcar, tema que dá título a este trabalho de tese.

\subsection{PRODUÇÃ̃ BIBLIOGRÁFICA}

$>\quad$ MEIGHAN, B. N.; LIMA, D. R. S.; CARDOSO, W. J.; BAÊTA, B. E. L.; ADARME, O. F. H.; SANTUCCI, B. S.; PIMENTAR, M. T. B.; AQUINO, S. F.; GURGEL, L. V. A. Two-stage fractionation of sugarcane bagasse by autohydrolysis and glycerol organosolv delignification in a lignocellulosic biorefinery concept. Industrial Crops and Products, v. 108, p. 431-441, 2017.

> SANTUCCI, B. S.; BRAS, J.; BELGACEM, M. N.; CURVELO, A. A. S.; PIMENTA, M. T. B. Evaluation of the effects of chemical composition and refining treatments on the properties of nanofibrillated cellulose films from sugarcane bagasse. Industrial Crops and Products, v. 91, p. 238-248, 2016.

$>\quad$ DRIEMEIER, C.; MENDES, F. M.; SANTUCCI, B. S.; PIMENTA, M. T. B. Cellulose co-crystallization and related phenomena occurring in hydrothermal treatment of sugarcane bagasse. Cellulose, v. 22, p. 2183-2195, 2015.

SANTUCCI, B. S.; MAZIERO, P.; RABELO, S. C.; CURVELO, A. A. S.; PIMENTA, M. T. B. Autohydrolysis of Hemicelluloses from Sugarcane Bagasse During Hydrothermal Pretreatment: a Kinetic Assessment. BioEnergy Research, v. 8, p. 1, 2015.

$>\quad$ SANTUCCI, B. S.; CURVELO, A. A. S.; PIMENTA, M. T. B. Evaluation of physicomechanical treatments on sugarcane bagasse cellulose hydrolysis. In: 13th European Workshop on Lignocellulosis and Pulp, 2014, Sevilha. 13th European Workshop on Lignocellulosis and Pulp - Proceedings Book, 2014. 


\section{CAPÍTULO 2. MOTIVAÇÃO E ESTADO DA ARTE}

\subsection{MOTIVAÇÃO}

\subsubsection{Biomassa para bioenergia: a necessidade sustentada pela oportunidade}

O fornecimento de energia e materiais de maneira sustentável é tema de grandes discussões ao redor do mundo e, apesar dos intensos esforços em pesquisa, ainda consiste em um dos maiores desafios desta e das próximas décadas. As matérias-primas de fonte fóssil têm sido importantes até o momento pelo fato de possibilitarem a obtenção de um conjunto imensurável de blocos químicos. Entretanto, além das preocupações ambientais causadas pela refinaria, uso e queima dos recursos de fontes fósseis, os preços do petróleo bruto e seus derivados vêm oscilando anualmente, acompanhados da possível limitação de sua disponibilidade (CHERUBINI; STRØMMAN, 2011; MOORE; BOTHA, 2014).

As agendas internacionais, descritas em conferências de proteção ambiental e mudanças climáticas, propõem a troca gradual dos recursos fósseis por insumos de fontes renováveis como uma das alternativas para o desenvolvimento humano (CGEE, 2012). Após 43 anos da realização da primeira conferência sobre o meio ambiente, no ano de 2015, 195 países aprovaram o Acordo de Paris na $21^{\circ}$ Conferência das Partes, com o objetivo central de conter a mudança climática global e seus impactos pela redução das emissões dos gases de efeito estufa (GEE). Para isto, cada país estabeleceu as próprias metas considerando o desenvolvimento social, econômico e, principalmente, ambiental. Neste quadro, o ambicioso compromisso brasileiro é de reduzir em 37\% as emissões de GEE até 2025 e em $43 \%$ até 2030, com base nas emissões registradas em 2005 (MMA, 2016).

Neste contexto, biomassas de fonte vegetal podem contribuir significantemente para suprir esta demanda. Enquanto o setor energético conta com um amplo espectro de recursos renováveis, como hidroelétrica, eólica e solar, a biomassa é a única fonte renovável rica em carbono. Obtida como produto em atividades agroindustriais e florestais, é matéria-prima potencial para a adequação a uma refinaria completa, uma vez que seu processamento sustentável possibilita a produção não só de energia, como de combustíveis, blocos químicos e uma gama de materiais em uma plataforma integrada. Desta forma, a biomassa apresenta a 
surpreendente oportunidade de abastecer diferentes setores econômicos (CHERUBINI; STRØMMAN, 2011; MENON; RAO, 2012).

Segundo dados publicados pela Agência Internacional de Energia (International Energy Agency, IEA), em 2017, 25\% da energia mundial foi produzida a partir de fontes renováveis, sendo $12 \%$ de contribuição da biomassa (bioenergia). Ainda segundo a agência, cálculos estimam que até 2022 a energia total consumida mundialmente será em 30\% provinda de fontes renováveis (IEA, 2017). Esta visão otimista foi reforçada desde 2006 com a criação da Associação Global em Bioenergia (Global Bioenergy Partnership, GBEP), onde representantes do governo, da academia e do setor privado trabalham para assegurar a promoção do uso da biomassa em diferentes ramos tecnológicos, além do desenvolvimento, produção e comercialização da bioenergia, tanto para o setor de eletricidade quanto de transporte (GBEP, 2011).

Poucos países com níveis razoáveis a altos de industrialização, como o Brasil, possuem uma matriz energética com tamanha importância da participação na energia renovável a partir de biomassa (FERREIRA-LEITÃO et al., 2010; WALTER; DOLZAN; PIACENTE, 2006). O histórico de produção energética primária no país indica que o crescimento da participação das fontes renováveis de energia acompanha a demanda de produção (Figura 1), desempenhando papel cada vez mais notório no consumo interno.

Este panorama privilegiado se deve primeiramente às condições climáticas favoráveis e à grande disponibilidade de água, que permitem uma diversidade de culturas de grande extensão (MOORE, BOTHA, 2014). No entanto, o papel da bioenergia foi de fato alavancado pelo setor de transporte com a indústria da cana-de-açúcar. Paralelamente, a elevação dos preços e a instabilidade de fornecimento de petróleo no mercado internacional levaram o Governo brasileiro da época a investir na produção do álcool combustível (GENOVESE; UDAETA; GALVAO, 2006).

Em 2013, os biocombustíveis proveram 3,5\% do consumo mundial total de combustíveis de transporte (IEA, 2013). Já em 2014, o Brasil e os EUA eram responsáveis por aproximadamente $60 \%$ da produção mundial de biocombustíveis, e $87 \%$ da produção de etanol, com o Brasil representando $26 \%$ dessa produção a partir do processamento da canade-açúcar (WBA, 2014). Análises realizadas pelo IEA apontam a previsão otimista de que a produção de biocombustíveis para transporte aumentará em 10 vezes até 2050, com os biocombustíveis provendo $25 \%$ da demanda mundial de combustíveis para transporte. 
Figura 1. Histórico de produção energética no Brasil por fonte (1970-2014).

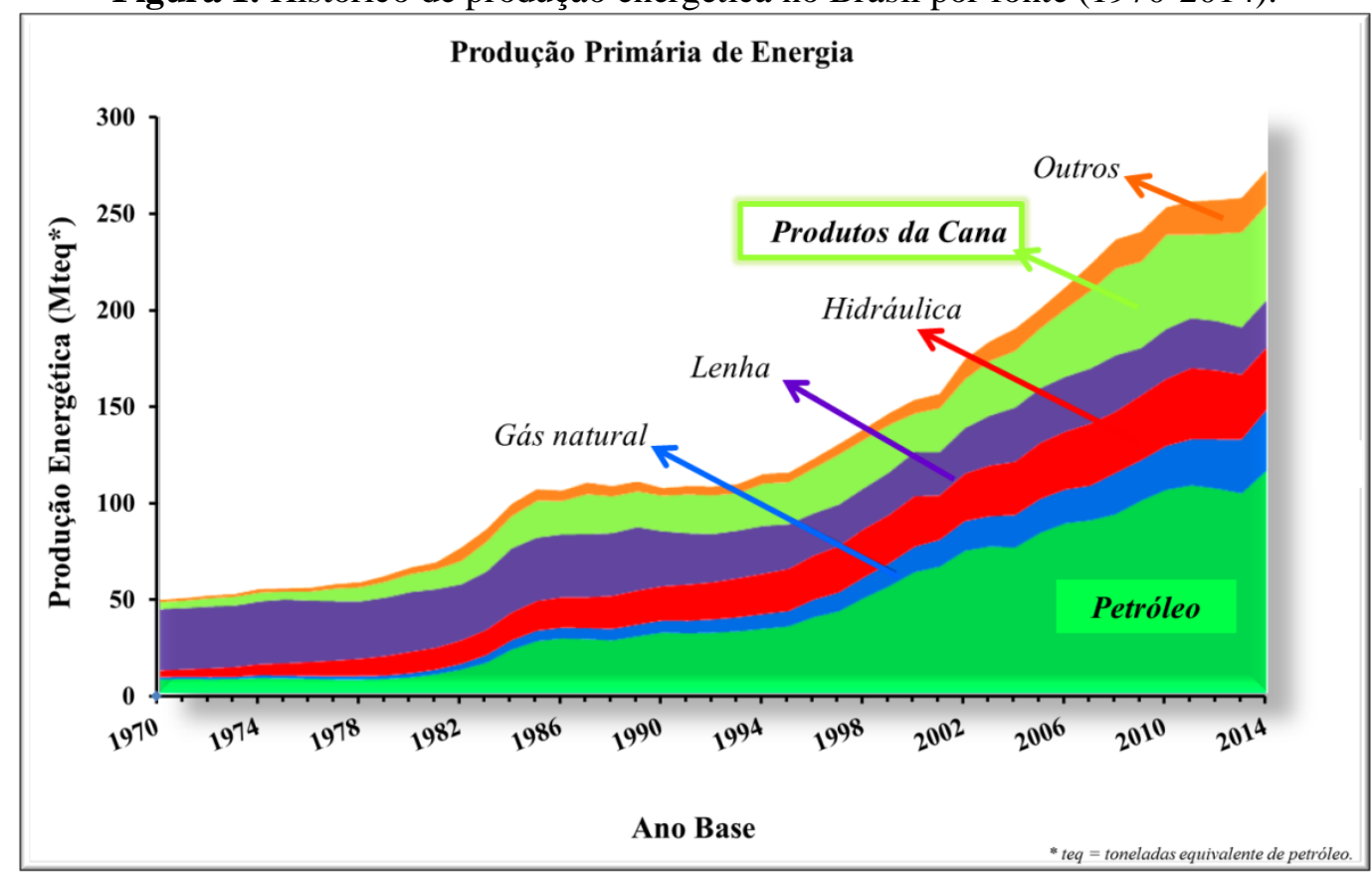

Fonte: Adaptado de: MINISTÉRIO DE MINAS E ENERGIA (MME). Balanço Energético Nacional 2015.

Entretanto, para que o uso da biomassa para a obtenção de combustíveis se enquadre nas conjunturas da atualidade e no preceito fundamental de sustentabilidade, é necessário que haja o aproveitamento eficiente da grande quantidade de produtos (e subprodutos) agrícolas produzidos, com especial atenção à biomassa lignocelulósica. Neste campo mais uma vez o Brasil apresenta posição de destaque pelo gigantesco potencial de aplicação. Entre os anos de 2014 e 2015, as agroindústrias do milho (84.672 kt), cana-de-açúcar (634.767kt), arroz (12.436 kt), mandioca (23.242 kt), trigo (6.230 kt), laranja (11.366 kt), coco (2.919 kt) e sorgo (2.055 kt) ocuparam aproximadamente 33 milhões de hectares de área agriculturável no Brasil, gerando mais de 575 milhões de toneladas de biomassa úmida como subproduto (CONAB, 2015; FAOSTAT, 2015).

Diante deste quadro, enfatiza-se que a necessidade de suprimento energético que gera grande interesse no uso dos recursos lignocelulósicos é suplementada pela oportunidade da sua imensa disponibilidade a baixo custo, que além de não competir com a produção de culturas alimentícias permitem o uso da terra de forma mais eficiente e com melhor balanço de emissões de carbono (CARDONA; QUINTERO; PAZ, 2010; WALTER; DOLZAN; PIACENTE, 2006). Combustíveis provindos de biomassas lignocelulósicas exercem um papel particularmente importante nas previsões de produção bioenergética, visto que podem fornecer, com infraestrutura compatível, combustíveis de baixo teor de emissões de GEE. 


\subsubsection{O papel da cana-de-açúcar no Brasil}

O Brasil é o maior produtor mundial de cana-de-açúcar, e sua cultura é um exemplo de matéria-prima potencial para ser adequada ao conceito de biorrefinaria. A produção de etanol de primeira-geração a partir da cana-de-açúcar no Brasil é uma tecnologia consolidada e apresenta mercado bem estabelecido.

Atualmente existem 373 usinas em operação, processando aproximadamente 657 milhões de toneladas de cana e gerando 28 bilhões de litros de etanol por ano (CONAB, 2017). O etanol diferencia-se dos combustíveis de fonte fóssil por apresentar alto teor de oxigênio (que constitui cerca de $35 \%$ em massa do etanol), o que permite uma combustão mais limpa e melhor desempenho dos motores veiculares, além de reduzir as emissões de dióxido de carbono (BNDES; CGEE, 2008).

O etanol combustível obtido a partir da cana-de-açúcar é primeiro exemplo brasileiro de produção energética em larga escala a partir de biomassa (CORTEZ; LORA; GÓMEZ, 2008). Desde sua inserção na matriz energética brasileira com a criação do Programa Nacional do Álcool, em 1975, o Brasil apresenta uma forte política de ampliação do mercado dos biocombustíveis, baseada no preceito de que a energia de biomassa é a alternativa mais acessível aos países em desenvolvimento (CGEE, 2012). Entretanto, a importância do mercado do etanol se estabeleceu com base em fatores tecnológicos e comerciais.

Nas últimas décadas a indústria sucroalcooleira apontou novos protagonistas: o bagaço e a palha. $\mathrm{O}$ alto volume de processamento das usinas produz anualmente uma quantidade expressiva de seus principais subprodutos, o que despertou o interesse no potencial para a produção de etanol a partir destes materiais lignocelulósicos. Estima-se que, entre as safras de 2016 e 2017, 184 milhões de toneladas de biomassa seca foram geradas (CONAB, 2017).

O bagaço de cana-de-açúcar é o material fibroso obtido após o processamento da cana para a obtenção do caldo (CARDONA; QUINTERO; PAZ, 2010). Estima-se que 83,5\% do bagaço gerado seja queimado em caldeiras nas usinas para a cogeração de energia (MME, 2015). A recuperação de energia a partir do bagaço é um dos motivos pelo qual a indústria sucroalcooleira possui um melhor balanço energético frente às demais culturas (MOORE; BOTHA, 2014). Um aumento no excedente de bagaço é previsto devido à otimização da eficiência das caldeiras e do sistema de geração de energia (SANTOS et al., 2016). Da 
produção anual total de palha, $50 \%$ é deixada no campo como forma de evitar a erosão e manter as propriedades agronômicas do solo (FERREIRA-LEITÃO et al., 2010).

Neste ponto destacam-se três realidades. Primeiramente depara-se com a oportunidade ligada a uma grande quantidade disponível de biomassa de alto valor energético, cujo potencial para a conversão em materiais e biocombustíveis permite aumentar seu valor econômico. Soma-se a necessidade de aumento de produção do etanol combustível para atender as demandas do mercado, porém limitado à área de cultivo de cana atual de forma a não concorrer com as culturas alimentícias (BNDES; CGEE, 2008). Por fim, é imprescindível a implementação de uma estrutura sólida de biorrefinaria como forma de diminuir a dependência dos recursos de fonte fóssil. Frente a este panorama, fica claro o papel dos lignocelulósicos provindos da cana-de-açúcar no setor energético brasileiro.

Os estudos científicos ligados ao setor apontam a rota de produção do etanol celulósico, ou de segunda geração, como o prelúdio da instituição desta nova economia. Em relatório publicado pelo IEA, concluiu-se que o etanol celulósico produzido a partir de $10 \%$ dos subprodutos lignocelulósicos globais poderá suprir até $4.1 \%$ da demanda projetada de combustíveis em 2030 (IEA, 2010). Contudo, a conversão eficiente de materiais lignocelulósicos em etanol, químicos e materiais de alto valor agregado é um dos maiores desafios na área de bioprocessos, posto que depende fortemente de grandes inovações científicas e tecnológicas para uma produção efetiva a baixo custo (MENON; RAO, 2012).

O processo de obtenção do etanol convencional, ou de primeira geração é baseado na reserva energética da cana, o caldo rico em sacarose, onde os açúcares encontram-se disponíveis para a fermentação. Diferentemente, os materiais lignocelulósicos, que representam a parte estrutural da planta, apresentam uma formação complexa representada pela interação físico-química dos seus macrocomponentes principais: a celulose, as hemiceluloses e a lignina.

Deste modo, a produção de etanol a partir do bagaço e da palha envolve uma sequência de processos para a desestruturação da matriz lignina-carboidratos e a hidrólise em açúcares passíveis à fermentação. Para um design eficiente de processo torna-se imprescindível o conhecimento das características destes materiais, assim como de seu comportamento frente a uma série de tratamentos de natureza química, física, mecânica ou biológica. 


\subsection{ESTADO DA ARTE}

\subsubsection{A cana-de-açúcar}

A cana-de-açúcar é uma gramínea pertencente à família Poaceae e ao gênero Saccharum, tipicamente cultivada nas regiões tropicais e subtropicais. As variedades de cana exploradas atualmente são híbridas de várias espécies, de forma que sua anatomia e morfologia são capazes de prover a habilidade de acumular altos teores de açúcares aliada à resistência mecânica e ao ataque de doenças (MOORE; BOTHA, 2014; DINARDOMIRANDA; VASCONCELOS; LANDELL, 2008).

Assim como outras gramíneas da mesma família, sua estrutura é dividida em duas regiões: a aérea, que compreende o colmo, as folhas e a inflorescência; e a subterrânea, que compreende o sistema radicular. O colmo é a seção onde se encontra o tecido responsável pela estocagem da sacarose, assim como o tecido responsável pelo crescimento da planta (DINARDO-MIRANDA; VASCONCELOS; LANDELL, 2008; MOORE; BOTHA, 2014).

Anatomicamente, o colmo é formado por tecidos que executam diferentes funções na planta. A epiderme é o tecido mais externo, formado por uma camada de células que recobre e protege o colmo. Nela alternam células alongadas e células curtas, ambas compostas por uma membrana cuticular e ceras epicuticulares (SAN'ANNA et al., 2013; SANDHU et al., 2016). O córtex (ou casca) é um tecido composto por várias camadas concêntricas de células esclerenquimáticas. Estas células são observadas como fibras alongadas, e caracterizam-se pela parede espessa e altamente lignificada, o que provê à planta força mecânica e resistência física à torção e compressão (DINARDO-MIRANDA; VASCONCELOS; LANDELL, 2008; SANDHU et al., 2016). A área interna do colmo (miolo) é formada por feixes vasculares diferenciados, alinhados paralelamente ao eixo do colmo e separados por células do tecido parenquimático (Figura 2 (A)) (MOORE; BOTHA, 2014; SAN'ANNA et al., 2013).

O tecido vascular é formado por células do xilema e do floema, com cada feixe envolto por camadas de fibras esclerenquimáticas (Figura 2 (B)) (MOORE; BOTHA, 2014; SAN'ANNA et al., 2013). O xilema, tecido responsável pela condução de água e nutrientes, é constituído por células diferenciadas, os traqueídes (fibras curtas) e os elementos de vasos, cuja parede lignificada permite que este tecido também atue na sustentação mecânica da planta. Já o floema é constituído de células crivadas (tipo peneira), cuja função é o transporte 
de seiva elaborada. O tamanho e a estrutura dos feixes vasculares dependem de sua posição no colmo. Nas regiões periféricas as células do xilema e do floema são mais numerosas, porém de menor dimensão, enquanto na região central do colmo, os feixes são mais espaçados e as dimensões das células são maiores (MOORE; BOTHA, 2014; SAN'ANNA et al., 2013; SANDHU et al., 2016).

O tecido parenquimático é o responsável pela reserva energética da planta, onde se encontra o caldo rico em sacarose. As células de parênquima apresentam parede celular delgada, e estão presentes em maior concentração na porção central do colmo (MOORE; BOTHA, 2014).

Figura 2. Estrutura anatômica do colmo da cana-de-açúcar (variedade CB 45-3): corte transversal do entrenó mostrando (A) os feixes vasculares e as células do tecido parenquimático, e (B) detalhe das células vasculares circundadas por fibras esclerenquimáticas.
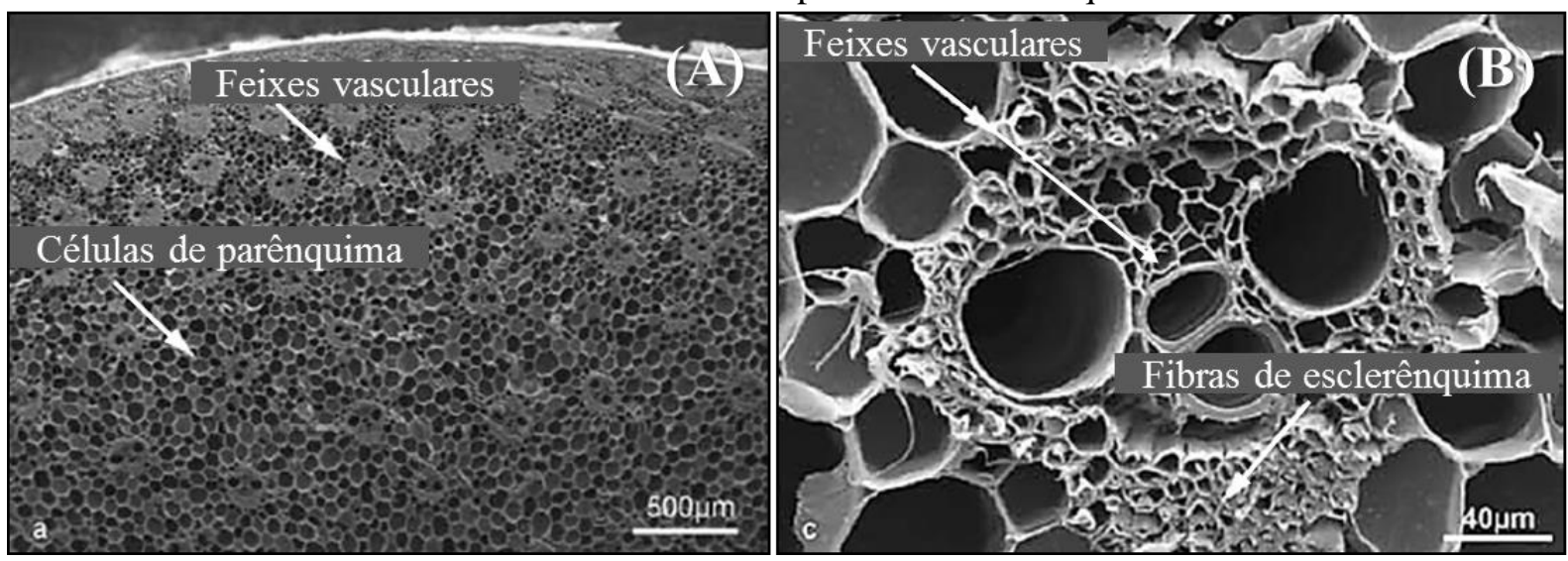

Fonte: Adaptado de: SANT'ANNA et al., 2013.

\subsubsection{O bagaço da cana-de-açúcar}

O bagaço de cana-de-açúcar é o material lignocelulósico fibroso obtido após a moagem do colmo da cana-de-açúcar nas usinas de $1^{\text {a }}$ geração para a extração do caldo. Fisicamente apresenta-se em fragmentos heterogêneos de diversas dimensões, cuja constituição é de $46-52 \%$ de umidade, $43-52 \%$ de estruturas fibrilares e 2-6\% de extrativos (sólidos solúveis) e componentes inorgânicos (sólidos insolúveis) (PATURAU, 1989).

Do ponto de vista morfológico, distinguem-se dois tipos de elementos: as fibras, células de parede rígida da casca e dos tecidos vasculares; e a medula, células de parede fina do tecido parenquimático interno do colmo. As fibras diferenciam da medula pela morfologia e pela razão de aspecto (relação comprimento/diâmetro), conforme detalhado na Tabela 1 a 
seguir. Os elementos de vasos, também associados aos feixes vasculares, devido ao caráter não fibroso são em alguns casos considerados na porção medula. Deste modo, é proposto que a composição do bagaço seja de $55 \%$ de fibras, $20 \%$ de medula, $20 \%$ de elementos de vasos e 5\% de outros elementos não fibrosos (epiderme) (PATURAU, 1989).

Tabela 1. Características dos elementos constituintes do bagaço de cana-de-açúcar.

\begin{tabular}{c|c|c|c|c|c}
\hline Elemento & Composição & Morfologia & $\begin{array}{c}\text { Teor } \\
(\%)\end{array}$ & $\begin{array}{c}\text { Comprimento } \\
\text { Médio (mm) }\end{array}$ & $\begin{array}{c}\text { Razão de } \\
\text { Aspecto }\end{array}$ \\
\hline Fibras & $\begin{array}{c}\text { Células de } \\
\text { esclerênquima e } \\
\text { fibrovasculares }\end{array}$ & $\begin{array}{c}\text { Fibras cilíndricas } \\
\text { de parede rígida }\end{array}$ & 55 & 1,5 & 70 \\
$\begin{array}{c}\text { Elementos } \\
\text { de vasos }\end{array}$ & Elementos de vasos & $\begin{array}{c}\text { Células de formato } \\
\text { irregular e parede } \\
\text { delgada }\end{array}$ & 20 & 0,3 & 5 \\
$\begin{array}{c}\text { Outros nálo } \\
\text { fibrosos }\end{array}$ & Células epidérmicas & --- & 20 & 1,0 & 9 \\
\hline
\end{tabular}

Fonte: Adaptado de: PATURAU, 1989.

\subsubsection{Composição química}

A composição do bagaço pode variar de acordo com o local de cultivo, a época de colheita, a composição do solo, a variedade assim como o período de maturação da planta; entretanto, os diferentes estudos de caracterização e aplicação deste material permitem inferir uma faixa de representação de cada componente (MOORE; BOTHA, 2014). A celulose, componente majoritário da parede celular, constitui de $40 \%$ a $50 \%$ da massa seca do bagaço, enquanto as hemiceluloses representam de $24 \%$ a $32 \%$. Já a lignina corresponde de $21 \%$ a $27 \%$, e os cerca de $2 \%$ a $8 \%$ restantes são representados pelos componentes de baixa massa molar (GURGEL, 2010; MARABEZI, 2014; MAZIERO, 2013; RABELO, 2010; SANTUCCI et al., 2015; SLUITER et al., 2016).

$\mathrm{Na}$ estrutura da parede celular dos materiais lignocelulósicos, os componentes macromoleculares encontram-se em íntima associação química e estrutural, o que dificulta seu fracionamento e quantificação. As hemiceluloses se unem às fibrilas de celulose e as 
interligam com a lignina, que pode ser considerada como um "cimento" celular, criando uma rede complexa de ligações que provê força estrutural. Consequentemente, nas diferentes etapas de análise, fragmentos de lignina permanecem unidos aos carboidratos, e mesmo celulose e hemiceluloses são dificilmente isoladas sem sofrer degradação e/ou mudanças nas propriedades moleculares (FENGEL; WEGENER, 1989).

\subsection{Celulose}

A celulose é o polissacarídeo mais abundante na natureza, uma vez que constitui a base estrutural das células das plantas.

Do ponto de vista químico, é um polímero de alta massa molecular composto exclusivamente de unidades $\beta$-D-glicopiranose arranjadas em um plano, unidas através de ligações do tipo $\beta$-1,4-glicosídicas (Figura 3). Sua formação se dá através da eliminação de uma molécula de água entre os grupos hidroxila presentes no C-1 e no C-4 de duas unidades de glicose adjacentes. Cada resíduo de glicose é rotacionado em $180^{\circ}$ em relação à glicose precedente na mesma cadeia, o que confere à celulose uma conformação linear e estendida. Portanto, é considerado como unidade repetitiva da celulose o dímero celobiose (FENGEL; WEGENER, 1989; MOORE; BOTHA, 2014).

Figura 3. Estrutura molecular da celulose.

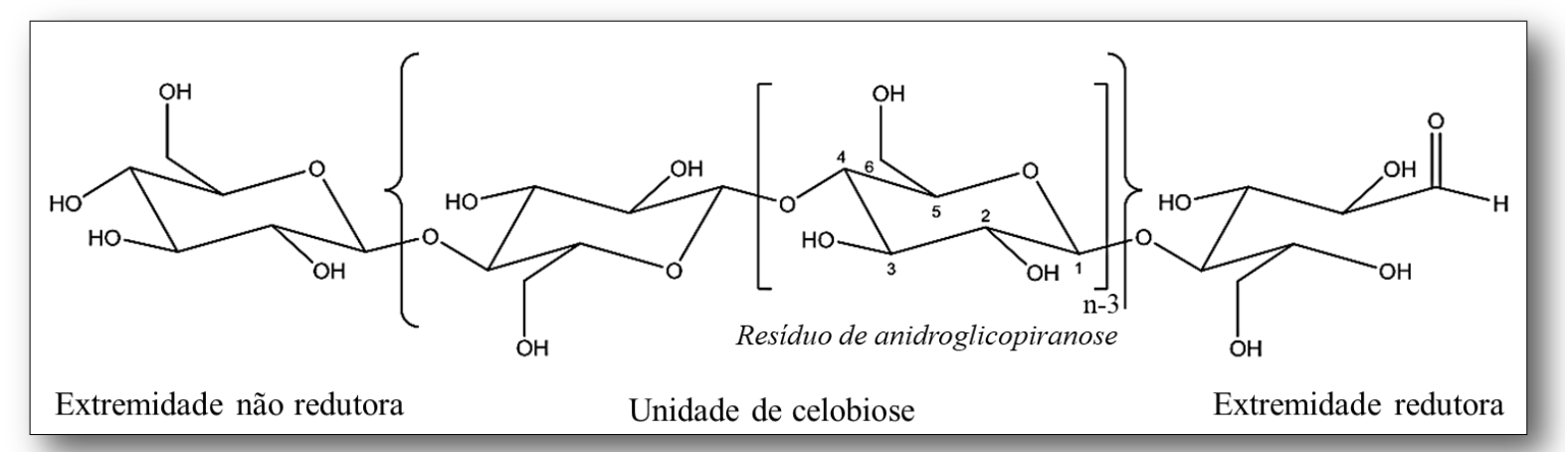

Fonte: Adaptado de: GURGEL, 2010.

A rotação dos resíduos de glicose e a conformação das cadeias permitem que os grupos hidroxilas presentes nas moléculas de celulose realizem interações de hidrogênio intramoleculares, entre unidades de glicose adjacentes, e intermoleculares, entre cadeias de celulose adjacentes. A rede de interações formada confere rigidez e promove o 
empacotamento das cadeias celulósicas em estruturas altamente ordenadas (FENGEL; WEGENER, 1989; MOON et al., 2011; MOORE; BOTHA, 2014). Deste modo, as interações de hidrogênios provêm às cadeias de celulose a tendência de formar arranjos periódicos, chamados cristais ou cristalitos, o que lhes proporciona estabilidade frente à degradação química e biológica (DRIEMEIER, 2017).

Os cristais de celulose podem existir em diferentes estruturas, chamadas de polimorfos. A celulose I é o tipo encontrado nos materiais que não sofreram qualquer transformação, ou seja, possui a configuração tal qual sintetizado na natureza (DRIEMEIER, 2017; FENGEL; WEGENER, 1989; MOORE; BOTHA, 2014). Por meio de tratamentos químicos, em condições ácidas, básicas e/ou térmicas, podem-se gerar os polimorfos II, III $_{\text {I }}$,

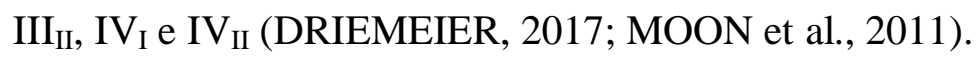

É proposto que a celulose I possua superfícies hidrofílicas e hidrofóbicas, que diferem de acordo com as interações com os componentes não celulósicos (hemiceluloses e lignina), assim como com cristais adjacentes de celulose (DRIEMEIER, 2017; MOORE; BOTHA, 2014). As faces hidrofílicas do cristal são determinadas pelos grupos hidroxila das pontas das cadeias celulósicas, enquanto as superfícies hidrofóbicas são determinadas pelas faces superior ou inferior dos anéis de glicose, as quais contribuem para a insolubilidade da celulose sob condições normais (Figura 4 (A)) (MOORE; BOTHA, 2014).

Figura 4. Seções transversais de (A) um cristal de celulose e (B) um agregado cristalino, onde os retângulos pretos representam as cadeias celulósicas e os círculos cinza representam polissacarídeos não cristalinos (hemiceluloses e celulose).

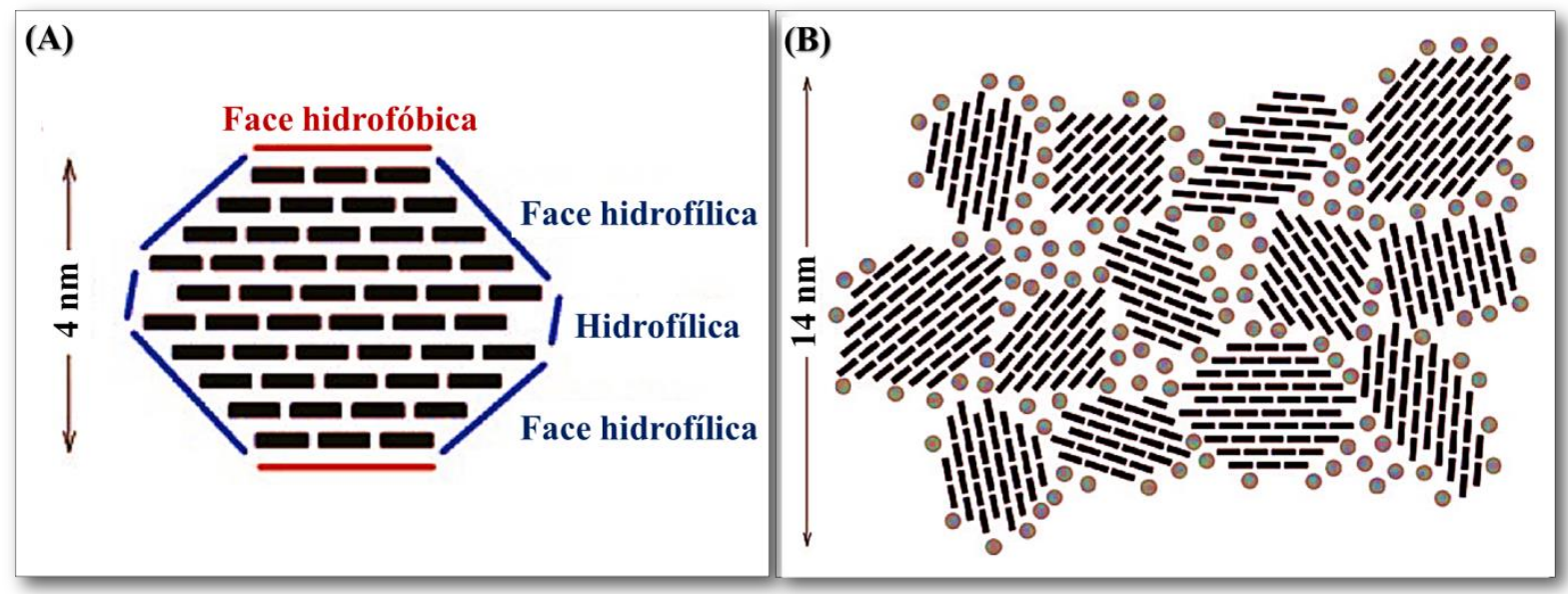

Fonte: Adaptado de: DRIEMEIER, 2017. 
Entretanto, a organização das cadeias de celulose não é uniforme ao longo de toda a estrutura, e parte dela pode ser encontrada como não cristalina ou, conforme descrito por alguns autores, como amorfa (FENGEL; WEGENER, 1989). Assim, uma medida de grau de cristalinidade indica a fração mássica de celulose cristalina em uma amostra (DRIEMEIER, 2017; MOORE; BOTHA, 2014).

\subsection{Hemiceluloses}

As hemiceluloses são polissacarídeos não celulósicos compostos de vários açúcares, como pentoses, hexoses, ácidos hexurônicos e desoxi-hexoses, cujas estruturas encontram-se reunidas na Figura 5 a seguir. As hemiceluloses diferem da celulose por serem compostas de unidades de diversos açúcares em cadeias curtas e, em alguns casos, ramificadas, enquanto a celulose é composta exclusivamente por unidades de celobiose (FENGEL; WEGENER, 1989). As principais diferenças entre estes dois carboidratos são listadas na Tabela 2 a seguir. Tanto a composição quanto a estrutura das hemiceluloses varia de acordo com a biomassa e com o tecido vegetal na qual se encontra presente.

Figura 5. Estrutura dos açúcares componentes das hemiceluloses.

Pentoses Aexoses

Fonte: Adaptado de: MARABEZI, 2014. 
A cadeia principal de hemiceluloses pode consistir de unidades de um único açúcar (homopolímero) ou de dois ou mais açúcares (heteropolímero). A xilana é um dos constituintes presentes em maior proporção no bagaço da cana-de-açúcar, sendo que a xilose contribui com aproximadamente $35 \%$ dos carboidratos da parede celular (DE SOUZA et al., 2013). Sua estrutura é composta de um esqueleto linear de resíduos de $\beta$-1,4-D-xilanopiranose ligados (FENGEL; WEGENER, 1989; MOORE; BOTHA, 2014).

Tabela 2. Principais diferenças entre as hemiceluloses e a celulose.

\begin{tabular}{|c|c|c|}
\hline Propriedade & Celulose & Hemiceluloses \\
\hline Unidade estrutural & Celobiose & 1 ou mais açúcares \\
\hline Ramificações & Não há & $\begin{array}{l}\text { Açúcares, ácidos orgânicos } \\
\text { e grupos fenólicos }\end{array}$ \\
\hline Grau de polimerização & Elevado & Baixo \\
\hline \multirow[t]{2}{*}{ Arranjo ultraestrutural } & $\begin{array}{l}\text { Regiões cristalinas e não } \\
\text { cristalinas }\end{array}$ & $\begin{array}{c}\text { Somente regiões não } \\
\text { cristalinas }\end{array}$ \\
\hline & Permite arranjo fibroso & Não forma arranjo fibroso \\
\hline \multirow[t]{2}{*}{ Reatividade } & $\begin{array}{l}\text { Hidrólise lenta em } \\
\text { condições ácidas diluídas }\end{array}$ & $\begin{array}{l}\text { Hidrólise rápida em } \\
\text { condições ácidas diluídas }\end{array}$ \\
\hline & Insolúvel em álcali & Solúvel em álcali \\
\hline
\end{tabular}

Fonte: Adaptado de: RABELO, 2010.

DE SOUZA et al. (2013), por meio de fracionamento dos carboidratos da parede celular, constataram que as xilanas das células do colmo da cana-de-açúcar podem estar presentes como cadeias não ramificadas, assim como acetiladas e/ou substituídas com monossacarídeos (cerca de $20 \%$ em massa). Desta forma, as cadeias de xilana podem conter, em intervalos irregulares, unidades arabinofuranose unidas por ligações $\alpha-(1 \rightarrow 3)$-glicosídicas aos resíduos de xilose, e muitos dos grupos hidroxilas presentes no C-2 e no C-3 das unidades xilanopiranosídicas se encontram acetilados. Ainda é possível a presença de unidades de ácido 4-O-metilglicurônico em ligações $\alpha$ - $(1 \rightarrow 2)$-glicosídicas com o esqueleto da xilana (FENGEL; WEGENER, 1989; MOORE; BOTHA, 2014). Um exemplo de estrutura de xilana em gramíneas é apresentado na Figura 6 a seguir. 
Os substituintes do tipo arabinose das cadeias de xilana podem ainda estar covalentemente ligados a resíduos de ácido ferúlico via reação de esterificação, formando um substituinte do tipo $\alpha$-L-arabinofuranosil (DE SOUZA et al., 2013; MOORE; BOTHA, 2014).

Figura 6. Possível estrutura molecular de xilana em gramíneas.

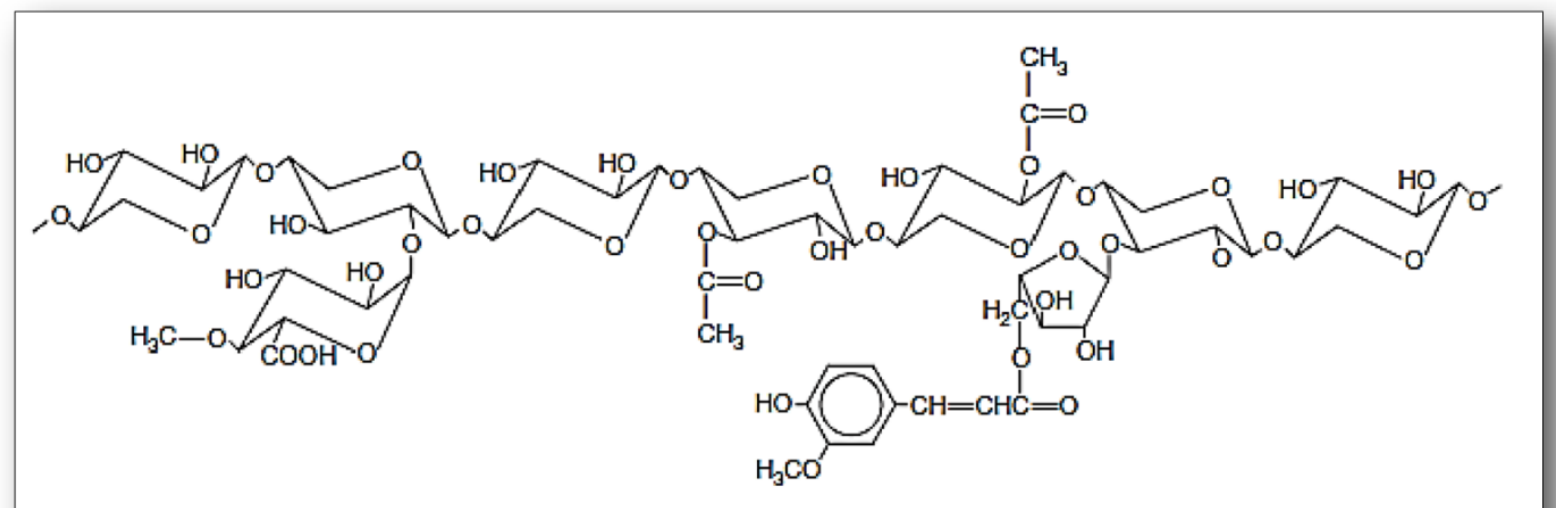

Fonte: Adaptado de: GURGEL, 2010.

\subsection{Lignina}

A lignina é uma macromolécula heterogênea, de natureza aromática e muito complexa, sintetizada principalmente no tecido esclerenquimático e no xilema. Sua formação está, portanto, relacionada à resistência mecânica dos vegetais, à impermeabilização das células condutoras de água, nutrientes e metabólitos, e à resistência a patogenias e ataques de insetos (FENGEL; WEGENER, 1989; MOORE; BOTHA, 2014). A lignina é também agente permanente de ligação entre as células, o que confere rigidez e sustentação ao colmo da planta (GHAFFAR; FAN, 2014).

Sua estrutura é baseada em unidades fenilpropânicas (unidades C-9) interligadas por meio da polimerização desidrogenativa dos álcoois p-cumarílico, coniferílico e sinapílico (Figura 7). Estes monolignóis levam à formação das três subunidades principais da lignina, nomeadas hidroxifenila $(\mathrm{H})$, guaiacila (G) e siringila (S) (DEL RÍO et al., 2012; FENGEL; WEGENER, 1989).

Assim como as hemiceluloses, tanto a composição quanto a estrutura da lignina varia de acordo com a espécie vegetal. Uma das principais diferenças da lignina presente nas gramíneas em relação às ligninas das madeiras é a presença em quantidades representativas da subunidade $\mathrm{H}$ além das subunidades $\mathrm{G}$ e $\mathrm{S}$, enquanto as madeiras das coníferas são ricas 
apenas em subunidades $\mathrm{G}$ e as madeiras das folhosas em subunidades $\mathrm{G}$ e $\mathrm{S}$ (GHAFFAR; FAN, 2014). A configuração da lignina é, portanto, determinada pela frequência das subunidades S/G/H, assim como sua reatividade (FENGEL; WEGENER, 1989).

Figura 7. Fórmula estrutural das unidades precursoras da lignina.

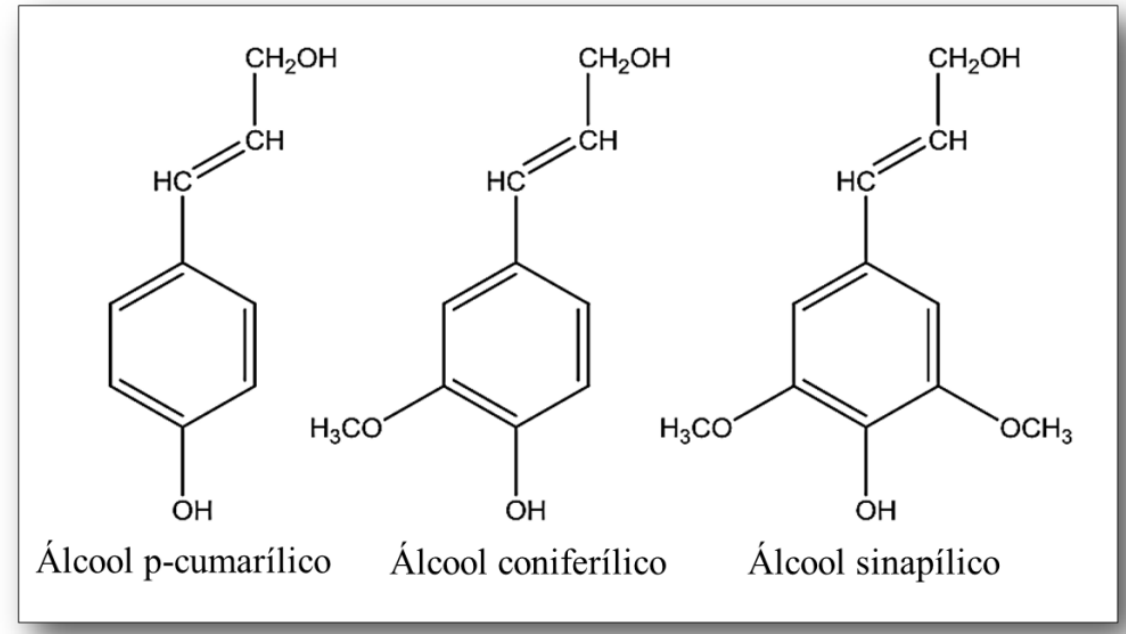

Fonte: Adaptado de: GURGEL, 2010.

Resíduos de ácidos fenólicos, principalmente, p-cumárico e ferúlico, podem ser encontrados ligados à estrutura da lignina por meio de ligações do tipo éster e éter, respectivamente. Conforme será detalhado posteriormente, é proposto que estes resíduos sejam encontrados na parede celular como agentes de interligação entre a lignina e os polissacarídeos (DEL RÍO et al., 2012; GHAFFAR; FAN, 2014).

Em suma, a molécula de lignina não pode ser descrita por uma simples combinação de poucas unidades monoméricas e/ou poucos tipos de ligação, como no caso da celulose e das hemiceluloses. Como consequência, a estrutura da lignina em diferentes fontes vegetais ainda é matéria de estudo, e modelos vêm sido propostos de forma a ilustrar os tipos e modos de ligação, assim como a proporção dos elementos estruturais (FENGEL; WEGENER, 1989; GHAFFAR; FAN, 2014). A Figura 8 apresenta as principais estruturas identificadas nas ligninas do capim elefante, gramínea pertencente à família Poaceae na qual a cana-de-açúcar também está inserida. 
Figura 8. Principais estruturas identificadas nas ligninas do capim elefante: $A=$ estruturas $\beta-\mathrm{O}-4$ '; $B$ $=$ fenilcumaranas formadas pelo acoplamento $\beta-5^{\prime} ; \mathrm{C}=$ resinóis formados pelo acoplamento $\beta-\beta$ '; $\mathrm{D}$ $=$ espirodienonas formadas pelo acoplamento $\beta-1$ '; $\mathrm{PCA}=$ unidades de $\mathrm{p}$-cumarato; $\mathrm{FA}=$ unidade de ferulato; I/I' = terminações dos álcoois $p$-hidroxicinamílicos; $\mathrm{H}=$ unidades $\mathrm{p}$-hidroxifenila; $\mathrm{G}=$ unidades guaiacila; $\mathrm{S}=$ unidades siringila.

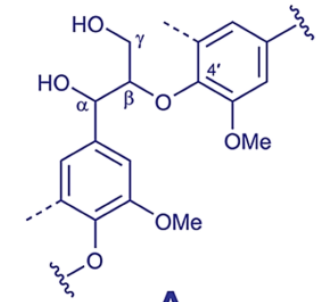

A

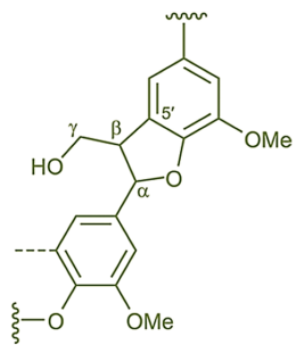

B

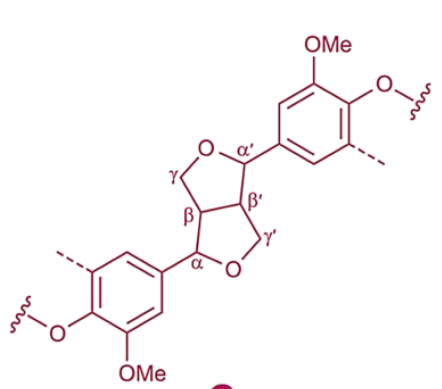

C

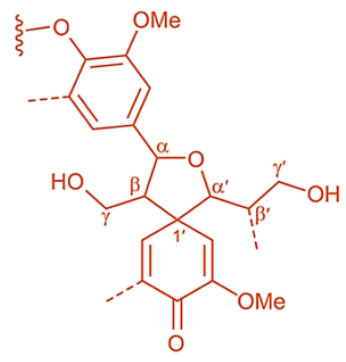

D

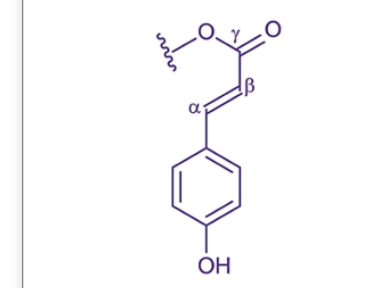

PCA

PCA<smiles>CCOc1ccc(/C=C/C(=O)O)cc1OC</smiles>

FA

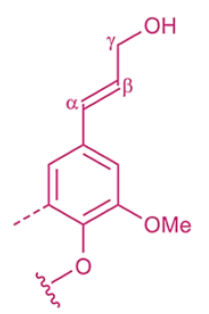

$\mathrm{I} / \mathrm{I}^{\prime}$

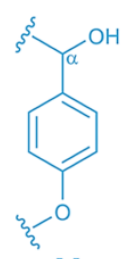

H

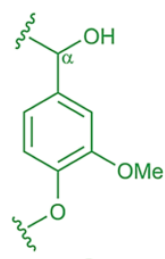

G

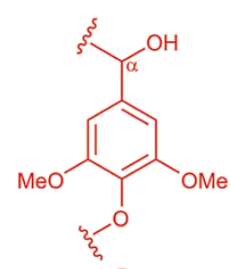

S

Fonte: Adaptado de: DEL RÍO et al., 2012.

\subsection{Extrativos e Cinzas}

As demais substâncias presentes no material lignocelulósico se referem a diferentes compostos químicos de baixa massa molar, divididos em material orgânico e inorgânico.

O material orgânico se refere a compostos que podem ser extraídos da matéria lignocelulósica pelo tratamento com solventes polares e apolares em estreitas faixas de temperatura. Os principais compostos orgânicos entre os extrativos são: compostos fenólicos (taninos), terpenos, ácidos graxos saturados e insaturados, proteínas e flavonoides.

Já o material inorgânico se refere a substâncias não passíveis de extração, determinadas como cinzas após a combustão da fração orgânica. Compreendem principalmente sais e óxidos de Ca, K, Mg, Mn e Na (FENGEL; WEGENER, 1989). 


\subsubsection{Ultraestrutura da parede celular}

A parede celular vegetal possui uma ultraestrutura complexa, onde os macrocomponentes se entrelaçam e interagem por meio de ligações covalentes e não covalentes, de forma a compor o alicerce estrutural das plantas (DE SOUZA et al., 2013).

As interações de hidrogênio formadas entre as hidroxilas das cadeias de celulose adjacentes permitem que este polímero cristalize em longos filamentos, cujo comprimento atinge vários micrômetros. Estes filamentos, usualmente nomeados de fibrilas elementares, constituem a base da nanoestrutura hierárquica dos materiais lignocelulósicos (DRIEMEIER, 2017; FENGEL; WEGENER, 1989). O número de cadeias de celulose em uma fibrila elementar pode variar de 18 a 36, o que lhe confere uma dimensão lateral de 2,4 a 3,4 nm (DRIEMEIER, 2017; DRIEMEIER; SANTOS; BUCKERIDGE, 2012).

$\mathrm{Na}$ parede celular, as fibrilas celulósicas agregam em estruturas fibrilares, cuja dimensão lateral pode variar entre 10-30 nm, portanto incluem vários cristais de celulose. (DRIEMEIER, 2017; MOON et al., 2011). A hierarquia nanoestrutural dos materiais lignocelulósicos é ilustrada na Figura 9 a seguir.

Figura 9. Possível esquema dos diferentes níveis hierárquicos da nanoestrutura dos materiais lignocelulósicos.

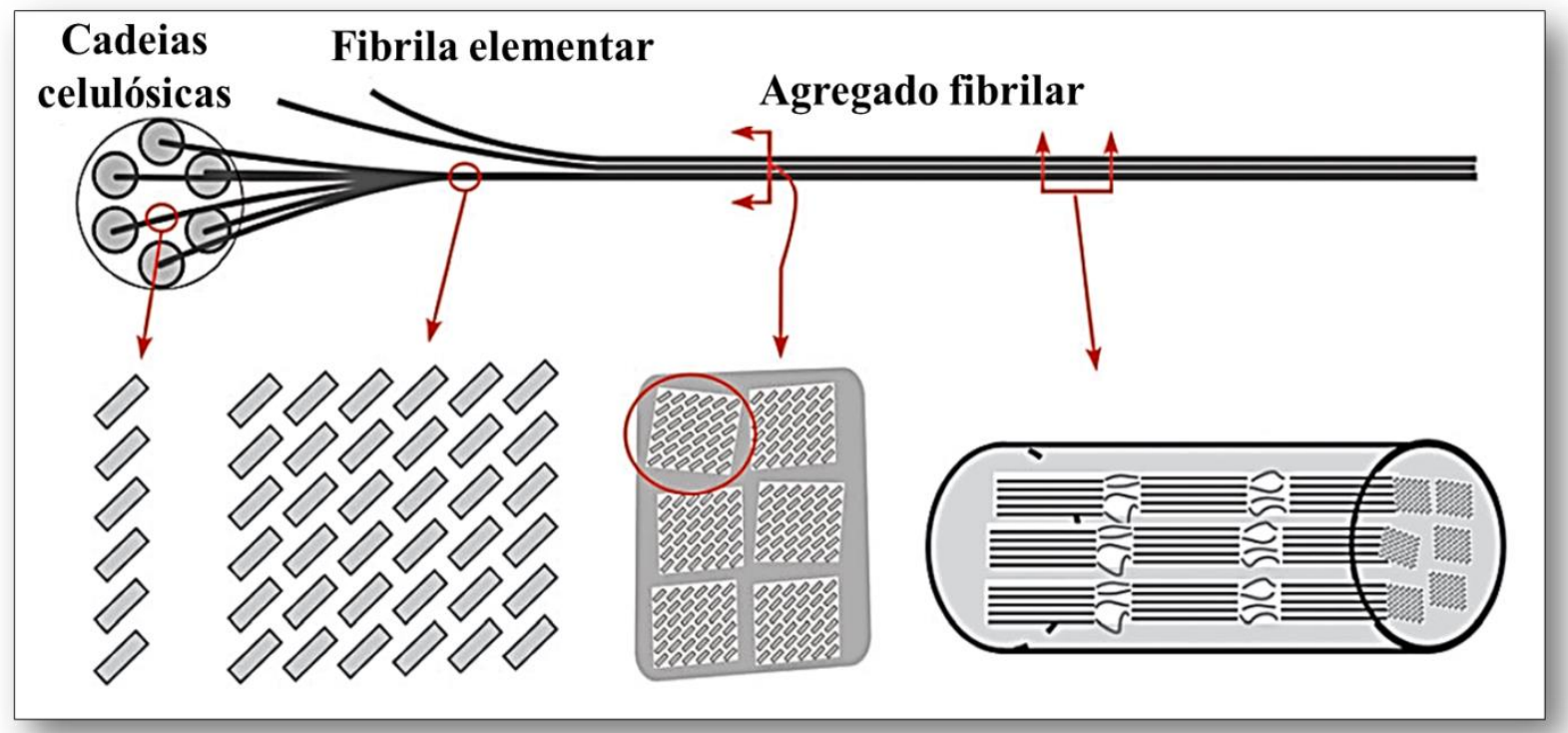

Fonte: Adaptado de: MOON et al., 2011. 
Diversos modelos de interação e associação entre os macrocomponentes da parede celular foram propostos. Em todos eles, as hemiceluloses aparecem como intermediárias entre as estruturas fibrilares e a lignina, formando uma rede de interações químicas e físicas que provêm à parede celular dos tecidos vegetais a resistência natural à desconstrução bioquímica, propriedade conhecida como recalcitrância (FENGEL; WEGENER, 1989).

As cadeias de hemiceluloses encontram-se dispostas em um arranjo paralelo em relação às fibrilas de celulose, interpenetrando as lacunas formadas dentro dos agregados fibrilares. Os tipos de interação formados entre estes polissacarídeos ainda não são bem esclarecidos; entretanto, nos diferentes estudos de processamento (fracionamento) físicoquímico da biomassa lignocelulósica, alguma quantidade residual de hemiceluloses é geralmente encontrada junto ao sólido celulósico, o que indica que ao menos uma fração deste polissacarídeo estabelece forte interação com a celulose (DE SOUZA et al., 2013; GAO et al., 2013; MESA et al, 2011; ROCHA et al., 2011; ROCHA et al., 2012; SANTUCCI et al., 2015; VALLEJOS et al., 2015).

Conforme mencionado anteriormente, nas células da cana-de-açúcar, os resíduos de arabinose ligados às xilanas podem estar covalentemente ligados a resíduos de ácido ferúlico via reação de esterificação, formando o substituinte $\alpha$-L-arabinofuranosil (DE SOUZA et al., 2013; MOORE; BOTHA, 2014). Este novo substituinte pode, por sua vez, reagir com monolignóis por meio de ligações do tipo éter, criando uma ponte lignina-ferulatopolissacarídeo. Do mesmo modo, a arabinose lateral também pode estabelecer ligação covalente com resíduos de ácido p-cumárico ou diretamente com a lignina (MOORE; BOTHA, 2014). Análises químicas e estruturais da parede celular indicam que os ácidos pcumárico e ferúlico são os principais agentes de interligação entre a lignina e os polissacarídeos (DE SOUZA et al., 2013; DEL RÍO et al., 2012; GHAFFAR; FAN, 2014).

Do ponto de vista morfológico, o crescimento das moléculas de lignina preenche os espaços entre os elementos fibrilares e os polissacarídeos pré-formados da parede celular (FENGEL; WEGENER, 1989; MOORE; BOTHA, 2014). Por conseguinte, as fibrilas de celulose encontram-se separadas umas das outras por uma camada de hemiceluloses, envoltas em uma matriz de lignina (FENGEL; WEGENER, 1989; MOORE; BOTHA, 2014; SANT'ANNA et al., 2013). 


\subsubsection{Arquitetura da parede celular}

$\mathrm{Na}$ formação da parede celular, as fibrilas elementares sintetizadas são depositadas em lamelas concêntricas, do exterior para o interior da célula. Sua morfologia é, portanto, caracterizada por camadas de diferentes texturas, cuja disposição e número variam de acordo com a biomassa de origem (DRIEMEIER, 2017; FENGEL; WEGENER, 1989). Dado que cada lamela possui dimensão lateral de 10-30 nm, é proposto que esta seja formada pelos agregados cristalinos (DRIEMEIER, 2017).

As primeiras lamelas depositadas formam a camada mais externa, a parede primária. Esta é seguida por camadas adicionais concêntricas, chamadas paredes secundárias, que são depositadas entre a parede primária e a membrana plasmática, conforme ilustrado na Figura 10 (A) (MOORE; BOTHA, 2014). A fina camada exterior às células, a lamela média, age como um adesivo que une as células vizinhas, evitando o seu deslocamento (MOORE; BOTHA, 2014; SANT'ANNA et al., 2013).

As diferentes paredes celulares formadas são distribuídas com diferenças em sua composição química, espessura, assim como na disposição e orientação dos macrocomponentes (MOORE; BOTHA, 2014). Enquanto a parede primária é fina e elástica, as paredes secundárias são espessas e rígidas (SANT'ANNA et al., 2013).

As paredes celulares secundárias são mais espessas nos tecidos que provêm resistência mecânica, como em células do xilema (traqueídes e elementos de vasos) e do esclerênquima (feixes de fibras). Estas células apresentam paredes secundárias caracteristicamente divididas em 3 subcamadas, S1, S2 e S3, com a subcamada S3 nem sempre evidente (MOORE; BOTHA, 2014; SANT’ANNA et al., 2013). Em alguns tecidos, a parede secundária pode ainda diferenciar-se em um número maior de camadas, distinguindo-se até a S8 ou mais (PARAMESWARAN; LIESE, 1976).

Em estudo publicado por SANT'ANNA e colaboradores (2013), constatou-se que nas células do colmo da cana-de-açúcar a subcamada S2 é a mais espessa (500-600 nm), seguida pela S3 (300-400 nm), e por último a S1 (200-300 nm) (Figura 10 (B)). Tem-se, portanto, que cada parede é formada por centenas de agregados cristalinos (DRIEMEIER, 2017). Uma visão geral da arquitetura da parede celular vegetal é ilustrada na Figura 11 a seguir. 
Figura 10. Parede celular da cana-de-açúcar, mostrando (A) as diferentes camadas (ML = lamela média, $\mathrm{PCW}=$ parede primária, $\mathrm{SCW}$ = parede secundária); e (B) detalhe da diferenciação das subcamadas secundárias.
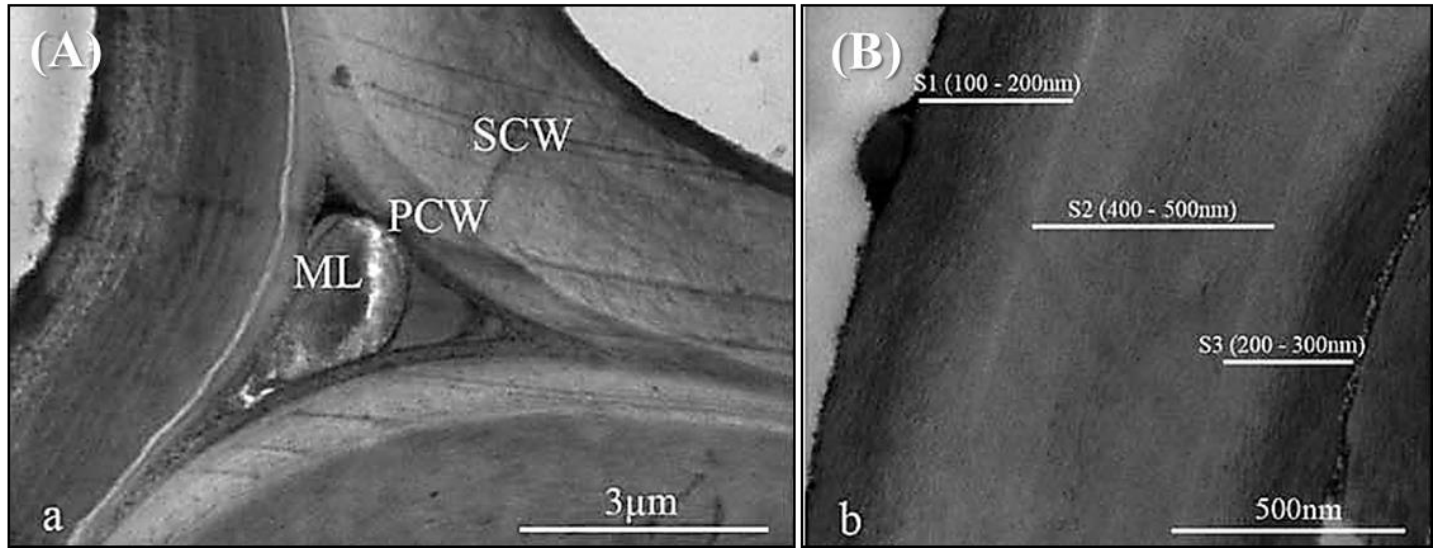

Fonte: Adaptado de: SANT'ANNA et al., 2013.

Figura 11. Arquitetura da parede celular das células vegetais.

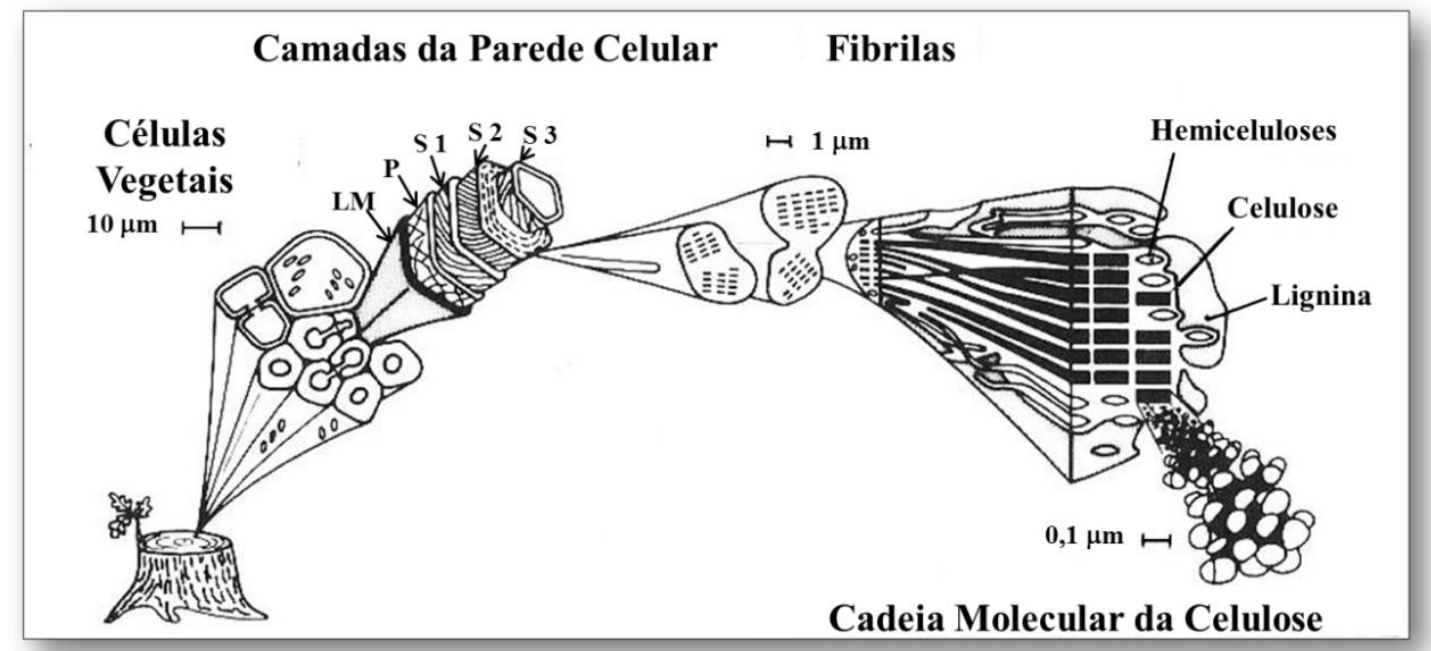

Fonte: Adaptado de: HOFFMANN; JONES, 1989.

Os espaços nanométricos interfibrilares e interlamelares, delimitados pela rede de polissacarídeos formada previamente, são denominado poros (ou nanoporos). É nos poros nanométricos que ocorre a deposição da lignina sintetizada na última fase de diferenciação na construção da parede celular (DRIEMEIER, 2017; FENGEL; WEGENER, 1989). Os nanoporos podem também ser preenchidos por moléculas de água, que estabelecem interações de hidrogênio com os sítios hidrofílicos disponíveis na superfície (monocamada) da celulose. Deste modo, tanto a estrutura cristalina da celulose quanto a ultraestrutura e arquitetura da parede celular afetam a hidratação das fibras (DRIEMEIER; MENDES; OLIVEIRA, 2012). 


\subsubsection{A biorrefinaria da cana-de-açúcar e os desafios do etanol celulósico}

A produção eficiente de biocombustíveis é vista como o principal fator promotor de uma futura refinaria de biomassas lignocelulósicas, devido particularmente às demandas do setor de transporte, que culminam em uma maior robustez de mercado, além da facilidade de entrega por meio de uma logística bem estabelecida neste último século. Entretanto, é reconhecido que não há apenas uma solução para a instalação efetiva dessas "bio-indústrias", mas sim o estudo de um conjunto de processos que levem a uma obtenção efetiva de vários produtos (CHERUBINI, 2010; SANTOS et al., 2016). Tendo isto em vista, institutos de pesquisa ao redor do mundo pesquisam as oportunidades ao redor das biomassas locais, e exploram o seu máximo potencial para que haja uma substituição gradual das matérias-primas de fonte fóssil na produção industrial não só de consumos energéticos (eletricidade, calor ou combustíveis) como de não energéticos (blocos químicos e materiais avançados). Além disso, espera-se que a produção de materiais de maior valor agregado dê suporte técnico e econômico à produção das commodities de alto volume em um complexo de manufaturas integradas (CHERUBINI, 2010).

Dentre as diversas possibilidades de biorrefinarias, a escolha mais adequada deve considerar a localização regional, a disponibilidade e a fonte de matéria-prima, além dos produtos finais de interesse do mercado local. Os dois últimos requisitos definirão as tecnologias empregadas, de forma a ter a maior eficiência industrial (CHERUBINI, 2010; KAJASTE, 2014; WERPY; PETERSEN, 2004). Neste ponto, cabe destacar a principal desvantagem das biomassas lignocelulósicas: uma maior diversidade de tecnologias de processamento é necessária para alcançar os produtos desejados, sendo que muitas ainda encontram-se na fase pré-comercial (KAJASTE, 2014).

A emergente biorrefinaria que tem sido descrita com maior frequência gira ao redor da produção do etanol combustível da cana-de-açúcar. Dentro desta indústria há duas rotas de interesse: a de $1^{\mathrm{a}}$ geração e a de $2^{\mathrm{a}}$ geração. As indústrias de primeira geração são as usinas atualmente instaladas e em operação, baseadas na extração e fermentação do caldo rico em sacarose (reserva energética da planta), que possuem e ainda possuirão considerável valor econômico. Entretanto, o seu potencial para alcançar as demandas do setor de transportes é limitado, principalmente pelo fato de sua expansão competir diretamente por área agriculturável com lavouras alimentícias, além de a redução das emissões de GEE por área 
plantada não corresponderem às metas planejadas. Por conseguinte, sua expansão é fortemente contestada por acarretar problemas de ordem social, política e ambiental (CHERUBINI, 2010; MOORE; BOTHA, 2014; PUTRO et al., 2016).

Um novo momento para a indústria canavieira é esperado, posto que nítidos esforços têm sido aplicados acerca da comercialização do etanol celulósico, ou de segunda geração. Este combustível, no entanto, é baseado nos subprodutos da indústria de primeira geração, ou seja, é produzido a partir dos elementos estruturais da planta. Logo, sua execução não compete com a indústria alimentícia, além de não haver custos com a produção da matériaprima (RABELO et al., 2011). Contudo, grande parte das publicações concordam quanto à implementação de uma indústria com a coprodução integrada, de forma que haja uma melhor performance da cadeia produtiva do etanol pelo benefício de toda a constituição do bagaço e pela redução do uso de fontes fósseis no suprimento energético (DIAS et al., 2012; FERNANDO et al., 2006; LASER et al., 2009; RABELO et al., 2011; SANTOS et al., 2016). O próprio etanol é, por sua vez, importante bloco químico, a partir do qual é possível a síntese de uma série de compostos, como o etileno, o ácido acético, o acetato etílico, o acetaldeído e o butadieno (CHERUBINI, 2010; LIGUORI; FARACO, 2016; WEUSTHUIS; AARTS; SANDERS, 2011). Um possível modelo de uma refinaria integrada da cana-de-açúcar é exemplificado na Figura 12 a seguir.

A principal vantagem da produção do etanol de primeira geração é que o açúcar utilizado na etapa de fermentação encontra-se disponível e em alta concentração na biomassa in natura; portanto, sua conversão é facilmente alcançada. Distintivamente, na biomassa lignocelulósica as principais fontes de açúcares fermentescíveis apresentam-se em estruturas poliméricas - celulose e hemiceluloses, logo não estão prontamente acessíveis para a conversão no processo fermentativo. Isto porque os microrganismos utilizados na fermentação alcóolica são capazes de metabolizar mono ou dissacarídeos como fonte de carbono e energia, porém não estão aptos a utilizar os carboidratos na forma polimérica. Os microrganismos mais conhecidos e comumente aplicados em nível industrial, Saccharomyces cerevisiae e Escherichia coli, são incapazes até mesmo de consumir pequenos oligossacarídeos (CHEN; DOU, 2016). Isto posto, tem-se que a primeira implicação do uso da biomassa lignocelulósica como matéria-prima para a obtenção de etanol e outras plataformas é a necessidade da prévia desconstrução da matriz lignina-carboidratos, e a subsequente despolimerização dos polissacarídeos em açúcares monoméricos (CARDONA; QUINTERO; PAZ, 2010). 
Figura 12. Possíveis rotas dentro de uma biorrefinaria da cana-de-açúcar.

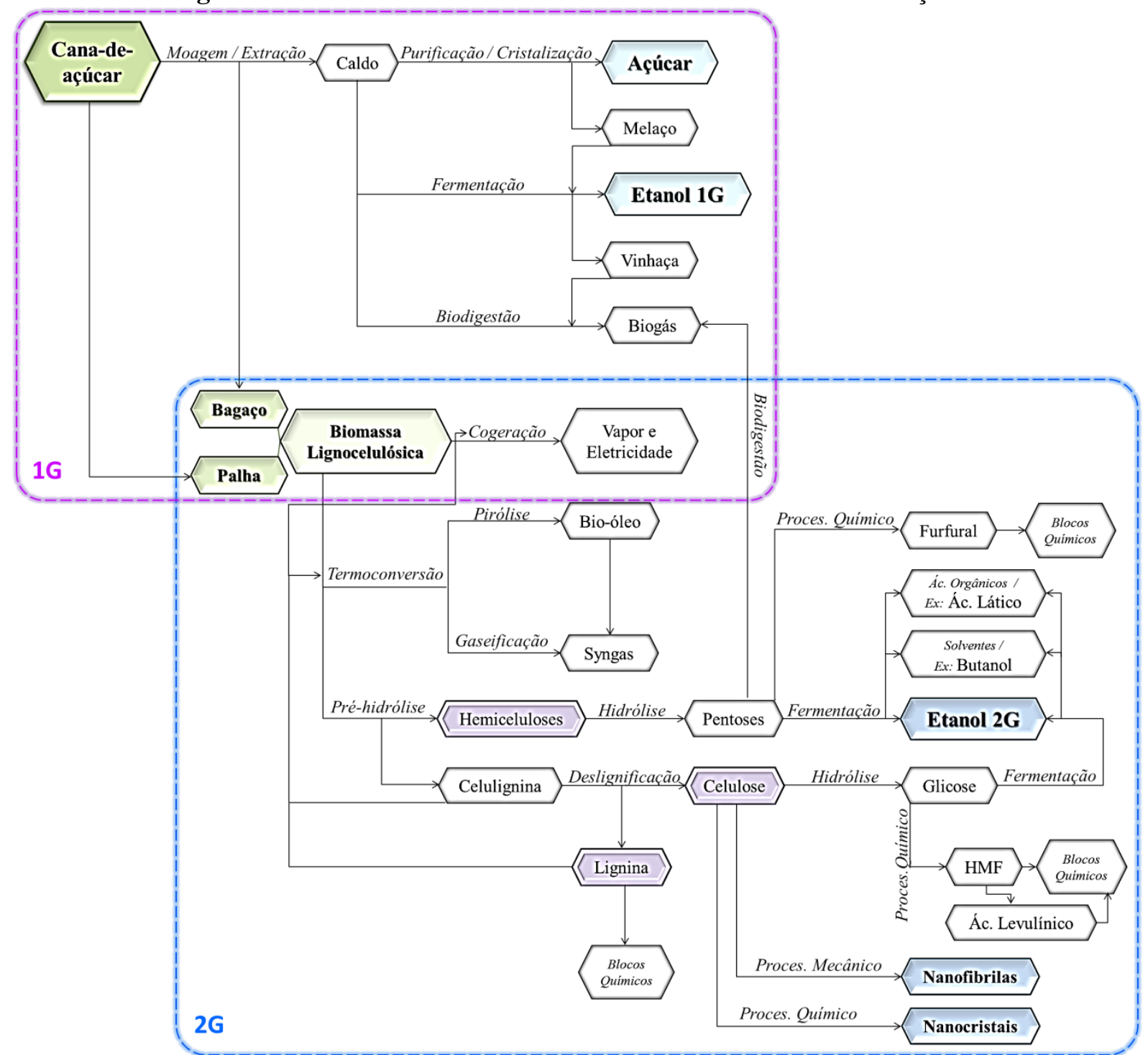

Fonte: Adaptado de: CHERUBINI; JUNGMEIER, 2010; DIAS et al., 2012; FERNANDO et al., 2006; SANTOS et al., 2016.

Com base nos pontos aqui explanados, a rota tecnológica para a conversão dos polissacarídeos da parede celular em açúcares fermentescíveis inclui alguns aspectos principais: 1) desestruturação da matriz lignocelulósica e consequente fracionamento dos macrocomponentes; 2) despolimerização da celulose e das hemiceluloses; 3) fermentação dos açúcares monoméricos formados; 4) recuperação e uso econômico da lignina residual; 5) integração de processos de forma a minimizar a demanda energética; e 6) recuperação e purificação do(s) produto(s) (etanol e outros) (ALVIRA et al., 2010; CANILHA et al., 2012; CARDONA; QUINTERO; PAZ, 2010; GALBE; ZACCHI, 2007; HAHN-HÄGERDAL et al., 2006; HENDRIKS; ZEEMAN, 2009; JÄGER; BÜCHS, 2012). 
Os açúcares obtidos após hidrólise da celulose e das hemiceluloses são fermentados, em etapas independentes, e convertidos a etanol (ou, no caso das pentoses, em outro bloco químico de interesse). A conversão dos polissacarídeos em açúcares monoméricos pode ser realizada tanto por catálise química, geralmente em condições ácidas (RINALDI; SCHÜTH, 2009), quanto por catálise enzimática (MENON; RAO, 2012; YANG et al., 2011).

A hidrólise ácida do material lignocelulósico pode ser realizada com o uso de ácidos concentrados a baixas temperaturas (CHOI; MATHEWS, 1996), ou de ácidos diluídos a elevadas temperaturas (GURGEL, 2010; KIM; LEE; TORGET, 2001; ZHAO; ZHOU; LIU, 2012). Dentre os ácidos mais utilizados estão o sulfúrico, o clorídrico e o fluorídrico (RINALDI; SCHÜTH, 2009). Os processos ácidos concentrados tendem a ser mais efetivos, e produzem elevados rendimentos de hidrólise em curtos tempos de reação. Porém, as grandes quantidades de ácido empregadas requerem sua recuperação industrial, cuja operação infere maiores custos, além do uso de reatores apropriados para que não ocorram problemas associados com a corrosão do equipamento (GURGEL, 2010; JÄGER; BÜCHS, 2012). Em comparação com o processo concentrado, a hidrólise ácida diluída é mais favorável do ponto de vista econômico pelo baixo consumo de ácido, que não requer sua recuperação e não exige reatores específicos. Todavia, o desenvolvimento deste processo em escala industrial não se demonstrou vantajoso até o momento. Ademais, o método diluído exige altas temperaturas e pressões para alcançar taxas de conversão aceitáveis (GURGEL, 2010).

Um dos entraves da hidrólise ácida é a incidência de reações de desidratação, que causam a decomposição dos açúcares hidrolisados e, consequentemente, reduzem a concentração do produto final. Isto ocorre principalmente com a fração de hemiceluloses, que é hidrolisada mais rapidamente que a celulose; logo, os monossacarídeos liberados são expostos no meio reacional por um longo tempo, o que leva a degradação e perda destes açucares (GURGEL, 2010; JÄGER; BÜCHS, 2012). Estes compostos de degradação atuam como inibidores da ação dos microrganismos fermentativos, sendo eles divididos em: ácidos carboxílicos, que compreendem o ácido fórmico, o ácido levulínico e o ácido acético; derivados furânicos, sendo estes o furfural (2-furaldeído), formado a partir das pentoses, e o HMF (5-hidroximetil-2-furaldeído), formado a partir das hexoses; e fenólicos provindos da hidrólise, oxidação e solubilização da lignina (FENGEL; WEGENER, 1989; GURGEL, 2010; JÄGER; BÜCHS, 2012; JÖNSSON; ALRIKSSON; NILVEBRANT, 2013; KO et al., 2015b). 
Na sacarificação enzimática, a hidrólise das cadeias de polissacarídeos é catalisada por enzimas específicas, denominadas enzimas celulolíticas ou celulases. Apesar do alto custo dos complexos enzimáticos comerciais, este método bioquímico é considerado a forma mais atrativa e promissora de conversão dos carboidratos devido à sua alta seletividade e especificidade, que resulta em altos rendimentos de açúcares monoméricos. Além disso, não há perda de substrato por alguma subsequente reação de degradação e, portanto, não há a formação de compostos inibidores dos microrganismos de fermentação. Em comparação aos métodos ácidos, apresenta ainda as vantagens de não demandar o uso de equipamentos anticorrosivos, ser de baixo consumo energético e não exigir posteriores etapas de tratamentos de efluentes, uma vez que atua em condições brandas de reação sem a necessidade da adição de reagentes químicos (ADSUL et al., 2011; CANILHA et al., 2012; CARDONA; QUINTERO; PAZ, 2010; GALBE; ZACCHI, 2007; HAHN-HÄGERDAL et al., 2006; JÄGER; BÜCHS, 2012; LIGUORI; FARACO, 2016; PRASAD; SINGH; JOSHI, 2007).

Com base nos argumentos apresentados, a rota enzimática é a mais aplicada atualmente nas tentativas laboratoriais e industriais de obtenção do etanol celulósico, apesar de ainda ser economicamente desfavorável. Comparada com outras reações catalisadas por enzimas, a produtividade volumétrica da conversão celulósica é limitada por uma baixa taxa inerente de digestão do material lignocelulósico, o que implica em tempos muito mais longos de reação (entre 24 e 72 horas) para atingir concentrações razoáveis de açúcares (ANDRIC' et al., 2010a; CARDONA; QUINTERO; PAZ, 2010; LIGUORI; FARACO, 2016). Conforme introduzido anteriormente (item 2.2.2.2), isto ocorre devido à complexidade ultraestrutural dos materiais lignocelulósicos, onde os macrocomponentes encontram-se intimamente associados por interações físicas e químicas, e à natureza parcialmente cristalina do substrato celulósico; estas propriedades constituem uma barreira física à penetração de agentes hidrolíticos nas fibras e inferem uma resistência natural dos substratos lignocelulósicos à digestibilidade enzimática (ALVIRA et al., 2010; CARDONA; QUINTERO; PAZ, 2010; DE SOUZA et al., 2013; GALBE; ZACCHI, 2007; SUN et al., 2016). Com tal característica, o desenvolvimento de uma tecnologia eficiente para a conversão da biomassa em etanol celulósico demanda a superação da recalcitrância intrínseca da parede celular (ADSUL et al., 2011; PUTRO et al., 2016). De antemão, registra-se que os principais fatores que afetam a acessibilidade enzimática aos polissacarídeos da parede celular (em especial à celulose) serão abordados em tópico posterior (item 2.2.5). 
Deste modo, a necessidade do fracionamento da biomassa é reforçada. A prévia desconstrução da matriz lignocelulósica pode ser realizada por métodos de diferentes naturezas, chamados de pré-tratamentos, pelos quais os polissacarídeos tornam-se acessíveis à ação das enzimas hidrolíticas. Esta abertura estrutural pode ocorrer pela solubilização (em etapas separadas ou combinadas) das hemiceluloses e da lignina, com a recuperação do sólido celulósico, pelo aumento da área superficial das fibras ou mesmo pela delaminação das camadas da parede celular (ADSUL et al., 2011; CHEN; DOU, 2016; MENON; RAO, 2012; PUTRO et al., 2016; RABEMANOLONTSOA; SAKA, 2016; SUN et al., 2016). Há inúmeras estratégias de pré-tratamentos baseadas em processos mecânicos, químicos, físico-químicos ou bioquímicos, cujos modos de ação serão detalhados no item 2.2.6.

Nota-se que muitos grupos de pesquisa do setor colocaram como foco o aumento do rendimento de sacarificação da biomassa lignocelulósica, investigando tanto as diferentes tecnologias de pré-tratamento quanto as possibilidades de complexos enzimáticos celulolíticos, de forma a prover toda a informação científica necessária para o desenvolvimento da tecnologia de segunda geração (ADSUL et al., 2011; AMORE et al., 2016; ANDRIC' et al., 2010a; CHEN et al., 2017; MENON; RAO, 2012; PUTRO et al., 2016; RABEMANOLONTSOA; SAKA, 2016; SUN et al., 2016; ZHAO; ZHANG; LIU, 2012). Contudo, os avanços obtidos ainda não permitiram uma produção eficaz a baixo custo, e as poucas plantas industriais instaladas encontram sérios problemas de operação, a ponto deste produto ainda não ser comerciável.

Como exemplos, no Brasil foram instaladas duas plantas de operação: a Bioflex (São Miguel dos Campos - AL), pertencente à empresa GranBio, com capacidade de produção de 82 milhões de litros de etanol por ano; e a planta industrial da empresa Raízen (Piracicaba SP), com capacidade de produzir cerca de 40 milhões de litros de etanol por ano. Ambas iniciaram suas atividades no segundo semestre de 2014, porém já cessaram inúmeras vezes (MARIANO, 2016). As empresas apontam a etapa de pré-tratamento como principal vilã da não concretização das metas publicadas. De fato o pré-tratamento é tido como uma das etapas de maior custo, porém menos madura dentro do processo (RABELO et al., 2011). Entretanto, pesquisadores relacionam a baixa efetividade desta etapa ao fato de que os processos e a engenharia até agora apresentados não se adequaram à realidade de cada biomassa, o que dificulta a transposição para a escala industrial (CHERUBINI; STRØMMAN, 2011; KAJASTE, 2014; MARIANO, 2016; MOORE; BOTHA, 2014). 
Esforços ainda são e continuarão sendo feitos com o intuito de tornar viável industrialmente a etapa de pré-tratamento, de modo que ela ainda permita gerar correntes de processo com características adequadas para a obtenção de compostos de interesse econômico (CHERUBINI, 2010; PUTRO et al., 2016; RABELO et al., 2011). Deve-se, porém, tomar como lição a experiência de indústrias bem estabelecidas, como a de papel e celulose, que conseguiu entender e lidar com a estrutura morfológica do bagaço de cana-de-açúcar para a produção de commodities, e ainda garantir a biorrefinaria do processo (GCE PAPÉIS; NOVO, 2016; RAINEY; COVEY, 2016; TAGUCHI, 2011).

\subsubsection{Hidrólise enzimática da biomassa lignocelulósica}

A hidrólise ou sacarificação enzimática do substrato lignocelulósico é a reação de despolimerização dos polissacarídeos da parede celular em açúcares redutores fermentescíveis, catalisada por enzimas específicas pertencentes ao grupo das $O$-glicosil hidrolases (AMORE et al., 2016; ANDERSEN, 2007; PRASAD; SINGH; JOSHI, 2007).

$\mathrm{Na}$ natureza a biomassa vegetal é degradada pela ação sinérgica de várias enzimas produzidas por microrganismos. O aprendizado deste sistema serviu como guia para o processo de sacarificação desenvolvido, que visa mimetizar a desconstrução natural, porém a uma maior taxa de reação (ADSUL et al., 2011; CHEN; DOU, 2016; YANG et al., 2011). Deste modo, enzimas hidrolíticas são extraídas de microrganismos e isoladas, e então recombinadas de múltiplas formas para obter a mistura enzimática que proverá o melhor desempenho, ou seja, o maior rendimento de açúcares monoméricos por tempo (RABEMANOLONTSOA; SAKA, 2016). Dentre estas enzimas enfatiza-se a ação das celulases, responsáveis pela digestão das cadeias celulósicas.

Apesar das vantagens apontadas anteriormente em relação ao processo ácido (item 2.2.3), a hidrólise catalisada enzimaticamente depende de condições otimizadas para sua eficiência máxima, como temperatura, $\mathrm{pH}$, balanço de atividades para o sinergismo, carga enzimática e concentração de substrato. Ademais, diversos fatores dependentes tanto do comportamento das enzimas hidrolíticas no meio reacional quanto das restrições estruturais da biomassa acarretam em uma baixa atividade catalítica e, portanto, em uma menor produtividade volumétrica de açúcares monoméricos (CANILHA et al., 2012; YANG et al., 2011). Entre os fatores relacionados às enzimas hidrolíticas, podem-se citar: a atividade por 
fonte microbiana, a inibição pelos produtos finais, a inativação térmica, a atividade específica e a tendência a ligações não específicas (YANG et al., 2011).

Como forma de aumentar a taxa de reação enzimática, e assim viabilizar sua comercialização dentro de uma biorrefinaria de materiais lignocelulósicos, pesquisas têm sido focadas na otimização do processo de hidrólise, na engenharia de reatores e na formulação de coquetéis celulolíticos com maiores eficiências catalíticas e termoestabilidade (ANDRIC' et al., 2010a; ANDRIC' et al., 2010b; MENON; RAO, 2012; ZHANG; ZHANG, 2013). Entretanto, as melhoras na performance das celulases alcançadas até o momento têm sido incrementais, e nenhum aumento representativo da atividade sobre o complexo substrato lignocelulósico foi de fato reportado. Sugere-se, portanto, que progressos adicionais no desempenho das celulases exigem uma melhor compreensão não só mecanismo catalítico e de atuação sobre as fibrilas celulósicas, como da interação destas proteínas hidrolíticas com toda a ultraestrutura da parede celular vegetal (MENON; RAO, 2012; ZHANG; ZHANG, 2013).

\subsubsection{Hidrolases glicosídicas: características e classificações}

As enzimas $O$-glicosil hidrolases (EC 3.2.1.-), ou hidrolases glicosídicas, são as principais enzimas envolvidas na conversão dos polissacarídeos constituintes dos substratos lignocelulósicos em açúcares redutores (AMORE et al., 2016; ANDERSEN, 2007; PRASAD; SINGH; JOSHI, 2007). Como o próprio nome sugere, são enzimas que catalisam a reação de hidrólise das ligações glicosídicas entre dois grupos sacarídeos ou entre um carboidrato e uma porção que não é carboidrato (ANDERSEN, 2007; YANG et al., 2011; ZHANG; ZHANG, 2013). Em geral, todas as enzimas celulolíticas pertencem às $O$-glicosil hidrolases (ANDERSEN, 2007).

Uma grande variedade de fungos e bactérias produzem enzimas celulolíticas e hemicelulolíticas capazes de hidrolisar os carboidratos poliméricos da parede celular vegetal em seus componentes monoméricos (CANILHA et al., 2012; MENON; RAO, 2012; RABEMANOLONTSOA; SAKA, 2016; YANG et al., 2011). Estes microrganismos podem ser aeróbicos ou anaeróbicos, mesofílicos ou termofílicos (PRASAD; SINGH; JOSHI, 2007; RABEMANOLONTSOA; SAKA, 2016). Entre as bactérias mencionam-se as pertencentes aos gêneros Clostridium, Cellulomonas, Bacillus, Thermomonospora, Ruminococcus, Bacteriodes, Erwinia, Acetovibrio, Microbispora, e Streptomyces. Entretanto, o maior número 
de pesquisas é voltado para a produção de celulases fúngicas. Estas são obtidas a partir de gêneros como Trichoderma, Aspergillus, Schizophyllum e Penicillium (CANILHA et al., 2012; PRASAD; SINGH; JOSHI, 2007; ZHANG; ZHANG, 2013).

Em princípio, deve-se ressaltar que a adsorção das enzimas hidrolíticas no substrato celulósico é o principal pré-requisito para que a reação de sacarificação ocorra (ANDRIC' et al., 2010a). Deste modo, muitas das hidrolases glicosídicas, tanto fúngicas quanto bacterianas, são enzimas modulares, ou seja, são compostas de unidades de estrutura e funcionalidade discretas cujas dobras são independentes, conhecidas como domínios ou módulos. Em geral, consistem de um domínio catalítico e um ou mais domínios não catalíticos, sendo o de maior importância o módulo de ligação ao carboidrato. Estes módulos encontram-se conectados por pontes polipeptídicas, sendo estas longas (30-44 aminoácidos) e flexíveis articulações que facilitam a operação eficiente e as funções independentes de ambos os domínios (Figura 13) (AMORE et al., 2016; ANDERSEN, 2007; BAYER et al., 1998; COUGHLAN, 1992; DAVIES; HENRISSAT, 1995; JÄGER; BÜCHS, 2012; YANG et al., 2011).

O domínio catalítico (Catalytic Domain, CD) possui a clara função de sítio ativo, ou seja, é o responsável por catalisar a reação de hidrólise das ligações glicosídicas em si (JÄGER; BÜCHS, 2012; MENON; RAO, 2012; YANG et al., 2011). A atividade celulolítica do domínio catalítico é influenciada pelos módulos acessórios, que podem suplementar ou modificar todas as propriedades da enzima (BAYER et al., 1998).

O domínio de ligação à celulose (Cellulose-Binding Domain, CBD - ou Carbohydrate-Binding Module, CBM) tem por função mediar o contato físico das enzimas com o substrato celulósico insolúvel e aumentar a capacidade de ligação do CD. Estes módulos não catalíticos adsorvem nos sítios acessíveis das fibrilas celulósicas, e permitem que o módulo catalítico se mantenha alinhado com o substrato para estabelecer uma alta concentração local de enzimas na superfície da celulose (função de proximidade) . Como consequência, o CBM também auxilia a transferência de fase da enzima da fração solúvel para a fração insolúvel, e implica na ruptura do substrato com maior eficiência. As enzimas que não possuem o $\mathrm{CBM}$, mas apenas o $\mathrm{CD}$, ainda apresentam a habilidade de adsorver na superfície da celulose, porém com menor afinidade quando comparadas com as enzimas “completas" (ANDERSEN, 2007; ANDRIC' et al., 2010a; ARANTES; SADDLER, 2010; JÄGER; BÜCHS, 2012; MENON; RAO, 2012; YANG et al., 2011; ZHANG; LYND, 2004). 
Figura 13. Representação da composição modular de uma enzima O-glicosil hidrolase.

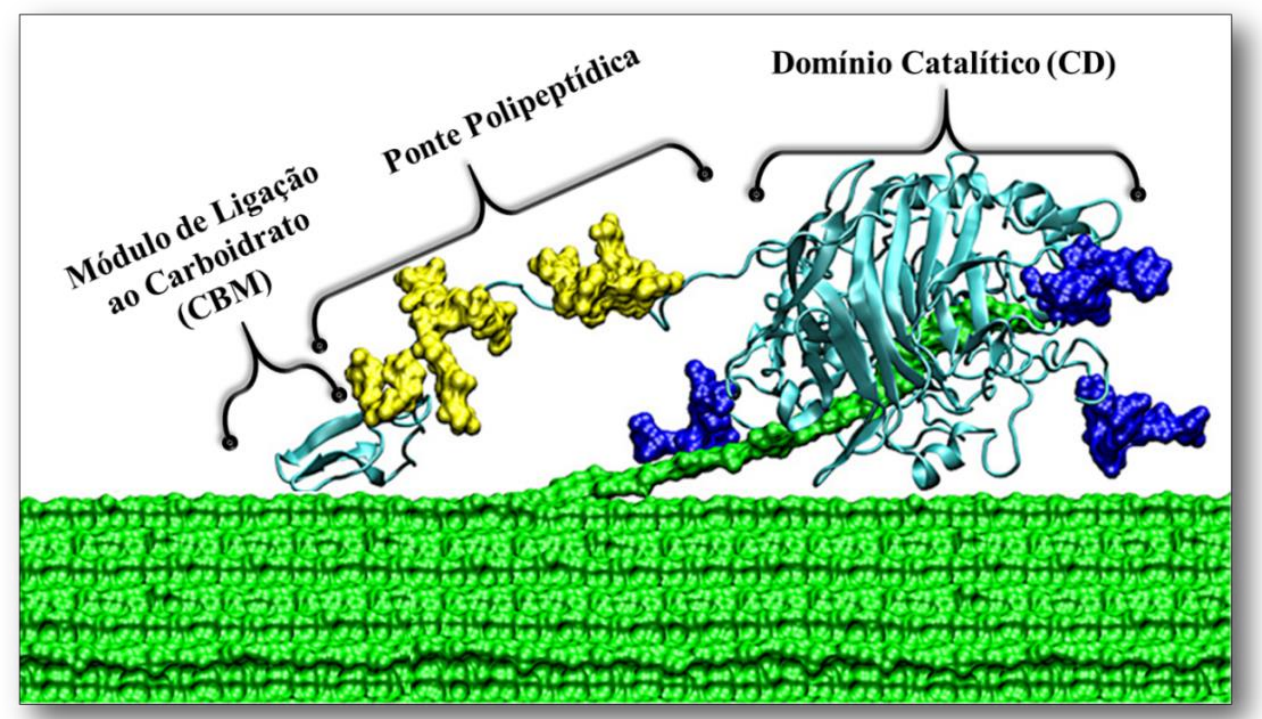

Fonte: Adaptado de: NREL, 2017.

Ademais, o CBM desempenha um papel mais ativo na despolimerização da celulose pela desagregação da estrutura fibrilar, ou seja, através da liberação não hidrolítica das cadeias celulósicas individuais alocadas nas regiões altamente ordenadas e firmemente empacotadas das fibrilas (ARANTES; SADDLER, 2010; BAYER et al., 1998; COUGHLAN, 1992). Isto pode ocorrer tanto pela ruptura das forças associativas não covalentes intra- e interfibrilares quanto pela alimentação das cadeias recentemente expostas através do módulo catalítico de hidrólise (ARANTES; SADDLER, 2010; BAYER et al., 1998).

Basicamente, há três modos de classificação das $O$-glicosil hidrolases, baseadas: 1) na estereoespecificidade do mecanismo de reação; 2) na especificidade a regiões do substrato; ou 3) nas similaridades estruturais da proteína (ANDERSEN, 2007; BAYER et al., 1998).

\subsection{Classificação mecanística}

As enzimas $O$-glicosil hidrolases clivam as ligações glicosídicas via catálise ácidobase segundo um mecanismo de substituição nucleofílica bimolecular (SN2), onde o ataque do nucleófilo no átomo de carbono anomérico é a etapa determinante, e que ocorre simultaneamente à saída do grupo abandonador. (ANDERSEN, 2007; BAYER et al., 1998; BHAUMIK; DHEPE, 2016; DAVIES; HENRISSAT, 1995; GLOSTER; DAVIES, 2010; KOSHLAND JR, 1953; SAHARAY; GUO; SMITH, 2010; WITHERS; WILLIAMS, 2017; ZECHEL; WITHERS, 2000; ZHANG; ZHANG, 2013). 
Assim como em qualquer reação de substituição nucleofílica enzimática, a hidrólise dos polissacarídeos se dá de maneira estereoespecífica (KOSHLAND JR, 1953; VOCADLO; DAVIES, 2008). Dois tipos de mecanismo catalítico são mais comumente encontrados nas reações enzimáticas: inversor ou retentor da configuração estereoquímica do centro anomérico (hemiacetal), conforme descrito pela primeira vez por KOSHLAND em 1953 (BAYER et al., 1998; DAVIES; HENRISSAT, 1995; GLOSTER; DAVIES, 2010; VOCADLO; DAVIES, 2008; WITHERS; WILLIAMS, 2017; ZECHEL; WITHERS, 2000).

A substituição ocorre no átomo de carbono anomérico C-1 da glicose, que culmina na clivagem da ligação com o oxigênio glicosídico. Nesta reação, o resíduo ácido atrai o par de elétrons não compartilhado do grupo abandonador, enfraquecendo a ligação C-1---O-4. Concomitantemente, o grupo doador de elétrons se aproxima por trás, e forma uma ligação com o átomo C-1. Deste modo, uma única substituição culmina na formação de um produto com configuração invertida em relação ao substrato inicial (KOSHLAND JR, 1953).

\subsection{Especificidade ao substrato}

Apesar das hidrolases glicosídicas atuarem em uma gama de substratos com diferentes características, as enzimas individuais apresentam uma determinada especificidade relacionada com sua função (GLOSTER; DAVIES, 2010). A especificidade com relação ao substrato celulósico se refere à afinidade da enzima pelo interior ou por umas das extremidades da cadeia de celulose, ou ainda por pequenos celo-oligômeros solúveis (ANDERSEN, 2007; WITHERS; WILLIAMS, 2017). Neste sentido, ao menos três classes majoritárias de enzimas estão envolvidas no processo de hidrólise da fração celulósica:

1) As endoglicanases, ou endo- $\beta$-1,4-glicanases (EG, E.C. 3.2.1.4), hidrolisam randomicamente as ligações $\beta$-1,4-glicosídicas internas da cadeia celulósica, e atuam principalmente nas regiões de baixa cristalinidade das fibras celulósicas;

2) As exoglicanases, ou exo- $\beta-1,4$-glicanases ou celobiohidrolases $(\mathrm{CBH}$, E.C. 3.2.1.91), fragmentam a cadeia celulósica pela dissociação sequencial de unidades de celobiose a partir das extremidades livres, e podem degradar tanto as regiões altamente cristalinas da celulose quanto as menos ordenadas;

3) As celobiases, ou $\beta$-glicosidases (BG, E.C. 3.2.1.21), hidrolisam as unidades de celobiose e, em alguns casos, pequenos celo-oligossacarídeos solúveis (grau de polimerização 
- DP - entre 1 e 6) em unidades de glicose (AMORE et al., 2016; ARANTES; GOURLAY; SADDLER, 2014; CANILHA et al., 2012; JÄGER; BÜCHS, 2012; KOBAYASHI; FUKUOKA, 2013; MENON; RAO, 2012; PRASAD; SINGH; JOSHI, 2007; RABEMANOLONTSOA; SAKA, 2016; VAN ZYL et al., 2011; WALKER; WILSON, 1991; ZHANG; ZHANG, 2013). As BG não são consideradas enzimas celulases, visto que hidrolisam apenas pequenos oligossacarídeos e, portanto, não atuam diretamente na celulose.

A eficiência da sacarificação da celulose depende da ação sinérgica entre as três classes enzimáticas, além do balanço apropriado de cada uma, que poderá variar entre as diferentes espécies de microrganismos que as produzem (ANDERSEN, 2007). Cada uma destas três categorias consiste de várias enzimas, o que aumenta a complexidade do sistema (WALKER; WILSON, 1991).

Em geral, exo e endoglicanases estão presentes como constituintes majoritários nas celulases fúngicas. Entretanto, a suplementação com $\beta$-glicosidase é necessária para reduzir os efeitos inibitórios causados pela celobiose formada no meio reacional, tanto nas EG quanto nas CBH (WALKER; WILSON, 1991). A inibição pelos produtos da reação diminui a taxa de conversão global do substrato lignocelulósico em glicose, fator particularmente proeminente durante reações com altos teores de sólidos (ANDRIC' et al., 2010a).

As enzimas celulolíticas ainda possuem a habilidade de reagir sobre uma variedade de substratos com similaridades estruturais à celulose. Os sistemas de enzimas ativos na celulose também apresentam atividade sobre as hemiceluloses, e as enzimas especificamente ativas nas hemiceluloses apresentam, em alguns casos, alguma atividade sobre a celulose (ANDERSEN, 2007; LYND et al., 2002).

\subsubsection{Atuação do complexo celulolítico}

A sacarificação enzimática da celulose é uma reação multi-passos que ocorre em meio heterogêneo, na qual o substrato insolúvel é hidrolisado em ambiente aquoso pela ação sinérgica das enzimas endoglicanases, celobiohidrolases e $\beta$-glicosidases (ANDRIC' et al., 2010a; ARANTES; SADDLER, 2010; KOBAYASHI; FUKUOKA, 2013; YANG et al., 2011). A mecânica pela qual esta "mistura" hidrolítica desconstrói a celulose é matéria de estudo há mais de 6 décadas, e compreende alterações em seus 3 níveis estruturais: cadeias poliméricas, agregados fibrilares e célula vegetal (REESE, 1956). 
Dentre as várias etapas envolvidas na reação podem-se listar: 1) transferência das enzimas da fase aquosa para a superfície das partículas celulósicas (fibras); 2) adsorção das enzimas e formação dos complexos enzima-substrato; 3) hidrólise da celulose insolúvel na interface sólido-líquido pela ação das EG e das $\mathrm{CBH}$; 4) transferência dos intermediários solúveis (celobiose e pequenos oligossacarídeos) da superfície das partículas celulósicas para a fase líquida; 5) hidrólise da celobiose e dos celo-oligômeros em glicose pela ação das BG; e, por fim, 6) dessorção das hidrolases (ANDRIC' et al., 2010a; ARANTES; SADDLER, 2010; KOBAYASHI; FUKUOKA, 2013; PRASAD; SINGH; JOSHI, 2007; WALKER; WILSON, 1991; YANG et al., 2011).

Os modelos atuais para a sacarificação celulósica foram elaborados a partir do conceito sugerido por REESE, SIU e LEVINSON (1950). Estes consideram que a reação decorre em três momentos de hidrólise, que ocorrem simultaneamente e são essenciais para explicar a digestão completa do substrato celulósico. Além da hidrólise primária (etapa 3), ou de formação dos intermediários solúveis, e da hidrólise secundária (etapa 5), ou de quebra destes intermediários, é proposto que haja a prévia ruptura estrutural da fibra, caracterizada por mudanças químicas e físicas na organização celulósica em fase sólida (ARANTES; SADDLER, 2010; BHAUMIK; DHEPE, 2016; GOURLAY; ARANTES; SADDLER, 2012; REESE, 1956; ZHANG; LYND, 2004).

Conforme estabelecido anteriormente, a base para que a reação ocorra é que a enzima esteja em contato com o substrato celulósico, o que leva à formação de um complexo enzimasubstrato antes de o produto final ser liberado; logo, a etapa 2 é considerada crítica para o processo (ANDRIC' et al., 2010a; WALKER; WILSON, 1991). Porém, para que as hidrolases possam acessar e adsorver na superfície da celulose insolúvel, e posteriormente quebrar as ligações glicosídicas dentro das cadeias, elas devem primeiramente ser capazes de difundir através da matriz densa e heterogênea das fibras lignocelulósicas. Por conseguinte, a adsorção é fortemente influenciada pelos parâmetros estruturais das fibras lignocelulósicas (GOURLAY; ARANTES; SADDLER, 2012; WALKER; WILSON, 1991). Como resultado, o grau de polimerização da celulose decai bastante devagar com relação aos métodos de hidrólise ácida (REESE, 1956).

Em estudo publicado por ARANTES, GOURLAY e SADDLER (2014) observou-se que, durante a hidrólise enzimática de materiais lignocelulósicos de diferentes composições químicas (teores de cada macrocomponente), houve uma rápida e substancial fragmentação 
das fibras nos estágios iniciais da reação (1 - 3h); porém, a nítida mudança morfológica não esteve relacionada a uma alta taxa de formação de açúcares solúveis. Ademais, as fibras dos materiais alcançaram dimensões finais similares em 6h, período a partir do qual não houve mais alterações físicas visíveis, apesar da maior porcentagem de produto (açúcares redutores) ser formada durante o período de 6 - 72h. Verificações similares foram efetuadas por GOURLAY et al. (2015), que associaram a rápida redução inicial do comprimento médio ao corte das fibras de maneira predominante nas regiões de desordem das fibrilas celulósicas (deslocamentos), aparentemente mais acessíveis às enzimas hidrolíticas. Estas constatações puderam ser relacionadas independentes da metodologia aplicada e das condições de prétratamento utilizadas (ARANTES; GOURLAY; SADDLER, 2014; GOURLAY et al., 2015).

Visto que a porção amorfa dentro dos deslocamentos é a mais acessível, a celulose hidrolisada nos estágios finais da reação usualmente apresenta um maior grau de cristalinidade do que a celulose presente nos estágios iniciais. Alguns autores ainda afirmam que a degradação da porção cristalina é mais lenta do que das partes amorfas, o que provoca a variação da velocidade da reação catalítica ao longo do tempo (ANDRIC' et al., 2010a; ARANTES; SADDLER, 2010; GOURLAY et al., 2015; ZHANG; LYND, 2004). No mesmo estudo publicado por GOURLAY e colaboradores (2015) observou-se, entretanto, que durante os primeiros 5 minutos da reação enzimática o grau de cristalinidade das fibras lignocelulósicas aumentou em pequena extensão, e se manteve constante durante o resto da hidrólise. Estes dados se relacionam com a interpretação de que há uma quantidade de celulose amorfa altamente acessível na superfície das fibras celulósicas, que é rapidamente hidrolisada nos primeiros minutos de reação; após este período, e a remoção da porção amorfa, o grau de cristalinidade da amostra não mais altera. Isto indica que, nos demais estágios da reação enzimática, tanto as regiões cristalinas quanto as amorfas são hidrolisadas simultaneamente, o que é consistente com o modelo de fragmentação das fibras apresentado anteriormente, onde a hidrólise ocorre de "camada por camada" (GOURLAY et al., 2015).

As mudanças químicas na celulose residual podem se manifestar como variações no grau de polimerização (Degree of Polimerization, DP) e na concentração de pontas redutoras: as endoglicanases aumentam a concentração de extremidades e reduzem significantemente o DP pelo ataque nas regiões internas das cadeias; já as exoglicanases diminuem o DP de modo incremental e apenas ocasionalmente diminuem a concentração de pontas redutoras. Logo, a atividade das EG é a principal responsável pelas mudanças químicas na fase sólida da 
celulose que ocorrem ao longo do curso da hidrólise, mas exerce influência minoritária na solubilização em relação às CBH (ZHANG; LYND, 2004).

Uma vez compreendido o mecanismo pelo qual a hidrólise enzimática procede, é reconhecido que este é essencialmente impedido pela organização ultraestrutural e pela recalcitrância da biomassa lignocelulósica, que determinam suas propriedades físicas. Em outras palavras, a acessibilidade à celulose é o principal fator limitante da hidrólise. Novamente, a área superficial total disponível para o contato físico entre as hidrolases e o substrato determina a adsorção e, portanto, reflete na taxa e no rendimento de sacarificação.

Para atingir a digestão efetiva da biomassa lignocelulósica, um coquetel enzimático deve conter enzimas acessórias como hemicelulases, monooxigenases e outras proteínas não hidrolíticas e não oxidativas, que facilitam a degradação dos carboidratos pela abertura da matriz lignocelulósica e são naturalmente secretadas por microrganismos desconstrutores (GOURLAY et al., 2015; GOURLAY; ARANTES; SADDLER, 2012; HU et al., 2015a). Entretanto, os coquetéis disponíveis comercialmente não são suplementados com tais, ou ainda são de custo muito elevado para a aplicação em escala industrial, o que torna o processo de pré-tratamento essencial para a posterior ação das enzimas hidrolíticas. O pré-tratamento atua promovendo a desestruturação das fibras por meio de modificações químicas e/ou físicas.

\subsubsection{Inibição por produto}

Uma característica da reação de hidrólise enzimática da celulose é que ao longo do curso da reação há o declínio pronunciado da taxa de conversão observada, até mesmo em baixos graus de solubilização de massa (GRUNO et al., 2004). Os sistemas celulolíticos mais aplicados, que incluem as amplamente estudadas enzimas de Trichoderma reesei, são significantemente inibidos pelos principais produtos da hidrólise, glicose e celobiose. Entretanto, todas as espécies produtoras de enzimas, tanto livres quanto adsorvidas ou complexadas, estão sujeitas à inibição (HOLTZAPPLE et al., 1990). A inibição por produto diminui a eficiência da reação catalisada enzimaticamente e, portanto, limita o rendimento de produto (ANDRIC' et al., 2010a; BHAUMIK; DHEPE, 2016; GRUNO et al., 2004; HOLTZAPPLE et al., 1990; PRASAD; SINGH; JOSHI, 2007).

A molécula de celobiose é altamente inibidora das enzimas hidrolíticas, ao mesmo passo que é inutilizável para a maioria dos microrganismos fermentativos. O papel das 
celobiases é hidrolisar a celobiose em monômeros de glicose, que apresenta menor potencial de inibição e é altamente fermentescível. Entretanto, tanto a glicose quanto a celobiose e os celo-oligossacarídeos, formados ao longo da reação, podem se alocar próximo ao sítio ativo das celulases, visto que suas estruturas fundamentais são similares à da celulose; destarte, formam um impedimento estérico ao alcance do $\mathrm{CD}$ da enzima pelas cadeias poliméricas (HOLTZAPPLE et al., 1990; SUN et al., 2016).

A celobiose, produto da ação das celobiohidrolases e, parcialmente, das endoglicanases, inibe diretamente ambas as enzimas; já a glicose inibe diretamente a ação das $\beta$-glicosidases, das CBH e das EG. Além disso, a inibição das BG pela glicose pode resultar no acúmulo de celobiose e provocar uma inibição indireta. Os celo-oligômeros e a celulose, mesmo sendo substratos, também podem exercer alguma inibição nas CBH e nas EG, assim como nas BG (ANDRIC' et al., 2010a).

A importância da inibição por produto é particularmente proeminente durante processos realizados a altas cargas de substrato, notadamente porque a concentração de produto aumentará no meio líquido. As reações enzimáticas das biomassas (ligno)celulósicas apresentam ainda a particularidade de o substrato inicial ser insolúvel, logo a adição de uma maior quantidade de substrato não diminui a competição pelo ataque enzimático como o inibidor (ANDRIC' et al., 2010a). No caso de limitações na difusão, uma fração muito pequena de proteína está de fato envolvida no complexo enzima-substrato, mesmo em altas concentrações de celulose. Tem-se, portanto, que a celulose é um competidor pobre pelo sítio ativo em relação às moléculas de rápida difusão, de forma que toda a enzima presente no meio pode se ligar efetivamente aos inibidores (HOLTZAPPLE et al., 1990).

HOLTZAPPLE e colaboradores, em estudo publicado em 1990, verificaram que a constante de ligação das celulases de Trichoderma reesei à celobiose é cerca de 6 vezes maior do que à glicose, o que indica que estas enzimas são mais significantemente inibidas pelo dímero do que pelo monômero. Deste modo, as celobiases desempenham importante papel no sistema enzimático como forma de reduzir o teor do principal inibidor. Com o intuito de reduzir a inibição por produto durante a sacarificação enzimática da celulose, diferentes abordagens são aplicadas além da suplementação do coquetel enzimático com $\beta$-glicosidases. Estas incluem o aumento da carga enzimática aplicada, a extração contínua dos açúcares formados com o tempo, e a fermentação simultânea dos açúcares em solução (CANILHA et al., 2012; PRASAD; SINGH; JOSHI, 2007). 


\subsubsection{Fatores estruturais do substrato lignocelulósico que influenciam a efetividade da hidrólise enzimática}

Conforme descrito anteriormente (item 2.2.4.2), para que a reação de hidrólise enzimática dos polissacarídeos da parede celular ocorra é necessário o contato físico direto entre as proteínas hidrolíticas e o substrato. Por consequência, a difusão das celulases através da estrutura da parede celular e sua subsequente adsorção na superfície das fibrilas celulósicas são passos primordiais para o início da reação catalítica. Uma vez que a penetração das enzimas é limitada pelo seu acesso, é reconhecido que a adsorção é essencialmente influenciada pelas propriedades estruturais das fibras lignocelulósicas em seus 3 níveis de organização: ultraestrutural, arquitetônica e morfológica (ANDERSEN, 2007; ARANTES; SADDLER, 2010; ARANTES; SADDLER, 2011; CHANG; HOLTZAPPLE, 2000; GOURLAY; ARANTES; SADDLER, 2012; HAHN-HÄGERDAL et al., 2006; JIANG et al., 2016; KHULLAR et al., 2013; LEU; ZHU, 2013; MOONEY et al., 1998; SUN et al., 2016; WALKER; WILSON, 1991; WIMAN et al., 2012; XU et al., 2016; YANG et al., 2011; ZHANG; LYND, 2004).

Ademais, a formação dos agregados fibrilares pela estrutura cristalina e altamente ordenada da celulose, juntamente com sua incorporação na matriz em associação com os demais macrocomponentes (lignina e hemiceluloses), formam uma estrutura firmemente empacotada que restringe a acessibilidade dos agentes hidrolíticos à porção celulósica e provê à parede celular dos tecidos vegetais resistência ao processo de sacarificação enzimática (ARANTES; SADDLER, 2010; WANG et al., 2014; YANG et al., 2011). Na maior parte dos casos, a taxa da reação de hidrólise enzimática dos polissacarídeos de uma biomassa lignocelulósica nativa é lenta, e sua extensão não excede $20 \%$ de solubilização da celulose original presente, o que implica em baixas produtividades volumétricas da conversão celulósica (ZHANG; LYND, 2004).

A elucidação e a quantificação da influência dos diferentes parâmetros estruturais do substrato tanto na taxa quanto na extensão da hidrólise enzimática dos polissacarídeos das fibras lignocelulósicas é de extrema importância, posto que fornece um guia para a modificação das características das biomassas de forma a melhorar as estratégias de avanço desta etapa do processo (FAN; LEE; BEARDMORE, 1980; HUANG et al., 2010; MENON; RAO, 2012; SINITSYN; GUSAKOV; VLASENKO, 1991; YANG et al., 2011; ZHANG; 
LYND, 2004). Com o intuito de investigar quais os aspectos fundamentais da estrutura da biomassa que afetam a acessibilidade da celulose às enzimas hidrolíticas, estudos recentes avaliaram os efeitos de diferentes tipos de processamento da biomassa no rendimento de açúcares redutores obtidos, e confrontaram com as alterações provocadas nas características do substrato. Entretanto, há ainda considerável divergência na literatura considerando a importância relativa de cada um destes fatores, e mesmo o modo como limitam a conversão enzimática não é bem compreendido (ARANTES; SADDLER, 2010; HAHN-HÄGERDAL et al., 2006; HUANG et al., 2010; LAUREANO-PEREZ et al., 2006; LEU; ZHU, 2013; WIMAN et al., 2012; YANG et al., 2011).

Entre os parâmetros que determinam a susceptibilidade dos materiais celulósicos à degradação enzimática estão:

1) Fatores inerentes da estrutura da fibra lignocelulósica: área superficial específica, descrita tanto pela estrutura capilar (tamanho e volume de poros) quanto pela morfologia (dimensões) das partículas;

2) Composição química: teor, natureza e distribuição dos componentes não celulósicos (lignina e hemiceluloses), interações entre os 3 macrocomponentes, grau de acetilação das cadeias hemicelulósicas e adsorção não produtiva das enzimas na lignina;

3) Fatores específicos da celulose: grau de cristalinidade e grau de polimerização das cadeias celulósicas (ALVIRA et al., 2010; ANDERSEN, 2007; ARANTES; SADDLER, 2010; ARANTES; SADDLER, 2011; BARAKAT; DE VRIES; ROUAU, 2013; CHANG; HOLTZAPPLE, 2000; FAN; LEE; BEARDMORE, 1980; GALBE; ZACCHI, 2007; HAHNHÄGERDAL et al., 2006; HENDRIKS; ZEEMAN, 2009; HU et al., 2015b; JIANG et al., 2016; KHULLAR et al., 2013; LEU; ZHU, 2013; MENON; RAO, 2012; MOONEY et al., 1998; PRASAD; SINGH; JOSHI, 2007; RABEMANOLONTSOA; SAKA, 2016; SINITSYN; GUSAKOV; VLASENKO, 1991; SUN et al., 2016; WALKER; WILSON, 1991; WANG et al., 2014; WIMAN et al., 2012; XU et al., 2016; YANG et al., 2011; ZHANG; LYND, 2004; ZHAO; ZHANG; LIU, 2012).

Todas essas propriedades dependem da espécie e do tecido vegetal no qual a célula se encontra, assim como dos tipos de processamento aos quais esta foi submetida (ALVIRA et al., 2010; BARAKAT; DE VRIES; ROUAU, 2013; MENON; RAO, 2012; PRASAD; SINGH; JOSHI, 2007; SUN et al., 2016; ZHANG; LYND, 2004). 
De modo geral, a dificuldade em interpretar a influência de cada um dos parâmetros estruturais isoladamente na efetividade da ação hidrolítica enzimática se dá pelo fato destes aspectos estarem inter-relacionados, além de que os métodos de processamento da biomassa alteram mais de uma propriedade ao mesmo tempo, o que gera uma grande variabilidade quanto aos resultados e interpretações (ALVIRA et al., 2010; ANDERSEN, 2007; SINITSYN; GUSAKOV; VLASENKO, 1991; WALKER; WILSON, 1991; XU et al., 2016; ZHANG; LYND, 2004). Além disso, a amplitude de técnicas desenvolvidas e utilizadas para analisar cada um destes parâmetros leva a diferentes conclusões. Outro motivo da complexidade de se extrair informações é a mudança nas características estruturais das fibras durante o curso da reação de hidrólise (WALKER; WILSON, 1991). ARANTES e SADDLER (2011) apontam ainda outros entraves nos estudos a respeito da caracterização da importância dos parâmetros estruturais na hidrólise enzimática, como o emprego de cargas enzimáticas relativamente altas, que pode mascarar qualquer diferença que poderia ser observada nas características do substrato, o uso de métodos de caracterização que requerem a secagem das amostras, e o estudo com apenas um número pequeno de amostras ou mesmo com modelos celulósicos puros, que não são indicativos do comportamento real das biomassas lignocelulósicas altamente heterogêneas.

Nesta seção serão introduzidos alguns dos principais efeitos que os fatores relacionados aos substratos exercem na etapa de hidrólise, descritos em diversos estudos e artigos de revisão, assim como alguns modelos desenvolvidos com a tentativa de descrever o processo e predizer o comportamento do sistema.

\subsubsection{1 Área superficial específica}

Baseado na premissa de que a hidrólise enzimática da celulose é uma reação de superfície, é esperado que a taxa e a extensão da conversão dos polissacarídeos seja uma função da área superficial da parede celular que é acessível às celulases. A área superficial acessível, por sua vez, é um reflexo coletivo dos demais aspectos do substrato, como o grau de ordenação fibrilar e a composição química (ANDERSEN, 2007; ARANTES; SADDLER, 2011; CHANG; HOLTZAPPLE, 2000; FAN; LEE; BEARDMORE, 1980; KUMAR et al., 2012; PIHLAJANIEMI et al., 2016; SINITSYN; GUSAKOV; VLASENKO, 1991; SUN et al., 2016; WANG et al., 2014; YANG et al., 2011; ZHANG; LYND, 2004). 
O efeito da área superficial específica da celulose na susceptibilidade à hidrólise enzimática foi discutido em diversos artigos publicados, em geral com a conclusão de que quanto maior a área superficial específica, maior a área de contato efetiva com as enzimas celulases, e maior o rendimento de sacarificação. THOMPSON, CHEN e GRETHLEIN (1992) observaram uma forte correlação linear $\left(R^{2}=0,88\right)$ entre a área superficial acessível de amostras de madeira de folhosas e o rendimento de glicose obtido por hidrólise enzimática, e afirmaram que a área superficial do substrato é o principal aspecto que deve ser alterado por métodos de pré-tratamento de forma a melhorar a efetividade da ação enzimática. De modo semelhante, WIMAN et al. (2012), a partir do pré-tratamento por explosão a vapor de uma amostra de cavaco de madeira de abeto, observaram correlações lineares positivas entre a taxa inicial de hidrólise enzimática (g/L.h) e a área superficial específica $\left(\mathrm{m}^{2} / \mathrm{g}\right)\left(\mathrm{R}^{2}=0,78\right)$ e a capacidade de adsorção das enzimas no substrato $(\mathrm{mg} / \mathrm{g})\left(\mathrm{R}^{2}=0,86\right)$.

Entretanto, a superfície exposta não necessariamente condiz com a área superficial específica e ativa da celulose na qual a hidrólise enzimática ocorre, havendo uma área superficial que não é sítio para o ataque enzimático (ANDERSEN, 2007; BANSAL et al., 2012; HUANG et al., 2010; LEU; ZHU, 2013; ZHANG; LYND, 2004). Portanto, um importante fator a ser considerado é a acessibilidade limitante e/ou desigual de todas as ligações $\beta$-glicosídicas do substrato às enzimas. A área ocupada por uma molécula de celulase adsorvida é muito maior do que a área da unidade de celobiose dentro de uma cela unitária de celulose. Apesar das diferenças geométricas entre as celulases, uma estimativa de primeira ordem dada por COWLING e KIRK (1976) é de que elas sejam um elipsoide de dimensões 33 x $200 \AA$, enquanto uma unidade de celobiose tem dimensão de, aproximadamente, 10,3.

Consequentemente, uma celulase ligada ao substrato cobre centenas de potenciais sítios de hidrólise (ligações $\beta$-glicosídicas). Em outras palavras, devido ao seu tamanho, as enzimas estão bloqueando histericamente o acesso umas das outras, e o número de proteínas que podem se ligar à superfície da celulose é substancialmente menor do que o número de sítios disponíveis na superfície do substrato (ANDERSEN, 2007; GRETHLEIN, 1985; ZHANG; LYND, 2004). Assim, as técnicas de análise podem superestimar da área acessível efetiva das celulases (LEU; ZHU, 2013; ZHANG; LYND, 2004). Além disso, a estrutura tridimensional da fibrila celulósica e sua organização em agregados limita o acesso ao seu interior, logo a ação das enzimas hidrolíticas é limitada às cadeias da superfície de um cristal (ANDERSEN, 2007; ARANTES; SADDLER, 2010; DRIEMEIER, 2017). 
Conforme explicitado no item 2.2.4.2, a hidrólise enzimática da celulose pode ocorrer pela delaminação sequencial das fibrilas de celulose tanto a partir da superfície externa quanto pela penetração de componentes das celulases nos poros existentes na parede celular antes do início do processo de despolimerização da celulose. Portanto, a área superficial específica de uma partícula é composta de duas frações, uma externa e outra interna.

A área superficial interna das partículas lignocelulósicas depende da estrutura capilar da parede celular, e consiste de poros intraparticulares, fissuras e micro-rachaduras que tipicamente surgem das descontinuidades do empacotamento molecular na formação do substrato celulósico, ou ainda criados pela remoção dos componentes não celulósicos durante tratamentos físico-químicos; espaços mais grosseiros, como o lúmen da célula e os poros nas membranas, que são visíveis sob microscopia ótica, não são incluídos. Já a área superficial externa é determinada pelo formato e pelo tamanho das partículas, e pode ser estimada tanto por observação microscópica quanto por análises de distribuição de tamanhos de partículas (ARANTES; SADDLER, 2011; FAN; LEE; BEARDMORE, 1980; GRETHLEIN, 1985; LI et al., 2015; WALKER; WILSON, 1991; ZHANG; LYND, 2004).

\subsubsection{1 Área superficial interna}

A estrutura capilar da parede celular é a responsável por limitar o transporte das celulases para o interior das camadas para que acessem a superfície das fibrilas celulósicas (DRIEMEIER, 2017; FAN; LEE; BEARDMORE, 1980; YANG et al., 2011). THYGESEN et al. (2011), usando enzimas marcadas fluorescentemente, mostraram que as celulases são capazes de penetrar na região porosa da celulose antes que qualquer despolimerização considerável da celulose ocorra.

A dimensão dos poros possui grande influência na digestibilidade enzimática, já que estes devem ser grandes o bastante para acomodar as enzimas hidrolíticas e para que estas acessem livremente os polissacarídeos; caso contrário, a reação de digestão da biomassa lignocelulósica seria limitada apenas à área superficial externa. Deste modo, o aumento na porosidade da parede celular implica em uma maior área superficial acessível às celulases e, portanto, em uma maior taxa de conversão dos polissacarídeos (ALVIRA et al., 2010; DRIEMEIER, 2017; GRETHLEIN, 1985; LI et al., 2015; SUN et al., 2016; XU et al., 2016). O volume de poros acessíveis a uma molécula de 4 Å é o caso limite para a molécula de água, 
também chamado de ponto de saturação da fibra. $\mathrm{O}$ volume de poros por grama de substrato acessível a cada soluto decresce conforme o diâmetro do soluto aumenta, até que não haja poros que possam acomodar um soluto de $560 \AA$ (GRETHLEIN, 1985).

Contudo, para moléculas grandes como as enzimas, nem todos os poros e capilares da parede celular são acessíveis. Por consequência, diversos pesquisadores concluíram que o tamanho dos poros do substrato em relação ao tamanho das enzimas é o principal fator que limita a conversão enzimática lignocelulósica (CHANDRA et al., 2007; GRETHLEIN, 1985; SINITSYN; GUSAKOV; VLASENKO, 1991; THOMPSON; CHEN; GRETHLEIN, 1992). A partir da análise do comportamento da taxa de hidrólise da celulose em relação à distribuição do tamanho dos poros, foi estimado que o tamanho dos poros inacessíveis, portanto limitante para a taxa de hidrólise, encontra-se na faixa de 50 - $100 \AA$ A. Deste modo, na determinação da área superficial acessível às enzimas celulolíticas, tamanhos similares devem ser relacionados (BURNS; OOSHIMA; CONVERSE, 1989; GRETHLEIN, 1985; HUANG et al., 2010; LI et al., 2015; MENG et al., 2013; PECIULYTE et al., 2015; PIHLAJANIEMI et al., 2016; SINITSYN; GUSAKOV; VLASENKO, 1991; WEIMER; WESTON, 1985).

A área superficial interna acessível tem sido estudada quanto a sua influência na taxa inicial e a extensão da hidrólise enzimática, e comumente observa-se o aumento da digestibilidade enzimática inicial com o aumento da área superficial interna (GRETHLEIN, 1985; HUANG et al., 2010; MOONEY et al., 1998; STONE et al., 1969; WONG et al., 1988).

O trabalho publicado por GRETHLEIN (1985) foi o primeiro a apresentar uma correlação entre o volume de poros acessíveis de substratos lignocelulósicos (de diferentes composições e origens vegetais) às celulases, e o rendimento de hidrólise enzimática. Com o intuito de compreender a razão da diferença na recalcitrância entre amostras de madeira de diferentes origens, o autor pré-tratou amostras de madeira de coníferas e folhosas por método ácido diluído sob diferentes severidades de reação, e confrontou os valores de volume de poros acessíveis $(\mathrm{mL} / \mathrm{g})$ e de área calculada acessível $\left(\mathrm{m}^{2} / \mathrm{g}\right)$ a solutos de diâmetros 51,90 e $110 \AA ̊$ aos rendimentos inicial (2h) e final (24h) de glicose. Primeiramente, o autor verificou que, para os substratos não tratados, menos de $20 \%$ do volume de poros é acessível a um soluto de $51 \AA$ A e menos de $7 \%$ é acessível a um soluto de 90 Å. Ademais, observou que a taxa inicial de hidrólise (rendimento de glicose obtido após $2 \mathrm{~h}$ de reação) correlacionou linearmente tanto com o volume de poros acessíveis quanto como a área superficial específica acessível a um soluto com diâmetro nominal de $51 \AA$ (diâmetro de uma esfera saturada de 
celulase), independente da natureza do substrato. Em vista disso, pôde-se inferir que quanto maior a porosidade do substrato, alcançada pela remoção seletiva das hemiceluloses, maior a acessibilidade às celulases, e maior a taxa inicial de hidrólise enzimática.

De modo similar, STONE et al. (1969) e WONG et al. (1988) encontraram correlações lineares positivas entre a taxa inicial de digestão de celulose e o volume de poros acessíveis a moléculas de 40 Å de diâmetro para amostras de fibras de algodão, e a moléculas de $50 \AA$ Ae diâmetro para amostras de Pinus radiata, respectivamente. HUANG et al. (2010) observaram, para amostras de espiga de milho pré-tratadas, uma correlação linear positiva entre a área superficial interna, acessível a moléculas de moléculas de $51 \AA$ de diâmetro, e o rendimento de hidrólise enzimática da celulose após $2 \mathrm{~h}$ de reação; os autores também verificaram um aumento em até 4 vezes na digestibilidade após $24 \mathrm{~h}$ com o aumento de 2 vezes na área superficial interna.

PIHLAJANIEMI e colaboradores (2016) publicaram recentemente um estudo detalhado a respeito da influência da porosidade, da área superficial da celulose, da cristalinidade e dos grupos hidroxila fenólicos acessíveis na superfície da lignina, na conversão enzimática da celulose da palha de trigo. Os autores observaram que os fatores que apresentam maior efeito positivo na taxa de hidrólise são a porosidade e a área superficial da celulose, enquanto que o teor de lignina apresenta o maior efeito negativo, sendo que estes parâmetros estão inter-relacionados. De maneira similar, o estudo publicado por XU et al. (2016) visou a correlação entre as alterações na composição química, na estrutura física (área superficial da celulose, área de poros e cristalinidade) e na morfologia, e o aumento no rendimento de glicose obtido por hidrólise enzimática de amostras de palha de arroz prétratadas com diferentes tipos de líquidos iônicos; novamente, foi observado que o aumento da área superficial da celulose e do volume de poros são os principais fatores responsáveis pela melhora na digestibilidade enzimática dos polissacarídeos, uma vez que estes parâmetros correlacionam linearmente e positivamente com o rendimento de açúcares monoméricos obtidos $\left(R^{2} \geq 0,91\right)$, e que estas propriedades estão inter-relacionadas.

No entanto, as alterações nos fatores estruturais reportadas nos trabalhos citados foram alcançadas com o processamento físico-químico da biomassa, isto é, com a alteração no teor de seus macrocomponentes, o que influencia diretamente nas características observadas. Conforme será descrito posteriormente (itens 2.2.5.2 e 2.2.8), o aumento na área de poros 
acessíveis pode ser alcançado tanto pela solubilização dos componentes não celulósicos quanto por processos de delaminação e intumescimento da parede celular vegetal.

De acordo com a definição apresentada no item 2.2.2.3, a estrutura de poros é responsável por estabelecer as relações da parede celular com a água. De modo similar, a presença da água influencia de maneira significante a estrutura interna da biomassa. $\mathrm{O}$ intumescimento leva ao aumento da estrutura capilar e, portanto, ao aumento da área superficial específica da celulose. Já a secagem das fibras lignocelulósicas a partir do estado intumescido promove o encolhimento sucessivo da capilaridade conforme o teor de umidade é reduzido, culminando em um processo irreversível chamado hornificação. A hornificação é um conjunto de fenômenos físico-químicos que ocorrem na parede celular durante o processo de remoção de água, onde as forças de tensão superficial causam o rearranjo dos polissacarídeos e a aproximação das superfícies vizinhas; como resultado tem-se a diminuição no tamanho e o colapso superficial dos poros. Por conseguinte, uma fibra hornificada apresenta a redução drástica da área superficial interna e da susceptibilidade à hidrólise enzimática, e a área superficial mensurada corresponderá majoritariamente à área externa. Este é um dos motivos pelos quais é recomentado que a análise da área superficial interna seja realizada por métodos que não exijam a secagem do material (ARANTES; SADDLER, 2011; FAN; LEE; BEARDMORE, 1980; GRETHLEIN, 1985; HENDRIKS; ZEEMAN, 2009; KUMAR et al., 2012; LEU; ZHU, 2013; WIMAN et al., 2012; ZHANG; LYND, 2004).

STONE e SCALLAN (1968) mostraram que a secagem resulta em reduções drásticas de até $80 \%$ na área superficial. FAN, LEE e BEARDMORE (1980) observaram que o rendimento de produção de glicose após $8 \mathrm{~h}$ de reação não apresenta qualquer tipo de correlação com a área superficial específica de amostras de celulose quando analisadas em estado seco. LUO e ZHU (2011) e LUO et al. (2011), em trabalhos correlatos, estudaram o efeito da prensagem a úmido e da secagem em uma variedade amostras lignocelulósicas prétratadas, e constataram que a única diferença na estrutura dos materiais foi o tamanho dos poros; ademais, verificaram que, para materiais provindos de uma mesma amostra nunca seca, o rendimento de sacarificação enzimática diminuiu de modo proporcional à redução no volume de poros do substrato. WANG et al. (2012a) observaram que, enquanto a digestibilidade enzimática de substratos de Pinus contorta pré-tratados aumenta linearmente $\left(\mathrm{R}^{2}=0,99\right)$ com o aumento na área de poros acessíveis a uma molécula de 51 Å, está é reduzida em mais de $90 \%$ quando o substrato é completamente hornificado, isto é, quando 
todos os poros colapsam. KUMAR et al. (2012), ao comparar amostras de madeira de conífera deslignificadas nunca secas e secas, observaram uma área superficial específica da celulose acessível à uma sonda de CBM muito maior para a amostra nunca seca; deste modo, quando ambos os substratos foram hidrolisados por $72 \mathrm{~h}$ a uma carga enzimática de $5 \mathrm{FPU} / \mathrm{g}$ de celulose, a amostra nunca seca foi hidrolisada completamente, enquanto a previamente seca permitiu uma hidrólise de apenas $53 \%$ da celulose original.

\subsubsection{2 Área superficial externa}

A área superficial externa relacionada também é considerada um fator crucial para a eficiência da conversão da celulose (ANDERSEN, 2007; HUANG et al., 2010; JIANG et al., 2016; KHULLAR et al., 2013; LEU; ZHU, 2013; LI et al., 2015). A diminuição no tamanho das partículas é um indicativo de mudanças na estrutura física da biomassa e pode resultar no aumento da digestibilidade pelo decaimento na resistência à transferência de massa ou pelo aumento na área superficial externa exposta às enzimas hidrolíticas (JIANG et al., 2016; KHULLAR et al., 2013; WANG et al., 2014). Em vista disto, métodos que geram a redução das dimensões das partículas são aplicados como pré-tratamento da biomassa lignocelulósica como forma de aumentar a área superficial específica e, consequentemente, a taxa e a extensão da reação hidrolítica enzimática (ANDERSEN, 2007; RIVERS; EMERT, 1988; SUN et al., 2016). No entanto, as conclusões reportadas a respeito da influência do tamanho das partículas na susceptibilidade do substrato lignocelulósico à sacarificação enzimática são extremamente divergentes. Enquanto alguns estudos notaram o aumento na digestibilidade com a redução no tamanho das partículas (DASARI; BERSON, 2007; HUANG et al., 2010; PEDERSEN; MEYER, 2009), outros mostraram que os efeitos na eficiência da ação das celulases são negligenciáveis (RIVERS; EMERT, 1988; ZENG et al., 2007).

ZENG et al. (2007) não observaram diferenças apreciáveis na conversão da celulose de amostras de palha de milho pré-tratadas, fracionadas em duas faixas de tamanhos de partículas: 53-75 $\mu \mathrm{m}$ e 425-710 $\mu \mathrm{m}$. RIVERS e EMERT (1988), a partir da moagem de amostras de bagaço de cana-de-açúcar e de palha de arroz em diferentes condições, não verificaram qualquer tipo de correlação entre o tamanho das partículas e o rendimento de glicose obtido, e concluíram que o tamanho das partículas do substrato não é um fator crucial que controla a susceptibilidade enzimática dentro da faixa de dimensões estudada $(224 \mu \mathrm{m}$ 
com $67 \%$ de elementos finos $(<53 \mu \mathrm{m})$ a $443 \mu \mathrm{m}$ com $15 \%$ de finos $)$. Já o estudo publicado por HUANG et al. (2010) mostrou uma correlação direta, apesar de não clara, entre a digestibilidade enzimática da celulose (tanto em $2 \mathrm{~h}$ quanto em $24 \mathrm{~h}$ ) e a área superficial externa, com os dados mostrando espalhamentos devido às influências de outros fatores.

DASARI e BERSON (2007) notaram que o rendimento de conversão da celulose de pastas de serragem é 50-55\% maior para partículas com tamanhos iniciais na faixa de 33-75 $\mu \mathrm{m}$ em relação a tamanhos iniciais na faixa de 590-850 $\mu \mathrm{m}$. ELSHAFEI et al. (1991) observou uma diferença menos significativa para as partículas de palha de milho, com tamanhos na faixa de 75-152 $\mu \mathrm{m}$ provendo rendimentos de conversão de $45 \%$, enquanto tamanhos na faixa de 1680-2000 $\mu \mathrm{m}$ apresentaram rendimentos de conversão de 35\%. LAMSAL, MADL e TSAKPUNIDIS (2011), a partir da análise de amostras de cascas de soja, palha de trigo e farelo de trigo, pré-tratadas e peneiradas em diferentes frações, observaram uma maior liberação de açúcar para frações de tamanhos de partículas menores que $132 \mu \mathrm{m}$. PEDERSEN e MEYER (2009) constataram que o rendimento de conversão da celulose da palha de trigo pré-tratada alcança $90 \%$ para as partículas de dimensões na faixa de 53-149 $\mu \mathrm{m}$, enquanto atinge apenas 65\% para partículas maiores na faixa de 2000-4000 $\mu \mathrm{m}$. KHULLAR et al. (2013) relataram que amostras de Miscanthus x giganteus moídas, tanto prétratadas em diferentes condições quanto não pré-tratadas, apresentaram uma conversão total dos carboidratos de $16 \%$ a $32 \%$ maior para partículas de diâmetro médio de $56 \mu$ m em relação às de diâmetro médio de $695 \mu \mathrm{m}$, enquanto as de diâmetro médio de $301 \mu \mathrm{m}$ e $695 \mu \mathrm{m}$ não apresentaram diferenças expressivas entre elas (de $2 \%$ a $10 \%$ ).

Todavia, deve-se atentar ao fato de que o tamanho das partículas em uma amostra pode variar entre uma abrangente faixa de dimensões, logo a noção de "tamanho médio" é relativa. Em uma ampla distribuição de tamanhos de partículas, as partículas menores e maiores podem distorcer a medida da área superficial externa, enquanto exercem mínimo efeito na hidrólise; caso as partículas fossem monodispersas, haveria uma maior probabilidade de correlação entre a digestibilidade enzimática e a área superficial externa mensurada (SINITSYN; GUSAKOV; VLASENKO, 1991).

SILVA et al. (2012) sugeriu que a redução mecânica no tamanho da biomassa deve superar um limite (cerca de $100 \mu \mathrm{m}$ ), onde ocorrerá a alteração da estrutura da biomassa em nível celular, para que o aumento na eficiência da hidrólise enzimática seja de fato 
considerável. A partir deste enunciado, JIANG et al. (2016) estudaram a relação entre o tamanho das partículas e o rendimento alcançado na hidrólise enzimática de partículas de madeira de coníferas cominuídas em nível celular por moagem em diferentes condições. Os autores verificaram que o aumento na conversão dos carboidratos correlaciona positivamente com a redução no tamanho médio das partículas; contudo, dois regimes puderam ser distinguidos: no primeiro regime, a redução no tamanho das partículas de $125 \mu \mathrm{m}$ até cerca de $30 \mu \mathrm{m}$ facilita em menor extensão a digestão enzimática pelo aumento na área superficial externa, e a conversão teórica dos carboidratos alcança apenas o limite de $40 \%$ devido à presença de agregados fibrilares e fibras inteiras com parede celular relativamente intacta; no segundo regime, uma menor redução no tamanho das partículas, de $30 \mu \mathrm{m}$ até aproximadamente $10 \mu \mathrm{m}$, permite um maior aumento na área superficial externa pela completa fragmentação da parede celular, suficiente para alcançar uma alta conversão de carboidratos (cerca de $77 \%$ do valor teórico).

Este comportamento foi fundamentado por LEU e ZHU (2013), que discerniram duas classes de redução de tamanho. Na classe 1, as fibras podem ser separadas, cortadas, fragmentadas, e fibriladas externamente de forma moderada por forças de cisalhamento; estes efeitos provocam o aumento na área superficial externa, porém não comprometem significantemente a integridade física da parede celular. Já a classe 2 de redução de tamanho promove uma maior desconstrução física da parede celular pela fibrilação interna induzida por compressão e pela expressiva quebra das ligações entre as fibrilas, de modo que partículas com dimensões micro ou nanométricas são produzidas. HOEGER et al. (2013), reportaram que a classe 1 de redução do tamanho, referente à quebra parcial das fibras e dos agregados fibrilares pelo processo de fibrilação, permitiu alcançar um rendimento de hidrólise das fibras de polpa de madeira de apenas $30 \%$, enquanto a classe 2, referente à completa desintegração da parede celular em microfibrilas, resultou em rendimentos de hidrólise de 60 a $90 \%$.

Apesar de tanto a área superficial externa quanto a interna fornecerem superfícies de contato para a adsorção das celulases, a contribuição da área externa para a efetividade da hidrólise enzimática é quase negligenciável para a maioria das biomassas lignocelulósicas. Estudos realizados com substratos de diferentes origens e composições demonstraram que a superfície interior dos poros contribui com mais de 90\% para a área superficial total acessível (HUANG et al., 2010; LI et al., 2015; LUO; ZHU, 2011; LUO et al., 2011; WANG et al., 
2012a; WONG et al., 1988). Esta é uma possível explicação da discordância nas interpretações a respeito da influência das dimensões das partículas na hidrolisabilidade dos materiais lignocelulósicos (ARANTES; SADDLER, 2011; LI et al., 2015).

Para os substratos lignocelulósicos nativos, não submetidos a nenhum tipo de processamento, a contribuição do aumento na superfície externa ao rendimento de sacarificação pode se tornar apreciável, visto que a maioria dos poros são muito pequenos para serem acessados pelas celulases, porém não permitirá alcançar sacarificações acima de $20 \%$ do rendimento teórico dos polissacarídeos. A contribuição da redução nas dimensões das partículas à digestão enzimática é menos notável para biomassas cuja área de poros tenha sido ampliada por algum método de desconstrução da parede celular (LEU; ZHU, 2013).

Com o objetivo de esclarecer a relevância da área superficial externa no rendimento de hidrólise, LI et al. (2015) aplicaram processos de moagem e peneiramento à amostras de palha de milho. Os autores notaram que o decréscimo no tamanho das partículas de 1,42 $\mathrm{mm}$ para 0,21 mm promoveu o aumento da área superficial específica externa de 0,02 para 0,1905 $\mathrm{m}^{2} / \mathrm{g}$, porém os rendimentos de hidrólise obtidos mantiveram-se aproximadamente iguais para as diferentes frações analisadas dentro de todos os tempos de reação (entre 2 e $72 \mathrm{~h}$ ) ou mesmo com diferentes cargas enzimáticas $(7,15$ ou $30 \mathrm{FPU} / \mathrm{g})$. Neste caso, as análises da área superficial específica total e dos tamanhos de poros internos mostraram que a superfície externa correspondeu a menos de $2 \%$ da área total, independente do tamanho da partícula. $\mathrm{O}$ trabalho desenvolvido por MOONEY e colaboradores (1998), que analisou quatro polpas de madeira de coníferas com diferentes teores de lignina, graus de intumescimento e tamanho médio das partículas, demonstrou que a taxa de reação e a eficiência da hidrólise enzimática são melhor descritas pela área superficial de poros do que pela área superficial acessível total, descrita juntamente pelos tamanhos de partículas e pelo volume de poros.

ARANTES e SADDLER (2011), com o objetivo de estabelecer uma relação confiável entre os principais fatores do substrato que governam a eficiência da hidrólise enzimática das biomassas lignocelulósicas, prepararam uma variedade de substratos lignocelulósicos, provindos de diversas fontes vegetais (resíduos agrícolas e madeiras de coníferas e folhosas) e pré-tratados por diferentes métodos (explosão a vapor e deslignificação organossolve). $\mathrm{O}$ estudo encontrou uma forte correlação linear, ou seja, uma forte dependência entre o aumento do rendimento de glicose obtido e o aumento da área superficial total acessível das fibrilas celulósicas à ligação das proteínas, descrita pela combinação das áreas superficiais interna e 
externa (ou seja, da porosidade e da morfologia das fibras); diferentemente, o estudo não encontrou correlação entre a área superficial externa, determinada pelas dimensões iniciais das fibras, e a quantidade mínima de proteína requerida para uma hidrólise eficaz. Com objetivo similar, o estudo publicado por SINITSYN, GUSAKOV e VLASENKO (1991) analisou amostras de celulose pura e de bagaço de cana-de-açúcar, pré-tratadas por tecnologias de diferentes naturezas (mecânica, física e química), quanto à morfologia e a estrutura física completa. Os autores deste trabalho encontraram correlações lineares definidas entre a área superficial das amostras celulósicas e lignocelulósicas acessível às proteínas hidrolíticas e a taxa inicial de hidrólise ou o rendimento de glicose após $24 \mathrm{~h}$ de reação $\left(\mathrm{R}^{2} \geq\right.$ 0,84); entretanto, constataram que a diminuição do tamanho médio das partículas, apesar de promover o aumento na área superficial externa, não influenciou em nenhuma extensão notável a eficiência da hidrólise.

WANG et al. (2014) e CIESIELSKI et al. (2014), em trabalhos complementares a respeito do pré-tratamento de amostras de palha de milho em reatores diferentes modos de ação mecânica (sob as mesmas condições nominais do método ácido diluído), constataram que, apesar das amostras apresentarem composições químicas similares, as diferenças significativas nas áreas superficiais interna e externa das partículas das biomassas, provocadas pelos distintos modos de ação dos reatores, resultaram em diferenças na acessibilidade da celulose às enzimas e, consequentemente, no rendimento de sacarificação. Em relação à morfologia das fibras analisadas, os autores encontraram correlações lineares negativas do rendimento de hidrólise tanto com relação à razão de aspecto $\left(\mathrm{R}^{2}=0,97\right)$ quanto ao tamanho médio das partículas $\left(\mathrm{R}^{2}=0,94\right)$, ou seja, as amostras que renderam maiores digestibilidades enzimáticas apresentaram partículas menores e mais uniformes; adicionalmente, verificaram uma correlação linear positiva entre a área de poros e a conversão da celulose $\left(R^{2}=1,0\right)$. As analises microscópicas indicaram que as amostras que proveram maiores rendimentos hidrolíticos eram mais porosas e apresentaram extensiva desestruturação da parede celular, evidenciada pela fragmentação, delaminação e nanofibrilação através e entre as diferentes paredes, ou seja, cada lamela foi separada em fibrilas individuais ou em pequenos agregados. WANG et al. (2014) também afirmou que os métodos de pré-tratamento que são mais destrutivos à integridade das fibras e promovem maior abertura da estrutura da parede celular, também provocam um maior espaçamento interfibrilar e a randomização das fibrilas celulósicas, o que também permite o aumento da acessibilidade às enzimas. 


\subsubsection{Composiçãa química}

Uma das características que tornam a biomassa lignocelulósica de difícil desconstrução enzimática é íntima relação química, física e estrutural que existe entre os componentes na parede celular vegetal, onde a área superficial dos polissacarídeos acessível à adsorção enzimática é extremamente restrita (COUGHLAN, 1992; LIN et al., 2010; YANG et al., 2011). Os complexos lignina-carboidratos são considerados restritivos à acessibilidade das enzimas hidrolíticas e contribuem para a contenção da desconstrução bioquímica (DE SOUZA et al., 2013; RAHIKAINEN et al., 2013; YANG et al., 2011). Deste modo, a quebra das interligações entre os três macrocomponentes resulta no aumento da área superficial interna (HUANG et al., 2010; LIN et al., 2010; MOONEY et al., 1998).

Contudo, as informações reportadas em diferentes trabalhos não permitem distinguir o tipo de impacto dos complexos lignina-carboidratos na restrição à hidrólise enzimática. Em geral, todos os constituintes da parede celular vegetal são modificados em diferentes extensões por métodos de processamento físico-químicos, dependendo da tecnologia e das condições empregadas; deste modo, é um desafio deduzir se a ruptura das associações entre os macrocomponentes ou a solubilização das hemiceluloses e da lignina que exerce maior contribuição para a efetividade da ação enzimática (YANG et al., 2011). RIVERS e EMERT (1988) demonstraram a importância da alteração específica na relação entre a lignina, as hemiceluloses e a celulose, ou seja, da ruptura da matriz lignocelulósica, no aumento da susceptibilidade enzimática das ligações $\beta$-1,4-glicosídicas dos resíduos agroindustriais à hidrólise enzimática. A partir do pré-tratamento em diferentes condições de amostras de bagaço de cana-de-açúcar e de palha de arroz, os autores observaram que a extensiva remoção da lignina permitiu um grande aumento no rendimento de glicose; entretanto, o incremento na susceptibilidade à hidrólise enzimática foi maior quando ocorreu, concomitantemente à redução da proporção lignina/celulose, a ruptura das ligações éster entre a lignina e as xilanas.

Dado que as cadeias hemicelulósicas encontram-se envoltas nas fibrilas de celulose e a lignina preenche os espaços interfibrilares e interlamelares, a remoção destes componentes da estrutura da parede celular causa o aumento extensivo da capilaridade, o que permite uma maior difusão dos agentes hidrolíticos às camadas mais interiores. Logo, os teores de lignina e hemiceluloses exercem um papel crucial na eficiência do processo de sacarificação enzimática pela criação e aumentos dos poros (ALVIRA et al., 2010; ARANTES; GOURLAY; 
SADDLER, 2014; BARAKAT; DE VRIES; ROUAU, 2013; JEOH et al., 2007; KUMAR et al., 2012; LEE et al., 2010; LIN et al., 2010; MOONEY et al., 1998; VÁRNAI; SIIKA-AHO; VIIKARI, 2010).

Com a dissolução dos componentes não celulósicos, há a amplificação dos poros existentes e mais poros de todos os tamanhos emergem. $\mathrm{O}$ aumento extensivo na porcentagem de dissolução pode novamente levar a amplificação dos poros existentes mais do que a formação de novos poros, e estes se tornam maiores do que o limite de detecção do método, o que diminui aparentemente a porosidade do sistema; os poros maiores podem ainda colapsar e levar ao decaimento na área superficial interna e, consequentemente, à redução do grau de digestibilidade da celulose (HUANG et al., 2010; PIHLAJANIEMI et al., 2016).

A importância relativa da remoção de um componente específico da biomassa em aumentar a acessibilidade à celulose é parcialmente dependente da cobertura do componente sobre as fibrilas celulósicas em uma dada biomassa (LEU; ZHU, 2013; YANG et al., 2011). Via de regra, a dissolução das hemiceluloses é associada com a formação de poros relativamente menores e uniformes, enquanto a dissolução da lignina leva a uma alteração mais volumosa da estrutura porosa (PIHLAJANIEMI et al., 2016). HUANG et al. (2010) verificaram o aumento em mais de duas vezes no valor da área superficial interna de amostras de espiga de milho com a aplicação de pré-tratamentos químicos, que promoveram a remoção dos componentes não celulósicos, ao mesmo passo que houve um aumento em até quatro vezes na digestibilidade enzimática da celulose. De modo similar, os autores relacionaram o baixo rendimento de hidrólise da amostra não tratada à inacessibilidade das ligações glicosídicas às celulases pela presença das hemiceluloses e da lignina.

\subsection{Hemiceluloses}

Visto que as hemiceluloses são componentes que limitam a acessibilidade das celulases às fibrilas celulósicas, sua remoção permite o aumento da efetividade da hidrólise enzimática por acarretar no intumescimento e no aumento dos poros da estrutura da parede celular (ALVIRA et al., 2010; ARANTES; GOURLAY; SADDLER, 2014; CHANDRA et al., 2007; DRIEMEIER, 2017; HU et al., 2013; PIHLAJANIEMI et al., 2016). No entanto, é válido relembrar que boa parte das enzimas celulolíticas digerem também as hemiceluloses, o 
que diminui o seu efeito bloqueador na digestibilidade da celulose (ANDERSEN, 2007; DRIEMEIER, 2017; KUMAR; WYMAN, 2009a; LYND et al., 2002).

No estudo publicado por XU et al. (2016) os autores não encontraram nenhuma relação clara entre a digestibilidade dos polissacarídeos e o teor de xilanas em amostras de palha de arroz, porém afirmaram que a remoção deste componente apresenta alguma contribuição na susceptibilidade à hidrólise enzimática. ZHU et al. (2012) e WANG et al. (2012b) observaram, para espécies de madeiras de folhosas, um aumento proporcional no rendimento de sacarificação com a redução no teor de hemiceluloses. Em estudo conduzido com o pré-tratamento de uma amostra de madeira de pinus contorta sob diferentes condições de reação, que resultaram em diferentes extensões de deslignificação e de remoção das hemiceluloses, ZHU et al. (2010) observaram que a digestibilidade enzimática aumentou de modo aproximadamente linear com o aumento na dissolução das hemiceluloses, enquanto apresentou significante variação na relação com remoção de lignina. Já para amostras com baixo teor de lignina (como a palha de milho e o "switchgrass"), MOXLEY et al. (2012) e WYMAN et al. (2011) demonstraram que a remoção das hemiceluloses é suficiente para alcançar um alto rendimento de sacarificação enzimática da celulose, sem ser necessária a posterior deslignificação da biomassa A partir de uma extensa revisão da literatura, LEU e ZHU (2013) afirmaram que a remoção das hemiceluloses é mais importante para o aumento da acessibilidade da celulose do que a remoção da lignina, posto que a lignina não está diretamente ligada às cadeias celulósicas na superfície das fibrilas elementares e que a remoção das hemiceluloses permite a criação de poros diretamente acessíveis às celulases. LIN et al. (2010) constataram que os complexos celulolíticos são eficientes em hidrolisar as hemiceluloses, e que a taxa inicial de hidrólise das hemiceluloses é muito mais rápida que a da celulose; os autores associaram este comportamento à estrutura heterogênea e amorfa das hemiceluloses, que pode ser mais facilmente hidrolisada que a celulose, polímero longo, cristalino e resistente.

Menor atenção tem sido dada ao grau de acetilação das cadeias hemicelulósicas das biomassas. Os métodos de processamento que promovem a solubilização das hemiceluloses acarretam na remoção simultânea dos grupos acetila e usualmente alteram a estrutura da lignina residual, o que dificulta o isolamento da influência de cada fator na performance enzimática (YANG et al., 2011). A desacetilação das cadeias de hemicelulose em muitos tipos 
de biomassa foi reportada como aumentando a extensão da digestibilidade da celulose (CHEN et al., 2012; CHEN et al., 2014; CHEN et al., 2016).

As observações realizadas no estudo de PIHLAJANIEMI et al. (2016) indicaram que as hemiceluloses apresentam praticamente nenhum efeito na conversão final dos carboidratos, já que são eficientemente hidrolisadas pelas enzimas celulolíticas. Adicionalmente, os resultados mostraram que a conversão das hemiceluloses de amostras de palha de trigo correlacionou linearmente com a conversão da celulose a uma razão constante, e que esta constante era menor quando a reação promovia um menor grau de desacetilação. Segundo os autores, após a remoção dos grupos acetila a hidrólise da celulose e das hemiceluloses procede lado a lado, independente da proporção relativa e do tempo de hidrólise.

Estudos recentes reportaram que os xilo-oligômeros são fortes inibidores das celulases, de forma que sua liberação durante a hidrólise enzimática pode diminuir substancialmente a taxa da hidrólise. Esta informação traz relevância à remoção das hemiceluloses das biomassas lignocelulósicas em etapa prévia à sacarificação da celulose (KUMAR; WYMAN, 2009b; QING; YANG; WYMAN, 2010).

\subsubsection{Lignina}

Os estudos publicados a respeito da restrição da ação enzimática na digestão das biomassas lignocelulósicas reportam que influência da lignina se dá de três modos. Além de agir como barreira física, impedindo estéricamente o acesso das celulases aos sítios de hidrólise (LEU; ZHU, 2013; KUMAR et al., 2012; MOONEY et al., 1998), a lignina pode bloquear a ação processiva das celobiohidrolases ao longo das cadeias celulósicas (MANSFIELD; MOONEY; SADDLER, 1999; VERMAAS et al., 2015; ZHANG; LYND, 2004), ou ainda reduzir a quantidade de proteínas disponíveis para catalisar a hidrólise dos polissacarídeos por se ligar de modo não produtivo e irreversível às enzimas celulolíticas (BERNARDEZ et al., 1993; OOSHIMA; BURNS; CONVERSE, 1990; RAHIKAINEN et al., 2013; VERMAAS et al., 2015). Por consequência, a redução no seu teor por alguma tecnologia de processamento prévia contribui para o melhoramento da produtividade da sacarificação enzimática (HENDRIKS; ZEEMAN, 2009; HUANG et al., 2010; JEOH et al., 2007; LYND et al., 2002; MENON; RAO, 2012; XU et al., 2016; YANG et al., 2011; ZHANG; LYND, 2004; ZHU et al., 2008). 
Diversos trabalhos exibiram uma boa correlação entre a porcentagem de deslignificação dos substratos lignocelulósicos e o aumento no rendimento de açúcares redutores obtidos (CHANG; HOLTZAPPLE, 2000; MOONEY et al., 1998; XU et al., 2016). XU et al. (2016) encontraram uma correlação linear negativa entre o teor de lignina e a digestibilidade dos polissacarídeos $\left(\mathrm{R}^{2}=0,87\right.$ para a celulose e $\mathrm{R}^{2}=0,81$ para as hemiceluloses). Já a análise realizada por PIHLAJANIEMI et al. (2016) demonstrou que o teor de lignina apresenta o maior efeito negativo na conversão final da celulose.

Consoante ao acima disposto, a presença da lignina em sua forma original delimita a área de poros. Logo, sua remoção foi relacionada ao aumento da área superficial interna da parede celular acessível à adsorção enzimática (JEOH et al., 2007; KUMAR et al., 2012; LEU; ZHU, 2013; MOONEY et al., 1998; NAKATANI et al., 2008; PIHLAJANIEMI et al., 2016; WONG et al., 1988).

A lignina pode também competir pelas celulases por meio de ligações não produtivas e irreversíveis, que ocorrem ao mesmo tempo em que a adsorção às cadeias celulósicas (BERNARDEZ et al., 1993; COUGHLAN, 1992; KO et al., 2015a; KO et al., 2015b; KO et al., 2015c; NAKAGAME; CHANDRA; SADDLER, 2010; NAKAGAME et al., 2011a; OOSHIMA; BURNS; CONVERSE, 1990; RAHIKAINEN et al., 2013; VERMAAS et al., 2015). OOSHIMA, BURNS e CONVERSE (1990) estimaram que a capacidade de adsorção das celulases de Trichoderma reesei na celulose aumenta quanto menor o teor de lignina em uma amostra de madeira de folhosa pré-tratada. NAKAGAME et al. (2011a) e KO et al. (2015a,c) demonstraram que o rendimento de hidrólise de amostras de celulose microcristalina decaem de $70 \%$ para $40-45 \%$ na presença de lignina isolada de madeiras de coníferas, e de $62,5 \%$ para $51 \%$ na presença de lignina isolada de madeiras de folhosas.

A adsorção das enzimas na lignina é primariamente mediada por interações hidrofóbicas, mas a complementariedade de formatos entre as enzimas e as superfícies fractais da lignina também desempenham algum papel (DRIEMEIER, 2017; NAKAGAME; CHANDRA; SADDLER, 2010; VERMAAS et al., 2015). Há ainda indícios de o CBM das celulases participa na ligação à lignina (PALONEN et al., 2004; RAHIKAINEN et al., 2013). RAHIKAINEN et al. (2013) observaram que a enzima Cel7A (CBH I) de T. reesei completa se liga consideravelmente mais rápido e em maior extensão a filmes de lignina em comparação à enzima sem o CBM e sem a ponte polipeptídica (apenas com o CD); a maior afinidade das enzimas completas em se ligar à lignina foi justificada pela existência das 
interações hidrofóbicas, identificadas como a principal força propulsora pelo processo de adsorção da TrCel7A na lignina. A afinidade do CBM em se ligar à celulose se origina em interações hidrofóbicas de empilhamento de anel entre os aminoácidos aromáticos do CBM e os anéis de glicose alinhados na celulose; interações de empilhamento de anel similares podem ocorrer com os anéis aromáticos da lignina.

Apesar da remoção da lignina resultar no aumento das taxas e dos rendimentos de hidrólise observados, ainda é discutido qual dos seus três mecanismos de restrição apresenta maior impacto no resultado final. VERMAAS et al. (2015), por meio da simulação da dinâmica molecular de um sistema lignocelulósico multi-componentes (diferentes graus de cristalinidade e teores de lignina) em reação com celulases Cel7A de Trichoderma reesei, elucidaram de modo detalhado os mecanismos da inibição da lignina na atividade enzimática durante a conversão da celulose, ilustrados na Figura 14. Primeiramente, os autores verificaram que aproximadamente $1 / 4$ da área superficial total das fibrilas celulósicas é consistentemente coberta pela lignina, o que reduz a acessibilidade às enzimas, e que esta se encontra associada à celulose preferencialmente nas faces hidrofóbicas dos cristais, sítios preferenciais de adsorção das celulases. Também observaram que a presença de moléculas de lignina na superfície da celulose interrompe o mecanismo processivo pelo bloqueio do caminho pelo qual a enzima ligada á cadeia celulósica percorre, reduzindo sua distância de atuação. Por outro lado, notaram que as enzimas se ligam à lignina por resíduos específicos de tirosina do CBM que são críticos para a adsorção e ligação da TrCel7A na celulose, com uma probabilidade de ligação à lignina aproximadamente cinco vezes maior do que à celulose; dado que estes resíduos do CBM se ligam exclusivamente a um componente, a lignina inibe a ligação à celulose por um mecanismo de caráter competitivo.

O trabalho publicado por MOONEY et al. (1998) demonstrou que um dos maiores efeitos da remoção da lignina na facilidade de hidrólise enzimática dos substratos lignocelulósicos é com relação ao aumento na área de poros acessíveis enzimaticamente. Pelo tratamento de polpas de madeira de conífera por sulfonação neutra, os autores alcançaram um maior grau de intumescimento do substrato sem a remoção da lignina; contudo, esta abertura na estrutura não permitiu um aumento expressivo na extensão da hidrólise por não alterar a porosidade do material, isto é, por não remover o impedimento estérico da lignina.

KUMAR et al. (2012) também compararam as contribuições relativas da lignina na restrição da hidrólise enzimática da celulose para uma amostra de madeira de conífera, e 
constataram que a lignina de fato exerce ambos os papéis, tanto na ligação direta com as celulases quanto na redução da acessibilidade à celulose do substrato. Entretanto, os autores observaram que o grau em que a lignina compete pelas enzimas esteve fortemente associado à área superficial. Para os substratos com menor acessibilidade à celulose, o efeito das interações não produtivas das celulases com a lignina foi mais intenso; conforme a acessibilidade à celulose aumentou, mesmo com a lignina presente em concentrações relativamente altas, ela exerceu um papel significantemente menor em impedir a efetividade da hidrólise enzimática como adsorvente não produtivo, posto que a celulose estava prontamente acessível para a adsorção enzimática. Deste modo, os autores concluíram que o principal papel da lignina é em restringir a hidrólise enzimática pela limitação da acessibilidade da celulose às enzimas.

Figura 14. Ilustração dos mecanismos de inibição exercidos pela lignina na atividade enzimática durante a hidrólise da celulose: as fibrilas celulósicas estão representadas em vermelho, as moléculas de lignina em azul e as enzimas TrCel7 A em verde (CBM em verde mais claro e CD mais escuro).

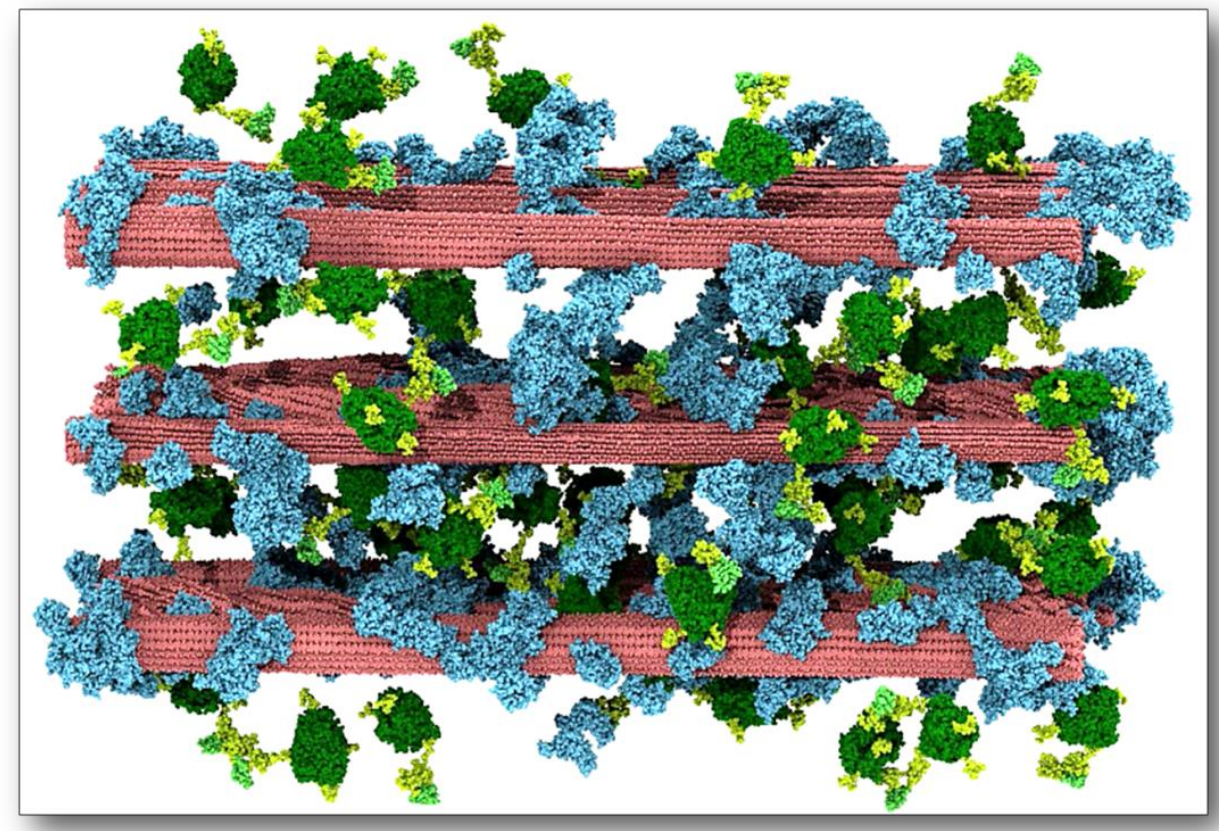

Fonte: Adaptado de: VERMAAS et al., 2015.

As interações lignina-celulases são dependentes da fonte vegetal, das propriedades de superfície da lignina e das modificações químicas realizadas em sua estrutura. Quanto mais condensada e hidrofóbica sua estrutura, uma melhor interação é encontrada entre a lignina e as enzimas hidrolíticas, o que resulta em uma inibição mais forte da reação de sacarificação da celulose (ARANTES; SADDLER, 2011; CONVERSE; OOSHIMA; BURNS, 1990; 
HUANG et al., 2010; KO et al., 2015b; KO et al., 2015c; MOONEY et al., 1998; NAKAGAME; CHANDRA; SADDLER, 2010; NAKAGAME et al., 2011a; RAHIKAINEN et al., 2013; WIMAN et al., 2012).

Quanto à sua natureza, as ligninas mais ricas em unidades guaiacila são mais reticuladas e, portanto, restringem em maior extensão a acessibilidade das enzimas (MOONEY et al., 1998; MOXLEY et al., 2012; NAKAGAME; CHANDRA; SADDLER, 2010; RAHIKAINEN et al., 2013). Já a presença de grupos hidroxila e ácido carboxílico está relacionada à diminuição da capacidade de ligação das celulases na superfície da lignina (NAKAGAME et al., 2011a; NAKAGAME et al., 2011b). Modificações na superfície da lignina que promovem o aumento de sua hidrofilicidade contribuem para a diminuição do efeito de adsorção não produtiva das celulases (PALONEN et al., 2004; PIHLAJANIEMI et al., 2016; RAHIKAINEN et al., 2013). ARANTES e SADDLER (2011) também observaram que a capacidade de adsorção máxima das proteínas nos polissacarídeos de biomassas prétratadas termicamente varia de acordo com o número de sítios de ligação na superfície das partículas de lignina pela preservação dos grupos funcionais hidroxil fenólicos e benzil, e pela formação de ramificações.

Em geral, os métodos de processamento térmicos em meio ácido solubilizam parcialmente os heteropolissacarídeos e promovem a ruptura das ligações ligninacarboidratos, porém preservam a maior parte da lignina no estado sólido; conforme as hemiceluloses são solubilizadas e o volume de poros aumenta, a quantidade de lignina exposta às celulases também aumenta (KO et al., 2015b; PIHLAJANIEMI et al., 2016; RAHIKAINEN et al., 2013). Entretanto, o pré-tratamento em temperaturas além da temperatura de transição vítrea da lignina pode provocar alterações em sua estrutura química devido à fusão e às reações de des- e repolimerização simultâneas da lignina, que coalesce em gotículas esféricas e é exposta na superfície das células vegetais ou depositada em poros abertos (KO et al., 2015a; KO et al., 2015b; KO et al., 2015c; LI; HENRIKSSON; GELLERSTEDT, 2007; MICHALOWICZ; TOUSSAINT; VIGNON, 1991; MOONEY et al., 1998; OOSHIMA; BURNS; CONVERSE, 1990; PIHLAJANIEMI et al., 2016; SELIG et al., 2007). Imagens de microscopia eletrônica de varredura e de força atômica revelaram partículas esféricas de lignina com diâmetros de $3 \mu \mathrm{m}$ e $1 \mu \mathrm{m}$, respectivamente (DONOHOE et al., 2008; HANSEN et al., 2011). 
Entre as principais mudanças químicas que ocorrem na estrutura da lignina durante pré-tratamentos térmicos em condições ácidas estão: a quebra das ligações aril éter $\beta-\mathrm{O}-4$ ' (despolimerização), o consequente aumento no teor total de grupos hidroxil-fenólicos, a formação de novas ligações $C-C$ (condensação) e o aumento no teor de estruturas $\beta-5$ ' na lignina (possíveis rearranjos entre as ligações interunidades). Estas mudanças provocadas na lignina aumentam sua hidrofobicidade devido à perda das funcionalidades hidroxila e ácido carboxílico e ao aumento da condensação de sua estrutura, o que aumenta a probabilidade da ligação não produtiva das enzimas na lignina (KO et al., 2015b; PIHLAJANIEMI et al., 2016; RAHIKAINEN et al., 2013). O aumento no teor de grupos hidroxil-fenólicos na lignina também tem sido indicado como um dos responsáveis pelo aumento na capacidade de ligação das celulases à lignina. Adicionalmente, o deslocamento da lignina para a superfície das fibras, ou ainda o aumento da área superficial acessível à lignina, levam a uma maior ocorrência de interações enzimas-lignina e diminuem a acessibilidade enzimática ao interior da parede celular. Deste modo, o efeito positivo do pré-tratamento pela abertura da matriz da parede celular pode ser comprometido (HANSEN et al., 2011; RAHIKAINEN et al., 2013).

RAHIKAINEN et al. (2013) observaram uma capacidade de adsorção expressivamente maior da enzima TrCel7A nas ligninas provindas das biomassas pré-tratadas termicamente em relação às provindas das não tratadas, o que culminou em um efeito inibitório da lignina mais pronunciado durante a hidrólise enzimática de uma amostra celulósica. WIMAN et al. (2012), a partir do pré-tratamento por explosão a vapor de uma amostra de cavaco de madeira de abeto, observaram que o aumento da severidade da reação de pré-tratamento resultou em uma área superficial celulósica acessível maior, expressa pelo aumento da área de poros acessíveis; concomitantemente foi verificado o aumento da concentração de lignina na superfície das partículas e do teor de lignina total, o que ocorreu devido à degradação mais extensiva dos carboidratos e à migração e deposição da lignina. Entretanto, os autores constataram que não houve nenhum impacto negativo pelo aumento do teor de lignina na superfície após o pré-tratamento em condições mais severas, sendo que uma hidrólise mais eficiente foi alcançada devido ao aumento no tamanho dos poros do substrato. Em outras palavras, os efeitos positivos da acessibilidade da celulose na taxa de hidrólise enzimática dominaram sobre os efeitos negativos da presença da lignina na superfície. Resultados e conclusões similares foram obtidos por NAKAGAME et al. (2011a). Uma vez que maiores severidades das reações de pré-tratamento implicam em uma pior qualidade da 
superfície total dos materiais, mas são necessárias para aumentar a acessibilidade à celulose, os autores propõem que a acessibilidade à celulose deve ser aumentada sem a alteração concomitante da lignina, isto é, por meio de tratamentos mecânicos, de forma a utilizar um processamento brando que evite a perda de carga enzimática pela ligação não produtiva das enzimas à lignina (WIMAN et al., 2012).

\subsubsection{Estrutura cristalina da celulose}

A cristalinidade do substrato celulósico é considerada um importante fator que contribui para sua resistência à degradação pela limitação da acessibilidade às celulases. KRÄSSING (1993) demonstrou que um alto grau de agregação fibrilar produz uma estrutura mais compacta, com menor quantidade e menor tamanho de interstícios, o que resulta em uma menor área superficial interna. Nas regiões altamente ordenadas dos cristais, as cadeias celulósicas estão empacotadas tão firmemente que até mesmo moléculas muito pequenas, como a água, não conseguem penetrar. No arranjo dos agregados fibrilares, aparentemente, apenas as moléculas de celulose situadas na superfície são susceptíveis à degradação enzimática. Além disso, a energia requerida para o desligamento da cadeia de celulose da superfície do cristal depende da sua localização dentro da seção transversal deste cristal. Deste modo, a organização cristalina afeta a capacidade de intumescimento e a taxa de difusão dos reagentes dentro das estruturas fibrilares e, portanto, desempenha importante papel na acessibilidade e na reatividade das cadeias celulósicas (ARANTES; SADDLER, 2010; SINITSYN; GUSAKOV; VLASENKO, 1991). DRIEMEIER (2017) afirma que a organização cristalina, mais do que o grau de cristalinidade, afeta a taxa de hidrólise.

De forma oposta, as cadeias de celulose presentes nas regiões definidas como amorfas, dentro dos deslocamentos e na superfície, são pontos mais frágeis e acessíveis dentro das fibras celulósicas. Por serem mais susceptíveis, as frações amorfas são mais rapidamente hidrolisadas pelas celulases e são responsáveis pela diminuição do comprimento médio das fibras ao longo da reação enzimática (GOURLAY et al., 2015; ZHANG; LYND, 2004). Por conseguinte, a redução na cristalinidade (ou o desordenamento da estrutura celulósica) pode ser acompanhada do aumento no espaço para o contato das enzimas dentro das fibrilas celulósicas, e é fortemente associada com o aumento na taxa inicial de hidrólise enzimática da celulose (ARANTES; SADDLER, 2010; BANSAL et al., 2010; BANSAL et al., 2012; 
BERTRAN; DALE, 1985; FAN; LEE; BEARDMORE, 1980; JIANG et al., 2016; LYND et al., 2002; MENON; RAO, 2012; PIHLAJANIEMI et al., 2016; PURI, 1984; RIVERS; EMERT, 1988; SINITSYN; GUSAKOV; VLASENKO, 1991; WALKER; WILSON, 1991; YANG et al., 2011; ZHANG; ZHANG, 2013). Estudos prévios mostraram que a taxa de hidrólise mediada por celulases fúngicas é tipicamente de 3 a 30 vezes mais rápida para a celulose amorfa quando comparada à celulose cristalina (JIANG et al., 2016; LYND et al., 2002; YANG et al., 2011; ZHANG; LYND, 2004; ZHAO; ZHANG; LIU, 2012).

BERTRAN e DALE (1985) mostraram que a redução na cristalinidade inicial da celulose está relacionada à uma maior extensão da conversão do substrato em açúcares solúveis. BANSAL et al. (2010) verificaram que a redução nos índices de cristalinidade de amostras de celulose tratadas com o uso de ácido fosfórico correlacionaram linearmente com o aumento nas taxas iniciais de hidrólise enzimática $\left(R^{2}>0,95\right)$, e afirmaram que a cristalinidade dos substratos celulósicos é uma das principais propriedades que afetam a reposta da ação celulolítica. HUANG et al. (2010) observaram que a taxa e a extensão da digestão da celulose aumentam com o aumento do grau de desconstrução das interações de hidrogênio, especialmente as intermoleculares, provocada por processamentos químicos aplicados a uma amostra de espiga de milho; isto porque as interações de hidrogênio intra- e intermoleculares das cadeias celulósicas estão intimamente relacionadas ao sistema cristalino e ao grau de regularidade intermolecular.

Se a hidrólise da celulose apenas ocorre na superfície dos agregados celulósicos, a área superficial acessível interna é possivelmente influenciada pelas propriedades cristalinas da celulose (ARANTES; SADDLER, 2010). No trabalho desenvolvido por SINITSYN, GUSAKOV e VLASENKO (1991) encontrou-se uma correlação linear negativa entre o índice de cristalinidade de amostras celulósicas puras, submetidas a métodos de processamento de diferentes naturezas, e a eficiência da hidrólise enzimática da celulose $\left(\mathrm{R}^{2}=0,92\right.$ e 0,88 em relação à taxa inicial de hidrólise e ao rendimento de glicose em $24 \mathrm{~h}$ de reação, respectivamente); ao mesmo passo, verificou-se uma correlação linear negativa entre o índice de cristalinidade das amostras e a área superficial específica acessível $\left(\mathrm{R}^{2}=0,86\right)$. WIMAN et al. (2012) afirmaram que o aumento na acessibilidade à celulose após reações de prétratamento é devido ao aumento no volume de poros, à fragmentação da parede celular e à redução na cristalinidade da celulose, sendo que estes fatores estão inter-relacionados e são de difícil separação na interpretação. 
Já FIEROBE et al. (2002), ao compararem a taxa de hidrólise de modelos de substratos celulósicos, concluíram que a acessibilidade à celulose é um fator mais determinante para a taxa de hidrólise do que o índice de cristalinidade. LEE e FAN (1982) reportaram que a extensão da adsorção enzimática aumenta de forma aproximadamente linear com o aumento da área superficial específica, enquanto a efetividade das enzimas adsorvidas na produção de açúcares redutores é fortemente dependente do índice de cristalinidade inicial do substrato celulósico.

A distinção entre as faces hidrofóbicas e hidrofílicas do cristal é outro ponto crítico para a desconstrução da celulose, visto que elas diferem qualitativamente quanto a suas interações com a lignina, com as hemiceluloses, com os cristais de celulose adjacentes, com o ambiente aquoso e com as enzimas hidrolíticas. As faces hidrofóbicas dos cristais de celulose são os sítios de adsorção preferencial do módulo de ligação ao carboidrato das enzimas celobiohidrolases, conforme determinado para a CBH I de $T$. reesei. Isto parece uma hipótese razoável, dado que esta face representa a parte superior dos anéis glicopiranosídicos, na qual as ligações $\beta$-glicosídicas são acessíveis às celulases (CHANZY; HENRISSAT; VUONG, 1984; DRIEMEIER, 2017; VERMAAS et al., 2015; ZHANG; LYND, 2004).

Apesar de ser esperado que o grau de cristalinidade da celulose aumente ao longo do curso da reação enzimática pela rápida hidrólise inicial da porção amorfa mais facilmente acessível, essa visão é atualmente desafiada; isto porque pequenas ou nenhuma mudança no grau de cristalinidade têm sido observadas durante a sacarificação enzimática dos materiais lignocelulósicos como resultado do consumo de ambas as frações (cristalina e amorfa) pelos componentes presentes nos complexos de celulases tipicamente aplicados (BANSAL et al., 2012; GOURLAY et al., 2015; PIHLAJANIEMI et al., 2016). O estudo publicado por BANSAL et al. (2012) demonstrou que, após uma conversão inicial, o grau de cristalinidade da celulose se mantém constante durante a hidrólise, o que levou os autores a afirmarem que, embora a cristalinidade seja fator determinante da taxa inicial da reação, ela não é um parâmetro que precisa ser levado em consideração durante a hidrólise em si. Isto está de acordo com as observações de PIHLAJANIEMI et al. (2016) e CHANG e HOLTZAPPLE (2000), que constataram que o grau de cristalinidade afeta a velocidade inicial da reação pela hidrólise mais rápida das regiões amorfas, porém afeta de forma menos significativa a conversão final, posto que as regiões cristalinas são hidrolisadas com o tempo de reação e são mais relevantes para o resultado total. 
Novamente, encontramos muitas controvérsias na literatura a respeito da importância relativa da cristalinidade na hidrólise da celulose, e apesar deste parâmetro ser considerado um fator que determina a taxa de hidrólise dos substratos lignocelulósicos, as investigações independentes indicam que este valor sozinho não explica a recalcitrância dos substratos lignocelulósicos (ALVIRA et al., 2010; ANDERSEN, 2007; BANSAL et al., 2012; COUGHLAN, 1992; DRIEMEIER, 2017; GOURLAY; ARANTES; SADDLER, 2012; HUANG et al., 2010). Além da demonstração de que tanto as porções cristalinas quanto as amorfas são consumidas durante a reação enzimática por diferentes componentes dos sistemas de celulases (item 2.2.4.2), são reportados casos em que a taxa de hidrólise é inversamente proporcional ao grau de cristalinidade (BANSAL et al., 2010; FAN; LEE; BEARDMORE, 1980; SINITSYN; GUSAKOV; VLASENKO, 1991), outros diretamente proporcional (HUANG et al., 2010; XU et al., 2016), e outros ainda em que a efetividade da hidrólise não é afetada significantemente pela cristalinidade (GRETHLEIN, 1985; RIVERS; EMERT, 1988).

Outro cuidado que se deve tomar na interpretação do impacto da cristalinidade na ação enzimática é sua relação com outras propriedades físicas do substrato, já que vários tratamentos que diminuem o grau de cristalinidade de uma amostra também aumentam sua área superficial, seja pela redução do tamanho das partículas ou pela desestruturação da parede celular (BANSAL et al., 2012; LEE; FAN, 1982; ZHANG; LYND, 2004).

FAN, LEE e BEARDMORE (1980) observaram uma correlação linear negativa, com alto grau de dependência, entre a produção de glicose após 8 h de reação enzimática e o índice de cristalinidade de amostras de celulose puras, independentemente de sua natureza ou histórico de tratamento. Os autores ainda concluíram que a taxa e a extensão da hidrólise são principalmente dependentes da ordem estrutural da celulose, que pode ser mais bem representada pela cristalinidade mais do que pela área superficial simplesmente. Já GRETHLEIN (1985) afirma que a cristalinidade não é um fator primordial que determina a acessibilidade, já que os índices de cristalinidade obtidos em seu estudo para diferentes substratos lignocelulósicos pré-tratados não apresentaram qualquer correlação com o grande aumento alcançado na taxa de hidrólise enzimática. No trabalho publicado por JIANG et al. (2016), a relação entre a conversão dos carboidratos por hidrólise enzimática e o índice de cristalinidade das partículas de madeira de conífera, cominuídas por moagem em diferentes condições, não apresentou comportamento linear $\left(\mathrm{R}^{2}=0,65\right)$. 
Ainda que a hidrólise enzimática de substratos celulósicos puros mostre uma boa correlação entre o decaimento do grau de cristalinidade e o aumento da taxa de hidrólise, a relação para os substratos lignocelulósicos não é tão clara, devido à natureza heterogênea destes materiais e às contribuições dos demais macrocomponentes já apontadas (BARAKAT; DE VRIES; ROUAU, 2013; MOONEY et al., 1998; SINITSYN; GUSAKOV; VLASENKO, 1991). O valor de "índice de cristalinidade" de uma biomassa se refere à fração relativa de celulose cristalina no sólido total, logo a presença de componentes não celulósicos pode resultar em artefatos que alteram a interpretação do efeito da cristalinidade na hidrolisabilidade do material (HUANG et al., 2010; ZHANG; LYND, 2004).

Ademais, os métodos de processamento que promovem a solubilização dos compostos não celulósicos afetam de diferentes modos a cristalinidade da celulose: reduzem pela ruptura das interações de hidrogênio dentro de um cristal, aumentam pela degradação da celulose amorfa, ou ainda não alteram (PIHLAJANIEMI et al., 2016). Em casos em que não há a alteração da estrutura cristalina da celulose, o aumento da hidrolisabilidade do material com o pré-tratamento é geralmente acompanhado do aumento do seu índice de cristalinidade devido à solubilização dos componentes não celulósicos (HU et al., 2015b; KIM et al., 2003; KNAPPERT; GRETHLEIN; CONVERSE, 1980; MANSFIELD; MOONEY; SADDLER, 1999). Já nos casos em que há a alteração da estrutura cristalina, o índice de cristalinidade aumenta com a severidade da reação pela dissolução dos componentes não celulósicos; entretanto, quando normalizado pelo teor de celulose, a tendência é oposta, e seu valor decai pela descritalização (PIHLAJANIEMI et al., 2016).

XU e colaboradores (2016) observaram que o pré-tratamento de uma amostra de palha de arroz com líquido iônico, que não altera a estrutura cristalina da celulose mas remove os componentes não celulósicos, resulta em uma relação positiva entre o aumento no índice de cristalinidade e o aumento na digestibilidade da celulose e das xilanas. HUANG et al. (2010) encontraram uma correlação linear positiva entre o aumento no índice de cristalinidade de amostras de espiga de milho pré-tratadas quimicamente e o aumento do teor de celulose $\left(\mathrm{R}^{2}=\right.$ 0,89). Entretanto, RIVERS e EMERT (1988) observaram que o aumento no rendimento de glicose para as amostras de bagaço e de palha de arroz tratadas apenas mecanicamente esteve associado com a redução no índice de cristalinidade do substrato antes da hidrólise, enquanto para as pré-tratadas quimicamente esteve associado com o aumento no índice de cristalinidade; entretanto não observaram correlações diretas e exatas. Deste modo, os autores 
concluíram que o valor do índice de cristalinidade medido não apresenta uma relação direta com a susceptibilidade das ligações $\beta$-glicosídicas à hidrólise enzimática, portanto com o rendimento de glicose obtido.

Esta falta de consenso nas interpretações pode também ser parcialmente atribuída às diferenças nas técnicas de medida usadas para calcular a cristalinidade da celulose, que implicam em incertezas significantes nos valores de índice de cristalinidade calculados, como também às variações nas condições de secagem e preparo do substrato antes da análise em si (BANSAL et al., 2012; ZHANG; LYND, 2004).

A organização cristalina da celulose pode afetar não só a adsorção das celulases como também a efetividade dos componentes adsorvidos. HU et al. (2015b) constataram que os valores de grau de sinergismo entre os componentes de um coquetel enzimático de Trichoderma reesei apresentaram uma relação linear positiva com a área superficial acessível da celulose com morfologia desordenada (acessada pela razão entre as adsorções enzimáticas na porção amorfa acessível e na porção cristalina acessível), isto é, uma maior cooperação sinérgica entre as celulases é encontrada na celulose acessível com maior percentual de regiões amorfas.

\subsubsection{Comportamento cinético da hidrólise enzimática da celulose}

Um dos maiores gargalos no desenvolvimento da etapa de hidrólise enzimática da biomassa lignocelulósica é o grande declínio observado na taxa de conversão da celulose com o tempo de reação. A curva de conversão da celulose em glicose por tempo, em processos enzimáticos batelada que aplicam as três classes de glicosil hidrolases mencionadas anteriormente, é caracterizada por três fases típicas, conforme ilustrado na Figura 15: inicialmente há a adsorção das celulases na porção celulósica prontamente acessível, seguida por uma hidrólise inicial de taxa rápida; entretanto, a reação rapidamente alcança uma fase intermediária de velocidade moderada, quando aproximadamente 50-70\% do substrato é hidrolisado; subsequentemente, uma fase muito lenta é caracterizada pela diminuição estável na velocidade da reação, que resulta em apenas um pequeno aumento na conversão da celulose restante (chamada de celulose "inacessível" ou recalcitrante) (ANDERSEN, 2007; ARANTES; SADDLER, 2011). 
Figura 15. Curva típica da conversão da celulose por tempo de reação de hidrólise enzimática.

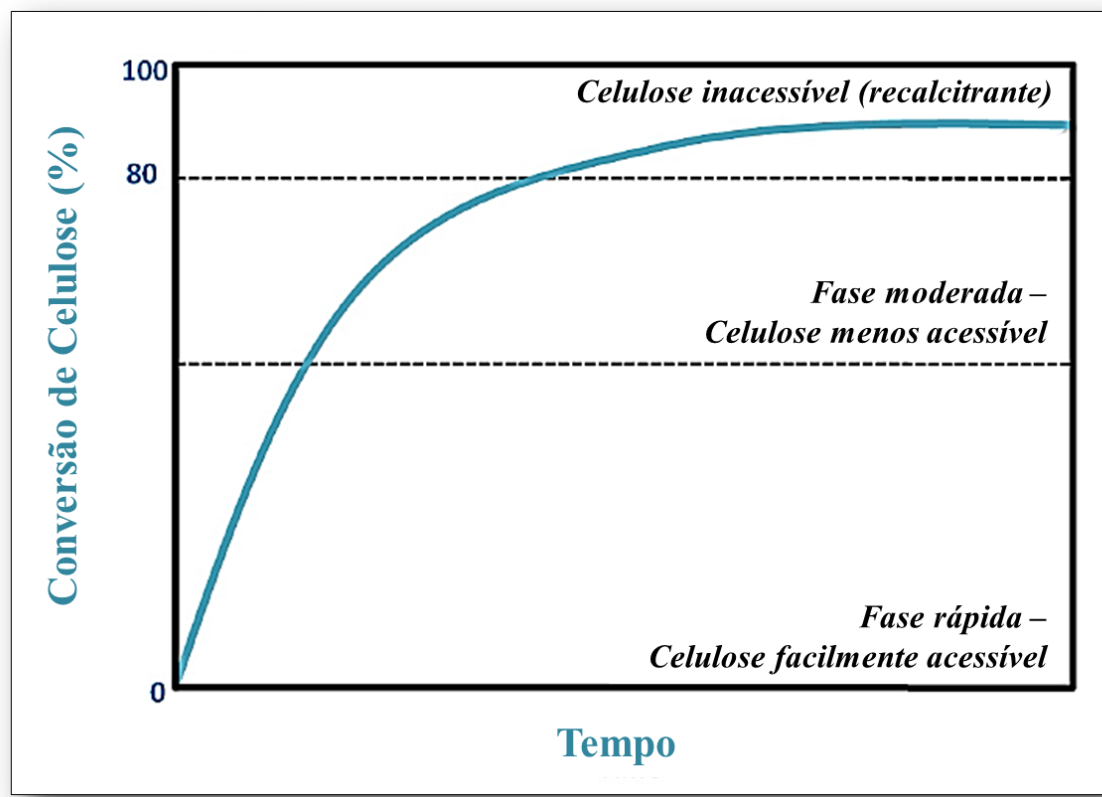

Fonte: Adaptado de: ARANTES; SADDLER, 2011.

Por conseguinte, a aplicação das enzimas em nível comercial é dificultada não só pelo seu alto custo, mas também pelos tempos de hidrólise mais extensos requeridos para alcançar uma conversão completa da celulose. Em alguns casos, dependendo da natureza do substrato e do método de pré-tratamento aplicado, até mesmo em cargas muito altas de proteínas e tempos extensos, a hidrólise completa da celulose não pode ser alcançada (ARANTES; SADDLER, 2011; BANSAL et al., 2012). Entre as hipóteses para o rápido declínio na taxa de reação da hidrólise da celulose estão:

- Fatores relacionados à atividade enzimática: a inativação das celulases, a queda no sinergismo entre os componentes e, principalmente, a inibição por produtos;

- Fatores relacionados ao substrato lignocelulósico: as mudanças na acessibilidade do substrato, o aumento no grau de cristalinidade da celulose, a queda no número de extremidades livres da cadeia celulósica para a atuação das $\mathrm{CBH}$, os obstáculos formados na superfície das fibrilas celulósicas e a exposição da lignina com o decorrer da reação.

Em relação ao substrato celulósico, é geralmente mencionado que o drástico declínio na velocidade com o progresso da reação é devido à sua transformação em uma forma "menos digestível". Visto que as regiões prontamente acessíveis da celulose são rapidamente hidrolisadas, nos tempos posteriores pode haver o acúmulo de celulose recalcitrante e, consequentemente, a diminuição da taxa de hidrólise com o decorrer da reação. Neste caso, tanto a acessibilidade quanto a reatividade do substrato celulósico são potenciais causas para o 
longo tempo de residência requerido para uma boa conversão em açúcares redutores (BANSAL et al., 2012; MOONEY et al., 1998; YANG et al., 2011).

O valor do grau de cristalinidade dos substratos celulósicos, conforme detalhado nos itens 2.2.4.2 e 2.2.5.3, explica a variação na taxa inicial da reação, porém não o valor de conversão final. Isto porque foi observado um pequeno aumento no grau de cristalinidade de substratos celulósicos nos tempos iniciais da reação hidrolítica pelo rápido consumo da porção amorfa altamente acessível; após esta rápida conversão inicial, a cristalinidade se mantém constante devido à digestão simultânea das frações cristalina e amorfa da celulose (BANSAL et al., 2012; CHANG; HOLTZAPPLE, 2000; GOURLAY et al., 2015; PIHLAJANIEMI et al., 2016). Em conclusão, enquanto é constatado o aumento do valor do grau de cristalinidade de forma apenas incremental e nos instantes iniciais da reação hidrolítica, a taxa de reação decai consideravelmente ao longo de um tempo maior.

Com o consumo dos polissacarídeos mais facilmente acessíveis, é esperado o decaimento na área superficial acessível da celulose residual com o tempo de reação enzimática. Entretanto, não há um consenso quanto ao comportamento da área superficial acessível com o decorrer da hidrólise e de como este parâmetro influencia a variação na velocidade da reação. BANSAL et al. (2012) constatou que a acessibilidade à celulose decaiu de modo constante até a reação alcançar 70\% de conversão. WANG et al. (2006) mostrou que a acessibilidade da celulose se torna limitada com a sua digestão. Já FAN, LEE e BEARDMORE (1980) observaram o aumento expressivo da área superficial específica da celulose durante o período inicial da reação enzimática (aproximadamente 3x nas primeiras 6h), que foi associado à redução no tamanho das partículas pelo fenômeno de fragmentação que ocorre durante a hidrólise; após este período, nenhuma mudança significativa foi observada na área superficial da celulose. Uma vez que a taxa de hidrólise decaiu substancialmente mesmo com o aumento na área superficial acessível da celulose, concluiu-se que este não é o principal fator que influencia a taxa de hidrólise nos últimos estágios.

A evolução na morfologia do substrato ao longo da hidrólise (erosão causada na superfície das fibrilas celulósicas) pode governar a taxa de reação pela inativação das enzimas celobiohidrolases, que ficam retidas nos defeitos estruturais por terem sua ação processiva impedida estéricamente (HU et al., 2015b; JALAK; VÄLJAMÄE, 2010; VÄLJAMÄE et al., 1998). Devido às grandes dimensões das celulases, estas também podem ficar aprisionadas dentro dos poros da parede celular ao longo da reação, havendo a perda de proteínas ativas 
para o sequenciamento da hidrólise (ZHANG; LYND, 2004). Ambos os fenômenos corroboram com as interpretações de CONVERSE et al. (1988), que relacionaram a redução na atividade e na concentração de enzimas adsorvidas ao longo da hidrólise com a desativação das enzimas, tanto pelo aprisionamento dentro do substrato celulósico quanto pela restrição espacial exercida pela superfície do substrato e por outras enzimas.

Outro parâmetro que exerce considerável efeito na redução da taxa da reação hidrolítica é a presença da lignina, que diminui a quantidade de proteínas para a sacarificação por se ligar de forma irreversível e não produtiva às celulases (item 2.2.5.2.2). VERMAAS et al. (2015) ainda sugeriu que, com o decorrer da reação, os resíduos do CBM das enzimas TrCel7A otimizam sua área superficial de contato com a lignina, de forma que a população enzimática se liga com maior probabilidade à lignina residual do substrato do que à celulose.

Em suma, todos os efeitos que resultam na redução da atividade catalítica, pela diminuição na capacidade de adsorção e pelo aprisionamento das enzimas com o tempo de reação, contribuem em alguma extensão para o decaimento na velocidade da hidrólise ao longo da conversão da celulose.

\subsubsection{Modelagem matemática da digestão enzimática da celulose}

Em vista do conteúdo explanado nos tópicos anteriores, é de acordo que a complexidade da estrutura das biomassas lignocelulósicas torna a elucidação e a previsão do comportamento do sistema verdadeiros desafios, de modo que avanços representativos ainda não foram alcançados na efetividade do processo global. Neste ponto, a questão a ser respondida é: em que extensão ou por qual fator cada um dos principais aspectos estruturais influenciam quantitativamente as taxas de adsorção enzimática e a produtividade final de açúcares redutores a partir da sacarificação dos polissacarídeos da parede celular?

Apesar da variedade de análises disponíveis para a caracterização das lignoceluloses em níveis morfológicos, micro e nanoestruturais, as propriedades encontram-se intervinculadas em tal ponto que a interpretação dos valores é em muitos casos dúbia. Soma-se o impasse de que muitos métodos de processamento aplicados às biomassas alteram mais de uma propriedade estrutural ao mesmo tempo. Uma possível alternativa para solucionar este impasse é o uso de ferramentas de análises computacionais e estatísticas baseadas em componentes principais, que podem relacionar as informações geradas nas demais 
capacidades de forma confiável, e então gerar modelos de predição. A quantificação da importância relativa dos diferentes aspectos limitantes da bioconversão por sua vez permitirá aprimorar a etapa prévia de processamento da biomassa por fornecer um guia de quais características do substrato devem ser alteradas.

Por definição, um modelo matemático é a descrição geral das características de um processo, objeto ou conceito, por meio de parâmetros matemáticos, de modo que a manipulação relativamente simples das variáveis permite determinar como o sistema se comporta em diferentes situações. Para o desenvolvimento de um modelo matemático que descreva quantitativamente o processo de hidrólise enzimática de um substrato lignocelulósico deve-se primeiramente identificar os aspectos mais cruciais que influenciam a sacarificação. Estes agregam todo o conhecimento acerca do processo, e incorporam parâmetros mensuráveis a respeito dos componentes glicosil hidrolíticos, dos aspectos estruturais da parede celular vegetal, assim como dos modos de interação entre eles no meio reacional, para predizer a conversão dos polissacarídeos em açúcares redutores. A comparação entre os valores preditos e os experimentais é uma maneira sistemática de verificar se o conhecimento associado é suficiente para explicar uma dada observação (ANDERSEN, 2007; ZHANG; LYND, 2004).

Entretanto, há uma profunda dificuldade em determinar um único modelo que antecipe a taxa de hidrólise enzimática da celulose, principalmente pelo fato de que os diferentes sistemas de celulases compreendem múltiplos componentes com distintos modos de atuação, e que são influenciados pelas propriedades dos substratos, que também variam de acordo com a fonte e o tecido vegetal. Ademais, outros aspectos inerentes da reação hidrolítica, como as mudanças na adsorção das enzimas e nos aspectos estruturais com o tempo e a de inibição por produtos, influenciam em grande extensão a resposta final (ANDERSEN, 2007; ARANTES; GOURLAY; SADDLER, 2014; WALKER; WILSON, 1991; ZHANG; LYND, 2004).

Muitos dos modelos quantitativos desenvolvidos e apresentados na literatura onde as propriedades do substrato lignocelulósico desempenham papel central são de natureza empírica (não mecanística) (ANDERSEN, 2007; WALKER; WILSON, 1991; ZHANG; LYND, 2004). Estes provêm correlações tanto para a conversão fracional quanto para a taxa de reação como função de vários fatores mensuráveis de entrada, como teor de lignina, área superficial e índice de cristalinidade. 
A correlação (linear ou de outra natureza) entre os parâmetros estruturais e o rendimento de açúcares obtidos por hidrólise possibilita a facilidade de utilizar métodos de análise para prever, de maneira rápida e com o uso de pequena quantidade de amostras, a conversão enzimática de uma determinada amostra (CHANG; HOLTZAPPLE, 2000; HUANG et al., 2010; JIANG et al., 2016). Entretanto, a regressão linear direta e individual de cada um dos parâmetros com a resposta final não pode ser aplicada de forma confiável para a estimativa da importância relativa entre as variáveis, já que estes fatores estão correlacionados entre si (PIHLAJANIEMI et al., 2016).

Uma expressão empírica desenvolvida por FAN, LEE e BEARDMORE (1981) para a extensão da hidrólise da celulose após $8 \mathrm{~h}$ de reação, obtida pela regressão linear dos dados experimentais, incluiu apenas a área superficial específica (ASE) e o índice de cristalinidade (ICr) como parâmetros estruturais; segundo os índices numéricos deste modelo, a taxa de hidrólise é mais sensível ao ICr do que à ASE. Resultados similares foram reportados por PENG et al. (2013) para o rendimento de glicose após 6h de hidrólise de amostras de celulose microcristalinas pré-tratadas por métodos físicos (moinho de bolas e/ou irradiação microondas). Os autores descreveram um modelo por meio da correlação e otimização com algoritmos de Levenberg-Marquardt dos dados experimentais de área superficial específica, índice de cristalinidade e grau de polimerização (DP) com a resposta; o quadrado do coeficiente de correlação para a equação gerada foi 0,849 , o que indica que o modelo pôde explicar $84,9 \%$ da variabilidade da resposta.

Já o modelo obtido por GHARPURAY, LEE e FAN (1983), que descreveu a influência das características estruturais da palha de trigo pré-tratada (por moagem e prétratamentos químicos em diferentes severidades) na extensão da conversão da celulose após 8h de hidrólise, considerou além da ASE e do ICr, o teor de lignina residual na amostra (L). Apesar de a conversão da celulose aumentar tanto com o aumento na área superficial acessível quanto com o decréscimo no índice de cristalinidade e no teor de lignina, a expressão gerada indicou que a taxa de hidrólise é mais sensitiva à ASE; entretanto, os autores afirmam que o fato de a ASE ter sido obtida por adsorção de nitrogênio em amostras secas fez com que este valor fosse enormemente subestimado, de modo que outras variáveis foram necessárias para alcançar uma correlação razoável.

CHANG e HOLTZAPPLE (2000) realizaram um estudo aplicando diferentes tipos de pré-tratamentos químicos e/ou mecânicos à madeira de álamo, de forma a obter 147 amostras 
de biomassa com um amplo espectro de teores de lignina, teores de grupo acetila e índices de cristalinidade, que permitissem identificar um modelo empírico que descrevesse o papel de cada uma destas três propriedades na hidrólise enzimática dos polissacarídeos. A equação obtida permitiu aos autores concluírem que o teor de lignina e o índice de cristalinidade apresentam o maior impacto na conversão final, enquanto o teor de acetila possui o menor efeito. Apesar da boa correlação obtida entre as dados calculados pelo modelo e os dados obtidos experimentalmente $\left(0,86<\mathrm{R}^{2}<0,91\right)$, os autores levantaram a hipótese da dispersão dos dados poder ser devida a outras características estruturais faltantes, cujas análises poderiam completar o modelo e predizer a digestibilidade, ou até mesmo ser devida ao uso do parâmetro "índice de cristalinidade" (medida não apropriada da cristalinidade da celulose na presença de componentes amorfos - lignina e hemiceluloses). Os autores também propuseram que o desvio no modelo para a conversão total após $72 \mathrm{~h}$ de reação foi ocasionado em alguma extensão pela alteração nas propriedades estruturais dos substratos com o decorrer da reação.

Recentemente JIANG et al. (2016) também especificaram um modelo para a predição empírica da conversão enzimática dos polissacarídeos de partículas de madeira de conífera, cominuídas mecanicamente em diferentes condições, a partir do estudo de sua morfologia e cristalinidade. Primeiramente, os autores observaram uma correlação linear entre o aumento da conversão dos carboidratos e a área superficial externa volumétrica $\left(\operatorname{ASEE}_{\mathrm{V}}, \mathrm{R}^{2}=0,93\right)$, e uma correlação independente entre a conversão e o ICr. Ademais, não encontraram correlação de nenhuma natureza entre os dois parâmetros, o que levou à conclusão de que a conversão dos carboidratos da amostra cominuída é afetada pela contribuição coletiva de ambos. O modelo pôde explicar $95,2 \%$ da variabilidade na resposta, sendo que o coeficiente positivo para a $\mathrm{ASEE}_{\mathrm{V}}$ indicou que o decaimento no tamanho das partículas e na razão de aspecto facilita a conversão pelo aumento na acessibilidade enzimática, enquanto o coeficiente negativo para o $\mathrm{ICr}$ indicou que o rompimento na estrutura cristalina da biomassa aumenta a digestibilidade dos carboidratos.

Autores de outros trabalhos, com o conhecimento da natureza heterogênea dos dados e da inter-correlação entre as propriedades estruturais, optaram pelo uso de análises estatísticas multivariadas visando reduzir a dimensionalidade das informações e, então, identificar e discriminar por qual fator cada um dos parâmetros analisados influencia na resposta final. Além disso, em alguns casos os objetivos foram determinar quais as análises necessárias para obter informações com grande acurácia a respeito das características do material. As análises 
estatísticas multivariadas são ferramentas matemáticas que podem ser aplicadas às análises químicas, uma vez que encontram a relação entre os parâmetros medidos baseado em suas variâncias e permitem modelar diferentes variáveis simultaneamente, o que é útil quando mais de uma medida é adquirida para cada amostra (LAUREANO-PEREZ et al., 2006).

A análise de componentes principais (principal component analysis, PCA) é uma das ferramentas de análise estatística multivariada que tem por finalidade a redução, a eliminação de sobreposições e a escolha das formas mais representativas de um conjunto de dados a partir de combinações lineares das variáveis originais. Esta análise transforma variáveis discretas inter-relacionadas que afetam a variabilidade do sistema em coeficientes linearmente descorrelacionados (as componentes principais, PCs), cujo número é menor ou igual ao número de variáveis originais. As PCs permitem identificar a relação entre várias características extraídas de amostras e reconhecer quais os aspectos fundamentais que explicam o comportamento das amostras no sistema (BAUM et al., 2010; HUANG et al., 2010; LAUREANO-PEREZ et al., 2006; XU et al., 2016).

A PCA consiste em promover uma transformação linear nos dados, de modo que os dados resultantes desta transformação tenham suas componentes mais relevantes nas primeiras dimensões, em eixos denominados principais. A componente principal primária (PC1) é o arranjo que melhor representa a distribuição dos dados e a componente secundária (PC2) é perpendicular à componente principal primária. A matriz de transformação utilizada para o cálculo da PCA consiste em uma matriz cujas colunas são os auto-vetores da matriz de covariância estimada dos dados. A matriz de covariância é uma matriz simétrica e definida positiva, que possui informação sobre as variâncias em todos os eixos onde os dados estão distribuídos; os auto-vetores desta matriz formam uma nova base que segue a variação dos dados. A PCA, portanto, consiste em uma mudança de base por decomposição em autovalores. Em outras palavras, as componentes principais são combinações lineares das variáveis originais, mais especificamente dos autovalores da matriz de covariância destas variáveis (LAUREANO-PEREZ et al., 2006; PIHLAJANIEMI et al., 2016; XU et al., 2016).

Em uma análise de componentes principais, o agrupamento das amostras define a estrutura dos dados através de gráficos de scores e loadings, cujos eixos são as componentes principais (PCs) nos quais os dados são projetados. Os scores fornecem a composição das PCs em relação às amostras, enquanto os loadings fornecem essa mesma composição em relação às variáveis. Como os PCs são ortogonais, os gráficos dos scores e dos loadings 
permitem estimar, separadamente, a influência de cada variável em cada amostra. Além disso, cada variável pode ser recombinada linearmente por seus loadings utilizando os scores individuais (BAUM et al., 2010; LAUREANO-PEREZ et al., 2006).

A regressão por componentes principais reduz o número de variáveis necessárias para descrever o comportamento de um sistema por descartar as combinações lineares com pequenas variâncias e estudar apenas as combinações com maior variância. Assim, a PCA tem se demonstrado como uma ferramenta de análise efetiva para a identificação dos fatores que afetam a taxa de conversão enzimática de biomassas lignocelulósicas, uma vez que simplifica os dados de análises e facilita a extração das informações importantes. Com a aplicação de análises multivariadas são desenvolvidos modelos empíricos para predizer a conversão de amostras desconhecidas baseado em suas características conhecidas. (BAUM et al., 2010; LAUREANO-PEREZ et al., 2006). No modelo desenvolvido, as componentes principais que contam para a maior parte da variância dos dados são combinadas linearmente de acordo com a magnitude e a direção do seu efeito, e o conjunto é então regredido com os dados de hidrólise (PIHLAJANIEMI et al., 2016; XU et al., 2016).

A seguir são descritos alguns dos estudos recentes que utilizaram a análise de componentes principais ou outras análises estatísticas multivariadas com o intuito de comparar quantitativamente os efeitos dos parâmetros estruturais na hidrolisabilidade enzimática da celulose das biomassas lignocelulósicas.

$\mathrm{Na}$ análise realizada por XU et al. (2016) para amostras de palha de arroz pré-tratadas, a variável combinada $\mathrm{PC} 1$ respondeu por $81,1 \%$ da variância total dos dados, o que indica sua adequação para caracterizar a recalcitrância da biomassa à degradação. Os altos valores de loadings obtidos significam que todas as propriedades analisadas contribuíram para a PC1 significantemente e, portanto, são importantes fatores que afetam a hidrólise enzimática dos polissacarídeos; dentre estas variáveis, a ASE e o volume de poros são as mais significativas. De modo complementar, provou-se que a PC1 é uma variável adequada para predizer a digestibilidade enzimática da biomassa, visto que se encontrou uma boa relação linear positiva entre a digestibilidade da celulose e os scores da PC1 $\left(\mathrm{R}^{2}=0,95\right)$. Pôde-se ainda afirmar que a digestibilidade dos polissacarídeos pode ser simplesmente caracterizada por um componente principal, ao invés de múltiplas e inter-correlacionadas variáveis, o que demonstra a efetividade da PCA para a redução da dimensionalidade do sistema. 
Já o estudo realizado por PIHLAJANIEMI et al. (2016) classificou os fatores por trás da hidrolisabilidade de amostras de palha de trigo, pré-tratadas em diferentes condições, quanto à sua importância relativa nas conversões inicial e final dos polissacarídeos. A maior importância relativa da área superficial da celulose enfatiza a importância da remoção das barreiras físicas e o papel cinético da superfície de celulose representando a quantidade de substrato disponível na reação.

A análise de mínimos quadrados, aplicada por HUANG et al. (2010) a amostras de espiga de milho pré-tratadas quimicamente, converteu os principais aspectos estruturais que afetam a taxa inicial (2h) e a extensão da digestibilidade enzimática $(24 \mathrm{~h})$ em variáveis $\left(\mathrm{PC}_{2}\right.$ e $\mathrm{PC}_{24}$ ) que responderam por $78 \%$ e $77 \%$ da variância total do sistema, respectivamente. Enquanto a componente $\mathrm{PC}_{2}$ foi principalmente influenciada pela área superficial acessível interna, pela desconstrução das interações de hidrogênio e pelo teor de lignina, a componente $\mathrm{PC}_{24}$ esteve principalmente relacionada com a área superficial acessível interna e o teor de lignina. Outras propriedades como a área superficial externa acessível, a quebra das interações de hidrogênio intramoleculares e a cristalinidade da celulose apresentaram pouco efeito na eficiência da hidrólise enzimática. Os autores atentam ao fato de que todas as amostras analisadas foram geradas por pré-tratamentos químicos, onde houve a alteração da composição química concomitantemente com a alteração dos demais parâmetros.

Uma vez discriminadas e dimensionadas as funções de cada propriedade estrutural em restringir a acessibilidade enzimática, adquire-se o conhecimento de como facilitar a atuação das proteínas hidrolíticas sobre os polissacarídeos constituintes da parede celular vegetal. Este domínio manifesta-se na oportunidade de desenvolver processos e/ou equipamentos que provoquem as alterações desejadas nas fibras da biomassa, de forma a alcançar a abertura máxima na estrutura com acesso aos carboidratos poliméricos, porém mantendo outras características de interesse (ARANTES; SADDLER, 2011; CHANG; HOLTZAPPLE, 2000; GOURLAY et al., 2015; HUANG et al., 2010; JIANG et al., 2016; MENON; RAO, 2012).

Convém aqui novamente definir o conceito de pré-tratamento, que é um conjunto de processos e tecnologias para a superação da recalcitrância intrínseca da parede celular pela alteração dos diferentes parâmetros estruturais. Estes compreendem métodos que promovam desde a solubilização seletiva dos componentes não celulósicos até a delaminação, o rompimento e a completa desestruturação da organização da parede celular (ALVIRA et al., 2010; MENON; RAO, 2012; SUN et al., 2016; ZHAO; ZHANG; LIU, 2012). 


\subsubsection{Pré-tratamentos aplicados às biomassas lignocelulósicas}

Conforme a própria denominação sugere, os pré-tratamentos são aplicados à biomassa lignocelulósica em etapa prévia à sacarificação enzimática dos polissacarídeos da parede celular. É esperado que as mudanças estruturais provocadas nas fibras permitam que a etapa posterior seja realizada com uma menor carga enzimática em um menor tempo de reação e com maior produtividade total dos açúcares redutores de interesse, o que viabiliza o processo como um todo (ALVIRA et al., 2010; AMORE et al., 2016; BANSAL et al., 2012; CANILHA et al., 2012; CARDONA; QUINTERO; PAZ, 2010; GALBE; ZACCHI, 2007; HAHN-HÄGERDAL et al., 2006; LEU; ZHU, 2013; MENON; RAO, 2012; PRASAD; SINGH; JOSHI, 2007; SUN et al., 2016; TAHERZADEH; KARIMI, 2008; ZHAO; ZHANG; LIU, 2012; ZHU; PAN, 2010).

Diferentes tecnologias de pré-tratamentos foram propostas ao longo das últimas décadas, com muitas tendo sua origem na ciência da madeira para a fabricação de polpa, papel e celulose (RABEMANOLONTSOA; SAKA, 2016). Estas são descritas quanto ao seu mecanismo de ação e forças aplicadas, além das vantagens e desvantagens dos pontos de vista operacionais, ambientais e econômicos. Já a eficiência do processo é geralmente reportada com base no rendimento da subsequente etapa de hidrólise dos polissacarídeos, em função da qual se determina experimentalmente a condição ótima de operação em cada caso.

Com relação à natureza do mecanismo de ação, os pré-tratamentos podem ser classificados em quatro grupos principais: físico-mecânicos, químicos, físico-químicos ou bioquímicos. Uma vez que cada um destes possui características favoráveis e desfavoráveis, algumas publicações ainda dissertam a respeito das vantagens das combinações entre estes no intuito não só de aumentar a probabilidade de interações entre as fibrilas celulósicas e as enzimas degradadoras, como também de garantir a recuperação dos derivados hemicelulósicos e da lignina nas demais correntes de processo, ambos com características adequadas para a obtenção de outros produtos de maior valor agregado (ALVIRA et al., 2010; CANILHA et al., 2012; GALBE; ZACCHI, 2007; MENON; RAO, 2012; SUN et al., 2016; TAHERZADEH; KARIMI, 2008; ZHAO; ZHANG; LIU, 2012; ZHU; PAN, 2010).

No que concerne à eficiência econômica e ambiental, o pré-tratamento deve atender as seguintes premissas: evitar a degradação da celulose; evitar a degradação dos açúcares liberados no meio reacional; evitar a formação de possíveis inibidores de enzimas hidrolíticas 
e dos micro-organismos de fermentação; permitir a recuperação da lignina e de outros coprodutos de maior valor agregado; minimizar a demanda energética; reduzir os custos de operação; reduzir o custo com materiais de confecção dos equipamentos de pré-tratamento; consumir pouco ou nenhum reagente químico; e produzir pequena ou nenhuma quantidade de resíduos (ALVIRA et al., 2010; CANILHA et al., 2012; CARDONA; QUINTERO; PAZ, 2010; GALBE; ZACCHI, 2007; HAHN-HÄGERDAL et al., 2006; MENON; RAO, 2012; PRASAD; SINGH; JOSHI, 2007; SUN et al., 2016; TAHERZADEH; KARIMI, 2008; ZHAO; ZHANG; LIU, 2012; ZHU; PAN, 2010).

Identificar um único método de pré-tratamento que seja universalmente efetivo é de extrema dificuldade, uma vez que os materiais lignocelulósicos provindos de diferentes fontes vegetais não possuem as mesmas propriedades químicas, físicas e morfológicas. Portanto, a escolha do método, assim como das condições de processamento empregadas, é baseada nas características iniciais do substrato e que se desejam alterar. A seguir serão resumidos os principais modos de atuação de cada uma das classes de pré-tratamento, assim como suas vantagens e desvantagens.

\section{- Físico-mecânicos:}

Os tratamentos físico-mecânicos promovem a ruptura da estrutura da parede celular tanto por fenômenos de corte quanto de quebra, fibrilação, delaminação e irradiação, enquanto mantêm os constituintes químicos inalterados (JIANG et al., 2016). Deste modo, tem-se o aumento da área superficial específica acessível do substrato lignocelulósico pela redução das dimensões das fibras, pelo aumento da porosidade total ou ainda pela ruptura da regularidade estrutural; em alguns casos ainda são reportadas a quebra do arranjo cristalino da celulose e a redução de seu grau de polimerização. Entre os diferentes tipos de tratamentos físicos estão os métodos de cominuição mecânica (picagem, esmerilhamento e moagem), de refino e de irradiação. Uma vez que estes pré-tratamentos não alteram a composição da parede celular e não requerem a adição de regentes químicos, apresentam a vantagem de promover a abertura da estrutura sem que haja a degradação da lignina e dos carboidratos, portanto a formação de compostos inibidores; ademais, não envolvem custos associados à recuperação de reagentes e tratamento de efluentes, logo são considerados "ambientalmente amigáveis". Entretanto, um consumo energético consideravelmente alto é requerido para a produção de substratos que alcancem altas taxas e rendimentos de hidrólise enzimática, o que diminui o interesse 
econômico nestes tipos de processamento (ALVIRA et al., 2010; CANILHA et al., 2012; GALBE; ZACCHI, 2007; HENDRIKS; ZEEMAN, 2009; MENON; RAO, 2012; SUN et al., 2016; TAHERZADEH; KARIMI, 2008; ZHAO; ZHANG; LIU, 2012; ZHU; PAN, 2010).

\section{- Químicos:}

Os pré-tratamento químicos são processos que envolvem a quebra da matriz ligninacarboidratos, a solubilização seletiva - parcial ou total - dos componentes não celulósicos ou ainda o intumescimento da parede celular pelo uso de ácidos, bases, solventes (orgânicos ou iônicos) ou reagentes oxidantes. Como consequência, há o aumento do volume de poros e da área superficial total acessível das enzimas aos polissacarídeos. Quando o método provoca a solubilização das hemiceluloses e da celulose menos ordenada, é observado o aumento do grau de cristalinidade, como é o caso do tratamento com ácidos diluídos; já métodos que acarretam no intumescimento e no rompimento da estrutura cristalina, como o uso de ácidos concentrados, álcalis e líquidos iônicos, implicam na redução do grau de cristalinidade. Entre as variáveis controladas dos processos estão a temperatura da reação, o tempo, o pH e a concentração dos reagentes, que se relacionam diretamente com sua severidade. Em geral, são os métodos mais viáveis economicamente pela simplicidade de execução e menor consumo energético. Contudo, condições mais severas de reação podem ocasionar a degradação da celulose, a desidratação dos açúcares liberados no meio reacional além da alta formação de compostos fenólicos. Problemas associados à corrosão de equipamentos, ao manuseio da corrente líquida, à recuperação e reciclo de reagentes e ao tratamento de efluentes são outras importantes restrições ao processo (ALVIRA et al., 2010; CANILHA et al., 2012; GALBE; ZACCHI, 2007; MENON; RAO, 2012; RABEMANOLONTSOA; SAKA, 2016; SUN et al., 2016; TAHERZADEH; KARIMI, 2008; ZHAO; ZHANG; LIU, 2012; ZHU; PAN, 2010).

\section{- Físico-químicos:}

Os tratamentos físico-químicos são métodos que combinam as ações dos processos químicos e físicos, ou seja, promovem a quebra das ligações do complexo ligninacarboidratos, a despolimerização e solubilização parcial dos componentes não celulósicos, a separação dos feixes de fibras e a ruptura física da estrutura das fibras. Logo, aumentam a digestibilidade enzimática das biomassas pelo aumento expressivo da estrutura porosa, pela redução das partículas e pela delaminação e intumescimento da parede celular. Para isto, 
fazem uso de elevadas temperaturas e/ou pressões. Entre os principais parâmetros controlados estão o tempo de residência no reator, a temperatura, a pressão, a aplicação ou não de vapor, e a concentração do reagente (no caso de processos catalisados). Os tratamentos físico-químicos são considerados os métodos de maior eficiência energética e ambiental, dentre os quais os mais amplamente estudados e aplicados são os de explosão a vapor e o hidrotérmico - ambos processos auto-catalíticos, a explosão das fibras com amônia (ammonia fiber explosion, $A F E X$ ), o micro-ondas (assessor aos tratamentos químicos) e o supercrítico catalisado com $\mathrm{CO}_{2}\left(\mathrm{SC}-\mathrm{CO}_{2}\right)$. Com exceção dos processos catalisados $\left(A F E X\right.$ e $\left.\mathrm{SC}-\mathrm{CO}_{2}\right)$, não exigem a adição de outros reagentes químicos, portanto não acrescentam a etapa de neutralização da corrente líquida. Quando realizados em condições brandas de reação, a concentração de inibidores formados é relativamente baixa, logo permitem a recuperação em grande porcentagem dos carboidratos. A maior desvantagem destes processos está associada ao alto custo de instalação das unidades operacionais (ALVIRA et al., 2010; CANILHA et al., 2012; LEU; ZHU, 2013; MENON; RAO, 2012; RABEMANOLONTSOA; SAKA, 2016; SUN et al., 2016; TAHERZADEH; KARIMI, 2008; ZHAO; ZHANG; LIU, 2012).

\section{- Bioquímicos:}

Os pré-tratamentos bioquímicos são uma alternativa aos processos químicos, onde microrganismos ou enzimas isoladas são aplicados para a modificação da composição da biomassa pela degradação seletiva ou da lignina ou dos polissacarídeos. Fungos de bolores marrom e suave são utilizados quando o intuito é a digestão dos polissacarídeos, porém com mínimo efeito sobre a lignina. Já os fungos de bolor branco (Phanerochaete chrysosporium, Ceriporia lacerata, Cyathus stercoreus, Ceriporiopsis subvermispora, Pycnoporus cinnabarinus e Pleurotus ostreatus) são os mais amplamente aplicados pela maior efetividade na degradação da lignina pela ação das enzimas laccases, lignina-peroxidases e manganêsperoxidases. Algumas bactérias (Pseudomonas e bactérias filamentosas como Actinomycetes) também têm sido aplicadas com a finalidade de deslignificação. Alguns fungos de bolor branco também secretam enzimas que atacam os polissacarídeos, o que instiga a aplicação das enzimas lignolíticas isoladas como forma de evitar a perda dos açúcares de interesse. São processos de baixo consumo energético, de condições brandas de reação e ambientalmente amigáveis; entretanto, são requeridos longos tempos de pré-tratamento (em torno de semanas) e condições controladas de crescimento, o que limita sua aplicação industrial; mesmo a 
eficiência da remoção da lignina é baixa quando comparada aos métodos químicos (ALVIRA et al., 2010; CANILHA et al., 2012; GALBE; ZACCHI, 2007; MENON; RAO, 2012; RABEMANOLONTSOA; SAKA, 2016; SUN et al., 2016; TAHERZADEH; KARIMI, 2008; ZHAO; ZHANG; LIU, 2012).

\section{- Análise de combinação:}

Segundo o explicitado nos tópicos acima, os vários métodos de pré-tratamentos existentes diminuem a recalcitrância dos materiais lignocelulósicos por modos de ação distintos; no entanto, a maioria destes processos superam apenas alguns dos fatores que restringem a atuação enzimática. Deste modo, combinações entre pré-tratamentos são muitas vezes consideradas para maximizar a digestibilidade da celulose e a produtividade total de açúcares fermentescíveis. Todavia, os custos associados à adição de mais de uma etapa no processo devem ser compensados pela recuperação e uso dos derivados hemicelulósicos e da lignina (AMORE et al., 2016; SUN et al., 2016).

Para facilitar a recuperação dos componentes não celulósicos com maior pureza, a aproximação é fraciona-los, isto é, removê-los da biomassa em etapas individuais, e reter o sólido rico em celulose para a posterior etapa de hidrólise enzimática (AMORE et al., 2016; SUN et al., 2016). Uma vez que as hemiceluloses estão em íntima associação química com a lignina, a maioria dos métodos de deslignificação é acompanhada da remoção das hemiceluloses, portanto é recomendado que a primeira etapa seja a de dissolução das hemiceluloses pela aplicação de pré-tratamentos como hidrotérmico, ácido ou explosão a vapor; a posterior etapa de deslignificação pode ser realizada pelos métodos organossolve, oxidativo, alcalino ou biológico. Já os pré-tratamentos físicos podem ser inseridos em associação com os demais na mesma etapa (explosão a vapor, $\mathrm{AFEX}, \mathrm{SC}-\mathrm{CO}_{2}$ ou microondas) ou posteriormente (moagem, refino ou irradiação) para uma abertura adicional da área superficial acessível (SUN et al., 2016). As ligninas isoladas a partir de amostras pré-tratadas contêm menos carboidratos ligados em comparação às amostras não tratadas, ou seja, apresentam maior pureza (RAHIKAINEN et al., 2013).

A seguir são fundamentados dois dos métodos adotados neste estudo: o pré-tratamento hidrotérmico e a deslignificação organossolve. Já os mecanismos de ação e os efeitos do refino mecânico, amplamente estudado no projeto de tese, serão detalhados no item 2.2.7. 


\subsubsection{Pré-tratamento hidrotérmico}

O pré-tratamento hidrotérmico é um método de fracionamento auto-catalítico da biomassa lignocelulósica que ocorre com o uso de água como solvente a elevadas temperaturas, cujo principal objetivo é a solubilização das hemiceluloses. Neste processo, pressões acima do ponto de saturação do vapor são alcançadas no sistema fechado para manter a água no estado líquido nas altas temperaturas de trabalho. A água sob alta pressão penetra na estrutura da parede celular, hidrata as fibrilas celulósicas, hidrolisa e solubiliza majoritariamente as hemiceluloses e parcialmente a lignina. Como consequência, tem-se o rompimento do complexo lignina-carboidratos, a abertura da estrutura, assim como o aumento da acessibilidade à celulose. Entre os produtos principais da reação estão uma corrente líquida composta essencialmente de derivados hemicelulósicos e um resíduo sólido rico em celulose e lignina (ALVIRA et al., 2010; BOUSSARSAR; ROGÉ; MATHLOUTHI, 2009; DA CRUZ et al., 2012; DOGARIS et al., 2009; FAN et al., 2016; HU; FOSTON; RAGAUSKAS, 2011; HU; RAGAUSKAS, 2011; KO et al., 2015b; MENON; RAO, 2012; NEGRO et al., 2003; NITSOS; MATIS; TRIANTAFYLLIDIS, 2013; SAHA et al., 2013; SILVA et al., 2011; SUN et al., 2016; TAHERZADEH; KARIMI, 2008; VALLEJOS et al., 2012; XIAO et al., 2013; YU et al., 2013a; ZHAO; ZHANG; LIU, 2012).

É sugerido que várias reações contribuem para o resultado final do processo. Em altas temperaturas e pressões, os polissacarídeos dos materiais lignocelulósicos sofrem reações de hidrólise na presença dos íons hidrônio $\left(\mathrm{H}_{3} \mathrm{O}^{+}\right)$gerados in situ pela auto ionização da água, que atuam como catalisadores e proporcionam a manutenção de componentes ácidos na solução. As ligações glicosídicas das cadeias hemicelulósicas são as mais susceptíveis a este tipo de reação, sendo convertidas principalmente em oligossacarídeos. Concomitantemente ocorre a clivagem dos grupos acetila presentes na fração hemiceluloses, o que leva à liberação de ácido acético e à consequente redução do $\mathrm{pH}$ do meio reacional para valores entre 5,5 e 2,5. Nos próximos estágios da reação, os íons hidrônio gerados pela auto ionização do ácido acético promovem a catálise das reações hidrolíticas de quebra das ligações glicosídicas das cadeias de hemiceluloses e, principalmente, dos xilo-oligossacarídeos liberados no meio líquido (ALVIRA et al., 2010; FAN et al., 2016; HU; RAGAUSKAS, 2011; KO et al., 2015b; MENON; RAO, 2012; NEGRO et al., 2003; NITSOS; MATIS; TRIANTAFYLLIDIS, 2013; RABEMANOLONTSOA; SAKA, 2016; SANTUCCI et al., 2015; SILVA et al., 2011; SUN 
et al., 2016; TAHERZADEH; KARIMI, 2008; VALLEJOS et al., 2012; XIAO et al., 2013; YU et al., 2013b; ZHAO; ZHANG; LIU, 2012).

Uma vez que o meio reacional passa a apresentar caráter ácido, a reação de hidrólise das ligações glicosídicas segue um mecanismo de reação de substituição nucleofílica unimolecular (SN1), descrito por FENGEL e WEGENER (1989) em três etapas sequenciais, e ilustrado na Figura 16: 1) primeiramente, o próton interage rapidamente com o oxigênio glicosídico que liga duas unidades de açúcar (I), com a consequente formação de um ácido conjugado (II); 2) esta etapa é seguida pela clivagem da ligação C-1---O-4 e pela formação de um carbocátion cíclico (III), estabilizado por ressonância; 3) finalmente, a molécula de água nucleofílica é adicionada ao carbocátion no C1 (IV), resultando em um produto final estável.

Conforme mencionado anteriormente, enquanto as características estruturais das hemiceluloses as tornam susceptíveis aos processos hidrolíticos, a estrutura cristalina e altamente empacotada das fibrilas de celulose faz com que estas sejam resistentes à despolimerização. Assim, sob condições hidrotérmicas, a hidrólise da celulose ocorre em extensões muito pequenas (FAN et al., 2016; NEGRO et al., 2003; SANTUCCI et al., 2015).

Como forma de prover altas taxas de solubilização das hemiceluloses, porém evitar a degradação da celulose, a temperatura do tratamento hidrotérmico é geralmente mantida entre $160^{\circ} \mathrm{C}$ e $240^{\circ} \mathrm{C}$. Já o tempo de reação pode variar entre poucos minutos a várias horas, e depende da temperatura aplicada. Há ainda a possibilidade de catalisar o processo com a adição de ácidos, álcalis ou cloretos metálicos para assistir a remoção das hemiceluloses e/ou da lignina e otimizar a recuperação dos sacarídeos (ALVIRA et al., 2010; BOUSSARSAR; ROGÉ; MATHLOUTHI, 2009; FAN et al., 2016; HU; FOSTON; RAGAUSKAS, 2011; HU; RAGAUSKAS, 2011; NITSOS; MATIS; TRIANTAFYLLIDIS, 2013; SILVA et al., 2011; SUN et al., 2016; VALLEJOS et al., 2012; XIAO et al., 2013; YU et al., 2013a).

O aumento na severidade (temperatura e tempo) da reação hidrotérmica acarreta na hidrólise mais intensa dos grupos acetilas das hemiceluloses, logo uma maior concentração de ácido acético é formada. Uma maior concentração de ácido, por sua vez, resulta em uma maior solubilização das hemiceluloses assim como em um menor rendimento de massa residual pré-tratada (FAN et al., 2016; HU; FOSTON; RAGAUSKAS, 2011; HU; RAGAUSKAS, 2011; MITTAL et al., 2009; NEGRO et al., 2003; NITSOS; MATIS; TRIANTAFYLLIDIS, 2013; SANTUCCI et al., 2015; XIAO et al., 2013). 
Figura 16. Mecanismo de hidrólise ácido-catalisada das ligações glicosídicas dos polissacarídeos.

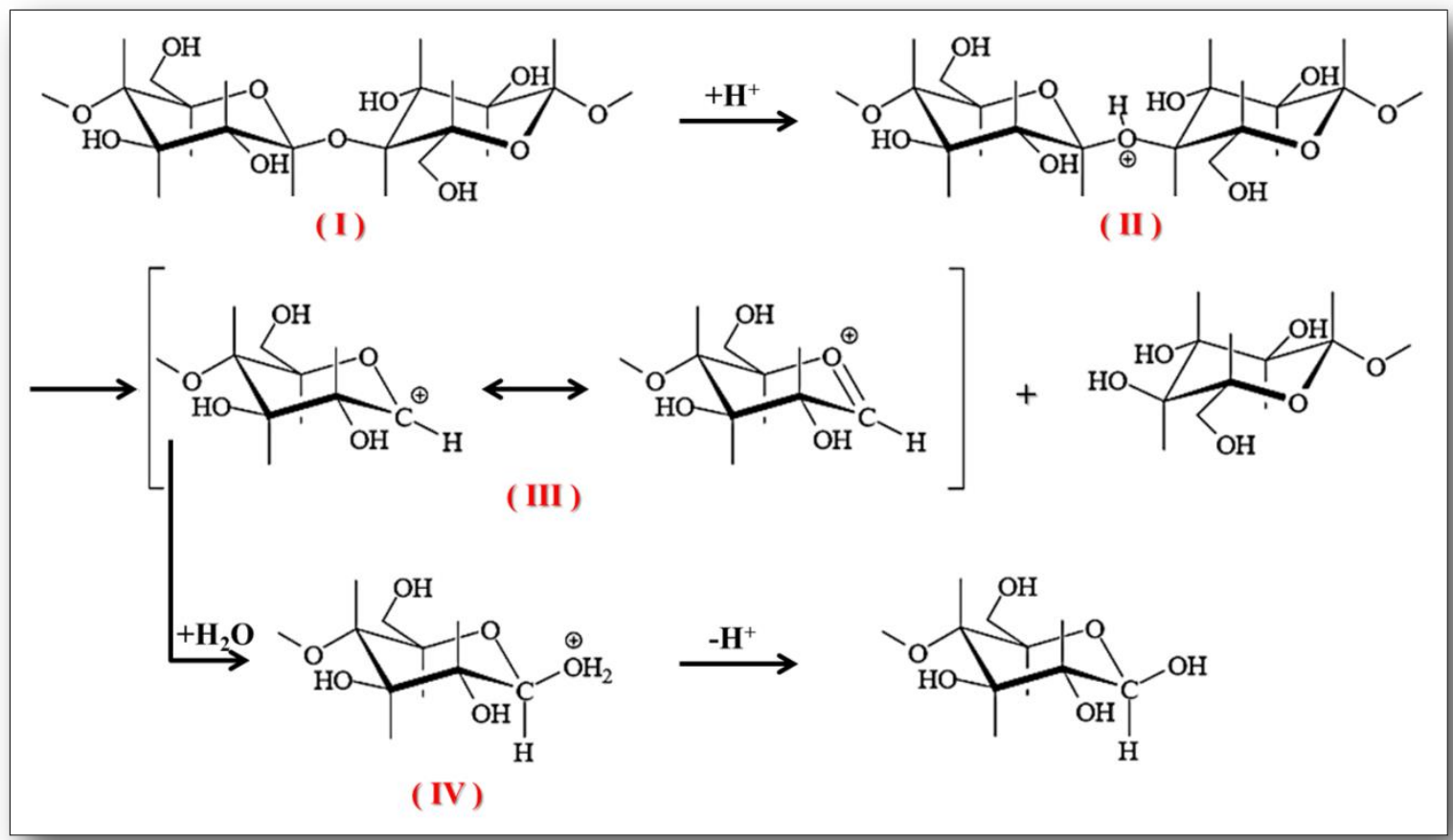

Fonte: Adaptado de: FENGEL;WEGENER, 1989; MARABEZI, 2009.

Entretanto, quando realizado em condições muito severas, o pré-tratamento pode reduzir a concentração de açúcares redutores formados no meio reacional devido às subsequentes reações de desidratação. A desidratação catalisada por ácidos de açúcares conduz à formação de açúcares anidros com ligações glicosídicas intramoleculares, que decorrem da eliminação de uma molécula de água a partir de dois grupos hidroxila. Visto que este tipo de ligação glicosídica é facilmente hidrolisável, uma série de produtos de degradação é prontamente formada. Os mais importantes produtos de degradação, considerando seu potencial de utilização, são o furfural (formado a partir das pentoses e ácidos urônicos) e o HMF (formado a partir das hexoses); estes derivados furânicos podem ainda ser degradados, onde o furfural forma ácido fórmico, e o HMF forma quantidades equimolares de ácido fórmico e ácido levulínico (Figura 17). Em razão destes produtos de degradação, assim como o ácido acético, atuarem como inibidores dos microrganismos de fermentação, pode ser necessária a separação entre os sólidos pré-tratados e o licor de reação, além da lavagem do resíduo sólido para a completa remoção destes compostos (FAN et al., 2016; FENGEL; WEGENER, 1989; KO et al., 2015b; NEGRO et al., 2003; NITSOS; MATIS; TRIANTAFYLLIDIS, 2013; XIAO et al., 2013). 
Segundo trabalhos previamente publicados, as concentrações de produtos de degradação formadas no licor durante o pré-tratamento hidrotérmico são relativamente baixas, e estas são consideradas como não significantemente inibitórias aos microrganismos fermentativos. Em geral, a concentração de HMF formada no meio líquido se mantém baixa e menor do que a de furfural pelo menor grau de hidrólise da celulose e consequente baixa formação de glicose no meio reacional (DA CRUZ et al., 2012; DOGARIS et al., 2009; NITSOS; MATIS; TRIANTAFYLLIDIS, 2013; SAHA et al., 2013; VALLEJOS et al., 2012).

Figura 17. Reações de formação do furfural, do HMF e outros produtos de degradação a partir dos monossacarídeos formados em meio ácido.

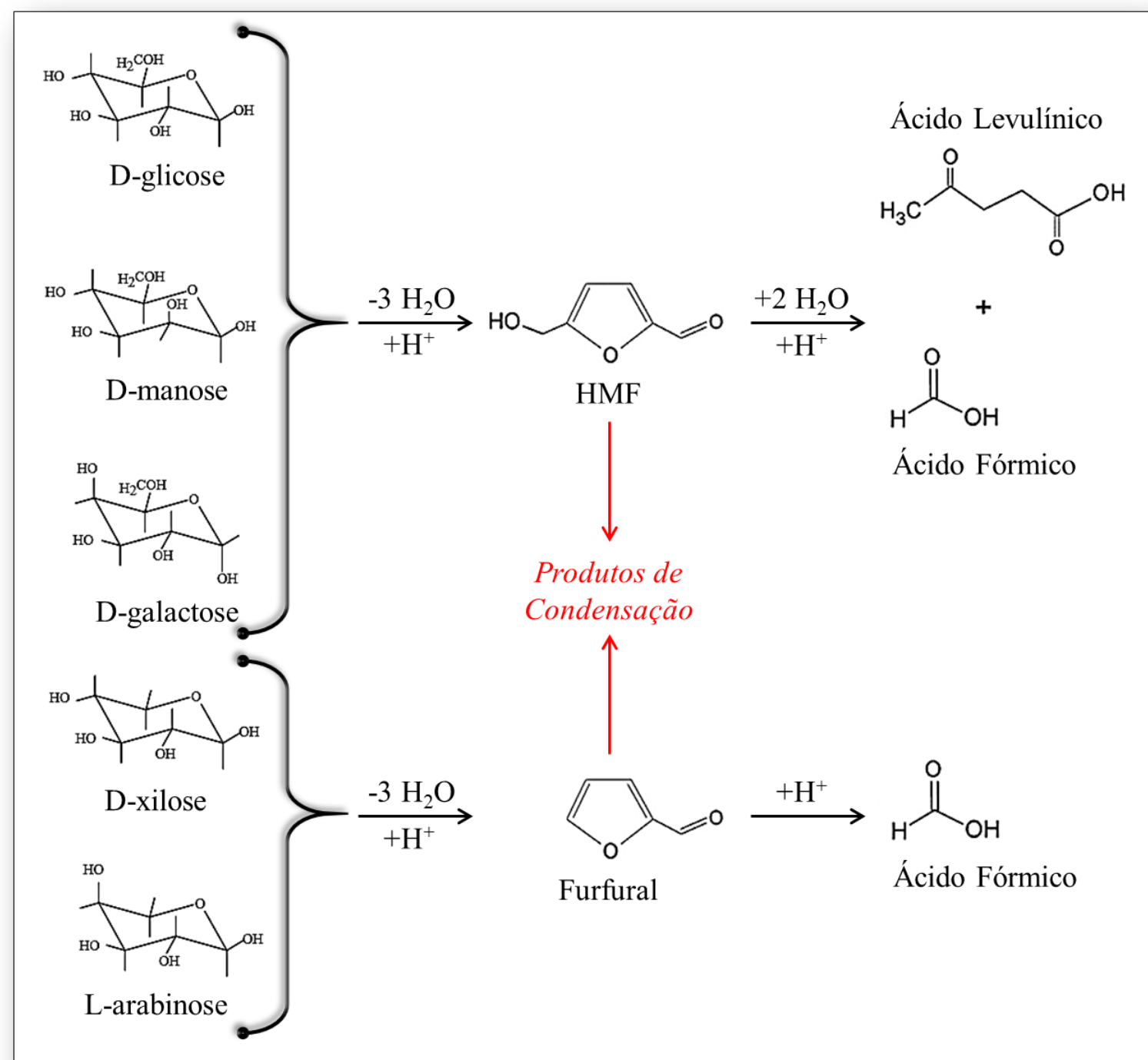

Fonte: Adaptado de: FENGEL;WEGENER, 1989; NITSOS; MATIS; TRIANTAFYLLIDIS, 2013. 
A severidade da reação afeta não só a solubilização das hemiceluloses como a razão entre o teor de oligos- e monossacarídeos e produtos de degradação formados na corrente líquida (KO et al., 2015b; NITSOS; MATIS; TRIANTAFYLLIDIS, 2013). A compreensão da cinética de hidrólise das hemiceluloses é fundamental para definir as condições ótimas para a solubilização máxima, junto da preservação dos açúcares no meio reacional e o controle da formação de inibidores (BOUSSARSAR; ROGÉ; MATHLOUTHI, 2009; DA CRUZ et al., 2012; MITTAL et al., 2009; NEGRO et al., 2003; NITSOS; MATIS; TRIANTAFYLLIDIS, 2013; SANTUCCI et al., 2015; VALLEJOS et al., 2012; XIAO et al., 2013).

Além da hidrólise das hemiceluloses, ocorre também a quebra das interligações da matriz lignina-polissacarídeos (ALVIRA et al., 2010; KO et al., 2015b; MENON; RAO, 2012; MERALI et al., 2013; RABEMANOLONTSOA; SAKA, 2016; SUN et al., 2016; TAHERZADEH; KARIMI, 2008; TRAJANO et al., 2013; ZHAO; ZHANG; LIU, 2012). MERALI et al. (2013) reportaram a solubilização dos ácidos p-cumárico, ferúlico e diferúlico, importantes agentes de interligação entre as hemiceluloses e a lignina, durante o prétratamento hidrotérmico da palha de trigo em proporções similares à solubilização das hemiceluloses. A redução nos teores destes componentes contribui para a desestruturação da parede celular, logo aumenta a acessibilidade às enzimas hidrolíticas (MERALI et al., 2013).

O pré-tratamento hidrotérmico pode ainda beneficiar a posterior etapa de hidrólise enzimática pela remoção, redistribuição e/ou modificação da lignina. Ao longo do tempo da reação, a lignina circula entre as fases sólida e líquida através de um mecanismo complexo que pode envolver sua transição de fase, despolimerização, solubilização e condensação, sendo que a ocorrência relativa de cada uma destas transformações é associada com a severidade da reação de pré-tratamento (FAN et al., 2016; TRAJANO et al., 2013).

Sob as condições do método hidrotérmico, a despolimerização da lignina ocorre predominantemente através da cisão ácido-catalisada das ligações alquil e aril éter (cujo mecanismo será demonstrado no item a seguir), onde as ligações $\beta-\mathrm{O}-4$ ' e $\alpha$-O-4' são as mais reativas (FAN et al., 2016; LESCHINSKY et al., 2008a; LESCHINSKY et al., 2008b; TRAJANO et al., 2013; XIAO et al., 2013). Entre os indícios de reações de fragmentação da lignina podem-se citar: a redução no teor de lignina no sólido residual, a redução da massa molecular da lignina, a perda de parte das ligações $\beta$-O-4' e de grupos metoxilas, o decorrente aumento no teor de grupos hidroxila-fenólicos, além da formação de fragmentos fenólicos no meio líquido. Com o aumento da severidade do pré-tratamento, a despolimerização da lignina 
é intensificada (FAN et al., 2016; HUIJGEN et al., 2012; NITSOS; MATIS; TRIANTAFYLLIDIS, 2013; OBAMA et al., 2012; TRAJANO et al., 2013).

Os fragmentos fenólicos formados no meio reacional também podem inibir ou desativar as celulases e as $\beta$-glicosidases via ligação irreversível ou por precipitação quando presentes em concentrações de micro- a milimolar. Ademais, fenólicos solúveis são tóxicos aos microrganismos de fermentação, e inibem seu crescimento e produção (KO et al., 2015b).

Em temperaturas mais elevadas e valores de $\mathrm{pH}$ mais baixos, os fragmentos de lignina solubilizados podem sofrer reações de condensação e depositar na superfície das fibras (ALVIRA et al., 2010; NITSOS; MATIS; TRIANTAFYLLIDIS, 2013; TAHERZADEH; KARIMI, 2008; XIAO et al., 2013; ZHAO; ZHANG; LIU, 2012). Sob condições ácidas, íons carbônio intermediários são formados dentro da estrutura da lignina com uma alta afinidade por nucleófilos. Enquanto reações de hidrólise e solvólise acarretam na despolimerização da lignina, reações entre os íons carbônio e os nucleófilos benzílicos levam ao aumento no grau de condensação pela formação de novas ligações carbono-carbono, como $\beta-\beta^{\prime}, \beta-1$ ' e $\beta-5$ ' (FAN et al., 2016; LESCHINSKY et al., 2008a; LESCHINSKY et al., 2008b; OBAMA et al., 2012; TRAJANO et al., 2013).

$\mathrm{O}$ aumento no teor de ligações $\mathrm{C}$ - $\mathrm{C}$ implica no aumento da massa molecular dos fragmentos de lignina. Devido à limitada solubilidade destes fragmentos condensados em meios aquosos acidificados, eles precipitam na superfície das fibras durante o resfriamento do reator, assumindo um formato esférico. A deposição da lignina condensada na superfície faz com que a porcentagem de solubilização da lignina calculada seja menor. Quanto maior a severidade da reação, maior a ocorrência das reações de condensação, e menor a quantidade e a diversidade de monômeros fenólicos encontrados no licor da reação (FAN et al., 2016; NITSOS; MATIS; TRIANTAFYLLIDIS, 2013; OBAMA et al., 2012; TRAJANO et al., 2013; XIAO et al., 2013).

Os fragmentos provindos da despolimerização da lignina podem ainda sofrer reações de condensação com produtos de degradação dos carboidratos, e acarretar na formação e acumulo de um material polimérico insolúvel em ácido, a "pseudo-lignina". Em alguns casos, é observado o aumento no teor de lignina insolúvel em ácido (lignina Klason) no resíduo sólido pré-tratado em relação ao material inicial, posto que as pseudo-ligninas não podem ser distinguidas da lignina Klason pelos métodos analíticos frequentemente empregados (FAN et al., 2016; HUIJGEN et al., 2012; PIHLAJANIEMI et al., 2016; TRAJANO et al., 2013; 
XIAO et al., 2013; YU et al., 2013b). A pseudo-lignina é mais resistente aos processos de deslignificação e, uma vez depositada na superfície das fibras, pode exercer papel crucial na efetividade da hidrólise enzimática (YU et al., 2013b).

Além do mais, foi demonstrado que a faixa de temperaturas geralmente empregadas no pré-tratamento hidrotérmico são próximas ou acima da temperatura de transição vítrea da lignina, que passa do estado rígido para o estado plástico. Como resultado, a lignina funde e coalesce em partículas esféricas, e se separa dos polissacarídeos; as gotículas formadas então migram gradualmente através das camadas da parede celular e depositam na superfície externa das fibras. Após o resfriamento, as gotículas formadas endurecem, alterando sua morfologia e distribuição (DONOHOE et al., 2008; FAN et al., 2016; HANSEN et al., 2011; TRAJANO et al., 2013; XIAO et al., 2013; YU et al., 2013a; YU et al., 2013b). YU et al (2013b) observaram, através de imagens de microscopia, que o tamanho médio das gotículas na superfície do material pré-tratado aumenta com o aumento na temperatura da reação.

Por conseguinte, apenas uma pequena porção da lignina é de fato removida durante o pré-tratamento hidrotérmico, sendo a maior parte deslocada e redistribuída na superfície das células vegetais com o aumento da severidade da reação. Este efeito aumenta a exposição e a área superficial de cobertura da lignina, o que promove o bloqueio do acesso das enzimas celulolíticas às fibrilas celulósicas, assim como aumenta a ocorrência da adsorção irreversível das enzimas na superfície da lignina. As alterações provocadas na estrutura química da lignina a tornam condensada, hidrofóbica e heterogênea, o que também aumenta o potencial de interações celulases-lignina não produtivas. Logo, o efeito positivo do pré-tratamento alcançado pelo rompimento da matriz da parede celular pode ser comprometido (DONOHOE et al., 2008; FAN et al., 2016; HANSEN et al., 2011; KO et al., 2015b; KUMAR et al., 2012; NITSOS; MATIS; TRIANTAFYLLIDIS, 2013; RAHIKAINEN et al., 2013; WIMAN et al., 2012; XIAO et al., 2013; YU et al., 2013b; ZHAO; CHENG; LIU, 2009).

Como forma de obter derivados hemicelulósicos com alto rendimento e uma lignina de maior pureza, o tratamento hidrotérmico pode ser aplicado como etapa precedente aos processos de deslignificação. A prévia remoção das xilanas sob condições brandas aumenta a capacidade de penetração e difusão dos solventes de deslignificação na matriz lignocelulósica; ademais, a quebra das interações lignina-carboidratos e a formação de fragmentos de lignina de menor massa molecular durante o pré-tratamento aumenta a eficiência da etapa de deslignificação (HUIJGEN et al., 2012; OBAMA et al., 2012; VALLEJOS et al., 2015). 
De modo similar, as mudanças químicas que ocorrem na lignina sob condições mais severas de pré-tratamento podem reduzir a eficiência de uma subsequente reação de deslignificação, posto que uma estrutura mais condensada e heterogênea é menos reativa, limita a transferência do solvente e dificulta a sua extração. Métodos de deslignificação não catalisados, que dependem de uma fonte endógena de íons para a clivagem das ligações da lignina, têm sua eficiência reduzida pelo prévio tratamento hidrotérmico, que provoca a desacetilação das hemiceluloses e previne que o meio reacional da polpação seja suficientemente ácido para a hidrólise catalítica sem uma fonte externa de íons (HUIJGEN et al., 2012; OBAMA et al., 2012; VALLEJOS et al., 2015).

O comportamento da área superficial específica da parede celular da biomassa segue as mudanças químicas e estruturais que ocorrem durante o pré-tratamento hidrotérmico. Em condições moderadas de reação, a remoção majoritária das hemiceluloses e parcial da lignina provoca a quebra do complexo lignina-polissacarídeos e o aumento da estrutura capilar, levando a aumentos expressivos na área superficial; já em condições mais severas, a área superficial acessível pode ser reduzida pelo colapso dos poros maiores assim como pela deposição de gotículas de lignina condensada na superfície das fibras (DOGARIS et al., 2009; NITSOS; MATIS; TRIANTAFYLLIDIS, 2013; XIAO et al., 2013).

O tratamento hidrotérmico realizado em condições brandas pode promover o aumento do índice de cristalinidade mensurado para o substrato, tanto pela hidrólise da celulose menos ordenada e mais acessível dentro dos deslocamentos e na superfície das fibrilas (HU; FOSTON; RAGAUSKAS, 2011; HU; RAGAUSKAS, 2011; XIAO et al., 2013), quanto pela remoção dos componentes não celulósicos (DOGARIS et al., 2009; NITSOS; MATIS; TRIANTAFYLLIDIS, 2013; YU et al., 2013a); já condições mais drásticas podem levar à redução do grau de cristalinidade pela desconstrução da estrutura cristalina.

Do ponto de vista morfológico, o pré-tratamento hidrotérmico provoca a perda da estrutura rígida e culmina na separação das células individuais, assim como na quebra parcial das fibras da biomassa, reduzindo o tamanho das partículas ao longo de seu comprimento (MERALI et al., 2013; NITSOS; MATIS; TRIANTAFYLLIDIS, 2013; XIAO et al., 2013).

Ao longo das duas últimas décadas, o pré-tratamento hidrotérmico foi amplamente estudado e aplicado para o processamento de uma diversidade de biomassas lignocelulósicas, não só com o intuito de aumentar a eficiência da hidrólise enzimática dos polissacarídeos (DA CRUZ et al., 2012; DOGARIS et al., 2009; HU; FOSTON; RAGAUSKAS, 2011; HU; 
RAGAUSKAS, 2011; MERALI et al., 2013; NEGRO et al., 2003; NITSOS; MATIS; TRIANTAFYLLIDIS, 2013; SAHA et al., 2013; SILVA et al., 2011; XIAO et al., 2013; YU et al., 2013a; YU et al., 2013b), como de estudar a cinética de formação de xilo-oligômeros, monossacarídeos e outros produtos no licor de reação (BOUSSARSAR; ROGÉ; MATHLOUTHI, 2009; DA CRUZ et al., 2012; MITTAL et al., 2009; NEGRO et al., 2003; NITSOS; MATIS; TRIANTAFYLLIDIS, 2013; SANTUCCI et al., 2015; VALLEJOS et al., 2012; XIAO et al., 2013). De modo geral, as pesquisas publicadas avaliaram os efeitos da temperatura e do tempo de reação, além das razões sólido/líquido (S/L), nas composições químicas do sólido residual e da corrente líquida obtidos no processo; remoções de massa de até $50 \%$ e solubilizações das hemiceluloses de até $100 \%$ foram reportadas.

A auto-hidrólise do bagaço de cana-de-açúcar foi também investigada por vários autores, em condições de reação que variaram entre temperaturas de $140^{\circ} \mathrm{C}$ a $220^{\circ} \mathrm{C}$, tempos de 2 a 240 minutos, e teores de sólidos de 5\% a 33\% (BOUSSARSAR; ROGÉ; MATHLOUTHI, 2009; DA CRUZ et al., 2012; SANTUCCI et al., 2015; SILVA et al., 2011; VALLEJOS et al., 2012; YU et al., 2013a; YU et al., 2013b).

Como exemplo, SILVA et al. (2011) aplicaram o tratamento hidrotérmico ao bagaço de cana-de-açúcar nas temperaturas entre $185^{\circ} \mathrm{C}$ e $195^{\circ} \mathrm{C}$ por $10 \mathrm{~min}(\mathrm{~S} / \mathrm{L}=1: 10)$, e obtiveram solubilizações de massa entre $44,5 \%$ e $50,4 \%$, de hemiceluloses entre $67,6 \%$ e $88,7 \%$, de celulose de até $26,6 \%$ e de lignina de até $41,8 \%$. Já SANTUCCI et al. (2015) submeteram o bagaço de cana-de-açúcar ao tratamento hidrotérmico nas temperaturas entre $160^{\circ} \mathrm{C}$ e $190^{\circ} \mathrm{C}$ em tempos entre 2,5 e 90 min $(\mathrm{S} / \mathrm{L}=1: 10)$, e atingiram solubilizações de massa que variaram entre $5 \%\left(160^{\circ} \mathrm{C} / 4 \mathrm{~min}\right)$ até $50 \%\left(190^{\circ} \mathrm{C} / 67 \mathrm{~min}\right)$, solubilizações de hemiceluloses entre $2 \%$ $\left(160^{\circ} \mathrm{C} / 4 \mathrm{~min}\right)$ até $94 \%\left(180^{\circ} \mathrm{C} / 90 \mathrm{~min}\right.$ e $\left.190^{\circ} \mathrm{C} / 67 \mathrm{~min}\right)$, de celulose de até $23 \%$, e de lignina de até 35\%. VALLEJOS et al. (2012) realizaram o tratamento hidrotérmico do bagaço de cana-de-açúcar nas temperaturas entre $143^{\circ} \mathrm{C}$ e $177^{\circ} \mathrm{C}$ em tempos entre 20 e $70 \mathrm{~min}(\mathrm{~S} / \mathrm{L}=$ $1: 1$ - 1:11), e observaram que solubilizações de massa entre $3,4 \%$ e $23,02 \%$, de hemiceluloses entre $5,4 \%$ e $61,1 \%$, de celulose de até $24 \%$ e de lignina de até $6,8 \%$.

Em linhas gerais, pode-se afirmar as mudanças provocadas na composição química e na estrutura física da biomassa durante o pré-tratamento hidrotérmico permitem melhorar a eficiência da posterior etapa enzimática junto com a recuperação com grande rendimento de açúcares hemicelulósicos. Ademais, o método possui a vantagem de produzir hidrolisados que resultam em pequena ou nenhuma inibição aos microrganismos de fermentação. 


\subsubsection{Deslignificação organossolve}

A deslignificação ou polpação organossolve também é um método de pré-tratamento e fracionamento da biomassa lignocelulósica, onde solventes orgânicos ou soluções aquosas dos mesmos são empregadas a altas temperaturas para promover a extração e a solubilização de fragmentos da lignina da parede celular vegetal. De modo similar à atuação da água no prétratamento hidrotérmico, o solvente orgânico em meio aquoso penetra e difunde através da parede celular, rompe o complexo lignina-carboidratos, hidrolisa e solubiliza em grande proporção as hemiceluloses e fragmentos de lignina (ALVIRA et al., 2010; HALLAC et al., 2010; LAI et al., 2014; SANNIGRAHI; RAGAUSKAS; MILLER, 2010; SUN et al., 2016; TAHERZADEH; KARIMI, 2008; VALLEJOS et al., 2015; WILDSCHUT et al., 2013; ZHAO; CHENG; LIU, 2009; ZHAO; ZHANG; LIU, 2012).

Como produtos do processo são formados uma corrente líquida rica em açúcares hemicelulósicos, uma fração lignina de alta pureza, além de um resíduo sólido rico em celulose. É uma tecnologia promissora, uma vez que tem se mostrado adequada para a abertura da estrutura de diferentes biomassas lignocelulósicas, facilitando sua bioconversão tanto pela baixa recalcitrância quanto pela alta área superficial e menor probabilidade de interações não produtivas. Além do mais, a lignina isolada é livre de enxofre e de baixo peso molecular, características que garantem seu potencial de aplicação em diversos produtos de alto valor agregado. Em outras palavras, a deslignificação organossolve possibilita uma biorrefinaria completa pela recuperação de todas as frações da biomassa (AGNIHOTRI et al., 2015; HALLAC et al., 2010; HUIJGEN et al., 2012; LAI et al., 2014; REISINGER et al., 2014; SANNIGRAHI; RAGAUSKAS; MILLER, 2010; TAHERZADEH; KARIMI, 2008; VALLEJOS et al., 2015; WILDSCHUT et al., 2013; ZHAO; CHENG; LIU, 2009).

O pré-tratamento organossolve apresenta vantagens econômicas e ambientais em comparação aos demais métodos de deslignificação químicos, visto que os solventes orgânicos reduzem a incidência de emissões, são de fácil recuperação por destilação e podem ser reciclados (HALLAC et al., 2010; LAI et al., 2014; SUN et al., 2016; ZHAO; CHENG; LIU, 2009). Entretanto, este método ainda aponta alguns entraves que limitam sua transposição para a escala industrial. As posteriores etapas de extração e recuperação dos solventes, que garantem a viabilidade econômica, aumentam o consumo energético do processo. Os solventes aplicados também devem ser removidos do resíduo sólido pré-tratado 
por serem inibitórios aos microrganismos de fermentação e, em alguns casos, às enzimas hidrolíticas. Adicionalmente, os sólidos pré-tratados precisam ser lavados com solventes orgânicos antes de serem lavados com água como forma de evitar a precipitação da lignina dissolvida sobre as fibras do resíduo celulósico (ALVIRA et al., 2010; GARCÍA; ALRIOLS; LABIDI, 2014; TAHERZADEH; KARIMI, 2008; ZHAO; CHENG; LIU, 2009).

Além da temperatura e do tempo de reação, a efetividade da deslignificação organossolve é determinada pelo $\mathrm{pH}$ do meio reacional e pela habilidade do solvente em participar das reações de despolimerização da lignina, assim como em solvatar os fragmentos formados no meio reacional (PIMENTA, 2005; SANNIGRAHI; RAGAUSKAS; MILLER, 2010; VALLEJOS et al., 2015).

Entre os solventes mais empregados estão: os de baixo ponto de ebulição, como metanol e etanol; os de maior ponto de ebulição, como etilenoglicol, glicerol e álcool tetraidrofurfurílico; os ácidos orgânicos, como os ácidos fórmico e acético; e outras classes de compostos orgânicos, como perácidos orgânicos, éteres, cetonas e fenóis. Os álcoois alifáticos de baixo peso molecular e baixo ponto de ebulição, como o metanol e o etanol, são preferencialmente aplicados devido aos menores custos, à maior facilidade de recuperação por destilação simples e por serem facilmente miscíveis em água (HALLAC et al., 2010; LAI et al., 2014; SUN et al., 2016; TAHERZADEH; KARIMI, 2008; VALLEJOS et al., 2015; WILDSCHUT et al., 2013; ZHAO; CHENG; LIU, 2009; ZHAO; ZHANG; LIU, 2012).

O processo organossolve pode ser realizado com ou sem a adição de catalisadores, dependendo da temperatura da reação e do tipo de solvente. Em geral, se o pré-tratamento é conduzido em altas temperaturas (entre $185^{\circ} \mathrm{C}$ e $250^{\circ} \mathrm{C}$ ), não há necessidade da incorporação de catalisadores, posto que a ruptura das ligações é auto-catalisada pelo ácido acético de fonte endógena. Para o uso de solventes de ação mais branda ou quando do emprego de menores temperaturas (entre $100^{\circ} \mathrm{C}$ e $180^{\circ} \mathrm{C}$ ), a reação pode ainda ser catalisada com ácidos (clorídrico, sulfúrico, fosfórico, fórmico, oxálico, salicílico, entre outros), álcalis (hidróxido de sódio, sulfito de sódio, amônia, sulfeto de amônio, entre outros) ou sais (cloretos, nitratos ou sulfatos de $\mathrm{Mg}, \mathrm{Ca}$ ou $\mathrm{Ba}$ ) com o intuito de aumentar as taxas das reações de hidrólise das hemiceluloses assim como de ruptura das ligações da lignina. Os catalisadores promovem a ativação de centros reativos da lignina, e compensam a utilização de nucleófilos fracos, como a água e/ou o solvente orgânico (PIMENTA, 2005; SUN et al., 2016; TAHERZADEH; KARIMI, 2008; ZHAO; CHENG; LIU, 2009; ZHAO; ZHANG; LIU, 2012). 
A despolimerização da lignina pelo método organossolve envolve necessariamente etapas de ruptura de ligações químicas, seguidas da solubilização e extração dos fragmentos de menor massa molecular produzidos, uma vez que os solventes orgânicos empregados possuem a capacidade de solubilizar moléculas orgânicas de baixa polaridade como a lignina. O rompimento destas ligações ocorre por meio de reações de hidrólise e, em alguns casos, reações de solvólise. Concomitantemente ocorre a hidrólise dos polissacarídeos da parede celular, segundo o mecanismo detalhado no item anterior (item 2.2.6.1) (PIMENTA, 2005).

Nas reações de solvólise não catalisadas, o meio reacional se torna acidificado devido tanto à auto ionização da água a altas temperaturas quanto à formação do ácido acético a partir clivagem dos grupos acetila das hemiceluloses, o que resulta no decaimento do $\mathrm{pH}$ e na quebra auto-ácido-catalisada de algumas ligações químicas (NOVO, 2012; SANNIGRAHI; RAGAUSKAS; MILLER, 2010; WILDSCHUT et al., 2013). As diferentes reações solvolíticas ácido-catalisadas da lignina podem ocorrer nos átomos de carbono da cadeia propânica lateral, nos átomos de carbono do anel aromático, no grupo metoxila e, com menor frequência, nas hidroxilas fenólicas (FENGEL; WEGENER, 1989).

As reações de fragmentação da lignina ocorrem principalmente através da protonação do oxigênio de hidroxilas ou ligações aril-éter na cadeia lateral, com a posterior formação de íons benzil carbônio intermediários e de grupos de saídas estáveis (água ou álcoois). Os carbocátions formados possuem alta afinidade por nucleófilos, e podem ser estabilizados por deslocalização da carga por ressonância, gerando sistemas carbocátion-oxônio; estes sistemas estão envolvidos em reações de fragmentação ou condensação da lignina, dependendo do tipo de nucleófilo presente no meio reacional. A protonação ocorre com maior frequência no oxigênio (hidroxila ou éter) ligado ao carbono $\alpha$, e culmina essencialmente na clivagem das ligações $\alpha$-aril éter e $\beta$-aril éter (FENGEL; WEGENER, 1989; SANNIGRAHI; RAGAUSKAS; MILLER, 2010; ZHAO; CHENG; LIU, 2009). O mecanismo de solvólise das ligações $\alpha-O-4$ ', uma das principais responsáveis pela ruptura da macromolécula de lignina durante a polpação organossolve, é apresentado na Figura 18.

De acordo com o solvente orgânico no qual a reação é realizada, outras moléculas além da água podem atuar como nucleófilos, o que depende da capacidade de doação de elétrons das mesmas. Como exemplo, o carbocátion intermediário gerado na solvólise da ligação $\alpha-\mathrm{O}-4$ que pode reagir com o solvente (p.e., um álcool), formando um éter benzílico, ou mesmo reagir com a água, formando um álcool benzílico (PIMENTA, 2005). 
Figura 18. Mecanismo de solvólise das ligações $\alpha-\mathrm{O}-4$ das ligninas via formação de sistemas carbônio-oxônio.

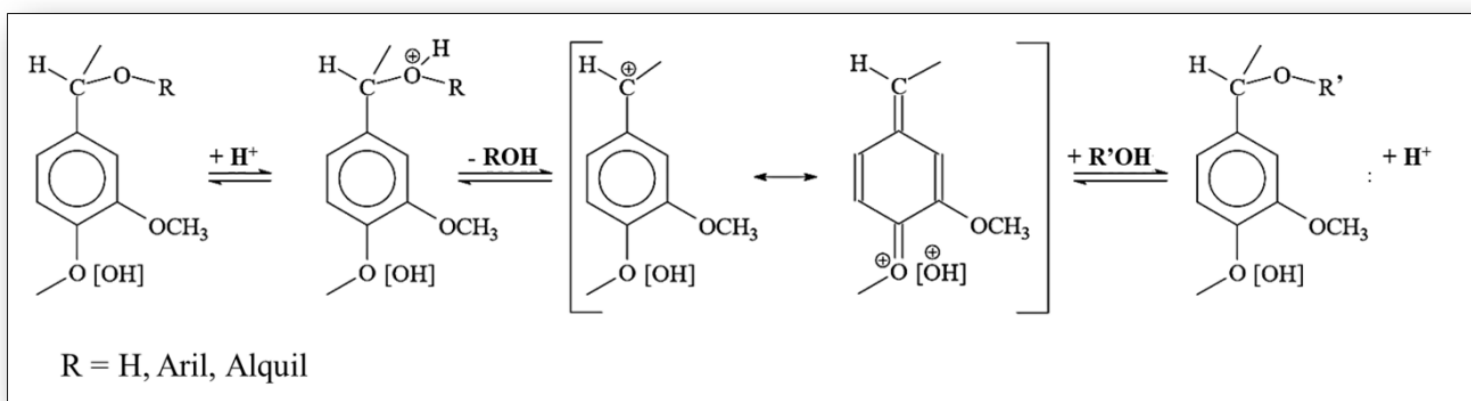

Fonte: Adaptado de: FENGEL;WEGENER, 1989; MARABEZI, 2009.

Contudo, quando empregadas soluções ácidas concentradas ou condições mais severas de reação, podem ocorrer reações secundárias de condensação entre os carbocátions intermediários e carbonos ricos em elétrons de anéis aromáticos de outros fragmentos de lignina, conforme exemplificado na Figura 19 a seguir (FENGEL; WEGENER, 1989; PIMENTA, 2005; SANNIGRAHI; RAGAUSKAS; MILLER, 2010). Nestes casos, ocorre a competição entre as reações de condensação e as de despolimerização, o que restringe a efetividade da deslignificação (HALLAC et al., 2010; NOVO, 2012).

Figura 19. Exemplo de reações de condensação entre fragmentos de lignina em meio ácido.<smiles>[R]Oc1ccc(C(C)O[R])cc1OC</smiles>

Fonte: Adaptado de: FENGEL;WEGENER, 1989; NOVO, 2012.

Segundo SANNIGRAHI, RAGAUSKAS e MILLER (2010), a polpação organossolve acarreta em modificações estruturais tanto na lignina residual no sólido pré-tratado quanto na lignina isolada no licor em relação à lignina encontrada na biomassa nativa. Entre as alterações mencionadas podem-se citar: as relacionadas com a despolimerização da lignina, 
como a redução no número de metoxilas por anel aromático, o aumento no número de grupos carboxílicos, a redução no teor de ligações $\beta-\mathrm{O}-4$ ', o aumento no teor de grupos hidroxilafenólicos e a redução expressiva na massa molecular dos fragmentos de lignina isolados no meio líquido; e as relacionadas com a condensação da lignina, como o aumento expressivo no teor de ligações $\mathrm{C}-\mathrm{C}$ e o aumento na massa molecular da lignina isolada no resíduo sólido.

A extensão da deslignificação depende fortemente das condições de processamento empregadas. De modo geral, as pesquisas publicadas concluíram, para diferentes biomassas lignocelulósicas, que o aumento na severidade da reação promove o aumento da remoção de massa, assim como o aumento da solubilização das hemiceluloses e de fragmentos de lignina. Como resultado, tem-se o aumento do teor relativo de celulose no sólido pré-tratado em comparação à biomassa nativa (AGNIHOTRI et al., 2015; GARCÍA; ALRIOLS; LABIDI, 2014; HALLAC et al., 2010; HUIJGEN et al., 2012; LAI et al., 2014; MESA et al., 2010; OBAMA et al., 2012; VALLEJOS et al., 2015; WILDSCHUT et al., 2013).

Com relação à concentração de solvente, o aumento na proporção solvente/água não necessariamente permite o aumento da solubilização de massa, uma vez que pode aumentar ou diminuir a porcentagem de deslignificação, porém diminui a remoção de xilanas. Uma maior concentração de solvente implica em uma menor severidade de reação pelo maior $\mathrm{pH}$ do meio reacional; este comportamento se deve à menor quantidade de água, portanto ao menor potencial de catálise ácida por de íons hidrônio. Enquanto a solubilização de xilanas é maior em menores valores de $\mathrm{pH}$, para a lignina é esperada uma maior deslignificação com o aumento na concentração de solvente; contudo, as hemiceluloses e a lignina são estruturalmente ligadas, e para a dissolução da lignina estas ligações devem primeiramente ser rompidas. Além do mais, a água é nucleófilo nas reações de hidrólise das ligações éter dentro da lignina. Por outro lado, o teor de solvente é importante para manter os fragmentos de lignina formados solvatados no meio reacional. Assim, a concentração ótima de solvente para a deslignificação é um balanço entre a solubilidade dos fragmentos de lignina produzidos e o pH do meio reacional necessário para a hidrólise das ligações éter (LAI et al., 2014; WILDSCHUT et al., 2013).

As remoções extensivas da lignina e das hemiceluloses promovidas pela polpação organossolve resultam na ruptura quase completa da matriz lignina-polissacarídeos e na ampla abertura da estrutura capilar das fibras, o que significa o grande aumento da área superficial específica (SUN et al., 2016; ZHAO; CHENG; LIU, 2009; ZHAO; ZHANG; LIU, 2012). 
O pré-tratamento organossolve realizado em condições brandas pode também promover o aumento do índice de cristalinidade do substrato, tanto pela hidrólise da celulose menos ordenada e mais acessível dentro dos deslocamentos e na superfície das fibrilas (PIMENTA, 2005), quanto pela remoção dos componentes não celulósicos (ZHAO; CHENG; LIU, 2009); já condições mais drásticas podem levar à redução do grau de cristalinidade pelo rompimento da estrutura cristalina (HALLAC et al., 2010). O modo como o pré-tratamento organossolve afeta a estrutura cristalina da celulose ainda não é bem esclarecido e exige posteriores investigações para maiores conclusões (ZHAO; CHENG; LIU, 2009; ZHAO; ZHANG; LIU, 2012). Todavia, é evidente que ocorre a cisão ácido-catalisada das cadeias de celulose nas regiões amorfas, reduzindo o seu grau de polimerização (HALLAC et al., 2010; OBAMA et al., 2012; PIMENTA, 2005; ZHAO; ZHANG; LIU, 2012).

$\mathrm{O}$ estudo do processo organossolve para sua adequação dentro de um contexto de biorrefinarias de materiais lignocelulósicos tem se intensificado recentemente, sendo aplicado a biomassas de diferentes espécies vegetais. Entre os objetivos das pesquisas publicadas podem-se citar a avaliação dos efeitos dos parâmetros da deslignificação - temperatura, tempo, concentração do solvente orgânico, concentração de catalisador e razão sólido/líquido (S/L) - na composição química e na digestibilidade enzimática do substrato pré-tratado, além da observação das alterações provocadas nas estruturas das ligninas durante o processamento. Solubilizações de hemiceluloses de até $95 \%$ e de lignina de até $84 \%$ foram reportadas (AGNIHOTRI et al., 2015; GARCÍA; ALRIOLS; LABIDI, 2014; HALLAC et al., 2010; HUIJGEN et al., 2012; LAI et al., 2014; MESA et al., 2010; OBAMA et al., 2012; REISINGER et al., 2014; VALLEJOS et al., 2015; WILDSCHUT et al., 2013).

A deslignificação organossolve do bagaço de cana-de-açúcar foi também investigada por diferentes autores. Como exemplo, AGNIHOTRI et al. (2015) aplicaram a deslignificação organossolve com a mistura solvente etanol/água (50\% v/v, S/L 1:20) ao bagaço de cana-deaçúcar nas temperaturas entre $157^{\circ} \mathrm{C}$ e $212^{\circ} \mathrm{C}$ por tempos que variaram entre 90 e 120 min e com a adição de ácido fórmico como catalisador $(0,05 \mathrm{~mol} / \mathrm{L})$; o estudo reportou solubilizações de hemiceluloses entre $9,1 \%$ e $88,9 \%$, e de lignina entre $21,9 \%$ e $82,6 \%$. Já MESA et al. (2010) submeteram o bagaço de cana-de-açúcar à deslignificação organossolve com a mistura solvente etanol/água $(50 \% \mathrm{v} / \mathrm{v}, \mathrm{S} / \mathrm{L} 1: 5)$, na temperatura de $175^{\circ} \mathrm{C}$ por tempos que variaram entre 60 e $90 \mathrm{~min}$, sendo o processo catalisado com o uso de $\mathrm{H}_{2} \mathrm{SO}_{4}$ ou $\mathrm{NaOH}$ $(1,25 \%$ ou $1,50 \%)$; com o uso de $\mathrm{NaOH}$ como catalisador as solubilizações de hemiceluloses 
variaram entre $14,7 \%$ e $51,6 \%$ e as de lignina variaram entre $9,4 \%$ e $44,3 \%$, enquanto com o uso de $\mathrm{H}_{2} \mathrm{SO}_{4}$ como catalisador as solubilizações de hemiceluloses variaram entre $35,6 \%$ e $60,1 \%$ e as de lignina variaram entre 9,3\% e 42,4\%. VALLEJOS et al. (2015) realizaram a deslignificação organossolve do bagaço de cana-de-açúcar com a mistura solvente etanol/água $(50 \% \mathrm{v} / \mathrm{v}, \mathrm{S} / \mathrm{L} 1: 3-1: 9)$ nas temperaturas entre $160^{\circ} \mathrm{C}$ e $190^{\circ} \mathrm{C}$ por tempos que variaram entre 30 e 150 min sem a adição de catalisadores, e observaram solubilizações de hemiceluloses entre $7,0 \%$ e $74,9 \%$, e de lignina entre $19,5 \%$ e $92,0 \%$.

Diante da conjuntura exposta, surge a oportunidade de investigar combinações de tecnologias de pré-tratamento, onde a alteração das variáveis de cada uma das metodologias permite produzir diferentes tipos de compostos nas correntes de processo, de acordo com a configuração da biorrefinaria escolhida. De todos os modos, é possível fracionar as biomassas provindas de distintas fontes vegetais em seus macrocomponentes principais, ou mesmo obter um substrato sólido facilmente susceptível à sacarificação enzimática.

\subsubsection{Processamento físico-mecânico da biomassa lignocelulósica}

O processamento físico-mecânico da biomassa lignocelulósica teve seu início na indústria de papel e celulose com a introdução dos métodos de polpação mecânica, cujo intuito desagregar as fibras lignocelulósicas fornecendo-lhes características adequadas para a formação de um papel de maior qualidade (FENGEL; WEGENER, 1989).

A polpação mecânica é o processo de separação da biomassa lignocelulósica em suas fibras constituintes individualmente por meio da ação de cisalhamento mecânico. Esta ação permite um aumento da área superficial das fibras e, consequentemente, um maior número de interações entre as fibrilas, o que garante um papel com maior resistência mecânica (FENGEL; WEGENER, 1989).

No processo de obtenção da polpa mecânica não há a alteração da composição química da biomassa, ou seja, os teores do macrocomponentes mantêm-se praticamente inalterados. Do ponto de vista morfológico, as polpas geradas consistem de uma mistura de fibras intactas, feixes de fibras aglomeradas, fibras danificadas e fragmentos de fibras (material fino), diferentemente da polpa química, onde há a obtenção apenas de fibras inteiras e completamente individualizadas. Visualmente, caracterizam-se pela alta opacidade (KLOCK; DE ANDRADE; HERNANDEZ, 2013). 
O termo polpa mecânica refere-se tanto à biomassa apenas desfibrada quanto ao material refinado. Um dos principais entraves na polpação mecânica é o alto consumo energético do processo. Entretanto, este fator é superado pela qualidade das polpas geradas, pelo alto rendimento em massa e pelo baixo custo global do processo (FENGEL; WEGENER, 1989; KLOCK; DE ANDRADE; HERNANDEZ, 2013).

A produção de pasta mecânica com o uso de refinadores de discos se iniciou em 1958 nos EUA, visando o aproveitamento de resíduos e madeiras tradicionalmente não processadas. O material obtido apresentava propriedades mecânicas superiores àquelas obtidas com desfibrador de pedra. Entretanto, apenas com o surgimento do processo de polpação termomecânica na década de 70 que os processos mecânicos ganharam real interesse, posto que o material obtido apresentava propriedades elevadas com alto rendimento (KLOCK; DE ANDRADE; HERNANDEZ, 2013). Através de variações no processo, surgiram as denominadas polpas de alto rendimento, cujo rendimento de massa na transformação da matéria-prima é superior a $80 \%$. Os processos de alto rendimento ganharam maior atenção ao longo das últimas décadas devido aos problemas ambientais relacionados ao tratamento de efluentes. Na indústria de papel e celulose, a importância dos processos mecânicos se dá pela menor perda de biomassa (FENGEL; WEGENER, 1989).

\subsubsection{Refino mecânico}

Define-se refino como o processo mecânico de compressão e cisalhamento das fibras em meio aquoso por ação de um refinador, que altera a morfologia das fibras e sua organização física, porém sem alterar sua composição química (BANAVATH; BHARDWAJ; RAY, 2011; DA SILVA, 1968; FERREIRA, 2000; TORRES et al., 2012).

A principal característica da polpação por refino mecânico é a aplicação de refinadores, de diferentes tipos e configurações, para o desfibramento e a fibrilação da biomassa, além de permitir o uso de materiais de diferentes fontes vegetais. As alterações estruturais provocadas nas fibras são obtidas a partir da aproximação entre as partes constituintes do refinador.

Os rendimentos do processo de refino são entre $91 \%$ e $98 \%$ e, de modo semelhante ao desfibramento sobre pedra, dependem da biomassa, das propriedades do refinador e das características do refino (FENGEL; WEGENER, 1989). 


\subsection{Teoria do refino}

Em geral, os refinadores são constituídos de duas partes bem definidas: um rotor e um estator; ambas as partes possuem um projeto de suas superfícies em alto relevo, a fim de promover a ação mecânica nesta etapa. Durante o processo de refino, a polpa celulósica ingressa entre o rotor e o estator, sendo submetida a um processo de esmagamento puramente mecânico que provoca o intumescimento da fibra (DA SILVA, 1968; GHAREHKHANI et al., 2015; TORRES et al., 2012). Conforme ilustrado na Figura 20, este processo ocorre em cinco estágios: primeiramente, as fibras rígidas em suspensão aquosa ingressam entre o conjunto refinador (rotor/estator), onde são retidas pelas lâminas, formando uma manta; posteriormente, as fibras da pasta são comprimidas pelas superfícies das lâminas rotoras e estatoras, até o ponto onde a pressão exercida sobre uma fibra alcança valor máximo; a partir deste ponto, inicia-se o relaxamento mecânico e as fibras são afetadas pelas forças de cisalhamento, provocadas tanto pelo contato lâmina-fibra quanto pelo contanto fibra-fibra; por fim, a pasta é empurrada até a dispersão do sistema (GHAREHKHANI et al., 2015).

Conforme explicitado anteriormente, os agregados fibrilares são formados por cristais de celulose dispostos paralelamente. Imergindo-se as fibras em água, ou em uma atmosfera saturada de vapor de água, uma quantidade de moléculas de água é adsorvida por todas as superfícies cristalinas expostas, o que provoca a hidratação das fibras. Segundo as teorias desenvolvidas por Campbell e Strachan, o fenômeno de refino permite a entrada de uma quantidade adicional de água na estrutura da fibra pelo aumento nos espaços existentes entre as fibrilas adjacentes, o que afeta as interações de hidrogênio entre as cadeias celulósicas das superfícies cristalinas e, consequentemente, diminui a atração de uma fibrila pela outra. Com o refino e o intumescimento das fibras, há o rompimento de determinada fração das ligações e a exposição das superfícies internas da celulose, debilitando a estrutura e promovendo assim a abertura física. (CAMPOS, 1999; D’ALMEIDA, 1988).

Devido à reduzida distância existente entre ambas as partes constituintes do equipamento, e às intensas zonas de fricção nas proximidades das lâminas do refinador, as características estruturais das fibras são modificadas. As mudanças físicas e morfológicas que ocorrem aumentam a acessibilidade aos macrocomponentes da fibra e afetam a distribuição destes na superfície e nas diferentes camadas da parede celular (BANAVATH; BHARDWAJ; RAY, 2011; BHARDWAJ; HOANG; NGUYEN, 2007; FARDIM; DURÁN, 2003). 
Figura 20. Representação da ação de um refinador nas fibras lignocelulósicas.

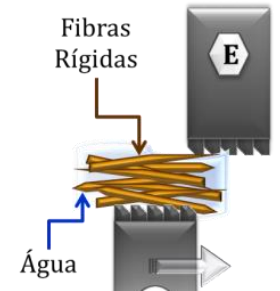

(R)

1. Formação da
Manta

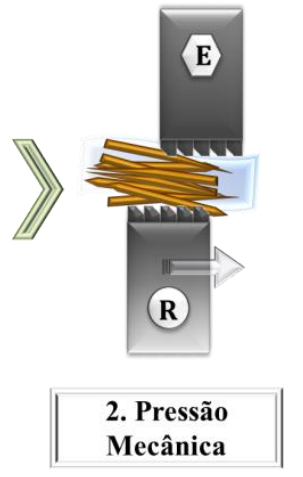

$\rightarrow$ Expulsão da água

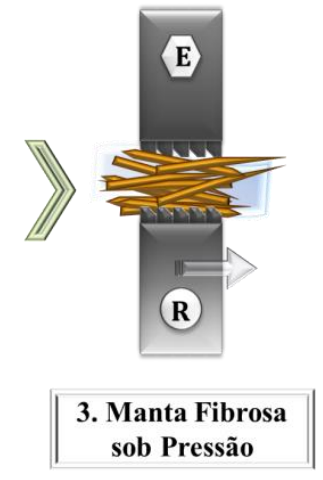
sob Pressão

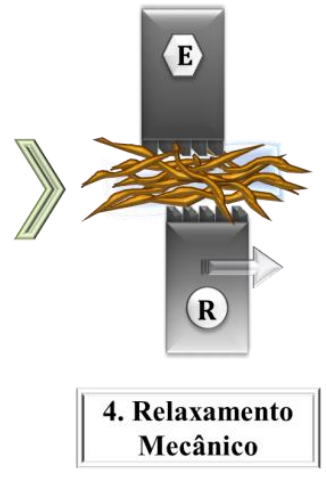

$\rightarrow$ Hidratação da fibra

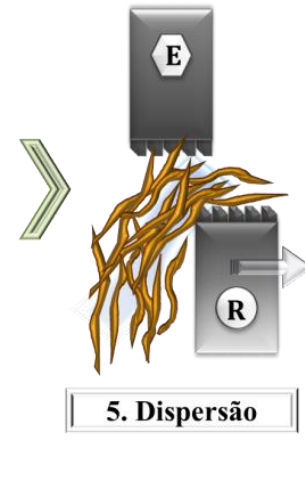

R

Fonte: Adaptado de: SENAI, 2011.

\subsection{Efeitos do refino}

Os efeitos provocados na fibra pelo processo de refino podem ser divididos em efeitos primários e efeitos secundários. Através da observação morfológica dos efeitos primários, ilustrados na Figura 21 a seguir, é que se diferencia uma fibra refinada de outra não refinada. Os principais efeitos primários de um processo de refino são: fibrilação externa e consequente formação de finos, fibrilação interna e encurtamento das fibras. Já os efeitos secundários compreendem as mudanças estruturais produzidas na fibra como consequência dos efeitos primários, dentre as quais se podem citar as alterações provocadas no(a): área superficial, acessada pelas dimensões das fibras e pela porosidade, volume específico, densidade, capacidade de absorção de água, flexibilidade, entre outros (BANAVATH; BHARDWAJ; RAY, 2011; CAMPOS, 1999; D’ALMEIDA, 1988; DEMUNER, 2001).

Figura 21. Efeitos primários do refino nas fibras lignocelulósicas.

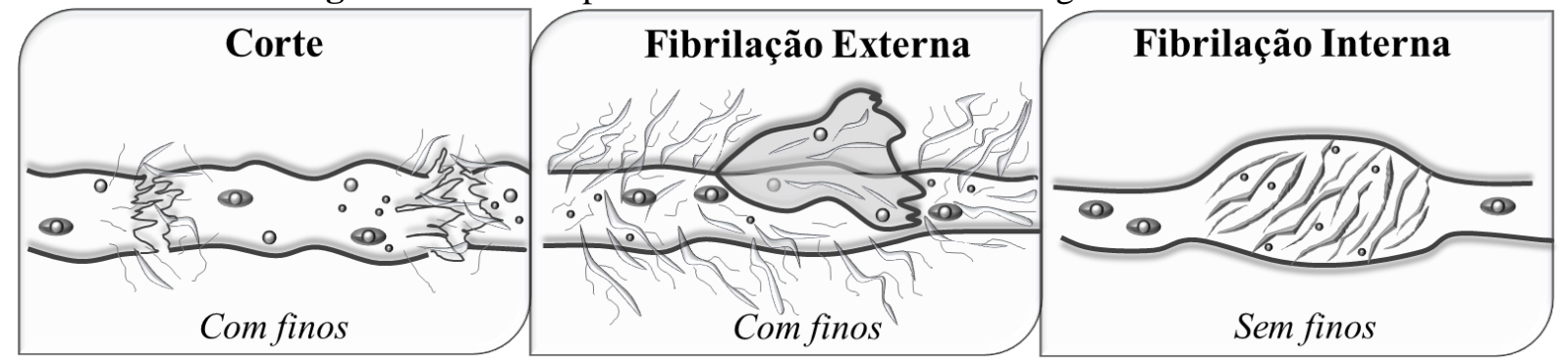

Fonte: Adaptado de: D’ALMEIDA, 1988. 
a. Fibrilação externa:

A fibrilação externa é o efeito de arranque parcial ou total das camadas mais externas da fibra, P e S1, e de exposição das fibrilas das camadas mais internas pelas forças cíclicas de compressão e cisalhamento. Após o refino, as microfibrilas destacadas, porém ainda ligadas à superfície, formam uma camada com múltiplos filamentos em volta do elemento fibroso (Figura 22). A desestruturação das paredes externas pelo refino aumenta a área superficial específica e a acessibilidade às camadas mais internas da parede celular (BANAVATH; BHARDWAJ; RAY, 2011; D’ALMEIDA, 1988; MOU et al., 2013; TORRES et al., 2012).

Figura 22. Comparação entre (A) uma fibra não refinada e (B) uma fibra refinada, mostrando a fibrilação externa com formação de finos.

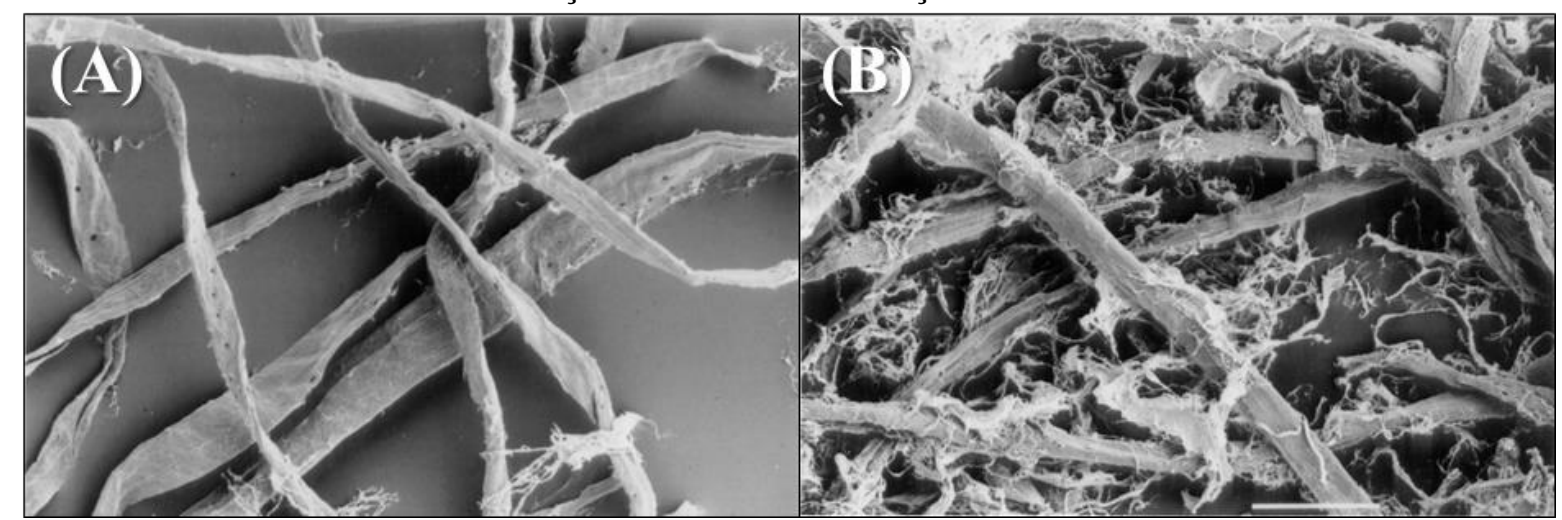

Fonte: Adaptado de: KEREKES, 2005.

\section{b. Formação de finos:}

Na fibrilação externa, parte das fibras que são tratadas dá origem aos elementos finos, fragmentos produzidos pelo arranque e trituração das camadas externas e por microfibrilas desprendidas. Conforme ilustrado na Figura 22 (B), os finos apresentam-se como pequenos filamentos ou placas, ou podem ainda estar presentes na forma de aglomerados, caso o refino seja realizado em baixa consistência de massa (CAMPOS, 1999; D’ALMEIDA, 1988).

c. Fibrilação interna:

A fibrilação interna, ilustrada na Figura 23, consiste em cisões internas à parede celular pela ação das lâminas (delaminações), que culminam na exposição das camadas internas. É o principal efeito da refinação. Quando se refina o material lignocelulósico, as 
interações de hidrogênio que interligam os polissacarídeos são rompidas pela ação mecânica, e os grupos hidroxilas das cadeias ficam livres para formar novas interações de hidrogênio, agora com moléculas de água, que entram na fibra devido à fibrilação externa; como resultado, tem-se a hidratação e o inchamento da parede celular (BANAVATH; BHARDWAJ; RAY, 2011; CAMPOS, 1999; D’ALMEIDA, 1988; TORRES et al., 2012).

Em outras palavras, a delaminação interna expande a capilaridade da estrutura da fibra, através da qual a água pode circular, e diminui a coesão entre as lamelas. Deste modo, a hidratação e o inchamento implicam no aumento da espessura da parede. A delaminação das fibras ainda provoca o aumento da flexibilidade, portanto da tendência à deformação, pela perda da estrutura das paredes mais rígidas (FARDIM; DURÁN, 2003; GHAREHKHANI et al., 2015; YASUMURA; D’ALMEIDA; PARK, 2008). Com o intumescimento e a propensão à deformação, a fibra tem sua densidade e volume específico alterados.

Figura 23. Ilustração da fibrilação interna de uma fibra, que provoca (A) o inchamento e (B) a delaminação das camadas internas da parede celular.

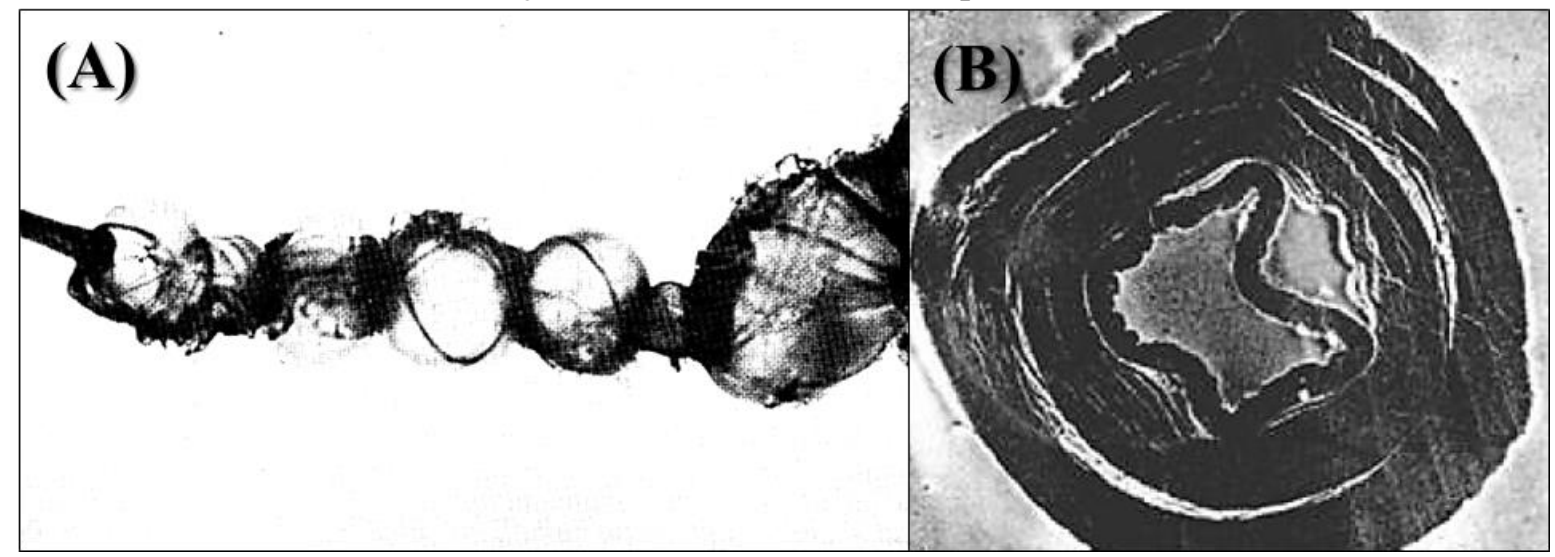

Fonte: Adaptado de: (A) SENAI, 2011; (B) CAMPOS, 2009.

d. Corte das fibras:

O fenômeno de corte é a redução no comprimento da fibra. O encurtamento de uma fibra pode ocorrer por ação da superfície do refinador através da sua região mais frágil (Figura 24 (A)) ou devido ao contato mútuo entre duas fibras (Figura 24 (B)) (CAMPOS, 1999; D’ALMEIDA, 1988). 
Figura 24. Ilustração da ação de corte das fibras pelo refino.

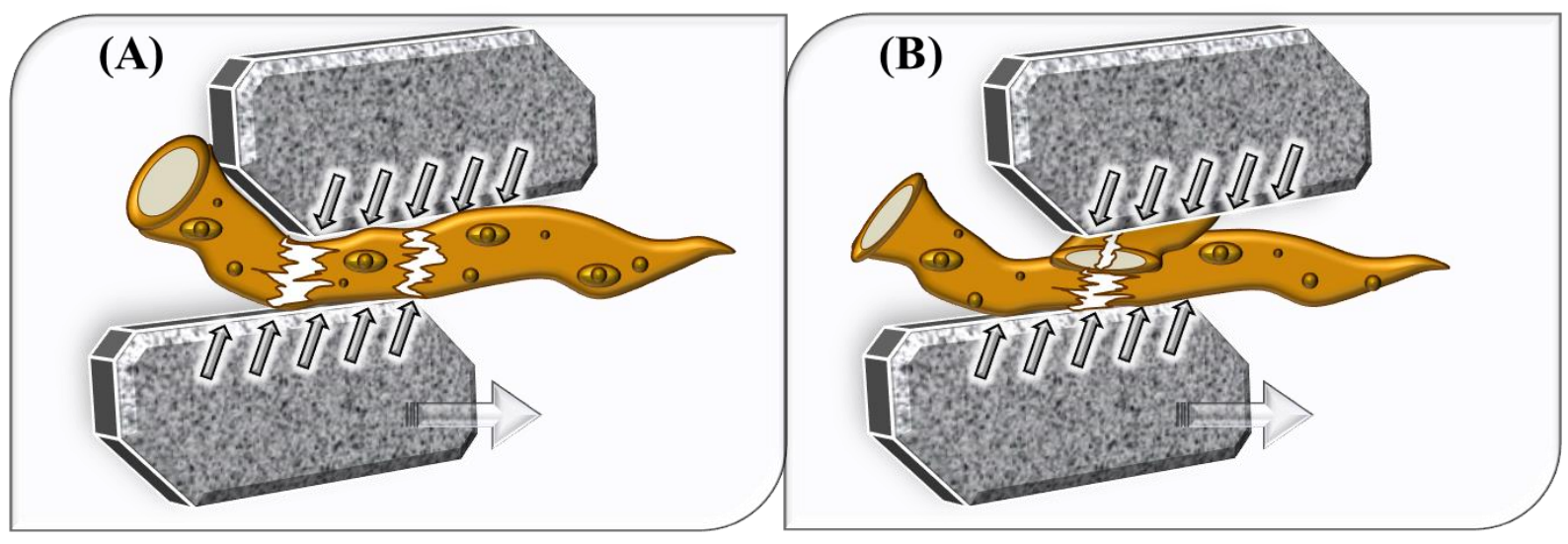

Fonte: Adaptado de: D'ALMEIDA, 1988.

Deve-se ainda mencionar outros efeitos primários provocados nas fibras, que influenciam em suas características, como: encurvamento, estreitamento e compressão do lúmen (CAMPOS, 2009). A Tabela 3 a seguir indica o grau de influência de cada um dos efeitos primários, de acordo com a descrição das alterações provocadas nas fibras, em alguns dos principais efeitos secundários.

Tabela 3. Relação entre os efeitos primários do refino e os efeitos secundários provocados nas fibras lignocelulósicas.

\begin{tabular}{|c|c|c|c|c|}
\hline \multirow[b]{2}{*}{ Efeitos Secundários } & \multicolumn{4}{|c|}{ Efeitos Primários } \\
\hline & Corte & $\begin{array}{l}\text { Produção de } \\
\text { Finos }\end{array}$ & $\begin{array}{c}\text { Fibrilação } \\
\text { Externa }\end{array}$ & $\begin{array}{c}\text { Fibrilação } \\
\text { Interna }\end{array}$ \\
\hline Volume Específico & --- & --- & Pouco & Muito \\
\hline $\begin{array}{l}\text { Área Superficial } \\
\text { Específica }\end{array}$ & --- & Muito & Muito & Muito \\
\hline Comprimento da Fibra & Muito & Pouco & --- & --- \\
\hline Densidade & --- & Pouco & --- & Muito \\
\hline Porosidade & --- & Pouco & Pouco & Muito \\
\hline Absorção de Água & --- & Pouco & Pouco & Muito \\
\hline $\begin{array}{l}\text { Superficies Unidas por } \\
\text { Interações de Hidrogênio }\end{array}$ & --- & Pouco & Pouco & Muito \\
\hline
\end{tabular}

Fonte: Adaptado de: CAMPOS, 2009; SENAI, 2011. 


\subsection{Fatores que influem no processo de refino}

A distribuição e o grau dos efeitos do refino nas fibras dos materiais lignocelulósicos são muito heterogêneos. Isto se deve ao fato de que uma gama de variáveis, intrínsecas do processo e do material, influi diretamente nas características das polpas obtidas. Essas variáveis são categorizadas em fatores dependentes: da biomassa, do refinador, das condições de processo, do volume de refino, da natureza do refino e do impacto aplicado sobre as fibras da biomassa (SENAI, 2011). A seguir são descritas as influências de algumas dessas variáveis, que possuem maior relevância para a compreensão dos efeitos provocados nas amostras lignocelulósicas estudadas neste trabalho.

a. Energia específica de impacto:

A energia específica é a parcela da energia aplicada que é de fato absorvida pelas fibras. O valor da energia específica depende não só da potência do motor do refinador, mas também de outros fatores, como a pressão aplicada entre o rotor e o estator e a consistência de massa utilizada. Altas pressões sobre as fibras acarretam em altos valores de energia específica e, consequentemente, em altos graus de refinação (CAMPOS, 2009; SENAI, 2011).

b. Intensidade do refino:

A intensidade do refino representa a severidade com que o processo é realizado (CAMPOS, 2009). As alterações provocadas nas propriedades físicas e morfológicas do material serão mais representativas quanto maior for a intensidade do refino, que é função do número de impactos sofridos pela fibra (SENAI, 2011).

Os elementos do conjunto de refino, rotor e estator, são basicamente constituídos de uma base e uma guarnição fixada sobre a superfície da base. A face externa da guarnição é constituída de elevações (ou lâminas), que podem formar diferentes desenhos e configurações, entre barras e espaços vazios (KLOCK; DE ANDRADE; HERNANDEZ, 2013).

O fator que relaciona a potência aplicada pelo refinador com o impacto sofrido pelas fibras é o comprimento das lâminas que se entrecruzam por unidade de tempo. Um comprimento de lâminas grande significa que uma baixa intensidade de refino foi aplicada sobre as fibras, promovendo um maior efeito de fibrilação interna e uma menor frequência de cortes (SENAI, 2011; TORRES et al., 2012). O comprimento das lâminas considera, entre 
outras coisas, o número de lâminas do rotor e do estator, a espessura das lâminas e o ângulo de intersecção das bordas das barras do refinador. Um conjunto de lâminas de menor espessura gera uma maior quantidade de impactos por área de refino, o que aumenta a distribuição da energia específica; deste modo, prevalecem os fenômenos de fibrilação e, consequentemente, de hidratação das fibras (SENAI, 2011).

\section{c. Distância entre o rotor e o estator (pressão específica):}

A distância entre o estator e o rotor do refinador, ou a pressão com que o conjunto de refino atua sobre as fibras, depende diretamente de outras três variáveis: da consistência de massa, do tipo de biomassa a ser refinada e da velocidade do rotor, ou seja, está intrinsecamente relacionada com a energia específica. Se a distância entre as partes constituintes for muito grande, o sólido em suspensão é apenas bombeado, implicando em grandes tempos de refino. Porém, se esta for muito pequena, há o risco de desgaste das elevações da configuração do refinador, dado que a reduzida distância não permite a formação do colchão de massa entre o rotor e o estator, logo o contato fibra - fibra. Com a diminuição gradativa da distância, inicialmente há a hidratação das fibras com pouca ocorrência de corte; em um determinado ponto, a redução na distância implica em um processo de corte mais intenso e frequente, desfavorecendo a hidratação das fibras (CAMPOS, 2009; D'ALMEIDA, 1988; ROBUSTI et al., 2014).

\section{d. Tipo de fibra:}

Os tipos de fibra também influenciam nas características do processo, sendo que suas propriedades dependem de sua fonte vegetal, assim como do processo pelo qual foram obtidas (BETINI; GALATTI; PROCELPA, 1995; CAMPOS, 2009; ROBUSTI et al., 2014). Fibras mais longas, com paredes mais grossas ou com maior resistência mecânica requerem maior energia de refino para alcançar propriedades equivalentes a fibras mais curtas, com paredes finas e flexíveis ou com menor resistência.

O processo químico pelo qual o material lignocelulósico é tratado também influi na operação de refino, em especial com relação ao teor de lignina e hemiceluloses que é removido das fibras, alterando a porosidade e a área superficial do material (BETINI; GALATTI; PROCELPA, 1995; D’ALMEIDA, 1988). A presença de lignina nos espaços interfibrilares e interlamelares impede que a água penetre nas camadas mais internas da fibra, 
de forma que a delaminação nas regiões onde se encontra a maior proporção de celulose é dificultada. Ademais, altos teores de lignina na estrutura da fibra fazem com que esta seja rígida e quebradiça, o que prejudica o refino e favorece o rompimento das fibras. Já a presença de hemiceluloses tende a facilitar o processo.

\section{e. Consistência de massa:}

O teor de sólidos em uma suspensão influencia diretamente no tempo de residência das fibras no interior do refinador, o que altera tanto o consumo de energia no processo como o ajuste da distância entre o rotor e o estator do refinador. A utilização de uma baixa consistência de massa durante o refino $(2,5 \%$ a 3,0\%) favorece o corte e a fibrilação externa das fibras pelo maior contato entre as lâminas e as fibras. Já a utilização de uma alta consistência $(5,0 \%$ a 5,5\%) permite um maior contato fibra-fibra, o que favorece a compressão longitudinal e a fibrilação interna, portanto desfavorece o corte e a formação de finos (BETINI; GALATTI; PROCELPA, 1995; CAMPOS, 2009; D’ALMEIDA, 1988; ROBUSTI et al., 2014).

\section{f. Duração do refino:}

O grau de um refino (corte das fibras, fibrilação e quebra das forças de ligação) depende diretamente de sua duração. O tempo de uma operação de refino é função do tipo de equipamento utilizado e da área útil de refinação. Quanto maior o número de elevações na configuração do rotor e do estator, aplicadas dentro de uma área útil, maior o número de batidas nas fibras por passagem pela área; consequentemente, maior é a hidratação alcançada pela fibra, assim como o grau de refino (D’ALMEIDA, 1988).

\section{g. Velocidade periférica ou de rotação:}

Apesar de ser uma variável importante, não possui aplicação prática, posto que a maioria dos equipamentos possui a velocidade de rotação do sistema refinador fixa. Entretanto, a análise desta variável permite identificar que quanto maior a velocidade periférica do rotor, menor é a frequência de corte das fibras e maiores são os efeitos de fibrilação e hidratação (D’ALMEIDA, 1988). Isto ocorre pelo aumento do número de impactos das lâminas sobre as fibras por tempo de refino (CAMPOS, 2009). 


\subsection{Tipos de refinadores}

As propriedades das polpas mecânicas dependem das características das fibras tratadas, que são uma função do número de etapas de refino e especialmente da configuração do refinador (FENGEL; WEGENER, 1989). Ao longo da história, refinadores de diferentes geometrias e configurações foram desenvolvidos e modificados com o intuito de atender as demandas industriais com o menor custo e o menor consumo energético. Já na escala laboratorial, refinadores de diferentes mecanismos de atuação foram propostos como forma de estudar os efeitos do refino nas propriedades estruturais das fibras e relacioná-las com a qualidade do papel obtido (GHAREHKHANI et al., 2015).

Entre os tipos de refinadores industriais podem-se citar as holandesas, os refinadores cônicos e os refinadores de discos. Já na escala laboratorial destacam-se os refinadores tipo Valley, PFI e Jokro. A seguir serão detalhadas as configurações e o modo de atuação dos refinadores de discos, PFI e Jokro.

\section{a. Refinadores de discos:}

Os refinadores de discos foram introduzidos na indústria em substituição aos refinadores cônicos, visto que consomem uma menor quantidade de energia por tonelada de biomassa processada e apresentam um menor custo operacional. Este equipamento também permite uma maior velocidade de rotação da parte móvel do sistema de refino, além de utilizar um conjunto rotor/estator com projeções no formato de lâminas de maior comprimento por área. Como a área de refinação é maior, um maior número de fibras é tratado simultaneamente (CAMPOS, 2009; ROBUSTI et al., 2014).

Basicamente, os refinadores de discos são compostos de dois discos dispostos paralelamente, um rotor e outro estator. Assim como os refinadores cônicos, ambos os discos possuem projeções no formato de lâminas em suas superfícies (Figura 25). Conforme ilustrado na Figura 26, no processamento em refinador de discos a pasta celulósica (em baixa consistência) é impulsionada a passar entre os discos rotor e estator, onde as forças de atuação das lâminas são perpendiculares ao eixo de rotação, permitindo um tratamento mais uniforme das fibras e um melhor aproveitamento das lâminas dos discos (CAMPOS, 2009).

A pressão exercida sobre o material também é controlada por um volante, que permite o ajuste da distância axial entre o rotor e o estator. 
Figura 25. (A) fotos de refinadores de discos e (B) ilustração indicando suas partes constituintes.
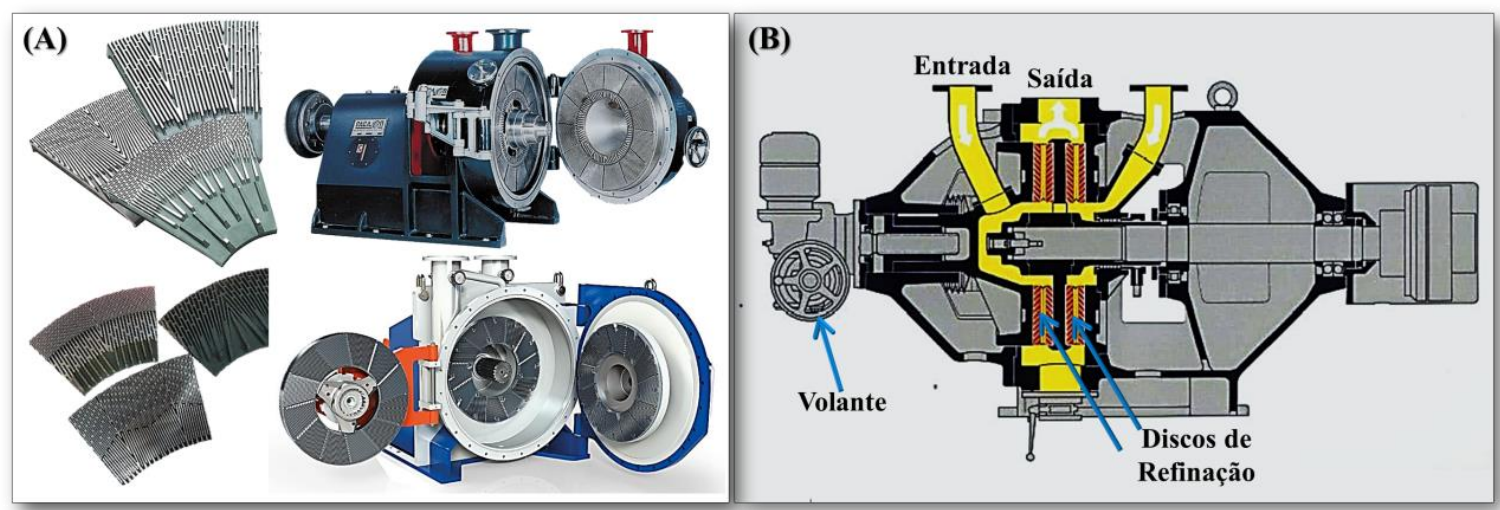

Fonte: Adaptado de: (A) HERGEN, 2017; KARTHA MÁQUINAS E EQUIPAMENTOS, 2017a; KARTHA MÁQUINAS E EQUIPAMENTOS, 2017c; TECHMELT, 2013; (B) SENAI, 2011.

Figura 26. Esquema de funionamento de um refinador de discos.

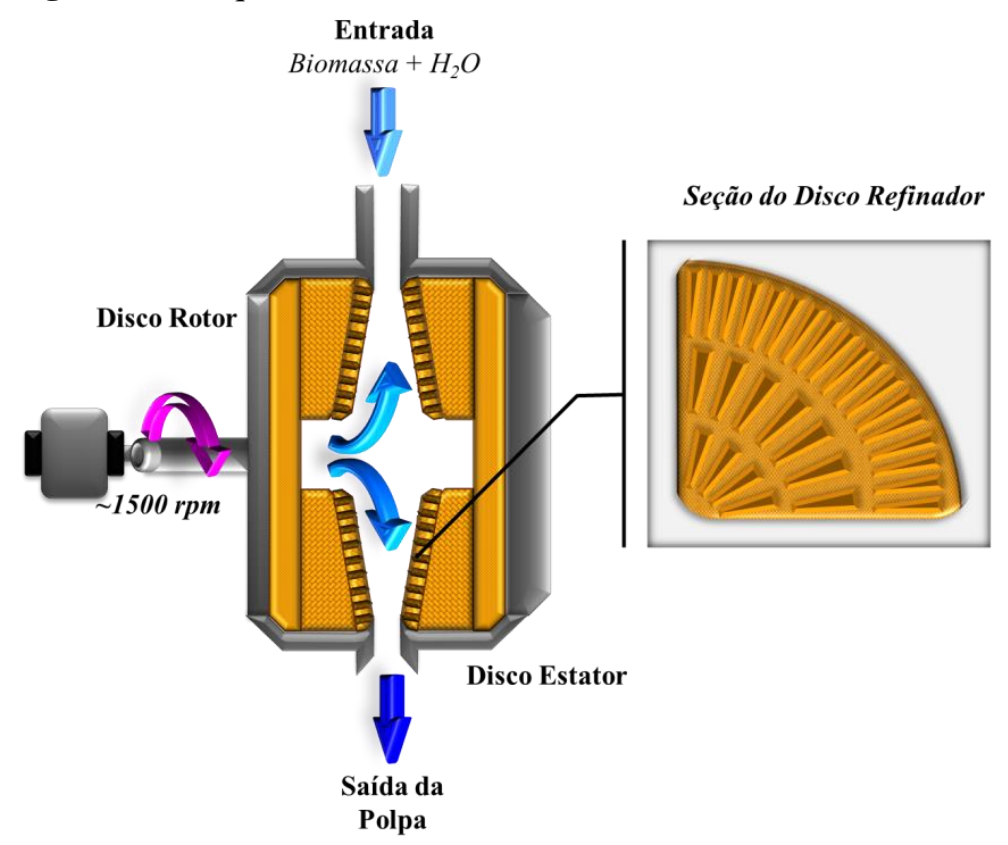

Fonte: Própria.

Consoante ao informado anteriormente, o conjunto rotor/estator possui uma gama de possibilidades de configuração das lâminas projetadas, que variam com relação à disposição, espessura, profundidade, espaçamento e ângulo. A escolha do desenho do conjunto de refino é feita de acordo com a biomassa e a aplicação final. Cada configuração é destinada a uma função específica: as barras grossas possuem a função de quebrar pedaços de biomassa mais grossos, as intermediárias de desfibrar em o material em fibras isoladas, e as mais finas de refinar a polpa. Adicionalmente, o desenho do arranjo das lâminas permite um maior ou menor número de impactos sobre as fibras (KLOCK; DE ANDRADE; HERNANDEZ, 2013). 
b. Moinho PFI:

O moinho PFI (Figura 27 (A)) é um refinador de escala laboratorial de baixa intensidade refino, porém de alta energia específica. O sistema de refino é formado por um cilindro rotativo com lâminas fixadas em sua lateral, inserido em uma panela cuja parede interior é ranhurada; ambos os elementos rotacionam, porém com velocidades periféricas diferentes. Durante o processo de refino, o material em suspensão aquosa é pressionado e distribuído uniformemente pela parede da panela por forças centrífugas, portanto a pressão aplicada sobre as fibras do material é homogênea em todos os pontos do conjunto. Assim, os efeitos de refino são provocados pela compressão das barras do rotor contra a parede da panela e pelo cisalhamento das fibras. Este equipamento permite que o refino seja realizado em uma ampla faixa de consistência de massa (de 5\% a 50\%), e o grau do refino é controlado pelo número de rotações do sistema (CHEN et al., 2013; GHAREHKHANI et al., 2015).

Figura 27. Partes constituintes dos refinadores laboratorials (A) tipo PFI e (B) tipo Jokro.

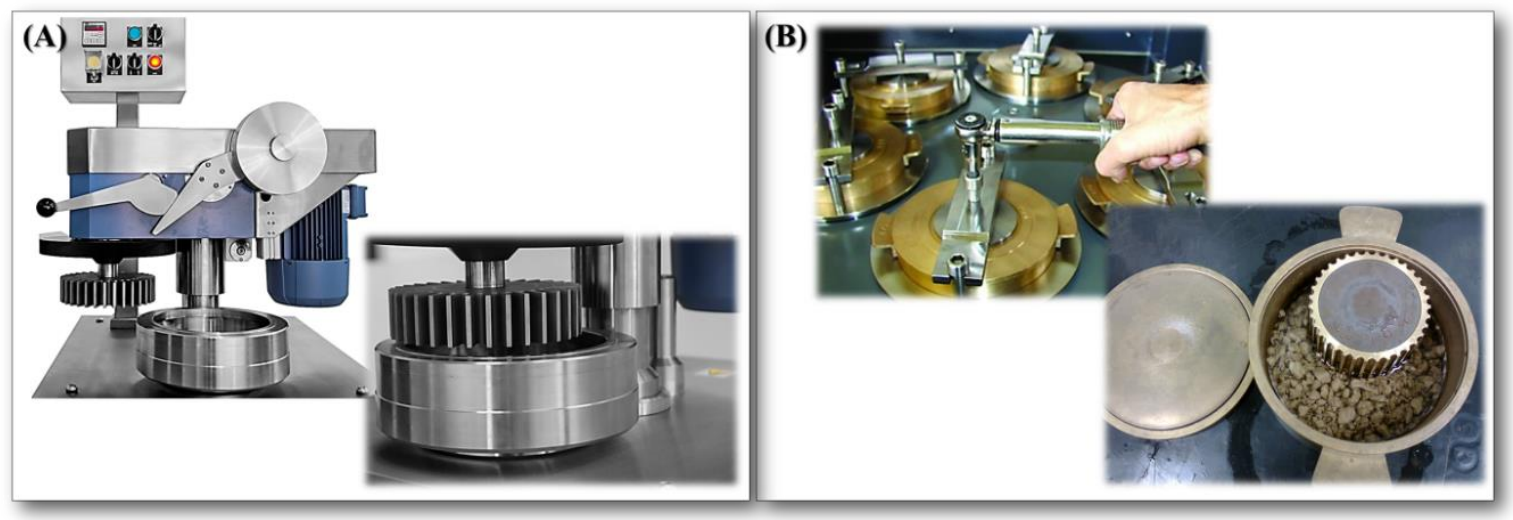

Fonte: Adaptado de: (A) IDM TEST, 2017b; (B) IDM TEST, 2017a; Própria.

c. Moinho Jokro:

Apesar de possuir o mesmo princípio de funcionamento do moinho PFI, o moinho Jokro (Figura 27 (B)) tem sido menos aplicado em estudos de refino de escala laboratorial. As diferenças entre o sistema de refino do moinho tipo Jokro em relação ao PFI consistem no controle do cilindro moente e na configuração das lâminas. Enquanto o conjunto rotor do PFI é controlado diretamente por um motor através de um eixo vertical, o moente do Jokro não é fixo e não possui controle direto; diferentemente, o conjunto de refino do moinho Jokro é inserido em um tambor que rotaciona a uma velocidade fixa, permitindo ao moente os movimentos de rotação e translação. Além disso, as lâminas do moente do moinho Jokro 
possuem menor espessura e menor profundidade em relação às lâminas do moente do PFI. O equipamento permite o refino apenas em baixa consistência de massa (6\%), e o grau do refino também é controlado pelo número de rotações do sistema (GHAREHKHANI et al., 2015).

Alguns cuidados devem ser tomados ao comparar os efeitos provocados nas fibras lignocelulósicas por equipamentos de escala laboratorial e industrial / piloto. As diferenças nas geometrias, nos modos de operação e nas consistências de sólido utilizadas implicam em variações nas intensidades de refino e, portanto, em uma distribuição de efeitos desigual. Os moinhos PFI e Jokro são refinadores de alta energia específica (cerca de 10 vezes a utilizada por refinadores industriais) e de baixa intensidade de refino (cerca de $10 \%$ da energia aplicada em uma fibra por impacto em comparação aos refinadores industriais). Uma menor intensidade de refino significa que as fibras sofreram um maior número de impactos, que são mais suaves; logo, o tratamento é mais homogêneo, com distribuição uniforme dos efeitos e acurácia no controle. Uma baixa intensidade de refino também implica no predomínio da fibrilação interna em detrimento da fibrilação externa e do corte das fibras (KEREKES, 2005; XU et al, 2014; YASUMURA; D’ALMEIDA; PARK, 2008; ZHANG et al., 2014).

Deste modo, enquanto os moinhos PFI e Jokro promovem uma fibrilação interna mais intensa pelo predomínio das forças de compressão, o refinador de discos acarreta na acentuada fibrilação externa pelo predomínio das forças de cisalhamento, apesar de ambos os efeitos ocorrerem nos dois casos (KEREKES, 2005; YASUMURA; D'ALMEIDA; PARK, 2008). Em outras palavras, enquanto os refinadores laboratoriais promovem um aumento mais expressivo no volume de poros internos da parede celular, os refinadores industriais culminam no aumento da área superficial externa pela redução das dimensões das fibras e pela formação de elementos finos.

\subsubsection{Influência dos métodos de refino na sacarificação de materiais lignocelulósicos}

As alterações físicas e morfológicas provocadas nas fibras pelo processo de refino promovem a desestruturação e a abertura da parede celular, o que é, consoante ao apresentado anteriormente, benéfico para a bioconversão dos polissacarídeos. Com todo o conhecimento adquirido neste ramo e a instalação das unidades operacionais de refino de biomassas em escala comercial, enfatiza-se o seu potencial de aplicação, em um curto tempo, como método 
de pré-tratamento visando o aumento da acessibilidade às enzimas hidrolíticas e da eficiência de produção de açúcares fermentescíveis (CHEN et al., 2012a; HUO et al., 2013; JONES et al., 2013; XU et al., 2014; ZHU et al., 2009). Todavia, a qualidade das fibras requerida para a formação do papel não é diretamente relevante para o aumento da produtividade da sacarificação enzimática. Destarte, pode-se otimizar as condições de processo de forma a reduzir o consumo energético e maximizar a abertura da estrutura da parede celular.

Entre as muitas propriedades estruturais da parede celular que são alteradas podem-se citar: o deslocamento e a separação intercelular; a redução das dimensões das partículas; a desorganização da matriz lignocelulósica; o aumento da capilaridade interfibrilar e interlamelar (porosidade); a separação em fibrilas individuais ou em agregados fibrilares; a exposição das microfibrilas na superfície externa; o rompimento das interações intermoleculares e da regularidade estrutural da celulose; o intumescimento da parede celular; e, em alguns casos, ainda é reportada a ruptura transversal da estrutura cristalina da celulose (CHEN et al., 2013; DE BARROS et al., 2013; JONES et al., 2013; PARK et al., 2016; SUN et al., 2016; ZHAO; ZHANG; LIU, 2012).

Em relação à composição química das biomassas lignocelulósicas, esta como um todo não é alterada pelo processo de refino, exceto pela remoção de alguns compostos solúveis em água. Isto significa que os teores de cada um dos macrocomponentes mantêm-se inalterados, conforme afirmado por diversos autores para a aplicação de uma variedade de métodos e consumos energéticos (CHEN et al., 2012b; DEL RIO; CHANDRA; SADDLER, 2011; GAO et al., 2012; JONES et al., 2014). Entretanto, a distribuição destes na superfície e nas diferentes camadas pode sofrer variações ao longo do refino. A ruptura das camadas exteriores e a delaminação expõem a as fibrilas celulósicas existentes nas camadas mais internas e as hemiceluloses presentes nos poros, portanto aumentam a área superficial livre dos polissacarídeos (BANAVATH; BHARDWAJ; RAY, 2011; BHARDWAJ; HOANG; NGUYEN, 2007; CHEN et al., 2012a; FARDIM; DURÁN, 2003; MOU et al., 2013; MOU; LI; FARDIM, 2014). Deste modo, ao mesmo passo que o refino altera a estrutura física e a morfologia das fibras, aumenta a concentração de carboidratos expostos em superfícies acessíveis e diminui a influência da cobertura da lignina. Este efeito é mais pronunciado em amostras com maiores teores de lignina, onde a acessibilidade inicial aos polissacarídeos é extremamente restrita (FARDIM; DURÁN, 2003; MOU et al., 2013). 
O refino mecânico ainda exibe algumas vantagens econômicas em relação aos demais métodos de pré-tratamento, que advêm de uma série de fatores. Visto que este processo não promove a alteração da composição química da biomassa, não há a formação de compostos fenólicos e não há a degradação dos carboidratos de interesse; por conseguinte, não há a formação de inibidores da ação dos microrganismos fermentativos. Com exceção dos processos termomecânicos e químico-termomecânicos, o refino também não demanda a adição de reagentes químicos e o uso de altas temperaturas de operação, portanto não envolve custos com recuperação de reagentes, tratamento de efluentes e materiais resistentes à corrosão (ALVIRA et al., 2010; CHEN et al., 2014; PARK et al., 2016; SUN et al., 2016).

Valendo-se da possibilidade de aumentar a acessibilidade enzimática e facilitar a etapa de hidrólise dos polissacarídeos utilizando uma tecnologia bem estabelecida e robusta, diversos estudos recentes demonstraram a efetividade da aplicação do refino mecânico na desconstrução da recalcitrância natural dos materiais lignocelulósicos. Dentro destes trabalhos, diferentes equipamentos de refino de escala laboratorial, piloto e industrial foram utilizados para o processamento de uma variedade de biomassas, submetidas ou não a uma etapa prévia de tratamento físico-químico.

Na Tabela 4 a seguir encontram-se resumidas as principais publicações encontradas no contexto da aplicação de métodos de refino como pré-tratamento de bagaço e palha de cana-de-açúcar visando a bioconversão enzimática. Não foram reportados trabalhos cujo foco não foi a investigação do processo de refino em si ou que estudaram métodos apenas de cominuição convencionais (moagem). Posto que o valor de conversão final dos polissacarídeos depende tanto do tipo e da concentração do complexo glicosil hidrolítico utilizado, como da origem vegetal e da composição da biomassa, a tabela apresenta apenas os valores dos incrementos alcançados nos rendimentos de açúcares redutores com o processo de refino em relação às amostras não refinadas, calculados segundo a Equação 1.

$$
\Delta R(\%)=\left[\left(R_{\text {pós-refino }}-R_{\text {não refinado }}\right) \times 100\right] / R_{\text {não refinado }}
$$

Onde $\Delta R(\%)$ é o aumento percentual no rendimento de açúcares redutores obtidos na hidrólise da biomassa em questão após o refino, $R_{\text {pós-refino é o rendimento total de açúcares }}$

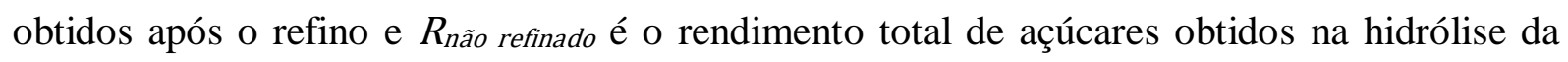
amostra de mesma composição não refinada. 
Tabela 4. Publicações acerca do uso de métodos de refino como pré-tratamento para o aumento da sacarificação enzimática do bagaço das lignoceluloses.

\begin{tabular}{|c|c|c|c|c|c|c|c|}
\hline \multicolumn{2}{|c|}{ Referência } & \multirow{2}{*}{ Biomassa } & \multirow{2}{*}{$\begin{array}{l}\text { Processamento } \\
\text { Físico-Químico }\end{array}$} & \multirow{2}{*}{$\begin{array}{l}\text { Processamento } \\
\text { Físico-Mecânico }\end{array}$} & \multirow{2}{*}{$\begin{array}{c}\text { Variáveis de Refino } \\
\text { Estudadas }\end{array}$} & \multirow{2}{*}{$\begin{array}{c}\text { Incrementos na } \\
\text { Digestibilidade Enzimática }\end{array}$} & \multirow{2}{*}{$\begin{array}{c}\text { Parâmetros } \\
\text { Estruturais } \\
\text { Estudados }\end{array}$} \\
\hline Ano & Autores & & & & & & \\
\hline 2010 & $\begin{array}{l}\text { DA SILVA } \\
\text { et al. }\end{array}$ & $\begin{array}{l}\text { Bagaço e } \\
\text { palha de } \\
\text { cana-de- } \\
\text { açúcar }\end{array}$ & --- & $\begin{array}{l}\text { (1) } \boldsymbol{R} \boldsymbol{D}^{*}: \mathrm{v}=1800 \mathrm{rpm} \\
\mathrm{Dd}=20-40 \mathrm{~mm},[\mathrm{~S}]= \\
2 \% ;(2) \boldsymbol{M B}: \mathrm{v}=400 \\
\mathrm{rpm}, 7 \text { bolas de } 15 \mathrm{~mm}\end{array}$ & $\begin{array}{l}\text { (1) } \boldsymbol{R} \boldsymbol{D}^{*}: \mathrm{GR}(1-20 \\
\text { ciclos, } 3 \text { - } 17 \mathrm{~min} \\
\text { cada); } \\
\text { (2) } \boldsymbol{M B}: \mathrm{t}_{\text {moagem }}(30- \\
120 \mathrm{~min})\end{array}$ & $\begin{array}{l}\text { (1) } \mathbf{R D} *: \text { Bagaço - G }=43- \\
124 \%, \mathbf{A}_{\mathbf{T}}=40-118 \% ; \text { Palha } \\
-\mathbf{G}=139-189 \%, \mathbf{A}_{\mathrm{T}}=133- \\
189 \% ;(\mathbf{2}) \mathbf{M B}: \text { Bagaço }-\mathbf{G}= \\
180-280 \%, \mathbf{A}_{\mathrm{T}}=198-300 \% \\
\text { Palha }-\mathbf{G}=90-249 \%, \mathbf{A}_{\mathrm{T}}= \\
89-264 \% .\end{array}$ & $\begin{array}{l}\text { Morfologia das } \\
\text { fibras } \\
\text { (microscopia), } \\
\text { distribuição de } \\
\text { tamanhos de } \\
\text { partículas e } \\
\text { cristalinidade }\end{array}$ \\
\hline \multirow[b]{2}{*}{2012} & $\begin{array}{l}\text { MIURA et } \\
\text { al. (a) }\end{array}$ & $\begin{array}{l}\text { Bagaço de } \\
\text { cana-de- } \\
\text { açúcar }\end{array}$ & $\begin{array}{l}\text { Pré-tratamento } \\
\text { básico diluído }\end{array}$ & $\begin{array}{l}\boldsymbol{R} \boldsymbol{D}^{*}: \mathrm{v}=1800 \mathrm{rpm}, \mathrm{Dd} \\
=0-100 \mathrm{~mm},[\mathrm{~S}]=2 \%\end{array}$ & GR: 4 a 7 ciclos & $\begin{array}{l}0 \% \mathrm{Na}_{2} \mathrm{CO}_{3}: \mathbf{G}=142-217 \% \\
6 \% \mathrm{Na}_{2} \mathrm{CO}_{3}: \mathbf{G}=89-105 \%\end{array}$ & $\begin{array}{c}\text { ASE e } \\
\text { cristalinidade }\end{array}$ \\
\hline & GAO et al. & $\begin{array}{l}\text { Bagaço de } \\
\text { cana-de- } \\
\text { açúcar }\end{array}$ & $\begin{array}{c}\text { Deslignificação } \\
\text { com peróxido de } \\
\text { hidrogênio - pós } \\
\text { refino }\end{array}$ & $\begin{array}{l}\boldsymbol{R} \boldsymbol{D}^{*}: \mathrm{v}=1800 \mathrm{rpm}, \mathrm{Dd} \\
=20-40 \mathrm{~mm},[\mathrm{~S}]=5 \% \\
10 \text { ciclos }\end{array}$ & $\begin{array}{l}\mathrm{T}_{\text {pré-tratamento }}: 0(\mathrm{sem} \\
\text { tratamento }), 50^{\circ} \mathrm{C} \text { ou } \\
70^{\circ} \mathrm{C}\end{array}$ & $\begin{array}{l}\text { Não-tratado: } \mathbf{G}=141 \% \\
50^{\circ} \mathrm{C}: \mathbf{G}=55 \% \\
70^{\circ} \mathrm{C}: \mathbf{G}=36 \%\end{array}$ & --- \\
\hline 2013 & $\begin{array}{l}\text { DE } \\
\text { BARROS } \\
\text { et al. }\end{array}$ & $\begin{array}{l}\text { Bagaço e } \\
\text { palha de } \\
\text { cana-de- } \\
\text { açúcar }\end{array}$ & $\begin{array}{l}\text { Deslignificação } \\
\text { por ozonólise - } \\
\text { (1) pré ou (2) pós } \\
\text { refino }\end{array}$ & $\begin{array}{l}\boldsymbol{R} \boldsymbol{D}^{*}: \mathrm{v}=1800 \mathrm{rpm}, \mathrm{Dd} \\
=20-40 \mathrm{~mm},[\mathrm{~S}]=2 \% \\
15 \text { ciclos }\end{array}$ & $\begin{array}{l}\text { GR: } 1 \text { - } 7 \text { ciclos } \\
\text { (biomassa não- } \\
\text { tratada) ou } 1 \text { - } 5 \\
\text { ciclos (biomassa pré- } \\
\text { tratada) }\end{array}$ & $\begin{array}{l}\text { PFM: Bagaço - G = 26- } \\
\text { 400\%; Palha - G = 7-169\%; } \\
\text { PFQ+PFM }(\boldsymbol{x} \mathbf{P F Q}): \text { Bagaço } \\
\text { - G = 5-51\%; Palha - G = 4- } \\
\text { 58\%; } \\
\mathbf{P F M + P F Q ~ ( x ~ P F Q ) : ~ B a g a c ̧ o ~} \\
-\mathbf{G}=6-37 \% ; \text { Palha }-\mathbf{G}=18- \\
109 \% .\end{array}$ & $\begin{array}{l}\text { Morfologia das } \\
\text { fibras } \\
\text { (microscopia) e } \\
\text { ASE }\end{array}$ \\
\hline 2015 & $\begin{array}{l}\text { BATALHA } \\
\quad \text { et al. }\end{array}$ & $\begin{array}{l}\text { Bagaço de } \\
\text { cana-de- } \\
\text { açúcar }\end{array}$ & $\begin{array}{l}\text { Pré-tratamento } \\
\text { hidrotérmico }\end{array}$ & $\begin{array}{l}\boldsymbol{P F I}:[\mathrm{S}]=10 \%, 6000 \\
\text { revoluções }\end{array}$ & $\begin{array}{l}\mathrm{T}_{\text {pré-tratamento }} \text { e } \mathrm{t}_{\text {pré- }} \\
\text { tratamento }\end{array}$ & $\begin{array}{l}180^{\circ} \mathrm{C} / 20^{\prime}: \mathbf{G}=23 \%, \mathbf{A}_{\mathrm{T}}=13 \% \\
180^{\circ} \mathrm{C} / 40^{\prime}: \mathbf{G}=12 \%, \mathbf{A}_{\mathrm{T}}=8 \% \\
190^{\circ} \mathrm{C} / 10^{\prime}: \mathbf{G}=16 \%, \mathbf{A}_{\mathrm{T}}=10 \%\end{array}$ & --- \\
\hline
\end{tabular}

Legenda: $\mathrm{RD}^{*}$ = refinador de discos - nanofibrilador Masuko; MB = moinho de bolas; PFI = moinho PFI; v = velocidade de rotação; Dd = distância entre os discos; [S] = teor de sólidos; $\mathrm{GR}=$ grau de refino; $\mathrm{t}_{\mathrm{mogem}}=$ tempo de moagem; $\mathrm{T}_{\text {pré-tratamento }}=$ temperatura do pré-tratamento físico-químico; $\mathrm{t}_{\text {pré-tratamento }}=$ tempo de pré-tratamento; $\mathrm{PFM}=$ pré-tratamento físico-mecânico; $\mathrm{PFQ}=$ pré-tratamento físico-químico; $\mathrm{G}=$ rendimento de glicose obtido por hidrólise enzimática; $\mathrm{A}_{\mathrm{T}}=$ rendimento de açúcares totais obtidos por hidrólise enzimática; ASE = área superficial específica. 
Em geral, os autores relacionam o aumento na acessibilidade enzimática com mais de um parâmetro estrutural alterado pelo refino. A seguir são resumidos alguns dos principais dados e discussões extraídas das referências mencionadas na Tabela 4, que permitem observar tendências e alcançar algumas conclusões.

- Área superficial externa das partículas:

É postulado na literatura que uma maior intensidade de refino provoca a diminuição das dimensões das fibras pelo predomínio dos fenômenos de corte, fibrilação externa e formação de elementos finos. Deste modo, é observada uma forte relação entre o aumento no grau de refino e o aumento na área superficial externa das fibras (BANAVATH; BHARDWAJ; RAY, 2011; BHARDWAJ; HOANG; NGUYEN, 2007).

CHEN et al. (2012a) associaram o aumento no rendimento de glicose obtido na hidrólise de amostras de palha de milho, após serem refinadas em moinho PFI, com a redução no diâmetro médio das partículas de $283 \mu \mathrm{m}$ para $143 \mu \mathrm{m}$.

- Área superficial interna das fibras:

O processo de fibrilação mecânica também promove a abertura efetiva da estrutura interna da parede celular pelo aumento da área de poros interlamelares e interfibrilares. Via de regra, a área superficial interna acessível às enzimas hidrolíticas aumenta com a elevação do grau de refino, enquanto a conversão enzimática dos polissacarídeos segue a mesma tendência da superfície interna (GAO et al., 2012; GONZALEZ et al., 2011).

DE BARROS et al. (2013) observaram que os aumentos nos rendimentos de hidrólise de amostras de bagaço e palha de cana-de-açúcar com o aumento no número de ciclos de refino estiveram relacionados aos incrementos nas áreas superficiais específicas, de aproximadamente 14 vezes para o bagaço e 25 vezes para a palha. Interpretação similar foi descrita por HUO et al. (2013) ao estudarem os efeitos do processamento em refinador de discos de amostras de fibras de eucalipto, tanto in natura quanto impregnadas com álcalis.

Todavia, com o aumento da intensidade do refino ou a prorrogação por tempos maiores, observa-se que tanto o volume de poros quanto a taxa de formação de açúcares redutores atingem um valor máximo, a partir do qual não aumentam de forma relevante. Este comportamento é justificado pelo fato de que há um limite na abertura da parede celular que pode ser alcançada pelo processamento físico-mecânico; em outras palavras, a melhoria que o 
refino pode estimular na conversão enzimática está atrelado à abertura máxima na estrutura de poros que decorre do processo sem a solubilização dos componentes não celulósicos (CHEN et al., 2014; CHEN et al., 2016; DA SILVA et al., 2010; HIDENO et al., 2009; HOEGER et al., 2013; JONES et al., 2013; JONES et al., 2014; KOO et al., 2011; LEE et al., 2010; MIURA et al., 2012a; MIURA et al., 2012b; XU et al., 2014; ZAKARIA et al., 2015).

Ainda, o aumento excessivo da severidade do refino pode culminar no processo de colapso dos poros maiores da estrutura interna das fibras, considerados acessíveis enzimaticamente, além do colapso do lúmen; apesar da formação concomitante de poros menores, a hidrólise dos polissacarídeos apresenta um decaimento pela diminuição na acessibilidade. Complementarmente, a lignina residual também pode se tornar mais exposta, principalmente a localizada na lamela média, o que aumenta a probabilidade de interações não produtivas (CHEN et al., 2013; JONES et al., 2013; JONES et al., 2014). Isto posto, concluise que uma alta severidade de refino pode impactar negativamente na eficiência enzimática.

- Área superficial interna x Composição química das biomassas:

Conforme explicitado anteriormente (item 2.2.6), os tratamentos físico-químicos promovem a abertura da estrutura da parede celular pela desconstrução da matriz ligninapolissacarídeos, pela remoção parcial ou ainda pela modificação dos componentes não celulósicos. Estas alterações provocadas nas fibras levam à criação e à expansão dos nanoporos interfibrilares e interlamelares, além da perda da rigidez macroscópica, fatores que auxiliam o efeito de delaminação nas camadas mais internas e propiciam o intumescimento. Por consequência, o refino proporciona a expansão adicional da área superficial interna da parede celular em amostras com menores teores de lignina e hemiceluloses. Diversas publicações recentes abordaram a combinação entre pré-tratamentos físico-químicos, realizados em condições brandas de reação, e o refino mecânico, e constataram uma maior facilidade na etapa de fibrilação com a consequente abertura da estrutura das fibras pela remoção parcial prévia dos componentes não celulósicos (HIDENO et al., 2012; MIURA et al., 2012a; MIURA et al., 2012b; ZHU et al., 2010).

Usualmente, quanto maior o teor de solubilização da lignina de uma biomassa, maior o grau de refino que pode ser alcançado aplicando a mesma intensidade ou o mesmo tempo de processamento, o que implica em volumes de poros superiores, logo em melhores taxas de conversão enzimática dos polissacarídeos (LEE et al., 2010; ZAKARIA et al., 2015). Em 
virtude do pré-tratamento físico-químico diminuir a resistência da biomassa ao processamento mecânico, também diminui o requerimento de altas intensidades ou tempos de tratamento (ZHU et al., 2010; ZHU; PAN, 2010). Em contrapartida, o refino permite reduzir a severidade do pré-tratamento químico e alcançar o mesmo nível de conversão dos polissacarídeos, o que resulta em uma menor perda em massa dos polissacarídeos de interesse e uma menor formação de compostos de degradação (JONES et al., 2013; PARK et al., 2016).

Uma constatação interessante é que muitos dos trabalhos que estudaram a combinação entre pré-tratamentos físico-químicos e o refino observaram a mesma tendência na taxa de conversão enzimática em relação à composição química do material lignocelulósico: quanto menor o percentual de componentes não celulósicos na biomassa, menor o acréscimo relativo no rendimento de açúcares redutores obtidos. Isto sugere que a abertura na estrutura da parede celular provocada pelo refino é mais significativa em amostras mais recalcitrantes, visto que as amostras com menores teores de lignina e hemiceluloses já possuem uma área superficial acessível considerável. Entretanto, as amostras com menores teores de componentes não celulósicos apresentam maiores valores absolutos de área superficial e rendimento de açúcares redutores, e a taxa de conversão enzimática dos polissacarídeos atinge o platô com menores demandas energéticas (BATALHA et al., 2015; DE BARROS et al., 2013; ERTAS et al., 2014; GAO et al., 2012; HAN et al., 2015; HOEGER et al., 2013; KOO et al., 2011; LEE et al., 2010; MIURA et al., 2012a; MIURA et al., 2012b; ZAKARIA et al., 2015).

MIURA et al. (2012a) verificaram que o aumento no rendimento de hidrólise de fibras de bagaço de cana-de-açúcar pré-tratadas hidrotérmicamente, após o processamento em refinador de discos, atingiu um platô após 6 ciclos para a amostra pré-tratada sem adição de álcali, enquanto atingiu um platô após 5 ciclos para a amostra pré-tratada com $6 \%$ de álcali devido à maior solubilização da lignina. Ademais, a melhoria na digestibilidade com o refino da amostra pré-tratada com $6 \%$ de álcali esteve relacionada a um menor aumento na área superficial específica interna (98\%) em relação à amostra pré-tratada sem álcali (175\%), o que corrobora com o comportamento dos incrementos no rendimento de glicose.

- Capacidade de retenção de água:

O refino também altera as interações com a água, conforme mensurado pela capacidade de retenção de água ou pelo grau de drenabilidade da polpa. A capacidade de retenção de água (water retention value, WRV) é uma medida da habilidade de hidratação e 
intumescimento de uma fibra. Esta é mensurada a partir da água presente nos poros interlamelares e -fibrilares, após a remoção da água retida no interior do lúmen e livre nas superfícies externas. A absorção de água no interior da parede celular é ainda influenciada pela natureza dos grupos superficiais expostos e pelo pH do meio (HOEGER et al., 2013).

Com relação ao processo de refino, a capacidade de retenção de água é um indicativo da dimensão dos fenômenos de fibrilação externa e delaminação interna. Isto significa que o aumento no WRV com o aumento da severidade do refino se relaciona com a criação de elementos finos, com a redução do tamanho das fibras, além do aumento do volume total de poros que podem ser ocupados por moléculas de água. Portanto, este valor a pode ser utilizado para representar o grau de fibrilação de uma amostra, ou ainda o aumento das áreas superficiais externa e interna (HOEGER et al., 2013).

O grau de drenabilidade é uma medida indireta da capacidade de retenção de água do substrato, isto é, quanto menor a drenabilidade de uma polpa, maior a capacidade de retenção de água (BANAVATH; BHARDWAJ; RAY, 2011; BHARDWAJ; HOANG; NGUYEN, 2007; FARDIM; DURÁN, 2003; JONES et al., 2014). O WRV assim como o grau de drenabilidade também variam com o teor de cada macrocomponente presente na estrutura da parede celular, sendo que a presença de lignina tende a restringir o intumescimento das fibras.

HOEGER et al. (2013), a partir do estudo da nanofibrilação em refinador de discos de amostras de madeira de pinus taeda, tanto deslignificada $(0,2 \%$ de lignina) quanto in natura (29,2\% de lignina), observaram uma clara correlação entre o aumento na capacidade de retenção de água e o aumento na digestibilidade enzimática das amostras. Entretanto, para um mesmo tempo de refino, o WRV da amostra deslignificada chegou a ser $47 \%$ a $99 \%$ maior que o da polpa mecânica, dado que a fibrilação é facilitada em amostras de menor recalcitrância e a presença de lignina restringe o intumescimento. XU et al. (2014) verificaram uma relação linear negativa entre o grau de drenabilidade de amostras de palha de milho e os rendimentos de açúcares redutores obtidos por hidrólise enzimática (glicose $-\mathrm{R}^{2}>0,92$, xilose $-\mathrm{R}^{2}>0,89$ ) com o aumento na duração do refino em moinho PFI.

- Estrutura cristalina da celulose:

CHEN et al. (2012b) reportaram que na fase inicial do refino apenas as regiões menos ordenadas da celulose são influenciadas pelas forças de compressão e cisalhamento aplicadas, 
logo o grau de cristalinidade mensurado aumenta; já nas últimas fases do refino as regiões cristalinas também são sujeitas aos estímulos, portanto há a redução do grau de cristalinidade.

MIURA et al. (2012a) observaram, para amostras de fibras de bagaço de cana-deaçúcar, reduções nos índices de cristalinidade com o processamento em refinador de discos de até $41 \%$, que estiveram diretamente relacionadas com os aumentos nos rendimentos de glicose obtidos por hidrólise enzimática.

Segundo HOEGER et al. (2013), o processo de cisalhamento contínuo das fibras pode reduzir o valor de cristalinidade por resultar na destruição dos cristais de celulose ao longo de seu comprimento. Ademais, os autores afirmaram que a taxa de redução da cristalinidade para biomassas deslignificadas é mais rápida do que para as integrais (com alto teor de lignina); isto é, enquanto a ruptura da cristalinidade das fibras deslignificadas ocorre durante os primeiros estágios de refino, no processamento das fibras lignocelulósicas a energia é aplicada primeiramente na quebra da estrutura reticulada da lignina antes da quebra da estrutura cristalina da celulose. Já VIRTANEN et al. (2015) asseguram que o refino não altera a cristalinidade, as dimensões dos cristais nem a dimensão lateral da fibrila celulósica, porém provoca um aumento no volume do sistema de poros micro- e nanométricos e o aumento da distância interfibrilar, o que reduz o efeito das moléculas nas vizinhanças.

- Comparação entre tipos de refinadores:

O tipo de refinador (configuração, modo de operação e mecanismo de tratamento) no qual o processamento é realizado também define o padrão das modificações nas características estruturais dos materiais lignocelulósicos. Isto significa que o tipo de refinador escolhido também coordenará as variações observadas na eficiência da subsequente conversão enzimática da celulose (CHEN et al., 2013; CHEN et al., 2016; CIESIELSKI et al., 2014; JONES et al., 2013; JONES et al., 2014; WANG et al., 2014).

JONES et al. (2013) compararam os efeitos provocados em uma amostra de madeira de folhosas, pré-tratada com licor verde, pelo uso de dois refinadores de escala laboratorial, PFI e Valley. Com o aumento na extensão do refino, os autores observaram que o processamento em moinho PFI não provocou grandes alterações nas dimensões das fibras (reduções no comprimento e $18 \%$ a 22,5\%), porém acarretou em aumentos consideráveis na capacidade de retenção de água da amostra (de $31 \%$ a $80 \%$ ); diferentemente, o processamento em refinador Valley provocou o decréscimo contínuo no comprimento das fibras (de 18\% a 
61\%), a formação extensiva de elementos finos (de $22 \%$ a 198\%), além do grande aumento na WRV (de $42 \%$ a 150\%). Deste modo, concluiu-se que o processamento em moinho PFI promove principalmente o mecanismo de fibrilação interna com o resultante intumescimento das fibras, enquanto o refinador Valley exerce, além da fibrilação, o fenômeno de corte. As alterações estruturais provocadas pelo refinador Valley promoveram uma maior abertura da estrutura da parede celular para o acesso das enzimas hidrolíticas, e resultaram em um maior valor de conversão da celulose em glicose.

\section{- Comparação entre refino e moagem:}

Neste contexto, deve-se também diferenciar os modos de atuação dos processos de cominuição mecânica (moagem) em relação aos processos de refino. Ambos promovem a abertura na estrutura da parede celular, porém com diferentes alterações nos parâmetros estruturais. HIDENO et al. (2009) compararam os efeitos provocados por um moinho de bolas e por um refinador de discos nas fibras de uma amostra de palha de arroz, e verificaram que, para um mesmo tempo de processamento, os dois equipamentos resultaram em substratos com hidrolisabilidades similares. Contudo, ao passo que o moinho de bolas provocou a cominuição das fibras de $500 \mu \mathrm{m}-2 \mathrm{~mm}$ (não moídas) para $30 \mu \mathrm{m}$ (moídas por $60 \mathrm{~min}$ ) e a drástica redução do índice de cristalinidade de 52\% para 13\%, o refinador de discos promoveu uma fibrilação gradativa com a redução da espessura das fibras e o aumento da área superficial, porém sem uma alteração significante da cristalinidade (redução máxima de 11\%). Comparação semelhante foi realizada por DA SILVA et al. (2010) para amostras de bagaço e palha de cana-de-açúcar, onde os autores concluíram que o moinho de bolas permite o aumento da digestibilidade enzimática das amostras pelo rompimento contínuo da estrutura cristalina da celulose e pela rápida redução do comprimento das fibras, diferentemente do refinador de discos, que aumenta a área acessível às enzimas hidrolíticas pela redução do comprimento e da espessura das fibras e de forma independente da cristalinidade.

Diante deste cenário, pode-se inferir que a implementação da tecnologia de refino como etapa da biorrefinaria auxiliará na superação da recalcitrância das biomassas lignocelulósicas à sacarificação, logo a produtividade da formação de açúcares redutores poderá ser intensificada com cargas enzimáticas atrativas. Ademais, enfrentará poucas barreiras tecnológicas à aplicação comercial. 


\section{CAPÍTULO 3. OBJETIVOS}

\subsection{OBJETIVO GERAL}

O trabalho apresentado teve início com o estudo cinético da remoção seletiva de hemiceluloses e lignina das fibras de bagaço de cana-de-açúcar segundo três rotas de prétratamentos físico-químicos, realizados em diferentes temperaturas e tempos de reação: 1 hidrotérmico, 2 - deslignificação organossolve das fibras pré-tratadas hidrotérmicamente, 3 deslignificação organossolve das fibras de bagaço. As amostras geradas foram caracterizadas quanto a sua composição química e suas características ultraestruturais. Os valores de rendimento de glicose obtidos por hidrólise enzimática permitiram a avaliação dos efeitos da composição química (teores de hemiceluloses e lignina) dos substratos na hidrolisabilidade dos materiais. Entretanto, todos os resultados gerados nas análises estruturais correlacionaram em igual extensão com a remoção dos componentes não celulósicos das fibras de bagaço, o que inviabilizou a interpretação de como as características físicas e morfológicas influenciam a acessibilidade à celulose pelas enzimas hidrolíticos.

Visando compreender o efeito das alterações nas propriedades físicas e morfológicas (dimensões morfológicas das fibras, porosidade da parede celular e organização cristalina das fibrilas celulósicas), na digestibilidade enzimática dos materiais lignocelulósicos, este projeto de tese apresenta o estudo da aplicação de tratamentos físico-mecânicos às fibras de bagaço de cana-açúcar como forma de promover modificações da estrutura da parede celular, porém com mínima ou nenhuma alteração de sua composição química.

Para este fim, foram empregados três tipos de equipamentos mecânicos cujo modo de ação, e consequente efeito sobre fibras, diferem entre si: moinho centrífugo tipo Jokro (refinador de escala laboratorial), refinador de discos Bauer (refinador de escala piloto) e moinho criogênico. $\mathrm{O}$ estudo das variáveis destes processos foi realizado empregando cinco amostras de diferentes composições químicas, com o intuito da obtenção de materiais cujas alterações físicas e morfológicas ocorressem em diferentes extensões.

Para uma melhor intepretação e discussão, os resultados obtidos foram organizados em duas sessões principais:

1) Estudo dos efeitos dos métodos físico-mecânicos nas propriedades estruturais da parede celular das amostras de bagaço, onde se interpretou como os efeitos primários do 
refino evoluem de acordo com a severidade e o tipo tratamento empregado a partir das caracterizações dos efeitos secundários;

2) Estudo dos efeitos das propriedades estruturais na efetividade da sacarificação enzimática dos polissacarídeos da parede celular, onde se confrontaram os valores numéricos obtidos nas análises físicas e morfológicas com o rendimento de sacarificação dos materiais.

Uma vez quantificados os efeitos de cada uma das propriedades estruturais analisadas na efetividade da sacarificação enzimática das amostras de bagaço, este trabalho teve como objetivo a identificação de um modelo empírico para a predição do comportamento das amostras de bagaço frente à hidrólise enzimática a partir de suas características estruturais analisadas. Mais do que isto, o fundamento deste trabalho foi a aquisição de um guia para a modificação das características da biomassa de forma a avançar as estratégias de prétratamento.

\subsection{OBJETIVOS ESPECÍFICOS}

Os objetivos específicos deste trabalho compreendem:

1) A compreensão dos efeitos dos métodos de pré-tratamento hidrotérmico e deslignificação organossolve na composição química das fibras de bagaço;

2) O estudo da influência dos efeitos primários do refino nas propriedades físicas e morfológicas das fibras lignocelulósicas;

3) A identificação da influência da composição química da biomassa na propensão das fibras aos efeitos do refino;

4) O estudo dos efeitos da composição química, das propriedades morfológicas e das características físicas na susceptibilidade das fibras lignocelulósica à sacarificação enzimática;

5) A obtenção por análise estatística de dados quantitativos que indiquem o fator por qual cada parâmetro estrutural influência nos valores de rendimento de glicose obtidos por hidrólise enzimática. 


\section{CAPÍTULO 4. MATERIAIS E MÉTODOS}

O fluxograma presente na Figura 28 a seguir descreve, de modo resumido, todas as etapas envolvidas no desenvolvimento experimental deste projeto de tese. Já o detalhamento das metodologias aplicadas em cada uma destas etapas encontra-se nos tópicos a seguir neste capítulo.

Figura 28. Fluxograma do desenvolvimento experimental deste projeto de tese.

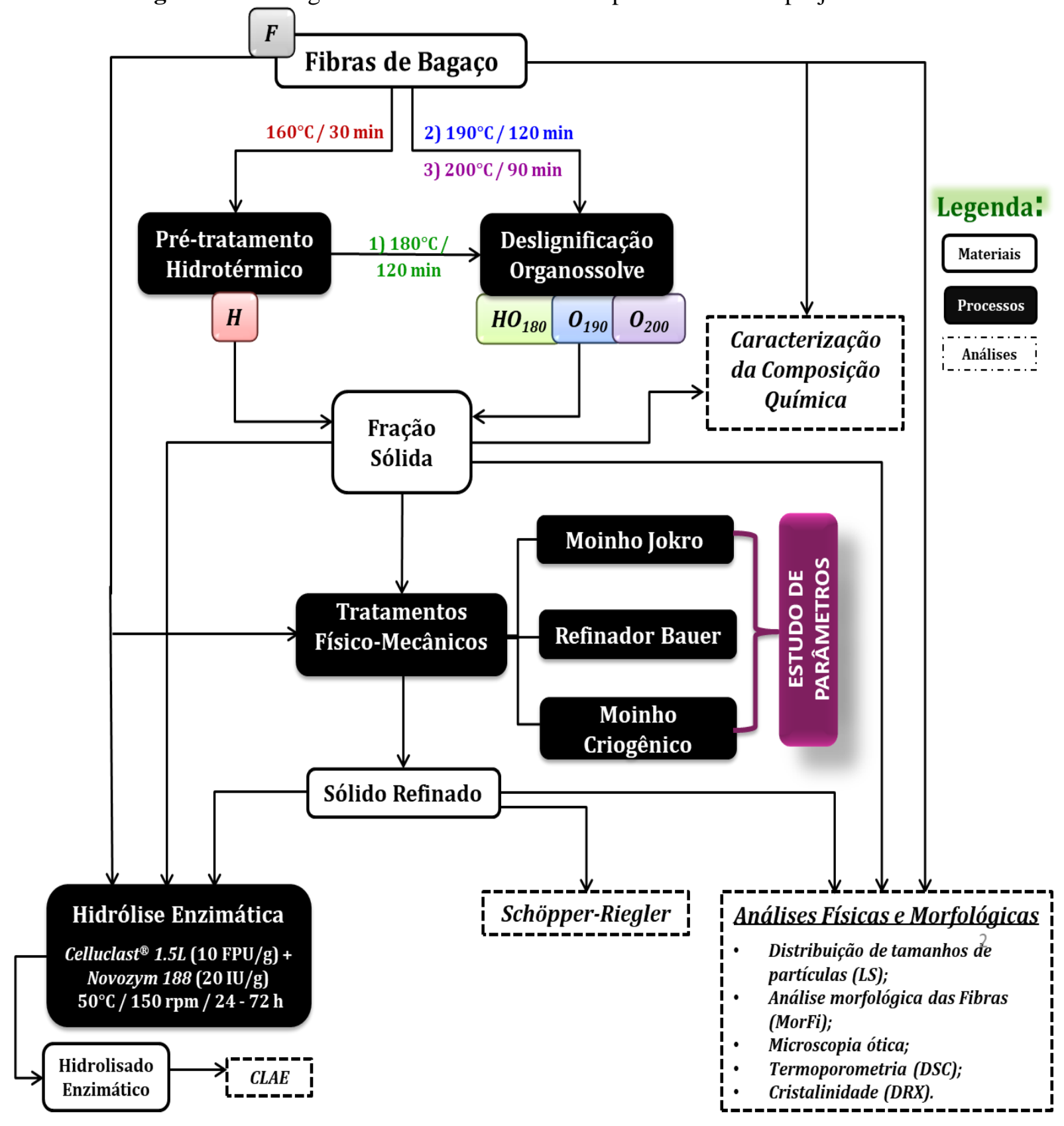




\subsection{MATÉRIA-PRIMA}

O bagaço de cana-de-açúcar utilizado neste trabalho foi gentilmente cedido pela Usina Iacanga de Açúcar e Álcool, localizada na cidade de Iacanga (São Paulo), obtido na safra de abril de 2013. Conforme mencionado no item 2.2.2, este material é composto por uma mistura de fibras e medula, e geralmente vem acompanhado de certa quantidade de impurezas oriundas do processo de colheita. Além disto, açúcares residuais, provenientes do caldo obtido na moagem da cana-de-açúcar, permanecem junto às fibras do material.

As células que compõem a fração fibra diferem das células que compõem a fração medula, não só quanto à morfologia, mas também quanto à composição química e à organização ultraestrutural da parede celular. Foi mencionado na literatura que as características das células da casca e dos tecidos vasculares da cana-de-açúcar conferem à fração fibra uma recalcitrância consideravelmente maior (MAZIERO et al., 2013; SIQUEIRA et al., 2011). Com o intuito de obter informações com maior acurácia a respeito dos efeitos dos tratamentos aplicados nos aspectos morfológicos, físicos e químicos da biomassa, no projeto proposto trabalhou-se apenas com a fração fibra do bagaço.

Assim, como etapa inicial, o bagaço integral foi submetido a um processo de lavagem e fracionamento para a remoção da fração medula e da sacarose aderida à superfície das fibras. Realizou-se a lavagem do material recebido em um recipiente contendo água a $80^{\circ} \mathrm{C}$ sob agitação por cerca de 1 hora e, em seguida, em água corrente fria utilizando um sistema de peneiras de diferentes malhas (16, 40 e 200 mesh). As fibras lavadas retidas nas peneiras de 16 e 40 mesh foram misturadas, secas sob condições ambientes até aproximadamente 10\% de umidade, e armazenadas como fração rica em fibras $(\boldsymbol{F})$ para os posteriores procedimentos.

\subsection{PRÉ-TRATAMENTOS FÍSICO-QUÍMICOS}

Nesta etapa realizou-se a remoção de componentes não celulósicos (extrativos, hemiceluloses e lignina) das fibras de bagaço de cana-de-açúcar. Para este fim, a fração rica em fibras $(\boldsymbol{F})$ foi tratada por métodos físico-químicos em reatores de aço inoxidável a altas temperaturas com o solvente determinado (água ou solução aquosa de etanol), mantendo-se uma razão sólido/líquido de 1:10 (m/v). Os pré-tratamentos estudados foram realizados em 
diferentes temperaturas e tempos de reação, de modo a obter materiais com diferentes composições químicas.

Ao fim do tempo reacional estabelecido para cada pré-tratamento, os reatores foram rapidamente resfriados em banho de gelo com o intuito de cessar a reação imediatamente. Depois de resfriados, despressurizados e abertos os reatores, separaram-se por filtração os materiais sólidos pré-tratados dos licores ricos em hemiceluloses e/ou lignina. Os resíduos sólidos foram então lavados exaustivamente em água corrente, como forma de remover completamente compostos solúveis inibitórios às enzimas hidrolíticas que foram gerados no licor de reação. Por fim, determinaram-se suas massas e teores de umidade, armazenando-os úmidos a $4^{\circ} \mathrm{C}$ para as posteriores etapas de caracterização e de tratamentos físico-mecânicos.

Os rendimentos percentuais de sólidos dos pré-tratamentos foram determinados a partir da razão entre a massa final do resíduo sólido obtido e a massa inicial de biomassa, conforme a Equação 2 a seguir:

$$
R(\%)=\frac{m_{f}}{m_{i}} \times 100
$$

Onde: $m_{i}$ é a massa inicial de amostra (base seca) (g), $m_{f}$ é a massa de biomassa pré-tratada (base seca) (g), e $R(\%)$ é o rendimento percentual de sólidos do processo. Já as solubilizações percentuais de massa, $S(\%)$, foram calculadas a partir dos valores de rendimento, segundo a Equação 3 seguir:

$$
S(\%)=100-R(\%)
$$

\subsubsection{Pré-tratamento hidrotérmico}

O pré-tratamento hidrotérmico das fibras de bagaço de cana-de-açúcar in natura foi realizado em reator rotativo laboratorial tipo autoclave eletrônica (modelo AU/E - 20, marca Regmed), cuja agitação ocorre por tombamento (rotação $360^{\circ}$ ) do conjunto reator e o aquecimento é fornecido por resistências elétricas. O interior deste reator é confeccionado de aço-inox AISI 304, com volume interno de 20 L e capacidade útil de 13,5 L. 
Adicionaram-se ao reator aproximadamente $1300 \mathrm{~g}$ (base seca) de material rico em fibras $(\boldsymbol{F})$ juntamente a $13 \mathrm{~L}$ de água destilada, sendo a reação conduzida sob a condição de $160^{\circ} \mathrm{C}$ e 30 minutos. O resíduo sólido obtido (celulignina) $(\boldsymbol{H})$ foi lavado exaustivamente em água corrente e armazenado úmido para as etapas posteriores. O procedimento de prétratamento hidrotérmico foi realizado em triplicata.

\subsubsection{Deslignificação organossolve}

A deslignificação organossolve das amostras de bagaço de cana-de-açúcar foi realizada sob três diferentes condições de reação, utilizando uma mistura solvente etanol/água $(1: 1 / \mathrm{v}: \mathrm{v})$ :

1) Deslignificação da amostra de bagaço pré-tratada hidrotérmicamente $(\boldsymbol{H})$ a $180^{\circ} \mathrm{C}$ e 120 minutos de reação $-\boldsymbol{H O}_{\mathbf{1 8 0}}$;

2) Deslignificação do bagaço in natura $(\boldsymbol{F})$ a $190^{\circ} \mathrm{C}$ e 120 minutos de reação - $\boldsymbol{O}_{190}$;

3) Deslignificação do bagaço in natura $(\boldsymbol{F})$ a $200^{\circ} \mathrm{C}$ e 90 minutos de reação $-\boldsymbol{O}_{200}$.

As reações (1) e (2) foram realizadas em reator laboratorial de alta temperatura e pressão (modelo Series 4580 HT, marca Parr), sem sistema de agitação e com aquecimento por resistências elétricas. O vaso interno deste reator é confeccionado de aço-inox 316L, com volume interno de 7,5 L e capacidade útil de 4,5 L. Para estas reações, adicionaram-se ao reator $450 \mathrm{~g}$ de material (base seca) juntamente a $4,5 \mathrm{~L}$ da mistura solvente.

Já a reação (3) foi realizada em reator tipo ampola com tampa de vedação em rosca, imerso em banho de aquecimento em glicerina pré-aquecido na temperatura de trabalho. Este reator é confeccionado de aço-inox 316L, com volume interno de $500 \mathrm{~mL}$ e capacidade útil de $300 \mathrm{~mL}$. Para esta reação, adicionaram-se ao reator $30 \mathrm{~g}$ de material (base seca) juntamente a $300 \mathrm{~mL}$ da mistura solvente.

Os resíduos sólidos obtidos (polpas celulósicas $\boldsymbol{H O}_{180}, \boldsymbol{O}_{190}$ e $\boldsymbol{O}_{200}$ ) foram primeiramente desfibrados em desintegrador mecânico com solução aquosa de $\mathrm{NaOH} 1 \%$ $(\mathrm{m} / \mathrm{v})$ a $2000 \mathrm{rpm}$ durante 2 minutos, como forma de promover a separação das fibras celulósicas umas das outras e remover fragmentos de lignina solubilizados que precipitaram sobre a superfície das fibras. Posteriormente, as polpas foram filtradas, lavadas exaustivamente em água corrente até $\mathrm{pH}$ neutro, e então armazenadas úmidas para as etapas posteriores. Os procedimentos de deslignificação organossolve foram realizados em duplicata. 


\subsection{DETERMINAÇÃO DA COMPOSIÇÃO QUÍMICA DA BIOMASSA IN NATURA E DAS AMOSTRAS PRÉ-TRATADAS}

Frações representativas das amostras de bagaço de cana-de-açúcar, tanto das fibras in natura $(\boldsymbol{F})$ quanto dos materiais pré-tratados $\left(\boldsymbol{H}, \boldsymbol{H} \boldsymbol{O}_{\mathbf{1 8 0}}, \boldsymbol{O}_{\mathbf{1 9 0}}\right.$ e $\left.\boldsymbol{O}_{\mathbf{2 0 0}}\right)$, foram submetidas a uma etapa prévia de moagem para a realização das análises de caracterização da composição química.

Nesta etapa utilizaram-se dois moinhos: um de facas e outro de impacto e cisalhamento (modelos Pulverisette 19 e Pulverisette 14, respectivamente, marca Fritsch) com peneiras acessórias de aberturas 0,50 e 0,08 mm, respectivamente.

\subsubsection{Teor de umidade}

Os teores de umidade das amostras foram determinados utilizando-se uma balança termogravimétrica analisadora de umidade (modelo MA35, marca Sartorius). Para cada análise utilizaram-se cerca de 2,0 g úmidos de amostra. Os valores de teor de umidade obtidos foram utilizados para a determinação da massa de amostra seca ( $\left.m_{\text {Amostra Seca }}\right)$ utilizada em cada análise, conforme a Equação 4:

$$
m_{\text {Amostra Seca }}=\frac{m_{\text {Úmida }} \times[100-U(\%)]}{100}
$$

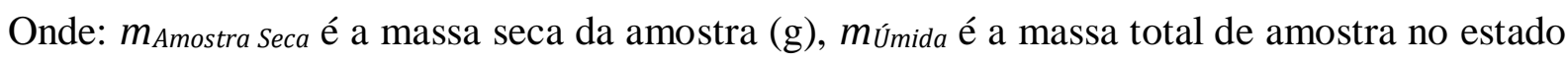
úmido (g), e $U(\%)$ é o teor percentual de umidade da amostra.

\subsubsection{Teor de cinzas}

Os teores de cinzas das fibras de bagaço de cana-de-açúcar in natura e dos materiais pré-tratados foram determinados gravimetricamente a partir dos teores de sólidos residuais resultantes da queima completa dos materiais, executada conforme o procedimento padrão "Determination of Ash in Biomass" do US National Renewable Energy Laboratory's (NREL) (SLUITER et al., 2005). A análise foi realizada em triplicata, adicionando-se cerca de 0,5 g de 
cada material (base seca), moído a 0,50 mm, a cadinhos de porcelana de massas conhecidas. Os materiais foram então carbonizados em uma mufla respeitando a seguinte rampa de aquecimento:

- $\quad$ Temperatura de $105^{\circ} \mathrm{C}$ por 12 minutos;

- $\quad$ Aquecimento até $250^{\circ} \mathrm{C}$ a $10^{\circ} \mathrm{C} /$ minuto;

- $\quad$ Temperatura de $250^{\circ} \mathrm{C}$ por 30 minutos;

- $\quad$ Aquecimento até $575^{\circ} \mathrm{C}$ a $20^{\circ} \mathrm{C} /$ minuto;

- $\quad$ Temperatura de $575^{\circ} \mathrm{C}$ por 180 minutos.

Ao fim do procedimento desligou-se a mufla e, alcançada a temperatura de $105^{\circ} \mathrm{C}$, transferiram-se os cadinhos contendo os resíduos para um dessecador. Após o resfriamento completo dos materiais, determinaram-se suas massas secas. Calculou-se o teor de cinzas de cada amostra com base na massa do resíduo obtido relativa à massa do material inicial seco, conforme a Equação 5 a seguir:

$$
\% \text { Cinzas }=\frac{m_{\text {Cinzas }}}{m_{\text {Amostra Seca }}} \times 100
$$

Onde: $m_{\text {Amostra Seca }}$ é a massa inicial de amostra seca $(\mathrm{g}), m_{\text {Cinzas }}$ é a massa final da amostra após a queima (g), e \%Cinzas é o teor percentual de cinzas presente no material.

\subsubsection{Teor de extrativos}

Este procedimento foi aplicado somente à amostra de bagaço in natura, e não às amostras pré-tratadas pelos métodos físico-químicos.

O teor de extrativos das fibras de bagaço in natura foi determinado gravimetricamente segundo o método de extração em soxhlet descrito na norma TAPPI T204 cm-97 (2007). Aproximadamente 10,0 g de amostra (base seca), moída a 0,5 $\mathrm{mm}$, foram inseridos no extrator e submetidos a diferentes ciclos de extração com refluxo de solventes sob aquecimento.

Primeiramente, a extração foi realizada utilizando-se $400 \mathrm{~mL}$ de uma mistura cicloexano/etanol (1:1, v/v), mantendo o refluxo do solvente por um período de 8 horas. Após a extração com solvente orgânico, realizou-se uma segunda etapa de extração utilizando-se 
$400 \mathrm{~mL}$ de água destilada como solvente. O procedimento de extração com água foi repetido por 5 vezes, mantendo 8 horas de refluxo do solvente em cada repetição. Esta análise foi realizada em duplicata.

Determinou-se o teor de extrativos da amostra in natura com base na diferença de massa do material seco antes e após o processo de extração, conforme a Equação 6 a seguir:

$$
\% \text { Extrativos }=\left(1-\frac{m_{\text {Amostra Extraída }}}{m_{\text {Amostra Seca }}}\right) \times 100
$$

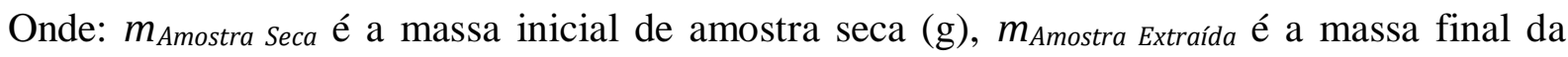
amostra após a extração (g), e \%Extrativos é o teor percentual de extrativos presente no material.

\subsubsection{Teores de lignina total, carboidratos, ácidos orgânicos, furfural e HMF}

Os teores de lignina e carboidratos, tanto das fibras de bagaço in natura quanto dos materiais pré-tratados, foram determinados de acordo com o procedimento padrão do NREL "Determination of Structural Carbohydrates and Lignin in Biomass" (SLUITER et al., 2008). Esta metodologia baseia-se na hidrólise ácida da biomassa lignocelulósica, gerando um resíduo sólido e um licor hidrolisado.

Enquanto o teor de lignina insolúvel foi determinado gravimetricamente a partir do resíduo sólido, os teores de lignina solúvel, açúcares, ácidos orgânicos, furfural e HMF foram quantificados a partir do hidrolisado obtido pelo procedimento acima citado, analisados e calculados de acordo com o procedimento validado por GOUVEIA e colaboradores (2009).

\subsubsection{Teor de lignina total}

\subsection{Teor de lignina insolúvel:}

Pesou-se cerca de 0,3 g de cada amostra (base seca), moída na granulometria 0,08 mm, em tubos de pressão. Hidrolisaram-se as amostras adicionando $3,0 \mathrm{~mL}$ de $\mathrm{H}_{2} \mathrm{SO}_{4} 72 \%$ e mantendo-as em banho termostatizado (modelo 1100, marca FANEM) a $30^{\circ} \mathrm{C}$ durante o 
período de 1 hora com agitação a cada 5 - 10 minutos. Finalizado o tempo de reação, removeram-se os tubos do banho e adicionaram-se $84 \mathrm{~mL}$ de água destilada a cada amostra, diluindo a concentração de ácido no meio para 4\%. Os tubos foram fechados com tampa apropriada, sendo em seguida autoclavados a temperatura de $121^{\circ} \mathrm{C}$ pelo período de 1 hora, com o intuito da hidrólise completa dos oligômeros formados em solução. Após o término deste período e a descompressão da autoclave, resfriaram-se os tubos até temperatura ambiente. Filtraram-se as suspensões obtidas em funis de placa porosa $n^{0} 4$ de massas conhecidas, retendo a lignina insolúvel e coletando o filtrado para posteriores análises de lignina solúvel, carboidratos, ácidos orgânicos e inibidores.

Os funis com lignina insolúvel foram então secos em estufa a $105 \pm 5{ }^{\circ} \mathrm{C}$ até massa constante. Após o resfriamento das amostras em dessecador até massa constante, determinouse gravimetricamente a massa da porção insolúvel. Sabendo que parte da fração insolúvel é constituída de lignina e outra parte de materiais inorgânicos, para que não houvesse a quantificação errônea do valor de lignina insolúvel, submeteram-se os resíduos insolúveis à carbonização em mufla, segundo a metodologia descrita no item 3.3.3.2, com o intuito de determinar o teor de cinzas.

Calculou-se a porcentagem de lignina insolúvel presente nas fibras in natura em relação à massa inicial de amostra seca utilizada no procedimento, segundo a Equação 7:

$$
\% \text { Lignina IN }=\left(\frac{m_{\text {Lignina IN }}-m_{\text {Cinzas }}}{m_{\text {Amostra Seca Pré-Extraída }}}\right) \times\left[1-\left(\frac{\% \text { Extrativos }}{100}\right)\right] \times 100
$$

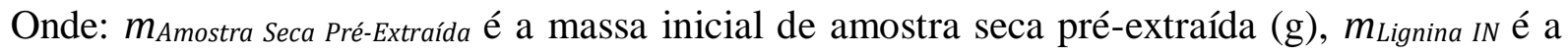
massa final de lignina insolúvel seca $(\mathrm{g}), m_{\text {Cinzas }}$ é a massa de cinzas presente na amostra $(\mathrm{g})$, \%Extrativos é o teor percentual de extrativos e \%Lignina IN é o teor percentual de lignina insolúvel presente no material.

Para as amostras pré-tratadas, onde o teor de extrativos é presumivelmente desprezível (supõe-se que os extrativos foram removidos na etapa de pré-tratamento), calculou-se o teor de lignina insolúvel segundo a Equação 8:

$$
\% \text { Lignina IN }=\left(\frac{m_{\text {Lignina IN }}-m_{\text {Cinzas }}}{m_{\text {Amostra Seca Pré-Extraída }}}\right) \times 100
$$




\subsection{Teor de lignina solúvel}

Para a determinação dos teores de lignina solúvel, separou-se uma fração de cada um dos filtrados obtidos na etapa de hidrólise ácida, e ajustaram-se seus pH em 12 utilizando $\mathrm{NaOH} 5$ mol.L $\mathrm{L}^{-1}$, de forma a garantir que toda lignina se mantivesse solubilizada. Os teores de lignina solúvel foram quantificados através da medida de absorbância dos filtrados obtidos no comprimento de onda de $280 \mathrm{~nm}$ em espectrofotômetro UV-Vis (modelo Evolution 300, marca Thermo Scientific). As concentrações de lignina solúvel nas amostras foram calculadas segundo as Equações 9 e $\mathbf{1 0}$ a seguir:

$$
\begin{gathered}
C_{\text {Lignina } S L}=\left[4,187 \times 10^{-2}\left(A_{\text {Total }}-A_{P D}\right)\right]-\left(3,279 \times 10^{-4}\right) \\
A_{P D}=\left(\varepsilon_{1} \times c_{1}\right)+\left(\varepsilon_{2} \times c_{2}\right)
\end{gathered}
$$

Onde: $C_{\text {Lignina } S L}$ é a concentração de lignina solúvel (g.L $\left.\mathrm{L}^{-1}\right), A_{\text {Total }}$ é a absorbância da solução de lignina junto com os produtos de degradação em $280 \mathrm{~nm}, A_{P D}$ é a absorbância em $280 \mathrm{~nm}$ dos produtos de decomposição dos açúcares, furfural e HMF, cujas concentrações $c_{1}$ e $c_{2}$ foram determinadas previamente por CLAE (cromatografia líquida de alta eficiência), e $\varepsilon_{1}$ e $\varepsilon_{2}$ são as absortividades do furfural e do $\operatorname{HMF}\left(146,85\right.$ e $114,00 \mathrm{~L} \cdot \mathrm{g}^{-1} \cdot \mathrm{cm}^{-1}$, respectivamente).

Assim, as porcentagens de lignina solúvel presentes na biomassa in natura e nas amostras pré-tratadas foram calculadas em relação à massa inicial de amostra seca préextraída utilizada no procedimento, segundo as Equações 12 e 13 a seguir, respectivamente:

$$
\begin{gathered}
\% \text { Lignina } S L=\left(\frac{C_{\text {Lignina SL }} \times V_{\text {Filtrado }} \times F D}{m_{\text {Amostra Seca Pré-Extraída }}}\right) \times\left[1-\left(\frac{\% \text { Extrativos }}{100}\right)\right] \times 100 \\
\text { \%Lignina } S L=\left(\frac{C_{\text {Lignina SL }} \times V_{\text {Filtrado }} \times F D}{m_{\text {Amostra Seca Pré-Extraída }}}\right) \times 100
\end{gathered}
$$

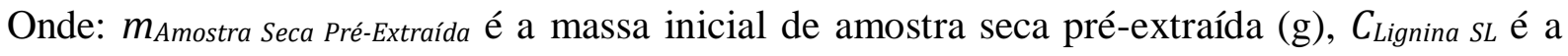

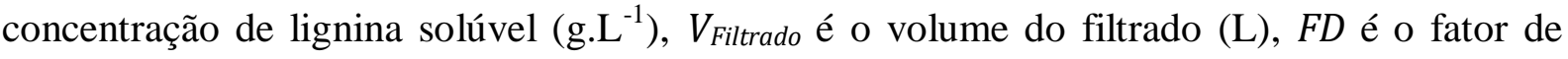
diluição para leitura de absorbância, \%Extrativos é o teor percentual de extrativos e \%Lignina SL é o teor percentual de lignina solúvel presente no material. 
Os teores de lignina total (\%Lignina Total) nas amostras foram determinados pela soma dos teores de lignina insolúvel (\%Lignina IN) e solúvel (\%Lignina SL), conforme a Equação 13:

$$
\% \text { Lignina Total }=\% \text { Lignina } I N+\% \text { Lignina } S L
$$

\subsubsection{Teores de carboidratos, ácidos orgânicos, furfural e HMF}

A determinação dos teores de carboidratos, ácidos orgânicos, furfural e hidroximetilfurfural foi realizada a partir da análise dos filtrados obtidos na etapa de hidrólise ácida, utilizando-se a técnica de cromatografia líquida de alta eficiência (CLAE) para a detecção dos seguintes compostos hidrolisados: celobiose, glicose, xilose, arabinose, ácido acético, ácido fórmico, furfural e HMF. Para a análise cromatográfica empregaram-se cromatógrafos com as seguintes especificações:

\section{Carboidratos e Ácidos Orgânicos:}

- $\quad$ Sistema de cromatografia líquida modelo Ultimate 3000, marca Dionex;

- $\quad$ Condições analíticas:

- Detector de índice de refração;

- Fluxo: 0,6 mL.min ${ }^{-1}$;

- Volume de injeção: $10 \mu \mathrm{L}$;

- Temperatura da coluna: $35^{\circ} \mathrm{C}$;

- Temperatura do detector: $35^{\circ} \mathrm{C}$;

- Pré-coluna: Cátion IG;

- Coluna: Aminex HPX-87H - 300 mm x 7,8 mm x $9 \mu \mathrm{m}$ (Bio-rad), com coluna de guarda Micro-Guard Cátion PC H Refill Cartridges (Bio-rad);

- Fase móvel: Solução $\mathrm{H}_{2} \mathrm{SO}_{4} 5 \mathrm{mM}$;

- Pressão típica no início: 1117 psi;

- Tempo de retenção/corrida: 30 min.

Furfural e HMF:

- $\quad$ Sistema de cromatografia líquida modelo Ultimate 3000, marca Dionex;

- Condições analíticas: 
- Detector UV no comprimento de onda de $274 \mathrm{~nm}$;

- Fluxo: 0,8 mL. $\mathrm{min}^{-1}$;

- Volume de injeção: $10 \mu \mathrm{L}$;

- Temperatura da coluna: ambiente (aproximadamente $25^{\circ} \mathrm{C}$ );

- Coluna: C18 - $150 \mathrm{~mm}$ x 4,6 mm x $3 \mu \mathrm{m}$ (Dionex 059133);

- Fase móvel: Água : acetonitrila 8:1 com 1\% de ácido acético (v/v);

- Pressão típica no início: 1600 psi;

- Tempo de retenção/corrida: $20 \mathrm{~min}$.

Todas as soluções contendo hidrolisado foram previamente submetidas à filtração em filtro Millex ${ }^{\mathrm{TM}} 0,45 \mathrm{e} / \mathrm{ou}$ 0,22 $\mathrm{mm}$ de poro, $13 \mathrm{~mm} \varnothing$.

O teor de celulose foi calculado a partir das concentrações de celobiose, glicose, ácido fórmico e HMF nos hidrolisados obtidos, segundo os fatores de conversão 0,950, 0,900, 3,522 e 1,29, respectivamente. Já o teor de hemiceluloses foi calculado a partir das concentrações de xilose, arabinose, furfural e ácido acético utilizando-se os fatores 0,880, 0,880, 1,375, e 0,717, respectivamente.

Determinou-se o teor de cada polissacarídeo presente nas amostras pré-tratadas (com teores de extrativos supostamente desprezíveis) a partir da Equação 14 a seguir:

$$
\% \text { Carboidrato }=\left[\frac{\sum\left(C_{C L A E} \times F C\right) \times V_{\text {Filtrado }}}{m_{\text {Amostra Seca Pré-Extraída }}}\right] \times 100
$$

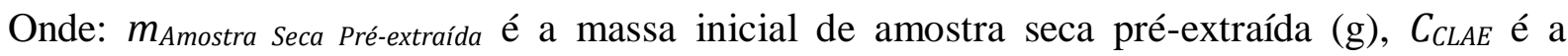
concentração do composto quantificado por CLAE (g.L $\left.\mathrm{L}^{-1}\right), F C$ é o fator de conversão utilizado para calcular a concentração polimérica dos açúcares a partir das concentrações monoméricas

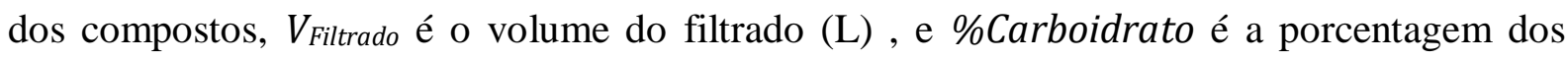
carboidratos poliméricos (celulose ou hemiceluloses) presentes no material.

Para as fibras de bagaço in natura, cujos teores de extrativos são consideráveis, o teor de cada polissacarídeo foi determinado a partir da Equação 15 a seguir:

$$
\% \text { Carboidrato }=\left[\frac{\sum\left(C_{C L A E} \times F C\right) \times V_{\text {Filtrado }}}{m_{\text {Amostra Seca Pré-Extraída }}}\right] \times\left[1-\left(\frac{\% \text { Extrativos }}{100}\right)\right] \times 100
$$


A partir dos teores de cada macrocomponente (celulose, hemiceluloses e lignina) determinados para as amostras pré-tratadas e para as fibras de bagaço in natura, calcularam-se os teores residuais destes macrocomponentes nos sólidos obtidos nos pré-tratamentos, assim como as solubilizações percentuais dos mesmos, segundo as Equações 16 e 17 a seguir:

$$
\begin{gathered}
C_{C O R}(\%)=\frac{C_{f}(\%) \times R(\%)}{100} \\
S_{C O M P}(\%)=\left(1-\frac{C_{C O R}(\%)}{C_{i}(\%)}\right) \times 100
\end{gathered}
$$

Onde: $C_{C O R}(\%)$ é o teor corrigido do componente, que representa seu teor residual no sólido pré-tratado, $C_{f}(\%)$ é o teor bruto do componente no sólido pré-tratado conforme determinado pelas técnicas mencionadas, $C_{i}(\%)$ é o teor do componente na amostra inicial não tratada, $R$ (\%) é o rendimento percentual de sólidos do processo de pré-tratamento, e $S_{\text {Сом }}(\%)$ é a solubilização percentual do componente promovida pelo pré-tratamento.

\subsection{TRATAMENTOS FÍSICO-MECÂNICOS}

O estudo dos tratamentos físico-mecânicos aplicados às fibras de bagaço de cana-deaçúcar, tanto pré-tratadas $\left(\boldsymbol{H}, \boldsymbol{H O}_{180}, \boldsymbol{O}_{190}\right.$ e $\left.\boldsymbol{O}_{200}\right)$ quanto in natura $(\mathbf{F})$, foi realizado empregando-se três tipos de equipamento: um moinho centrífugo laboratorial tipo Jokro, um refinador de discos Bauer e um moinho criogênico. A proposta de emprego destes três equipamentos foi fundamentada nos seguintes requisitos:

- $\quad$ Possibilidade de processamento de amostras no estado úmido;

- $\quad$ Diferentes modos de atuação das forças de refino;

- Diferentes intensidades de refino (impactos por fibra);

- Diferentes energias específicas.

Já a escolha das condições de tratamento foi baseada nas limitações de cada equipamento e na tentativa de produzir materiais com diferentes extensões de modificação das características físicas e morfológicas, lembrando que a qualidade das fibras que geralmente deve ser alcançada com o refino para a formação do papel não é relevante no caso deste 
trabalho. O acompanhamento dos efeitos dos diferentes processos físico-mecânicos nas fibras dos cinco materiais em estudo foi efetuado pela determinação do grau de refino pelo método Schöpper-Riegler ( $\left.{ }^{\circ} S R\right)$.

Ao fim de cada processo físico-mecânico, os materiais tratados foram coletados e filtrados para a remoção do excesso de água livre. Os resíduos sólidos foram então armazenados úmidos a $4^{\circ} \mathrm{C}$ para as posteriores etapas de caracterização. $\mathrm{O}$ intuito do armazenamento dos materiais, tanto pré-tratados pelos métodos físico-químicos quanto pelos físico-mecânicos, no estado úmido foi evitar o fenômeno de hornificação, que leva ao colapso irreversível dos poros nanométricos da parede celular e à drástica mudança das características ultraestruturais das fibras.

\subsubsection{Moinho centrífugo tipo Jokro}

Esta etapa do projeto foi realizada no Departamento de Ciência Florestal - Faculdade de Ciências Agronômicas da UNESP - Campus Lageado, na cidade de Botucatu (São Paulo).

O moinho centrífugo laboratorial tipo Jokro (modelo JK-21, marca Regmed), representado na Figura 29, consiste de um tambor onde é alocado um conjunto de seis tubos cilíndricos de bronze (panelas), cada um com um cilindro ranhurado (moente) em seu interior, atuando em movimento planetário em um processo descontínuo (batelada). Este equipamento opera com baixas consistências de massa, e o grau de refino é regulado pelo número de rotações do sistema (tempo de refino).

No refino em moinho Jokro, o material lignocelulósico é inserido em suspensão aquosa no interior da panela, cujo volume interno útil - considerando o volume ocupado pelo moente - é de aproximadamente $400 \mathrm{~mL}$. Como forma de evitar que o moente colida diretamente contra a parede da panela de refino, e assim danifique o equipamento, a massa mínima de material necessária em cada uma das panelas para a formação da pasta durante a operação é de $16 \mathrm{~g}$ (base seca). Este valor de massa é especificado pelo fabricante com o ideal para que o moente atue somente em contato com as fibras lignocelulósicas.

Para a prática dos ensaios de refino utilizando $16 \mathrm{~g}$ de material (base seca), a menor consistência de massa permitida é de $4 \%$, onde o volume interno útil da panela é completamente ocupado; entretanto, com o uso desta consistência de massa há o risco de vazamento de água entre a tampa e a panela com o decorrer do processo. Já o uso de 
consistências de massa maiores que $6 \%$ implicam em baixos volumes de água adicionados (iguais ou menores que $200 \mathrm{~mL}$ ); baixos volumes de água dificultam a formação da manta e, consequentemente, a rotação do moente no interior da panela, o que é mais expressivo no caso de amostras mais fibrosas ou com maiores teores de lignina. $\mathrm{O}$ uso de baixos volumes de água também implica no aumento excessivo da temperatura no interior da panela devido à fricção mecânica de alta intensidade, o que acarreta tanto na danificação do equipamento quanto na modificação indesejável das características da biomassa.

Figura 29. (A) Foto e (B) desenho das partes constituintes do moinho tipo Jokro.

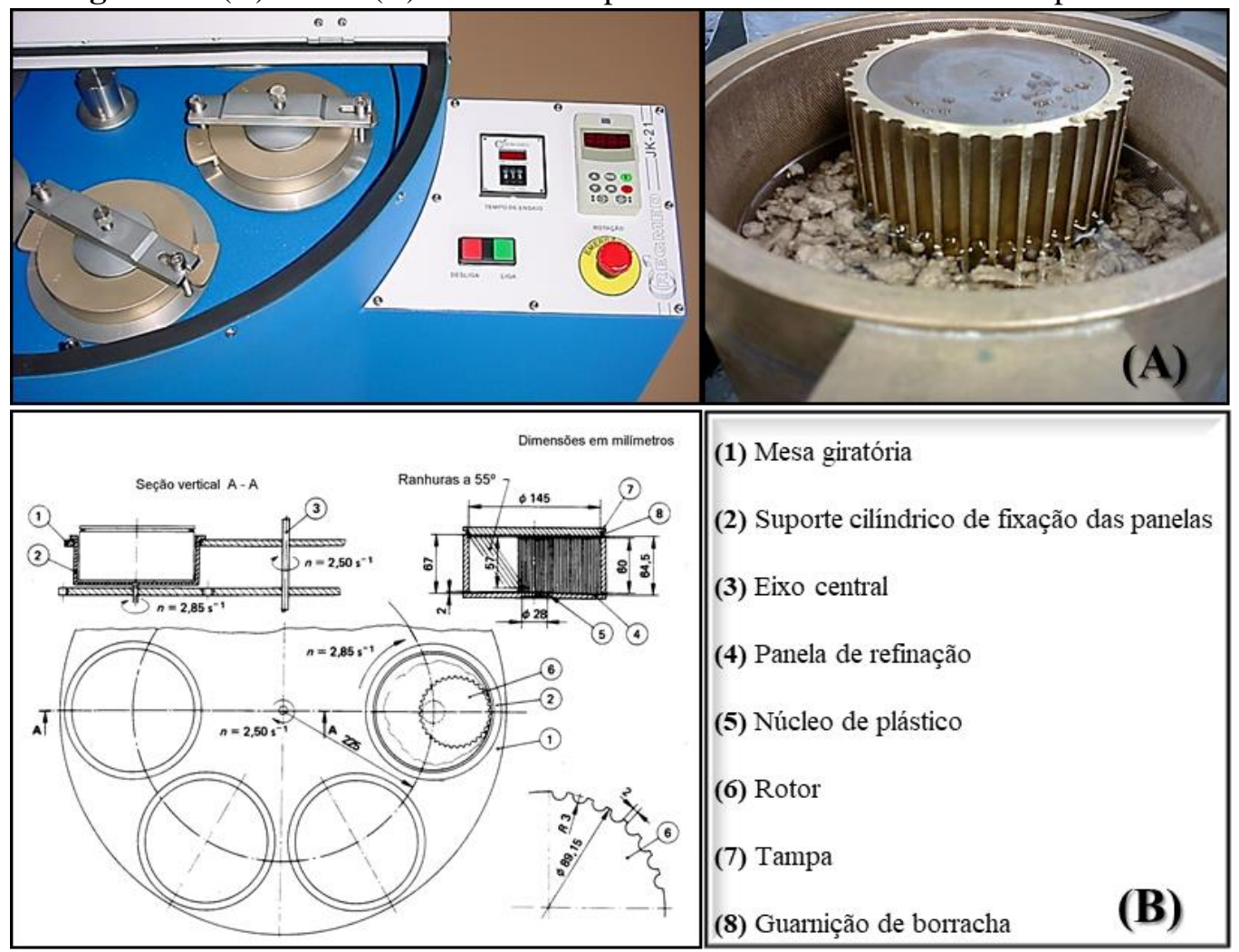

Fonte: Primeira foto e desenho: adaptados de arquivos enviados por e-mail pela Regmed Indústria Técnica de Precisão Ltda. Segunda foto: fonte própria.

Deste modo, os ensaios de refino no moinho Jokro $(\boldsymbol{M J})$, tanto das amostras obtidas nos pré-tratamentos físico-químicos $\left(\boldsymbol{H}, \boldsymbol{H O}_{\mathbf{1 8 0}}, \boldsymbol{O}_{\mathbf{1 9 0}}\right.$ e $\left.\boldsymbol{O}_{\mathbf{2 0 0}}\right)$ como das fibras de bagaço $(\boldsymbol{F})$, foram realizados utilizando-se $16 \mathrm{~g}$ de material (base seca) em cada panela, a $\mathbf{6 \%}$ de consistência de massa. O movimento planetário do equipamento ocorre a uma velocidade fixa de $150 \mathrm{rpm}$, sendo o tempo de refino a variável do processo estudada, definida como o número de revoluções do equipamento. $\mathrm{O}$ impacto do tempo de refino nos materiais em estudo foi observado pelo acompanhamento do grau de refino Schöpper-Riegler ( $\left.{ }^{\circ} S R\right)$. 
Selecionaram-se primeiramente quatro diferentes tempos de refino (números de revoluções) para o tratamento das diferentes amostras estudadas, sendo estabelecidos os valores 3, 6, 9 e 18 mil revoluções. A partir dos valores de ${ }^{\circ} S R$ obtidos foram definidos outros tempos de refino para cada um dos materiais. As fibras de bagaço in natura $(\boldsymbol{F})$ apresentaram uma grande divergência do ${ }^{\circ} S R$ quando refinadas nos tempos de 60 e 120 minutos (9 e 18 mil revoluções, respectivamente); assim, para este material, adicionaram-se os tempos de refino correspondentes a 12 e 15 mil revoluções. Diferentemente, as amostras obtidas nos pré-tratamentos físico-químicos $\left(\boldsymbol{H}, \boldsymbol{H O}_{\mathbf{1 8 0}}\right.$ e $\left.\boldsymbol{O}_{190}\right)$ não apresentaram variação significativa do ${ }^{\circ} S R$ quando refinadas entre os tempos de 40, 60 e 120 minutos $(6,9$ e 18 mil revoluções, respectivamente), optando-se por acrescentar pontos de refino nos tempos correspondentes a 1, 2, 3, 4 e 5 mil revoluções.

Com o intuito de complementar a compreensão dos efeitos provocados e verificar a extensão do processo de refino em moinho Jokro, realizou-se o tratamento da terceira polpa organossolve produzida, de menores teores de lignina e hemiceluloses, na melhor condição deste processo. Assim, a polpa $\boldsymbol{O}_{200}$ foi refinada em $\boldsymbol{M J}$ por 60 minutos (9 mil revoluções).

\subsubsection{Refinador de discos Bauer}

O refinador de discos simples do tipo Bauer (modelo MD-3000, marca Regmed), representado na Figura 30, consiste de um disco rotativo (rotor) e outro estacionário (estator), sendo o plano de ação do refinador perpendicular ao eixo de rotação dos discos. O material, em suspensão aquosa, é introduzido no equipamento por uma abertura na parte superior do tanque de entrada, e a vazão de saída da pasta é controlada por uma válvula na parte inferior do sistema de recirculação de massa. As fibras da biomassa em suspensão são empurradas sob pressão para o centro dos discos, passando entre as lâminas do rotor e do estator em um processo contínuo, ou seja, com a recirculação do material pelo sistema.

Este refinador opera com baixas consistências de massa, e o grau de refino pode ser regulado tanto pela distância axial entre os discos quanto pelo número de ciclos de passagem do material pela região dos discos (tempo de refino). O controle hidráulico é exercido por um volante, que permite aumentar ou diminuir a pressão exercida sobre as fibras, ou seja, a distância entre o rotor e o estator. Junto do volante encontra-se uma escala graduada para a determinação da posição dos discos, onde cada divisão indica uma movimentação (avanço ou 
retrocesso) de $0,025 \mathrm{~mm}$. O afastamento máximo determinado para os discos do equipamento utilizado era de 373 unidades $(9,325 \mathrm{~mm})$.

Conforme descrito anteriormente (item 2.2.7.1.3.c), os discos do conjunto de refino podem ser encontrados com diferentes configurações das lâminas projetadas. A configuração dos discos do refinador Bauer utilizado neste trabalho é a recomendada para fibras celulósicas curtas, cuja espessura das lâminas é de $3 \mathrm{~mm}$. Já a rotação dos discos deste equipamento ocorre a uma velocidade fixa de 1750 rpm.

Figura 30. Fotos (A) do refinador de discos Bauer utilizado e (B) seus discos constituintes.

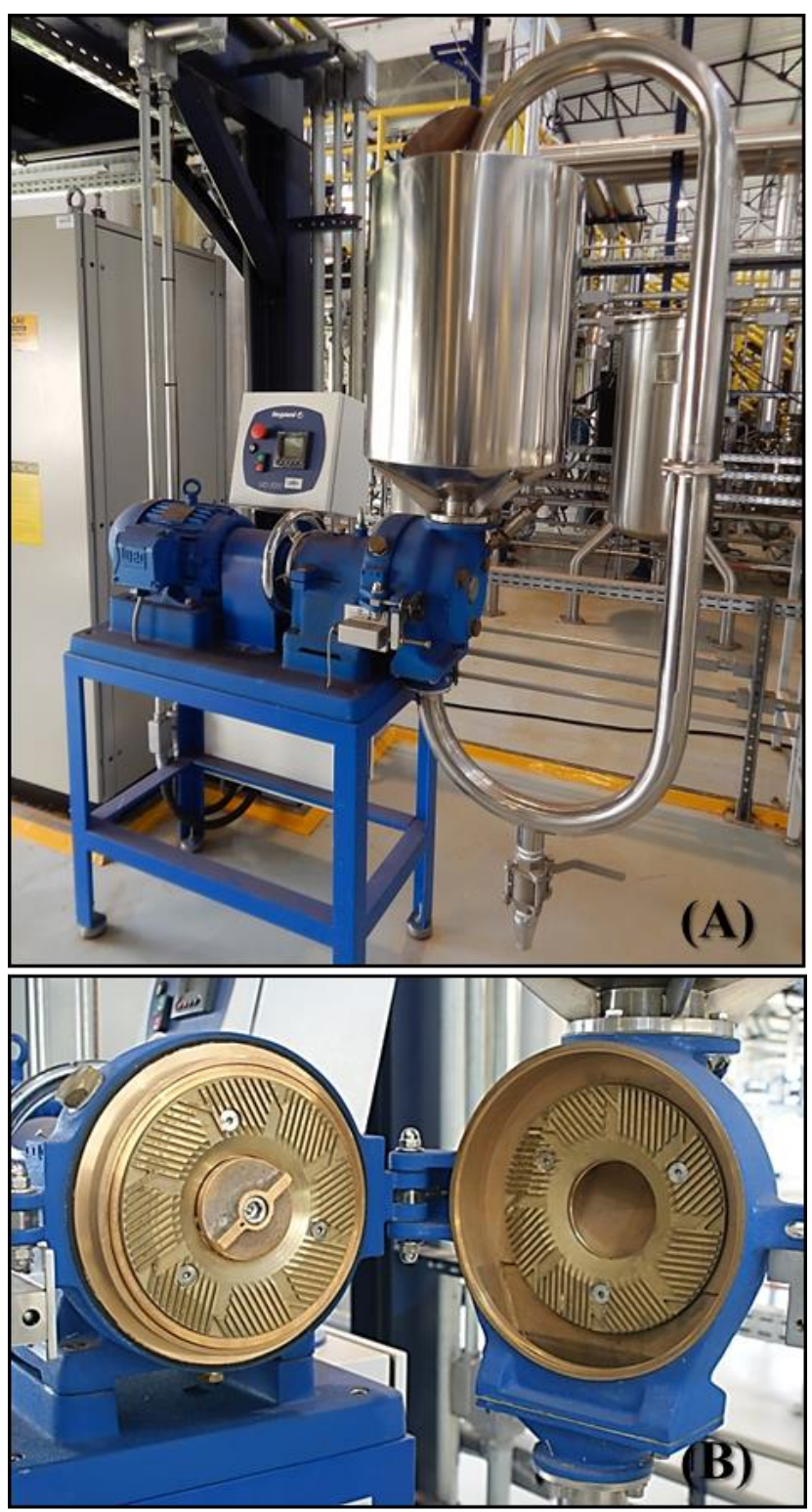

Fonte: Própria. 
Utilizando-se o refinador de discos Bauer não foi possível aplicar o procedimento completo para as fibras de bagaço não tratadas $(\boldsymbol{F})$ e pré-tratadas hidrotérmicamente $(\boldsymbol{H})$. Além de estes materiais apresentarem estruturas agregadas, fibrosas e rígidas, não formaram suspensões homogêneas em meio aquoso durante a movimentação dos discos que empurra a pasta. Com o espaçamento dos discos mais afastado, observou-se que os materiais fibrosos decantaram rapidamente na região da válvula de saída do sistema, entupindo-a antes de qualquer fenômeno de refino iniciar-se. Aproximando-se os discos, verificou-se que o tempo de residência das fibras destes materiais no interior dos discos foi muito longo devido à ineficiência da configuração dos discos do equipamento (para refino de fibras curtas) em trata-las, o que acarretou a retenção de material entre as lâminas dos discos, o impedimento da passagem em fluxo da massa e o entupimento da entrada dos discos.

Portanto, processaram-se em refinador Bauer $(\boldsymbol{R D})$, dotado de sistema de recirculação e discos para fibras curtas, apenas as polpas organossolve em estudo $\left(\boldsymbol{H O}_{\mathbf{1 8 0}}, \boldsymbol{O}_{\mathbf{1 9 0}}\right.$ e $\left.\boldsymbol{O}_{\mathbf{2 0 0}}\right)$, cujas fibras curtas e deslignificadas (logo menos rígidas) foram eficientemente refinadas quando em suspensão aquosa em baixa consistência de sólidos.

Considerando as dimensões do equipamento e o volume do tanque de entrada dos discos (50 L), fixou-se o volume mínimo de suspensão de trabalho em 20 L, de modo a possibilitar a recirculação do material pelo sistema e manter os discos sempre em contato com a água. Além disto, como forma de prevenir o superaquecimento do equipamento pelo atrito entre os discos e o material, deve-se evitar o processo com uso de baixos volumes de água.

O teor de sólidos em uma suspensão influencia diretamente no tempo de residência das fibras no interior do refinador e, consequentemente, no ajuste da distância entre o rotor e o estator do refinador. Altos teores de sólidos implicam em altos tempos de residência da pasta no interior dos discos, o que pode provocar o entupimento dos discos e da entrada do sistema, além da possibilidade do processo de refino não ocorrer de forma homogênea e completa ao longo de toda a amostra. Assim, os ensaios de refino em $\boldsymbol{R} \boldsymbol{D}$ foram realizados utilizando-se $400 \mathrm{~g}$ de polpa celulósica (base seca) em suspensão aquosa com a consistência de massa fixada em $\mathbf{2 \%}$, de forma a provocar o efeito de fibrilação nas fibras das polpas em estudo de forma adequada e proteger as partes constituintes do sistema de refino de serem danificadas.

Os tempos de refino de $\boldsymbol{H O}_{18 \boldsymbol{0}}$ e $\boldsymbol{O}_{\mathbf{1 9 0}}$, nos quais alíquotas de amostras foram coletadas, foram selecionados de forma a obter-se um comparativo entre as amostras produzidas nos mesmos intervalos de tempo de tratamento em refinador de discos e em moinho Jokro. A 
primeira alíquota foi retirada após 13 minutos e 20 segundos de refino, e evoluiu-se o processamento ao tempo máximo de $\mathbf{6 0}$ minutos de forma a evitar o superaquecimento do equipamento. Já a distância entre os discos foi ajustada a cada intervalo de tempo conforme a facilidade de pressurização da polpa. O tratamento foi iniciado no afastamento máximo entre o rotor e o estator, com o primeiro aperto realizado após 6 minutos e 40 segundos de refino para uma distância de $5,70 \mathrm{~mm}$, e alcançando após 33 minutos e 40 segundos o aperto máximo permitido sem a fricção entre as barras metálicas em relevo dos discos $(\mathbf{0 , 0 2 5} \mathbf{~ m m})$.

A sequência de ajustes da aproximação entre os discos, assim como os tempos de retiradas de alíquotas, encontram-se organizados na Tabela 5 a seguir. A coleta das alíquotas foi realizada com o equipamento ligado, de forma a manter a concentração de sólidos da suspensão e evitar o entupimento da entrada dos discos e da saída com a sedimentação do material. Os efeitos do tempo de refino e da distância entre os discos nas fibras dos materiais em estudo também foram observados pelo acompanhamento do ${ }^{\circ} S R$.

Novamente, como forma de integralizar o entendimento dos efeitos provocados pelo processamento em refinador de discos Bauer, realizou-se o tratamento da polpa organossolve $\boldsymbol{O}_{200}$ em $\boldsymbol{R D}$ por $\mathbf{6 0}$ minutos, realizando a mesma sequência de ajustes da pressurização entre os discos até a distância mínima de $\mathbf{0 , 0 2 5} \mathbf{~ m m}$.

Tabela 5. Sequência de ajustes da aproximação entre os discos e tempos de retiradas de alíquotas aplicados nos ensaios de tratamento físico-mecânico em refinador de discos Bauer.

\begin{tabular}{|c|c|c|c|c|c|}
\hline \multirow[b]{2}{*}{ Amotra } & \multicolumn{3}{|c|}{ Tempo de Refino } & \multirow{2}{*}{$\begin{array}{c}\text { Aproximação } \\
\text { (unidades) }\end{array}$} & \multirow{2}{*}{$\begin{array}{c}\text { Aproximação } \\
(\mathbf{m m})\end{array}$} \\
\hline & $\begin{array}{l}\text { Ajuste dos } \\
\text { discos }\end{array}$ & - & $\begin{array}{c}\text { Retirada da } \\
\text { Alíquota }\end{array}$ & & \\
\hline- & 0 & - & $6 ’ 40^{\prime \prime}$ & 0 & 9,325 \\
\hline 1 & 6'40’' & - & $13 ’ 20$ ' & +145 & 5,700 \\
\hline 2 & $13^{\prime} 20^{\prime \prime}$ & - & $20 ’ 00^{\prime \prime}$ & +190 & 4,575 \\
\hline 3 & $20 ’ 00^{\prime \prime}$ & - & $26^{\prime} 40^{\prime \prime}$ & +240 & 3,325 \\
\hline 4 & $26^{\prime} 40^{\prime \prime}$ & - & $33^{\prime} 20^{\prime \prime}$ & +340 & 0,825 \\
\hline 5 & $333^{\prime} 20^{\prime \prime}$ & - & $40^{\prime} 00^{\prime \prime}$ & +372 & 0,025 \\
\hline 6 & $40^{\prime} 00^{\prime \prime}$ & - & $46^{\prime} 40^{\prime \prime}$ & +372 & 0,025 \\
\hline 7 & $46^{\prime} 40^{\prime \prime}$ & - & $53^{\prime} 20^{\prime \prime}$ & +372 & 0,025 \\
\hline 8 & $533^{\prime} 20^{\prime \prime}$ & - & $60 ’ 00^{\prime \prime}$ & +372 & 0,025 \\
\hline
\end{tabular}




\subsubsection{Moinho criogênico}

O moinho criogênico (modelo 6970EFM Enclosed Freezer/ Mill, marca SPEX® SamplePrep), representado na Figura 31, é um equipamento que pulveriza amostras em temperaturas criogênicas pela ação de um impelidor. Consiste de um tanque, onde nitrogênio líquido $\left(\mathrm{N}_{2}(\mathrm{l})\right)$ é inserido por um sistema de autopreenchimento, dotado de duas câmaras de moagem. Através de uma porta externa ao tanque de $\mathrm{N}_{2}(\mathrm{l})$, é inserido dentro de cada uma das câmaras um frasco de policarbonato, vedado em suas extremidades por tampas estacionárias de aço-inox 440C, contendo as amostras a serem moídas e o impelidor, também de aço-inox.

Figura 30. (A) Foto e (B) esquema de um moinho criogênico.

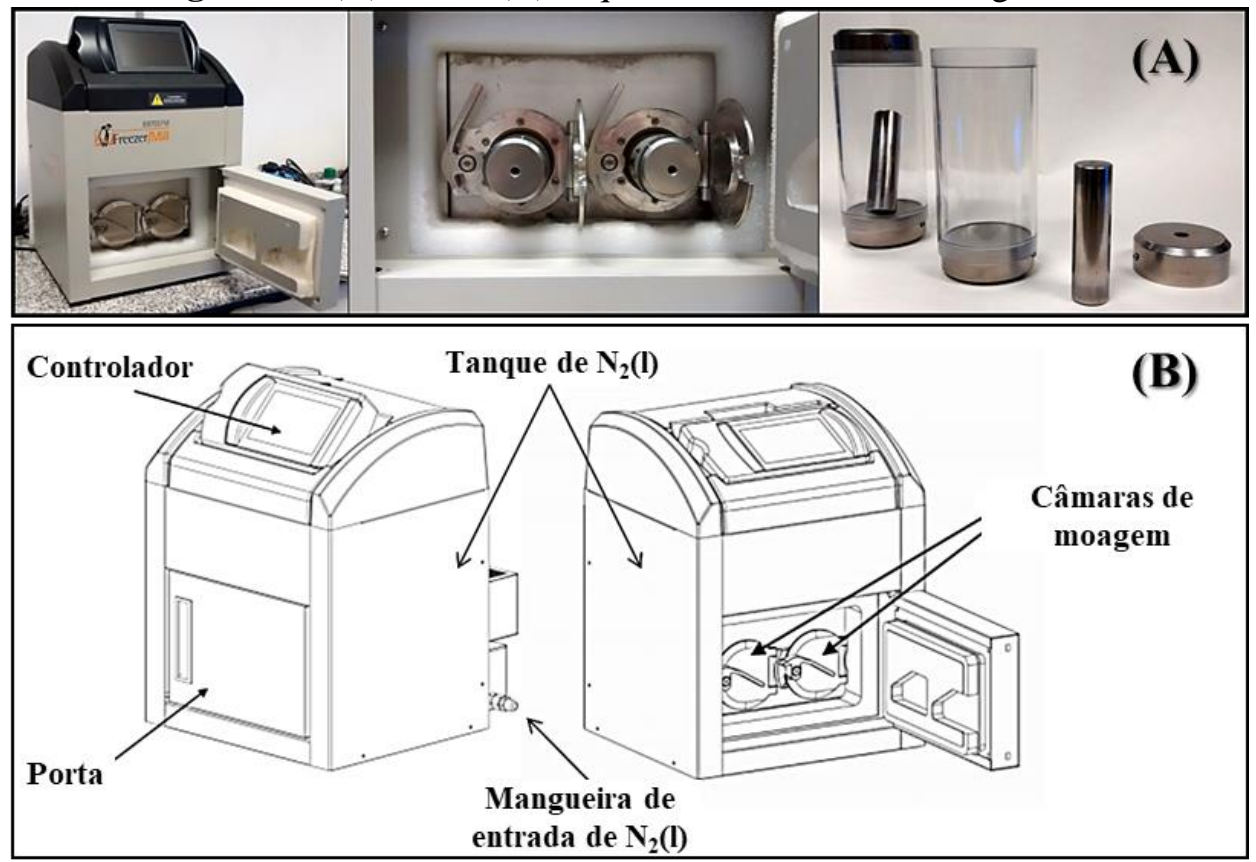

Fonte: (A) Própria; (B) Adaptado de: SPEX® SAMPLEPREP, 2011.

Durante a operação, o $\mathrm{N}_{2}(\mathrm{l})$ circunda o exterior das câmaras, provocando o congelamento das amostras inseridas nos frascos; entretanto, os frascos não entram em contato direto com o N2(l). A moagem se processa pela ação do impelidor contra as duas tampas estacionárias, em movimentos de ida "para frente e para trás" ( 1 ciclo), dirigido por dois eletromagnetos.

Devido ao fato do tanque de $\mathrm{N}_{2}(1)$ se manter preenchido durante todo o ciclo de moagem, as amostras se mantêm congeladas ao longo do processo e seus aspectos são preservados. Deste modo, o moinho criogênico permite a moagem de amostras úmidas, sem a 
perda desta umidade, e de amostras cuja estrutura ou composição é alterada pelo calor gerado pelo processo de moagem convencional.

Os parâmetros programáveis do equipamento definem as possíveis variáveis do processo de moagem criogênica, sendo estes:

- $\quad$ Tempo de pré-congelamento (TPC): tempo necessário para o congelamento da amostra anterior ao início do primeiro ciclo de moagem;

- $\quad$ Ciclos de moagem (CM): número de períodos de moagem direta, intercalados com períodos de recongelamento da amostra;

- $\quad$ Tempo de moagem (TM): tempo de moagem direta, em cada ciclo;

- $\quad$ Tempo de congelamento (TC): tempo do intervalo de recongelamento da amostra entre cada ciclo de moagem (com o impelidor inativo);

- Velocidade de moagem (VM): velocidade, em ciclos por segundo, de movimentação do impelidor. Um ciclo pode ser definido como um movimento do impelidor de ida "para frente e para trás" contra as tampas estacionárias, ou seja, uma velocidade de 10 representa 20 impactos por segundo; a menor velocidade possível é de 5 ciclos/s, e a maior 15 ciclos/s.

Dado que a moagem criogênica provoca apenas a quebra das fibras congeladas, realizou-se um estudo das variáveis do processo aplicado às fibras de bagaço de cana-deaçúcar in natura $(\boldsymbol{F})$, material de maior recalcitrância entre os analisados. A finalidade deste estudo foi a definição das melhores condições de moagem para a obtenção de amostras homogêneas do ponto de vista macroscópico. As principais observações deste estudo foram:

- Teor de umidade da amostra: baixos teores de umidade não possibilitam um congelamento efetivo das fibras; entretanto valores excessivos de teor de umidade implicam no congelamento de água livre ao redor das fibras, o que prejudica sua moagem. Teores de umidades em torno de $\mathbf{6 0 \%}$ e $\mathbf{7 0 \%}$, que correspondem à água de hidratação das fibras, mostraram-se ideais para o processo de moagem criogênica das fibras de bagaço.

- Massa de amostra seca em cada frasco: as dimensões do frasco, que contém a amostra e o impelidor, definem a maior quantidade possível de massa seca a ser inserida em cada um. O preenchimento do frasco em mais da metade de seu volume interno impede a movimentação do impelidor durante a moagem; assim, para o frasco utilizado neste estudo (tamanho médio), deve-se evitar inserir quantidades de massa seca de fibras maiores que $\mathbf{3} \mathbf{g}$ (aproximadamente $10 \mathrm{~g}$ úmidos). 
- Tempo de pré-congelamento $(T P C)$ : longos tempos de pré-congelamento não são necessários. Uma vez congelada a amostra, a moagem ocorre de forma efetiva. Para $10 \mathrm{~g}$ úmidos de fibras de bagaço, 10 minutos de pré-congelamento mostraram-se suficientes.

- Ciclos de moagem $(C M)$ : para a obtenção de amostras macroscopicamente homogêneas quanto à granulometria, foram requeridos ao menos 6 períodos de moagem direta, cada um com duração de 2 minutos (tempo de moagem - TM). Longos tempos de moagem direta não são efetivos, posto que há o descongelamento da amostra ao longo do processo; logo, é preferível executar a moagem criogênica pela intercalação de curtos ciclos de moagem com períodos de recongelamento.

- Tempo de congelamento (TC): intervalos de 2 minutos mostraram-se suficientes para o recongelamento da amostra.

- Velocidade de moagem (VM): altas velocidades de movimentação do impelidor podem acarretar o arraste das fibras para as laterais do frasco, sem provocar sua moagem. Moagens realizadas com baixas velocidades mostraram-se mais eficientes, o que incentivou o estabelecimento do valor de 6 ciclos/s.

Assim, os ensaios de moagem pelo processo criogênico $(\boldsymbol{M C})$, tanto das fibras de bagaço in natura $(\boldsymbol{F})$ quanto das amostras obtidas nos pré-tratamentos físico-químicos $(\boldsymbol{H}$, $\boldsymbol{H O}_{180}$ e $\boldsymbol{O}_{190}$ ), foram realizados utilizando-se $\mathbf{3} \mathbf{g}$ de material (base seca) em cada frasco, com umidades entre $\mathbf{6 0 \%}$ e $\mathbf{7 0 \%}$, e os parâmetros programáveis do equipamento fixados nas seguintes condições: $T P C=10$ minutos; $C M=\mathbf{6}$ períodos; $T M=\mathbf{2}$ minutos; $T C=\mathbf{2}$ minutos; $V M=\mathbf{6}$ ciclos/s. $\mathrm{O}$ acompanhamento do efeito da moagem criogênica nas fibras dos materiais em estudo também foi realizado pela determinação do ${ }^{\circ} S R$.

Na Tabela 6 a seguir encontram-se resumidas e organizadas as condições de processamento empregadas nos pré-tratamentos físico-químicos e físico-mecânicos.

\subsubsection{Determinação do Grau de Refino Schöpper-Riegler}

O grau Schöpper-Riegler $\left({ }^{\circ} S R\right)$ de uma polpa é a medida de sua drenabilidade quando em suspensão aquosa. O ${ }^{\circ} S R$ permite comparar o grau de intumescimento provocado pelo refino entre uma polpa e outra, medindo diretamente a quantidade de líquido que atravessa uma tela padronizada e indiretamente a quantidade retida pelas fibras da polpa. Quanto menor for o volume de líquido drenado, maior será o grau de refino da polpa analisada. 
O equipamento para a determinação do ${ }^{\circ} S R$, conforme esquematizado na Figura 32, é dotado de um cone de vedação, uma tela padronizada de malha fina (100 mesh), através de onde a suspensão irá escoar, e um funil provido de dois orifícios calibrados, um em sua parte inferior e outro em sua lateral. O filtrado que escoa pelo orifício lateral é recolhido em um copo graduado em unidades ${ }^{\circ} S R$ : uma descarga de $1000 \mathrm{~mL}$ corresponde à zero em unidades ${ }^{\circ} S R$; zero de descarga corresponde a $100{ }^{\circ} S R$; a cada $10 \mathrm{~mL}$ escoados equivalem a $-10{ }^{\circ} \mathrm{S} R$.

A determinação do ${ }^{\circ} S R$, dos materiais não refinados e dos materiais refinados, foi realizada segundo o procedimento da norma "SCAN-C19:65 - Drainability of pulp by the Schopper-Riegler method" (SCANDINAVIAN PULP, PAPER AND BOARD TESTING COMMITTEE, 1964). A polpa analisada foi diluída em uma suspensão de aproximadamente 2,0 g/L em água, e posta sob agitação em um distribuidor. Ainda sob agitação, 1 L da suspensão foi adicionado ao equipamento sobre o cone de vedação da tela; após 5 segundos, o cone de vedação foi levantado cuidadosamente, deixando a suspensão escoar através de tela. Anotou-se a medida do ${ }^{\circ} S R$ no copo graduado depois de cessado completamente o gotejamento de água através do orifício lateral. A análise do ${ }^{\circ} S R$ foi realizada em duplicata.

Figura 31. Esquema do equipamento para a determinação do grau de refino Schöpper-Riegler.

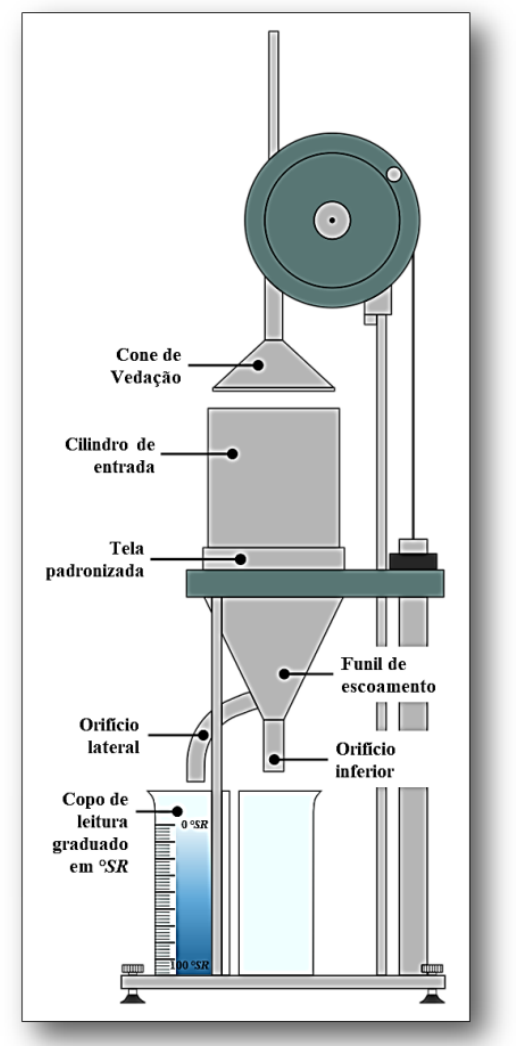

Fonte: Adaptado de: WIKIPEDIA, 2013. 
Tabela 6. Resumo das condições de processamento empregadas nos pré-tratamentos físico-químicos e físico-mecânicos.

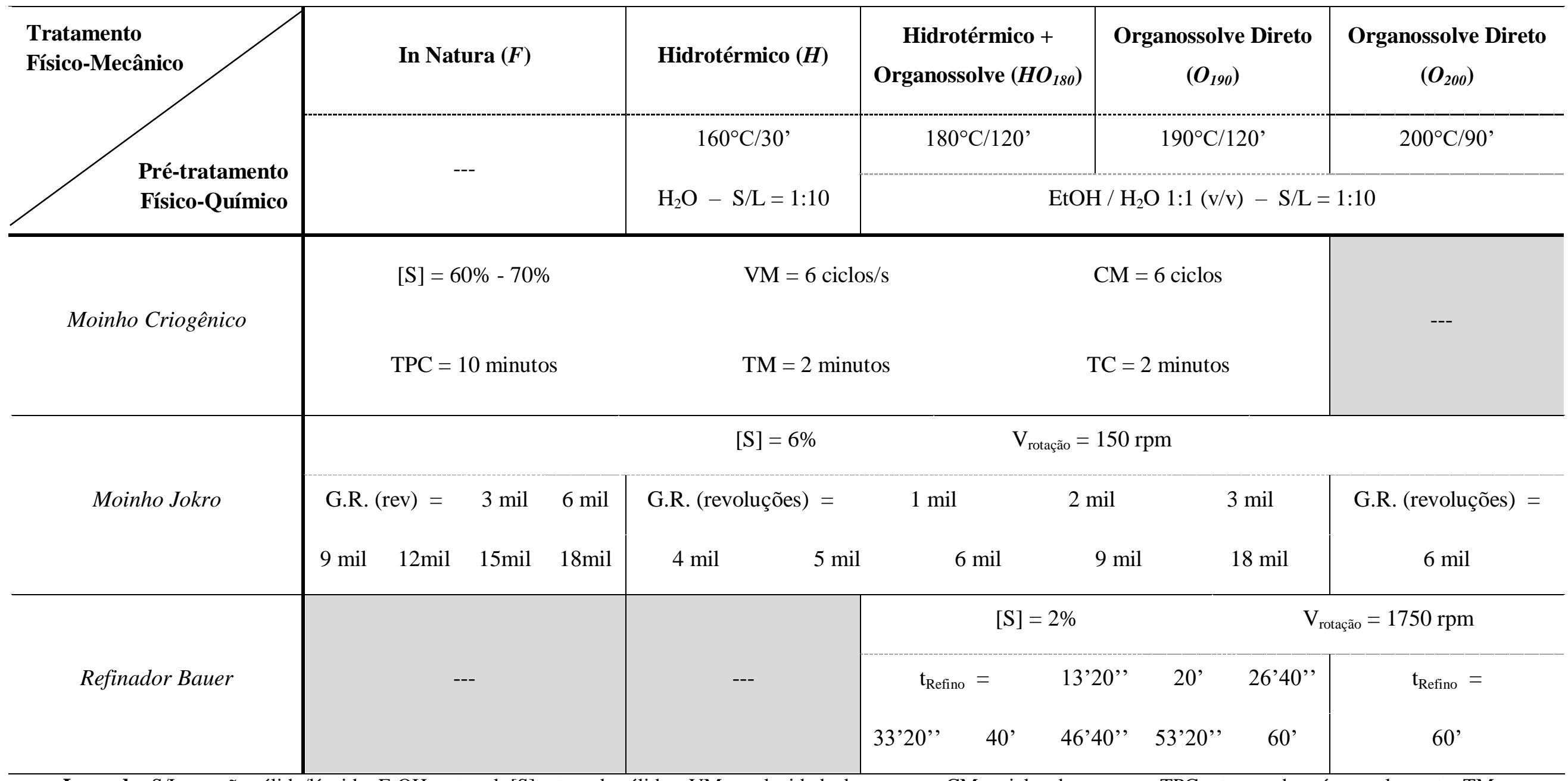

Legenda: $\mathrm{S} / \mathrm{L}=$ razão sólido/líquido; $\mathrm{EtOH}$ = etanol; $[\mathrm{S}]$ = teor de sólidos; $\mathrm{VM}$ = velocidade de moagem; $\mathrm{CM}=$ ciclos de moagem; TPC = tempo de pré-congelamento; TM = tempo de moagem; $\mathrm{TC}=$ tempo de congelamento; $\mathrm{V}_{\text {rotação }}=$ velocidade de rotação do equipamento; G.R. = grau de refino; $\mathrm{t}_{\mathrm{Refino}}=$ tempo de refino. 


\subsection{CARACTERIZAÇÕES FÍSICAS E MORFOLÓGICAS}

Para que se possam discriminar os efeitos de cada um dos tratamentos aplicados nas características das fibras de bagaço de cana, as técnicas de análise precisam ser distintas o suficiente para quantificarem, com grande acurácia, uma ampla faixa de modificações que ocorrem em diferentes níveis de organização estrutural da biomassa. Com esta perspectiva, escolheram-se métodos de análise físicos e morfológicos que permitem medidas em diferentes ordens de magnitude: de ångströms a nanômetros - difração de raios-X e termoporometria, e de micrômetros a milímetros - distribuição de tamanhos de partículas e análises morfológicas.

Estas técnicas provêm não só informações quantitativas da extensão e do mecanismo de ruptura da estrutura lignocelulósica induzida pelo método aplicado (físico-químico ou físico-mecânico), como também apresentam o potencial de monitorar a acessibilidade aos polissacarídeos por proverem medidas das áreas superficiais externa (dimensões médias das fibras) e interna (volume de poros da parede celular), além de descreverem o comportamento da estrutura cristalina da celulose (grau de cristalinidade e parâmetros do cristalito).

Deste modo, a caracterização física da ultraestrutura das fibras de bagaço in natura, e das amostras obtidas tanto nos pré-tratamentos físico-químicos quanto nos processos físicomecânicos, foi realizada através das técnicas de termoporometria e difração de raios-X. Já a caracterização morfológica das fibras foi realizada por técnicas de microscopia (ótica e eletrônica de varredura), pela determinação da distribuição de tamanhos de partículas por difração a laser, e pela análise das propriedades morfológicas por imagem.

\subsubsection{Distribuição de tamanhos de partículas}

O analisador de tamanhos de partículas por difração a laser (modelo LS 13 320, marca Beckman Coulter) é um equipamento que mensura a distribuição de tamanhos de partículas em uma amostra, estejam elas em suspensão (como no caso deste estudo) ou em forma de pó seco, utilizando os princípios de padrão de espalhamento de luz incidida por um feixe de laser. Os padrões de luz espalhada se relacionam diretamente com o tamanho de cada partícula presente na amostra.

A luz incidente, ao atingir certa quantidade de partículas, forma um invólucro tridimensional de luz, cujo tamanho e formato são afetados pelo índice de refração da 
partícula, pelo comprimento de onda da luz, e pelo formato e tamanho da partícula. Os detectores do equipamento são posicionados de forma a medir a intensidade e o ângulo da luz espalhada, gerando sinais que são convertidos em medidas de tamanhos de partículas segundo modelos matemáticos. Enquanto o ângulo de difração da luz é inversamente proporcional ao tamanho da partícula, a intensidade relativa da luz espalhada é uma medida do volume relativo de partículas (\%) equivalentes ao tamanho em questão.

O modelo matemático utilizado na análise foi baseado na teoria de Franhoufer, que aproxima as amostras a partículas de formatos esféricos, maiores que o comprimento de onda do feixe incidente, e transparentes, desconsiderando efeitos de absorção e interferência de luz.

As análises utilizando o Módulo Universal Líquido foram realizadas gotejando-se as amostras, em suspensões aquosas diluídas, no canal de entrada do equipamento até massa suficiente para a medida. As amostras em suspensão foram então impulsionadas por uma bomba até o canal onde se encontra o laser e as lentes de difração. Este método permite a análise de partículas com dimensões de até $2000 \mu \mathrm{m}$, sendo o limite de detecção de $0,375 \mu \mathrm{m}$.

Os resultados finais das análises, computados pelo software do equipamento, foram fornecidos como duas curvas de distribuição: do volume incremental de partículas analisadas (\%) em função do diâmetro $(\mu \mathrm{m})$, e do volume cumulativo de partículas $(\%)$ em função do diâmetro da "esfera" $(\mu \mathrm{m})$. A análise ainda fornece outras medidas importantes para a comparação entre os processos aplicados, entre as quais estão:

- Média $(\mu m)$ : média ponderada dos diâmetros de todos os elementos da amostra analisados;

- Moda $(\mu m)$ : valor de diâmetro mais frequente entre todos os elementos da amostra analisados;

- $\quad$ Desvio padrão $(\mu m)$ : medida da dispersão dos valores de diâmetro em torno da média calculada.

Com base no estudo de JIANG et al. (2016) (item 2.2.5.1.2), registraram-se também os valores de volume cumulativo de partículas (\%) com diâmetros de até $100 \mu \mathrm{m}$ e de até $30 \mu \mathrm{m}$, cujos valores foram retirados da curva de distribuição acima mencionada.

Por fim, estimou-se a área superficial específica externa das partículas para cada amostra analisada, assumindo seus formatos como sendo esféricos e negligenciando a rugosidade das superfícies, através de adaptações dos cálculos propostos por HUANG et al. (2010), LI et al. (2015) e ZHU et al. (2009). 
Sendo $d(\mathrm{~m})$ o diâmetro da partícula analisada e $A_{e}\left(\mathrm{~m}^{2}\right)$ a área desta partícula enquanto esfera (Equação 18), pode-se calcular a área superficial externa total das partículas na amostra analisada $A_{T}\left(\mathrm{~m}^{2}\right)$ a partir da Equação 19:

$$
\begin{gathered}
A_{e}=\pi d^{2} \\
A_{T}=\pi \sum_{i} d_{i}^{2} \times n_{i}
\end{gathered}
$$

Onde: $n_{i}$ é o número de partículas com diâmetro $d_{i}$. Já a área superficial específica externa das partículas na amostra $A_{S E}\left(\mathrm{~m}^{2} / \mathrm{g}\right)$ é calculada a partir da razão entre a área superficial externa total e a massa de partículas analisadas $m$ (g) (Equação 20). A massa de partículas analisadas foi estimada a partir do volume superficial total das partículas na amostra $V_{T}\left(\mathrm{~m}^{3}\right)$ e da densidade aparente das partículas $\rho_{a p}\left(\mathrm{~g} / \mathrm{m}^{3}\right)$, conforme a Equação 21:

$$
\begin{gathered}
A_{S E}=\frac{A_{T}}{m} \\
m=\rho_{a p} \times V_{T}
\end{gathered}
$$

Sendo $V_{e}\left(\mathrm{~m}^{3}\right)$ o volume de uma partícula esférica (Equação 22), pode-se calcular o volume superficial total das partículas na amostra analisada $V_{T}\left(\mathrm{~m}^{3}\right)$ a partir da Equação 23:

$$
\begin{gathered}
V_{e}=\frac{\pi d^{3}}{6} \\
V_{T}=\frac{\pi}{6} \sum_{i} d_{i}^{3} \times n_{i}
\end{gathered}
$$

A densidade aparente das partículas, por sua vez, é função da densidade real das partículas $\rho_{\text {real }}\left(\mathrm{g} / \mathrm{m}^{3}\right)$ (Equação 24), cujo valor foi calculado a partir dos teores dos macrocomponentes e de suas densidades, conforme a Equação 25: 


$$
\begin{gathered}
\rho_{\text {ap }}=\frac{\rho_{\text {real }}}{1+\rho_{\text {real }} \times V_{\text {Poros }}} \\
\rho_{\text {real }}=\left(x_{\text {cel }} \times \rho_{\text {cel }}\right)+\left(x_{a m} \times \rho_{\text {am }}\right)
\end{gathered}
$$

Onde: $V_{\text {Poros }}\left(\mathrm{m}^{3} / \mathrm{g}\right)$ é o volume específico total de poros da partícula mensurado pela técnica de termoporometria, $\rho_{c e l}$ é a densidade da celulose (estimada por HUANG et al. (2010) como sendo $1,58 \mathrm{~g} / \mathrm{cm}^{3}$ ), $\rho_{a m}$ é a densidade combinada dos componentes não celulósicos (hemiceluloses e lignina, estimada por HUANG et al. (2010) como sendo $1,37 \mathrm{~g} / \mathrm{cm}^{3}$ ), $x_{c e l}$ é o teor de celulose na amostra analisada e $x_{a m}$ é o teor de componentes não celulósicos $\left(x_{c e l}+X_{a m}\right.$ =1). Enquanto a densidade real é a razão entre a massa da partícula e o volume ocupado pelo material sólido que compõe a partícula, e não inclui o volume dos poros existentes na estrutura, a densidade aparente é a razão entre a massa da partícula e a soma dos volumes ocupados pela matéria sólida na partícula e pelo poros existentes na estrutura.

Por fim, tem-se que a área superficial específica externa das partículas na amostra é expressa pela Equação 26. A Equação 27 expressa a forma simplificada do cálculo da $A_{S E}$ $\left(\mathrm{m}^{2} / \mathrm{g}\right)$, aplicada neste trabalho, onde $\bar{d}(\mathrm{~m})$ é o diâmetro médio das partículas analisadas.

$$
\begin{gathered}
A_{S E}=\frac{6 \sum_{i} d_{i}^{2} \times n_{i}}{\rho_{a p} \sum_{i} d_{i}^{3} \times n_{i}} \\
A_{S E}=\frac{6}{\rho_{a p} \times \bar{d}}
\end{gathered}
$$

\subsubsection{Análise morfológica das fibras}

A análise das propriedades morfológicas das fibras das amostras em estudo, tanto prétratadas pelos métodos físico-químicos quanto pelos métodos físico-mecânicos, foi realizada em um equipamento MorFi LABO (modelo LB-01, marca Techpap, Inc.) no Laboratoire de Génie des Procédés Papetiers (LGP2) do Institut Polytechnique de Grenoble - Pagora, na cidade de Grenoble (França). 
Este equipamento permite a caracterização das medidas morfológicas das fibras por obtenção e análise de imagens das amostras quando em fluxo de água laminar, utilizando uma câmera com dispositivo de carga acoplada e os princípios básicos de microscopia ótica. $\mathrm{O}$ analisador de fibras MorFi LABO determina simultaneamente o comprimento, o diâmetro e a forma de cada fibra em uma suspensão aquosa, enquanto esta é bombeada e recircula no canal onde a câmera encontra-se acoplada.

Para as medidas, utilizaram-se aproximadamente $300 \mathrm{mg}$ (base seca) de porções representativas de cada amostra em suspensão aquosa. O equipamento é dotado de válvula de autopreenchimento, ajustando o volume final da suspensão para 5 L. Este método permite a análise de partículas com dimensões de até $10 \mathrm{~mm}$, sendo o limite de detecção de $5 \mu \mathrm{m}$. De modo a obterem-se dados estatisticamente significativos, utilizou-se uma contagem de aproximadamente 5000 fibras (ou feixe de fibras) morfologicamente medidas para cada amostra analisada.

Os resultados finais das análises, computados pelo software do equipamento, foram fornecidos como dois gráficos de distribuição: do percentual numérico de partículas analisadas $(\%)$ em função de faixas de larguras $(\mu \mathrm{m})$, e do percentual numérico de partículas (\%) em função de faixas de comprimentos de fibras $(\mathrm{mm})$. A análise ainda fornece outras medidas morfológicas das fibras importantes para a comparação entre os processos aplicados, entre as quais estão:

- $\quad$ Comprimento médio $(\mathrm{mm})$ : média aritmética ou ponderada dos comprimentos de todas as fibras da porção representativa de amostra analisada. Enquanto a média aritmética do comprimento é utilizada para caracterizar a amostra como um todo, a média ponderada representa de maneira mais adequada o comportamento dos elementos desta amostra quando submetida a diferentes métodos de processamento. Isto porque esta segunda medida reflete a proporção de partículas em cada faixa de comprimento e permite minimizar o efeito da presença de fibras muito curtas. As fibras mais curtas contribuem pouco para o comprimento total medido, porém quando presentes em grande proporção numérica apresentam importante influência no comportamento da amostra como um todo;

- $\quad$ Teor de elementos finos (\%): porcentagem do comprimento total de todas as partículas analisadas (fibras e finos), quando postas em um filamento contínuo, que é ocupada apenas por finos, ou seja, por partículas de comprimento menor que $0,2 \mathrm{~mm}$; 
- $\quad$ Largura média $(\mu m)$ : média aritmética das larguras de todas as fibras da porção de amostra analisada, considerando a largura de uma fibra a medida de seu maior diâmetro ao longo de seu comprimento. Esta medida pode ainda ser estabelecida como a razão entre a superfície ocupada pela fibra e o seu comprimento;

- $\quad$ Massa linear $(\mathrm{mg} / \mathrm{m})$ : definida como a massa de fibras por unidade de comprimento, esta medida informa massa de um comprimento definido de fibras, de uma extremidade à outra, quando postas em um filamento contínuo. A massa linear é função não só do comprimento como de todas as outras propriedades morfológicas da parede celular da fibra, como largura, espessura e densidade.

A partir dos valores de comprimento e de largura médios das fibras, calculou-se a razão de aspecto média de cada uma das amostras analisadas a partir da Equação 28 a seguir:

$$
\text { Razão de Aspecto }=\bar{C} / \bar{L}
$$

Onde: $\overline{\boldsymbol{C}}$ é o comprimento médio ponderado (m) e $\overline{\boldsymbol{L}}$ é a largura média das fibras na porção representativa de amostra analisada. O cálculo da razão de aspecto permite inferir que as fibras apresentam um formato próximo a um cilindro ou a uma fita. Frente a este conhecimento, ZHU et al. (2009) sugeriram para o cálculo da área superficial específica externa a aplicação de um modelo cilíndrico para cada fibra ou feixe de fibras individual, cuja espessura da parede é extremamente fina. Os autores ainda assumiram o lúmen como um espaço vazio, logo a área superficial externa da fibra poderia ser considerada simplesmente duas vezes a superfície específica de um cilindro. Entretanto, devido às dificuldades em determinar a estrutura interna do lúmen, sua área superficial pode ser desprezada; esta consideração é razoável uma vez que alguns processos mecânicos causam o colapso do lúmen, o que torna sua superfície de difícil acesso às enzimas hidrolíticas.

O modelo cilíndrico permite um cálculo mais aproximado da superfície externa das fibras do que o modelo de esferas; entretanto, o formato real da fibra afeta a acurácia do cálculo proposto, e desvios de $40 \%$ a $450 \%$ são esperados dependendo da forma da seção transversal desta fibra. Ainda assim, considerando que a análise é realizada com as fibras suspensas em meio aquoso, no qual elas podem rotacionar livremente, a probabilidade da medida projetada ser de sua largura ou espessura é a mesma, o que reduz significantemente o erro do modelo quando milhares de fibras são caracterizadas (ZHU et al., 2009). 
Por fim, estimou-se a área superficial específica externa das partículas para cada amostra analisada, assumindo seus formatos como sendo cilíndricos e negligenciando a rugosidade das superfícies, através de adaptações do cálculo proposto por ZHU et al. (2009).

Sendo $C(\mathrm{~m})$ e $L(\mathrm{~m})$ o comprimento e a largura, respectivamente, da partícula analisada e $A_{c}\left(\mathrm{~m}^{2}\right)$ a área desta partícula enquanto cilindro (Equação 29), pode-se calcular a área superficial externa total das partículas na amostra analisada $A_{T}\left(\mathrm{~m}^{2}\right)$ pela da Equação 30:

$$
\begin{gathered}
A_{c}=\frac{\pi}{2}\left(2 L C+L^{2}\right) \\
A_{T}=\frac{\pi}{2} \sum_{i}\left(2 L_{i} C_{i}+L_{i}^{2}\right) \times n_{i}
\end{gathered}
$$

Onde: $n_{i}$ é o número de partículas com comprimento $C_{i}$ e largura $L_{i}$. Já a área superficial específica externa das partículas na amostra $A_{S E}\left(\mathrm{~m}^{2} / \mathrm{g}\right)$ é calculada a partir da razão entre a área superficial externa total e a massa de partículas analisadas $m(\mathrm{~g})$, conforme as Equações 20 e 21 apresentadas no item anterior.

Sendo $V_{c}\left(\mathrm{~m}^{3}\right)$ o volume de uma partícula cilíndrica (Equação 31), pode-se calcular o volume superficial total das partículas na amostra analisada $V_{T}\left(\mathrm{~m}^{3}\right)$ a partir da Equação 32:

$$
\begin{gathered}
V_{c}=\frac{\pi}{4}\left(C L^{2}\right) \\
V_{T}=\frac{\pi}{4} \sum_{i}\left(C_{i} L_{i}^{2}\right) \times n_{i}
\end{gathered}
$$

A densidade aparente das partículas foi calculada a partir das Equações 24 e 25 apresentadas no item anterior. Por fim, tem-se que a área superficial específica externa das partículas na amostra é expressa pela Equação 33. A Equação 34 expressa a forma simplificada do cálculo da $A_{S E}\left(\mathrm{~m}^{2} / \mathrm{g}\right)$, aplicada neste trabalho, onde $\bar{C}$ (m) é o comprimento médio e $\bar{L}(\mathrm{~m})$ é o diâmetro médio das partículas analisadas. 


$$
\begin{gathered}
A_{S E}=\frac{2 \sum_{i}\left(2 L_{i} C_{i}+L_{i}^{2}\right) \times n_{i}}{\rho_{a p} \sum_{i}\left(C_{i} L_{i}^{2}\right) \times n_{i}} \\
A_{S E}=\frac{2}{\rho_{a p}} \times\left(\frac{2 \bar{C}+\bar{L}}{\bar{C} \bar{L}}\right)
\end{gathered}
$$

\subsubsection{Microscopia ótica}

A morfologia das fibras de determinadas amostras também foi examinada utilizandose um microscópio ótico Axio Imager.A2 com câmera acoplada AxioCam MRm (marca Carl Zeiss). Para a análise, adicionou-se uma gota de uma suspensão aquosa da amostra, de concentração aproximada de $0,2 \%(\mathrm{~m} / \mathrm{v})$, em uma lâmina de vidro e recobriu-se com uma lamínula. As microscopias foram obtidas com magnificação de 100x, e analisadas com o software Axio Vision Rel 4.8.

\subsubsection{Termoporometria}

A análise de termoporometria (TP) permite medir a quantidade de água existente nos poros nanométricos, interlamelares e interfibrilares. Esta técnica é baseada no decaimento da temperatura de transição de fase gelo - água (temperatura de fusão do gelo ou de congelamento da água) quando as moléculas de água estão confinadas dentro de poros. O decaimento na temperatura de fusão ocorre devido à menor pressão nas interfaces curvas das cavidades, e se relaciona diretamente com seus diâmetros.

Quando realizada pela técnica de análise de calorimetria diferencial de varredura (TPDSC), os volumes dos poros são inferidos pelas medidas de fluxo de calor devido à transição de fase. A termoporometria por DSC é um dos métodos mais adequados para determinar a área superficial específica interna da parede celular de biomassas lignocelulósicas, uma vez que analisa a superfície interna dos poros sem exigir a secagem da amostra.

Os resultados providos pela técnica de TP-DSC são discriminados em três tipos de água: 1) água livre, ou água não ligada; 2) água ligada congelável (freezing bound water, FBW); e 3) água ligada não congelável (non-freezing bound water, NFW). A água livre não é uma propriedade intrínseca do material, uma vez que representa o excesso de água adicionada 
durante o preparo da amostra; esta é medida a partir da quantidade de gelo que funde a $0^{\circ} \mathrm{C}$. A água ligada congelável (FBW) é a água que se encontra confinada dentro dos capilares do sólido lignocelulósico, onde as redes de interações de hidrogênio se propagam de modo que há o deslocamento da transição de fase gelo - água para temperaturas menores; é medida a partir da quantidade de gelo que funde em temperaturas abaixo de $0^{\circ} \mathrm{C}$. Já a água não congelável (NFW) origina de poucas camadas de água adjacentes às superfícies do substrato, que não congelam porque a mobilidade e a conformação destas moléculas de água se tornam espacialmente restringidas; esta é estimada a partir da diferença entre a quantidade total de água da amostra e a quantidade total de água congelável (livre e ligada).

As porosidades dos materiais em estudo foram determinadas segundo o método de termoporometria validado por DRIEMEIER, MENDES e OLIVEIRA (2012). As análises foram realizadas utilizando-se um calorímetro diferencial de varredura (modelo DSC-Q200, marca TA Instruments) com unidade de congelamento RCS90, utilizando-se de $1-3 \mathrm{mg}$ (base seca) de amostras úmidas saturadas inseridas em panelas de alumínio hermeticamente seladas (modelo Tzero®, marca TA Instruments). As massas do conjunto panela - tampa, vazio e preenchido com a amostra úmida, foram determinadas gravimetricamente; a diferença entre estes valores foi registrada como a massa de amostra úmida. Após a análise de TP-DSC, as tampas foram perfuradas e a água presente nas amostras evaporada a $105^{\circ} \mathrm{C}$ durante $2 \mathrm{~h}$; as massas das amostras secas resultantes foram registradas. A massa de água presente em cada amostra foi calculada como a diferença entre as massas de amostra úmida e de amostra seca.

Para a análise de TP-DSC, as amostras úmidas saturadas foram inicialmente congeladas a $-70^{\circ} \mathrm{C}$, e então aquecidas passo-a-passo para a fusão do gelo até a temperatura de $0,5^{\circ} \mathrm{C}$. No total, $N=18$ passos de aquecimento foram executados sequencialmente, cada um composto por uma rampa de aquecimento a $1^{\circ} \mathrm{C} / \mathrm{min}$ e uma isoterma de equilíbrio. A massa de gelo $M_{i}(\mathrm{~g})$ que funde em cada passo de aquecimento $(i=2, \ldots, N-1)$ foi calculada a partir dos calores de fusão do gelo $Q_{i}(\mathrm{~J})$ detectados calorimetricamente, subtraindo o calor requerido para o aumento da temperatura da amostra, conforme descrito na Equação 35:

$$
M_{i}=\frac{Q_{i}-C_{i} \times \delta T_{i}}{q_{i}}
$$


Onde: $q_{i}(\mathrm{~J} / \mathrm{g})$ é a entalpia específica de fusão do gelo, $C_{i}(\mathrm{~J} / \mathrm{K})$ é a capacidade calorífica da amostra, e $\delta T_{i}(\mathrm{~K})$ é o aumento programado de temperatura no passo de aquecimento $i$.

Assume-se que no primeiro passo de aquecimento $(i=1)$ não ocorre fusão de gelo $\left(M_{1}\right.$ $=0$ ), e a água ligada congelável funde a partir do passo $i=2$ até $N-2$. A água livre, congelada fora dos poros determinados, funde a $0^{\circ} \mathrm{C}$ durante o passo $N-1$. O último passo de aquecimento $N$ ocorre acima de $0^{\circ} \mathrm{C}$, onde não há mais fusão de gelo $\left(M_{N}=0\right)$ e, assim como no primeiro passo, apenas serve para determinar a capacidade calorífica da amostra.

A entalpia específica $q_{i}$ foi calculada considerando sua dependência com a temperatura de aquecimento durante o passo $i$, conforme descrito detalhadamente em DRIEMEIER, MENDES e OLIVEIRA (2012). Já a estimativa de $C_{i}$ considera que a capacidade calorífica da amostra em cada fase é uma função da temperatura e que a capacidade calorífica específica muda quando o gelo funde em água.

A quantidade de gelo que fundiu em temperaturas abaixo de $0^{\circ} \mathrm{C}$ foi identificada como gelo confinado em poros, ou ainda como massa de FBW. O decaimento da temperatura $\Delta T$ de transição de fase de gelo em água, quando esta é confinada em poros, pode ser descrito pela seguinte equação fundamental (Equação 36):

$$
\Delta T=-K_{C} \times \frac{\delta S}{\delta V}
$$

Onde: $S$ é a área de interface gelo - água, $V$ é o volume da fase gelo, e $K_{c}$ é uma função simples da entalpia e da temperatura de transição de fase, da densidade do líquido e da energia superficial de interface gelo - água. Esta equação descreve a remoção da barreira energética para a fusão do gelo. A derivada desta equação pode então ser integrada para estimar, separadamente, a área cumulativa de poros $A_{P i}\left(\mathrm{~m}^{2} / \mathrm{g}\right)$ em cada passo discreto de aquecimento, conforme a Equação 37:

$$
A_{P_{i}}=\int \frac{-\Delta T}{K_{C} \times \rho_{\text {gelo }}} d M
$$

Onde o volume diferencial do sólido $d V$ foi substituído pela massa diferencial do sólido $d M$ dividida pela densidade do gelo $\rho_{\text {gelo }}$. 
Apesar da superfície do poro ser a variável natural da termoporometria, é conveniente expressar a porosidade como função dos diâmetros estimados dos poros. Os diâmetros dos poros $x(\mathrm{~nm})$ foram calculados a partir da curva de variação da temperatura de fusão de acordo com a equação de Gibbs-Thomson (Equação 38), comumente utilizada na termoporometria, que assume que os poros apresentam geometria cilíndrica:

$$
x=\frac{-2 K_{C}}{\Delta T}
$$

Onde: $K_{c}=19,8$ nm.K para amostras celulósicas (PARK et al., 2006). A distribuição de diâmetros de poros das amostras foi medida na faixa de 0,66 a 396,00 nm, que representa a porosidade da parede celular, e exclui o lúmen, que tipicamente possui dezenas de micrômetros de diâmetro.

Os resultados da análise de TP-DSC foram gerados como duas curvas de distribuição: de massa acumulada de água confinada nos poros (FBW) por unidade de massa seca de $\operatorname{amostra}(\mathrm{g} / \mathrm{g})$ em função do diâmetro do poro $x(\mathrm{~nm})$, e de área cumulativa de poros $A_{P i}$ por unidade de massa seca de amostra $\left(\mathrm{m}^{2} / \mathrm{g}\right)$ em função do diâmetro do poro $x(\mathrm{~nm})$. Para a conversão da massa acumulada de gelo fundido em volume cumulativo de poros $\left(\mathrm{m}^{3} / \mathrm{g}\right)$, os valores de $M_{i}$ determinados para cada diâmetro de poro equivalente foram divididos pela densidade do gelo $\left(\rho_{\text {gelo }}=0,917 \mathrm{~g} / \mathrm{cm}^{3}\right)$. Uma vez que a quantidade de NFW é a diferença de duas quantidades muito grandes, seu valor é alvo de incertezas significantes, logo optou-se por não reportar esta variável neste trabalho.

Uma vez que a termoporometria mede somente a água confinada dentro dos poros da parede celular, e não acessa a superfície externa das partículas, calcularam-se as áreas superficiais específicas internas das amostras analisadas $A_{S I}\left(\mathrm{~m}^{2} / \mathrm{g}\right)$ a partir da Equação 39:

$$
A_{S I}=\sum_{i=2}^{N-2} A_{P_{i}}
$$

Onde: $A_{P i}\left(\mathrm{~m}^{2} / \mathrm{g}\right)$ é a área cumulativa de poros com diâmetro $x_{i}$.

Já as áreas superficiais internas de poros estimados como acessíveis às enzimas celulolíticas, foram calculadas considerando o somatório da área de cumulativa de poros com 
diâmetros maiores ou iguais aos seguintes tamanhos nominais: 3,96 nm ( $i=7$ até $N-2), 6,60$ $\mathrm{nm}(i=8$ até $N-2)$ e $9,90 \mathrm{~nm}(i=9$ até $N-2)$. Estes valores de diâmetros de poros foram selecionados de acordo com os valores referenciados na literatura (item 2.2.5.1.1), que correspondem a tamanhos maiores que as dimensões elípticas estimadas para as celulases e considerados limitantes à sua penetração na estrutura da parede celular.

\subsubsection{Difração de raios- $X$}

A determinação dos parâmetros cristalinos e do grau de cristalinidade de cada uma das amostras obtidas, tanto nos pré-tratamentos físico-químicos quanto nos físico-mecânicos, foi realizada pela técnica de difração de raios-X (DRX) segundo o método validado por DRIEMEIER et al. (2015).

Primeiramente, as amostras a serem analisadas foram secas sob condições ambientes, e então inseridas em tubos capilares de vidro de $2 \mathrm{~mm}$ de espessura (marca Charles Supper). As análises de difração de raios-X foram realizadas utilizando-se um gerador de ânodo rotativo Rigaku ultraX-18HF operado com radiação $\mathrm{CuK} \alpha$ (comprimento de onda $\lambda=1.5418$ A) e monocromador óptico VariMax HR. Os tubos capilares foram alinhados perpendicularmente ao feixe de raios-X, e rotacionados $360^{\circ}$ em torno de seu eixo durante a exposição aos raios-X. Utilizou-se uma placa de imagem mar345 para detectar e coletar os padrões de difração de raios-X e um diodo Xenocs PIN para monitorar a intensidade da transmissão dos raios- $\mathrm{X}$ através das amostras.

Os padrões bidimensionais de difração foram analisados empregando-se o modelo CRAFS (cellulose Rietveld analysis for fine structure), que ajusta os padrões de raios-X calculados aos experimentais (OLIVEIRA; DRIEMEIER, 2013; DRIEMEIER, 2014). Os dados obtidos pelo modelo CRAFS são baseados na estrutura do polimorfo cristalino da celulose I $\beta$.

Os principais picos gerados nos difratogramas - $(110)_{\mathrm{m}},(1-10)_{\mathrm{m}},(200)_{\mathrm{m}}$ e $(004)_{\mathrm{m}}-$ foram ajustados por funções de Lorentzian, segundo o modelo de Delf para alargamento de tamanho. Os parâmetros CRAFS de formato dos picos de difração $(p)$ foram mantidos fixos durante as análises nos seguintes valores: $p_{200}=0,75 ; p_{\text {diag }}\left(=p_{110}=p_{1 \underline{10}}\right)=0,50$; e $p_{004}=$ 0,75. Os parâmetros refinados, determinados pelo ajuste automatizado dos difratogramas por CRAFS, foram: 
- As dimensões e o ângulo da cela unitária monoclínica do polimorfo I $\beta$ da celulose: parâmetros $a(\AA), b(\AA), c(\AA)$ e $\gamma\left(^{\circ}\right)$;

- $\quad$ As larguras dos picos de difração;

- $\quad$ A intensidade dos sinais cristalinos;

- $\quad$ E a intensidade do background polinomial.

A distância interplanar $d_{200}(\AA ̊)$, ou o espaçamento ao longo do plano de interações de hidrogênio intermoleculares $(200)_{\mathrm{m}}$, foi calculada a partir dos parâmetros de cela unitária mensurados pela Equação 40:

$$
d_{200}=1 / 2 \operatorname{asen}(\gamma)
$$

As dimensões laterais do cristalito de celulose $\left(L_{200}\right.$ e $\left.L_{110}=L_{110}=L_{\text {diag }}\right)$, assim como o comprimento aparente do cristalito $\left(L_{004}\right)$, foram inferidos pela equação de Scherrer. A equação de Scherrer é aplicada às larguras dos picos de difração obtidos na metade de sua intensidade, e descreve que picos de difração mais estreitos implicam em dimensões de cristalitos maiores (LANGFORD; WILSON, 1978).

O cálculo do grau de cristalinidade desenvolvido por DRIEMEIER e CALLIGARIS (2011) considera, entre outros parâmetros, o teor de umidade, o teor de lignina e o teor de cinzas da amostra, os espalhamentos incoerentes, a textura dos cristais, a intensidade em branco adquirida a partir da exposição dos tubos capilares vazios, e as intensidades de raios-X transmitidos durante a exposição dos tubos com amostras e vazios. A precisão no cálculo do grau de cristalinidade, definido como massa de celulose cristalina por massa de amostra seca, é criticamente influenciada pela incerteza na subtração do branco, e esta incerteza é propagada nos desvios calculados do grau de cristalinidade mensurado. Devido à transferência de instalação do equipamento utilizado para as análises por difração de raios-X para uma nova infraestrutura, não foi possível obter com devida acurácia os parâmetros de correção do branco para parte das amostras estudadas. Por este motivo, não serão reportados os valores de grau de cristalinidade calculados segundo o método acima mencionado.

Com o intuito de obter-se um comparativo entre a proporção de material cristalino em cada amostra analisada, aplicou-se o método de cálculo conhecido como "altura de pico" desenvolvido por SEGAL e colaboradores (1959). Neste método, os índices de cristalinidade 
ICr das amostras são calculados a partir das intensidades dos picos dos difratogramas em $2 \theta$ a aproximadamente $18^{\circ}\left(I_{a m}\right)$ e $22^{\circ}\left(I_{200}\right)$, segundo a Equação 41:

$$
I C r=1-\left(\frac{I_{a m}}{I_{200}}\right)
$$

Onde: $I_{a m}$ é a intensidade mínima da região entre os picos $(110)_{\mathrm{m}}$ e $(200)_{\mathrm{m}}$, ou a intensidade associada à porção amorfa; $I_{200}$ é a intensidade máxima do pico referente ao plano cristalino $(200)_{\mathrm{m}}$, ou a intensidade total (regiões amorfas + cristalinas); e $I_{200}$ - $I_{a m}$ é a intensidade associada à porção cristalina.

Uma vez que o cálculo do índice de cristalinidade é influenciado pela presença de componentes não celulósicos amorfos, para determinar se os métodos de pré-tratamento aplicados promovem a alteração real da proporção de material cristalino na amostra, alguns cálculos adicionais foram feitos. Os índices de cristalinidade esperados para as amostras prétratadas foram calculados de modo relativo ao bagaço in natura, considerando suas composições químicas (teores de celulose), segundo a Equação 42 a seguir:

$$
I C r_{\text {Esperado }}=I C r_{\text {In Natura }} \times \frac{\% \text { Celulose }_{\text {Pré-tratada }}}{\% \text { Celulose }_{\text {In natura }}}
$$

Onde: $I C r_{\text {Esperado }}$ é o índice de cristalinidade esperado para a amostra pré-tratada, $I C r_{I n}$ Natura é o índice de cristalinidade mensurado experimentalmente para a amostra de bagaço in natura

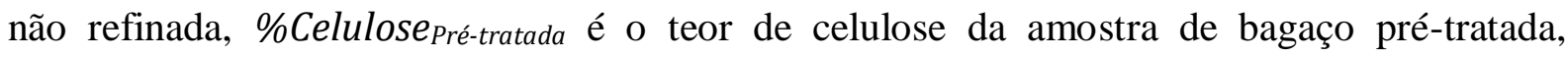
\%Celulose In Natura é o teor de celulose das fibras de bagaço in natura $(F)$. A diferença entre o valor esperado e o valor obtido experimentalmente nos fornece o decréscimo da cristalinidade da celulose, conforme a Equação 43:

$$
\operatorname{DCr}(\%)=\left(\frac{I C r_{\text {Esperado }}-I C r_{\text {Experimental }}}{I C r_{\text {Esperado }}}\right) \times 100
$$

Onde: $I C r_{\text {Experimental }}$ é o índice de cristalinidade mensurado experimentalmente para a amostra de bagaço pré-tratada, e $D C r$ é a diminuição do índice de cristalinidade provocada pelo método de pré-tratamento aplicado. 


\subsection{SACARIFICAÇÃO ENZIMÁTICA DOS POLISSACARÍDEOS DA BIOMASSA LIGNOCELULÓSICA}

As reações de hidrólise enzimática para a obtenção de açúcares fermentescíveis a partir das amostras de bagaço de cana-de-açúcar, tanto pré-tratadas pelos métodos físicoquímicos quanto pelos métodos físico-mecânicos, foram realizadas segundo o protocolo padrão utilizado no Laboratório Nacional de Ciência e Tecnologia do Bioetanol (CTBE), que emprega dois coquetéis enzimáticos:

1) Celluclast ${ }^{\circledR}$ 1.5L (Cellulase from Trichoderma reesei ATCC 26921, Novozymes Latin America Ltda), que consiste de um complexo de enzimas celulases (42 mg de proteína por $\mathrm{mL}$ de coquetel) extraídas do fungo filamentoso Trichoderma reesei;

2) Novozym 188 (Cellobiase from Aspergillus niger, Novozymes Latin America Ltda), que consiste de um complexo de $\beta$-glicosidases (45 mg de proteína por $\mathrm{mL}$ de coquetel) extraídas do fungo Aspergillus niger.

A seguir encontram-se descritas as metodologias aplicadas para a determinação das atividades enzimáticas de cada um dos tipos de coquetel enzimático, assim como para a realização da reação de sacarificação enzimática e da quantificação dos açúcares liberados no meio reacional.

\subsubsection{Determinação da atividade enzimática do complexo celulolítico}

A atividade celulolítica total do coquetel de celulases Celluclast ${ }^{\circledR} 1.5 \mathrm{~L}$ foi determinada empregando-se o protocolo padrão validado no CTBE, que segue o método "papel de filtro" proposto por GHOSE (1987), e expressa a atividade em unidades de papel de filtro (filter paper units, $\boldsymbol{F P U}$ ) por volume do coquetel original.

Este método baseia-se na quantificação da concentração de glicose liberada após a hidrólise de uma amostra de papel de filtro (padrão de celulose) quando em contato com uma solução de concentração conhecida da enzima analisada, adicionada em condições favoráveis para a degradação da amostra. Uma unidade da atividade enzimática da celulase, em FPU por mL de solução, representa a liberação de exatamente $0,2 \mathrm{mg}$ de glicose de uma amostra de 5,0 mg de papel de filtro por $50 \mu \mathrm{L}$ de solução enzimática diluída após 60 minutos de reação (ADNEY; BAKER, 1996; WOOD; BHAT, 1988). 
A concentração de glicose liberada na análise foi quantificada pelo método DNS descrito por MILLER (1959), que se baseia na capacidade de redução do ácido 3,5dinitrossalicílico (DNS) na presença de açúcares redutores em meio alcalino a $95^{\circ} \mathrm{C}$, formando o ácido 3-amino-5-nitrossalicílico, ao mesmo tempo em que o grupo aldeído do açúcar é oxidado a grupo carboxílico (Figura 33). O composto aromático ácido 3-amino-5nitrossalicílico possui coloração avermelhada e absorção máxima no visível em $540 \mathrm{~nm}$. Deste modo, pode-se estabelecer uma relação direta entre a medida espectrofotométrica da solução após a reação com a concentração de glicose formada no meio reacional.

Figura 32. Reação para a quantificação espectrofotométrica de açúcares redutores, baseada na conversão do ácido 3,5-dinitrosalicílico em seu análogo reduzido.<smiles>O=C(O)c1cc([N+](=O)[O-])cc([N+](=O)[O-])c1O</smiles>

Ácido 3,5dinitrossalicílico<smiles></smiles>

AR = Açúcar

Redutor<smiles>Nc1cc([N+](=O)[O-])cc(C(=O)O)c1O</smiles>

Ácido 3-amino5-nitrossalicílico<smiles>O=C(O)C1CCCCCC1</smiles>

Ácido Aldônico

Fonte: Adaptado de: SILVA et al., 2003.

Para o ensaio de determinação da atividade enzimática do complexo celulolítico, primeiramente preparou-se uma sequência de soluções que foram empregadas na reação, sendo estas:

- $\quad$ Solução tampão citrato $0,05 \mathrm{~mol} / \mathrm{L}(\mathrm{pH} 4,8)$ : preparou-se o tampão citrato a partir de uma solução aquosa de ácido cítrico $0,1 \mathrm{~mol} / \mathrm{L}$, uma solução aquosa de citrato de sódio 0,1 mol/L e água, misturados na proporção de 23:27:50 (v/v/v), respectivamente. Adicionou-se à solução azida sódica na concentração $0,02 \%(\mathrm{~m} / \mathrm{v})$, com o intuito de inibir o crescimento microbiano durante as reações de sacarificação.

- $\quad$ Reagente de DNS: preparou-se a solução de DNS pela dissolução em $1416 \mathrm{~mL}$ de água, a $70^{\circ} \mathrm{C}$ e sob constante agitação, 10,6 g de ácido 3,5-dinitrossalicílico (0,0465 mol), 19,8 g de hidróxido de sódio $(0,4950 \mathrm{~mol}), 306,0 \mathrm{~g}$ de tartarato de sódio e 
potássio tetrahidratado $(1,0847 \mathrm{~mol}), 8,3 \mathrm{~g}$ de metabissulfito de sódio $(0,0437 \mathrm{~mol}) \mathrm{e}$ 7,6 mL de fenol (0,0755 mol). Armazenou-se a solução de DNS em frasco âmbar.

- Curva padrão de glicose: prepararam-se oito soluções pela dissolução de padrão de glicose em tampão citrato $0,05 \mathrm{~mol} / \mathrm{L}$, cujas concentrações variaram entre 0,526 g/L e 10,0 g/L. Estas soluções foram utilizadas na construção de uma curva de calibração de glicose.

- Soluções do complexo celulolítico: prepararam-se seis diluições do coquetel de celulases em tampão citrato $0,05 \mathrm{~mol} / \mathrm{L}$, cujas concentrações variaram entre $2,5 \mu \mathrm{L}$ Enzima $/ \mathrm{mL}_{\text {Solução }}$ e $20,0 \mu \mathrm{L}_{\text {Enzima }} / \mathrm{mL}_{\text {Solução. }}$

Durante as reações de hidrólise, parte da concentração de glicose mensurada pode ser provinda da própria enzima e/ou do substrato, uma vez que o complexo enzimático utilizado pode conter açúcares nutrientes, assim como as extremidades da celulose podem, em alguns casos, serem quantificadas como açúcar redutor. Por esta razão, amostras de controle, que consistem na solução de enzima sem a adição de substrato, e no substrato sem a adição de enzima, são incluídas nas análises. Estas amostras de controle têm seus valores de absorbância subtraídos dos valores das absorbâncias registrados para as amostras de solução enzimática em contato com o substrato. Assim, a quantificação da concentração de glicose liberada após a hidrólise enzimática envolve três categorias de reações: branco reacional, para zerar o espectrofotômetro; amostras a serem quantificadas; e controles da enzima a do substrato.

O ensaio de determinação da atividade enzimática do coquetel de celulases foi realizado em tubos de ensaio inseridos em banho termostatizado, divididos em:

- Tubos de amostras, nos quais foram inseridos $15 \mathrm{mg}$ de papel de filtro padrão $\left(\mathrm{n}^{\circ} 1\right.$, marca Whatman) no formato de discos (aproximadamente 9 discos), no total de 1 tubo para cada solução enzimática preparada (6 tubos). Posteriormente, foram adicionados $300 \mu \mathrm{L}$ de tampão citrato em cada tubo, tomando o devido cuidado para que todos os discos de papel ficassem saturados pelo tampão;

- Tubos de controle das amostras, nos quais foram adicionados apenas $300 \mu \mathrm{L}$ de tampão citrato, no total de 1 tubo para cada solução enzimática preparada (6 tubos);

- Tubo de controle do substrato, no qual foram inseridos $15 \mathrm{mg}$ de papel de filtro em discos e $450 \mu \mathrm{L}$ de tampão citrato; 
- Tubo do branco, no qual foram adicionados $450 \mu \mathrm{L}$ de tampão citrato (sem substrato e sem enzima);

- Tubos da curva padrão da glicose, nos quais foram adicionados $150 \mu \mathrm{L}$ de uma das soluções de glicose diluída (total de 8 tubos) e $300 \mu \mathrm{L}$ de tampão citrato.

Encubaram-se todos os tubos no banho termostatizado a $50^{\circ} \mathrm{C}$ por 5 minutos. Após este período foram adicionados em cada tubo de amostra e de controle de amostra $150 \mu \mathrm{L}$ de uma das diluições do coquetel de celulases. A reação foi realizada encubando-se todos os tubos a $50^{\circ} \mathrm{C}$ por 60 minutos. Finalizado este período, removeram-se os tubos do banho termostatizado, e interrompeu-se imediatamente a reação pela adição de $900 \mu \mathrm{L}$ da solução de DNS. Os tubos foram então transferidos para outro banho termostatizado a $95^{\circ} \mathrm{C}$ e mantidos por 5 minutos, e posteriormente transferidos para um banho de gelo fundente, com o intuito de cessar completamente a reação. Por fim, adicionaram-se $6,0 \mathrm{~mL}$ de água, homogeneizando-se as soluções finais e deixando-se os resíduos de polpa de papel decantarem no fundo do frasco. Mediram-se as absorbâncias das soluções finais em espectrofotômetro UV-Vis a $540 \mathrm{~nm}$.

A partir da medida das absorbâncias das soluções dos tubos da curva padrão de glicose, traçou-se um gráfico linear da concentração de glicose em função da absorbância em $540 \mathrm{~nm}$. A equação da reta obtida foi utilizada para calcular a concentração de glicose liberada por cada amostra de enzima a partir dos seus valores de absorbância em $540 \mathrm{~nm}$, subtraídos os valores de absorbância obtidos para os controles das amostras e do substrato.

Traçou-se então um segundo gráfico linear do logaritmo da concentração da solução de celulases em função da concentração de glicose liberada por cada diluição da enzima. A equação deste segundo gráfico foi aplicada para o cálculo da concentração de enzima necessária para liberar exatamente $0,2 \mathrm{mg}$ de glicose do padrão de celulose (papel de filtro).

Calculou-se a atividade enzimática do complexo celulolítico empregado através da Equação 44 a seguir:

$$
\begin{aligned}
\text { FPU } . m L^{-1} & =\frac{0,2}{(0,18016 \times 0,05 \times 60 \times[\text { Enzima }])} \mu m o l . \mathrm{min}^{-1} \cdot m L^{-1} \\
& =\frac{0,37}{[\text { Enzima }]}
\end{aligned}
$$


Onde: o termo " 0,2 " se refere à liberação de $0,2 \mathrm{mg}$ de glicose equivalente, "0,18016" se refere à massa molar da glicose $(180,16 \mathrm{~g} / \mathrm{mol}=0,18016 \mathrm{mg} / \mu \mathrm{mol})$, “0,05" se refere ao volume de enzima diluída utilizado $(50 \mu \mathrm{L})$, “60" se refere ao tempo da reação de hidrólise (60 min), e [Enzima] se refere à proporção volumétrica $(\mathrm{mL}$ Enzima $/ \mathrm{mL}$ Solução $)$ do coquetel enzimático original presente em cada diluição da enzima.

\subsubsection{Determinação da atividade enzimática do complexo $\beta$-glicosídico}

A atividade enzimática do coquetel de $\beta$-glicosidases Novozym 188 foi determinada empregando-se o protocolo padrão validado no CTBE, que segue o método "p-NPG" descrito por WOOD e BHAT (1988), e expressa a atividade em unidade internacional (UI) por volume do coquetel original.

Este método baseia-se na quantificação estimada da concentração de para-nitrofenol (p-NP) liberada pela ação da enzima $\beta$-glicosidase sobre o para-nitrofenil- $\beta$-Dglicopiranosídeo (p-NPG). Uma unidade internacional de atividade enzimática da celobiase, em UI por mL de solução, é definida como a quantidade de enzima capaz de catalisar a liberação de $1 \mathrm{mmol}$ de p-NP por minuto de reação realizada a $50^{\circ} \mathrm{C}$ (WOOD; BHAT, 1988).

Para o ensaio de determinação da atividade enzimática do complexo $\beta$-glicosídico, primeiramente preparou-se uma sequência de soluções que foram empregadas na reação, sendo estas:

- Solução tampão citrato $0,05 \mathrm{~mol} / \mathrm{L}$ ( $\mathrm{pH} \mathrm{4,8):} \mathrm{preparada} \mathrm{conforme} \mathrm{descrito}$ anteriormente no item 4.6.1.

- $\quad$ Solução de p-NPG $1 \mathrm{mmol} / \mathrm{L}$ : preparou-se a solução de $\mathrm{p}-\mathrm{NPG}$ pela dissolução de 30,125 g de 4-nitrofenil- $\beta$-D-glicopiranosídeo em $100 \mathrm{~mL}$ de tampão citrato 0,05 $\mathrm{mol} / \mathrm{L}$.

- $\quad$ Curva padrão de p-NP: prepararam-se oito soluções pela dissolução de 4nitrofenol em tampão citrato $0,05 \mathrm{~mol} / \mathrm{L}$, cujas concentrações variaram entre 0,01 $\mathrm{mmol} / \mathrm{L}$ e $0,25 \mathrm{mmol} / \mathrm{L}$. Estas soluções foram utilizadas na construção de uma curva de calibração de p-NP.

- $\quad$ Solução de carbonato de sódio $1 \mathrm{~mol} / \mathrm{L}$ : preparou-se uma solução a partir da dissolução de 10,599 g de carbonato de sódio anidro em 100 mL de água destilada. 
- $\quad$ Soluções de $\beta$-glicosidase: prepararam-se sete diluições do coquetel de celobiases em tampão citrato $0,05 \mathrm{~mol} / \mathrm{L}$, cujas concentrações variaram entre 0,0250 $\mu \mathrm{L}_{\text {Enzima }} / \mathrm{mL}_{\text {Solução }}$ e $0,3333 \mu \mathrm{L}_{\text {Enzima }} / \mathrm{mL}_{\text {Solução. }}$

O ensaio de determinação da atividade enzimática do coquetel de celobiases empregado foi realizado em tubos de ensaio inseridos em banho termostatizado, divididos em:

- Tubos de amostras, nos quais foram adicionados 3,2 $\mathrm{mL}$ da solução de p-NPG 1 $\mathrm{mmol} / \mathrm{L}$ e $800 \mu \mathrm{L}$ de uma das diluições do coquetel de celobiases (total de 7 tubos).

- Tubos de controle das amostras, nos quais foram adicionados, nesta sequência, 4,0 $\mathrm{mL}$ da solução de carbonato de sódio $1 \mathrm{~mol} / \mathrm{L}, 3,2 \mathrm{~mL}$ da solução de p-NPG $1 \mathrm{mmol} / \mathrm{L}$ e 800 $\mu \mathrm{L}$ de uma das diluições do coquetel de celobiases (total de 7 tubos);

- $\underline{\text { Tubo do branco, }}$ no qual foram adicionados 3,2 mL da solução de p-NPG 1 mmol/L e $800 \mu \mathrm{L}$ de tampão citrato;

- Tubos da curva padrão de p-NP, nos quais foram adicionados $4,0 \mathrm{~mL}$ de uma das soluções de p-NP diluído (total de 8 tubos) e 4,0 mL da solução de carbonato de sódio 1 $\mathrm{mol} / \mathrm{L}$.

A reação foi realizada encubando-se todos os tubos no banho termostatizado a $50^{\circ} \mathrm{C}$ por 30minutos. Finalizado este período, removeram-se os tubos do banho, e interrompeu-se imediatamente a reação pela adição de $4,0 \mathrm{~mL}$ da solução de carbonato de sódio $1 \mathrm{~mol} / \mathrm{L}$ em cada tubo de amostra e do branco. Homogeneizaram-se as soluções finais e mediram-se suas absorbâncias em espectrofotômetro UV-Vis a $400 \mathrm{~nm}$.

A partir da medida das absorbâncias das soluções dos tubos da curva padrão de p-NP, traçou-se um gráfico linear da concentração de p-NP em função da absorbância em $400 \mathrm{~nm}$. A equação da reta obtida foi então utilizada para calcular a concentração de p-NP liberado por cada amostra de enzima a partir dos seus valores de absorbância em $400 \mathrm{~nm}$, subtraídos os valores de absorbância obtidos para os respectivos controles.

Calculou-se a atividade enzimática do coquetel de $\beta$-glicosidases empregado através da Equação 45 a seguir:

$$
U I \cdot m L^{-1}=\frac{[p-N P] \times F D \times V_{T}}{t \times V_{E}} \mu m o l \cdot \min ^{-1} \cdot m L^{-1}
$$


Onde: $[p-N P]$ é a concentração de p-NP liberada após a reação de hidrólise do p-NPG ( $\mu \mathrm{mol} / \mathrm{mL}), F D$ é o fator de diluição da enzima, $V_{T}$ é o volume reacional total $(8,0 \mathrm{~mL}), t$ é o tempo reacional (30 minutos) e $V_{E}$ é o volume da solução enzimática utilizada (800 $\mu \mathrm{L}$ ).

\subsubsection{Reação de hidrólise enzimática aplicada às amostras de bagaço}

Uma vez que o coquetel enzimático Celluclast ${ }^{\circledR} 1.5 \mathrm{~L}$, derivado do fungo filamentoso T. reesei, consiste principalmente de celobiohidrolases e endoglicanases (56\% Cel7 A, 12\% Cel6A, 5\% Cel7B e 6\% Cel5A) (HU et al., 2015), este é suplementado com $\beta$-glicosidase para impedir qualquer inibição por produto causada pelo acumulo de celobiose. As concentrações de ambos os coquetéis empregados foram definidas em condições otimizadas para evitar o uso excessivo de proteína e garantir o máximo efeito sinérgico entre as todas as glicosil hidrolases no meio reacional.

As atividades enzimáticas determinadas para os coquetéis empregados foram:

- Celluclast ${ }^{\circledR}$ 1.5L: $83,53 \mathrm{FPU} / \mathrm{mL}$;

- Novozym 188: 544,37 UI/mL.

As reações de sacarificação foram realizadas em meio de tampão citrato $0,05 \mathrm{~mol} / \mathrm{L}$ ( $\mathrm{pH} 4,8)$, sob agitação constante em shaker a 150 rpm mantendo-se a temperatura de hidrólise em $50^{\circ} \mathrm{C}$. Já as cargas enzimáticas empregadas foram de 10 FPU/g de amostra (base seca) para o coquetel de celulases e 20 UI/g de amostra (base seca) para o coquetel de celobiases.

Pesaram-se 5,0 g de amostra (base seca) em erlenmeyers de $250 \mathrm{~mL}$ providos de tampa. Adicionaram-se os volumes requeridos dos coquetéis enzimáticos e da solução tampão citrato, mantendo-se a razão sólido/líquido em 1:10 (m/v) (volume total final = $50 \mathrm{~mL})$. Em uma reação realizada com $\mathbf{5 , 0 g}$ de massa seca de biomassa utilizaram-se, em cada replicata, $\mathbf{5 9 8 , 6} \mu \mathbf{L}$ (correspondente a $\mathbf{5 0}$ FPU e $\mathbf{2 5 , 1} \mathbf{~ m g}$ de proteína) do coquetel de celulases e 183,7 $\mu \mathbf{L}$ (correspondente a 100 UI e $8,3 \mathbf{~ m g}$ de proteína) do coquetel de celobiases.

As reações foram estendidas pelo tempo total de $72 \mathrm{~h}$, retirando-se alíquotas a cada 24h. Ao fim da reação, resfriaram-se os frascos contendo as amostras em banho de gelo por 30 minutos com o intuito de cessar a atividade enzimática. As suspensões obtidas foram então centrifugadas a $9000 \mathrm{rpm}$ por 15 minutos, recuperando-se o hidrolisado para a posterior análise cromatográfica. As reações de hidrólise enzimática das amostras de bagaço de canade-açúcar foram realizadas em duplicata. 


\subsubsection{Determinação da concentração de açúcares nos hidrolisados enzimáticos}

A determinação dos teores de açúcares monoméricos formados nos hidrolisados obtidos foi realizada através da análise por cromatografia líquida de alta eficiência (CLAE), a partir da detecção dos seguintes compostos: celobiose, glicose, xilose e arabinose. As condições cromatográficas empregadas seguiram as especificações detalhadas no item 4.3.4.2. A digestibilidade da celulose foi calculada em termos de rendimento de glicose, como a razão entre a massa de glicose obtida após a hidrólise e a massa de glicose presente inicialmente na amostra, conforme descrito na Equação 46 a seguir:

$$
R_{\text {Glicose }}(\%)=\left[\frac{[\text { Glicose }] \times F C \times V_{\text {Filtrado }}}{m_{\text {Amostra Seca }} \times \% \text { Celulose }}\right] \times 100
$$

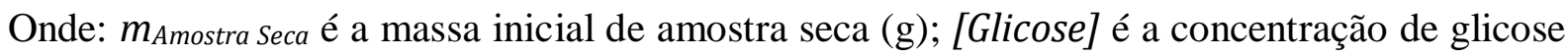
formada no licor e quantificada por CLAE $\left(\mathrm{g} . \mathrm{L}^{-1}\right) ; F C$ é o fator de conversão utilizado para calcular a concentração polimérica dos açúcares a partir das concentrações monoméricas (no caso, $F C=0,9$, conversão de glicose para celulose); $V_{\text {Filtrado }}$ é o volume do hidrolisado (L); \%Celulose é o teor de celulose presente na amostra de bagaço inicial (anterior à reação); e

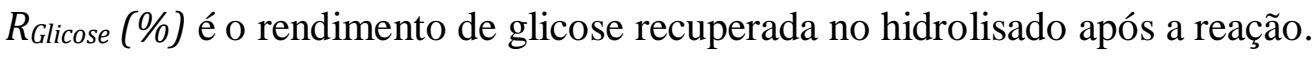

As concentrações de celobiose formadas no meio reacional foram muito pequenas devido à suplementação do coquetel enzimático de celulases com a $\beta$-glicosidase. Deste modo, a glicose foi o principal produto derivado da celulose formado no meio reacional durante a hidrólise enzimática das biomassas, e sua concentração sozinha foi um índice suficiente para a comparação entre os processos. Já a digestibilidade das hemiceluloses foi calculada a partir da razão entre a massa de xilose obtida após a hidrólise e a massa de xilose presente inicialmente na amostra, conforme descrito na Equação 47 a seguir:

$$
R_{\text {Xilose }}(\%)=\left[\frac{[\text { Xilose }] \times V_{\text {Filtrado }}}{m_{\text {Amostra Seca }} \times \% \text { Xilose }}\right] \times 100
$$

Onde: [Xilose] é a concentração de xilose formada no licor e quantificada por CLAE (g. $\left.\mathrm{L}^{-1}\right)$; \%Xilose é o teor de xilose presente na amostra de bagaço inicial (anterior à reação); e $R_{X i l o s e}$ (\%) é o rendimento de xilose recuperada no hidrolisado após a reação. 


\subsection{ANÁLISE DE COMPONENTES PRINCIPAIS E CONSTRUÇÃO DO MODELO DE PREDIÇÃo DA CONVERSÃO ENZIMÁTICA DA CELULOSE}

Os métodos de pré-tratamento aplicados, físico-químicos e -mecânicos, resultaram em de amostras cujas composições químicas e propriedades estruturais diferiram significantemente entre si. Ademais, as técnicas de análise de caracterização proveram um conjunto de dados que permite observar tendências e analisar o grau de influência de cada parâmetro no comportamento destas amostras frente aos processos hidrolíticos.

Com o intuito de quantificar por qual fator cada uma das características fundamentais da biomassa - químicas, físicas e morfológicas - influencia na taxa de conversão enzimática dos polissacarídeos da parede celular em açúcares monoméricos, analisou-se estatisticamente o conjunto de dados obtidos. A técnica estatística escolhida foi a análise de componentes principais (PCA), cuja finalidade e fundamentos foram detalhados no item 2.2.5.5.

A PCA permite classificar a importância relativa dos vários fatores que afetam a digestibilidade enzimática da biomassa pela redução da dimensionalidade e eliminação de sobreposições de uma grande e multivariada fonte de dados. A mudança de base dos dados promovida pela PCA possibilita que as variáveis inter-relacionadas que afetam a variabilidade do sistema sejam representadas por poucas variáveis linearmente não relacionadas - as componentes principais (PCs), que são combinações lineares das variáveis originais (BAUM et al., 2010; HUANG et al., 2010; LAUREANO-PEREZ et al., 2006; XU et al., 2016).

Os componentes que contam para a maior parte da variância dos dados são então usados como novas variáveis, às quais a resposta é linearmente regredida. Ademais, podemse determinar quais as análises necessárias para caracterizar, com grande acurácia, as biomassas estudadas. Com esta visão, um segundo objetivo da aplicação desta análise estatística foi estimar e propor um modelo de predição do comportamento da biomassa frente à hidrólise enzimática de acordo com suas propriedades estruturais, porém que exigisse o menor esforço em termos de análise de caracterizações.

A PCA foi realizada utilizando-se o pacote estatístico do software MATLAB R2013a (MathWorks@). Os passos para calcular as componentes principais são:

1) Obter os dados, organizados em uma matriz $m \times n$, onde $m$ é o número de observações (amostras) e $n$ é o número de dimensões (variáveis ou parâmetros analisados que descrevem as amostras); 
2) Normalizar os dados dentro de cada coluna das $n$ variáveis utilizando a média e o desvio padrão dos $m$ pontos, de modo que todas as dimensões apresentem a mesma grandeza;

3) Realizar a análise de PCA para a matriz de dados utilizando o comando "pca". Neste ponto, as $n$ variáveis são transformadas em novas variáveis, as componentes principais.

3.a) Os cálculos por trás deste comando envolvem primeiramente a construção da matriz de covariância $n \times n$ do conjunto de dados de $n$ dimensões, onde cada elemento é a covariância calculada para cada combinação de 2 dimensões.

3.b) Posteriormente são calculados os auto-vetores (de comprimento unitário e ortogonais entre si) e os autovalores da matriz de covariância. Enquanto os auto-vetores mostram como as diferentes dimensões estão relacionadas, os autovalores explicam a importância de cada auto-vetor na caracterização dos dados. Os auto-vetores representam as novas variáveis, as componentes principais PC; já os autovalores representam a contribuição de cada PC para explicar a variabilidade do sistema. Pode-se então expressar os dados em termos de auto-vetores ao invés das dimensões ou variáveis originalmente inseridas.

3.c) Nesta etapa inicia-se a compreensão do comportamento dos dados e a redução de sua dimensionalidade. Uma vez organizados os auto-vetores de acordo com o seu autovalor, pode-se escolher manter os auto-vetores (PCs) com maiores autovalores associados, ou seja, os que representam as combinações lineares mais significantes entre as variáveis iniciais, e descartar os de menores autovalores ou de menores significâncias. Os auto-vetores selecionados são então organizados em uma nova matriz, o vetor característica, em ordem decrescente em relação à sua variância associada, onde cada coluna é um auto-vetor.

3.d) Por fim, é formado um novo conjunto de dados, que são expressos nos termos dos vetores escolhidos ao invés de nos termos das $n$ variáveis originais. Este novo conjunto é derivado do produto entre a matriz transposta do vetor característica e a transposta da matriz original dos dados normalizados. Como alguns auto-vetores são removidos, os novos dados são apenas em termos dos vetores que se decidiram manter, reduzindo-se assim sua dimensionalidade.

As ações solicitadas dentro do comando " $p c a$ " incluem:

- coeff: obtidos como uma matriz $n \times n$, representam os loadings de cada variável dentro de cada PC, onde cada coluna corresponde à uma PC - da de maior variância à esquerda para a de menor variância à direita, e cada linha representa a contribuição (direção e magnitude) de cada variável original para esta PC; 
- $\quad$ score: obtidos como uma matriz $m \times n$, representam os scores de cada PC para cada amostra, onde cada coluna corresponde à uma PC, e cada linha a representação da observação na nova direção PC;

- $\quad$ explained: obtido como matriz $n \times 1$, representa os autovalores dos autovetores da matriz de covariância em porcentagem, onde cada linha é o autovalor de uma PC. Estes indicam a variância dos dados explicados por cada um dos auto-vetores calculados, ou seja, a ordem de importância de cada PC;

Os gráficos de loadings e scores, onde cada eixo é uma PC, ainda permitem examinar o grau de influência de cada variável original no comportamento de cada tipo de amostra.

4) Interpretar e reconstruir os dados. Após a execução dos passos anteriores, obtiveram-se as seguintes informações: as PCs que contam para a maior variância dentro do sistema, a contribuição de cada variável original para cada PC (loadings), e a representação de cada amostra dentro de cada PC (scores). O score de cada amostra dentro de cada PC pode ser calculado pelo somatório do produto entre cada loading de uma variável e o seu valor original normalizado, conforme descrito na Equação 48 a seguir:

$$
P C_{i}(\text { scores })=\sum_{n} L_{n_{i}} \times v_{n}
$$

Onde: $L_{n i}$ é o valor de loading para a variável $n$ dentro da $P C_{i}$, e $v_{n}$ é o valor da variável $n$ (normalizado) para a amostra em questão.

5) Construir o modelo. O somatório dos scores de cada amostra, ponderados pela contribuição de cada PC (variância), pode por fim ser regredido contra sua resposta final (concentração conhecida), que no caso deste trabalho é o rendimento de conversão enzimática dos polissacarídeos da parede celular. A equação da curva obtida é então utilizada para a construção do modelo empírico de predição da conversão enzimática de amostras desconhecidas de acordo com os seus parâmetros estruturais (variáveis de entrada) analisados.

Em suma, o modelo representará uma regressão entre a resposta e a combinação linear múltipla das variáveis originais que mais contam para a variabilidade do sistema. 


\section{CAPÍTULO 5. RESULTADOS E DISCUSSÃO}

\subsection{CARACTERIZAÇÃO DA COMPOSIÇÃO QUÍMICA DAS AMOSTRAS DE BAGAÇO DE CANA-DE-AÇÚCAR IN NATURA É PRÉ-TRATADAS}

Com o intuito de compreender de modo abrangente os efeitos de cada um dos métodos físico-mecânicos propostos nas características estruturais dos materiais lignocelulósicos, e assim aumentar a riqueza das interpretações acerca dos resultados obtidos nas análises físicas e morfológicas, as fibras de bagaço de cana-de-açúcar foram previamente tratadas por métodos físico-químicos. Os pré-tratamentos foram realizados em diferentes condições reacionais, de modo a obter cinco materiais cujas composições químicas e organizações estruturais diferissem entre si.

As composições químicas das fibras de bagaço in natura $(\boldsymbol{F})$, pré-tratadas hidrotérmicamente $(\boldsymbol{H})$ e deslignificadas por processo organossolve $\left(\boldsymbol{H O}_{\mathbf{1 8 0}}, \boldsymbol{O}_{\mathbf{1 9 0}}\right.$ e $\left.\boldsymbol{O}_{\mathbf{2 0 0}}\right)$ encontram-se na Tabela 7 a seguir. Já os valores das solubilizações de massa e de cada um dos macrocomponentes da parede celular após os pré-tratamentos físico-químicos aplicados encontram-se organizados na Figura 34.

Tabela 7. Composição química das amostras de bagaço de cana-de-açúcar em estudo.

\begin{tabular}{c|c|c|c|c|c|c}
\hline \multirow{2}{*}{ Amostra } & $\begin{array}{c}\text { Extrativos } \\
(\boldsymbol{\%})\end{array}$ & $\begin{array}{c}\text { Cinzas } \\
(\boldsymbol{\%})\end{array}$ & $\begin{array}{c}\text { Celulose } \\
(\boldsymbol{\%})\end{array}$ & $\begin{array}{c}\text { Lignina } \\
\mathbf{( \% )}\end{array}$ & $\begin{array}{c}\text { Hemiceluloses } \\
(\boldsymbol{\%})\end{array}$ & Total (\%) \\
\hline$F$ & $1,2 \pm 0,2$ & $0,5 \pm 0,0$ & $44,1 \pm 0,4$ & $22,3 \pm 0,1$ & $31,8 \pm 0,7$ & $99,8 \pm 0,9$ \\
$H$ & n.d. & $0,4 \pm 0,0$ & $56,2 \pm 0,1$ & $24,9 \pm 0,1$ & $19,3 \pm 0,1$ & $100,7 \pm 0,1$ \\
$H O_{180}$ & n.d. & $0,3 \pm 0,0$ & $76,0 \pm 5,5$ & $9,4 \pm 0,1$ & $14,1 \pm 1,8$ & $99,8 \pm 8,9$ \\
$O_{190}$ & n.d. & $2,6 \pm 0,1$ & $82,5 \pm 0,2$ & $5,0 \pm 0,4$ & $13,4 \pm 0,1$ & $103,5 \pm 0,0$ \\
$O_{200}$ & n.d. & $0,7 \pm 0,0$ & $91,9 \pm 0,0$ & $2,9 \pm 0,3$ & $3,9 \pm 0,4$ & $99,9 \pm 0,0$ \\
\hline
\end{tabular}

Legenda: n.d. = não determinado. 
Figura 33. Valores das solubilizações totais (massa) e de cada um dos macrocomponentes da parede celular após o pré-tratamento das fibras de bagaço de cana-de-açúcar em diferentes condições.

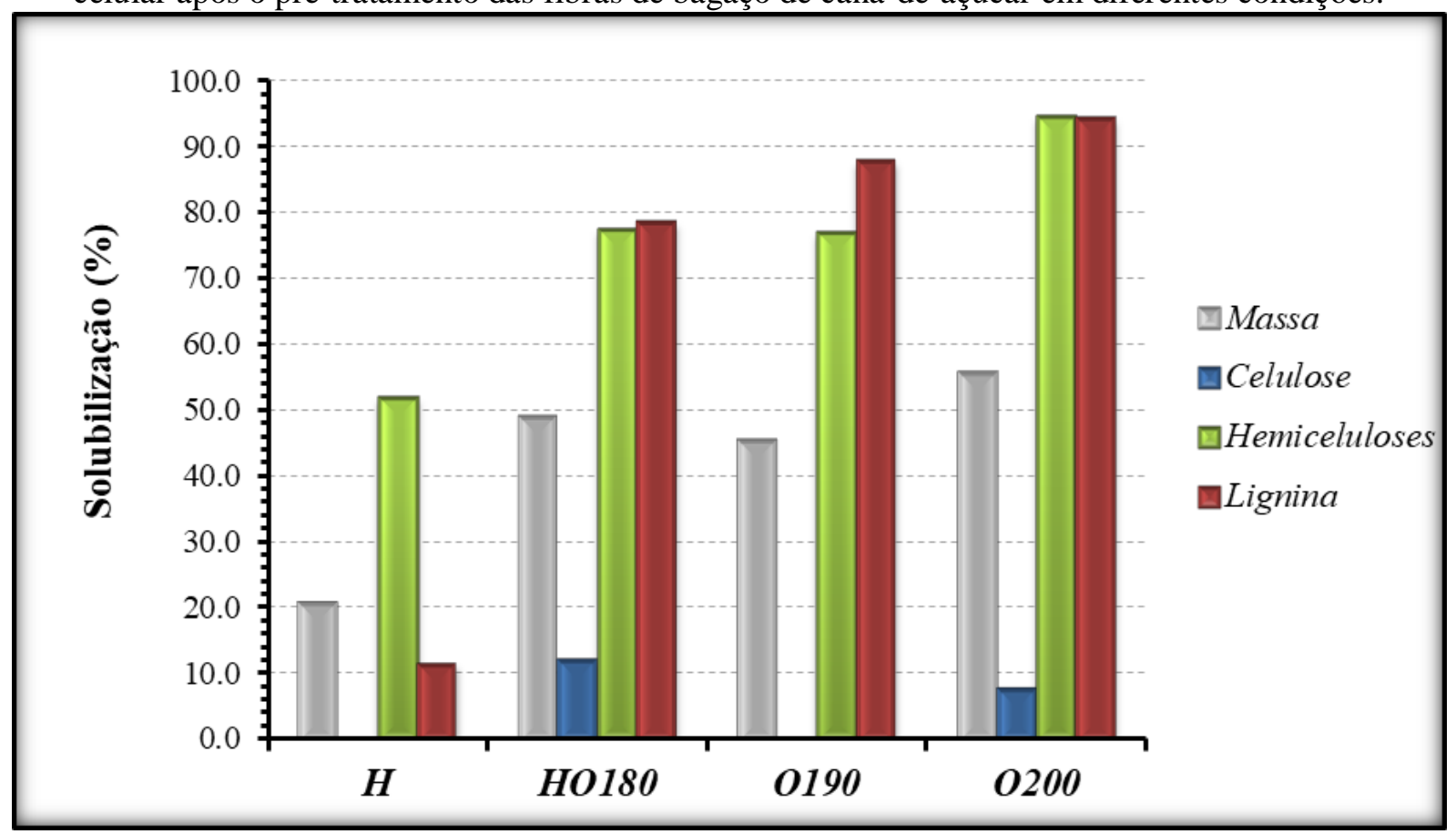

A partir dos resultados obtidos pôde-se primeiramente observar que os teores de cada componente nas fibras do bagaço de cana-de-açúcar in natura $(\boldsymbol{F})$ estão de acordo com a faixa de valores reportados na literatura, considerando as variações de composição que decorrem do local de cultivo, da época de colheita, da composição do solo, da variedade as sim como do período de maturação da planta (GURGEL, 2010; MARABEZI, 2014; MAZIERO, 2013; MOORE; BOTHA, 2014 RABELO, 2010; SANTUCCI et al., 2015; SLUITER et al., 2016). Constatou-se também que quanto maior a severidade da reação de pré-tratamento, maiores os valores de remoção de massa e de solubilização dos componentes não celulósicos. Concomitante às remoções dos compostos extrativos, das hemiceluloses e/ou da lignina, houve o aumento no teor relativo de celulose presente no material.

O pré-tratamento hidrotérmico, realizado em condição branda de reação $-160^{\circ} \mathrm{C} / 30$ min $(\boldsymbol{H})$, provocou uma baixa solubilização de massa $(20,6 \%)$, removendo $51,7 \%$ das hemiceluloses e 11,3\% da lignina presente nas fibras. Devido à baixa severidade da reação hidrolítica e à estrutura cristalina e altamente empacotada das fibrilas de celulose, que lhes confere resistência às reações de despolimerização, a quantidade total de celulose no resíduo sólido após o pré-tratamento hidrotérmico foi preservada. Já as propriedades estruturais das cadeias hemicelulósicas - curtas, ramificadas e sem padrão de empacotamento cristalino - 
fazem com que suas ligações glicosídicas sejam as mais susceptíveis aos processos hidrolíticos, logo solubilizadas em grande extensão e majoritariamente, mesmo em baixas temperaturas e/ou curtos tempos de reação.

Consoante ao descrito no item 2.2.6.1, a acidificação do meio que ocorre durante o pré-tratamento hidrotérmico promove a solubilização dos heteropolissacarídeos e a ruptura das interligações da matriz lignina-polissacarídeos, porém preserva a maior porcentagem da fração lignina no estado sólido. Nas condições hidrotérmicas empregadas nesta etapa do trabalho, apenas uma pequena porcentagem da lignina foi fragmentada pela cisão de ligações $\beta$-O-4' e $\alpha$-O-4' devido ao baixo potencial ácido-catalítico do meio reacional. Uma vez que solubilização da lignina ocorreu em baixa extensão e considerando-se a remoção abundante de hemiceluloses, seu teor relativo na biomassa pré-tratada aumentou em relação às fibras de bagaço in natura $(\boldsymbol{F})$.

A posterior deslignificação do material pré-tratado por meio do processo organossolve realizado na condição 1 ( $\left.\boldsymbol{H O}_{180}\right)$ proporcionou a remoção de massa adicional de 35,5\% (total de $48,8 \%$ ), resultando em um material com teores $55,5 \%$ e 58,0\% menores de hemiceluloses e lignina, respectivamente, e 72,4\% maior de celulose que a amostra $\boldsymbol{F}$. Conforme detalhado no item 2.2.6.2, o processo de deslignificação organossolve promove a solubilização em grande proporção tanto das hemiceluloses quanto de lignina. As prévias remoção parcial das xilanas, quebra das interações lignina-carboidratos e provável formação de fragmentos de lignina de menor massa molecular durante o pré-tratamento hidrotérmico são fatores que ampliam a capacidade de penetração e difusão de solventes na matriz lignocelulósica, logo aumentam o percentual de extração da lignina durante os processos de polpação subsequentes. Entretanto, não foi observada uma maior taxa de deslignificação da biomassa no processo sequencial em relação à polpação organossolve direta.

A deslignificação organossolve direta das fibras de bagaço in natura sob a condição 2 $\left(\boldsymbol{O}_{190}\right)$ resultou em um material com maior teor de celulose $(8,5 \%)$ e menores teores de lignina e hemiceluloses (46,6 e 5,2\%, respectivamente) do que a polpa $\boldsymbol{H O}_{180}$, porém com uma perda de massa no processo 7,3\% menor por não afetar a estrutura da celulose. A menor eficiência na solubilização de lignina observada para o processo de deslignificação sequencial $\left(\boldsymbol{H O}_{\mathbf{1 8 0}}\right)$ pode ser explicada principalmente por dois fatores: 1) devido à remoção prévia dos grupos acetila presentes na fração hemiceluloses durante o prévio tratamento hidrotérmico, o que reduziu o potencial de auto-catálise da reação de deslignificação pela falta de uma fonte 
endógena de grupos ácidos; e 2) devido à deposição de lignina na superfície das fibras durante o pré-tratamento hidrotérmico, o que possivelmente limitou a transferência do solvente e dificultou a sua extração (AGNIHOTRI et al., 2015; GARCÍA; ALRIOLS; LABIDI, 2014; HALLAC et al., 2010; HUIJGEN et al., 2012; LAI et al., 2014; MESA et al., 2010; OBAMA et al., 2012; VALLEJOS et al., 2015; WILDSCHUT et al., 2013).

Já a deslignificação organossolve direta sob a condição $3\left(\boldsymbol{O}_{200}\right)$ proporcionou a remoção de $94,5 \%$ das hemiceluloses e $94,2 \%$ da lignina presente nas fibras do bagaço, com a perda de apenas $7,4 \%$ do teor de celulose. Devido à forte interação entre os macrocomponentes na estrutura da parede celular, para uma possível extração total da lignina das fibras da biomassa seria necessário o emprego de condições muito severas de reação, o que poderia implicar na perda em maior extensão da celulose ou na ocorrência de reações secundárias de condensação entre os fragmentos de lignina formados, restringindo assim a efetividade da deslignificação (FENGEL; WEGENER, 1989; PIMENTA, 2005; SANNIGRAHI; RAGAUSKAS; MILLER, 2010).

Cabe relembrar que, além da solubilização das hemiceluloses e da lignina, durante os pré-tratamento estudados (hidrotérmico e organossolve) ocorre a quebra das interligações da matriz lignina-polissacarídeos pela hidrólise das unidades arabinofuranose laterais das hemiceluloses e pela solubilização dos ácidos p-cumárico e ferúlico (ALVIRA et al., 2010; KO et al., 2015b; MENON; RAO, 2012; MERALI et al., 2013; RABEMANOLONTSOA; SAKA, 2016; SUN et al., 2016; TAHERZADEH; KARIMI, 2008; TRAJANO et al., 2013; ZHAO; ZHANG; LIU, 2012).

Os métodos de pré-tratamento atuam não só na modificação da composição química como também de toda a estrutura da parede celular. Estas cinco amostras de bagaço de canade-açúcar $\left(\boldsymbol{F}, \boldsymbol{H}, \boldsymbol{H O}_{\mathbf{1 8 0}}, \boldsymbol{O}_{\mathbf{1 9 0}}, \boldsymbol{O}_{\mathbf{2 0 0}}\right)$ foram então submetidas aos processos físico-mecânicos propostos, em um estudo amplo das variáveis de tratamento que permitiu observar separadamente as alterações químicas, físicas e morfológicas que ocorrem nas fibras lignocelulósicas. 


\subsection{AVALIAÇÃO DOS TRATAMENTOS FÍSICO-MECÂNICOS APLICADOS ÀS AMOSTRAS DE BAGAÇO DE CANA-DE-AÇÚCAR}

Visando elucidar os efeitos das propriedades físicas e morfológicas (dimensões das fibras, porosidade da parede celular e estrutura cristalina da celulose) na acessibilidade e na efetividade da sacarificação enzimática dos materiais lignocelulósicos, esta etapa do trabalho propõe o uso de tratamentos físico-mecânicos aplicados às fibras de bagaço de cana-açúcar como forma de modificação da ultraestrutura da parede celular.

O estudo dos tratamentos físico-mecânicos foi realizado empregando-se equipamentos de diferentes tipos e configurações, cujos modos de ação e consequente impacto nas fibras diferem entre si, sendo estes:

- Moinho centrífugo laboratorial tipo Jokro $(\boldsymbol{M J})$ : refino do material por forças de impacto e cisalhamento, aplicadas em todas as direções das fibras em suspensão aquosa, que são espremidas contra a parede da panela pelo moente rotor;

- $\quad$ Refinador de discos Bauer $(\boldsymbol{R D})$ : tratamento por pressão da polpa celulósica entre os discos do equipamento, onde as forças de cisalhamento são aplicadas pelas lâminas apenas na direção em que as fibras são empurradas no fluxo em meio aquoso;

- Moinho criogênico $(\boldsymbol{M C})$ : processamento dos materiais úmidos quando congelados, ocorrendo a quebra das fibras lignocelulósicas por impacto contra a parede do frasco por ação do impelidor.

A princípio, deve-se esclarecer os motivos pelos quais não foi realizada uma avaliação da eficiência energética dos processos físico-mecânicos apresentados. Primeiramente, os equipamentos utilizados neste trabalho operam em diferentes escalas e com diferentes consistências de massa. Para uma comparação apropriada e uma boa aplicabilidade da avaliação energética, primeiramente haveria que transpor as tecnologias para equipamentos que reproduzissem os efeitos de cada método em escalas similares e com a mesma capacidade de processamento. Isto feito, a comparação seria então em termos de rendimento de açúcares fermentescíveis obtidos após a sacarificação do material em relação à energia total consumida para o processamento da massa. Em contrapartida, o principal objetivo desta etapa do trabalho foi compreender quais os principais parâmetros da parede celular que afetam a taxa de hidrólise dos polissacarídeos da biomassa lignocelulósica, cujos resultados e interpretações 
permitirão então a busca de sistemas de refino que provoquem a devida abertura da estrutura física das fibras aos agentes hidrolíticos.

De acordo com a teoria apresentada no item 2.2.7.1.2, as forças de compressão e cisalhamento provocadas pelo refino resultam em três efeitos principais na estrutura da parede celular das fibras: 1) a fibrilação externa, fenômeno de "descascamento" da parede celular e de destacamento das fibrilas enquanto as mantém ligadas à superfície; 2) a fibrilação interna, processo de delaminação e intumescimento da parede celular causado pelo rompimento das interações de hidrogênio que interligam as fibrilas, pela expansão da capilaridade e pela inserção de moléculas de água; e 3) o corte, redução das dimensões da fibra pela ação da superfície do refinador ao longo do comprimento da parede celular. Adicionalmente, o refino pode causar o encurvamento e o estreitamento da fibra, além do colapso do lúmen devido à compressão da fibra.

Como resultado, são observados o desfibramento, a alteração nas propriedades morfológicas, o aumento no volume de poros interfibrilares e interlamelares e, em alguns casos, a quebra da organização cristalina da porção celulósica. Diversos autores reportam que durante os processos de refino não ocorre a alteração da composição química da biomassa, exceto pela remoção de alguns compostos solúveis em água; portanto, neste trabalho, considerou-se que as amostras de bagaço apresentaram o mesmo teor relativo de cada um dos macrocomponentes antes e após o processamento físico-mecânico (CHEN et al., 2012b; DEL RIO; CHANDRA; SADDLER, 2011; GAO et al., 2012; JONES et al., 2014).

Em todos os métodos de refino, estes três efeitos primários ocorrem simultaneamente, porém em diferentes extensões ou distribuições dependendo do tipo de equipamento, das variáveis de processo adotadas e das características iniciais da biomassa. Deste modo, ao comparar as mudanças provocadas nas características das fibras lignocelulósicas por refinadores de escala laboratorial e industrial / piloto ou ainda por equipamentos de cominuição mecânica, deve-se atentar às diferenças nas geometrias do conjunto refinador (rotor/estator), nos modos de operação (velocidade e forma de ajuste do grau de refino) e nas consistências de sólidos empregadas, que implicarão em variações nas energias específicas e nas intensidades de refino, portanto em diferentes extensões de cada um dos efeitos.

O resultado principal da avaliação conjunta dos efeitos primários é visualizado como o aumento do grau de hidratação das fibras lignocelulósicas. Isto porque o refino promove o rompimento das forças de ligação e o afastamento entre as fibrilas adjacentes, ao mesmo 
passo que permite a penetração de uma maior quantidade de água pelo aumento das áreas superficiais externa e interna (ALVIRA et al., 2010; BHARDWAJ; HOANG; NGUYEN, 2007; CAMPOS, 1999; DA SILVA, 1968; DEMUNER, 2001; HENDRIKS; ZEEMAN, 2009). Isto significa que o aumento no grau de refino implica na redução da taxa de drenagem de água da polpa, ou ainda no aumento da capacidade de retenção de água da mesma pela redução das dimensões das fibras, pela criação de elementos finos além da expansão da estrutura capilar. Destarte, uma primeira abordagem da quantificação do resultado do refino pode ser realizada pela medida do grau de drenabilidade de uma polpa.

O acompanhamento do efeito dos processos físico-mecânicos nas fibras dos materiais em estudo $\left(\boldsymbol{F}, \boldsymbol{H}, \boldsymbol{H} \boldsymbol{O}_{180}, \boldsymbol{O}_{190}\right.$ e $\left.\boldsymbol{O}_{200}\right)$ foi realizado pela determinação do grau de refino pelo método Schöpper-Riegler ( ${ }^{\circ} S R$ ). Os valores de ${ }^{\circ} S R$ em função do tempo de refino em moinho Jokro $(\boldsymbol{M J})$, em função do tempo de refino e da distância entre os discos em refinador Bauer $(\boldsymbol{R D})$ e em função da moagem criogênica $(\boldsymbol{M C})$, obtidos para as 5 amostras em estudo, encontram-se organizados na Figura 35 a seguir.

A partir dos resultados obtidos para o refino das amostras em estudo em moinho Jokro (MJ) pôde-se observar que quanto maior a intensidade do refino (tempo) maior o valor do grau Schöpper-Riegler alcançado pelas fibras do material. Um maior tempo de refino implica em um maior número de impactos sofridos pelas fibras, o que reflete em modificações mais representativas das propriedades físicas e morfológicas, logo em um maior grau de refino e uma maior hidratação das fibras.

Observou-se também que, para um mesmo tempo de refino, os materiais deslignificados $\left(\boldsymbol{H O}_{\mathbf{1 8 0}}\right.$ e $\left.\boldsymbol{O}_{190}\right)$ alcançaram maiores valores de ${ }^{\circ} S R$ que a amostra apenas prétratada hidrotérmicamente $(\boldsymbol{H})$, que por sua vez atingiu maiores valores que as fibras de bagaço in natura $(\boldsymbol{F})$. Conforme o conceito desenvolvido nos itens 2.2.7.1.3 e 2.2.8, a facilidade do processo de fibrilação se relaciona com a composição química do material lignocelulósico, uma vez que a recalcitrância dificulta a inserção de água entre as fibrilas e a abertura da estrutura física do material. Além disto, presença de lignina nos espaços interfibrilares e interlamelares tende a restringir o intumescimento das fibras e as torna rígidas e quebradiças. Portanto, o valor de ${ }^{\circ} S R$ alcançado nos diferentes tempos de refino é maior após a prévia abertura da estrutura da parede celular pela desestruturação da matriz ligninapolissacarídeos promovida pelos tratamentos físico-químicos, e tende a aumentar com a redução no teor de componentes não celulósicos nas fibras do material. 
Figura 34. Variação do grau Schöpper-Riegler ( $\left.{ }^{\circ} S R\right)$ com (A) o tempo de refino em moinho Jokro, (B) o tempo de refino em refinador Bauer e (C) a moagem

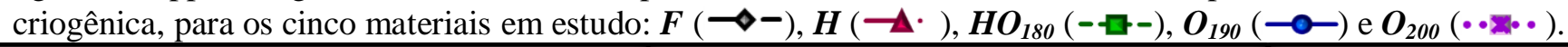

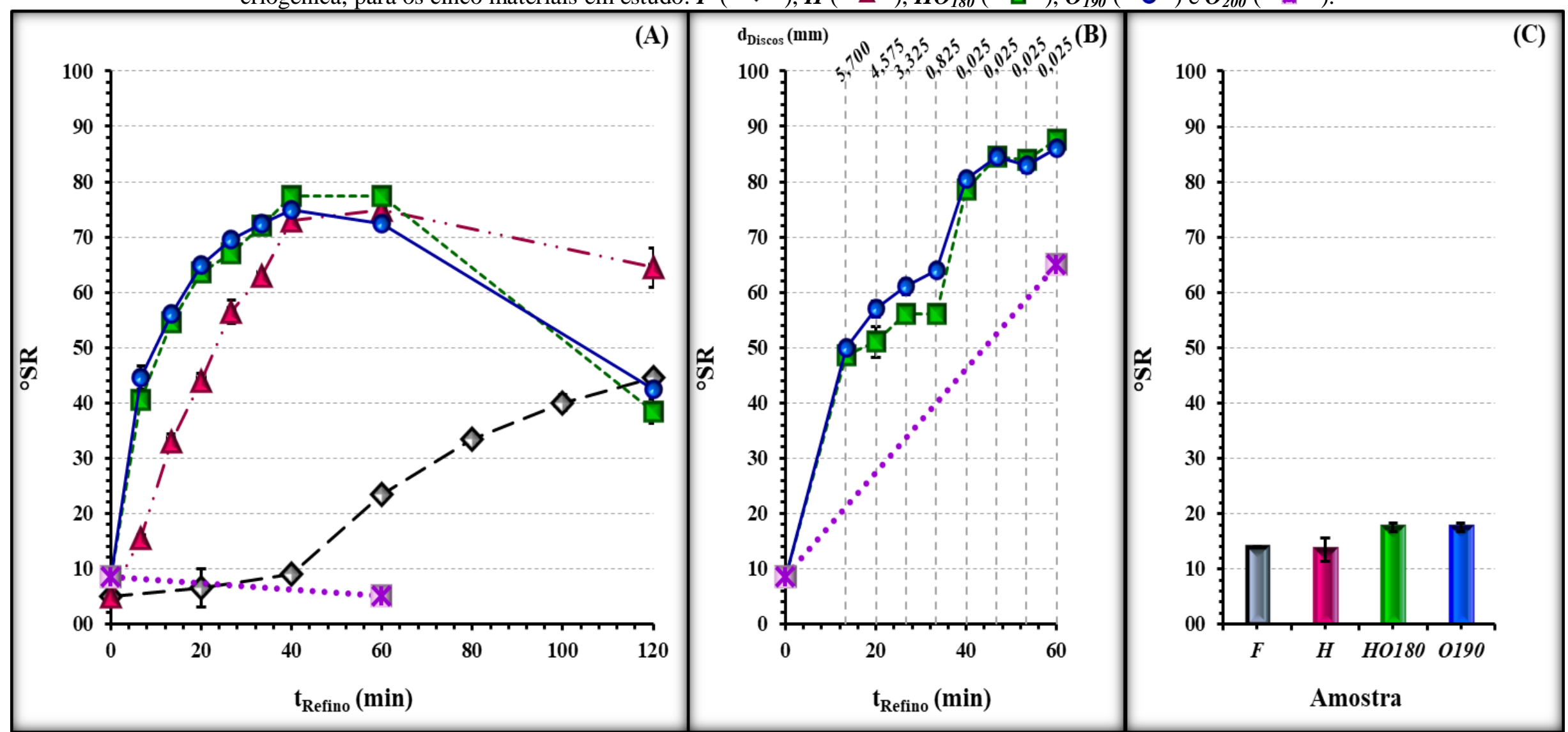

Legenda: $\mathrm{t}_{\text {Refino }}=$ tempo de refino; $\mathrm{d}_{\text {Discos }}=$ distância entre os discos. 
O maior valor de ${ }^{\circ} S R$ obtido para o refino em $\boldsymbol{M J}$ das fibras de bagaço in natura foi de $44,5^{\circ} S R$ em 18000 revoluções (120 minutos), enquanto os materiais pré-tratados quimicamente alcançaram valores maiores que $73,0^{\circ} S R$ com apenas 6000 revoluções (40 minutos). Para um mesmo tempo de refino (intervalo entre 0 e 60 minutos), a celulignina $\boldsymbol{H}$ e as polpas $\boldsymbol{H O}_{180}$ e $\boldsymbol{O}_{190}$ apresentaram valores de ${ }^{\circ} S R$ de 2 a 7 vezes e de 2 a 9 vezes maiores que os obtidos para as fibras de bagaço in natura $\boldsymbol{F}$. Conclui-se que os materiais mais recalcitrantes requerem uma maior intensidade de refino ou uma maior demanda energética para alcançar propriedades equivalentes às fibras mais desestruturadas e com maiores áreas superficiais específicas; diferentemente, o pré-tratamento físico-químico apresenta a possibilidade de diminuir a resistência da biomassa ao processamento mecânico.

O material $\boldsymbol{H}$ exibiu um crescimento contínuo do valor de ${ }^{\circ} S R$ com o tempo de refino, atingindo um platô entre $73,0-75,0^{\circ} S R$ após 40 minutos de refino. Já as polpas $\boldsymbol{H O}_{180}$ e $\boldsymbol{O}_{190}$ apresentaram comportamentos e valores de ${ }^{\circ} S R$ semelhantes quando refinadas sob as mesmas condições de processo, e alcançaram um platô entre $72,0-77,5^{\circ} S R$ após 33,3 minutos de refino; para estes materiais, o valor do ${ }^{\circ} S R$ aumentou continuamente com o tempo de refino, porém com uma taxa de acréscimo menor com o aumento da severidade do refino em relação ao material $\boldsymbol{H}$. Este comportamento é explicado pelo fato da abertura na estrutura da parede celular provocada pelo refino ser mais relevante em amostras mais recalcitrantes, visto que as amostras com menores teores de lignina e hemiceluloses já possuem uma área superficial significativamente grande. Já o material in natura $\boldsymbol{F}$ apenas evidenciou um crescimento mais representativo do ${ }^{\circ} S R$ após 40 minutos de refino.

O refino em moinho Jokro promove a delaminação das camadas internas da parede celular pela compressão das barras do sistema rotor contra as paredes internas do estator, culminando no aumento da área superficial interna das fibras; ademais, as forças de cisalhamento aplicadas pelo movimento das barras do rotor contra a parede do estator provocam a fibrilação da superfície externa das fibras. A observação do comportamento do grau de refino para o processamento em $\boldsymbol{M J}$ permitiu inferir a distribuição dos efeitos de acordo com a intensidade do refino. Em menores severidades de refino há o predomínio dos fenômenos de fibrilação, principalmente interna, o que implica no aumento contínuo no grau Schöpper-Riegler (ou da capacidade de absorção de água) pelo aumento da estrutura capilar interna da parede celular além da maior área superficial externa. Ademais, o refino altera a distribuição dos componentes nas superfícies das fibras, aumentando a área de exposição dos 
carboidratos aptos a estabelecer interações de hidrogênio com moléculas de água. Com a extensão do refino para tempos maiores, há a competição entre a fibrilação, a formação de elementos finos e o corte, havendo a redução em grande proporção das dimensões das fibras. Deste modo, há indícios de que há um limite na abertura da estrutura interna da parede celular que pode ser promovida pelo refino em moinho Jokro, interpretação que será esclarecida posteriormente (item 5.3) a partir do confronto entre os dados obtidos nas análises morfológicas e físicas.

Entretanto, as amostras pré-tratadas hidrotérmicamente e/ou deslignificadas apresentaram uma redução no valor de grau Schöpper-Riegler obtido em intensidades muito severas de refino (18000 revoluções): de 75,0 para $64,5^{\circ} S R$, de 77,5 para $38,5^{\circ} S R$ e de 72,5 para $42,5^{\circ} \mathrm{SR}$ respectivamente para os materiais $\boldsymbol{H}, \boldsymbol{H O}_{180}$ e $\boldsymbol{O}_{\mathbf{1 9 0}}$. O uso de condições mais severas de tratamentos mecânicos, associado à maior facilidade de processamento da biomassa, implica na formação de materiais cuja granulometria é menor que a abertura da peneira padronizada do equipamento de determinação de ${ }^{\circ} S R$ (inferior a $100 \mathrm{mesh}$ ), havendo a passagem destes juntamente com a água para o copo de leitura; isto acarreta na diminuição da quantidade de amostra necessária para a análise de retenção de água na peneira (aproximadamente $2 \mathrm{~g}$ ) e, consequentemente, infere um erro na análise destas amostras.

Diferentemente, o tratamento em refinador Bauer $(\boldsymbol{R D})$ das polpas organossolve $\boldsymbol{H O}_{\mathbf{1 8 0}}$ e $\boldsymbol{O}_{190}$ provocou um aumento contínuo do ${ }^{\circ} S R$ com a extensão do tempo de refino quando aplicados maiores espaçamentos entre os discos, porém menos expressivo do que o aumento obtido quando os discos do refinador foram ajustados para a aproximação máxima entre eles. Com maiores espaçamentos entre os discos, os materiais $\boldsymbol{H O}_{180}$ e $\boldsymbol{O}_{\mathbf{1 9 0}}$ refinados por 33,3 minutos apresentaram valores de ${ }^{\circ} S R 15,5 \%$ e $28,0 \%$, respectivamente, maiores que os refinados por 13,3 minutos; já no menor espaçamento e quando refinadas por 60 minutos, as polpas exibiram valores de ${ }^{\circ} S R 56,3 \%$ e $34,4 \%$, respectivamente, maiores que as refinadas por 33,3 minutos.

Neste caso, a severidade do refino é representada conjuntamente por sua duração e pela pressão exercida sobre as fibras, sendo que quanto maior a severidade, mais expressivas são as modificações promovidas nas propriedades estruturais das fibras, resultando em uma maior capacidade de retenção de água. Entretanto, a redução da distância entre os discos mostrou maior influência no aumento do grau de refino do que a extensão do tempo de processamento. A aplicação de altas pressões sobre as fibras acarreta em altos valores de 
energia específica e, consequentemente, em um alto grau de influência nas características da parede celular das fibras.

Consoante à teoria dos fatores que influenciam no processo de refino (item 2.2.7.1.3), a redução gradativa da distância entre as partes constituintes do refinador (rotor e estator) acarreta inicialmente na hidratação das fibras com pouca ocorrência de formação de elementos finos ou ainda de corte; em uma determinada posição dos discos, a aproximação estimula um processo mais intenso e frequente de fibrilação das paredes externas, promovendo concomitantemente o aumento das áreas superficiais interna e externa das fibras, o que aumenta a resistência à drenabilidade da polpa (CAMPOS, 2009; D'ALMEIDA, 1988; ROBUSTI et al., 2014). Deste modo, há indícios de que as alterações provocadas nas estruturas interna e externa da parede celular promovidas pelo refinador de discos tipo Bauer depende conjuntamente das diferentes variáveis do processo, interpretação que será embasada posteriormente (item 5.3).

Já com o uso de distâncias muito pequenas entre os discos, há uma dificuldade na formação do colchão de massa, logo há uma maior probabilidade da fricção direta entre as lâminas dos discos e as fibras do que o contato fibra-fibra, o que implica no aumento da temperatura do sistema. Por conseguinte, não se pôde prolongar o refino em $\boldsymbol{R} \boldsymbol{D}$ por tempos muito extensos quando este foi realizado no espaçamento mínimo entre os discos como forma de evitar o superaquecimento do sistema.

Para o refino em $\boldsymbol{R} \boldsymbol{D}$, observou-se também que o material deslignificado diretamente na condição $2\left(\boldsymbol{O}_{190}\right)$ apresentou valores de ${ }^{\circ} S R$ ligeiramente maiores (entre 3,1 e 14,3\%) do que o material pré-tratado e deslignificado $\left(\boldsymbol{H O}_{180}\right)$ quando refinados com maiores espaçamentos entre os discos (até 33,3 minutos), e valores similares para o refino na aproximação máxima entre os discos (0,025 mm a partir de 40 minutos). Este comportamento se deve ao fato de que durante o refino realizado em maiores distâncias entre os discos a fibrilação é facilitada pelo menor teor de lignina; deste modo, maiores valores de ${ }^{\circ} S R$ são alcançados para a mesma intensidade ou o mesmo tempo de processamento pela redução do impedimento à penetração da água nos espaços interfibrilares e interlamelares. Já o processamento mecânico em refinador Bauer no menor espaçamento entre os discos fornece uma maior área de atrito entre as lâminas e as fibras, logo uma fração da energia consumida pelo refinador se transforma em calor, o que implica no aumento da temperatura da massa (CAMPOS, 2009). A temperatura alcançada pelo sistema $\left(\sim 80^{\circ} \mathrm{C}\right)$ pode promover o 
amolecimento da lignina, o que facilita o processo de desconstrução da parede celular promovido pelo refino (ASUNCIÓN, 2003; CONTRALL, 1950). Consequentemente, um maior teor de lignina tende a facilitar o refino quando aplicadas maiores energias sobre as fibras. Além do mais, no menor espaçamento entre os discos a energia de refino aplicada sobre as fibras foi máxima, de modo que houve a notável desestruturação do material.

Comparativamente, o processo em $\boldsymbol{R} \boldsymbol{D}$ proveu materiais com valores de ${ }^{\circ} S R$ menores do que os obtidos nos mesmos tempos de refino em $\boldsymbol{M J}$ enquanto aplicando maiores espaçamentos entre os discos, e ${ }^{\circ} S R$ maiores para o refino realizado na aproximação máxima entre os discos. Os maiores valores de ${ }^{\circ} S R$ obtidos para o tratamento das polpas $\boldsymbol{H O}_{180}$ e $\boldsymbol{O}_{190}$ em $\boldsymbol{R} \boldsymbol{D}$ da foram, respectivamente, 87,5 e $86,0^{\circ} S R$ em 60 minutos de refino, valores $12,9 \%$ e $18,6 \%$ maiores que os obtidos para os mesmos materiais refinados em moinho Jokro $(\boldsymbol{M J})$ durante o mesmo intervalo de tempo.

Novamente, o refino em $\boldsymbol{R} \boldsymbol{D}$ realizado com maiores espaçamentos entre os discos promove um tratamento mais suave com a ocorrência predominante da fibrilação interna; com a redução da distância entre os elementos refinadores, há uma maior ocorrência da fibrilação externa pela aplicação de uma maior energia sobre as fibras, entretanto sem o seu expressivo corte. Apesar de ser esperado que o processamento em $\boldsymbol{R} \boldsymbol{D}$ favorecesse uma maior formação de elementos finos além do corte mais intenso das fibras em relação ao refino em $\boldsymbol{M J}$ por ser efetuado com menores consistências de massa, logo com predomínio do contato lâminasfibras, este é realizado a uma velocidade de rotação da parte móvel cerca de 10 vezes maior. Quanto maior a velocidade periférica do rotor, maior o comprimento das lâminas que se entrecruzam por unidade de tempo e menor a intensidade de refino aplicada sobre as fibras, promovendo um maior efeito de fibrilação interna e hidratação em detrimento da fibrilação externa e do corte das fibras. Ademais, o refinador de discos possui um conjunto rotor/estator com projeções no formato de lâminas de maior comprimento por área, isto é, um maior número de fibras é tratado simultaneamente, fator que também resulta em no predomínio da delaminação das paredes internas com uma menor frequência de cortes.

Diferentemente, seria esperado que o refino em $\boldsymbol{M J}$ favorecesse a fibrilação interna e desfavorecesse o corte e a formação de finos por ser realizado com um maior teor de sólidos, logo com maior contato fibra-fibra, e pela menor espessura das lâminas do moente, que gera uma maior quantidade de impactos por área de refino; entretanto, o impacto direto e contínuo do moente do moinho Jokro sobre as fibras do material contra a parede do refinador, o que 
seria equivalente ao menor espaçamento entre as partes constituintes do refinador, promove simultaneamente ambos os efeitos de fibrilação, além de uma maior frequência do corte das fibras em maiores tempos de refino.

A polpa organossolve $\boldsymbol{O}_{200}$, cujo teor de lignina é respectivamente $68,8 \%$ e $41,5 \%$ menor do que nas polpas $\boldsymbol{H O}_{180}$ e $\boldsymbol{O}_{190}$, apresentou valores de ${ }^{\circ} S R$ menores do que os obtidos para as duas outras polpas citadas quando refinada sob as mesmas condições em $\boldsymbol{M J}$ e em $\boldsymbol{R} \boldsymbol{D}$ (5,0 e $65,0^{\circ} S R$, respectivamente). Conforme mencionado anteriormente, quanto menor o teor de lignina no material menor a sua rigidez estrutural e maior a porosidade interfibrilar e interlamelar da parede celular; consequentemente, mais intensos são os efeitos de fibrilação externa, de formação de elementos finos e de corte provocados pelos processos de refino. Quando refinada em moinho Jokro, a polpa $\boldsymbol{O}_{200}$ foi rapidamente fibrilada e formou um material extremamente fino, cuja granulometria era menor que a abertura da peneira padronizada do equipamento de determinação de ${ }^{\circ} S R$. Por fim, o material $\boldsymbol{O}_{200}$ apresentou apenas um crescimento no valor de ${ }^{\circ} S R$ após o refino, porém menor do que as demais polpas também pela formação de um material com dimensões muito reduzidas.

Em suma, enquanto o refinador de discos promove o aumento expressivo no volume de poros internos da parede celular, com evidências de fibrilação da superfície externa das fibras com a aplicação de maiores energias de refino, o moinho laboratorial tipo Jokro culmina simultaneamente no aumento da estrutura capilar e da área superficial externa, tanto pela formação de elementos finos quanto pela redução das dimensões das fibras por corte.

A composição química da biomassa também afeta de modos distintos a facilidade de processamento pelos dois métodos de refino estudados. Materiais mais rígidos com maiores teores de hemiceluloses e lignina sofrem menores alterações estruturais quando refinados em moinho Jokro, uma vez que resistem à compressão e à delaminação provocadas pela atuação do moente. Diferentemente, os componentes não celulósicos facilitam o efeito de fibrilação promovido pelo processamento em refinador Bauer quando aplicado o menor espaçamento entre os discos, onde o aumento da temperatura do sistema promove o amolecimento da lignina.

Nos parâmetros definidos para a moagem criogênica $(\boldsymbol{M C})$ das amostras $\boldsymbol{F}, \boldsymbol{H}, \boldsymbol{H O}_{180}$ e $\boldsymbol{O}_{190}$, obtiveram-se materiais com valores de grau de refino Schöpper-Riegler baixos e muito próximos entre si $\left(14,0^{\circ} S R, 13,5^{\circ} S R, 17,5^{\circ} S R\right.$ e $17,5^{\circ} S R$, respectivamente). Conforme discutido anteriormente, os baixos valores de ${ }^{\circ} S R$ obtidos são devidos à granulometria dos 
materiais produzidos, menores que a abertura da peneira padronizada do equipamento de determinação de ${ }^{\circ} S R$, havendo a perda de material e provocando a diminuição na quantidade de amostra necessária para a análise.

Segundo as produções científicas recentes, sumarizadas no item 2.2.8, a desestruturação da parede celular provocada nas fibras pelo processo de refino confere a esta tecnologia o potencial de aplicação como método de pré-tratamento visando o aumento da acessibilidade às enzimas hidrolíticas e, consequentemente, da eficiência de produção de açúcares fermentescíveis.

O rompimento da organização estrutural da parede celular das fibras lignocelulósicas promovido pelo refino pode também ser monitorado em termos dos efeitos secundários. Estes compreendem análises das alterações nas propriedades físicas e morfológicas. Neste trabalho, as evidências de possíveis rupturas mecano-físicas das amostras foram acessadas a partir da determinação das áreas superficiais externa (dimensões das fibras) e interna (porosidade da parede celular), além das alterações na organização do empacotamento cristalino das fibrilas celulósicas. O diferentes métodos de análise empregados foram escolhidos com o intuito de investigar o impacto das configurações dos equipamentos mecânicos nas macro-, micro- e nano- estruturas da parede celular da biomassa; além disto, objetivou-se a comparação quantitativa do grau de abertura física alcançado pelas amostras, e a identificação das características críticas responsáveis pelas diferenças na digestibilidade enzimática dos materiais pré-tratados.

As discussões dos dados obtidos neste capítulo foram então organizadas em dois blocos que vêm a seguir:

- $\quad$ Estudo dos efeitos dos métodos físico-mecânicos nas propriedades estruturais da parede celular das amostras de bagaço, onde se interpretou como os efeitos primários do refino (fibrilação interna, fibrilação externa, formação de elementos finos e corte) evoluem de acordo com a severidade e o tipo tratamento empregado a partir das caracterizações dos efeitos secundários (características físicas e morfológicas);

- $\quad$ Estudo dos efeitos das propriedades estruturais na efetividade da sacarificação enzimática dos polissacarídeos da parede celular, onde se confrontaram os valores numéricos obtidos nas análises físicas e morfológicas com o rendimento de sacarificação dos materiais. 


\subsection{EFEITOS DOS TRATAMENTOS FÍSICO-MECÂNICOS NAS PROPRIEDADES ESTRUTURAIS DAS AMOSTRAS DE BAGAÇO DE CANA-DE-AÇÚCAR}

\subsubsection{Distribuição de tamanhos de partículas}

Em geral, todos os métodos de processamento físico-mecânicos modificam em alguma extensão a estrutura das fibras da biomassa lignocelulósica quanto às dimensões, isto é, à área superficial específica externa, sendo que o grau de modificação depende do modo de ação do equipamento e da severidade do tratamento. As dimensões das fibras são principalmente afetas pelos fenômenos de corte e de fibrilação externa com a consequente formação de elementos finos. O arranque parcial ou total das camadas mais externas das fibras provocado pelo refino produz poucos fragmentos de dimensões muito menores, e aumenta de modo sutil a área superficial específica externa das partículas. Já o corte promove uma redução mais expressiva no comprimento da fibra, logo afeta de modo mais representativo a área superficial externa, produzindo agregados de diversos tamanhos.

A fibrilação interna afeta a área superficial interna, mas praticamente não apresenta efeito nas dimensões das fibras, exceto pelo inchamento da parede celular e o consequente aumento da espessura, que ocorrem pela expansão da capilaridade e pela redução da coesão entre as lamelas. Segundo os princípios apresentados no item 2.2.7.1.2, a delaminação ainda provoca o aumento da flexibilidade, portanto da propensão à deformação pela quebra da rigidez estrutural; este fator pode afetar a leitura das dimensões reais de uma fibra por métodos de análise indiretos (como por difração a laser) pela maior probabilidade da análise de uma partícula no estado contorcido ou enrolado.

Nas Figuras 36 e 37 a seguir são apresentados os gráficos comparativos da distribuição do volume incremental de partículas analisadas (\%) em função do diâmetro da partícula - aproximada como uma esfera - obtidos pela técnica de difração a laser para as cinco amostras em estudo $\left(\boldsymbol{F}, \boldsymbol{H}, \boldsymbol{H O}_{180}, \boldsymbol{O}_{190}\right.$ e $\left.\boldsymbol{O}_{200}\right)$, tanto não refinadas quanto processadas em moinho Jokro $(\boldsymbol{M J})$, em refinador de discos Bauer $(\boldsymbol{R D})$ e em moinho criogênico $(\boldsymbol{M C})$. Já os valores fornecidos pela análise de diâmetro médio, diâmetro mais frequente (moda) e dispersão dos valores de diâmetro das partículas em torno da média calculada (desvio) encontram-se organizados nos gráficos dos Anexos A, B e C, e os valores calculados de área superficial externa das partículas na Figura 38. 
Figura 35. Curvas de distribuição do volume incremental de partículas analisadas (\%) em função do diâmetro da partícula $(\mu \mathrm{m})$ de acordo com o tempo de refino em moinho Jokro para as amostras (A) $\boldsymbol{F}$,

(B) $\boldsymbol{H},(\mathrm{C}) \boldsymbol{H O}_{180}$, e (D) $\boldsymbol{O}_{190}$.

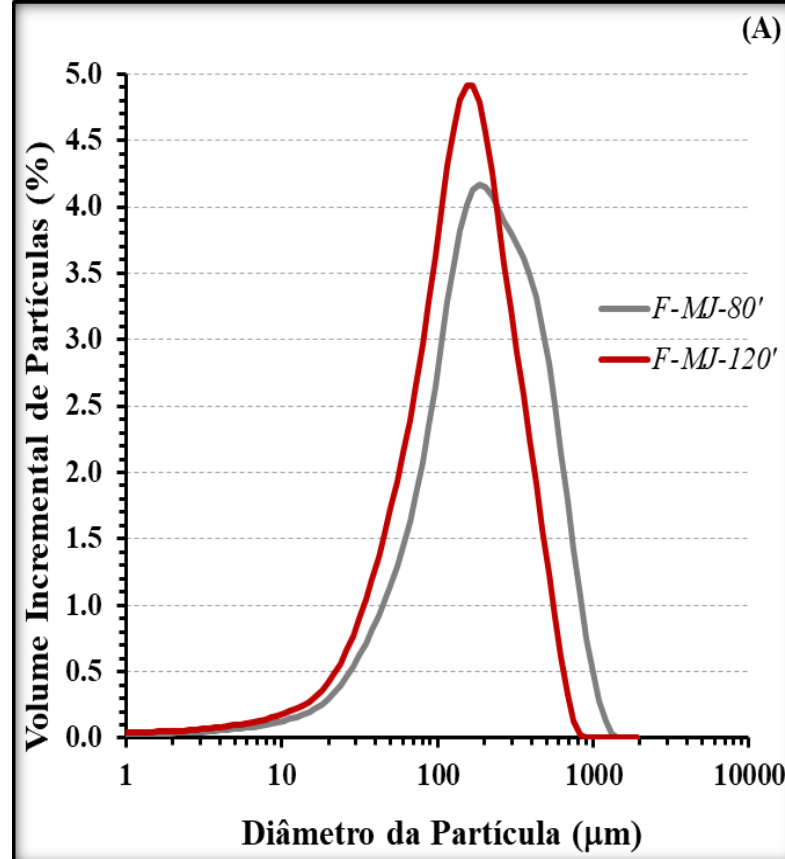

(B)
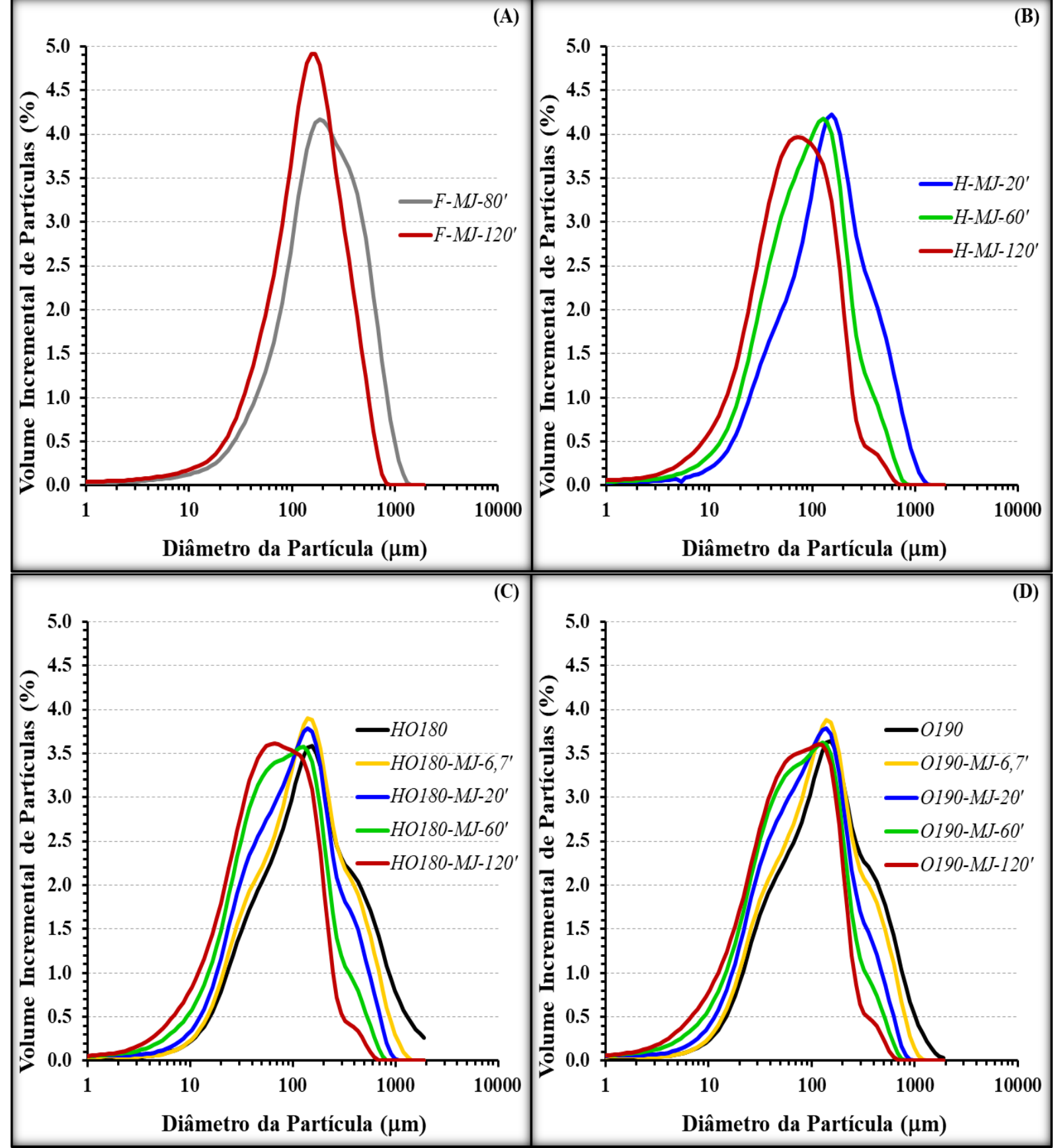
Figura 36. Curvas de distribuição do volume incremental de partículas analisadas (\%) em função do diâmetro da partícula $(\mu \mathrm{m})$ de acordo com o tempo de refino em refinador Bauer para as amostras (A) $\boldsymbol{H O}_{180}$ e (B) $\boldsymbol{O}_{190}$, (C) de acordo com o refino em moinho Jokro e em refinador Bauer para a amostra $\boldsymbol{O}_{200}$, e (D) de acordo com o moagem criogênica para as amostras $\boldsymbol{F}, \boldsymbol{H}, \boldsymbol{H} \boldsymbol{O}_{180}$ e $\boldsymbol{O}_{1900}$.

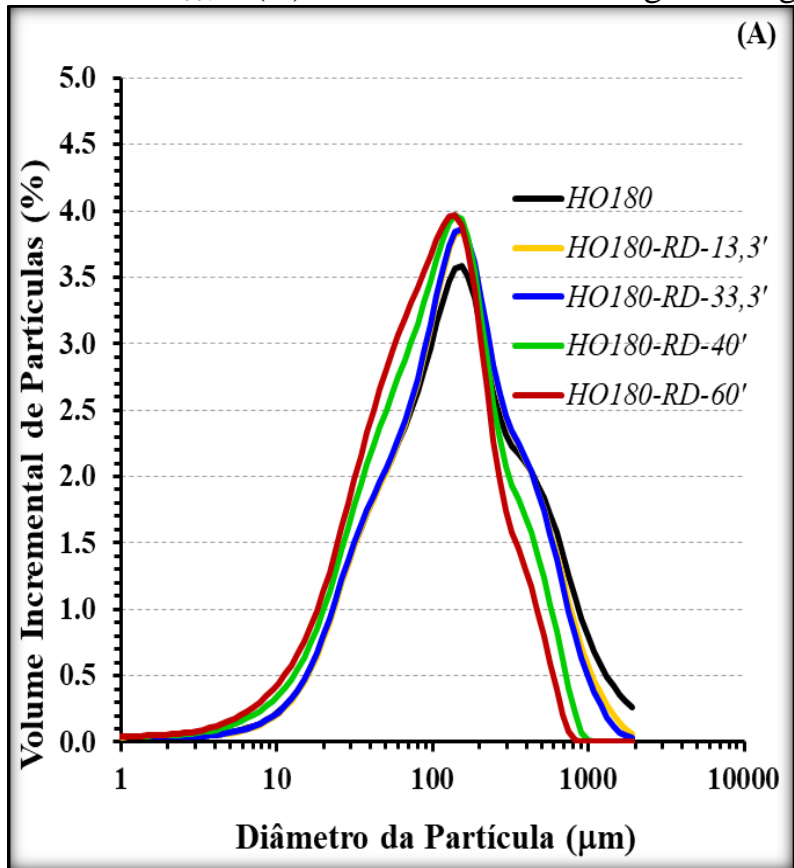

(A)
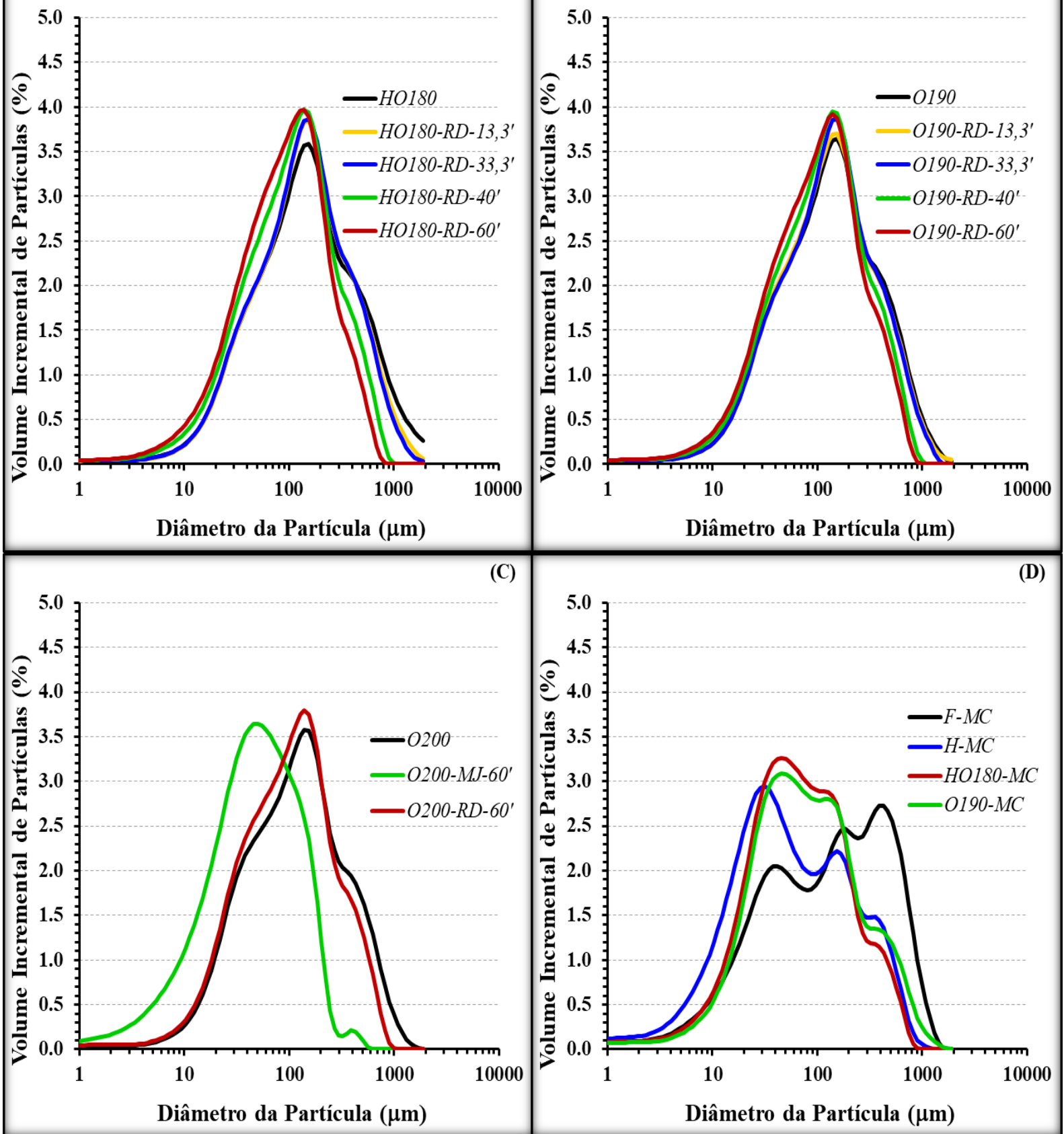

(D)

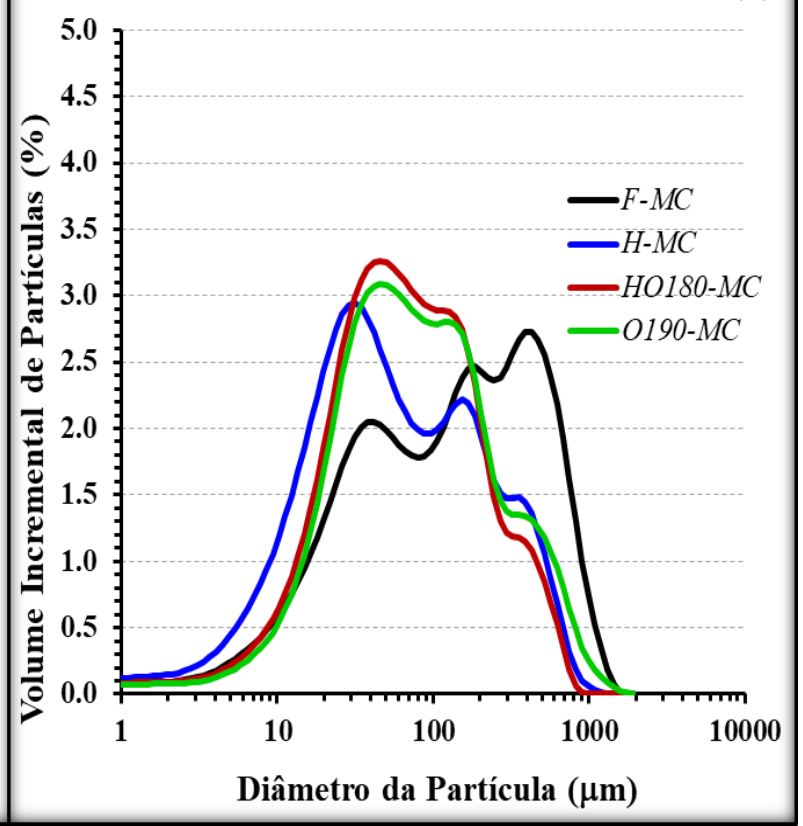


Figura 37. Variação da área superficial específica externa (ASE $-\mathrm{m}^{2} / \mathrm{g}$ ) com (A) o tempo de refino em moinho Jokro, (B) o tempo de refino em refinador

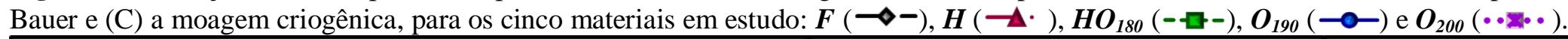

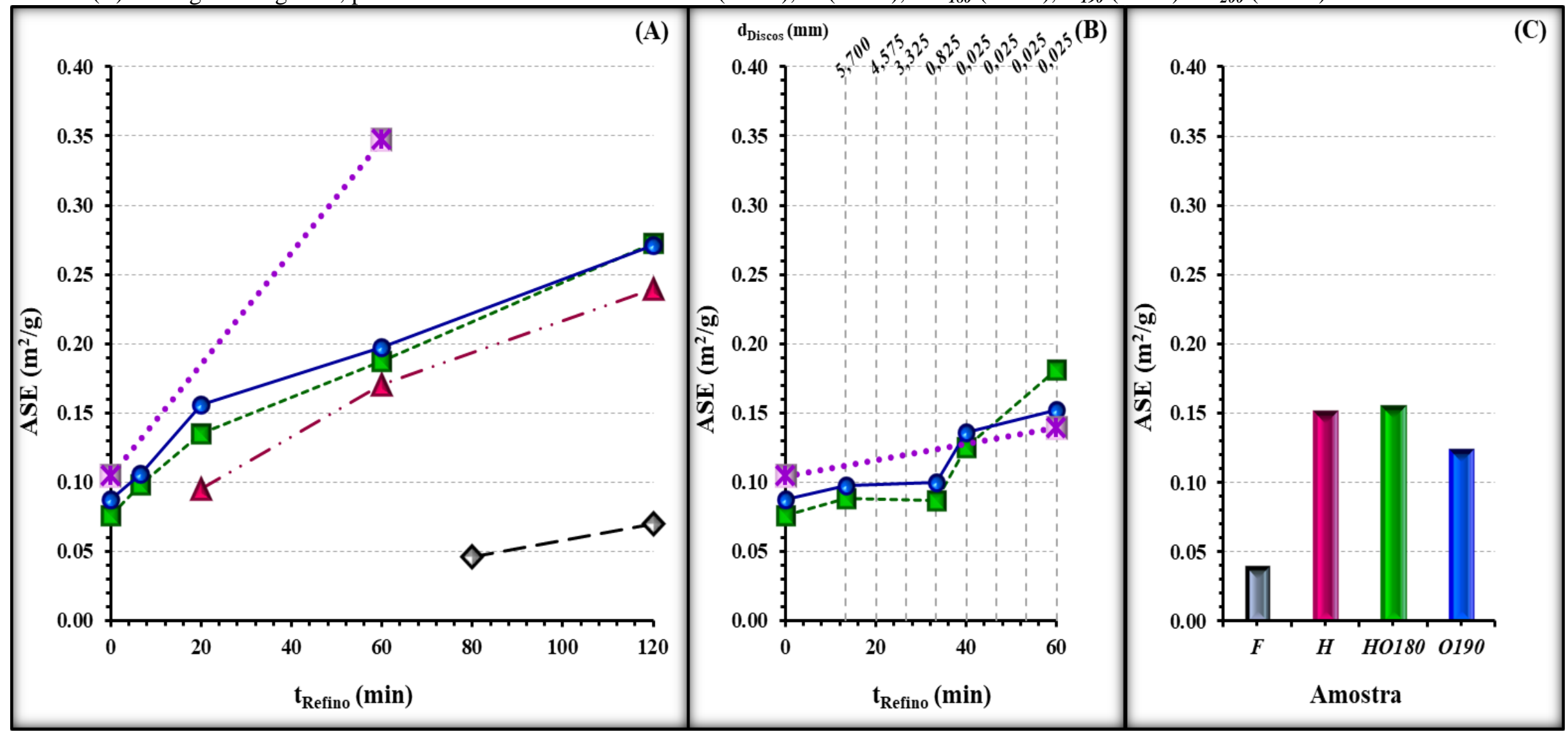

Legenda: $\mathrm{t}_{\text {Refino }}=$ tempo de refino; $\mathrm{d}_{\text {Discos }}=$ distância entre os discos; $\mathrm{ASE}$ = área superficial específica externa. 
Uma vez que o método de determinação da distribuição de tamanhos de partículas por espalhamento de luz somente permite a análise de amostras de dimensões inferiores a $2 \mathrm{~mm}$, amostras com comprimentos de fibras superiores (como as fibras de bagaço in natura $\boldsymbol{F}$ e prétratadas hidrotérmicamente $\boldsymbol{H}$ ) não puderam ser analisadas pelo método. Por este motivo, apresentam-se as curvas de distribuição de tamanhos de partículas para os materiais $\boldsymbol{F}$ e $\boldsymbol{H}$ refinados em $\boldsymbol{M J}$ apenas a partir de 12 mil revoluções (80 minutos) e de 3 mil revoluções (20 minutos), respectivamente.

De modo geral, os gráficos de distribuição do volume incremental de partículas em função do diâmetro obtidos para fibras lignocelulósicas apresentam uma curva que se estende entre tamanhos maiores e menores de partículas com um pico típico. O diâmetro médio representa a média ponderada dos diâmetros de todos os elementos da amostra analisados, ou seja, fornece uma visão geral do comportamento do sistema. Já o diâmetro moda representa o diâmetro mais frequente entre todas as partículas analisadas, ou seja, demonstra o comportamento do pico da curva de distribuição. O desvio da média ilustra o grau de homogeneidade (ou heterogeneidade) do sistema acessada pela superfície externa das partículas.

A partir das curvas de distribuição geradas para as amostras $\boldsymbol{F}, \boldsymbol{H}, \boldsymbol{H} \boldsymbol{O}_{180}$ e $\boldsymbol{O}_{190}$ tratadas em moinho Jokro (Figura 36), observou-se o deslocamento do pico de intensidade máxima (maior porcentagem em volume de amostra) para diâmetros de partículas menores com o aumento do tempo de refino, consequência da diminuição do tamanho das fibras pela ação conjunta dos fenômenos de fibrilação externa e de corte que ocorrem ao longo do processo. Enquanto as amostras não refinadas apresentam picos com maiores áreas de distribuição de tamanhos (mais largos), indicando a heterogeneidade de dimensões da amostra, o aumento da severidade (tempo) do refino promove o estreitamento e o aumento da intensidade do pico, que é deslocado para regiões menores tamanhos de partículas.

Conjuntamente, são observadas as reduções contínuas dos valores de diâmetro médio (Anexo A (A)) e diâmetro moda das partículas (Anexo B (A)), assim como o aumento da homogeneidade de tamanhos das partículas do sistema (menor valor de desvio do diâmetro médio - Anexo C (A)) com o aumento da intensidade do refino. Isto significa que as alterações provocadas na morfologia das fibras do material são mais representativas quanto maior é a intensidade do refino, que é função do número de impactos sofridos pela fibra. Um 
maior grau de refino, por sua vez, significa que os efeitos de fibrilação externa, de formação de finos e de corte ocorrem com maior frequência.

Tanto para as amostras iniciais quanto os materiais refinados no mesmo intervalo de tempo em $\boldsymbol{M J}$, observou-se que menores teores de componentes não celulósicos implicaram em menores valores de diâmetro médio e diâmetro moda, assim como de desvio do diâmetro médio, ou seja, acarretaram em partículas menores e mais homogêneas. Isto porque a abertura da superfície externa das partículas tanto pela fibrilação externa quanto pelo corte das fibras é facilitado pela redução da recalcitrância do material, ou seja, pela solubilização dos componentes não celulósicos e pelo aumento da estrutura capilar da parede celular (HIDENO et al., 2012; MIURA et al., 2012a; MIURA et al., 2012b; ZHU et al., 2010).

O comportamento do diâmetro médio das partículas de uma amostra, juntamente com as mudanças em sua densidade que decorrem do refino, reflete em variações na área superficial específica externa (ASE) calculada a partir do modelo de partículas esféricas proposto (item 4.5.1). Deste modo, observou-se que maiores tempos de refino em $\boldsymbol{M J}$ e menores teores de componentes não celulósicos implicam em uma maior área superficial externa das partículas da amostra (Figura 38 (A)). Entretanto, pôde-se observar que os valores calculados de ASE das partículas são muito pequenos e, conforme será discutido nos itens 5.3.2 e 5.3.3, são menores que os valores de ASE calculados pelo modelo de partículas cilíndricas proposto no item 4.5.2, e quase negligenciáveis com relação aos valores de área superficial interna calculada a partir da análise da estrutura de poros da parede celular.

As curvas presentes no gráfico da Figura 36 (A), obtidas para as fibras de bagaço in natura $(\boldsymbol{F})$ refinadas em $\boldsymbol{M J}$, apresentam um aumento na proporção de partículas com diâmetros em torno de $100 \mu \mathrm{m}$ e uma redução na proporção de partículas com diâmetros em torno de $1000 \mu \mathrm{m}$ com o aumento no tempo de refino, além do deslocamento do pico de intensidade máxima (diâmetro mais frequente entre as partículas da amostra) para valores de diâmetro menores. Neste caso, o estreitamento da curva pode indicar um desfibramento do material altamente agregado ao invés de um processo intenso de corte ou fibrilação externa. Para amostras com maiores teores de lignina, a energia aplicada pelo refino é utilizada para a individualização das células a partir das estruturas aglomeradas antes de ser utilizada para a abertura da estrutura da parede celular. Com o aumento no tempo de refino de 80 minutos para 120 minutos, observaram-se reduções em 32,2\% e 17,0\% no diâmetro médio e no diâmetro moda das partículas da amostra $\boldsymbol{F}$, que alcançaram valores de 175,0 e 161,4 $\mu \mathrm{m}$, 
respectivamente, assim como a redução em 36,8\% no desvio do diâmetro médio; ademais, observou-se o aumento da área superficial específica de 0,046 para $0,070 \mathrm{~m}^{2} / \mathrm{g}$.

Observações similares foram geradas para a análise das amostras de bagaço prétratado hidrotérmicamente $(\boldsymbol{H})$ refinadas em $\boldsymbol{M J}$ (Figura 36 (B)). O aumento no tempo de refino promoveu a redução na proporção de partículas com diâmetros em torno de $1000 \mu \mathrm{m}$ (diminuição do ombro visualizado à direita da curva), deslocou o pico de intensidade máxima para diâmetros menores, e aumentou a proporção de partículas com diâmetros menores que $100 \mu \mathrm{m}$ (aumento do ombro visualizado à esquerda curva). Após o refino da amostra $\boldsymbol{H}$ por 18 mil revoluções (120 minutos), observou-se o deslocamento mais intenso do pico de intensidade máxima para diâmetros de partícula menores que $100 \mu \mathrm{m}$. Com o aumento no tempo de refino de 20 minutos para 60 minutos, observaram-se reduções em 36,8\% e 17,0\% no diâmetro médio e no diâmetro moda, respectivamente, das partículas da amostra $\boldsymbol{H}$, assim como a redução em 71,2\% no desvio do diâmetro médio e o aumento da área superficial específica de 0,096 para $0,171 \mathrm{~m}^{2} / \mathrm{g}$. Após 120 minutos, a amostra alcançou valores de diâmetros médio e moda de 87,5 e $72,9 \mu \mathrm{m}$, respectivamente.

Já as curvas obtidas para os três materiais deslignificados $\left(\boldsymbol{H O}_{\mathbf{1 8 0}}, \boldsymbol{O}_{\mathbf{1 9 0}}\right.$ e $\left.\boldsymbol{O}_{\mathbf{2 0 0}}\right)$ não refinados apresentaram o mesmo perfil de distribuição, sendo praticamente sobrepostas (Figuras 36 (C), 36 (D) e 37 (C)). As menores dimensões iniciais das polpas em relação aos materiais $\boldsymbol{F}$ e $\boldsymbol{H}$ se devem ao fato da reação de deslignificação promover a separação das células individuais, sendo que quanto maior a severidade da reação, maior o teor de solubilização dos componentes não celulósicos, e maior a redução de suas dimensões iniciais. De modo similar, as polpas $\boldsymbol{H O}_{180}$ e $\boldsymbol{O}_{\mathbf{1 9 0}}$ refinadas nos mesmos tempos em moinho Jokro $(\boldsymbol{M J})$ apresentaram perfis de distribuição semelhantes, com deslocamentos mais expressivos da curva para diâmetros de partícula menores com o aumento do tempo de refino em relação às amostras $\boldsymbol{H}$ e $\boldsymbol{F}$ (Figura $36(\mathbf{C})$ e $36(\mathbf{D})$ ). Os materiais refinados em tempos maiores ou iguais a 60 minutos apresentaram deslocamentos mais intenso do pico de intensidade máxima para diâmetros de partícula menores que $100 \mu \mathrm{m}$, indicando um intenso fenômeno de corte das fibras além da produção em maior proporção de elementos finos. Estes materiais também apresentaram comportamentos similares de redução contínua do diâmetro médio das partículas e de aumento da homogeneidade de tamanhos com o aumento do tempo de refino. Após 60 minutos de refino, as amostras $\boldsymbol{H O}_{\mathbf{1 8 0}}$ e $\boldsymbol{O}_{\mathbf{1 9 0}}$ refinadas em $\boldsymbol{M J}$ alcançaram valores de 
diâmetro médio, de diâmetro moda e de área superficial específica externa de aproximadamente $106 \mu \mathrm{m}, 128 \mu \mathrm{m}$ e $0,217 \mathrm{~m}^{2} / \mathrm{g}$, respectivamente.

Para as amostras pré-tratadas $\boldsymbol{H}, \boldsymbol{H O}_{180}$ e $\boldsymbol{O}_{190}$, observou-se que os valores de diâmetro médio, de diâmetro moda e de desvio do diâmetro médio decresceram continuamente com o tempo, porém com uma taxa de decréscimo menor com o aumento da severidade do refino. Adicionalmente, a diferença tanto do diâmetro médio quanto do moda, assim como do "grau de homogeneidade", entre as amostras de diferentes composições diminuiu com o tempo de refino, ou seja, os materiais com maiores teores de componentes não celulósicos apresentaram maiores acréscimos em suas superfícies externas frente ao aumento da intensidade do refino, e após a extensão do refino para maiores tempos ( $\geq 60$ minutos) as amostras pré-tratadas $(\boldsymbol{H}$, $\boldsymbol{H O}_{180}$ e $\boldsymbol{O}_{190}$ ) atingiram diâmetros médios e homogeneidades similares. Possivelmente, isto ocorre devido à alta intensidade do refino, que após um determinado tempo alcança a desestruturação máxima das partículas, havendo a redução em grande proporção das dimensões das partículas pelo predomínio do fenômeno de corte das fibras além da maior formação de elementos finos.

Estes dados reforçam a interpretação de que há um limite na abertura da estrutura da parede celular que pode ser promovida pelo refino em moinho Jokro de acordo com as suas características iniciais. Ademais, as mudanças estruturais promovidas nas fibras pelo refino são mais significativas em amostras mais recalcitrantes, visto que as amostras com menores teores de lignina e hemiceluloses apresentam áreas superficiais iniciais consideravelmente altas. Diferentemente, para alcançar um determinado valor de diâmetro médio ou de diâmetro moda, as amostras com menores teores de lignina exigiram tempos menores de refino, isto porque suas características morfológicas iniciais eram mais reduzidas e suas menores recalcitrâncias diminuíram a resistência das fibras ao processamento mecânico, logo uma menor demanda energética foi necessária para a desestruturação da parede celular.

Os valores de diâmetro médio alcançados na maior intensidade de refino em $\boldsymbol{M J}$ (120 minutos) justificam a redução no valor de ${ }^{\circ} S R$ mensurado, uma vez que as partículas formadas apresentaram dimensões menores do que a abertura da peneira padronizada do equipamento de determinação de ${ }^{\circ} S R$ (cerca de $149 \mu \mathrm{m}$ ).

Novamente, as polpas $\boldsymbol{H O}_{180}$ e $\boldsymbol{O}_{\mathbf{1 9 0}}$ refinadas nos mesmos tempos em refinador Bauer $(\boldsymbol{R D})$ apresentaram perfis similares de distribuição volumétrica de tamanhos de partículas (Figuras 37 (A) e 37 (B)). Entretanto, diferentemente das polpas $\boldsymbol{H O}_{180}$ e $\boldsymbol{O}_{190}$ processadas 
em moinho Jokro, as curvas obtidas para os materiais refinados em todos os tempos e distâncias entre os discos estudadas não apresentaram modificações expressivas em relação aos perfis obtidos para os materiais não refinados, sugerindo que não ocorreram fenômenos intensos de corte e de rompimento de célula utilizando este equipamento. Observou-se que aumento no tempo de refino em $\boldsymbol{R} \boldsymbol{D}$ promoveu a redução de forma sutil da proporção de partículas com diâmetros em torno de $1000 \mu \mathrm{m}$ (diminuição do ombro visualizado à direita da curva), praticamente não deslocou o pico de intensidade máxima (diâmetro mais frequente), e aumentou também de forma tênue a proporção de partículas com diâmetros menores que 100 $\mu \mathrm{m}$ (aumento do ombro visualizado à esquerda curva) em relação à amostra não refinada. Enquanto constatam-se as reduções contínuas do diâmetro médio (Anexo A (B)) e do desvio do diâmetro (Anexo C (B)) com o aumento da severidade do refino (aumento do tempo e, principalmente, redução do espaçamento entre os discos), foram observadas reduções no diâmetro moda (Anexo B (B)) e aumentos na área superficial externa (Figura 38 (B)) apenas de modo sutil, com alterações visíveis apenas para o refino realizado no menor espaçamento entre os discos.

Para tratamento em RD realizado com maiores espaçamentos entre os discos, os materiais $\boldsymbol{H O}_{180}$ e $\boldsymbol{O}_{190}$ refinados por 33,3 minutos apresentaram valores de diâmetro médio $4,5 \%$ e 2,9\%, respectivamente, menores que os refinados por 13,3 minutos, porém sem alterações na ASE; já no menor espaçamento entre os discos e quando refinadas por 60 minutos, as polpas exibiram, respectivamente, valores de valores de diâmetro médio 37,8\% e 25,8\% menores e de ASE 109,7\% e 52,3\% maiores que as refinadas por 33,3 minutos.

Mais uma vez, a redução da distância entre os discos mostrou maior influência na alteração da morfologia das fibras do que a duração do refino por acarretar no fornecimento de altas energias específicas. Estes resultados sustentam a interpretação de que durante o refino em $\boldsymbol{R} \boldsymbol{D}$ realizado com maiores espaçamentos entre os discos há pouca ocorrência de formação de elementos finos ou ainda de corte, e que a redução na distância para o espaçamento mínimo entre os discos implica em um processo de fibrilação das paredes externa mais intenso e frequente pela maior interação entre as fibras diretamente com as lâminas dos discos, promovendo o aumento da área superficial externa das fibras.

Observou-se também que o material deslignificado diretamente na condição $2\left(\boldsymbol{O}_{190}\right)$ apresentou valores de diâmetro médio menores (entre 5,8 e 7,4\%) com uma maior homogeneidade de tamanhos de partículas $(\sim 8 \%)$ do que o material pré-tratado e 
deslignificado $\left(\boldsymbol{H O}_{\mathbf{1 8 0}}\right)$ quando refinados com maiores espaçamentos entre os discos (até 33,3 minutos), e valores de diâmetro médio maiores (entre 4,6 e 12,2\%) para o refino na aproximação máxima entre os discos $(0,025 \mathrm{~mm}$ a partir de 40 minutos $)$. Justifica-se este comportamento novamente pelo fato de que durante o refino realizado em maiores distâncias entre os discos a fibrilação é facilitada pelo maior teor de solubilização da lignina, resultando em maiores reduções das dimensões das fibras para a mesma intensidade ou o mesmo tempo de processamento empregado pela redução da resistência estrutural. Diferentemente, a presença da lignina tende a facilitar o processamento mecânico em refinador Bauer quando aplicadas maiores energias sobre as fibras, uma vez que o calor gerado pela maior frequência de fricção entre as lâminas dos discos e as fibras provoca o amolecimento da lignina, que passa a apresentar propriedade plastificante que auxilia a atuação do refinador.

Comparativamente, o processo em $\boldsymbol{R} \boldsymbol{D}$ promoveu uma menor alteração morfológica nas fibras do material em relação ao refino em $\mathbf{M J}$. Em todos os tempos de refino, as amostras refinadas em $\boldsymbol{M J}$ apresentam diâmetros médios menores e maiores ASE do que as amostras processadas em $\boldsymbol{R} \boldsymbol{D}$ nos mesmos tempos e em todos os espaçamentos entre os discos aplicados. Os menores valores de diâmetro médio e os maiores valores de ASE obtidos para o tratamento das polpas $\boldsymbol{H O}_{180}$ e $\boldsymbol{O}_{190}$ em $\boldsymbol{R D}$ da foram, respectivamente, 129,1 e 144,8 $\mu \mathrm{m}$ e 0,181 e $0,152 \mathrm{~m}^{2} / \mathrm{g}$ em 60 minutos de refino, valores respectivamente $19,4 \%$ e $37,0 \%$ maiores de diâmetro médio e 3,3\% e 22,7\% menores de ASE que os obtidos para os mesmos materiais refinados em $\boldsymbol{M J}$ durante o mesmo intervalo de tempo. O conjunto de resultados fornecidos pela análise de distribuição de tamanhos de partículas por difração a laser embasa a interpretação realizada no item 5.2 de que, enquanto o processo em refinador de discos Bauer promove alterações morfológicas sutis, o refino em moinho Jokro é mais destrutivo à integridade da biomassa.

O refino em $\boldsymbol{R} \boldsymbol{D}$ realizado com maiores espaçamentos entre os discos promove um tratamento mais suave onde praticamente não são observadas alterações nas dimensões das partículas; com a redução da distância entre os elementos refinadores, há uma maior ocorrência da fibrilação externa pela aplicação de uma maior energia sobre as fibras, entretanto sem o seu expressivo corte. Diferentemente, o refino em $\boldsymbol{M J}$ promove simultaneamente os efeitos de fibrilação externa e de corte das fibras, principalmente em maiores tempos de refino. 
Quando refinada durante o mesmo período de tempo de refino em $\boldsymbol{M J}$ e em $\boldsymbol{R} \boldsymbol{D}$ (Figura $37(\mathbf{C})$ ), a polpa $\boldsymbol{O}_{200}$ apresentou comportamentos muito distintos. O refino em $\boldsymbol{M J}$ promoveu um deslocamento intenso na curva de distribuição de tamanhos de partículas em relação ao material não refinado, com diminuição expressiva da proporção de partículas maiores (ombro à direita) e com o aumento da proporção de partículas menores (ombro à esquerda), além da diminuição expressiva do diâmetro mais frequente; diferentemente o refino em $\boldsymbol{R} \boldsymbol{D}$ promoveu alterações discretas nas proporções de partículas locais. Após o refino em $\boldsymbol{M J}$ por 60 minutos, a polpa $\boldsymbol{O}_{200}$ apresentou um decréscimo intenso do diâmetro médio e do diâmetro moda ( 64\%), formando um material extremamente fino com o menor diâmetro médio $(65,6 \mu \mathrm{m})$, a maior $\operatorname{ASE}\left(0,347 \mathrm{~m}^{2 /} \mathrm{g}\right)$ e a maior homogeneidade volumétrica entre todos os materiais estudados. Entretanto, quando refinada pelo mesmo tempo em $\boldsymbol{R} \boldsymbol{D}$, apresentou um decréscimo menos intenso do diâmetro médio (19,8\%) e um acréscimo menor na $\operatorname{ASE}(33,5 \%)$ e em relação à polpa inicial, alcançando um diâmetro médio similar à polpa $\boldsymbol{O}_{190}$ e uma ASE menor que as polpas $\boldsymbol{H O}_{180}$ e $\boldsymbol{O}_{190}$ refinadas no mesmo intervalor de tempo (60 minutos); além disto, não apresentou qualquer decréscimo do diâmetro moda após o refino em relação à polpa inicial.

Já a moagem criogênica resultou em amostras extremamente heterogêneas, com curvas de distribuição tipicamente com três picos máximos (Figura 37 (D)). A amostra $\boldsymbol{H}$ apresentou o maior deslocamento da curva, com o aumento da intensidade do pico presente em regiões de diâmetros de partículas menores e a diminuição expressiva do pico presente em regiões de diâmetros de partículas maiores em relação ao material $\boldsymbol{F}$. As duas amostras deslignificadas $\left(\boldsymbol{H O}_{\mathbf{1 8 0}}\right.$ e $\left.\boldsymbol{O}_{\mathbf{1 9 0}}\right)$ apresentaram perfis similares, com o material $\boldsymbol{H O}_{\mathbf{1 8 0}}$ apresentando uma diminuição pouco maior do pico em diâmetros maiores e um aumento pouco maior do pico em diâmetros menores. Em relação aos materiais iniciais não refinados de mesma composição química, a amostra $\boldsymbol{H}$ apresentou a maior redução do diâmetro médio e o maior aumento da ASE, seguida das amostras $\boldsymbol{H O}_{180}$ e $\boldsymbol{O}_{190}($ Anexo A (C) e Figura 38 (C)). A explicação para este comportamento decorre do fato de que a presença de maiores teores de lignina na estrutura das fibras confere maior rigidez ao material, tornando-o quebradiço; deste modo, quando congelados, os materiais recalcitrantes pulverizam mais facilmente.

Os resultados obtidos na análise de distribuição de tamanhos de partículas permite assim inferir que os métodos de refino produzem partículas mais homogêneas do que a moagem convencional, que produz agregados de diferentes dimensões. 
Por fim, avaliaram-se os incrementos promovidos nos volumes cumulativos de partículas (em porcentagem) com diâmetros menores que $100 \mu \mathrm{m}$ e $30 \mu \mathrm{m}$ em função do tempo de refino em $\boldsymbol{M J}$, em função do tempo de refino e da distância entre os discos em $\boldsymbol{R} \boldsymbol{D}$ e em função da moagem criogênica (figuras presentes nos Anexos D e E). Segundo JIANG et al. (2016), LEU e ZHU (2013) e HOEGER et al. (2013), a redução no tamanho médio das partículas para tamanhos menores que $100 \mu \mathrm{m}$ indica que as fibras do material foram separadas, cortadas, fragmentadas, e fibriladas externamente de forma moderada pelas forças de cisalhamento, porém sem comprometimento significantemente da integridade física da estrutura da parede celular; já a redução no tamanho médio das partículas para tamanhos menores que $30 \mu \mathrm{m}$ indica que ocorreu uma maior desconstrução física da parede celular.

As curvas de volume cumulativo de partículas, tanto com diâmetros menores que 100 $\mu \mathrm{m}$ quanto menores $30 \mu \mathrm{m}$ apresentaram comportamentos similares frente ao tipo de à severidade do refino, assim como à composição química das biomassas em estudo, sendo um reflexo do comportamento da distribuição de tamanhos. Sumariamente, o refino em $\boldsymbol{M J}$ foi mais destrutivo tanto com relação à morfologia quanto à integridade da parede celular, sendo esta transformação mais intensa com o aumento da severidade do refino e com a redução no teor de componentes não celulósicos das fibras de bagaço. De modo distinto, o refino em $\boldsymbol{R} \boldsymbol{D}$ promoveu um efeito mais brando de fibrilação externa e fragmentação das fibras, sem afetar de modo significativo a estrutura da parede celular, com mudanças sutis apenas observadas quando do emprego do menor espaçamento entre os discos.

Após 60 minutos de refino em $\boldsymbol{M J}$, os materiais $\boldsymbol{H}, \boldsymbol{H O}_{\mathbf{1 8 0}}, \boldsymbol{O}_{\mathbf{1 9 0}}$ e $\boldsymbol{O}_{\mathbf{2 0 0}}$ apresentaram $54,9 \%, 61,7 \%, 61,8 \%$ e 78,9\% das partículas com diâmetros menores que $100 \mu \mathrm{m}$, e 14,2\%, 20,3\%, 21,0\% e 34,1\% das partículas com diâmetros menores que $30 \mu \mathrm{m}$. Após o mesmo intervalo de tempo de refino em $\boldsymbol{R D}$ (menor espaçamento entre os discos), os materiais $\boldsymbol{H} \boldsymbol{O}_{\mathbf{1 8 0}}$, $\boldsymbol{O}_{190}$ e $\boldsymbol{O}_{200}$ apresentaram 53,1\%, 49,7\% e 50,0\% das partículas com diâmetros menores que $100 \mu \mathrm{m}$, e 15,5\%,14,2\% e 14,4\% das partículas com diâmetros menores que $30 \mu \mathrm{m}$.

Com relação aos materiais moídos criogenicamente, o aumento da desconstrução da parede celular foi maior quanto maior o teor de componentes não celulósicos, com exceção das fibras de bagaço in natura. Os materiais $\boldsymbol{F}, \boldsymbol{H}, \boldsymbol{H O}_{\mathbf{1 8 0}}$ e $\boldsymbol{O}_{\mathbf{1 9 0}}$ apresentaram 44,2\%, 66,0\%, $64,8 \%$ e 59,9\% das partículas com diâmetros menores que $100 \mu \mathrm{m}$, e 19,2\%, 34,9\%, 24,4\% e 21,5\% das partículas com diâmetros menores que $30 \mu \mathrm{m}$. 


\subsubsection{Análise morfológica das fibras}

A caracterização morfológica das fibras da biomassa envolve a determinação de sua forma, comprimento e largura, propriedades estas que variam de acordo com o tipo e a severidade do tratamento ao que o material foi submetido. Estas características, por sua vez, se relacionam diretamente com a área superficial específica das fibras. Os resultados obtidos na análise morfológicas das fibras - comprimento médio das fibras, teor de elementos finos, largura média e massa linear - das cinco amostras em estudo $\left(\boldsymbol{F}, \boldsymbol{H}, \boldsymbol{H} \boldsymbol{O}_{180}, \boldsymbol{O}_{190}\right.$ e $\left.\boldsymbol{O}_{200}\right)$, tanto não refinadas quanto processadas em moinho Jokro $(\boldsymbol{M J})$, em refinador de discos Bauer $(\boldsymbol{R D})$ e em moinho criogênico ( $\boldsymbol{M C}$ ), encontram-se organizados nos gráficos das Figuras 39, 40, 41 e 44. Já os valores calculados de razão de aspecto e de área superficial externa das partículas encontram-se organizados nas Figuras 42 e 43.

Uma vez que o método de análise das características morfológicas somente permite a análise de fibras de dimensões inferiores a $10 \mathrm{~mm}$, novamente as amostras de fibras de bagaço in natura $\boldsymbol{F}$ e pré-tratadas hidrotérmicamente $\boldsymbol{H}$ não puderam ser analisadas. Por este motivo, apresentam-se os dados morfológicos para os materiais $\boldsymbol{F}$ e $\boldsymbol{H}$ refinados em $\boldsymbol{M J}$ apenas a partir de 12 mil revoluções (80 minutos) e de 3 mil revoluções (20 minutos), respectivamente.

A partir dos resultados obtidos para o refino das cinco amostras em estudo em moinho Jokro $(\boldsymbol{M J})$ pôde-se observar que quanto maior a intensidade do refino (tempo) maior a desestruturação das fibras, evidenciada tanto pela redução do comprimento médio ponderado das fibras quanto pelo aumento expressivo do teor de partículas consideradas como elementos finos (Figuras 39 (A) e 40 (A)). Este comportamento está de acordo com os resultados observados para a distribuição de tamanhos de partículas e para o grau de drenabilidade Schöpper-Riegler, sendo justificado pelos mesmos princípios de alteração das propriedades morfológicas com relação à frequência de impactos sofridos pelas fibras.

Observou-se também que, para um mesmo tempo de refino, os materiais deslignificados $\left(\boldsymbol{H O}_{\mathbf{1 8 0}}, \boldsymbol{O}_{\mathbf{1 9 0}}\right.$ e $\left.\boldsymbol{O}_{\mathbf{2 0 0}}\right)$ alcançaram valores de comprimentos médios menores e teores de finos maiores que os obtidos para a amostra apenas pré-tratada hidrotérmicamente $(\boldsymbol{H})$, que por sua vez atingiu valores de comprimentos médios menores e teores de finos maiores que as fibras de bagaço in natura $(\boldsymbol{F})$. 
Figura 38. Variação do comprimento médio ponderado (mm) das fibras com (A) o tempo de refino em moinho Jokro, (B) o tempo de refino em refinador

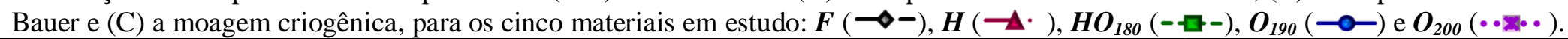
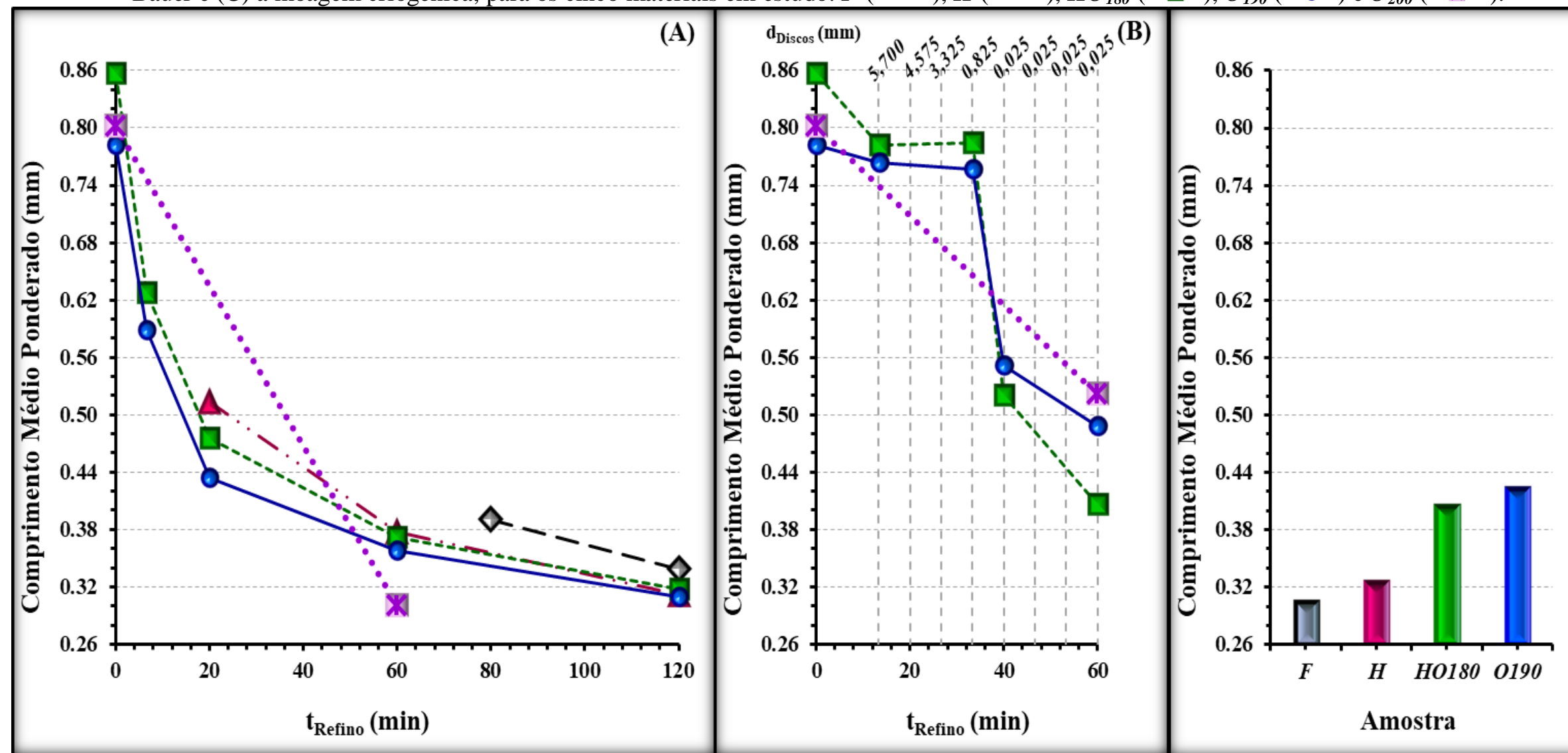

Legenda: $\mathrm{t}_{\text {Refino }}=$ tempo de refino; $\mathrm{d}_{\text {Discos }}=$ distância entre os discos. 
Figura 39. Variação do teor de finos (\%) com (A) o tempo de refino em moinho Jokro, (B) o tempo de refino em refinador Bauer e (C) a moagem criogênica,

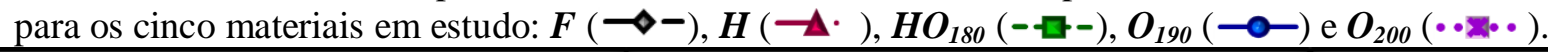

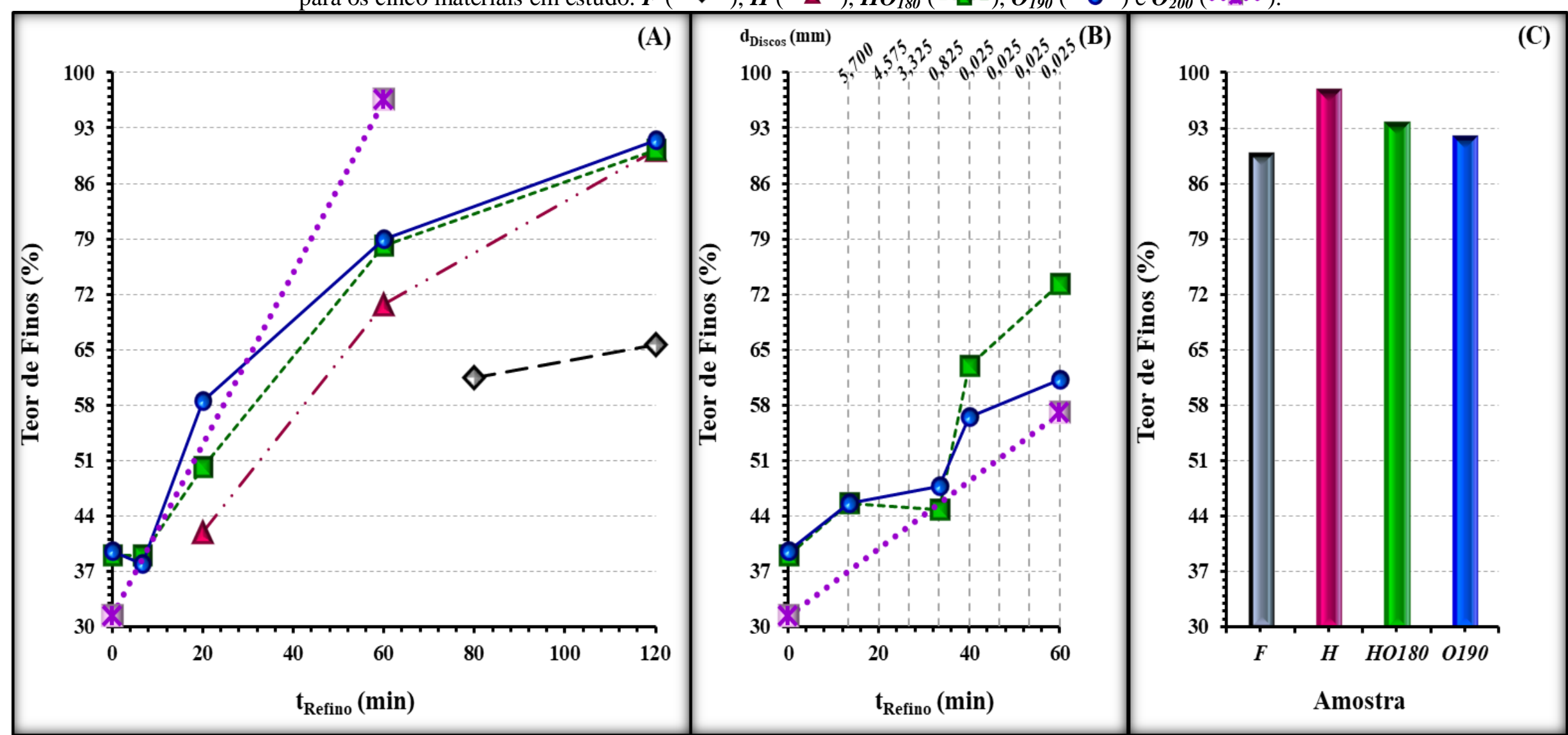

Legenda: $\mathrm{t}_{\text {Refino }}=$ tempo de refino; $\mathrm{d}_{\text {Discos }}=$ distância entre os discos. 
O menor valor de comprimento médio obtido para o refino em $\boldsymbol{M J}$ das fibras de bagaço in natura foi de $0,338 \mathrm{~mm}$, associado a um teor de $65,6 \%$ de elementos finos, em 18000 revoluções (120 minutos), enquanto os materiais pré-tratados quimicamente alcançaram teores de elementos finos maiores que 70\% com apenas 6000 revoluções (40 minutos). Novamente, as modificações promovidas na superfície externa das fibras pelos efeitos do refino são facilitadas pela remoção das hemiceluloses e da lignina, ou seja, a prévia desestruturação da parede celular minimiza a resistência a das fibras em sofrerem influências das forças de impacto e cisalhamento.

Os materiais pré-tratados $\boldsymbol{H}, \boldsymbol{H O}_{180}$ e $\boldsymbol{O}_{190}$ exibiram comportamentos semelhantes de reduções contínuas dos comprimentos médios das fibras com o aumento do tempo de refino em $\boldsymbol{M J}$, seguidas de aumentos em grande proporção do teor de elementos finos. Adicionalmente, a diferença tanto do comprimento médio das fibras quanto do teor de elementos finos entre as amostras de diferentes composições diminui com o tempo de refino, comportamento que permite novamente inferir que os materiais com maiores teores de componentes não celulósicos apresentam maiores acréscimos em suas superfícies externas frente ao aumento da intensidade do refino. Após a extensão do refino em $\boldsymbol{M J}$ por 120 minutos, as amostras $\boldsymbol{H}, \boldsymbol{H O}_{180}$ e $\boldsymbol{O}_{190}$ atingiram valores próximos de comprimentos médios ponderados e teores de finos similares, de aproximadamente 0,31 $\mathrm{mm}$ e $90 \%$, respectivamente. Neste ponto, o predomínio do corte das fibras e a maior formação de elementos finos culminaram na máxima desestruturação morfológica possível de se alcançar com o refino, isto é, as fibras dos materiais atingiram as menores dimensões que poderiam ser alcançadas com este tipo de processamento de acordo com suas propriedades iniciais. Já o material in natura $\boldsymbol{F}$, apesar de apresentar um comprimento médio similar aos demais materiais na maior intensidade de refino, apresentou um menor teor de finos, indicando que a energia aplicada foi primeiramente absorvida para os processos de desfibramento e redução do comprimento antes de formar partículas extremamente finas e promover a fibrilação externa com o arranque de material das paredes mais externas.

Por fim, a polpa $\boldsymbol{O}_{200}$, material de menor teor de lignina entre os estudados, quando refinado por 60 minutos em $\boldsymbol{M J}$ apresentou um decréscimo de 62,6\% no comprimento médio e o notório aumento no teor de finos de $31,3 \%$ para $96,5 \%$, formando um material de granulometria extremamente fina com as menores dimensões entre todos os estudados. 
Associado à redução do comprimento médio $\boldsymbol{M J}$, observou-se o alargamento das fibras dos materiais com o aumento do tempo de refino (Figura 41 (A)). Entretanto, as relações da largura média das fibras com a severidade do refino mudam de acordo com a composição química do material. O fenômeno de fibrilação externa promove a delaminação das paredes externas da fibra, resultando em reduções sutis nas larguras médias das fibras. Já a fibrilação interna expande a estrutura capilar, diminui a coesão entre as lamelas e implica diretamente em um maior volume de água na estrutura, acarretando em uma maior espessura da parede celular das fibras. Por conseguinte, o achatamento das fibras promovido pela frequência de impactos indica que a energia absorvida pela parede da fibra pode ser utilizada para alteração de seu formato de tubular para achatado além da redução de suas dimensões.

As polpas organossolve $\boldsymbol{H O}_{180}$ e $\boldsymbol{O}_{190}$ apresentaram comportamentos similares de modificação da largura média das fibras com relação ao grau de refino em $\boldsymbol{M J}$, atingindo valores também similares que variaram entre $\sim 28 \mu \mathrm{m}$ (6,7 minutos) e $33 \mu \mathrm{m}$ (120 minutos). Para estas amostras, o refino no tempo mais curto promoveu um pequeno decréscimo da largura pelo provável efeito de delaminação das camadas mais externas da parede celular; com o aumento do tempo de refino, as dimensões da largura média somaram os efeitos de intumescimento e compressão do lúmen, que se sobrepuseram ao efeito de redução por delaminação, logo culminaram no achatamento e no consequente aumento da largura mensurada. Após refinadas em $\boldsymbol{M J}$ por $120 \mathrm{~min}$, as polpas $\boldsymbol{H O}_{\mathbf{1 8 0} \boldsymbol{0}}, \boldsymbol{O}_{\mathbf{1 9 0}}$ e $\boldsymbol{O}_{\mathbf{2 0 0}}$ apresentaram incrementos de $11,1 \%, 17,5 \%$ e 11,3\%, respectivamente, na largura média das fibras em relação às suas larguras iniciais. Em contrapartida, estas amostras apresentam menores valores de largura média inicial das fibras em relação aos materiais $\boldsymbol{F}$ e $\boldsymbol{H}$ pela ampla solubilização da lignina presente na lamela média, que proporcionou a separação das células individuais.

Já para o material $\boldsymbol{H}$, de aspecto inicial altamente agregado, a variação da largura das fibras com o tempo de refino foi um reflexo da competição entre quatro fenômenos: o desfibramento (individualização das células a partir das estruturas aglomeradas) e a delaminação, que diminuem a largura; e o intumescimento e achatamento da fibra (compressão do lúmen), que aumentam a largura mensurada. Portanto, o incremento de 12,1\% observado na largura média das fibras com a extensão do tempo de refino de 20 para 120 min indica que o intumescimento e o achatamento afetaram de forma mais expressiva as fibras do que o processo de delaminação das paredes externas. Pode-se afirmar comportamento similar para a largura média do material $\boldsymbol{F}$ quando este é refinado em $\boldsymbol{M J}$ por tempos maiores. 
Figura 40. Variação da largura média $(\mu \mathrm{m})$ das fibras com $(\mathrm{A})$ o tempo de refino em moinho Jokro, $(\mathrm{B})$ o tempo de refino em refinador Bauer e $(\mathrm{C})$ a moagem

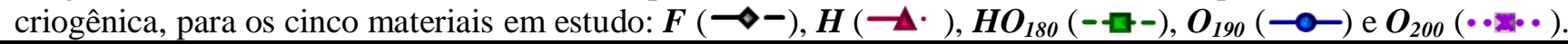

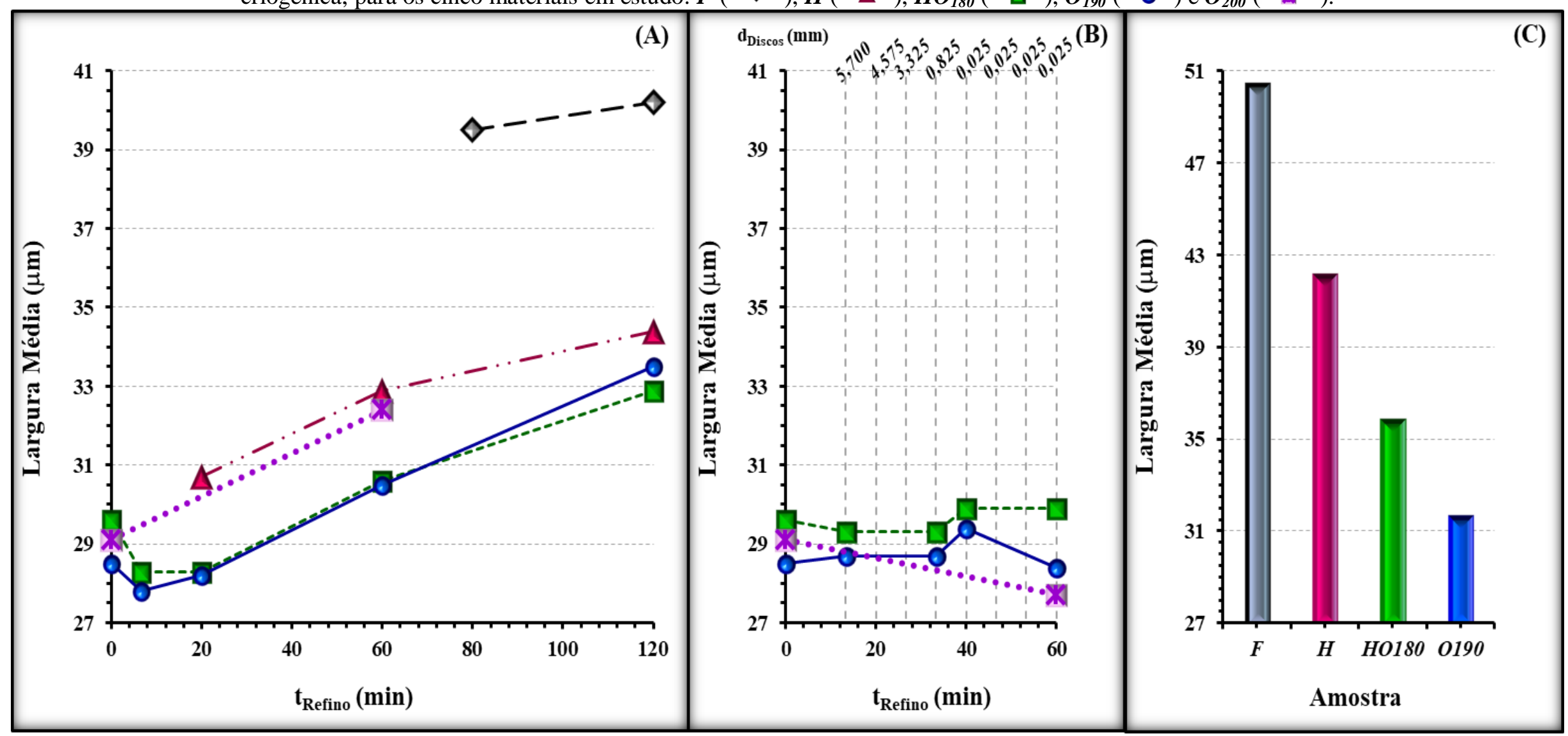

Legenda: $\mathrm{t}_{\text {Refino }}=$ tempo de refino; $\mathrm{d}_{\text {Discos }}=$ distância entre os discos. 
De forma distinta às polpas refinadas em $\boldsymbol{M J}$, as polpas $\boldsymbol{H O}_{180}$ e $\boldsymbol{O}_{190}$ processadas em refinador Bauer $(\boldsymbol{R} \boldsymbol{D})$ não apresentaram alterações significativas nas características morfológicas das fibras quando aplicados maiores espaçamentos entre os discos, verificandose reduções expressivas no comprimento médio ponderado e aumentos consideráveis no teor de elementos finos somente quando os discos do refinador foram ajustados para a aproximação máxima entre eles (Figuras 39 (B) e 40 (B)). Com maiores espaçamentos entre os discos, os materiais $\boldsymbol{H O}_{\mathbf{1 8 0}}$ e $\boldsymbol{O}_{\mathbf{1 9 0}}$ refinados por 33,3 minutos apresentaram reduções de $8,5 \%$ e $3,2 \%$, respectivamente, no comprimento médio das fibras e incrementos de $14,9 \%$ e $21,0 \%$, respectivamente, no teor de elementos finos em relação às respectivas polpas não refinadas. Já no menor espaçamento e quando refinadas por 60 minutos, as polpas exibiram reduções de 48,2\% e 35,5\%, respectivamente, no comprimento médio das fibras e incrementos de $63,6 \%$ e $28,0 \%$, respectivamente, no teor de elementos finos em relação às polpas refinadas por 33,3 minutos. Este comportamento dos dados também acorda com os resultados das análises de distribuição de tamanhos de partículas e de drenabilidade SchöpperRiegler, onde a aproximação entre os discos constituintes do refinador determinou de modo mais importante as alterações provocadas nas fibras dos materiais em detrimento da prolongação do tratamento. Deste modo, apenas com a aplicação de maiores energias específicas houve a intensificação do processo de arranque das camadas externas da parede celular das fibras, reduzindo assim suas dimensões e aumentando a taxa de formação de finos.

Ainda para o refino em $\boldsymbol{R} \boldsymbol{D}$, observou-se que o material deslignificado diretamente na condição $2\left(\boldsymbol{O}_{190}\right)$ apresentou valores de comprimento médio ligeiramente menores (entre $2,3 \%$ e $3,4 \%$ ) e teores de elementos finos similares que o material pré-tratado e deslignificado ( $\boldsymbol{H O}_{180}$ ) quando refinados com maiores espaçamentos entre os discos (até 33,3 minutos) devido à sua menor recalcitrância (menor teor de lignina) e maior propensão à fibrilação. Já na aproximação máxima entre os discos $(0,025 \mathrm{~mm}$ a partir de 40 minutos $)$, o material $\boldsymbol{H O}_{180}$ exibiu valores de comprimento médio menores (entre 5,6\% e 16,8\%) e teores de elementos finos maiores que a polpa $\boldsymbol{O}_{190}$ devido ao amolecimento da lignina com o aumento da temperatura do sistema pelo intenso atrito lâminas-fibras a uma alta velocidade. A polpa $\boldsymbol{O}_{\mathbf{2 0 0}}$, por sua vez, sofreu um decréscimo de seu comprimento médio e um acréscimo do teor de finos menos intensos após o refino em $\boldsymbol{R} \boldsymbol{D}$ por 60 minutos, resultando em um material com comprimento médio $28,3 \%$ e $6,8 \%$ maior e teor de elementos finos $22,2 \%$ e $6,9 \%$ menor que as que as demais polpas refinadas no mesmo tempo. 
Com relação à largura média das fibras, comportamentos divergentes foram observados para as polpas organossolve de diferentes composições químicas quando refinadas em $\boldsymbol{R D}$ (Figura 41 (B)). A polpa organossolve $\boldsymbol{H O}_{180}$ não apresentou qualquer alteração da largura média das fibras quando refinada com maiores espaçamentos entre os discos, porém sofreu um pequeno acréscimo da largura quando refinada no espaçamento mínimo entre os discos devido ao intumescimento ou um suave achatamento da fibra pela compressão do lúmen. De modo similar, a polpa organossolve $\boldsymbol{O}_{190}$ não apresentou qualquer alteração da largura das fibras quando refinada com maiores espaçamentos entre os discos, sofreu um pequeno acréscimo da largura quando os discos foram ajustados para o menor espaçamento entre os discos, e novamente apresentou um pequeno decréscimo pequeno para a maior intensidade devido à provável delaminação das paredes externas. Já a polpa $\boldsymbol{O}_{200}$ exibiu uma redução da largura das fibras devido à um provável fenômeno de delaminação das paredes externas mais intenso e frequente do que o intumescimento. Aparentemente, o refino em $\boldsymbol{R} \boldsymbol{D}$ não promove o achatamento considerável das fibras por não provocar impactos diretos das lâminas contra a fibra, como ocorre pela ação do moente durante o refino em $\boldsymbol{M J}$.

No que concerne à moagem criogênica, esta produziu materiais com comprimentos médios pequenos, porém maiores que os comprimentos médios observados para os materiais refinados nas maiores intensidades de cada método $(\boldsymbol{M J}$ ou $\boldsymbol{R D})$ (Figura $39(\mathbf{C})$ ). Entretanto, os teores de elementos finos formados pela $\boldsymbol{M C}$ foram extremamente altos e maiores que os observados para os materiais refinados nas maiores intensidades (Figura 40 (C)); isto significa que a moagem criogênica promoveu a cominuição das fibras em tal intensidade que a maior porcentagem dos elementos foi reduzida a dimensões de finos, restando poucas fibras de maiores dimensões. Para este método físico-mecânico, pôde-se constatar que quanto maior o teor de lignina no material, menor o comprimento médio das fibras e maior o teor de finos do material formado, com exceção do material in natura que apresentou a menor porcentagem de elementos finos após a moagem pelo alto grau de agregação do material inicial; isto porque maiores teores de lignina conferem maior rigidez aos materiais, que pulverizam em maior extensão quando congelados e submetidos ao impacto mecânico.

Já a largura média das fibras moídas criogenicamente apresentou comportamento contrário (Figura 41 (C)). O material $\boldsymbol{F}$ apresentou maiores larguras pelo maior grau de agregação fibrilar. $\mathrm{O}$ material $\boldsymbol{H}$ também apresentou grandes larguras médias, porém menores que $\boldsymbol{F}$ pela remoção parcial dos componentes não celulósicos. Já os materiais deslignificados 
$\boldsymbol{H O}_{180}$ e $\boldsymbol{O}_{190}$ apresentaram maiores larguras que os materiais iniciais após a moagem pela provável compressão do lúmen e achatamento das fibras, causados pelo alto impacto promovido pelo impelidor movimentado a alta velocidade; entretanto, estas polpas exibiram menores larguras que os materiais não deslignificados pela individualização das células promovida pela reação de polpação.

A razão de aspecto é um reflexo das variações no comprimento médio e na largura das fibras. Entretanto, por ser uma razão direta entre as duas medidas e pela dimensão da largura ser três ordens de magnitude menor que o comprimento, esta medida acaba apresentando um comportamento em relação ao tempo de refino mais semelhante à variação do comprimento médio. Isto significa que quanto maior a severidade do refino em $\boldsymbol{M J}$, menor a razão de aspecto encontrada. Para um mesmo tempo de refino, todos os materiais em estudo, com exceção da polpa $\boldsymbol{O}_{200}$, apresentaram razões de aspecto similares, que variaram entre aproximadamente 22 (6,7 $\mathrm{min})$ e 9 (120 $\mathrm{min})$ (Figura 42 (A)). O material in natura, apesar de possuir comprimentos médios maiores que as demais amostras refinadas nos mesmos tempos, apresentou razões de aspecto similares pelas pronunciadas larguras das fibras. O material $\boldsymbol{H}$, quando refinado por tempos mais baixos, também exibiu razões de aspecto comparáveis pelas maiores larguras médias das fibras, apesar de apresentar comprimentos médios pouco maiores que as obtidos para as polpas celulósicas. Já a polpa $\boldsymbol{O}_{200}$ apresentou um comprimento médio pronunciadamente menor que os demais materiais quando refinada em $\boldsymbol{M J}$ por 60 min, resultando no material com menor razão de aspecto entre os refinados pelo mesmo tempo.

Uma vez que o refino em $\boldsymbol{R} \boldsymbol{D}$ não altera a largura das fibras de forma representativa, as alterações observadas na razão de aspecto são uma função direta das alterações provocadas no comprimento médio das fibras, apresentando comportamentos similares frente ao tempo e ao espaçamento entre os discos aplicado, além das relações com as composições químicas dos materiais (Figura 42 (B)). Isto significa que quanto maior a intensidade do refino em $\boldsymbol{R} \boldsymbol{D}$, menor a razão de aspecto encontrada. Para o refino realizado em maiores espaçamentos entre os discos, as polpas $\boldsymbol{H O}_{\mathbf{1 8 0}}$ e $\boldsymbol{O}_{\mathbf{1 9 0}}$ atingiram razões de aspecto de aproximadamente 27 (33,3 minutos); já o refino das polpas $\boldsymbol{H O}_{180}, \boldsymbol{O}_{190}$ e $\boldsymbol{O}_{200}$ no espaçamento mínimo entre os discos por 60 min resultou em amostras com razões de aspecto de 13,6, 17,2 e 18,8, respectivamente.

Considerando-se os resultados obtidos no processamento em moinho criogênico, verificou-se que quanto maior o teor de lignina no material, menor a razão de aspecto das fibras (Figura $42(\mathbf{C})$ ). 
Figura 41.Variação da razão de aspecto com (A) o tempo de refino em moinho Jokro, (B) o tempo de refino em refinador Bauer e (C) a moagem criogênica,

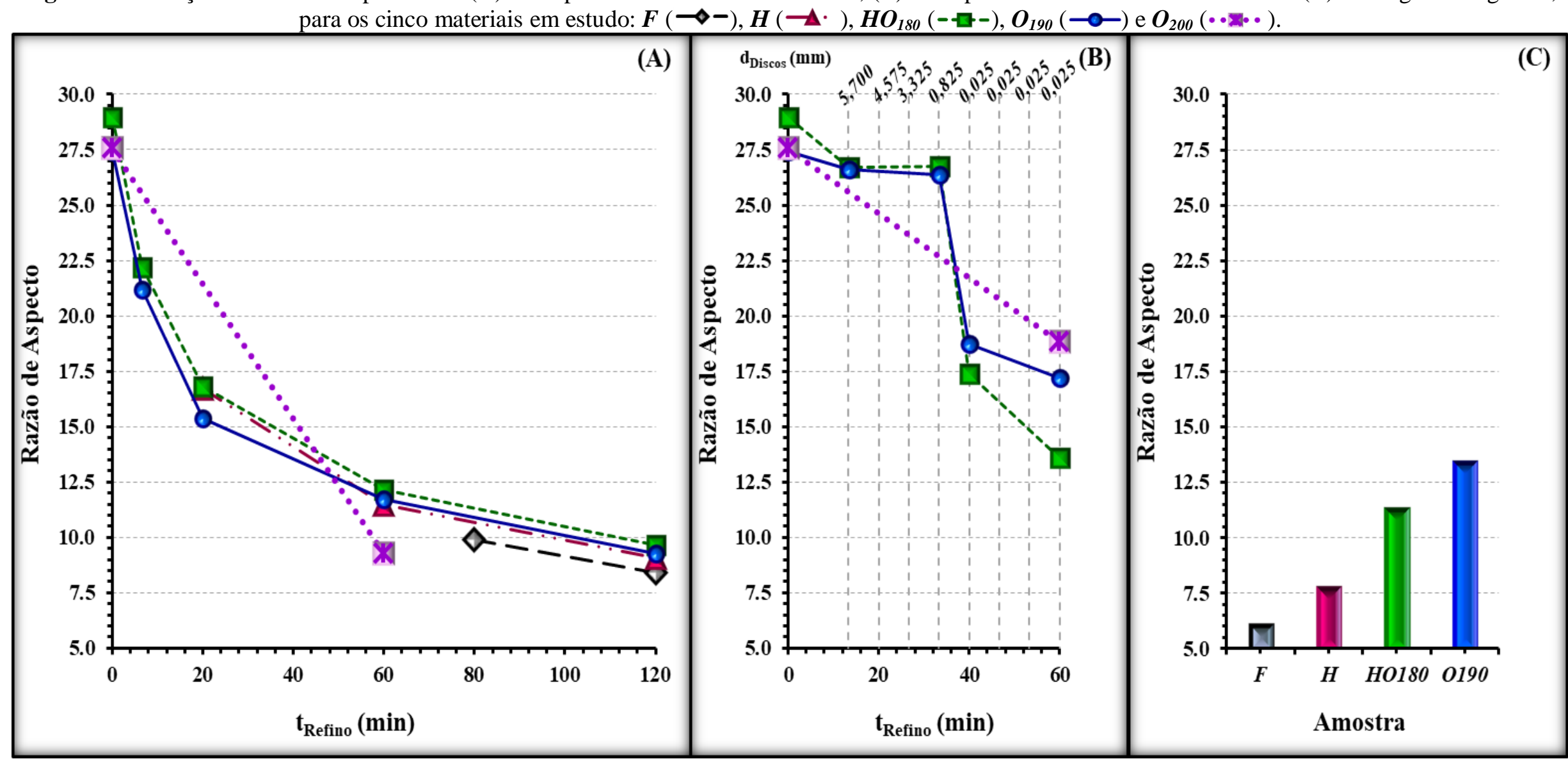

Legenda: $\mathrm{t}_{\text {Refino }}=$ tempo de refino; $\mathrm{d}_{\text {Discos }}=$ distância entre os discos. 
Os altos valores de razão de aspecto obtidos para os materiais, mesmo quando refinados com altas severidades, levam à conclusão do formato cilíndrico ou de fita das partículas. Esta observação embasou o cálculo da área superficial específica externa das partículas utilizando o modelo de partículas cilíndricas, conforme proposto no item 4.5.2. A área superficial externa (ASE) calculada por este modelo também é uma função das variações no comprimento médio e na largura das fibras, juntamente com as mudanças alcançadas em sua densidade que decorrem do refino. De modo contrário à razão de aspecto, tanto o comprimento quanto a largura média das fibras afetam a área superficial externa: enquanto a redução no comprimento médio das fibras afeta positivamente na ASE, o alargamento afeta negativamente.

O comportamento da ASE com o refino em $\boldsymbol{M J}$ divergiu entre as amostras de diferentes composições químicas (Figura $43(\mathrm{~A})$ ). As polpas organossolve $\boldsymbol{H O}_{180}$ e $\boldsymbol{O}_{190}$ apresentaram comportamentos similares de modificação da ASE das fibras com relação ao grau de refino em $\boldsymbol{M J}$. Em tempos de refino de até 20 minutos, observaram-se aumentos nas ASE das polpas $\boldsymbol{H O}_{18 \boldsymbol{0}}$ e $\boldsymbol{O}_{190}$ de 12,3\% e 14,7\%, respectivamente, pelas reduções expressivas dos comprimentos médios das fibras associadas a pequenas reduções nas larguras médias; após 60 minutos de refino constataram-se pequenas reduções nas ASE (4,1\% e 4,0\%, respectivamente), fruto dos alargamentos expressivos das fibras associados reduções menos intensas dos comprimentos médios; posteriormente verificaram-se novamente pequenos aumentos na ASE das fibras das polpas (5,2\% e 5,5\%, respectivamente). Já o material $\boldsymbol{H}$ apresentou um aumento mais sutil da ASE após o refino $(6,8 \%)$, apesar das reduções expressivas em seu comprimento médio com o aumento da intensidade do refino, uma vez que apresentou maiores larguras pelo seu alto grau de agregação associado ao intumescimento e achatamento. As fibras de bagaço in natura $(\boldsymbol{F})$ apresentaram as menores ASE (em torno de $0,21 \mathrm{~m}^{2} / \mathrm{g}$ ) pelo alto grau de agregação fibrilar, ou seja, pelos grandes comprimentos e larguras das fibras, mesmo após refinadas. Enfim, o refino em $\boldsymbol{M J}$ por 60 minutos da polpa $\boldsymbol{O}_{200}$ resultou em um material que apresentou o menor comprimento médio entre todos os materiais, porém associado a um grande alargamento, resultando em uma área superficial específica não muito maior que as outras polpas refinadas no mesmo intervalo de tempo em $\boldsymbol{M J}\left(0,493 \mathrm{~m}^{2} / \mathrm{g}\right.$ contra 0,4601 e $0,475 \mathrm{~m}^{2} / \mathrm{g}$ para as polpas $\boldsymbol{H} \boldsymbol{O}_{180}$ e $\boldsymbol{O}_{190}$, respectivamente). 
Os valores de área superficial específica externa calculados a partir do modelo de partículas cilíndrico utilizando os dados obtidos na análise de MorFi mostraram-se de 29,7\% a $82,1 \%$ maiores que os obtidos pelo modelo de partículas esféricas para as amostras refinadas em MJ. Entretanto, conforme será apresentado no item 5.3.3, são menores que os valores de área superficial interna calculados a partir da análise da estrutura de poros da parede celular, ou seja, a contribuição da área superficial externa para a área total é quase negligenciável para a maioria das biomassas lignocelulósicas estudadas.

De modo similar, a ASE dos materiais refinados em $\boldsymbol{R} \boldsymbol{D}$ aumentou com o tempo de refino, porém de forma expressiva apenas quando do uso do espaçamento mínimo entre os discos (Figura 43 (B)). Os valores de ASE obtidos para os materiais processados em moinho criogênico também demonstram uma relação negativa entre o teor de componentes não celulósicos e a área superficial, que foi mais expressivamente afetada pelos valores de largura média das fibras (Figura 43 (C)).

Ressalta-se novamente que o processo em $\boldsymbol{R} \boldsymbol{D}$ proveu materiais com menor desestruturação morfológica das fibras (maior comprimento médio e menor teor de finos) nos intervalos de tempo comparáveis ao refino em $\boldsymbol{M J}$, reforçando a conclusão de que o refino em $\boldsymbol{R D}$ provoca apenas os fenômenos de fibrilação e delaminação da parede celular, enquanto o refino em $\boldsymbol{M J}$ provoca ambos os fenômenos além do corte das fibras pela maior frequência e intensidade de impactos diretos do moente contra a fibra. Ademais, o refino em $\boldsymbol{M J}$ promove um maior alargamento da fibra pelos intensos fenômenos de intumescimento e de compressão do lúmen, enquanto o refino em $\boldsymbol{R} \boldsymbol{D}$ provoca apenas, e de modo sutil, a delaminação das paredes externas que compete com o intumescimento das fibras.

A combinação destes efeitos pode ser mais bem visualizada pelo comportamento da área superficial externa: quando realizados no mesmo intervalo de tempo, o refino em $\boldsymbol{M J}$ proveu amostras com maiores $\mathrm{ASE}$ do que o processamento em $\boldsymbol{R} \boldsymbol{D}$ com maiores espaçamentos entre os discos pela maior redução do comprimento das fibras; de modo contrário, o refino em $\boldsymbol{R} \boldsymbol{D}$ realizado no espaçamento mínimo entre os discos resultou em amostras com maiores ASE por promover a redução no comprimento sem alterar em grande extensão a largura das fibras. Os maiores valores de ASE obtidos para o tratamento das polpas $\boldsymbol{H O}_{180}, \boldsymbol{O}_{190}$ e $\boldsymbol{O}_{200}$ em $\boldsymbol{R D}$ da foram, respectivamente, 0,541, 0,533 e 0,512 $\mathrm{m}^{2} / \mathrm{g}$ em 60 minutos de refino, valores respectivamente $17,6 \%, 12,3 \%$ e 3,8\% maiores que os obtidos para os mesmos materiais refinados em $\boldsymbol{M J}$ durante o mesmo intervalo de tempo. 
Figura 42. Variação da área superficial específica externa (ASE $-\mathrm{m}^{2} / \mathrm{g}$ ) com (A) o tempo de refino em moinho Jokro, (B) o tempo de refino em refinador

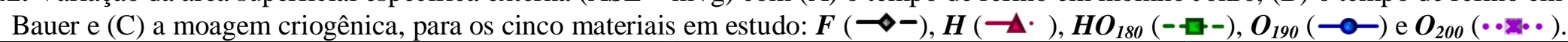

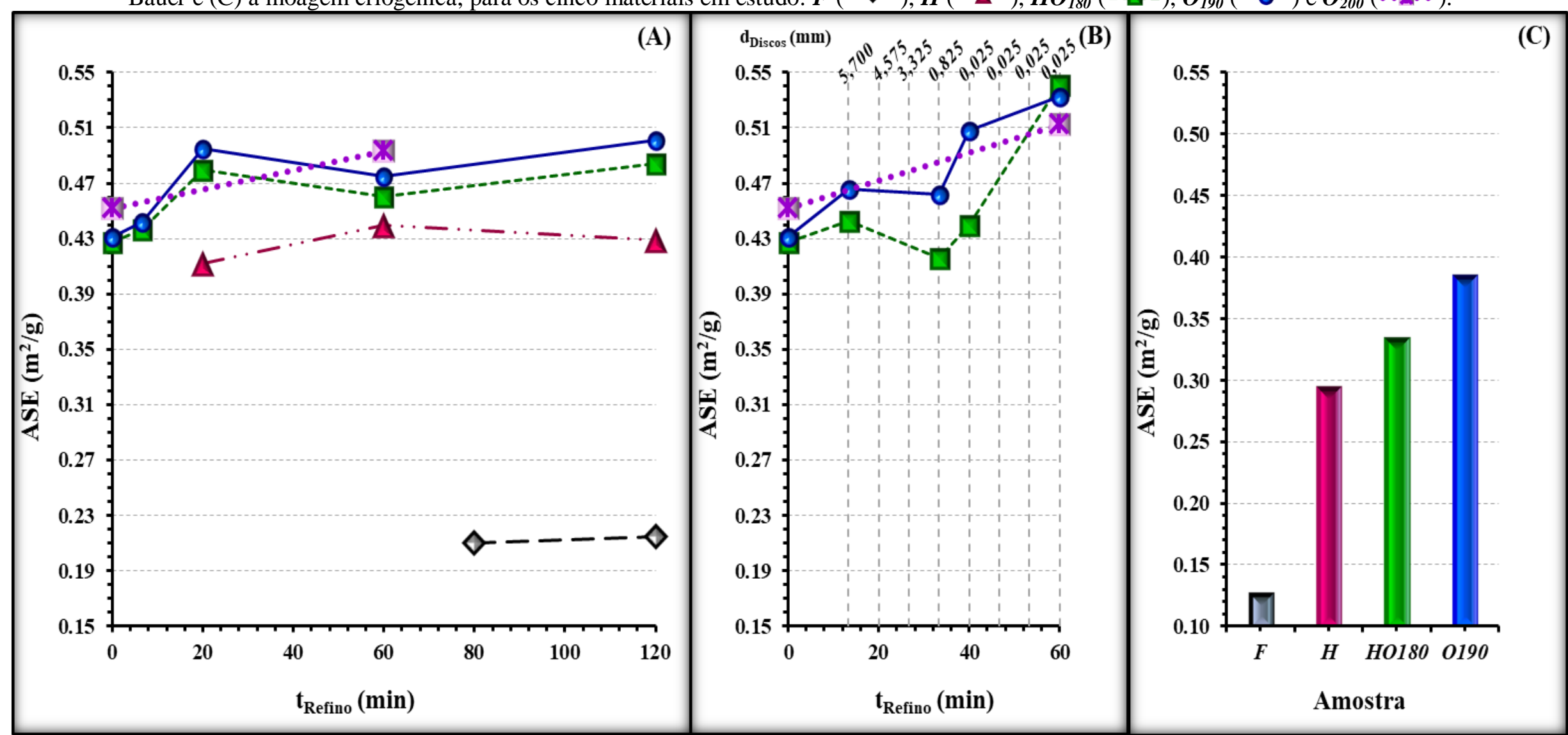

Legenda: $\mathrm{t}_{\text {Refino }}=$ tempo de refino; $\mathrm{d}_{\text {Discos }}=$ distância entre os discos; ASE = área superficial específica externa. 
Figura 43. Variação da massa linear $(\mathrm{mg} / \mathrm{m})$ com $(\mathrm{A})$ o tempo de refino em moinho Jokro, (B) o tempo de refino em refinador Bauer e (C) a moagem

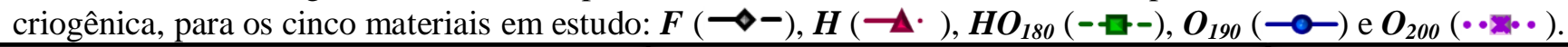

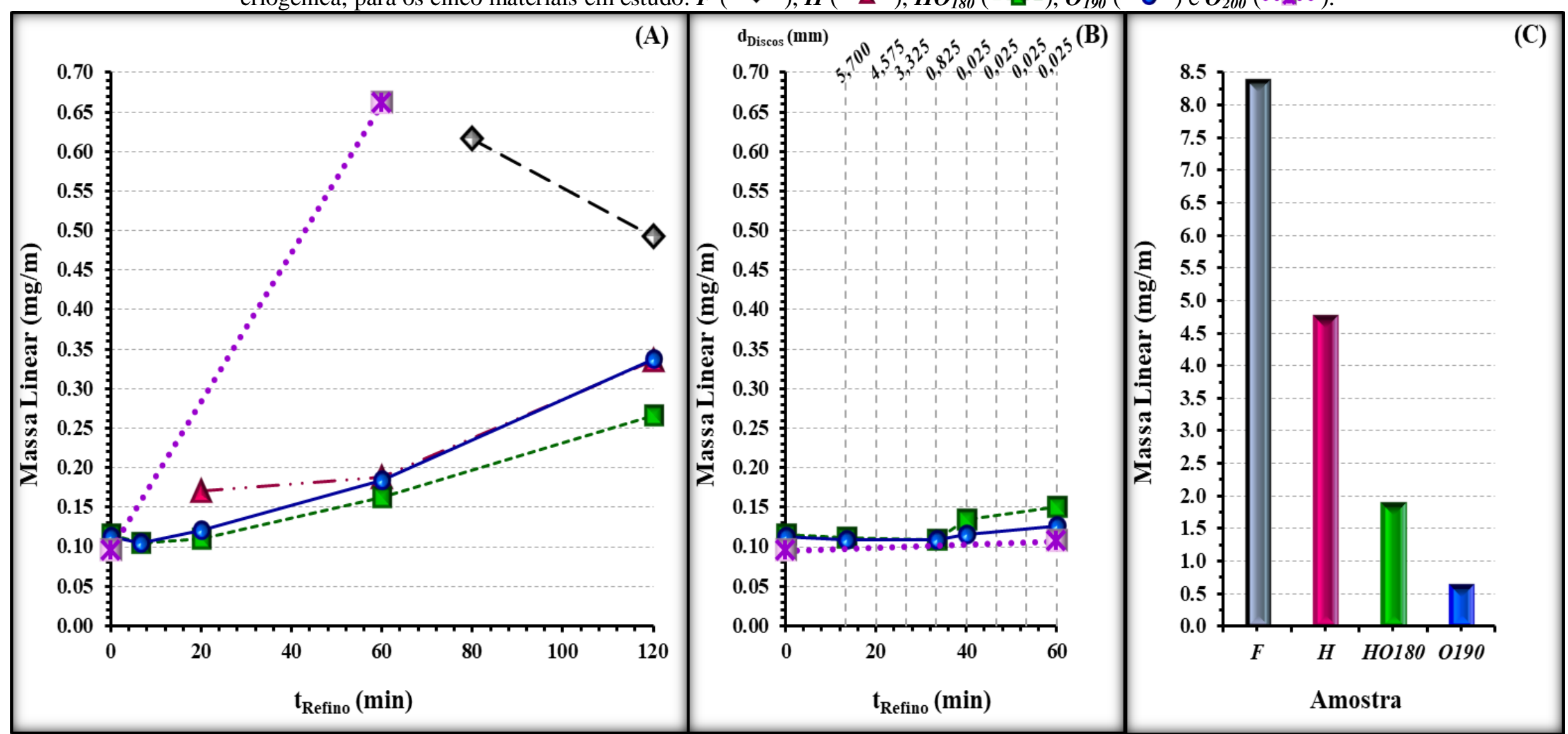

Legenda: $\mathrm{t}_{\text {Refino }}=$ tempo de refino; $\mathrm{d}_{\text {Discos }}=$ distância entre os discos. 
Os dados de massa linear obtidos, que representam a massa de fibras por unidade de comprimento em uma amostra, permitem confirmar as interpretações realizadas, uma vez que e estão fortemente relacionados com a formação de elementos finos e, principalmente, com a redução das dimensões pelo corte. A partir dos dados apresentados na Figura 43, pode-se observar que o refino em $\boldsymbol{M J}$ promove um aumento mais intenso da massa linear com o aumento da severidade do refino, assim como a moagem criogênica; diferentemente, o processamento em refinador de discos praticamente não altera a massa linear por não promover alterações acentuadas nas dimensões das fibras.

As microscopias óticas presentes na Figura 45 foram obtidas para polpa organossolve $\boldsymbol{O}_{200}$, tanto não refinada (Figura 45 (A)) quanto refinada por 60 minutos em $\boldsymbol{M J}$ (Figura 45 (B)) e em $R D$ (Figura 45 (C)), e para a polpa $\boldsymbol{O}_{190}$ moída criogenicamente (Figura 45 (D)), exemplificam os efeitos provocados por cada um dos tratamentos mecânicos estudados nas fibras dos materiais. As imagens apresentadas permitem observar que o refino em moinho Jokro provoca a delaminação e o rompimento estrutural da parede das fibras de modo mais agressivo que o processamento em refinador Bauer, que promove uma fibrilação mais branda das fibras. Distintamente, observa-se que o processo criogênico provoca a apenas a redução do tamanho das fibras pela quebra das mesmas.

Figura 44. Imagens microscopia ótica obtidas para as fibras de polpa organossolve (A) não refinadas e processadas em (B) moinho Jokro, (C) refinador Bauer e (D) moinho criogênico.
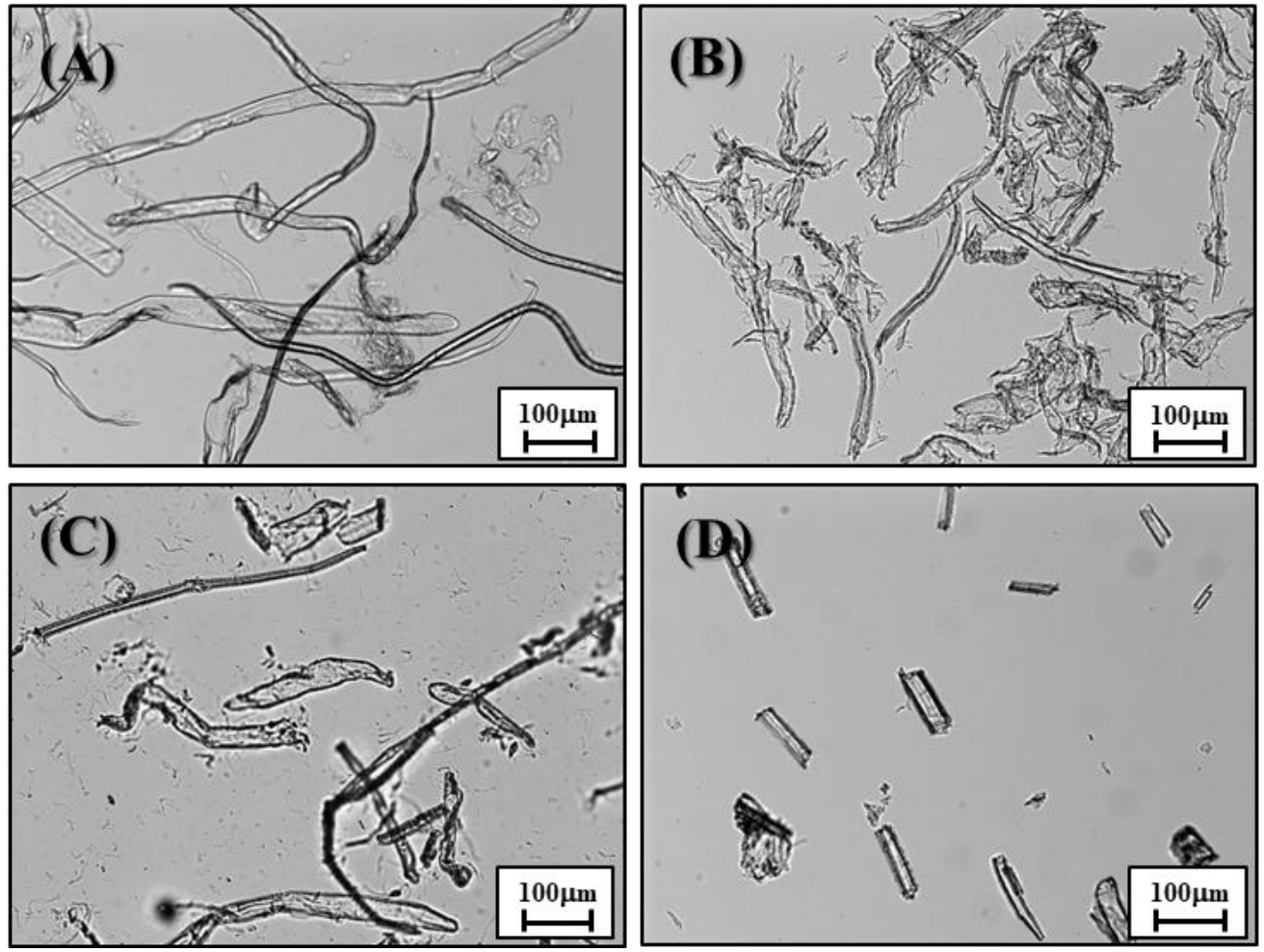


\subsubsection{Distribuição de áreas de poros das fibras}

Consoante ao conteúdo explanado no item 2.2.5.1, a área superficial interna das fibras lignocelulósicas é representada pela estrutura de poros interfibrilares e interlamelares. Estes se manifestam quando da infrequência no empacotamento das fibrilas celulósicas na formação das diferentes camadas da parede celular. Segundo PECIULYTE et al. (2015), o diâmetro de um poro definido por termoporometria (TP-DSC) com geometria cilíndrica é uma simplificação decente para redes de fibrilas embebidas em componentes não celulósicos; já em um material completamente deslignificado, o diâmetro de um poro pode melhor representar a distância entre agregados fibrilares na matriz da parede celular.

O processamento da biomassa pode aumentar a porosidade da parede celular segundo pelo menos dois mecanismos. O primeiro é pela solubilização dos componentes não celulósicos durante tratamentos físico-químicos; se as cadeias hemicelulósicas encontram-se envoltas nas fibrilas de celulose e a lignina preenche os espaços delimitados pelos polissacarídeos previamente depositados, é esperado que a remoção destes componentes restabeleça os poros nanométricos. O segundo mecanismo está relacionado com a desestruturação mecânica da organização da parede celular por métodos de refino, que promovem a separação das lamelas adjacentes, além do afastamento entre os componentes estruturais e do rompimento das interligações entre as fibrilas. A expansão da estrutura capilar pode ainda ser melhorada pela combinação de ambos os tipos de processo.

No que concerne os métodos de refino, a capilaridade da parede celular é principalmente afetada pelo fenômeno de fibrilação interna. As cisões provocadas nas camadas internas culminam no afastamento entre lamelas e fibrilas adjacentes, aumentando assim a área de exposição das cadeias celulósicas. Já o fenômeno de fibrilação externa influencia de modo indireto a área de poros, uma vez abertura das camadas mais externas promovida pelo refino aumenta a capacidade de inserção de moléculas de água no interior da estrutura. Assim como constatado para a morfologia das fibras, o grau de modificação da porosidade depende do modo de ação do equipamento e da severidade do tratamento.

Conforme descrito no item 4.5.4, os resultados das análises de termoporometria por DSC são reportados em base de massa acumulada de água confinada em poros, convertida em área cumulativa de poros por unidade de massa seca de amostra em função do diâmetro do poro. Apesar das curvas de distribuição do volume total de poros proverem uma boa noção do 
aumento da porosidade total do sistema, estas não permitem observar de modo mais detalhado a influência dos diferentes tratamentos aplicados nas regiões de poros de diferentes diâmetros.

Nas Figuras 46 e 47 a seguir são apresentados os gráficos comparativos da distribuição da área cumulativa de poros $\left(\mathrm{m}^{2} / \mathrm{g}\right)$ em função do diâmetro do poro obtidos para as cinco amostras em estudo $\left(\boldsymbol{F}, \boldsymbol{H}, \boldsymbol{H O}_{180}, \boldsymbol{O}_{190}\right.$ e $\left.\boldsymbol{O}_{200}\right)$, tanto não refinadas quanto processadas em moinho Jokro $(\boldsymbol{M J})$, em refinador de discos Bauer $(\boldsymbol{R D})$ e em moinho criogênico $(\boldsymbol{M C})$. Já os valores calculados de área superficial interna (ASI) das partículas, ou de área total de poros, encontram-se organizados nos gráficos da Figura 48.

Figura 45. Curvas de distribuição da área cumulativa de poros $\left(\mathrm{m}^{2} / \mathrm{g}\right)$ em função do diâmetro do poro de acordo com o tempo de refino em $\boldsymbol{M J}$ para as amostras (A) $\boldsymbol{F}$, (B) $\boldsymbol{H}$, (C) $\boldsymbol{H} \boldsymbol{O}_{180}$, e (D) $\boldsymbol{O}_{\mathbf{1 9 0}}$.

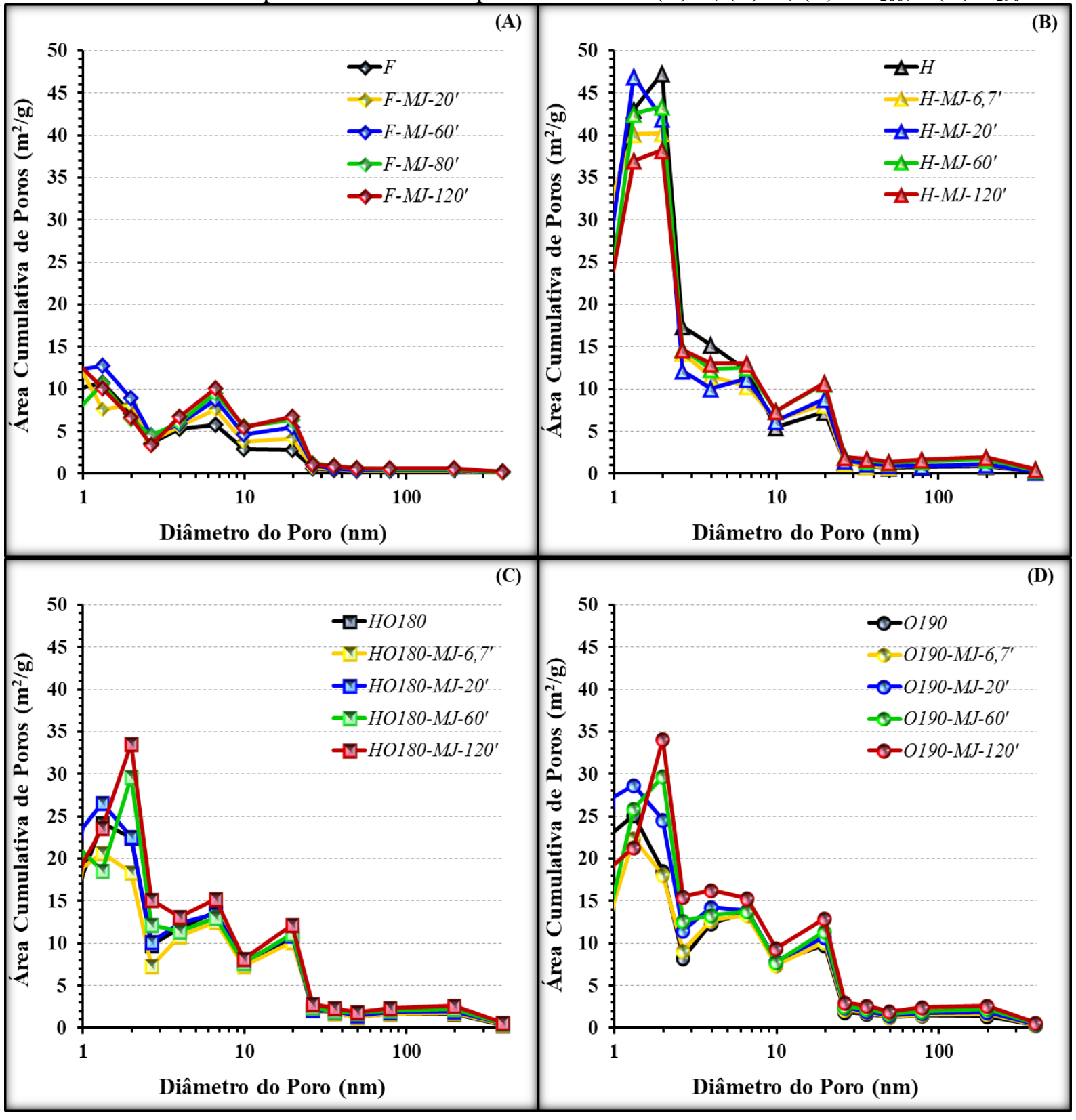


Os comportamentos das áreas cumulativas em função dos diâmetros dos poros, assim como das áreas totais de poros, apresentam relações não triviais de acordo com o tipo e a severidade do tratamento físico-mecânico, assim como de acordo com a composição química do material, e exigem uma análise pontual das variações.

Com respeito aos tratamentos físico-químicos, o pré-tratamento hidrotérmico $(\boldsymbol{H})$ (Figura 46 (B)) promoveu o aumento nas áreas de poros de todos os diâmetros nas fibras em relação ao bagaço in natura $(\boldsymbol{F})$ (Figura 46 (A)), notoriamente com diâmetros entre 0,99 e 19,8 nm, resultando em uma área total de poros cerca de 2,5 vezes maior (Figura 48 (A)). Isto porque o pré-tratamento hidrotérmico ocasiona a extensa criação de poros de pequenos diâmetros pela solubilização das hemiceluloses, que atuam como espaçadores entre as fibrilas adjacentes. A posterior deslignificação das fibras pré-tratadas $\left(H_{\boldsymbol{O}_{180}}\right)$ (Figura 46 (C)) resultou na redução das áreas de poros com diâmetros menores $(\leq 3,96 \mathrm{~nm})$ e o aumento das áreas de poros entre 6,6 e $396 \mathrm{~nm}$. Neste caso, a reação de polpação realizada após a autohidrólise expandiu os poros pré-existentes na estrutura em maior proporção do que formou novos poros de menores diâmetros, o que reforça o conhecimento da deposição da lignina em espaços maiores (interlamelares além de interfibrilares).

A deslignificação direta na condição $2\left(\boldsymbol{O}_{190}\right)$ (Figura $\left.46(\mathrm{D})\right)$ promoveu o aumento nas áreas de poros com todos os diâmetros nas fibras em relação à amostra $\boldsymbol{F}$, especialmente com diâmetros entre 0,99 e 19,8 nm, resultando em uma área total de poros cerca de 152,0\% maior. Entretanto, apresentou áreas de poros de todos os diâmetros similares à polpa $\boldsymbol{H O}_{\mathbf{1 8 0}}$, indicando que a polpação organossolve promove a solubilização das hemiceluloses e da lignina altamente associadas e depositadas nos espaçados entre as fibrilas celulósicas. Já a deslignificação direta na condição $3\left(\boldsymbol{O}_{200}\right)$ (Figura $47(\mathbf{C})$ ) proporcionou o aumento nas áreas totais de poros de todos os diâmetros em maior extensão que as polpações nas outras duas condições pela solubilização mais proeminente dos componentes não celulósicos, resultando em uma área total de poros $188,2 \%$ maior que a obtida para a amostra in natura.

De modo peculiar, as amostras deslignificadas $\boldsymbol{H O}_{180}, \boldsymbol{O}_{\mathbf{1 9 0}}$ e $\boldsymbol{O}_{\mathbf{2 0 0}}$ exibiram áreas totais de poros 31,9\%, 28,6\% e 18,3\%, respectivamente, menores que amostra $\boldsymbol{H}$ (Figura 48 (A)); este resultado pode estar atrelado a um evento de expansão dos poros existentes para diâmetros maiores que o limite de detecção do método de TP-DSC, ou ainda ao colapso dos poros maiores, porém sem a significativa formação de poros de menores diâmetros.

O comportamento das áreas de poros observado para as amostras pré-tratadas quimicamente está de acordo com reportado por PIHLAJANIEMI et al. (2016), que afirmou 
que a dissolução das hemiceluloses está associada com a formação de poros relativamente menores e uniformes, enquanto a dissolução da lignina leva a uma ampliação mais volumosa da estrutura capilar. Conforme já mencionado no item 2.2.5.1, diversos outros autores reportaram o aumento da estrutura capilar quando do emprego de condições moderadas de pré-tratamentos físico-químicos, assim como a redução da área superficial interna com o uso de condições mais severas de reação (DOGARIS et al., 2009; HUANG et al., 2010; NITSOS; MATIS; TRIANTAFYLLIDIS, 2013; PIHLAJANIEMI et al., 2016 ; XIAO et al., 2013).

Figura 46. Curvas de distribuição da área cumulativa de poros $\left(\mathrm{m}^{2} / \mathrm{g}\right)$ em função do diâmetro do poro de acordo com o tempo de refino em $\boldsymbol{R} \boldsymbol{D}$ para as amostras (A) $\boldsymbol{H} \boldsymbol{O}_{180}$ e (B) $\boldsymbol{O}_{\mathbf{1 9 0}}$, (C) de acordo com o refino em $\boldsymbol{M J}$ e em $\boldsymbol{R D}$ para $\boldsymbol{O}_{200}$, e (D) de acordo com $\boldsymbol{M C}$ para $\boldsymbol{F}, \boldsymbol{H}, \boldsymbol{H} \boldsymbol{O}_{180}$ e $\boldsymbol{O}_{190}$.

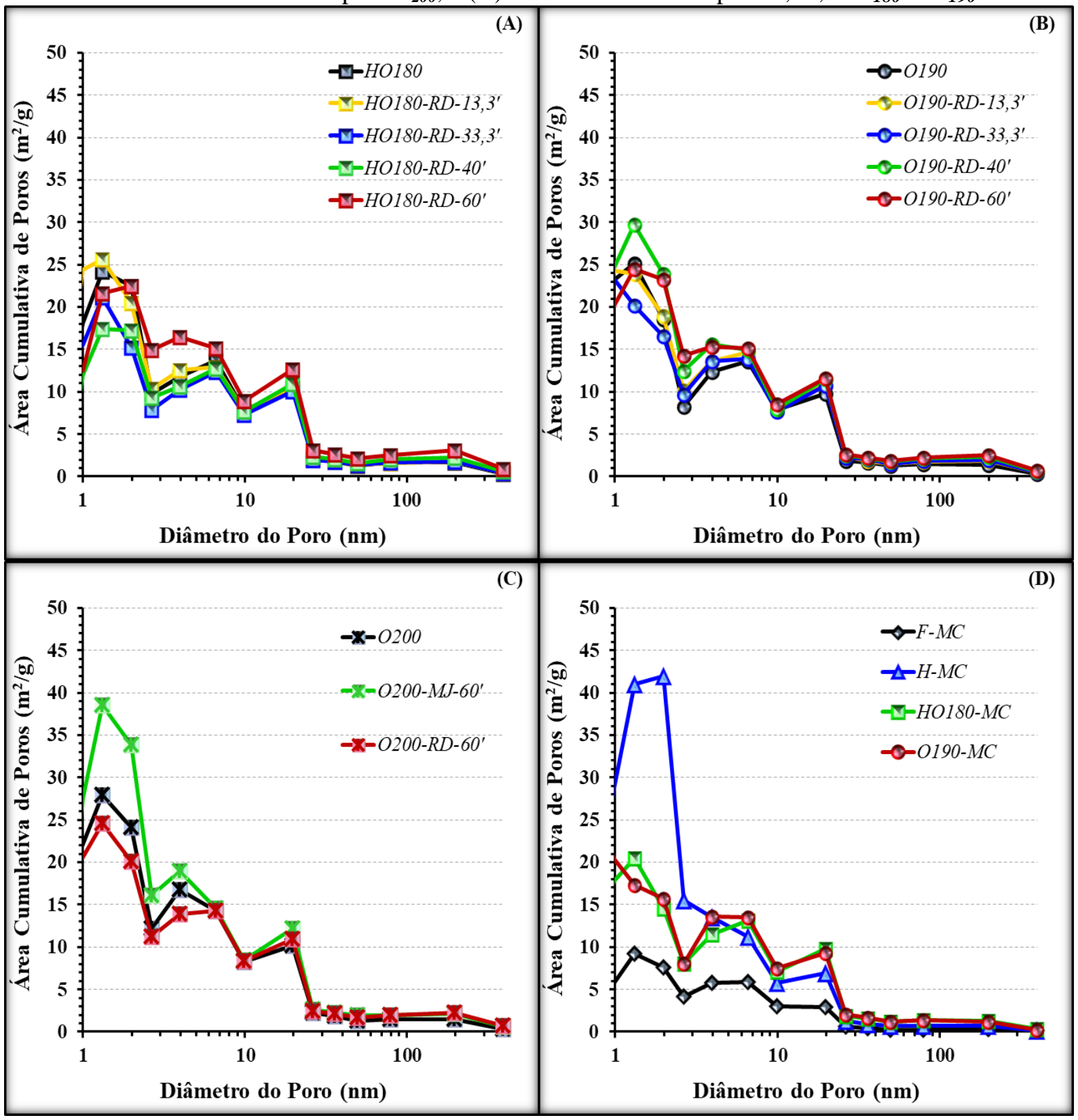


Figura 47. Variação da área total de poros $\left(\mathrm{m}^{2} / \mathrm{g}\right) \operatorname{com}(\mathrm{A})$ o tempo de refino em moinho Jokro, (B) o tempo de refino em refinador Bauer e (C) a moagem

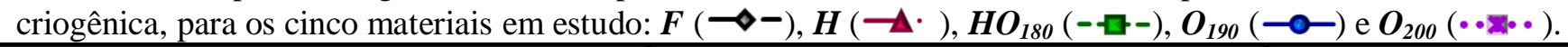

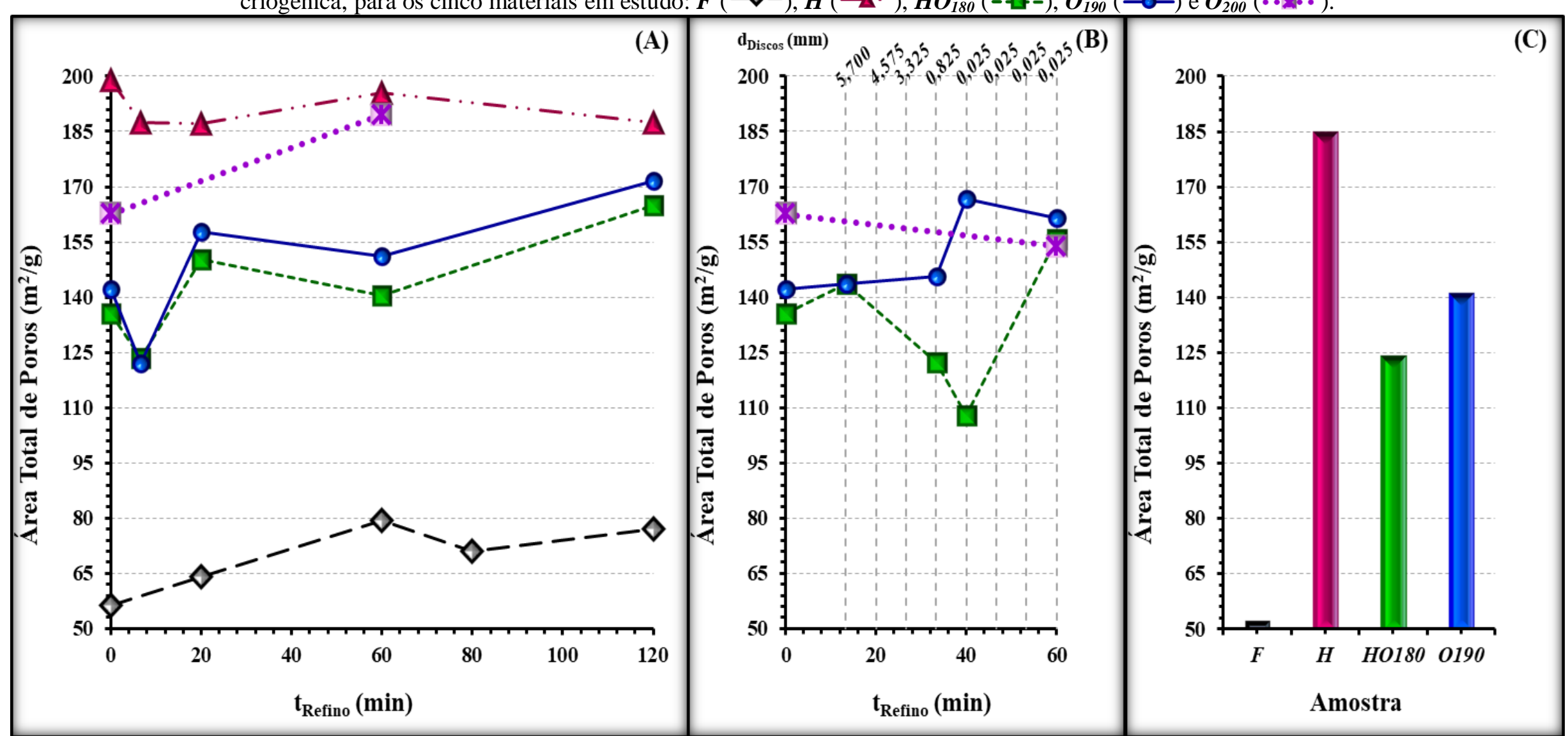

Legenda: $\mathrm{t}_{\text {Refino }}=$ tempo de refino; $\mathrm{d}_{\text {Discos }}=$ distância entre os discos. 
Já as alterações provocadas na estrutura de poros pelos tratamentos físico-mecânicos foram menos intensas que as provocadas pela solubilização dos componentes não celulósicos. Esta observação consolida a interpretação de que há um limite na amplitude da abertura da estrutura da parede celular que o refino pode estimular sem a solubilização dos componentes não celulósicos. Apesar de o refino promover o aumento da porosidade do sistema pela delaminação das paredes internas, a presença de componentes não celulósicos ainda desempenha importante papel na restrição da acessibilidade à celulose e, portanto, no intumescimento das fibras. Por exemplo, as fibras de bagaço in natura refinadas em $\boldsymbol{M J}$ na maior severidade (120 minutos) alcançaram uma área total de poros de $76,9 \mathrm{~m}^{2} / \mathrm{g}$, enquanto a amostra pré-tratada em condição hidrotérmica branda $(\boldsymbol{H})$ não refinada apresentou uma ASI de $198,9 \mathrm{~m}^{2} / \mathrm{g}$. De forma contrária, o refino mecânico realizado após o tratamento físicoquímico da amostra de bagaço proveu uma expansão adicional nas áreas de poros, notoriamente de diâmetros maiores, previamente criados pela remoção dos componentes não celulósicos, resultando em um maior grau de desconstrução estrutural das fibras.

Com relação à severidade do refino mecânico, puderam-se extrair outros tipos de correlações. Quando o refino provocou decréscimos nas áreas de poros de menores dimensões, que foram expandidos e refletiram em maiores áreas de poros com maiores diâmetros, observou-se ou o aumento da área total de poros como resultado do alargamento dos poros pré-existentes (F-MJ-20', F-MJ-120', H-MJ-60', HO180-MJ-120', O190-MJ120', O190-RD-33,3'), ou a redução da área total de poros como reflexo da expansão dos poros existentes para diâmetros maiores que o limite de detecção do método de TP-DSC, ou ainda do colapso dos poros maiores, porém sem a significativa formação de poros de menores diâmetros (F-MJ-80', H-MJ-6,7', H-MJ-120', HO180-MJ-6,7', HO180-MJ-60', O190-MJ6,7', O190-MJ-60', HO180-RD-33,3', HO180-RD-40', O190-RD-60', O200-RD-60'). Diferentemente, quando o refino provocou acréscimos nas áreas de poros de todos os diâmetros, observou-se apenas o aumento da área total de poros como consequência da criação de novos poros de menores dimensões ao mesmo passo que os demais poros foram expandidos (F-MJ-60', HO180-MJ-20', O190-MJ-20', O200-MJ-60', HO180-RD-13,3', HO180-RD-60', O190-RD-13,3', O190-RD-40'). Ainda, a moagem criogênica provocou a redução nas áreas de poros de todos os diâmetros das amostras de diferentes composições químicas estudadas $(\boldsymbol{F}, \boldsymbol{H}, \boldsymbol{H O 1 8 0}$ e $\mathbf{O 1 9 0})$ em relação às respectivas amostras iniciais, resultado da intensa compressão dos poros provocada pelos impactos promovidos pelo 
impelidor contra as fibras, levando a uma pequena redução nas áreas totais de poros destes materiais.

As dimensões dos poros da biomassa exerce grande influência na eficiência da digestibilidade enzimática dos polissacarídeos constituintes da parede celular, visto que estes devem ser grandes o bastante para permitir o acesso livre e acomodar as hidrolases. Consoante ao panorama apresentado no item 2.2.5.1.2, apesar de tanto a área superficial externa quanto a interna fornecerem superfícies de contato para as enzimas, diversos autores reportaram, para biomassas de diferentes origens vegetais e composições químicas, que a contribuição da área superficial externa representa menos de $10 \%$ da área superficial total acessível (HUANG et al., 2010; LI et al., 2015; LUO; ZHU, 2011; LUO et al., 2011; WANG et al., 2012a; WONG et al., 1988). No caso deste estudo, pôde-se constatar para todas as amostras de bagaço analisadas, tanto pré-tratadas por métodos físico-químicos quanto por físico-mecânicos, que a área superficial interna, descrita como a área total de poros, correspondeu a mais de $99,5 \%$ da área específica total das fibras.

Contudo, para proteínas de grandes dimensões como as celulases, nem todos os poros da parede celular são acessíveis. Uma extensa revisão da literatura permitiu inferir que os diâmetros de poros considerados limitantes para a eficiência da atuação enzimática incluem desde valores maiores que 4,0 nm e até valores maiores 10,0 nm (BURNS; OOSHIMA; CONVERSE, 1989; GRETHLEIN, 1985; HUANG et al., 2010; LI et al., 2015; MENG et al., 2013; PECIULYTE et al., 2015; PIHLAJANIEMI et al., 2016; SINITSYN; GUSAKOV; VLASENKO, 1991; WEIMER; WESTON, 1985). Em vista desta informação, calcularam-se as áreas superficiais internas de poros com diâmetros considerados acessíveis às enzimas celulolíticas para as amostras de bagaço em estudo utilizando-se três faixas de diâmetros de poros: $\geq 3,96 \mathrm{~nm}, \geq 6,60 \mathrm{~nm} \mathrm{e} \geq 9,90 \mathrm{~nm}$. Se considerarmos a área superficial interna apenas como o somatório das áreas de poros acessíveis às enzimas hidrolíticas, esta ainda correspondeu a mais que $99,0 \%$ (poros de diâmetros $\geq 3,96 \mathrm{~nm}$ ), 98,7\% ( $\geq 6,60 \mathrm{~nm}$ ) ou 98,1\% $(\geq 9,90 \mathrm{~nm})$ da área específica total das fibras para todas as amostras de bagaço analisadas, tanto pré-tratadas por métodos físico-químicos quanto por físico-mecânicos.

Os gráficos das variações das áreas de poros com diâmetros maiores ou iguais a 9,90 $\mathrm{nm}, 6,60 \mathrm{~nm}$ e $3,96 \mathrm{~nm}$, das cinco amostras em estudo refinadas ou processadas em moinho Jokro $(\boldsymbol{M J})$, em refinador de discos Bauer $(\boldsymbol{R D})$ e em moinho criogênico $(\boldsymbol{M C})$, encontram-se organizados na Figura 49 e nos Anexos F e G, respectivamente. 
Figura 48. Variação da área de poros $\left(\mathrm{m}^{2} / \mathrm{g}\right)$ com diâmetros maiores ou iguais a $9,90 \mathrm{~nm}$ com (A) o tempo de refino em moinho Jokro, (B) o tempo de refino

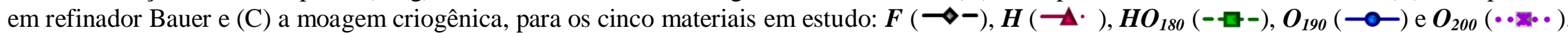

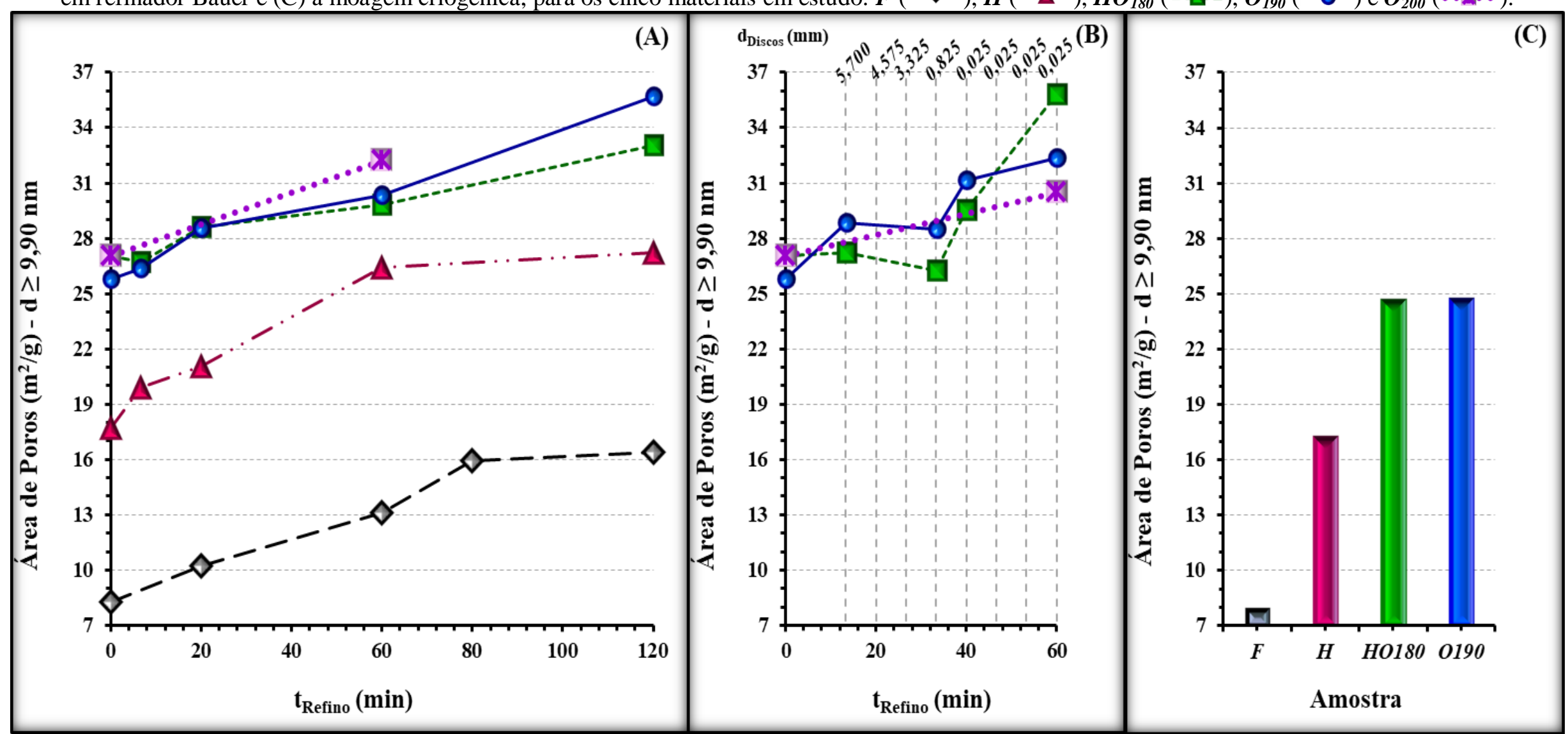

Legenda: $\mathrm{t}_{\text {Refino }}=$ tempo de refino; $\mathrm{d}_{\text {Discos }}=$ distância entre os discos; $\mathrm{d}=$ diâmetro do poro. 
A primeira constatação importante fornecida pelo conjunto de dados obtidos é que, para as fibras de bagaço não processada por nenhum método (físico-químico ou físicomecânicos), 34,4\% da área total de poros se mostrou acessível a moléculas com diâmetros nominais maiores ou iguais a $3,96 \mathrm{~nm}, 25,0 \%$ a moléculas maiores ou iguais a $6,60 \mathrm{~nm}$ e apenas $14,7 \%$ a moléculas maiores ou iguais a 9,90 $\mathrm{nm}$. Pôde-se também reconhecer que as áreas cumulativas de poros maiores que $9,90 \mathrm{~nm}, 6,60 \mathrm{~nm}$ ou 3,96 $\mathrm{nm}$ apresentaram perfis de comportamentos similares frente ao tipo e à severidade do refino, assim como em relação à composição química do material, que serão descritos a seguir.

Comparando-se os valores obtidos para as cinco amostras de bagaço $\left(\boldsymbol{F}, \boldsymbol{H}, \mathbf{H O}_{180}\right.$, $\boldsymbol{O}_{190}$ e $\boldsymbol{O}_{200}$ ) não refinadas verificou-se que, quanto maior a severidade do tratamento físicoquímico, maior a área de poros acessíveis devido à remoção mais expressiva dos componentes hemiceluloses e lignina das fibras do material. O material pré-tratado hidrotérmicamente $(\boldsymbol{H})$ apresentou um aumento de $114,0 \%$ na área de poros acessíveis a moléculas maiores ou iguais a $9,90 \mathrm{~nm}$ em relação às fibras de bagaço in natura $(\boldsymbol{F})$, alcançando o valor de $17,7 \mathrm{~m}^{2} / \mathrm{g}$. Já as polpas organossolve estudadas - $\boldsymbol{H O}_{180}, \boldsymbol{O}_{190}$ e $\boldsymbol{O}_{200}$ - foram obtidas com área de poros acessíveis $(\geq 9,90 \mathrm{~nm})$ cerca de 3 vezes a área apresentada por $\boldsymbol{F}$ e cerca de 1,5 a expressada por $\boldsymbol{H}$, atingindo os valores de $27,0 \mathrm{~m}^{2} / \mathrm{g}\left(\boldsymbol{H O}_{\mathbf{1 8 0}}\right.$ e $\left.\boldsymbol{O}_{\mathbf{2 0 0}}\right)$ e $25,8 \mathrm{~m}^{2} / \mathrm{g}\left(\boldsymbol{O}_{\mathbf{1 9 0}}\right)$.

Do mesmo modo que o observado para o comportamento das áreas totais de poros, as alterações provocadas nas áreas de poros acessíveis pelos métodos de refino mecânico foram menos expressivas que as proporcionadas pela solubilização dos componentes não celulósicos. As fibras de bagaço in natura refinadas em $\boldsymbol{M J}$ na maior severidade (120 minutos) alcançaram uma área de poros acessíveis $(\geq 9,90 \mathrm{~nm}) \mathrm{de} 16,4 \mathrm{~m}^{2} / \mathrm{g}$, valor menor que o obtido para a amostra pré-tratada hidrotérmicamente $(\boldsymbol{H})$ não refinada $\left(17,7 \mathrm{~m}^{2} / \mathrm{g}\right)$. De modo similar, a amostra $\boldsymbol{H}$ refinada na maior severidade em $\boldsymbol{M J}$ atingiu uma área de poros acessíveis comparável às obtidas pelas polpas celulósicas não refinadas $\left(27,3 \mathrm{~m}^{2} / \mathrm{g}\right)$.

A partir dos resultados de TP-DSC obtidos para as amostras refinadas em moinho Jokro $(\boldsymbol{M J})$ pôde-se observar o aumento contínuo das áreas de poros acessíveis $(\geq 9,90 \mathrm{~nm}, \geq$ $6,60 \mathrm{~nm}$ ou $\geq 3,96 \mathrm{~nm}$ ) alcançadas pelas fibras dos materiais com o aumento do tempo de refino. Isto significa que a ampliação da estrutura capilar da parede celular é mais proeminente quanto maior o número de impactos sofridos pelas fibras, evento que está intrinsecamente relacionado com o aumento observado no item 5.2 para o grau de drenabilidade. Quando o refino mecânico foi aplicado após o pré-tratamento físico-químico 
do bagaço, este permitiu uma exposição adicional da superfície interna da parede celular pelo aumento da área de poros acessíveis $(\geq 9,90 \mathrm{~nm}, \geq 6,60 \mathrm{~nm}$ ou $\geq 3,96 \mathrm{~nm}$ ) previamente criados e/ou expandidos pela solubilização das hemiceluloses e da lignina.

Para um mesmo tempo de refino em $\boldsymbol{M J}$, constatou-se que os materiais deslignificados $\left(\boldsymbol{H O}_{180}\right.$ e $\left.\boldsymbol{O}_{190}\right)$ alcançaram maiores valores áreas de poros acessíveis que a amostra apenas pré-tratada hidrotérmicamente $(\boldsymbol{H})$, que por sua vez atingiu maiores valores que as fibras de bagaço in natura $(\boldsymbol{F})$. Seguindo as tendências observadas para os resultados das análises morfológicas e do ${ }^{\circ} S R$, este comportamento era previsto pelo fato da fibrilação das paredes internas e do consequente intumescimento da parede celular serem facilitados pela redução da recalcitrância e pela remoção da barreira física constituída pelos componentes não celulósicos. Após 60 minutos de refino em $\boldsymbol{M J}$, as amostras $\boldsymbol{F}, \boldsymbol{H}, \boldsymbol{H O}_{180}, \boldsymbol{O}_{190}$ e $\boldsymbol{O}_{200}$ alcançaram valores de áreas de poros acessíveis $(\geq 9,90 \mathrm{~nm})$ de, respectivamente, 13,1, 26,4, $29,8,30,3$ e $32,2 \mathrm{~m}^{2} / \mathrm{g}$; estes valores representam incrementos de, respectivamente, $58,4 \%$ $\left(4,8 \mathrm{~m}^{2} / \mathrm{g}\right), 49,4 \%\left(8,7 \mathrm{~m}^{2} / \mathrm{g}\right), 10,4 \%\left(2,8 \mathrm{~m}^{2} / \mathrm{g}\right), 17,6 \%\left(4,6 \mathrm{~m}^{2} / \mathrm{g}\right)$ e $19,2 \%\left(5,2 \mathrm{~m}^{2} / \mathrm{g}\right)$ em relação às áreas de poros acessíveis dos referentes materiais não refinados de mesma composição química.

Novamente, a abertura da estrutura interna da parede celular provocada pelo refino mecânico foi mais notória em amostras com maiores teores de lignina e hemiceluloses, posto que as polpas celulósicas possuíam grandes áreas de poros acessíveis precedentemente à fibrilação. Contudo, a maior facilidade de processamento das fibras com menores quantidades de componentes não celulósicos acarretou em maiores incrementos nas áreas de poros acessíveis das polpas organossolve em estudo.

Os valores de áreas de poros acessíveis ( $\geq 9,90 \mathrm{~nm}, \geq 6,60 \mathrm{~nm}$ ou $\geq 3,96 \mathrm{~nm}$ ) obtidos para as polpas $\boldsymbol{H O}_{180}$ e $\boldsymbol{O}_{\mathbf{1 9 0}}$ processadas em refinador Bauer $(\boldsymbol{R D})$ apresentaram comportamento semelhante ao reportado para os resultados das análises morfológicas e do ${ }^{\circ} S R$. Para o refino em $\boldsymbol{R} \boldsymbol{D}$ realizado com maiores espaçamentos entre os discos, observou-se um aumento sutil de $11,9 \%$ na área de poros acessíveis $\left(\geq 9,90 \mathrm{~nm}\right.$ ) da polpa $\boldsymbol{O}_{190}$ (teor de lignina igual a 5,0\%), enquanto a polpa $\boldsymbol{H O}_{180}$ (teor de lignina igual a 9,4\%) não apresentou ganhos em sua área de poros acessíveis. Já para o refino realizado na aproximação máxima entre os discos, observaram-se incrementos mais expressivos nas áreas de poros acessíveis de ambas as polpas - 32,5\% (8,8 $\left.\mathrm{m}^{2} / \mathrm{g}\right)$ e $25,4 \%\left(6,6 \mathrm{~m}^{2} / \mathrm{g}\right)$, respectivamente, para $\boldsymbol{H O}_{18 \boldsymbol{0}}$ e $\boldsymbol{O}_{\boldsymbol{1 9 0}}$ após 60 minutos de refino em relação às polpas não refinadas. Estes resultados corroboram 
com as observações do maior efeito da energia específica aplicada sobre as fibras, controlada pela aproximação entre o rotor e o estator, na abertura da ultraestrutura dos materiais lignocelulósicos em detrimento da duração do refino em $\boldsymbol{R D}$.

Quando processadas na maior severidade em $\boldsymbol{R} \boldsymbol{D}(0,025 \mathrm{~mm}$ de espaçamento entre os discos e 60 minutos de duração), as polpas $\boldsymbol{H O}_{180}, \boldsymbol{O}_{190}$ e $\boldsymbol{O}_{200}$ alcançaram valores de áreas de poros acessíveis $(\geq 9,90 \mathrm{~nm}) \mathrm{de}$, respectivamente, $35,8,32,4$ e $30,5 \mathrm{~m}^{2} / \mathrm{g}$, apesar de apresentarem valores de acessibilidade iniciais semelhantes. Neste caso, a maior facilidade de processamento de amostras de maiores teores de lignina quando do uso de altas energias específicas novamente se faz presente.

As diferenças na facilidade de processamento nos métodos de refino propostos, de acordo com a composição química das amostras, são enfatizadas nos dados de áreas de poros acessíveis. Comparativamente, as polpas $\boldsymbol{H O}_{\mathbf{1 8 0}}$ (9,4\% de lignina) e $\boldsymbol{O}_{\mathbf{1 9 0}}$ (5,0\% de lignina) apresentaram maiores valores de áreas de poros acessíveis quando refinadas por $60 \mathrm{~min}$ em $\boldsymbol{R} \boldsymbol{D}$ em relação ao refino em $\boldsymbol{M J}$ pelo mesmo intervalo de tempo, enquanto a polpa $\boldsymbol{O}_{\mathbf{2 0 0}}$ apresentou maior área de poros acessíveis quando refinada por $60 \mathrm{~min}$ em $\boldsymbol{M J}$ do que em $\boldsymbol{R} \boldsymbol{D}$.

Em contrapartida, a moagem criogênica promoveu uma pequena redução nas áreas de poros acessíveis de todas as amostras em comparação às amostras iniciais não tratadas mecanicamente, do mesmo modo observado para o comportamento das áreas de poros totais. Os valores de áreas de poros acessíveis ( $\geq 9,90 \mathrm{~nm}$ ) obtidos para as amostras $\boldsymbol{F}, \boldsymbol{H}, \boldsymbol{H} \boldsymbol{O}_{180} \mathrm{e}$ $\boldsymbol{O}_{190}$ processadas em $\boldsymbol{M C}$ foram, respectivamente, $7,8,17,2,24,6$ e $24,7 \mathrm{~m}^{2} / \mathrm{g}$.

\subsubsection{Estrutura cristalina da celulose}

Além das dimensões morfológicas e da estrutura capilar da parede celular, a organização cristalina das cadeias celulósicas também pode ser afetada de modo considerável por tratamentos físico-mecânicos, sendo que o grau de modificação dos arranjos cristalinos depende do modo de ação do equipamento além da severidade do tratamento.

Além de expandir a área superficial interna das fibras, as forças de compressão e cisalhamento exercidas pelo refino afetam as interações de hidrogênio entre as cadeias celulósicas das superfícies cristalinas e, consequentemente, diminuem a atração entre fibrilas adjacentes. Ademais, a delaminação das paredes internas promove o afastamento dos componentes nas vizinhanças das fibrilas e altera suas distribuições nas superfícies expostas. 
Os resultados obtidos pela análise de difração de raios-X - dimensões laterais do cristalito de celulose ( $L_{200}$ e $L_{\text {diag }}$ ), distância interplanar $d_{200}$ e parâmetro $b$ da cela unitária monoclínica do polimorfo I $\beta$ da celulose - para as cinco amostras em estudo $\left(\boldsymbol{F}, \boldsymbol{H}, \boldsymbol{H} \boldsymbol{O}_{180}\right.$, $\boldsymbol{O}_{190}$ e $\boldsymbol{O}_{200}$ ), tanto não refinadas quanto processadas em moinho Jokro $(\boldsymbol{M J})$, em refinador de discos Bauer $(\boldsymbol{R D})$ e em moinho criogênico $(\boldsymbol{M C})$, encontram-se organizados nos gráficos das Figuras 50, 51, 52 e 53, respectivamente. Já os valores calculados de decréscimo percentual da cristalinidade da celulose encontram-se organizados na Figura 54. Os comportamentos dos dados permitiram avaliar, separadamente, o efeito da solubilização dos componentes não celulósicos e das forças mecânicas na organização do empacotamento cristalino da celulose; adicionalmente, interpretou-se a influência da recalcitrância da biomassa na habilidade das alterações promovidas por cada método de tratamento físico-mecânico proposto.

No que concerne os pré-tratamentos físico-químicos, observou-se que a solubilização dos componentes não celulósicos - lignina e hemiceluloses - resultou em aumentos expressivos das dimensões laterais do cristalito de celulose $\left(L_{200}\right.$ e $L_{d i a g}-$ Figuras 50 (A) e 51 (A)). Estudos publicados também reportaram o aumento das dimensões laterais dos cristalitos de celulose de biomassas lignocelulósicas quando estas foram submetidas a uma variedade de tratamentos químicos a altas temperaturas, e atribuíram este comportamento ao fenômeno denominado como co-cristalização da celulose (DRIEMEIER et al.; 2011; DRIEMEIER et al.; 2015; SUN et al., 2014). Os autores destes trabalhos observaram que os aumentos nas dimensões laterais dos cristalitos de celulose correlacionam fortemente com as mudanças nas composições químicas das biomassas, isto é, com o aumento no extensão de solubilização dos componentes não celulósicos, que atuam como espaçadores interfibrilares na ultraestrutura da parede celular. De modo similar, a formação de cristais com maior número de cadeias de celulose é frequentemente correlacionada com o aumento da pureza do substrato celulósico.

Com relação às fibras de bagaço in natura $(\boldsymbol{F})$, o pré-tratamento hidrotérmico $(\boldsymbol{H})$ e as polpações organossolve realizadas nas condições 1, 2 e $3\left(\boldsymbol{H O}_{\mathbf{1 8 0}}, \boldsymbol{O}_{\mathbf{1 9 0}}\right.$ e $\left.\boldsymbol{O}_{\mathbf{2 0 0}}\right)$, resultaram em alargamentos da dimensão lateral $L_{200}$ de, respectivamente, $11,4 \%, 22,7 \%, 24,3 \%$ e 45,9\%. Os mecanismos precisos que envolvem a co-cristalização ainda não são bem compreendidos. Entretanto, é proposto que a água de hidratação das interfaces cristal-cristal seja expelida durante o aumento da temperatura do processo como forma de aumentar a entropia do sistema, o que envolve a superação das rotações existentes entre cristais adjacentes no plano transversal e, consequentemente, viabiliza este tipo particular de agregação. 
Figura 49. Variação da dimensão lateral do cristalito de celulose $(\AA ̊)$ na direção do plano $(200)_{\mathrm{m}}$ com $(\mathrm{A})$ o tempo de refino em moinho Jokro, (B) o tempo de

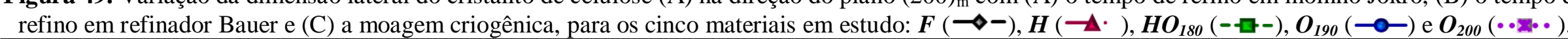

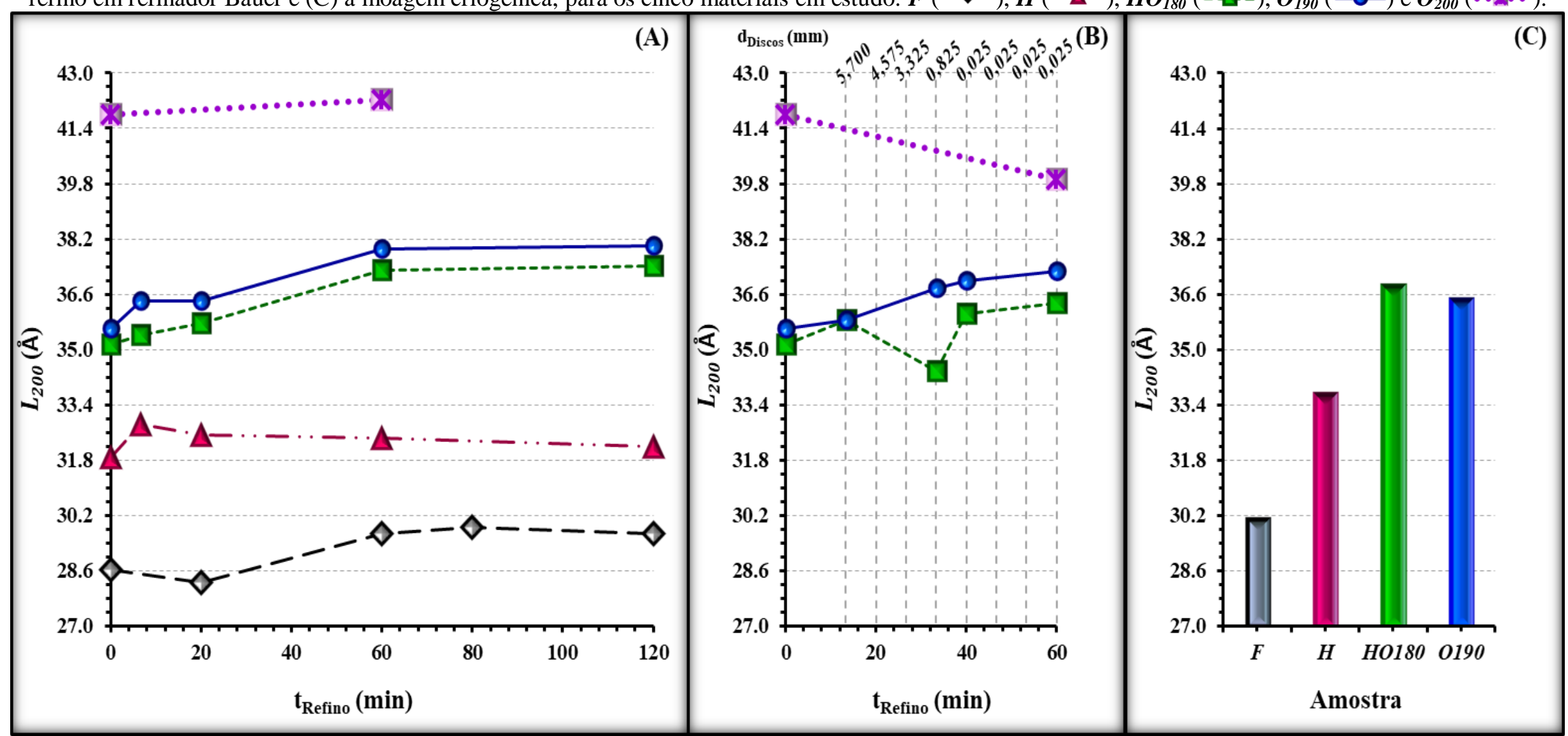

Legenda: $t_{\text {Refino }}=$ tempo de refino; $d_{\text {Discos }}=$ distância entre os discos; $L_{200}=$ dimensão lateral do cristalito de celulose na direção do plano $(200)_{\mathrm{m}}$. 
Figura 50. Variação da dimensão lateral do cristalito de celulose $(\AA)$ na direção dos planos $(110)_{\mathrm{m}} \mathrm{e}(1-10)_{\mathrm{m}}$ com $(\mathrm{A})$ o tempo de refino em moinho Jokro, (B) o tempo de refino em refinador Bauer e $(\mathrm{C})$ a moagem criogênica, para os cinco materiais em estudo: $\boldsymbol{F}(\longrightarrow-), \boldsymbol{H}(\rightarrow \boldsymbol{\Delta} \cdot), \boldsymbol{H O}_{180}(-\rightarrow-), \boldsymbol{O}_{190}(\longrightarrow \boldsymbol{0}-)$ e $\boldsymbol{O}_{200}$

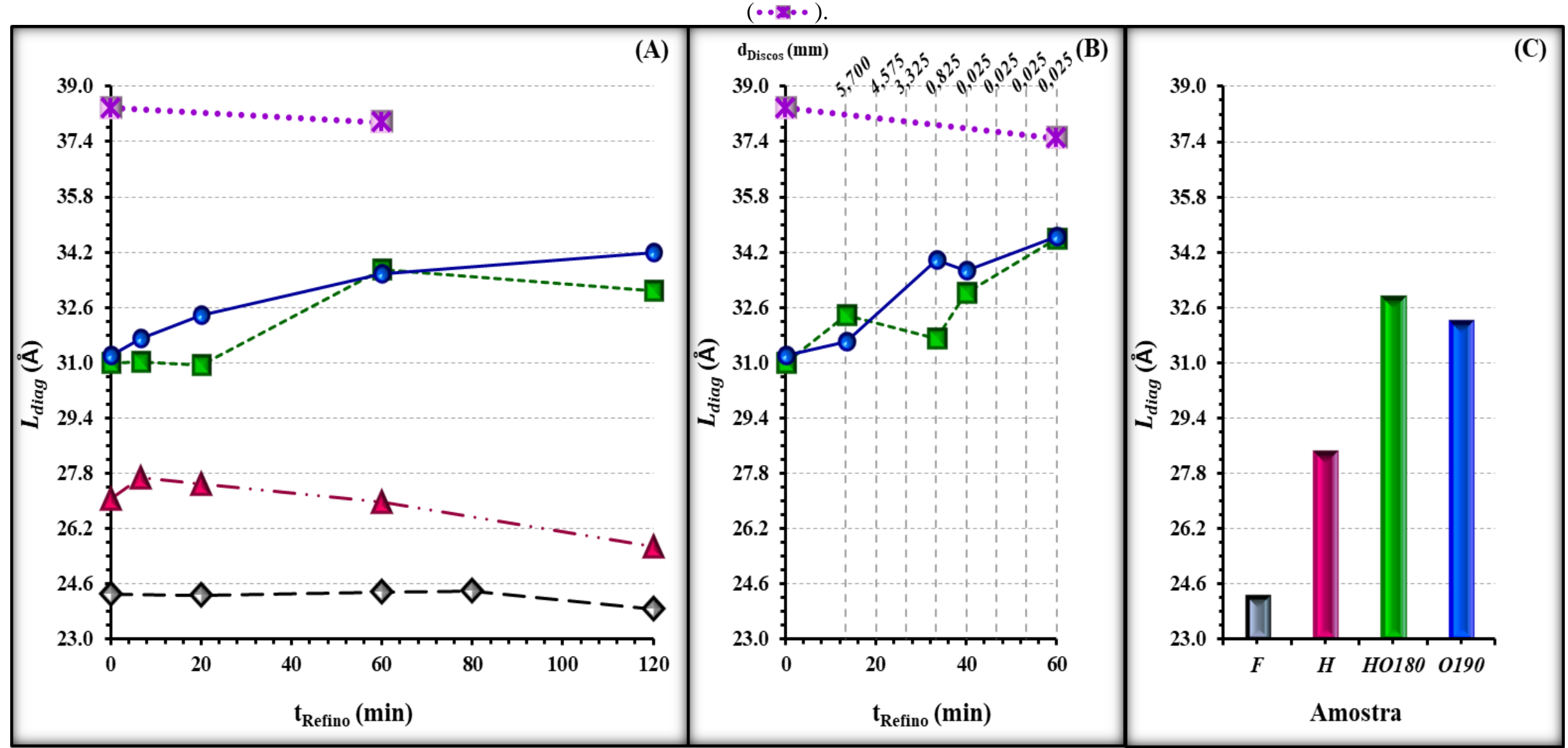

Legenda: $t_{\text {Refino }}=$ tempo de refino; $\mathrm{d}_{\text {Discos }}=$ distância entre os discos; $L_{\text {diag }}=$ dimensão lateral do cristalito de celulose na direção dos planos $(110)_{\mathrm{m}} \mathrm{e}(1-10)_{\mathrm{m}}$. 
Concomitante ao aumento nas dimensões laterais do cristalito de celulose, foi observada a sutil redução da distância interplanar $d_{200}$ (Figura 52 (A)). Este valor representa o espaçamento relativo entre camadas de celulose adjacentes ao longo do plano $(200)_{\mathrm{m}}$ interligadas por interações de hidrogênio na estrutura do polimorfo I $\beta$; deste modo, uma redução no valor deste parâmetro indica que o aumento do número de cadeias constituintes do cristalito implica diretamente na aproximação entre estas cadeias dentro do cristal.

O parâmetro $d_{200}$ é também sensitivo às variações que ocorrem na matriz que envolve o cristal, ou ainda à distância de separação e à orientação relativa entre as fibrilas. Portanto, seu valor pode ser um indicativo do grau de distorção do cristalito que surge da competição entre o volume ocupado por um cristal e as superfícies dos componentes na sua vizinhança (DRIEMEIER et al.; 2011). A aproximação do valor deste parâmetro com a referência para o cristal I $\beta(3,87 \AA ̊$ ) significa que a solubilização dos componentes não celulósicos promovida pelos tratamentos físico-químicos, e a consequente remoção da interferência promovida pelos espaçadores interfibrilares, permite a redução da distorção do cristalito de celulose (DRIEMEIER et al.; 2011; DRIEMEIER et al.; 2015). Comportamento similar é atribuído ao parâmetro $b$ da cela unitária, que aumentou e também se aproximou do valor de referência para o cristal I $\beta(8,2 \AA ̊$ ) com o aumento da solubilização dos componentes não celulósicos (Figura $53(\mathrm{~A}))$.

Com o aumento da severidade do pré-tratamento físico-químico, ou ainda com o aumento do teor de solubilização das hemiceluloses e da lignina, constatou-se o decréscimo acentuado do valor de cristalinidade mensurado em relação ao esperado para a amostra. Enquanto o pré-tratamento hidrotérmico (solubilização de 51,7\% das hemiceluloses e 11,3\% da lignina) provocou uma redução de 15,8\% no valor de cristalinidade em relação ao esperado, as polpações organossolve nas três diferentes condições provocaram reduções de aproximadamente 43\% (Figura 54 (A)). Se a medida de índice de cristalinidade de uma biomassa se refere à fração relativa de celulose cristalina no sólido, a redução no seu valor por alguma metodologia de processamento indica a desconstrução da organização cristalina da celulose, seja pela quebra do cristal ao longo de seu comprimento ou mesmo pela ruptura das interações eletrostáticas ao longo do plano; um tratamento pode ainda promover o aumento do índice de cristalidade mensurado para uma amostra se este resulta na degradação da celulose menos ordenada e mais acessível dentro dos deslocamentos e na superfície das fibrilas (PIHLAJANIEMI et al., 2016). 
Figura 51. Variação da distância intermolecular $(\AA)$ ao longo do plano (200) mo cristalito de celulose com (A) o tempo de refino em moinho Jokro, (B) o tempo de refino em refinador Bauer e $(\mathrm{C})$ a moagem criogênica, para os cinco materiais em estudo: $\boldsymbol{F}(\rightarrow-), \boldsymbol{H}(\rightarrow \mathbf{\Delta} \cdot), \boldsymbol{H} \boldsymbol{O}_{180}(-\boldsymbol{-}-), \boldsymbol{O}_{190}(\rightarrow \mathbf{O}-)$ e $\boldsymbol{O}_{200}$

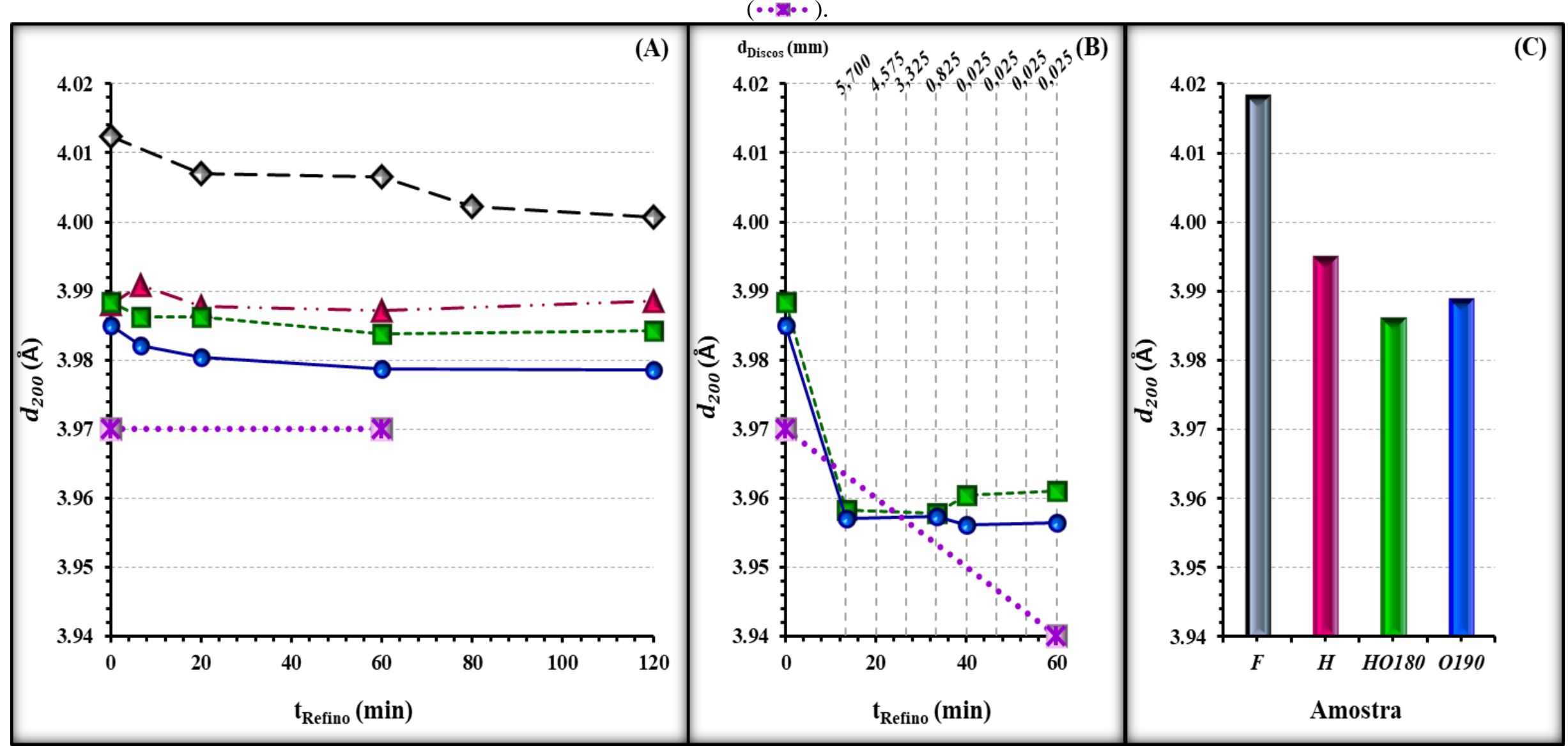

Legenda: $\mathrm{t}_{\mathrm{Refino}}=$ tempo de refino; $\mathrm{d}_{\text {Discos }}=$ distância entre os discos; $d_{200}=$ distância intermolecular ao longo do plano $(200)_{\mathrm{m}}$ no cristalito de celulose . 
Figura 52. Variação da dimensão b (Å) da cela unitária monoclínica do polimorfo I $\beta$ da celulose com (A) o tempo de refino em moinho Jokro, (B) o tempo de refino em refinador Bauer e $(\mathrm{C})$ a moagem criogênica, para os cinco materiais em estudo: $\boldsymbol{F}(\longrightarrow-), \boldsymbol{H}(\rightarrow \mathbf{\Delta} \cdot), \boldsymbol{H}_{180}(-\rightarrow-), \boldsymbol{O}_{190}(-\boldsymbol{O}-)$ e $\boldsymbol{O}_{200}(\bullet \bullet \bullet \bullet)$.

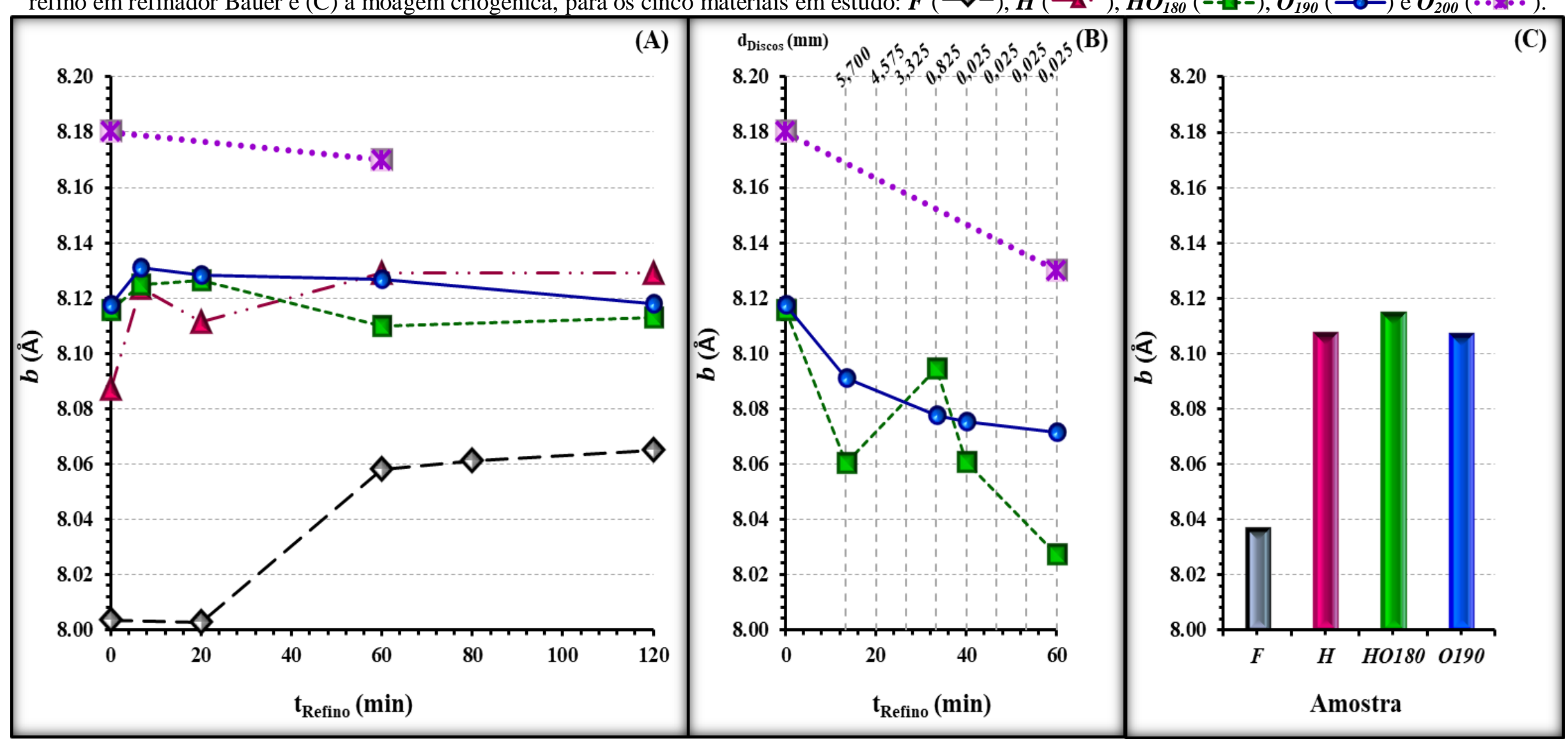

Legenda: $\mathrm{t}_{\text {Refino }}=$ tempo de refino; $\mathrm{d}_{\text {Discos }}=$ distância entre os discos; $b=$ dimensão $b$ da cela unitária monoclínica do polimorfo I $\beta$ da celulose. 
Figura 53. Variação do decréscimo da cristalinidade da celulose (\%) com (A) o tempo de refino em moinho Jokro, (B) o tempo de refino em refinador Bauer

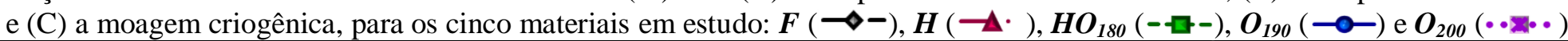

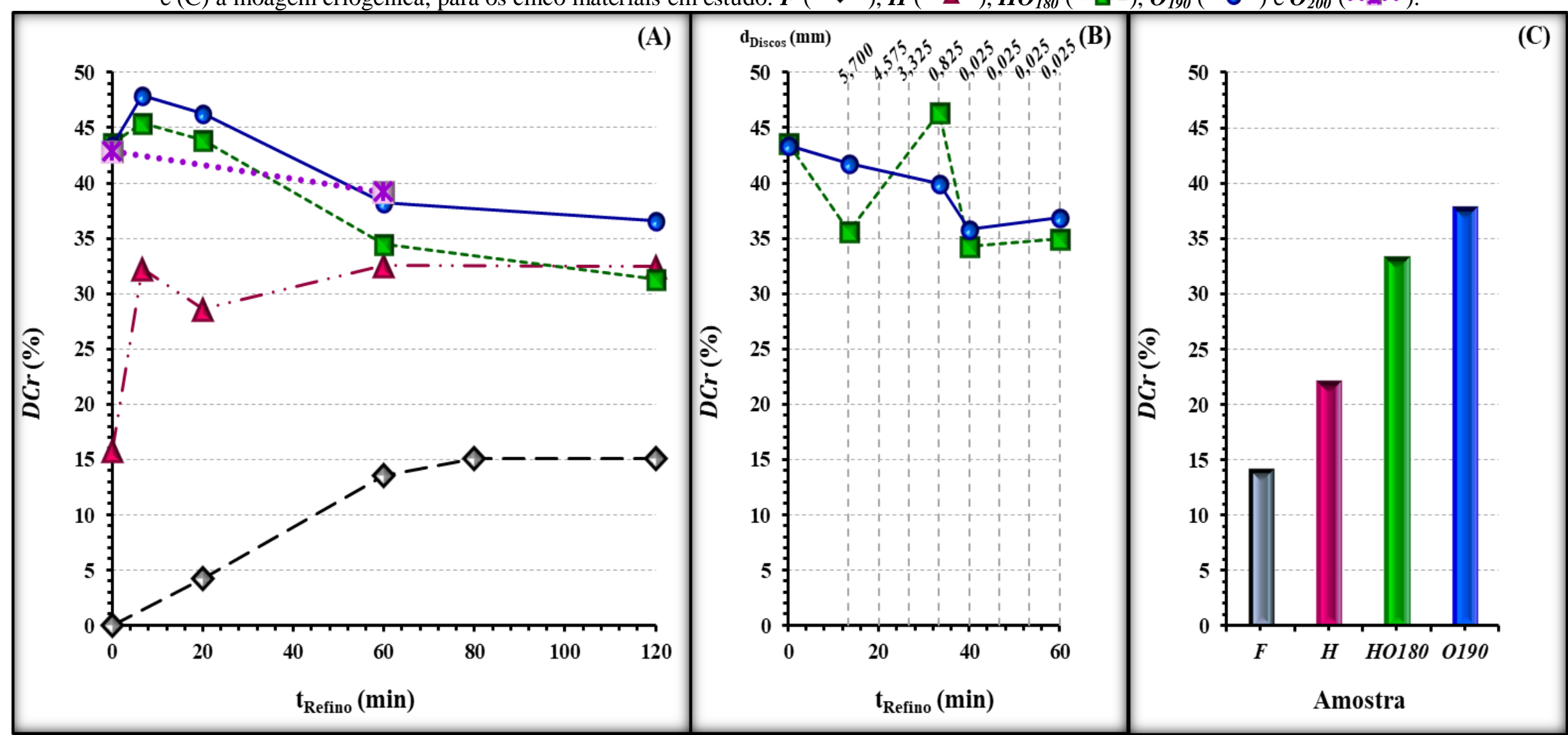

Legenda: $\mathrm{t}_{\text {Refino }}=$ tempo de refino; $\mathrm{d}_{\text {Discos }}=$ distância entre os discos; $D C r=$ diminuição percentual do índice de cristalinidade. 
DRIEMEIER et al. (2015) propôs a visão de que, uma vez removidos os componentes não ordenados das interfaces entre os cristais (predominantemente hemiceluloses), a desordem interfacial deve ser reestabelecida como forma de manter a transição entre cristalitos adjacentes com orientações cristalográficas contraditórias. Deste modo, após a solubilização das hemiceluloses e a consequente co-cristalização, uma fração da celulose pode ser descristalizada para exercer essa função estrutural de espaçador interfibrilar não cristalino. Uma interpretação alternativa para a redução da cristalinidade observada em coexistência à co-cristalização é o fato de um maior tamanho de cristal implicar em um maior número de cadeias na superfície dos cristais. A configuração adotada pelas cadeias celulósicas pertencentes à superfície dos cristais permite uma maior mobilidade dos grupos hidroximetila, logo estas cadeias apresentam uma menor rigidez pela inviabilidade da formação de algumas interações de hidrogênio intramoleculares; ademais, as cadeias da superfície de sofrem maior influência da matriz de polissacarídeos do entorno do cristal (ATALLA; VANDERHART, 1999; MOORE; BOTHA, 2014; VIËTOR et al., 2002).

Enquanto a co-cristalização é o processo de coesão entre cristais dentro de cada lamela da parede celular, a delaminação é o fenômeno de separação entre lamelas adjacentes. A avaliação conjunta dos parâmetros cristalinos - $L_{200}, L_{\text {diag }}, d_{200}, b$ e $D C r$ - obtidos para as amostras tratadas permitiu a constatação e a interpretação de diferentes comportamentos frente aos tipos e à severidade do refino para as cinco amostras de diferentes composições químicas.

A partir dos resultados de análise obtidos para o refino das cinco amostras em estudo em moinho Jokro $(\boldsymbol{M J})$ pôde-se observar aumentos sutis nas dimensões laterais do cristalito de celulose ( $L_{200}$ e $L_{\text {diag }}$ - Figuras 50 (A) e 51 (A)), notoriamente após altos tempos de refino ( $\geq 60$ minutos). Entretanto, estes incrementos foram menos representativos que os observados após os pré-tratamentos físico-químicos. Após 60 minutos de refino em $M J$, observaram-se alargamentos das dimensões laterais $L_{200}$ dos materiais $\boldsymbol{F}, \boldsymbol{H}, \boldsymbol{H} \boldsymbol{O}_{\mathbf{1 8 0}}, \boldsymbol{O}_{\mathbf{1 9 0}}$ e $\boldsymbol{O}_{\mathbf{2 0 0}}$ de, respectivamente, $3,6 \%(1,04 \AA), 1,8 \%(0,56 \AA), 6,1 \%(2,13 \AA), 6,5 \%(2,31 \AA$ ) e $1,0 \%(0,43 \AA)$. Ao mesmo passo, verificou-se alguma tendência de redução da distância interplanar $d_{200}$ (Figura 52 (A)) e de aumento do parâmetro $b$ da cela unitária (Figura 53 (A)), ambos se aproximando dos valores de referência para o cristal I $\beta$, sendo que estas variações foram mais significativas para as fibras de bagaço $(\boldsymbol{F})$ refinadas. 
As pequenas variações apresentadas nas larguras das amostras com o aumento do tempo de refino em $\boldsymbol{M J}$ podem ser atribuídas a um alargamento "aparente" do cristal de celulose, promovido pelo relaxamento do cristalito quando dos fenômenos de fibrilação e inserção de água. Isto porque a separação entre as lamelas implica no afastamento das vizinhanças (componentes espaçadores das fibrilas dentro dos agregados), e reduzem o efeito de distorção dos cristalitos, conforme suportado pelos dados de distância interplanar $d_{200}$ e de parâmetro de cela unitária. Outra possível explicação para este comportamento é que as altas energias específicas fornecidas às fibras pelo refino, associadas ao efeito de fibrilação criado nas paredes internas em meio aquoso, podem culminar na quebra e solubilização em pequena extensão dos carboidratos poliméricos menos ordenados encontrados nos interstícios entre as fibrilas. Com o arranque e a solubilização em pequena proporção destes compostos espaçadores, e o pequeno aquecimento do sistema pelo fornecimento de uma alta energia de fricção, pode-se supor algum efeito de migração e rearranjo das cadeias celulósicas das superfícies de cristalitos adjacentes, resultando na co-cristalização da celulose.

Comportamentos similares de alargamentos dos cristalitos de celulose de biomassa lignocelulósica promovidos por métodos de processamento físico-mecânicos não foram encontrados na literatura. Entretanto, ambas as suposições parecem coerentes e justificam o fato da polpa $\boldsymbol{O}_{200}(91,9 \%$ de celulose) refinada em $\boldsymbol{M J}$ por 60 minutos apresentar o menor alargamento e a menor redução da distorção dos cristalitos entre todos os materiais, visto que este material possuía a menor quantidade de compostos não cristalinos nas interfaces entre os cristalitos. De modo semelhante, estas hipóteses justificam o fato das fibras de bagaço in natura apresentarem a maior redução da distorção dos cristalitos entre todos os materiais. De forma singular, as polpas $\boldsymbol{H O}_{180}$ e $\boldsymbol{O}_{\mathbf{1 9 0}}$, quando refinadas em $\boldsymbol{M J}$ por tempos maiores ou iguais a 60 minutos, apresentaram alargamentos dos cristalitos mais pronunciados.

Com o aumento da severidade do refino em $\boldsymbol{M J}$, observou-se o decréscimo contínuo do valor de cristalinidade da amostra $\boldsymbol{F}$ em relação ao valor esperado, atingindo uma redução de $15,1 \%$ em 120 minutos de processamento. Este resultado decorreu como reflexo ou do provável fenômeno de co-cristalização ou de rupturas de interações eletrostáticas ao longo do plano. Já amostra $\boldsymbol{H}$ atingiu uma rápida redução adicional de 16,4 pontos percentuais no valor de cristalinidade em relação ao valor esperado após 6,7 minutos de refino, tempo depois do qual não foram observados incrementos representativos, o que relacionou diretamente com o comportamento observado para as dimensões laterais dos cristalitos. 
As polpas organossolve $\boldsymbol{H O}_{180}$ e $\boldsymbol{O}_{190}$ também apresentaram pequenas reduções adicionais (1,8 e 4,5 pontos percentuais, respectivamente) no valor de cristalinidade mensurado em relação ao esperado após 6,7 min de refino em $\boldsymbol{M J}$; entretanto, após este tempo, observaram-se aumentos de até 14,1 e 11,3 pontos percentuais, respectivamente, nos valores de cristalinidade mensurados em relação aos valores esperados. Há pelo menos duas hipóteses que justificam este comportamento. As altas severidades de refino associadas à maior facilidade de processamento das polpas de menos recalcitrantes podem resultar na degradação da porção celulósica mais acessível e menos ordenada dentro dos deslocamentos e nas superfícies das fibrilas pelas forças de compressão e cisalhamento aplicadas. Como alternativa, se ocorre uma solubilização em pequena extensão dos carboidratos poliméricos durante o processo de delaminação, esta influencia no valor de índice de cristalinidade mensurado, que será maior; um maior valor de índice de cristalinidade, por sua vez, implica em um menor valor de decréscimo de cristalinidade calculado.

De forma semelhante, o processamento em refinado de discos Bauer $(\boldsymbol{R D})$ também implicou em aumentos sutis nas dimensões laterais dos cristalitos de celulose das polpas $\boldsymbol{H O}_{180}$ e $\boldsymbol{O}_{190}$. Novamente, estes incrementos foram menos representativos que os observados após os pré-tratamentos físico-químicos. Após 60 minutos de refino em $\boldsymbol{R D}$, observaram-se alargamentos das dimensões laterais $L_{200}$ e $L_{\text {diag }}$ (Figuras 50 (B) e 51 (B)) de, respectivamente: $3,4 \%(1,18 \AA \AA)$ e $11,5 \%(3,57 \AA ̊)$ para a polpa $\boldsymbol{H O}_{180}, 4,7 \%(1,69 \AA$ A $)$ e $11,0 \%$ $(3,42 \AA)$, para a polpa $\boldsymbol{O}_{190}$. Ao mesmo passo, também se verificou uma tendência mais pronunciada de redução da distância interplanar $d_{200}$ (Figura 52 (B)), porém com acompanhada de uma redução do parâmetro $b$ da cela unitária (Figura 53 (B)), o que indica uma redução da distorção do cristalito no sentido do plano $(200)_{\mathrm{m}}$ e um aumento da distorção no sentido dos planos $(110)_{\mathrm{m}}$ e $(1-10)_{\mathrm{m}}$. Uma exceção foi observada para a polpa $\boldsymbol{O}_{200}$, que apresentou reduções de $4,5 \%$ e $2,3 \%$ nas dimensões laterais $L_{200}$ e $L_{\text {diag }}$, respectivamente.

Enquanto os alargamentos nas dimensões laterais dos cristalitos das amostras $\boldsymbol{H O}_{180} \mathrm{e}$ $\boldsymbol{O}_{190}$ com o aumento do tempo de refino em $\boldsymbol{R} \boldsymbol{D}$ podem ser atribuídas aos anteriormente mencionados fenômenos de relaxamento "aparente" do cristalito ou de co-cristalização da celulose, a redução nas dimensões laterais dos cristalitos da polpa $\boldsymbol{O}_{200}$ pode estar relacionada à quebra da estrutura com o desligamento das cadeias das superfícies dos cristalitos. Quando refinadas por 60 minutos em $\boldsymbol{R D}$, as polpas organossolve $\boldsymbol{H O}_{18 \boldsymbol{0}}$ e $\boldsymbol{O}_{190}$ também apresentaram pequenos aumentos de $19,7 \%$ e $15,1 \%$, respectivamente, nos valores de cristalinidade 
mensurados em relação aos esperados, ou pela degradação da porção celulósica amorfa dentro dos deslocamentos ou por artefatos na medida do índice de cristalinidade devido a algum teor de solubilização de componentes não cristalinos (Figura 54 (B)).

Nos parâmetros definidos para a moagem criogênica $(\boldsymbol{M C})$, as amostras em estudo apresentaram as mesmas tendências observadas para o refino em $\boldsymbol{M J}$ (Figuras 50 (C) e 51 (C)). Todos os materiais apresentaram aumentos das dimensões laterais dos cristalitos. Foram registrados alargamentos das $L_{200}$ dos materiais $\boldsymbol{F}, \boldsymbol{H}, \boldsymbol{H O}_{180}$ e $\boldsymbol{O}_{190}$ de, respectivamente, $5,13 \%(1,47 \AA), 5,7 \%(1,81 \AA ̊), 4,8 \%(1,69 \AA ̊)$ e $2,4 \%$ (0,85 $)$. Contudo, enquanto as amostras $\boldsymbol{F}$ e $\boldsymbol{H}$ exibiram reduções nos valores cristalinidade de 14,0 e 6,2 pontos percentuais em relação aos esperados, as polpas $\boldsymbol{H O}_{180}$ e $\boldsymbol{O}_{190}$ apresentaram acréscimos de 10,4 e 5,7 pontos percentuais, respectivamente (Figura $54(\mathbf{C})$ ).

Consoante ao mencionado no item 2.2.5.3, a alta agregação das fibrilas celulósicas se relaciona à restrição da área superficial interna da parede celular. Em outras palavras, a estrutura capilar é influenciada pelas propriedades cristalinas da celulose (ARANTES; SADDLER, 2010). Neste sentido, seria então esperado que a formação de cristais com maiores dimensões ocorresse ao mesmo passo que o volumes de poros fosse reduzido.

Observando os parâmetros cristalinos obtidos para as amostras submetidas aos processos físico-mecânicos, constatou-se que estes foram principalmente afetados pela delaminação das paredes internas, que induz o alargamento das dimensões laterais dos cristalitos pelo afastamento dos componentes nas vizinhanças (interfaces fibrilares). Todavia, este mesmo efeito primário do refino é responsável por expandir a estrutura capilar da parede celular e promover o intumescimento. Com esta visão, confrontaram-se os dados de dimensão de cristalito $L_{200}$, obtidos para as amostras em estudo, com seus respectivos volumes de poros mensurados por TP-DSC, conforme apresentado na Figura 55.

A forte correlação observada no gráfico acima entre as dimensões laterais dos cristais na direção do plano $(200)_{\mathrm{m}}$ e os volumes totais de poros das amostras de diferentes composições químicas, e submetidas a diferentes métodos de processamento físicomecânicos, demonstra que estas propriedades estão, de algum modo, inter-relacionadas. Por conseguinte, um maior grau de agregação fibrilar foi induzido ao mesmo passo que uma maior quantidade de interstícios (poros interfibrilares e interlamelares) foi criada dentro da estrutura da parede celular, resultando em uma maior área superficial interna. Esta observação está de acordo com o reportado por VIRTANEN et al. (2015), que afirmaram que o 
cisalhamento mecânico implica tanto no aumento do volume de poros micro- e nanométricos quanto no aumento da distância interfibrilar, o que reduz o efeito das moléculas nas vizinhanças das configurações cristalinas.

Figura 54. Variação da dimensão lateral do cristalito de celulose $(\AA)$ na direção do plano $(200)_{\mathrm{m}}$ com o volume de poros $(\mathrm{cm} 3 / \mathrm{g})$ da parede celular para os diferentes materiais em estudo.

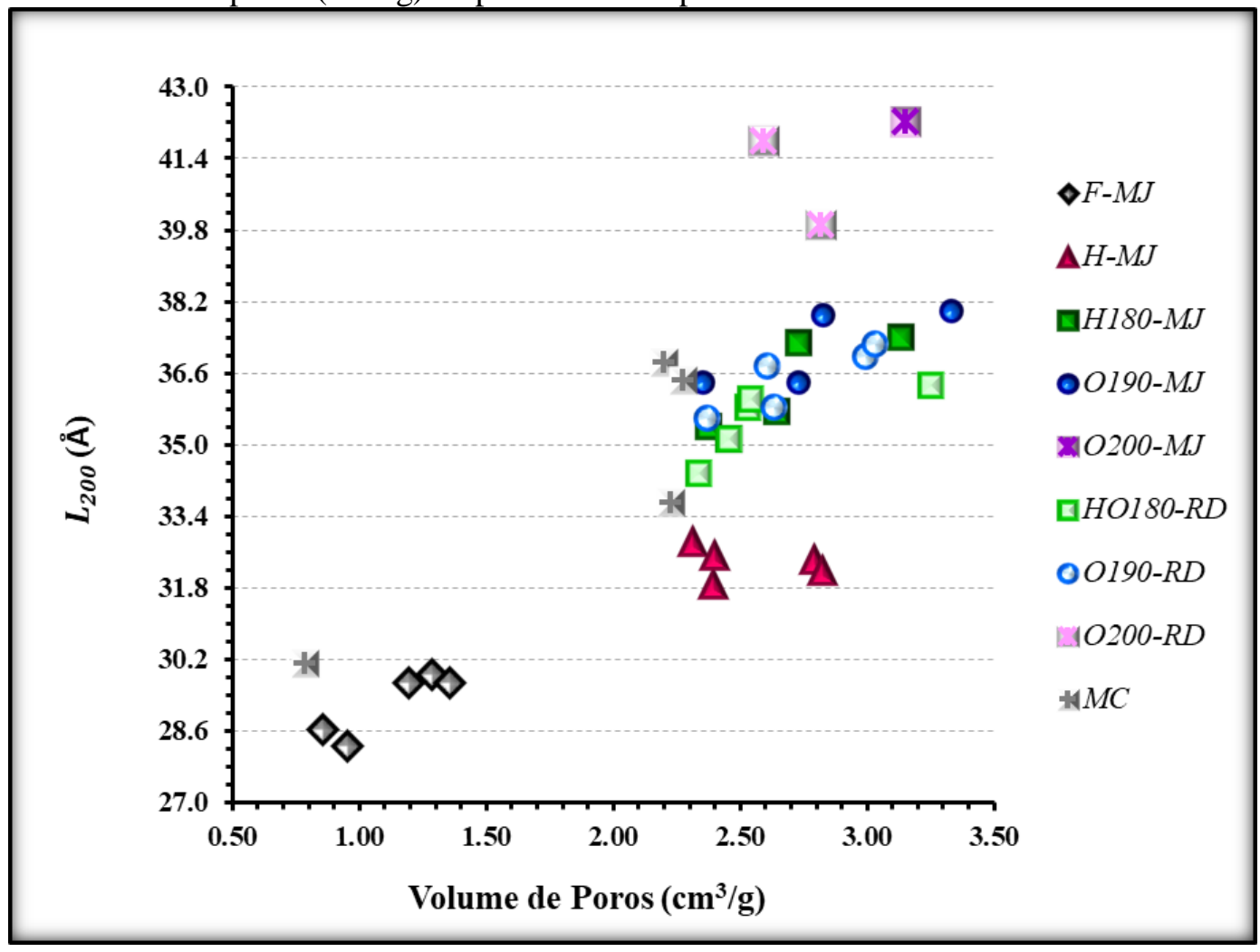

\subsection{EFEITOS DAS PROPRIEDADES ESTRUTURAIS NA EFETIVIDADE DA SACARIFICAÇÃO ENZIMÁTICA DAS AMOSTRAS DE BAGAÇO}

\subsubsection{Sacarificação enzimática}

As mudanças nas propriedades físicas e morfológicas das fibras lignocelulósicas provocadas pelos processos de refino promovem a abertura estrutural da parede celular, de modo que são observados o aumento da acessibilidade aos carboidratos poliméricos constituintes e a redistribuição destes na superfície e nas diferentes camadas da parede celular (BANAVATH; BHARDWAJ; RAY，2011; BHARDWAJ; HOANG; NGUYEN, 2007; FARDIM; DURÁN, 2003). Os dados obtidos nas caracterizações físicas e morfológicas das 
amostras de bagaço submetidas a diferentes pré-tratamentos e ao refino mecânico (item 5.3) permitiram concluir que esta tecnologia leva ao rompimento da organização estrutural da parede celular por descontruir as camadas mais externas, expor as camadas mais internas, alterar os espaços interfibrilares e afetar a organização cristalina das fibras lignocelulósicas.

De acordo com o cenário apresentado no item 2.2.8, estas alterações são essenciais para a viabilidade da bioconversão dos polissacarídeos presentes nas fibras lignocelulósicas. Valendo-se da oportunidade de aumentar a acessibilidade das enzimas hidrolíticas e, consequentemente, a eficiência de produção de açúcares fermentescíveis a partir do bagaço de cana-de-açúcar, estudou-se a efetividade da aplicação do refino mecânico como método de pré-tratamento para diminuir a recalcitrância e desconstruir as fibras lignocelulósicas.

Dentro deste trabalho, equipamentos físico-mecânicos de diferentes tipos e operados em diferentes condições foram empregados para o processamento de amostras de bagaço de diferentes composições químicas. Observou-se então a influência da alteração de cada parâmetro estrutural na eficiência da conversão bioquímica da celulose em açúcar fermentescível. Os diferentes mecanismos de ação destes equipamentos nas fibras dos materiais resultaram em diferentes incrementos observados na taxa de conversão enzimática da biomassa por promoverem distintos níveis de abertura na estrutura da parede celular.

Os valores de rendimento de glicose obtidos a partir da hidrólise enzimática das 5 amostras de bagaço de cana-de-açúcar em estudo encontram-se na Tabela 8. Já os valores de rendimento de glicose destes 5 materiais em função do tempo de refino em moinho Jokro (A), em função do tempo de refino e da distância entre os discos em refinador Bauer (B) e em função da moagem criogênica (C), após $24 \mathrm{~h}, 48 \mathrm{~h}$ e $72 \mathrm{~h}$ de reação enzimática, encontram-se organizados nas Figuras 57, 58 e 59, respectivamente.

Tabela 8. Valores de rendimento de glicose (\%) obtidos após $24 \mathrm{~h}, 48 \mathrm{~h}$ e $72 \mathrm{~h}$ de hidrólise enzimática para as cinco as amostras de bagaço de cana-de-açúcar em estudo.

\begin{tabular}{c|c|c|c}
\hline \multirow{2}{*}{ Amostra } & \multicolumn{3}{|c}{$\boldsymbol{R}_{\text {Glicose }}(\boldsymbol{\%})$} \\
\cline { 3 - 4 } & $\mathbf{2 4 h}$ & $\mathbf{4 8 h}$ & $\mathbf{7 2 h}$ \\
\hline$F$ & $6,7 \pm 0,0$ & $7,3 \pm 0,2$ & $7,8 \pm 0,3$ \\
$H$ & $13,9 \pm 0,5$ & $15,7 \pm 0,8$ & $17,2 \pm 0,3$ \\
$H O_{180}$ & $28,4 \pm 0,6$ & $31,5 \pm 0,8$ & $31,7 \pm 0,9$ \\
$O_{190}$ & $39,1 \pm 0,9$ & $42,3 \pm 0,6$ & $45,1 \pm 0,6$ \\
$O_{200}$ & $67,0 \pm 1,7$ & $75,5 \pm 0,7$ & $76,8 \pm 2,0$ \\
\hline
\end{tabular}


A Tabela 8 e os gráficos presentes nas Figuras 57, 58 e 59 permitiram constatar que a conversão da celulose em glicose ocorreu em maior extensão nas primeiras $24 \mathrm{~h}$ de reação, e apenas de modo incremental nas $48 \mathrm{~h}$ restantes, indicando a redução da taxa de conversão catalítica da celulose com o decorrer da reação de hidrólise. Pôde-se também observar que os incrementos brutos nos valores de rendimento de glicose pela extensão da reação de hidrólise por $72 \mathrm{~h}$ em relação ao rendimento obtido após $24 \mathrm{~h}$ de reação $\left(R_{72 h}-R_{24 h}\right)$ foi maior quanto menor a recalcitrância do material. Entretanto, os incrementos percentuais não apresentaram a mesma relação $\left(\left[\left(R_{72 h}-R_{24 h}\right) \times 100\right] / R_{24 h}\right)$. Por exemplo, os rendimentos de glicose obtidos para os materiais $\boldsymbol{F}, \boldsymbol{H}, \boldsymbol{H O}_{180}, \boldsymbol{O}_{190}$ e $\boldsymbol{O}_{200}$ não refinados após $72 \mathrm{~h}$ de reação foram aumentados em $1,1 \%, 3,3 \%, 3,3 \%, 6,1 \%$ e 9,8\%, respectivamente, em relação aos valores obtidos após $24 \mathrm{~h}$ de reação.

Conforme introduzido no item 2.2.5.4, o comportamento cinético da reação de hidrólise da celulose, aplicando as endoglicanases, celobiohidrolases e $\beta$-glicosidases em processos batelada, é caracterizado pelo declínio pronunciado da taxa de conversão observada ao longo do curso da reação, até mesmo quando é formada uma baixa concentração de açúcares redutores no hidrolisado final. Em suma, entre os diversos motivos apontados na literatura para a variação da velocidade da reação catalítica ao longo do tempo podem-se citar:

- A inibição das enzimas celulolíticas pelos principais produtos da hidrólise, glicose e celobiose, o que diminui a eficiência da reação catalítica e, portanto, limita o rendimento final de produto (ANDERSEN, 2007; ANDRIC' et al., 2010a; BHAUMIK; DHEPE, 2016; GRUNO et al., 2004; HOLTZAPPLE et al., 1990; JÄGER; BÜCHS, 2012; MENON; RAO, 2012; PRASAD; SINGH; JOSHI, 2007; RABINOVICH; MELNICK; BOLOBOVA, 2002; SUN et al., 2016);

- $\quad$ A adsorção de celulases inativadas (ou inibidas) na superfície da celulose, o que impede ou bloqueia a aproximação de outras enzimas ativas;

- A digestão da porção amorfa mais acessível dentro dos deslocamentos e na superfície das fibrilas celulósicas durante os primeiros estágios da reação, o que pode resultar em um acumulo de substrato com maior grau de cristalinidade, cuja velocidade de degradação é mais lenta (ANDRIC' et al., 2010a; ARANTES; SADDLER, 2010; BANSAL et al., 2012; GOURLAY et al., 2015; MOONEY et al., 1998; YANG et al., 2011; ZHANG; LYND, 2004). 
- A redução da área superficial acessível com o decorrer da reação, uma vez que há a digestão dos polissacarídeos mais acessíveis durante os primeiros estágios (ANDERSEN, 2007; ARANTES; SADDLER, 2011; BANSAL et al., 2012; MOONEY et al., 1998; WANG et al., 2006; YANG et al., 2011).

- $\quad \mathrm{O}$ aumento da probabilidade de interações não produtivas entre as celulases e a lignina com o consumo dos carboidratos acessíveis e a consequente maior área superficial exposta da lignina (VERMAAS et al., 2015).

- $\quad \mathrm{O}$ impedimento estérico da ação processiva das $\mathrm{CBH}$ (componentes majoritários dos complexos celulolíticos fúngicos) devido à superfície erodida das fibrilas, onde a enzima fica retida nos defeitos estruturais durante a reação hidrolítica (ANDERSEN, 2007; DAVIES; HENRISSAT, 1995; HU et al., 2015b; JÄGER; BÜCHS, 2012; JALAK; V ÄLJAMÄE, 2010; VÄLJAMÄE et al., 1998).

- A desativação das enzimas pelo aprisionamento dentro dos poros da parede celular ao longo da reação, o que reduz a atividade proteica (CONVERSE et al., 1988; ZHANG; LYND, 2004).

Outro ponto a ser considerado é que os modelos de substratos celulósicos utilizados para determinar a atividade enzimática dos coquetéis empregados não necessariamente predizem sua performance hidrolítica nos materiais lignocelulósicos heterogêneos. Além disso, a atividade enzimática é determinada de acordo com os produtos formados nos primeiros tempos, e não consideram a potencial inibição pelo produto formado e o aumento da recalcitrância do substrato com o decorrer da reação (HU et al., 2013; HU et al., 2015b).

Observou-se que os valores de rendimento de glicose obtidos nos diferentes tempos de reação enzimática foram maiores quanto maiores as solubilizações dos componentes não celulósicos promovidas pelos prévios tratamentos físico-químicos. Uma vez que as associações existentes entre os macrocomponentes na ultraestrutura da parede celular restringem o acesso das enzimas à superfície das fibrilas celulósicas, é esperado que a quebra das interações lignina-carboidratos e a solubilização das hemiceluloses e da lignina promovam o aumento da eficiência da reação catalítica de hidrólise bioquímica da celulose; isto porque a remoção destes componentes causa o aumento extensivo da porosidade da parede celular, o que permite uma maior difusão dos agentes hidrolíticos às camadas mais interiores (ARANTES; GOURLAY; SADDLER, 2014; BARAKAT; DE VRIES; ROUAU, 
2013; JEOH et al., 2007; KUMAR et al., 2012; LEE et al., 2010; LIN et al., 2010; MOONEY et al., 1998; VÁRNAI; SIIKA-AHO; VIIKARI, 2010).

O pré-tratamento hidrotérmico, realizado em condição branda de reação $(\boldsymbol{H})$, hidrolisou e solubilizou majoritariamente as hemiceluloses $(51,7 \%)$ e parcialmente a lignina $(11,3 \%)$, promovendo o rompimento do complexo lignina-carboidratos, o aumento de $114,0 \%$ na área de poros acessíveis $(\geq 9,90 \mathrm{~nm})$ em relação às fibras de bagaço in natura, além da alteração na organização cristalina da celulose. As mudanças provocadas na composição química e na estrutura física da biomassa durante o pré-tratamento hidrotérmico permitiram melhorar a eficiência da posterior etapa de hidrólise enzimática, levando a um aumento no rendimento de glicose por hidrólise enzimática de 118,8\% em relação às fibras de bagaço in natura, atingindo o rendimento de $17,2 \%$ em $72 \mathrm{~h}$ de reação.

Uma vez que apenas uma pequena porção da lignina foi de fato removida durante o pré-tratamento hidrotérmico e houve o aumento no seu teor relativo na biomassa pré-tratada, poderia ser esperado o aumento da área superficial de cobertura da lignina; uma maior exposição da lignina, por sua vez, promove o bloqueio do acesso das enzimas celulolíticas às fibrilas celulósicas, assim como aumenta a ocorrência da adsorção irreversível das enzimas na superfície da lignina. Entretanto, não houve nenhum impacto negativo no rendimento de hidrólise pelo aumento no teor de lignina após o pré-tratamento, uma vez que o aumento na acessibilidade da celulose pela solubilização das hemiceluloses compensou o papel restritivo da lignina (DONOHOE et al., 2008; FAN et al., 2016; KO et al., 2015b; XIAO et al., 2013).

Apesar da remoção das hemiceluloses promovida pelo prévio tratamento hidrotérmico implicar no significante aumento da hidrolisabilidade enzimática das cadeias celulósicas, observou-se que as hemiceluloses residuais foram digeridas em igual extensão pelas enzimas hidrolíticas, independente da proporção relativa de cada polissacarídeo nas fibras do material e das modificações estruturais promovidas pelas diferentes técnicas e intensidades de tratamento físico-mecânico. A partir do gráfico presente na Figura 56, pôde-se constatar que a conversão das hemiceluloses correlaciona linearmente com a conversão da celulose a uma razão constante. Este comportamento é justificado pelo fato de que as proteínas constituintes dos coquetéis enzimáticos empregados na reação hidrolítica também possuem a habilidade de hidrolisar hemiceluloses e xilo-oligossacarídeos em xilose, o que diminui o seu efeito bloqueador na digestibilidade da celulose (ANDERSEN, 2007; DRIEMEIER, 2017; KUMAR; WYMAN, 2009a; LIN et al., 2010; LYND et al., 2002). 
Se as hemiceluloses são consumidas em igual extensão pelas enzimas celulolíticas, mesmo quando o processo não altera a composição química do material, a influência do prétratamento hidrotérmico na melhora da hidrolisabilidade enzimática das fibras de bagaço está mais atrelada ao aumento da área superficial interna e ao rompimento das interligações lignina-polissacarídeos, que permitem a criação de caminhos nanométricos para a penetração das enzimas na estrutura da parede celular, do que a remoção das hemiceluloses por si.

Figura 55. Variação do rendimento de xilose (\%) obtido após $72 \mathrm{~h}$ de hidrólise enzimática com o rendimento de glicose (\%) para os diferentes materiais em estudo.

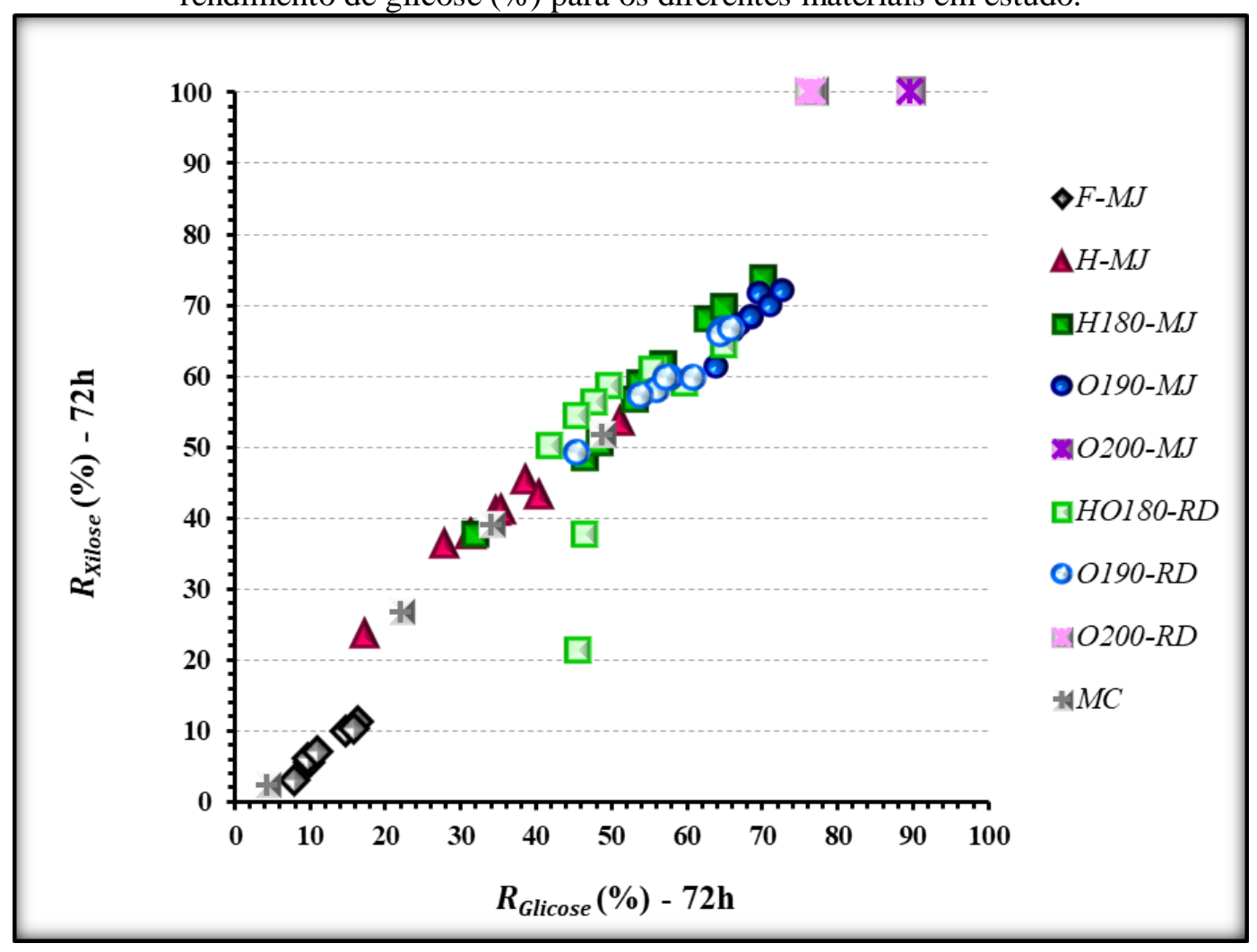

A posterior deslignificação do material pré-tratado por meio do processo organossolve realizado na condição $1\left(\boldsymbol{H O}_{180}\right)$ proporcionou a remoção adicional de $52,8 \%$ das hemiceluloses e 75,7\% da lignina, resultando em um aumento de 52,7\% na área de poros acessíveis $(\geq 9,90 \mathrm{~nm})$ em relação às fibras de bagaço pré-tratadas $\boldsymbol{H}$. A solubilização em maior extensão tanto das hemiceluloses quanto da lignina permitiram melhorar a capacidade de penetração e difusão das enzimas hidrolíticas, e resultaram em um aumento no rendimento de glicose por hidrólise enzimática de $84,7 \%$ em relação às fibras de bagaço pré-tratadas hidrotérmicamente, atingindo o rendimento de $31,7 \%$ em $72 \mathrm{~h}$ de reação. 
A deslignificação organossolve direta das fibras de bagaço in natura sob a condição 2 $\left(\boldsymbol{O}_{190}\right)$ resultou em um material com teores de lignina e hemiceluloses 46,6\% e 5,2\%, respectivamente, menores do que a polpa $\boldsymbol{H O}_{180}$, porém com uma área de poros acessíveis $(\geq$ $9,90 \mathrm{~nm})$ similar $\left(25,8 \mathrm{~m}^{2} / \mathrm{g}\right)$. Apesar da área superficial interna similar, a polpa $\boldsymbol{O}_{190}$ resultou em uma maior eficiência da reação enzimática, proporcionando um rendimento de glicose 42,3\% maior em relação ao obtido para a polpa $\boldsymbol{H O}_{180}$, atingindo o rendimento de $45,1 \%$ em $72 \mathrm{~h}$ de reação.

Os menores valores de rendimento de glicose obtidos para a polpa $\boldsymbol{H O}_{180}$ em relação à polpa $\boldsymbol{O}_{190}$ podem então ser atribuídos ao maior teor relativo de lignina presentes nas fibras do material obtido pelo processo sequencial. Conforme amplamente detalhado no item 2.2.5.2.2, a restrição exercida pela lignina na ação enzimática de digestão das biomassas lignocelulósicas se dá de três modos: 1) como barreira física ao acesso das celulases às ligações glicosídicas dos polissacarídeos; 2) como agente bloqueador da ação processiva das CBH ao longo das cadeias celulósicas; e 3) como ligante não produtivo e irreversível nas enzimas celulolíticas, reduzindo a quantidade de proteínas disponíveis para catalisar a hidrólise dos polissacarídeos.

Já a deslignificação organossolve direta sob a condição $3\left(\boldsymbol{O}_{\mathbf{2 0 0}}\right)$ provocou a extensa remoção de $94,5 \%$ das hemiceluloses e $94,2 \%$ da lignina presente nas fibras do bagaço; entretanto, a polpa obtida apresentou uma área de poros acessíveis $(\geq 9,90 \mathrm{~nm})$ similar às demais polpas $\left(27,0 \mathrm{~m}^{2} / \mathrm{g}\right)$. Neste caso, as remoções extensivas da lignina e das hemiceluloses implicaram na ruptura quase completa da matriz lignina-polissacarídeos, o que resultou em um significante aumento de quase 9 vezes no rendimento de glicose por hidrólise enzimática em relação às fibras de bagaço in natura, atingindo o rendimento de 76,8\% em 72h de reação.

Se o tipo de equipamento físico-mecânico empregado, as variáveis do processo e a intensidade do tratamento definem o padrão das modificações nas propriedades estruturais das fibras lignocelulósicas, estes também regerão as variações nos rendimentos de açúcares fermentescíveis obtidos na subsequente etapa de sacarificação enzimática. Na tabela presente no Anexo H encontram-se organizados os valores dos incrementos alcançados nos rendimentos de açúcares redutores (glicose e xilose) com os diferentes processos físicomecânicos em relação às amostras não refinadas de mesma composição química, calculados segundo a Equação 1. 
Figura 56. Variação do rendimento de glicose (\%) após $24 \mathrm{~h}$ de hidrólise enzimática com (A) o tempo de refino em moinho Jokro, (B) o tempo de refino em refinador Bauer e (C) a moagem criogênica, para os cinco materiais em estudo: $\boldsymbol{F}(\rightarrow-), \boldsymbol{H}(\rightarrow \mathbf{\Delta} \cdot), \boldsymbol{H} \boldsymbol{O}_{180}(-\rightarrow-), \boldsymbol{O}_{190}(-0-)$ e $\boldsymbol{O}_{200}\left(\cdot \bullet \cdot \boldsymbol{m}_{\bullet \bullet} \cdot\right)$.

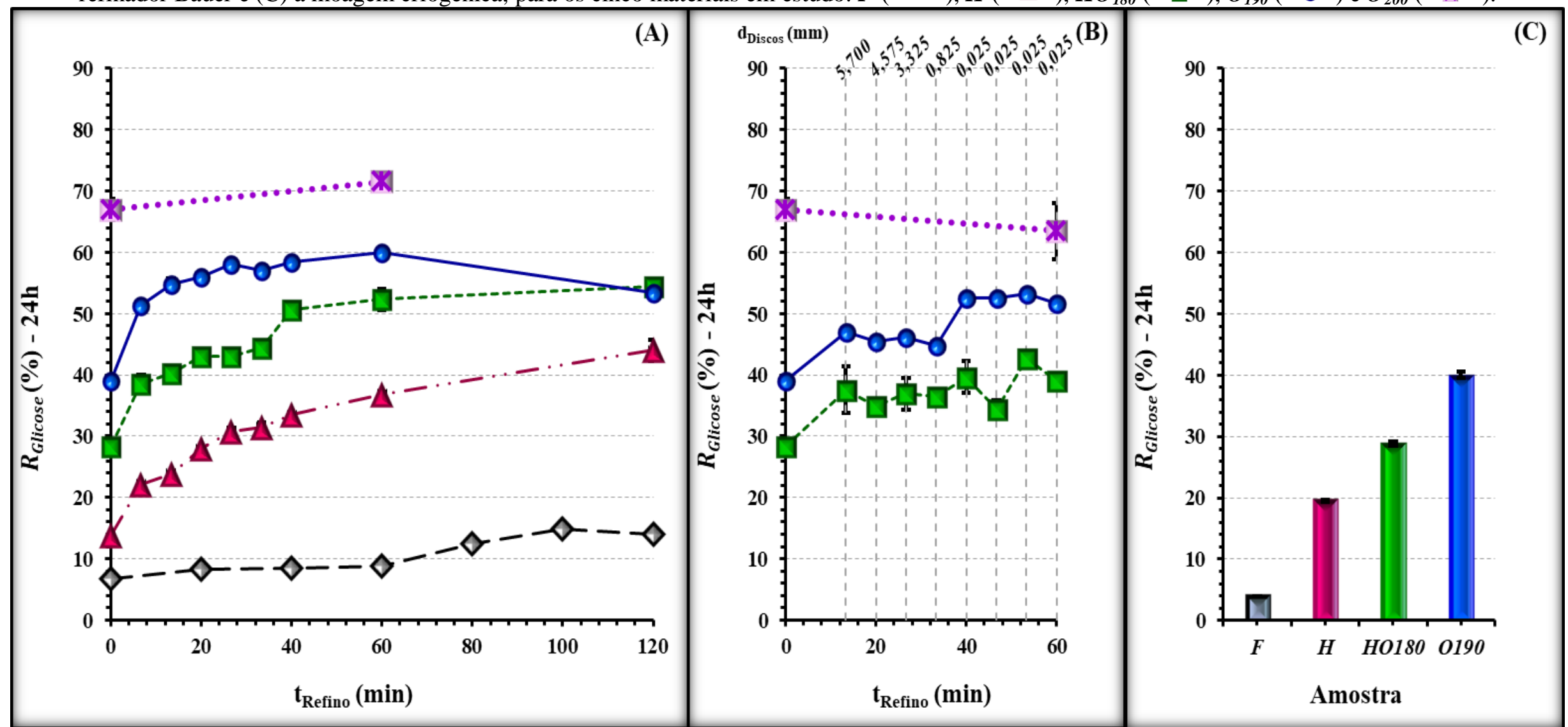

Legenda: $\mathrm{t}_{\mathrm{Refino}}=$ tempo de refino; $\mathrm{d}_{\text {Discos }}=$ distância entre os discos; $R_{\text {Glicose }}=$ rendimento percentual de glicose obtida por hidrólise enzimática. 
Figura 57. Variação do rendimento de glicose (\%) após 48h de hidrólise enzimática com (A) o tempo de refino em moinho Jokro, (B) o tempo de refino em refinador Bauer e (C) a moagem criogênica, para os cinco materiais em estudo: $\boldsymbol{F}(\rightarrow-), \boldsymbol{H}(\rightarrow \mathbf{\Delta} \cdot), \boldsymbol{H} \boldsymbol{O}_{180}(-\square-), \boldsymbol{O}_{190}(-0-)$ e $\boldsymbol{O}_{200}\left(\bullet \bullet \boldsymbol{m}_{\bullet \bullet} \cdot\right)$

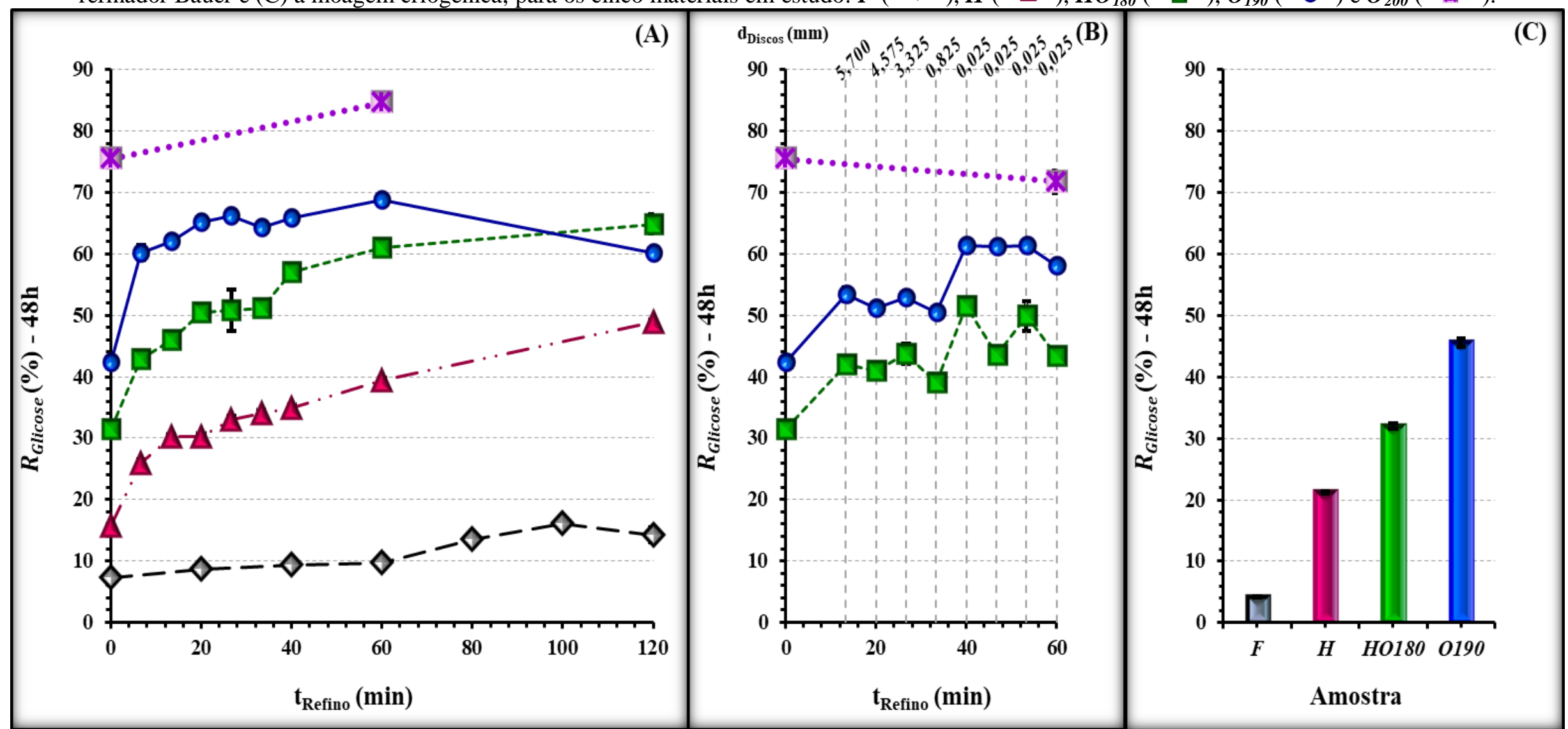

Legenda: $\mathrm{t}_{\text {Refino }}=$ tempo de refino; $\mathrm{d}_{\text {Discos }}=$ distância entre os discos; $R_{\text {Glicose }}=$ rendimento percentual de glicose obtida por hidrólise enzimática. 
Figura 58. Variação do rendimento de glicose (\%) após 72h de hidrólise enzimática com (A) o tempo de refino em moinho Jokro, (B) o tempo de refino em

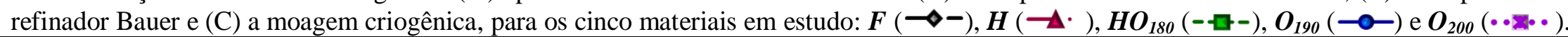

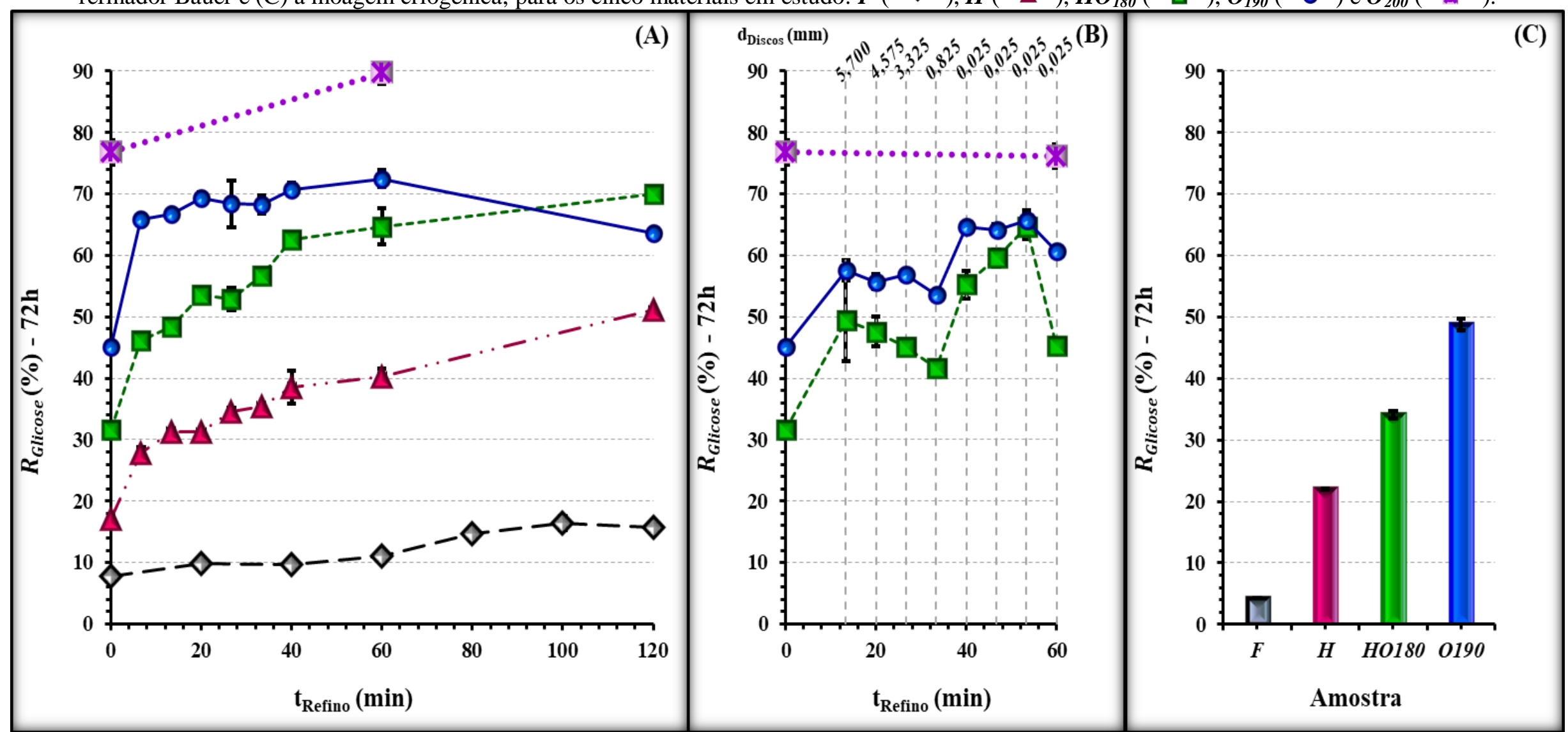

Legenda: $\mathrm{t}_{\text {Refino }}=$ tempo de refino; $\mathrm{d}_{\text {Discos }}=$ distância entre os discos; $R_{\text {Glicose }}=$ rendimento percentual de glicose obtida por hidrólise enzimática. 
A partir dos resultados obtidos para o refino das amostras em estudo em moinho Jokro $(\boldsymbol{M J})$ pôde-se observar que quanto maior a intensidade do refino (tempo) maior o valor do rendimento de glicose alcançado pelas fibras do material em relação às amostras de mesma composição química. Consoante ao estudado no item 5.3, um maior tempo de refino em $\boldsymbol{M J}$ implicou em modificações mais representativas tanto nas propriedades morfológicas das fibras quanto na estrutura capilar da parede celular e na organização cristalina da celulose. Isto porque um maior tempo de refino significou que as fibras sofreram um maior número de impactos, portanto foram submetidas a uma maior intensidade dos fenômenos de corte e de fibrilação externa com consequente formação de finos, assim como de delaminação das paredes internas com o consequente intumescimento.

A ruptura das camadas exteriores e a delaminação das camadas interiores aumentam a área de exposição das fibrilas celulósicas existentes nas camadas mais internas e das hemiceluloses presentes nos poros. Uma vez que a abertura da estrutura da parece celular provocada pelo refino também resulta no aumento da acessibilidade às hemiceluloses e acarreta no seu maior rendimento de hidrólise, a maior digestibilidade da celulose é também resultado da redução da cobertura das fibrilas pelas hemiceluloses (BANAVATH; BHARDWAJ; RAY, 2011; BHARDWAJ; HOANG; NGUYEN, 2007; CHEN et al., 2012a; CHEN et al., 2013; MOU et al., 2013; MOU; LI; FARDIM, 2014). Este efeito foi mais pronunciado em amostras com maiores teores de lignina, onde a acessibilidade inicial aos polissacarídeos era extremamente restrita, com exceção do material não tradado.

Para as diferentes amostras de bagaço em estudo $\left(\boldsymbol{F}, \boldsymbol{H}, \boldsymbol{H} \boldsymbol{O}_{180}, \boldsymbol{O}_{190}\right.$ e $\left.\boldsymbol{O}_{200}\right)$, conforme o refino proporcionou o aumento da acessibilidade às fibrilas celulósicas, houve a redução da influência da cobertura da lignina, que exerceu um papel significantemente menor em impedir a efetividade da hidrólise enzimática; isto foi verdade mesmo quando a lignina esteve presente em concentrações relativamente altas, posto que a celulose estava mais acessível para a adsorção enzimática. Entretanto, não foi possível alcançar a conversão total ou mesmo incrementos muito expressivos nos rendimentos de hidrólise das diferentes amostras de bagaço com a aplicação dos métodos físico-mecânicos, o que mostra que a lignina pode exercer, além do efeito restritivo da área superficial, os efeitos de adsorção não produtiva e bloqueador da processividade (KUMAR et al., 2012; MOONEY et al., 1998).

Deste modo, os incrementos alcançados nos rendimentos de açúcares fermentescíveis pela aplicação dos tratamentos físico-mecânicos foram menos expressivos que os obtidos 
através da solubilização dos componentes não celulósicos. Diante deste cenário, enfatiza-se que há um limite no incremento do rendimento de sacarificação que o refino pode promover sem alterar a composição química do material, o que condiz com as interpretações acerca dos parâmetros físicos e morfológicos.

Para um mesmo tempo de refino em $\boldsymbol{M J}$, constatou-se que os materiais deslignificados $\left(\boldsymbol{H O}_{180}\right.$ e $\left.\boldsymbol{O}_{190}\right)$ alcançaram maiores valores rendimento de glicose por hidrólise enzimática que a amostra apenas pré-tratada hidrotérmicamente $(\boldsymbol{H})$, que por sua vez atingiu maiores valores que as fibras de bagaço in natura $(\boldsymbol{F})$. Este comportamento segue exatamente as tendências observadas para os resultados das análises morfológicas, de porosidade e do ${ }^{\circ} S R$, devido ao fato da fibrilação e do consequente aumento da abertura da estrutura da parede celular serem facilitados pela redução da recalcitrância e pela remoção da barreira física constituída pelos componentes não celulósicos. Uma vez que os pré-tratamentos físicoquímicos diminuíram a resistência da biomassa ao processamento mecânico, menores intensidades ou tempos de tratamento foram necessários para obter um maior valor de conversão enzimática dos polissacarídeos. Em contrapartida, o refino apresenta a possibilidade de reduzir a severidade do pré-tratamento químico e alcançar o mesmo rendimento de sacarificação.

As fibras de bagaço in natura $(\boldsymbol{F})$, cujo teor de celulose é $44,1 \%$, apresentaram os menores valores de rendimento de glicose, alcançando o valor máximo de 16,4\% (72h de hidrólise) após refinadas em $\boldsymbol{M J}$ por 100 minutos (15000 revoluções), valor que corresponde a um aumento de 109,0\% no rendimento de glicose quando comparado ao material não refinado $(7,8 \%)$. Já a amostra de bagaço pré-tratada hidrotérmicamente $(\boldsymbol{H})$ e as polpas organossolve $\boldsymbol{H O}_{18 \boldsymbol{0}}$ e $\boldsymbol{O}_{\mathbf{1 9 0}}$, quando processadas na menor intensidade de refino em $\boldsymbol{M J}$ (6,7 minutos) apresentaram aumentos de $62,3 \%$ e aproximadamente $46 \%$ nos rendimentos de glicose em relação às respectivas amostras não refinadas, alcançando os valores de $27,9 \%$, $46,2 \%$ e $65,8 \%$, respectivamente (72h de hidrólise).

Após 60 minutos de refino em $\boldsymbol{M J}$, as amostras $\boldsymbol{F}, \boldsymbol{H}, \boldsymbol{H} \boldsymbol{O}_{180}, \boldsymbol{O}_{190}$ e $\boldsymbol{O}_{200}$ alcançaram valores de rendimento de glicose de, respectivamente, $11,0 \%, 40,3 \%, 64,7 \%, 72,5 \%$ e $89,7 \%$ (72h de hidrólise); estes valores representam incrementos de, respectivamente, 40,5\% (3,2), $134,9 \%(23,2), 104,1 \%(33,0), 60,7 \%(27,4)$ e $16,8 \%(12,9)$ em relação aos valores de rendimento de hidrólise obtidos para os respectivos materiais não refinados de mesma composição química. De modo semelhante a diversas publicações que estudaram a 
combinação entre pré-tratamentos físico-químicos e físico-mecânicos, observou-se que um menor percentual de componentes não celulósicos implicou em um menor acréscimo relativo no rendimento de açúcares redutores obtidos após a hidrólise enzimática da amostra; esta constatação foi verdade para todos os materiais de diferentes composições químicas, com exceção das fibras de bagaço in natura $(\boldsymbol{F})$, cuja estrutura inicial era extremamente agregada e exigiu maiores energias de refino para apresentar alterações representativas. Novamente, os resultados das análises do item anterior embasam as intepretações de que os materiais com menores teores de lignina e hemiceluloses, por possuírem superfícies interna e externa significantemente acessíveis, apresentavam baixos impedimentos à ação enzimática mesmo em etapa precedente ao refino. Ademais, a alta de intensidade do refino implicou que, após um determinado tempo, alcançou-se a desestruturação máxima das fibras que o refino mecânico pode provocar.

Diferentemente, o tratamento em refinador Bauer $(\boldsymbol{R D})$ das polpas organossolve $\boldsymbol{H O}_{180}$ e $\boldsymbol{O}_{190}$ na menor severidade (menor tempo e maior espaçamento entre os discos) provocou um aumento nos rendimentos de açúcares fermentescíveis alcançados pelas fibras dos materiais em relação às amostras de mesma composição química inicial; contudo, maiores tempos de refino não proveram incrementos adicionais nas hidrolisabilidades dos materiais. Novos acréscimos nos rendimentos de sacarificação só foram atingidos quando da aplicação da aproximação máxima entre os discos na etapa de refino mecânico; mais uma vez, maiores tempos de refino não foram benéficos para as hidrolisabilidades das polpas de bagaço. Com o maior espaçamento entre os discos e após 13,3 minutos de refino, os materiais $\boldsymbol{H O}_{180}$ e $\boldsymbol{O}_{190}$ refinados forneceram valores de rendimento de glicose $55,9 \%$ e $27,5 \%$, respectivamente, maiores que os referentes materiais não refinados, atingindo os rendimentos de 49,4\% e $57,5 \%$ ( $72 \mathrm{~h}$ de hidrólise). Já no menor espaçamento e quando refinadas por 40 minutos, as polpas exibiram incrementos adicionais de $11,7 \%(5,8)$ e $12,3 \%(7,1)$, respectivamente, nos valores de rendimento de glicose em relação às polpas refinadas por 13,3 minutos, alcançando os rendimentos de 55,2\% e 64,6\% (72h de hidrólise).

Estes dados corroboram com o grau de modificação das fibras com o processamento em refinador de discos, sendo consequência tanto da sua duração quanto da pressão exercida sobre as fibras pelos discos. A aplicação do refino mecânico com menores valores de energias específicas acarretou no aumento da capilaridade e no intumescimento da parede celular, porém sem significativas mudanças nos aspectos morfológicos das fibras, resultando no 
aumento da acessibilidade às paredes internas pelas enzimas hidrolíticas. Contudo, a aplicação do refino no menor espaçamento entre os discos (maior energia específica) acarretou em modificações mais expressivas das propriedades estruturais das fibras, visto que além da expansão da estrutura de poros, observou-se uma maior alteração das dimensões das fibras com o consequente aumento do teor de elementos finos presentes nas amostras. Ademais, atrelado à restrição na extensão da abertura da parede celular (superfícies externa e interna) que pôde ser alcançada pelo refino mecânico em cada faixa de estímulo aplicado, foi observado o limite da conversão enzimática dos polissacarídeos constituintes da biomassa.

Comparativamente, para uma amostra de mesma composição química, as diferenças significativas nos aspectos físicos e morfológicos das fibras provocadas pelos distintos modos de ação dos refinadores resultaram em diferenças na acessibilidade à celulose pelas enzimas hidrolíticas e, consequentemente, no rendimento de sacarificação. O refino em $\boldsymbol{M J}$ proveu materiais cujos valores de rendimento de açúcares redutores, obtidos por hidrólise enzimática, foram maiores do que os obtidos nos mesmos tempos de processamento em $\boldsymbol{R D}$ : de 0 a 36,3\% para a polpa $\boldsymbol{H O}_{180}$ e de 8,7\% a 21,5\% para a polpa $\boldsymbol{O}_{190}$ (72h de hidrólise). Após 40 minutos de refino, os valores de rendimento de glicose obtidos para as polpas $\boldsymbol{H O}_{18 \boldsymbol{0}}$ e $\boldsymbol{O}_{190}$ tratadas em $\boldsymbol{M J}$ foram, respectivamente, $62,6 \%$ e 70,8\% (72h de hidrólise), valores 13,4\% e 9,6\% maiores que os obtidos para os mesmos materiais refinados em $\boldsymbol{R} \boldsymbol{D}$ no mesmo intervalo de tempo.

A polpa organossolve $\boldsymbol{O}_{200}$, cujo teor de lignina é respectivamente $68,8 \%$ e $41,5 \%$ menor do que nas polpas $\boldsymbol{H O}_{180}$ e $\boldsymbol{O}_{190}$, apresentou menores incrementos nos rendimentos de glicose do que as duas outras polpas quando refinadas em $\boldsymbol{M J}$ e em $\boldsymbol{R D}$ por 60 minutos: de $16,7 \%$ e 0 , respectivamente. Consoante ao já mencionado, um menor teor de lignina no material implica em uma menor rigidez estrutural e uma maior a porosidade interfibrilar e interlamelar da parede celular; consequentemente, maior é a susceptibilidade deste material à ação enzimática, mesmo sem as alterações provocadas pelos processos de refino.

A disparidade no comportamento da polpa $\boldsymbol{O}_{200}$ frente aos dois métodos de refino também corrobora com as observações acerca da área de poros acessíveis enzimaticamente e das dimensões das partículas obtidas descritas no item anterior. Quando refinada em $\boldsymbol{M J}$, esta polpa foi rapidamente fibrilada, formando um material extremamente fino e com uma maior área de poros (incrementos nas áreas de poros acessíveis de 19,2\% (se $\geq 9,90 \mathrm{~nm}$ ) e 13,1\% (se $\geq 3,96 \mathrm{~nm}$ )), o que proporcionou o aumento observado no rendimento de hidrólise enzimática. Diferentemente, após o tratamento em $\boldsymbol{R D}$, teve suas dimensões alteradas em menor extensão, 
assim como sua área de poros acessíveis enzimaticamente (incrementos de 12,8\% (se $\geq 9,90$ $\mathrm{nm})$ e $1,0 \%$ (se $\geq 3,96 \mathrm{~nm}$ )), o que não propiciou ganhos adicionais na hidrolisabilidade visto a baixa resistência inicial à penetração enzimática na estrutura da parede celular.

Por conseguinte, os resultados obtidos nas análises estruturais e nos ensaios de hidrólise enzimática das amostras de bagaço permitem inferir que apesar da área de poros interiores da parede celular acessíveis às proteínas celulolíticas ser uma das principais responsáveis pelo aumento do rendimento de açúcares redutores obtidos, a desconstrução das paredes externas e a concomitante redução das dimensões das partículas também são essenciais para expandir a área e facilitar a atuação enzimática.

Um comportamento interessante a ser ressaltado foi a redução nos rendimentos de hidrólise das amostras $\boldsymbol{O}_{190}-\mathbf{M J}, \boldsymbol{O}_{\mathbf{1 9 0}} \boldsymbol{R D}, \mathbf{H O}_{\mathbf{1 8 0}}-\boldsymbol{R D}$ e $\boldsymbol{O}_{\mathbf{2 0 0}} \boldsymbol{R D}$ quando estas foram previamente refinadas nas maiores intensidades de cada método (120 minutos em $\boldsymbol{M J}$ ou 60 minutos em $\boldsymbol{R} \boldsymbol{D}$ ) em comparação aos materiais refinados em menores intensidades. Uma primeira aproximação para explicar este decaimento seria o impacto negativo que altas intensidades de refino podem provocar na eficiência da sacarificação enzimática pelo colapso dos poros maiores da estrutura interna das fibras, considerados acessíveis às enzimas hidrolíticas; entretanto, não foi observada a redução da área de poros acessíveis para estes materiais refinados nos tempos mencionados. Segundo a hipótese levantada no item 5.3.4, se as altas energias de atrito do refino associadas à maior facilidade de processamento destas polpas resultam no aquecimento do sistema e na degradação de alguma porção dos polissacarídeos menos ordenados presentes nos espaços interfibrilares, o valor de rendimento de açúcares recuperados após a hidrólise enzimática é menor. Complementarmente, a lignina residual também pode se tornar mais exposta com o refino realizado em altas severidades, o que aumenta a probabilidade de interações não produtivas entre as celulases e a lignina (CHEN et al., 2013; JONES et al., 2013; JONES et al., 2014).

Como última suposição, tem-se que as altas áreas superficiais expostas destes materiais levam a uma taxa de conversão dos polissacarídeos mais rápida, logo os açúcares redutores são liberados no meio reacional em tempos anteriores; esta alta taxa de formação de açúcares pode ocasionar na inibição precoce das enzimas hidrolíticas pela alta concentração de produtos da reação, isto é, em uma inibição pronunciada em tempos mais curtos de reação. Uma possível inibição por produtos parece uma teoria razoável quando se observa a cinética 
da reação hidrolítica dos materiais mencionados, já que este decaimento foi mais pronunciado em maiores tempos da reação de hidrólise enzimática.

Diferentemente, o efeito da redução pronunciada nas dimensões das partículas pelo processo criogênico $(\boldsymbol{M C})$ proveu um aumento na digestibilidade enzimática apenas da amostra de bagaço pré-tratada hidrotérmicamente $(\boldsymbol{H})$ (28\% em $72 \mathrm{~h}$ de hidrólise), obtendo-se um rendimento de glicose de 22,0\%. Já as polpas organossolve $\boldsymbol{H O}_{\mathbf{1 8 0}}$ e $\boldsymbol{O}_{\mathbf{1 9 0}}$ moídas criogenicamente apresentaram incrementos de 7,5\% e 8,2\%, respectivamente, nas digestibilidades enzimáticas em relação às amostras de mesma composição não moídas, obtendo-se rendimentos de glicose de $34,1 \%$ e $48,8 \%$.

Em suma, o refino em moinho laboratorial tipo Jokro promoveu os maiores acréscimos nas digestibilidades enzimáticas das amostras de bagaço por culminar simultaneamente no aumento da estrutura capilar pela intensa fibrilação interna, e da área superficial externa tanto pela formação de elementos finos quanto pela redução das dimensões das fibras por corte. Já o refinador de discos Bauer levou a uma melhoria menos pronunciada na hidrolisabilidade dos materiais por resultar no aumento expressivo no volume de poros internos da parede celular, porém com evidências de fibrilação externa das fibras gradativa e apenas quando da aplicação de altas energias específicas e sem o seu expressivo corte. Diferentemente, a moagem criogênica promoveu apenas a drástica e heterogênea redução das dimensões das fibras pela quebra destas quando no estado congelado, enquanto não permitiu mudanças significativas na área de poros acessíveis enzimaticamente.

Estes resultados podem significar que a redução nas dimensões das fibras sozinha não explica o aumento na digestibilidade enzimática dos polissacarídeos, e que o efeito desta quando se observa algum aumento no valor do rendimento de sacarificação está intimamente atrelado ao efeito de fibrilação externa, com o arranque das camadas mais externas da parede celular e a formação de elementos finos, em detrimento do fenômeno de corte. Ademais, a expansão da porosidade promove o aumento da conversão da celulose, porém sozinha também não permite alcançar a máxima taxa de conversão. O somatório dos efeitos de fibrilação interna e externa resultam na intensa desestruturação da parede celular e no consequente aumento da acessibilidade à penetração das enzimas celulolíticas.

A partir dos resultados gerados nas análises estruturais, pôde-se observar que os métodos de tratamento físico-mecânicos aplicados neste trabalho, assim como as variações nas condições de processamento, permitiram a obtenção de amostras que apresentaram 
diferentes graus de variação de seus parâmetros físicos e morfológicos em relação aos materiais não processados de mesma composição química. Além disso, os valores de rendimento de glicose obtidos na hidrólise enzimática das amostras estudadas demonstraram que cada um dos parâmetros estruturais das fibras influencia de maneira diferente na acessibilidade da celulose às enzimas hidrolíticas.

\subsubsection{Avaliação dos efeitos das propriedades estruturais na sacarificação enzimática}

Nesta etapa do trabalho, é empregada uma abordagem para a compreensão e a quantificação da importância relativa que alguns dos diferentes parâmetros estruturais do substrato exercem na extensão da hidrólise enzimática dos polissacarídeos das lignoceluloses, de modo a fornecer um guia das características das biomassas que devem ser modificadas para ampliar a acessibilidade enzimática e assim aumentar os rendimentos de obtenção dos açúcares fermentescíveis. Para isto, confrontaram-se sistematicamente as alterações provocadas nas características dos substratos pelos diferentes tipos de processamento da biomassa - físico-químicos e -mecânicos - com o rendimento de açúcares redutores obtidos.

Entre os parâmetros avaliados, que possivelmente determinam a susceptibilidade dos materiais celulósicos à degradação enzimática estão: 1) Fatores morfológicos, descritos pelas dimensões das partículas; 2) Fatores internos da parede celular, descritos pela estrutura capilar (áreas de poros); e 3) Fatores específicos da celulose, descritos pelos parâmetros cristalinos das fibrilas celulósicas. Ao analisar todos estes fatores, foram interpretadas e discriminadas as possíveis inter-relações entre os parâmetros alterados, assim como a influência da composição química das amostras (teores de componentes não celulósicos). A quantificação da concentração de açúcares liberados pelas hidrolases ao fim da reação sacarificação de um material lignocelulósico é, por sua vez, uma medida indireta da desconstrução deste substrato.

Primeiramente, avaliaram-se as influências diretas de cada parâmetro separadamente com relação ao rendimento de glicose obtido. Esta identificação foi realizada através da obtenção dos parâmetros de correlação linear entre os fatores de entrada (propriedades estruturais) e as respostas finais (rendimento de glicose). Dado que o comportamento do rendimento de glicose se assemelhou nos diferentes tempos de reação, as plotagens dos parâmetros estruturais foram feitas contra o rendimento de glicose (\%) obtido no ponto de 72h. Este tempo de reação foi considerado como o ponto de conversão final do substrato, que 
por sua vez se relaciona com a acessibilidade total do substrato. Não há qualquer motivo para acreditar que estas relações sejam lineares, porém servem como um informativo do grau de dependência da resposta final com determinado parâmetro. As influências dos parâmetros físicos e dos parâmetros morfológicos na taxa de conversão enzimática são apresentadas nos gráficos das Figuras 60 a 63 e dos Anexos I a T. Já os parâmetros de correlação linear encontram-se organizados na tabela do Anexo U.

Posto que a hidrólise enzimática da celulose pode ocorrer tanto a partir da superfície externa exposta quanto pela penetração das celulases nos poros existentes no interior da parede celular, as dimensões morfológicas externas das fibras também são consideradas fatores cruciais para a eficiência da conversão da celulose. Além disto, a diminuição no tamanho das partículas pode contribuir para a melhora da digestibilidade pelo decaimento na resistência à transferência de massa (ANDERSEN, 2007; HUANG et al., 2010; JIANG et al., 2016; KHULLAR et al., 2013; LEU; ZHU, 2013; LI et al., 2015; WANG et al., 2014).

A influência das dimensões das fibras na susceptibilidade das amostras de bagaço em estudo à sacarificação foi avaliada a partir da análise do comportamento do rendimento de glicose, obtido após $72 \mathrm{~h}$ de hidrólise enzimática, em função: do diâmetro médio das partículas (Anexo I), do volume cumulativo de partículas com diâmetros de até $30 \mu \mathrm{m}$ (Anexo J) ou $100 \mu \mathrm{m}$ (Anexo K), do comprimento médio (Anexo L) e da largura média (Anexo M) das fibras, do teor de elementos finos (Anexo N), e das áreas superficiais específicas externas (ASE) calculadas por distribuição de tamanhos de partículas (Figura 60) ou por análise morfológica das fibras (Figura 61).

Para todas as medidas confrontadas, pôde-se notar uma mesma tendência de aumento no rendimento de glicose alcançado na sacarificação enzimática com relação à redução nas dimensões das partículas das amostras de bagaço refinadas por diferentes processos e condições. Entretanto, esta relação foi mais clara para a análise das amostras de mesma composição química, o que indica que estas variáveis não estão inter-relacionadas. Para um mesmo valor de diâmetro médio das partículas, de volume cumulativo de partículas com diâmetros de até $30 \mu \mathrm{m}$ ou $100 \mu \mathrm{m}$, de comprimento médio, de teor de finos ou de ASE, as amostras com menores teores de hemiceluloses e lignina apresentaram maiores valores de rendimento de glicose.

Um comportamento a ser destacado é o da variação do rendimento de glicose com a largura média das fibras, uma vez que a hidrolisabilidade tende a aumentar com o 
alargamento das fibras provocado pelo refino, ao mesmo tempo em que também aumenta com a redução da largura provocada pela desagregação com a solubilização da lignina. Outro ponto a ser enfatizado é que os dados correspondentes às amostras moídas criogenicamente não seguiram a mesma tendência dos dados referentes às amostras refinadas e, mesmo que estas apresentassem as menores dimensões das partículas, não estiveram relacionadas a um aumento expressivo no rendimento de sacarificação das amostras de bagaço.

Em geral, agrupando-se as 5 amostras de diferentes composições químicas, as propriedades morfológicas das fibras, em todas as faixas de dimensões, não são capazes de permitir sozinhas a previsão do comportamento da digestibilidade enzimática da celulose do bagaço de cana-de-açúcar. Esta constatação pode indicar que as dimensões das fibras têm efeito negligenciável na eficiência da ação enzimática, e que o efeito da redução das partículas está atrelado ao descascamento da parede celular provocado pelo efeito de fibrilação externa. Ademais, as alterações morfológicas provocadas pelos métodos físico-mecânicos ocorrem em concomitância a outras alterações estruturais nas fibras, que influenciam nas interpretações e corroboram com a dispersão nos resultados obtidos. De fato, é esperado que a área superficial externa exerça papel minoritário na contribuição à sacarificação total, uma vez que os cálculos mostraram que a superfície externa corresponde a menos de $2 \%$ da área específica total das fibras de todas as amostras de bagaço analisadas, tanto in natura quanto pré-tratadas por métodos físico-químicos e/ou por físico-mecânicos.

Enquanto os valores de área superficial externa das amostras de bagaço calculados por distribuição de tamanhos de partículas (difração a laser - Figura 60) apresentaram uma relação menos clara com a eficiência da produção de açúcares redutores por hidrólise enzimática, os calculados por análise morfológica das fibras (MorFi - Figura 61) mostraram uma dependência próxima à linear $\left(\mathrm{R}^{2} \approx 0,69\right)$. Entretanto, novamente esta relação foi mais direta apenas para as amostras pré-tratadas, sendo que para estas uma pequena variação na área superficial externa esteve relacionada a um grande incremento no rendimento de hidrólise. Esta melhor relação entre os rendimentos de glicose obtidos e as ASE calculadas por MorFi pode ser devida ao fato desta análise fornecer estimativas menos grosseiras das dimensões das fibras, e do cálculo da ASE pelo modelo cilíndrico incluir medidas morfológicas de mais de uma dimensão além do volume total de poros da parede celular. 
Figura 59. Variação do rendimento de glicose (\%) obtido após 72h de hidrólise enzimática com a área superficial específica externa (ASE $-\mathrm{m}^{2} / \mathrm{g}$ ) calculada por distribuição de tamanhos de partículas.

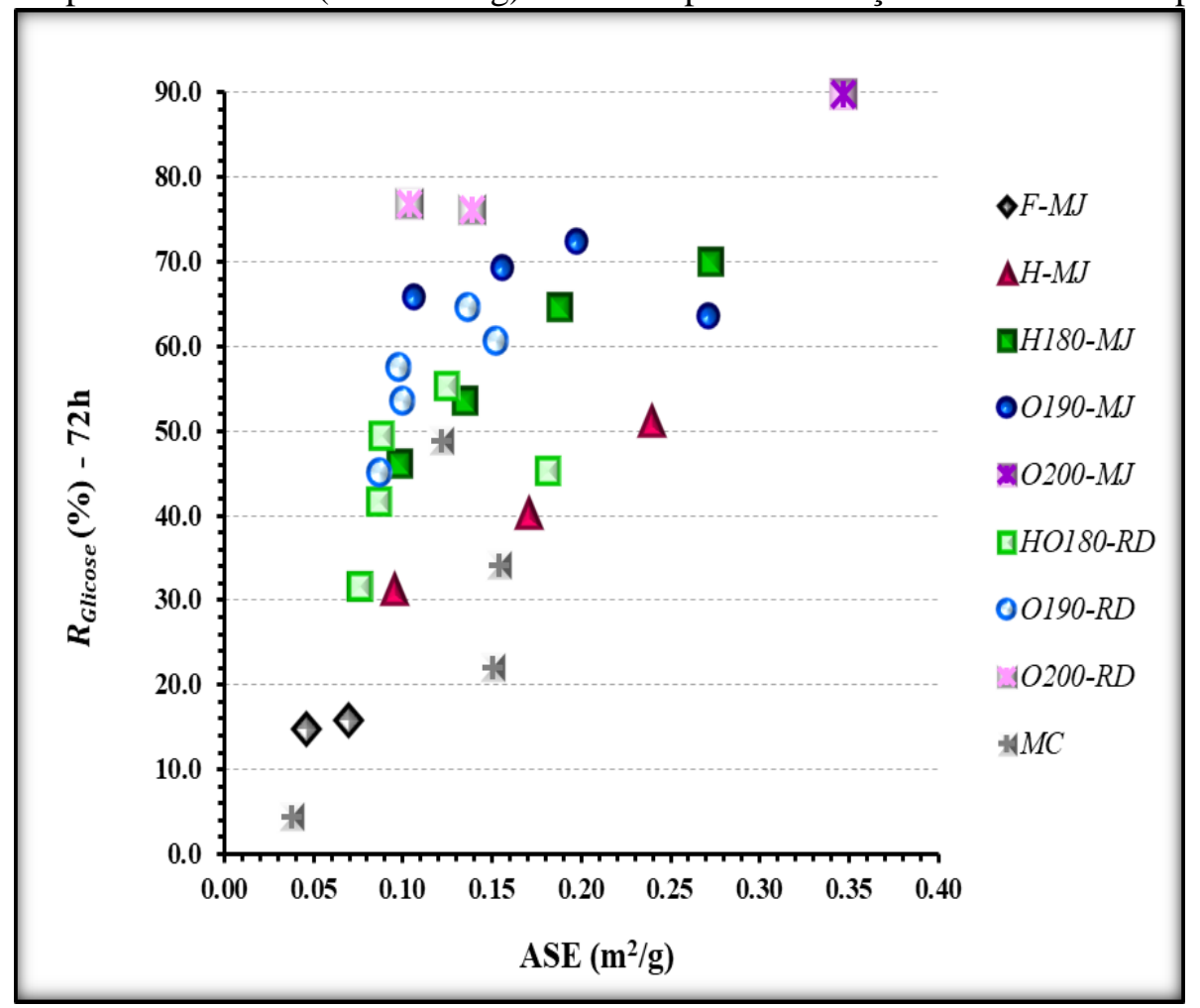

Figura 60. Variação do rendimento de glicose (\%) obtido após $72 \mathrm{~h}$ de hidrólise enzimática com a área superficial específica externa (ASE $-\mathrm{m}^{2} / \mathrm{g}$ ) calculada por MorFi.

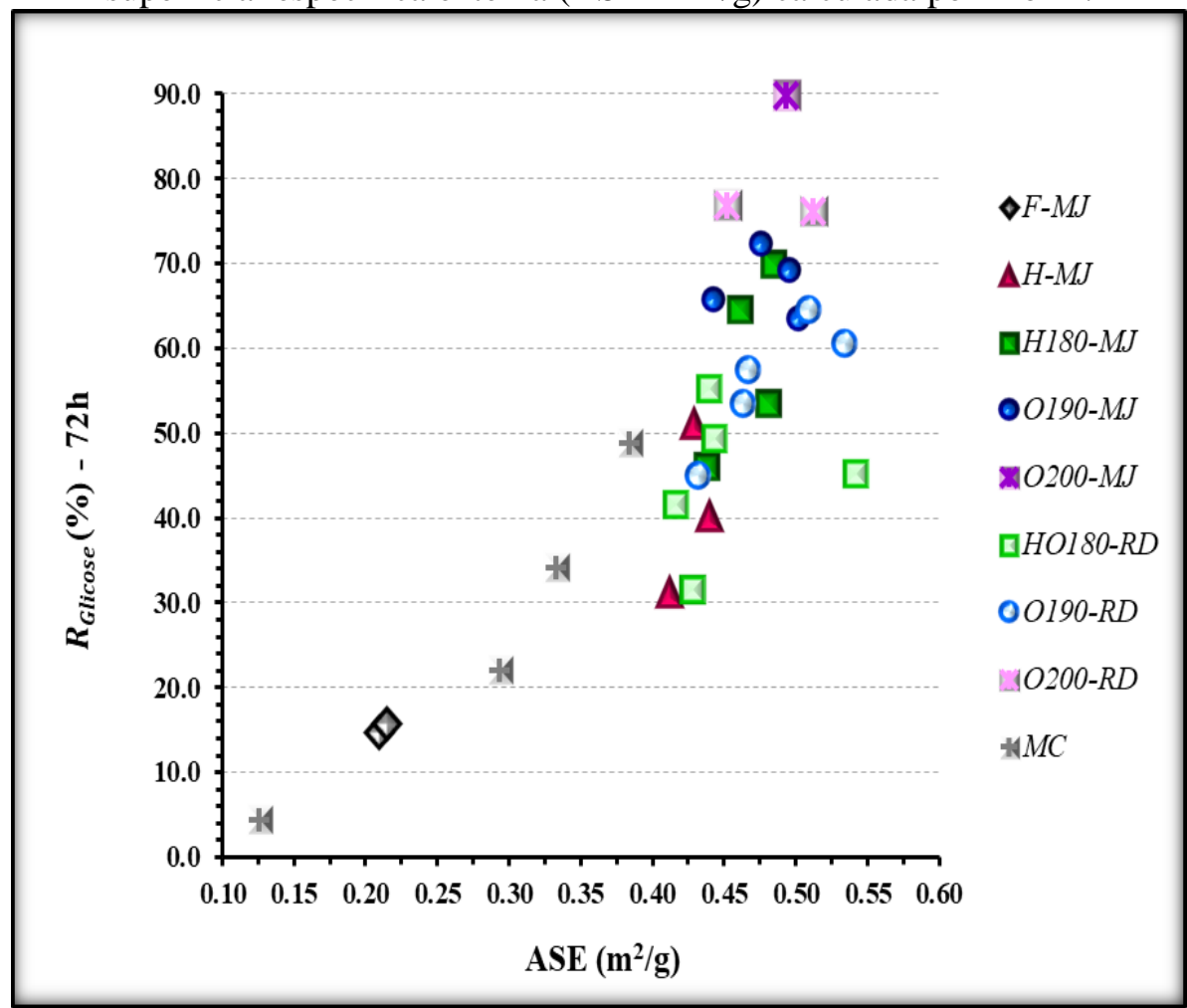


Os modelos de fragmentação das fibras pelas celulases apontam que estas enzimas penetram e difundem através da estrutura porosa da parede celular antes que qualquer despolimerização considerável da celulose ocorra. Isto significa que a área de poros acessíveis é o fator limitante do transporte das hidrolases para o interior das camadas, para que estas então acessem as superfícies das fibrilas celulósicas. Deste modo, a expansão da capilaridade da parede celular é considerada como um dos maiores agentes propulsores da melhora da atuação enzimática (DRIEMEIER, 2017; FAN; LEE; BEARDMORE, 1980; THYGESEN et al., 2011; YANG et al., 2011).

A área superficial interna acessível é, por sua vez, um reflexo não só dos espaçamentos interfibrilares e interlamelares em si como também da composição química e do grau de ordenação fibrilar. Entretanto, deve-se relembrar que a área superficial interna total não necessariamente condiz com a área de contato efetiva com as celulases na qual a hidrólise ocorre, visto que existe uma dimensão mínima que os poros devem apresentar para garantir a entrada e a atuação enzimática (ANDERSEN, 2007; BANSAL et al., 2012; CHANDRA et al., 2007; GRETHLEIN, 1985; HUANG et al., 2010; LEU; ZHU, 2013; SINITSYN; GUSAKOV; VLASENKO, 1991; THOMPSON; CHEN; GRETHLEIN, 1992WANG et al., 2014; ZHANG; LYND, 2004).

A influência da estrutura porosa da parede celular das fibras na susceptibilidade das amostras de bagaço em estudo à sacarificação foi avaliada a partir da análise do comportamento do rendimento de glicose, obtido após $72 \mathrm{~h}$ de hidrólise enzimática, em função: da área total de poros (Anexo O) e das áreas de poros com diâmetros maiores ou iguais a 6,60 nm (Anexo P), 3,96 nm (Anexo Q) ou 9,90 nm (Figura 62).

A partir da análise do comportamento da conversão da celulose em relação à área total de poros, não se pôde estabelecer uma única relação. Apesar da perceptível tendência de aumento nos valores de rendimento de glicose alcançados com o aumento da área total de poros das fibras, o grau de dependência entre estas variáveis dependeu do teor de solubilização dos componentes não celulósicos das amostras de bagaço promovido pelo prévio tratamento físico-químico. Isto porque as remoções de hemiceluloses e de lignina levam à formação e à expansão dos poros nanométricos em diferentes escalas de diâmetros e em diferentes extensões.

Diferentemente, os valores de rendimento de glicose obtidos apresentaram o mesmo perfil de comportamento com relação às medidas de áreas de poros considerados acessíveis às 
enzimas celulolíticas utilizando-se as três faixas de diâmetros de poros propostos $(\geq 3,96 \mathrm{~nm}$, $\geq 6,60 \mathrm{~nm}$ e $\geq 9,90 \mathrm{~nm})$. Isto é, constou-se a mesma dependência linear positiva $\left(0,77 \geq \mathrm{R}^{2} \geq\right.$ 0,76) entre o aumento no rendimento de hidrólise alcançado na sacarificação enzimática com relação à área de poros acessíveis das amostras de bagaço - de diferentes composições químicas e refinadas por diferentes processos e condições - estando o diâmetro de poro limitante na faixa entre $3,96 \mathrm{~nm} \mathrm{9,90} \mathrm{nm}$.

Figura 61. Variação do rendimento de glicose (\%) obtido após $72 \mathrm{~h}$ de hidrólise enzimática com a área de poros $\left(\mathrm{m}^{2} / \mathrm{g}\right)$ com diâmetros maiores ou iguais a $9,90 \mathrm{~nm}$.

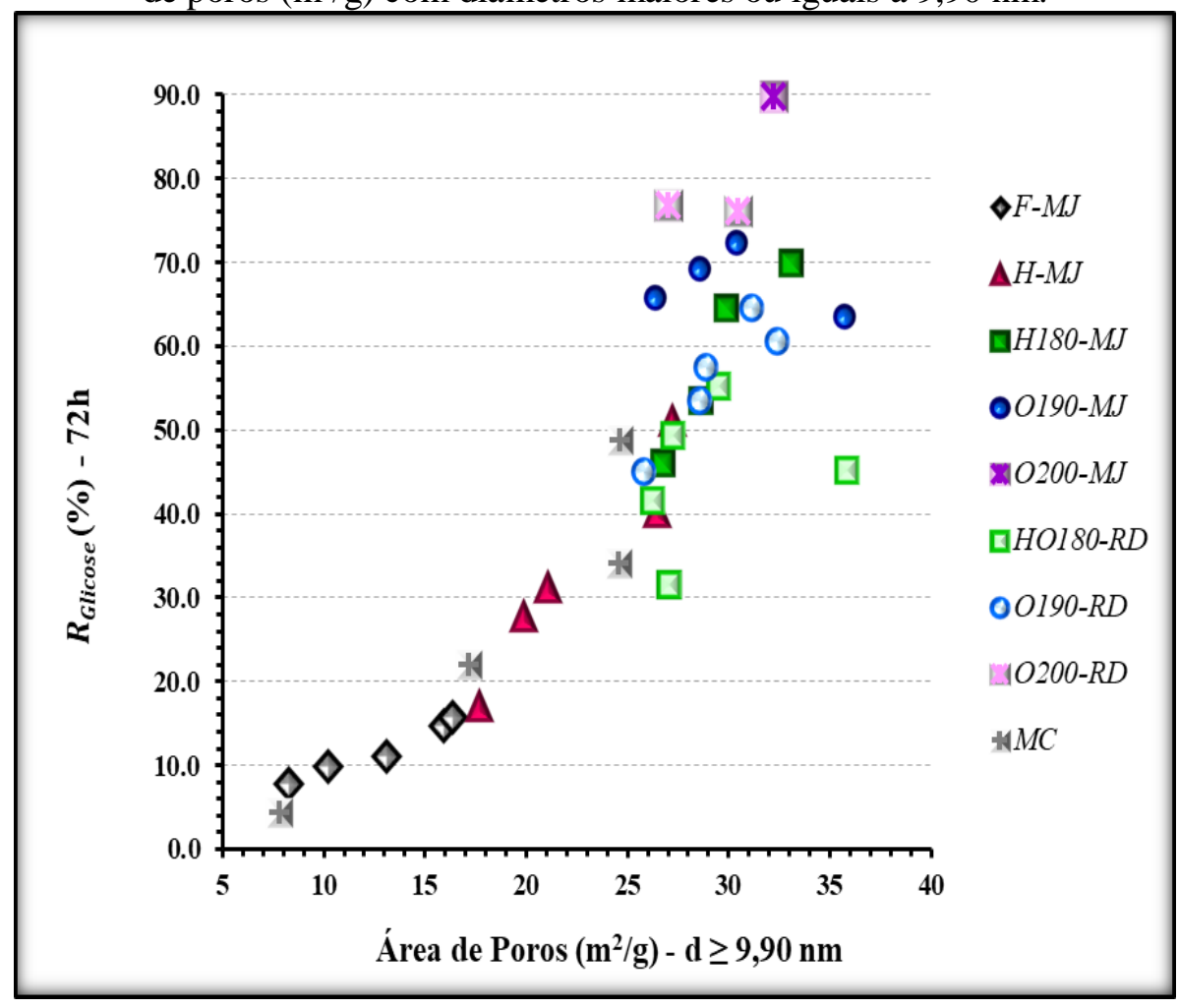

Estes diâmetros de poros considerados limitantes para a atuação enzimática encontram-se dentro da faixa reportada em diversas publicações (BURNS; OOSHIMA; CONVERSE, 1989; GRETHLEIN, 1985; HUANG et al., 2010; LI et al., 2015; MENG et al., 2013; PECIULYTE et al., 2015; PIHLAJANIEMI et al., 2016; SINITSYN; GUSAKOV; VLASENKO, 1991; WEIMER; WESTON, 1985). Em vista destes resultados, pôde-se inferir que quanto maior a porosidade acessível do substrato, alcançada tanto pela remoção seletiva dos componentes não celulósicos quanto pela delaminação e intumescimento das camadas internas da parede celular, maior a taxa de conversão enzimática da celulose. 
Diversos autores apontam que o principal papel da remoção da lignina e das hemiceluloses na eficiência do processo de sacarificação enzimática das biomassas é na criação de poros acessíveis à difusão e atuação das enzimas celulolíticas, o que justifica o alto grau de correlação entre estes dois parâmetros (ALVIRA et al., 2010; ARANTES; GOURLAY; SADDLER, 2014; BARAKAT; DE VRIES; ROUAU, 2013; JEOH et al., 2007; KUMAR et al., 2012; LEE et al., 2010; LIN et al., 2010; MOONEY et al., 1998; VÁRNAI; SIIKA-AHO; VIIKARI, 2010). Já o processo de fibrilação mecânica, além de modificar a morfologia das fibras lignocelulósicas, também promove a abertura efetiva da estrutura interna da parede celular pelo aumento dos espaços interlamelares e interfibrilares acessíveis às enzimas hidrolíticas, contudo sem provocar a alteração de sua composição química (GAO et al., 2012; GONZALEZ et al., 2011).

Todavia, os gráficos da relação entre os valores de rendimento de glicose obtidos e as áreas superficiais internas acessíveis $(\geq 3,96 \mathrm{~nm}, \geq 6,60 \mathrm{~nm}$ ou $\geq 9,90 \mathrm{~nm})$ permitiram distinguir diferentes regimes para as amostras pré-tratadas e para as fibras de bagaço in natura. Ademais, observou-se o aumento do desvio da linearidade para as amostras que proveram maiores rendimentos de glicose. Para a amostra $\boldsymbol{F}$, observou-se que aumentos na área de poros acessíveis proveram incrementos menos expressivos nos valores de rendimento de glicose, visto que esta amostra possuía um maior teor inicial de lignina com menor superfície diretamente exposta de celulose. Com relação ao desvio do comportamento linear, sugere-se que as maiores porcentagens de solubilização dos componentes não celulósicos, somadas às altas intensidades de refino mecânico, levaram à amplificação excessiva dos poros da estrutura interna das fibras; desta forma, estes podem ter alcançado diâmetros maiores que o limite de detecção do método de TP-DSC, o que aparentemente diminui a porosidade do sistema mensurada, enquanto os valores de rendimento de sacarificação continuam a aumentar (HUANG et al., 2010; PIHLAJANIEMI et al., 2016). Outra possível explicação pra este comportamento é que outros parâmetros estruturais das fibras são alterados pelo refino mecânico em concomitância à área de poros acessíveis, como o grau de agregação fibrilar.

Ainda, conforme sugerido no item 2.2.5.1, uma enzima ligada à celulose cobre centenas de potenciais sítios de hidrólise (ligações $\beta$-glicosídicas), portanto o número de moléculas de celulase que podem se ligar à superfície da celulose é substancialmente menor do que o número de sítios disponíveis. Como resultado, as técnicas de análise podem superestimar a área acessível de fato efetiva à ação das celulases (ANDERSEN, 2007; LEU; 
ZHU, 2013; ZHANG; LYND, 2004). Uma vez removida a cobertura diretamente associada à superfície das fibrilas, a competição pelo sítio de adsorção se torna significantemente menor, logo mais enzimas podem adsorver e hidrolisar as cadeias celulósicas.

As análises dos materiais de diferentes composições químicas e refinados segundo diferentes métodos e intensidades demonstraram que a produtividade da sacarificação enzimática é mais bem descrita pela área superficial de poros acessíveis do que pela área superficial total, descrita juntamente pelas dimensões das partículas e pela área total de poros. Esta intepretação condiz com o fato da área superficial de poros internos acessíveis representar mais de $98 \%$ da área superficial total das fibras de bagaço.

Posto que a área superficial interna da parede celular é influenciada pelo grau de agregação fibrilar, os parâmetros cristalinos da celulose são considerados termos importantes na identificação dos fatores que tornam a biomassa resistente à degradação bioquímica. Isto porque a estrutura firmemente empacotada dos cristalitos de celulose limita o acesso ao seu interior, logo a ação das enzimas celulolíticas é restrita às cadeias da superfície de um cristal ou dentro dos deslocamentos, em regiões definidas como amorfas. Deste modo, seria esperado que um alto grau de agregação fibrilar implicasse em menores espaçamentos interfibrilares e, consequentemente, em menores taxas de difusão das hidrolases no interior da parede celular (ANDERSEN, 2007; ARANTES; SADDLER, 2010; DRIEMEIER, 2017; KRÄSSING, 1993; SINITSYN; GUSAKOV; VLASENKO, 1991).

A influência da estrutura cristalina da celulose na susceptibilidade das amostras de bagaço em estudo à sacarificação foi avaliada a partir da análise do comportamento do rendimento de glicose, obtido após $72 \mathrm{~h}$ de hidrólise enzimática, em função: das dimensões laterais do cristalito de celulose $(\AA)$ na direção dos planos $(200)_{\mathrm{m}}$ (Figura 63) e $(110)_{\mathrm{m}}$ e $(1$ 10) $)_{\mathrm{m}}$ (Anexo R), do índice de cristalinidade (Anexo S) e do decréscimo na cristalinidade da celulose (Anexo T).

A análise do comportamento do rendimento de glicose demonstrou uma forte correlação entre o aumento na eficiência da sacarificação e o aumento na dimensão lateral do cristalito de celulose. Esta constatação foi verdadeira para o alargamento dos cristais promovido pelo fenômeno de co-cristalização quando da solubilização dos componentes não celulósicos, assim como pelo afastamento ou possível solubilização dos componentes nas vizinhanças (espaçadores interfibrilares dentro dos agregados) promovida pelo refino mecânico. As análises realizadas neste trabalho (item 4.5), ao contrário do pressuposto na 
literatura, indicaram que um maior grau de agregação fibrilar foi induzido ao mesmo passo que houve um aumento na área superficial interna, e que estes parâmetros estão fortemente inter-relacionados. Por conseguinte, os fenômenos de modificação estrutural promovidos pelos métodos de processamento empregados, que resultaram em maiores dimensões laterais dos cristalinos de celulose, foram benéficos para o acesso e a atuação das celulases.

Figura 62. Variação do rendimento de glicose (\%) obtido após 72h de hidrólise enzimática com a dimensão lateral do cristalito de celulose $(\AA)$ na direção do plano $(200)_{\mathrm{m}}$.

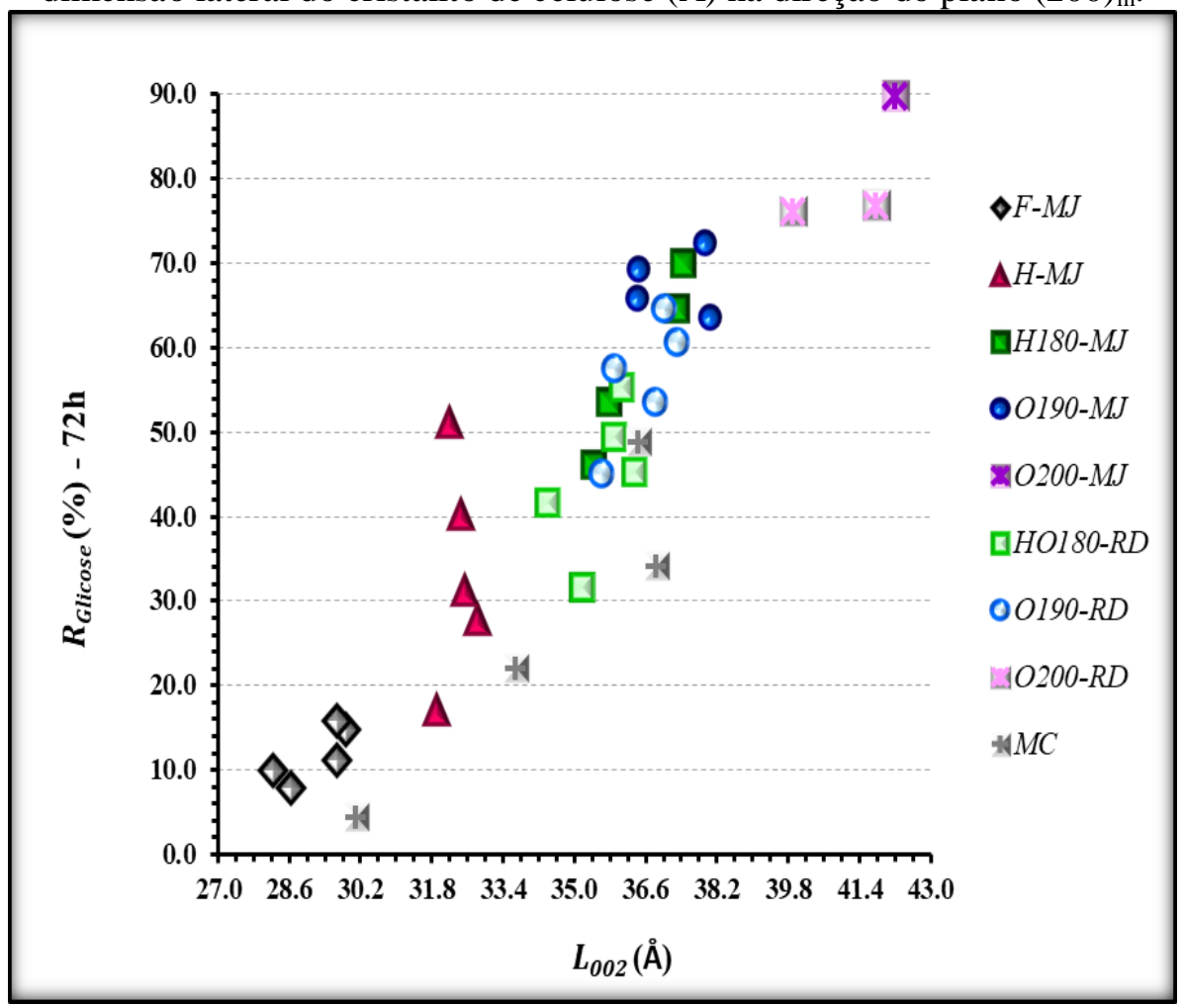

Enquanto a solubilização das hemiceluloses cria espaços diretamente acessíveis às superfícies fibrilares, a solubilização da lignina implica na remoção da cobertura associada às faces hidrofóbicas dos cristais, consideradas sítio de adsorção preferencial das celulases de $T$. reesei (VERMAAS et al., 2015). Já o refino mecânico, ao promover o intumescimento da parede celular, culmina na ruptura das interações e no afastamento de outros componentes não cristalinos presentes nas interfaces entre as fibrilas, criando espaços passíveis da entrada e da atuação enzimática.

Já os valores de índice de cristalinidade mensurados não apresentaram qualquer tipo de relação com o resultado final de rendimento de glicose obtido por hidrólise enzimática. 
Esta observação decorre do fato de que esta medida é fortemente influenciada pela presença de componentes não celulósicos. Ademais, as cristalinidades das amostras de diferentes composições químicas (proporções relativas entre os macrocomponentes da parede celular) respondem de modos distintos ao tipo e à severidade do tratamento físico-mecânico aplicado.

Destarte, uma relação mais confiável pode ser visualizada a partir do confronto entre os resultados da sacarificação enzimática e a porcentagem de redução na cristalinidade calculada em relação à esperada. Novamente, puderam-se diferenciar os comportamentos dos rendimentos de glicose obtidos em função das reduções na cristalinidade em relação à esperada para as amostras de diferentes composições químicas. Para as amostras mais recalcitrantes, $\boldsymbol{F}$ e $\boldsymbol{H}$, observou-se o aumento do rendimento de hidrólise com a descristalização contínua da celulose promovida pelo refino mecânico, como reflexo de um provável fenômeno de co-cristalização ou de rupturas de interações eletrostáticas ao longo do plano. Neste caso, a redução no valor de cristalinidade em relação ao esperado foi acompanhada do aumento no espaço para o contato das enzimas dentro das fibrilas celulósicas, resultando no aumento da extensão final da hidrólise enzimática da celulose.

Já para as amostras provindas das reações de deslignificação foi observada uma tendência oposta, isto é, de aumento do rendimento de glicose com o aumento no valor de cristalinidade em relação ao esperado. Conforme proposto nas discussões anteriores, as altas energias específicas aplicadas associadas à maior susceptibilidade das polpas organossolve aos processos físico-mecânicos podem resultar ou na degradação da porção celulósica mais acessível e menos ordenada (deslocamentos e superfícies das fibrilas celulósicas), ou na solubilização em pequena extensão dos carboidratos poliméricos menos ordenados presentes nos espaços interfibrilares.

Estas investigações permitem inferir que, apesar do grau de cristalinidade da celulose ser considerado determinante para a taxa inicial da reação de hidrólise dos substratos lignocelulósicos, este valor sozinho não explica a recalcitrância dos substratos lignocelulósicos, logo o valor de conversão final da celulose. Isto porque a redução no valor de cristalinidade mensurado em relação ao esperado foi um reflexo de alterações na estrutura das fibras como um todo, compreendendo a capilaridade interfibrilar e interlamelar e a acomodação do sistema cristalino da celulose. Além do mais, após a rápida conversão inicial das porções mais acessíveis da celulose, tanto as regiões cristalinas quanto as amorfas são hidrolisadas simultaneamente pelas glicosil hidrolases presentes no coquetel enzimático 
empregado (ALVIRA et al., 2010; ANDERSEN, 2007; BANSAL et al., 2012; COUGHLAN, 1992; DRIEMEIER, 2017; GOURLAY et al., 2015; GOURLAY; ARANTES; SADDLER, 2012; HUANG et al., 2010; PIHLAJANIEMI et al., 2016). Diferentemente, um maior grau de influência nos rendimentos de açúcares fermentescíveis obtidos foi constatado com relação à organização cristalina da celulose, e de como esta é rearranjada com o decorrer dos processos físico-químicos e/ou -mecânicos ou com a expansão da estrutura porosa da parede celular.

\subsubsection{Análise de componentes principais e construção do modelo de predição da conversão enzimática da celulose}

Ante os resultados aqui explanados e discutidos, é de acordo que a complexidade estrutural das fibras de bagaço de cana-de-açúcar dificulta a elucidação do comportamento do sistema frente aos processos hidrolíticos. Isto porque as propriedades morfológicas e nanoestruturais encontram-se inter-vinculadas em tal ponto que as interpretações das correlações foram, em muitos casos, dúbias. Adicionalmente, os métodos de processamento empregados alteraram mais de uma propriedade estrutural das fibras simultaneamente, mesmo quando não houve a alteração da composição química do material.

Em vista destas constatações, como passo final desta etapa do trabalho objetivou-se identificar a inter-relação entre as propriedades mensuradas e quantificar o grau de influência de cada uma destas na resposta do sistema à sacarificação enzimática, isto é, por qual fator cada uma das características da biomassa - químicas, físicas e morfológicas - influencia no rendimento de conversão da celulose em glicose. Para trabalhar esta questão, estudou-se estatisticamente o conjunto de dados obtidos pela análise de componentes principais (PCA). A PCA permite reduzir a dimensionalidade das informações e eliminar sobreposições pela identificação das variáveis que melhor contribuem para a variabilidade do sistema.

Para a execução da PCA, organizaram-se as observações ( $m=35$ amostras) e as dimensões ( $n=31$ parâmetros analisados ou calculados) em uma matriz $m \times n$, que foi posteriormente normalizada. A análise multivariada promoveu então a transformada das $n$ variáveis originais em $n$ novas variáveis linearmente descorrelacionadas, as componentes principais (PCs). Para cada PC, a análise forneceu: a importância para explicar a variância total dos dados dentro do sistema; os loadings - contribuição (direção e magnitude) de cada 
variável original para a formação desta PC; e os scores - representação de cada amostra na nova direção PC.

Os resultados da análise de componentes principais foram organizados em um de gráfico de loadings e um gráfico de scores, ambos presentes na Figura 64. Os eixos destes gráficos são as componentes principais (PCs) de maiores variâncias nos quais os dados foram projetados, sendo que estas novas variáveis são combinações lineares das variáveis originais. As variáveis inseridas na matriz para a PCA encontram-se descritas na legenda da figura referenciada. A componente principal primária $(P C 1)$ é o arranjo que melhor representou a distribuição dos dados, sendo responsável por $51,2 \%$ da variância total do sistema. Já a componente secundária $(P C 2)$ é perpendicular à componente principal primária, e explicou $16,9 \%$ da variância dos dados analisados.

O gráfico de loadings (Figura 64 (A)), onde o eixo horizontal é a PC1 e o eixo vertical é a $P C 2$, exibiu as magnitudes (valores) assim como as direções (sinais) pelas quais cada aspecto estrutural influencia nas componentes de maiores variâncias. Primeiramente, pôde-se observar que as variáveis originais que mais contribuíram positivamente para a formação da $P C$ de maior variância foram as relacionadas à solubilização dos componentes não celulósicos, à área superficial interna acessível da parede celular e à organização cristalina (dimensões laterais dos cristalitos) da celulose. Conforme discutido anteriormente, estes parâmetros encontram-se inter-relacionados e são de difícil separação nas interpretações, fato que é confirmado pelos valores similares de loadings destas variáveis na formação da $P C$ primária.

Outra variável que contribuiu em igual extensão para a PC1 é a área superficial externa calculada por análise morfológica das fibras, que considerou além das dimensões morfológicas (comprimento e largura médios) das fibras, o volume total de poros da parede celular. Já a $P C$ secundária foi mais influenciada pelos parâmetros morfológicos das fibras.

O gráfico de scores (Figura 64 (B)), onde os eixos horizontal e vertical também são a $P C 1$ e a $P C 2$, exprimiu o grau de influência de cada variável original no comportamento de cada tipo de amostra. Esta influência pôde ser averiguada primeiramente na possibilidade de agrupamento das amostras de diferentes composições químicas. Os cinco grupos de amostras de diferentes composições $\left(F, H, H O_{180}, O_{190}\right.$ e $\left.O_{200}\right)$ apresentaram valores crescentes de scores na PC1 conforme seus teores de hemiceluloses e lignina foram menores, o que comprova a relação da composição química das amostras com a área superficial interna acessível e com os parâmetros cristalinos da celulose. Observou-se também que as amostras 
refinadas em $M J$ e em $R D$ foram influenciadas em extensões similares pela PC1 (aumento do score com o aumento do grau de refino), porém apenas as processadas em $M J$ foram positivamente influenciadas pela $P C 2$. As relações dos valores de scores na $P C 2$ para os diferentes grupos de amostras não forneceram uma influência clara dos parâmetros morfológicos no comportamento total do sistema.

Após esta etapa de compreensão do comportamento dos dados, iniciou-se a redução de sua dimensionalidade. Uma vez organizadas as PCs de acordo com a sua variância, e as variáveis originais de acordo com a sua contribuição para cada PC, escolheu-se manter apenas a PC com maior variância associada, ou seja, a que representou a combinação linear mais significante. Dentro desta, mantiveram-se as variáveis originais mais relevantes para representar o sistema.

Em vista dos resultados da PCA, pôde-se discriminar que os principais parâmetros necessários para obter informações com grande acurácia a respeito das características do conjunto de amostra são: 1) a área superficial externa, calculada a partir do comprimento médio, da largura média e do volume total de poros das fibras (ASE-MorFI); 2) a área cumulativa de poros com diâmetros maiores ou iguais a 3,96 nm $\left(A_{\text {Poros }} A(\geq 3,96)\right)$; e 3$)$ a dimensão lateral do cristalito de celulose na direção do plano $(200)_{\mathrm{m}}\left(L_{200}\right)$. Descartaram-se os parâmetros relativos apenas à composição química dos materiais, uma vez que todos as variáveis selecionadas eram diretamente afetadas pelo teor relativo dos componentes não celulósicos. Descartaram-se também outras variáveis inter-relacionadas, obtidas segundo a mesma análise de caracterização e que explicavam a mesma alteração estrutural nas fibras das amostras de bagaço, porém com contribuição pouco menor para a PC1.

Foi então formada uma nova matriz de dados, que agrupou apenas as variáveis originais escolhidas que mais contribuíram para a PC1. Ao invés de 31 variáveis, esta nova matriz contou apenas com três das variáveis originais para representar o mesmo conjunto de 35 amostras. A análise multivariada promoveu então a transformada destas $n=3$ variáveis originais em três novas variáveis linearmente descorrelacionadas. Os resultados da PCA foram organizados em um novo gráfico de loadings, presente na Figura 65 (A), cujos eixos são as novas componentes principais (PCs) de maiores variâncias nos quais os dados foram projetados. Nesta nova análise, o arranjo que melhor representou a distribuição dos dados (PC1), respondeu por $87,2 \%$ da variância total do sistema, enquanto a componente secundária (PC2) explicou 10,6\% desta variância. 
Figura 63. Variabilidade do sistema de amostras de bagaço estudado representada pelos parâmetros físicos e morfológicos: (A) influência (loadings) das variáveis originais nas componentes principais; (B) representação das amostras (scores) de acordo com as componentes principais PC1 e PC2.
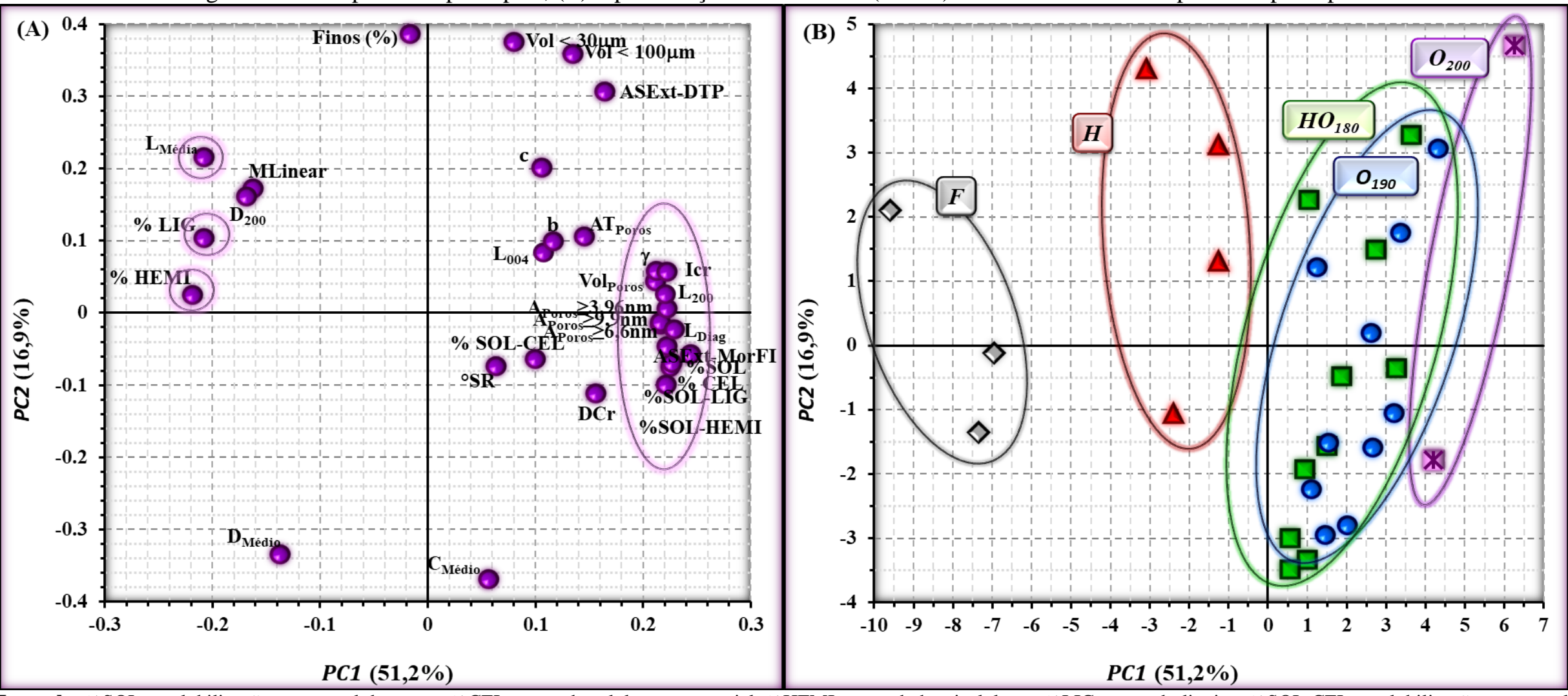

Legenda: \%SOL = solubilização percentual de massa; \%CEL = teor de celulose no material; \%HEMI = teor de hemiceluloses; \%LIG = teor de lignina; \%SOL-CEL = solubilização percentual de celulose; \%SOL-HEMI = solubilização de hemiceluloses; \%SOL-LIG = solubilização de lignina; ${ }^{\circ} \mathrm{SR}=$ grau Schöpper-Riegler; $\mathrm{D}_{\mathrm{Médio}}=$ diâmetro médio das partículas; Vol < $30 \mu \mathrm{mm}=$ volume cumulativo de partículas com diâmetros de até $30 \mu \mathrm{m}$; Vol < 100 $\mu \mathrm{m}=$ volume de partículas com diâmetros de até $100 \mu \mathrm{m}$; ASExt-DTP = área superficial específica externa calculada por distribuição de tamanhos de partículas por difração a laser; $\mathrm{C}_{\text {Médio }}=$ comprimento médio das fibras; $\mathrm{L}_{\text {Média }}=$ largura média das fibras; ASExt-MorFI = área superficial externa calculada por análise morfológica das fibras; Finos $(\%)=$ teor de finos; MLinear = massa linear das fibras; $\mathrm{Vol}_{\text {Poros }}=$ volume total de poros; $\mathrm{AT}_{\text {Poros }}=$ área total de poros; $\mathrm{A}_{\text {Poros }} \geq 9,9 \mathrm{~nm}=$ área cumulativa de poros maiores ou iguais a $9,9 \mathrm{~nm} ; A_{\text {Poros }} \geq 6,6 \mathrm{~nm}=$ área de poros maiores ou iguais a $6,6 \mathrm{~nm} ; A_{\text {Poros }} \geq 3,96 \mathrm{~nm}=$ área de poros maiores ou iguais a $3,96 \mathrm{~nm}$; $\mathrm{L}_{200}=$ dimensão lateral do cristalito de celulose na direção do plano $(200)_{\mathrm{m}} ; \mathrm{L}_{\mathrm{diag}}=$ dimensão lateral do cristalito de celulose na direção dos planos $(110)_{\mathrm{m}} \mathrm{e}(110)_{\mathrm{m}}$; $\mathrm{L}_{004}=$ comprimento aparente do cristalito de celulose na direção do plano $(004)_{m}$; b, c e $\gamma=$ parâmetros de cela unitária do cristal $\mathrm{I} \beta$ de celulose; $\mathrm{ICr}=$ índice de cristalinidade da celulose; $\mathrm{DCr}=$ decréscimo da cristalinidade da celulose. 
Figura 64. Modelo de variação da digestibilidade enzimática das amostra de bagaço estudadas com os parâmetros estruturais que mais contam para a vairabilidade do sistema: (A) influência (loadings) das variáveis originais nas componentes principais; (B) correlação entre os valores de rendimento de glicose (\% - 72h) mensurados e as representações das amostras (scores) de acordo com a componente principal PC1.
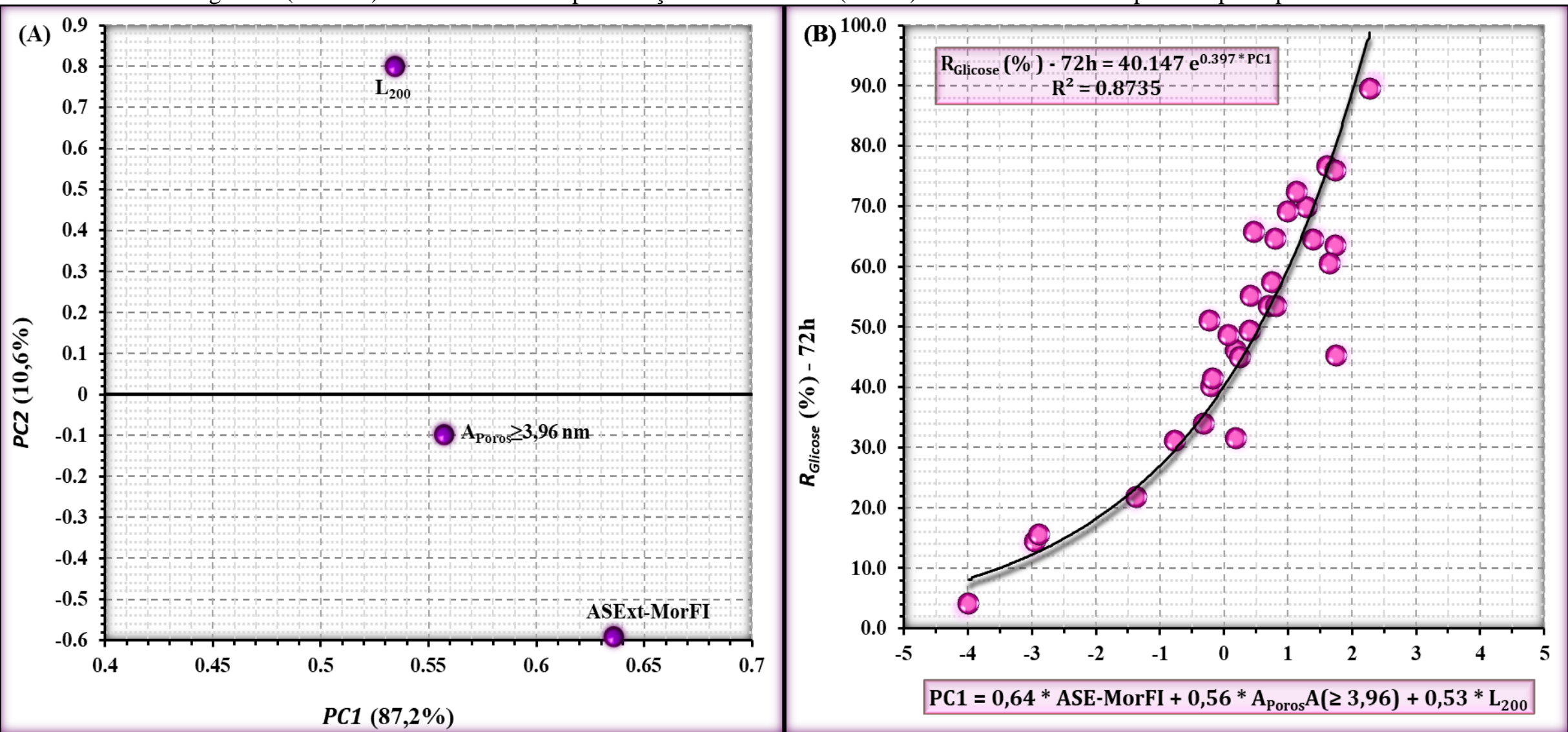

Legenda: ASExt-MorFI = área superficial específica externa calculada por análise morfológica das fibras; $\mathrm{A}_{\text {Poros }} \geq 3,96 \mathrm{~nm}=$ área de poros maiores ou iguais a 3,96 nm; $\mathrm{L}_{200}$ $=$ dimensão lateral do cristalito de celulose na direção do plano $(200)_{\mathrm{m}}$. 
Os altos valores de loadings das três variáveis originais na formação da nova PC1 significam que estas propriedades estruturais influenciam em grande extensão para a maior variância do sistema, portanto devem ser incluídas em modelos que representam o seu comportamento. Já na formação da nova $P C 2$, a área superficial externa apresentou grande influência negativa, a área de poros acessíveis pouco influenciou, e a dimensão lateral do cristalito apresentou expressiva influência positiva.

Os valores de variância das novas PCs indicaram que a nova PC1 é uma variável adequada e suficiente para representar o comportamento do sistema. Deste modo, a regressão por componentes principais permitiu reduzir o número de variáveis necessárias para descrever o comportamento do conjunto de amostras de bagaço, pré-tratada segundo diferentes métodos físico-químicos e/ou -mecânicos. Assim, a PCA pôde ser utilizada como ferramenta de análise na tentativa da identificação dos fatores que afetam a taxa de conversão enzimática dos polissacarídeos constituintes da parede celular, uma vez que simplificou os dados das análises de caracterização e facilitou a extração das informações importantes.

A partir destes resultados, um segundo objetivo da aplicação da análise estatística foi estimar e propor um modelo empírico para predizer a conversão enzimática dos polissacarídeos das amostras de bagaço em açúcares redutores baseado em suas características conhecidas (propriedades estruturais analisadas). No modelo desenvolvido, os aspectos estruturais que constituíram a nova componente principal de maior variância (PC1 loadings) foram combinados linearmente de acordo com a magnitude e a direção do seu efeito. Os valores da nova representação do conjunto de amostras (PC1 scores) foram então regredidos com os valores de rendimento de glicose obtidos após $72 \mathrm{~h}$ de hidrólise enzimática (valores conhecidos de resposta final das amostras estudadas), conforme visualizado na Figura 65 (B). O score de cada amostra dentro de cada nova PC, por sua vez, pôde ser calculado pelo somatório do produto entre cada loading de uma variável e o seu valor original normalizado. A equação da curva obtida na regressão foi então utilizada para a construção do modelo empírico de predição da conversão enzimática de amostras desconhecidas de acordo com os seus parâmetros estruturais (variáveis de entrada) analisados. O tipo de ajuste que se melhor adequou ao conjunto de dados foi o exponencial, conforme visualizado na Figura 65 (B).

Em suma, o modelo representou uma regressão exponencial entre a resposta e a combinação linear múltipla das variáveis originais que mais contaram para a variabilidade do sistema, segundo a Equação 49 a seguir: 
$R_{\text {Glicose }}(\%)=40,147 \times e^{\left\{0,397 \times\left[(0,64 \times A S E-M o r F I)+\left(0,56 \times A_{\text {Poros }} A(\geq 3,96)\right)+\left(0,53 \times L_{200}\right)\right]\right\}}$

Onde as variáveis são os valores normalizados de: $A S E-M o r F I$ é a área superficial específica externa calculada por análise morfológica das fibras; $A_{\text {Poros }} A(\geq 3,96)$ é a área cumulativa de poros maiores ou iguais a $3,96 \mathrm{~nm}$; e $L_{200}$ é a dimensão lateral do cristalito de celulose na direção do plano $(200)_{\mathrm{m}}$. Os coeficientes positivos dos parâmetros estruturais selecionados indicaram que a abertura das superfícies externa e interna da parede celular, além reorganização do sistema cristalino da celulose, são fatores que auxiliam em grande extensão a digestibilidade enzimática das cadeias de celulose. Já o rendimento de glicose após $72 \mathrm{~h}$ de hidrólise $\left(R_{\text {Glicose }}\right)$ possui limite superior de $100 \%$. O quadrado do coeficiente de correlação para a equação gerada foi 0,874 , o que indica que o modelo pôde explicar $87,4 \%$ da variabilidade da resposta.

Pelo fato deste modelo ser não mecanístico (ou empírico), este não levou em conta explicitamente a reação de hidrólise ou o mecanismo de ação das enzimas em si, mas provê uma correlação para a conversão final como função dos valores de caracterização mensuráveis dos substratos. Entretanto, os diferentes sistemas e coquetéis de celulases compreendem múltiplos componentes com distintos modos de atuação, e que são influenciados pelas condições de reação e pelas propriedades dos substratos; a propriedades estruturais, por sua vez, variam de acordo com a fonte e o tecido vegetal. Deste modo, deve-se enfatizar que o modelo aqui apresentado é adequado para prever apenas o comportamento da sacarificação enzimática de fibras de bagaço de cana-de-açúcar sob as mesmas condições de reação e utilizando os mesmos coquetéis enzimáticos mencionados no item 4.6.

Para validar o modelo proposto, realizou-se a análise estatística de variância (ANOVA). Esta análise permitiu determinar a significância do modelo em representar o conjunto de dados experimentais, ou ainda, verificar se o modelo é de fato válido para predizer os valores de rendimento de glicose (72h de hidrólise enzimática) de cada uma das amostras segundo seus parâmetros estruturais. Os resultados números da ANOVA encontramse organizados na Tabela 9 a seguir.

Primeiramente, analisou-se a "regressão por resíduo" do conjunto de amostras, que mostra a correlação linear existente entre dados experimentais (reais) e os preditos pelo modelo proposto. Quanto mais próximo da linearidade estiver a correlação, mais estatisticamente significativa será a capacidade do modelo em representar (descrever) o 
comportamento do sistema. Para isto, realizou-se o teste $F$ para a distribuição de dados e comparou-se com o valor tabelado para uma distribuição $F$ com $99 \%$ de confiança dentro dos mesmos graus de liberdade. Para que o modelo proposto seja estatisticamente representativo dos dados experimentais, é esperado que o valor de $F$ calculado seja maior que o tabelado. Uma vez que o valor de $F$ calculado foi 40 vezes o valor tabelado, pôde-se concluir que o modelo é representativo para o conjunto de dados experimentais regredidos.

Tabela 9. Resultados da análise estatística de variância (ANOVA) aplicada ao modelo empírico proposto para predizer a conversão enzimática dos polissacarídeos do bagaço de cana-de-açúcar.

\begin{tabular}{|c|c|c|c|c|}
\hline Análise ANOVA & \multicolumn{2}{|c|}{ Regressão por resíduo } & \multicolumn{2}{|c|}{ Falta de ajuste (erro puro) } \\
\hline \multirow{2}{*}{ Quadrática $(Q)$} & $\underset{(\text { amostra) }}{Q M A}$ & $\underset{\text { (replicata) }}{Q M R}$ & $\underset{(\text { amostra) }}{Q M A}$ & $\underset{\text { (amostra) }}{Q M R R}$ \\
\hline & $(\hat{\boldsymbol{Y}}-\overline{\boldsymbol{Y}})^{2}$ & $\left(Y_{i}-\hat{Y}\right)^{2}$ & $\left(\bar{Y}_{i}-\hat{\boldsymbol{Y}}\right)^{2}$ & $\left(\boldsymbol{Y}_{i}-\overline{\boldsymbol{Y}}_{i}\right)^{2}$ \\
\hline Grau de liberdade (GL) & 1 & 58 & 28 & 30 \\
\hline Quadrática média (QM) & 29759,6 & 106,4 & 217,4 & 2,8 \\
\hline F cálculado & \multicolumn{2}{|c|}{279,7} & \multicolumn{2}{|c|}{77,4} \\
\hline $\begin{array}{l}\text { F tabelado (nível de } \\
\text { significância de } 1 \% \text { ) }\end{array}$ & \multicolumn{2}{|c|}{6,8} & \multicolumn{2}{|c|}{2,3} \\
\hline
\end{tabular}

Onde: $\hat{\boldsymbol{Y}}=$ é o rendimento de glicose (72h de hidrólise enzimática) previsto pelo modelo proposto; $\overline{\boldsymbol{Y}}=$ é a média dos valores de rendimento médio de glicose (72h de hidrólise enzimática) obtidos experimentalmente para todas as amostras; $\boldsymbol{Y}_{i}=$ é o valor de rendimento de glicose ( $72 \mathrm{~h}$ de hidrólise enzimática) obtido experimentalmente para a amostra "i" em cada replicata; $\overline{\boldsymbol{Y}}_{i}=$ é o valor de rendimento médio de glicose (72h de hidrólise enzimática) obtido experimentalmente para a amostra "i"; Grau de liberdade $(\boldsymbol{G L})$ - para 30 amostras (*algumas amostras não puderam ser analisadas estastisticamente pelo fato de determinados métodos de análises não poderem ser aplicados a tais) analisadas em duplicata; Quadrática Média - $Q M A=\left(\sum Q\right) \times 2 / G L$ dentro de cada amostra ou $Q M R=\left(\sum Q i 1+\sum Q i 2\right) / G L$ entre cada replicata; $\boldsymbol{F}$ calculado $=Q M A / Q M R$.

Calculou-se também o "erro por falta de ajuste", que mostra a incapacidade do modelo em representar o comportamento dos dados reais estudados. Isto pode ser visualizado com um maior espalhamento dos dados experimentais ao redor da curva de ajuste do modelo; quanto maior este espalhamento, menor a capacidade do modelo em predizer o comportamento do sistema. Uma vez que erro puro (experimental) foi baixo para reação enzimática, o erro total do modelo foi mais representado pelo pela falta de ajuste. Novamente, realizou-se o teste $F$ para a distribuição de dados e comparou-se com o valor tabelado para uma distribuição $F$ com 99\% de confiança. Para que o modelo proposto seja estatisticamente significativo dentro da faixa de significância definida, e possa predizer com acurácia o comportamento de amostras 
desconhecidas a partir dos dados experimentais, é esperado que o valor de $\mathrm{F}$ calculado seja menor tabelado. Uma vez que o valor de $F$ calculado foi aproximadamente 30 vezes o valor tabelado, pôde-se concluir que o modelo não prevê com a mesma acurácia dos desvios experimentais o comportamento de amostras desconhecidas.

Apesar da boa correlação obtida entre os dados calculados pelo modelo e os dados obtidos experimentalmente, há diversas hipóteses para a dispersão dos dados ao redor da curva de predição, ou do desvio no modelo para a conversão total após $72 \mathrm{~h}$ de reação. Esta poder ser simplesmente devida a outras características estruturais faltantes, cujos valores poderiam completar o modelo e predizer a digestibilidade; como exemplo, poderia ser incluída no modelo alguma medida da área diretamente acessível às cadeias celulósicas ao invés da superfície interna total da parede celular, ou ainda alguma medida do grau de interações hidrofóbicas entre as celulases e a lignina. Ademais, outros aspectos inerentes da reação hidrolítica, como a inibição pelos produtos da reação, as mudanças na adsorção das enzimas e as alterações dos aspectos estruturais dos substratos lignocelulósicos com o decorrer do tempo, influenciam em grande extensão a resposta final (ARANTES; GOURLAY; SADDLER, 2014; WALKER; WILSON, 1991; ZHANG; LYND, 2004).

Considerando a complexidade da estrutura lignocelulósica e dos mecanismos enzimáticos, as correlações podem ser consideradas satisfatórias para predizer a digestibilidade enzimática dos polissacarídeos, que pôde ser simplesmente caracterizada por um componente principal, ao invés de múltiplas e inter-correlacionadas variáveis. Assim, a correlação exponencial entre os parâmetros estruturais e o rendimento de açúcares obtidos por hidrólise forneceu a possibilidade de utilizar métodos de análise para prever a conversão enzimática de uma determinada amostra de bagaço.

Uma vez discriminadas e dimensionadas as funções de cada propriedade estrutural em restringir a acessibilidade enzimática, adquiriu-se o conhecimento de como facilitar a atuação das proteínas hidrolíticas sobre os polissacarídeos constituintes da parede celular vegetal. A maior importância relativa de fatores que representam a área superficial das fibras enfatiza a importância da remoção das barreiras físicas em etapa anterior à sacarificação das amostras de bagaço de cana-de-açúcar. 


\section{CAPÍTULO 6. CONCLUSÕES}

A partir dos valores de rendimento de glicose obtidos por hidrólise enzimática e dos resultados das análises físicas e morfológicas, conclui-se que os métodos de refino são eficientes em promover a abertura da estrutura física das fibras de bagaço de cana-de-açúcar aos agentes hidrolíticos.

O refino em moinho centrífugo tipo Jokro proveu os maiores incrementos na digestibilidade enzimática da biomassa em relação ao material não refinado, de $17 \%$ a $200 \%$ dependendo da composição química do material. Quanto maior a recalcitrância do material, mais intenso foi o efeito do refino na abertura da estrutura da parede celular, tendência observada tanto nos valores de rendimento de hidrólise quanto nas dimensões das fibras e na área de poros acessíveis. Maiores intensidades de refinos (tempo de processamento mecânico) provocaram maiores alterações nas propriedades dos materiais estudados.

As amostras de bagaço, quando processadas em refinador de discos Bauer, somente apresentaram alterações estruturais e aumentos expressivos na digestibilidade da celulose quando refinadas na aproximação máxima entre os discos constituintes do equipamento. Apesar de apresentarem um alto valor de área de poros acessíveis enzimaticamente, a redução nas dimensões das fibras foi menos significativa quando comparada ao efeito provocado pelo refino em moinho Jokro, implicando em rendimentos máximos de glicose de 10 a $21 \%$ menores

Considerando o processamento em moinho criogênico, as expressivas alterações nas dimensões dos materiais provocadas pela quebra das fibras não acarretaram em melhorias na digestibilidade enzimática.

Em suma, o refino em moinho laboratorial tipo Jokro promoveu os maiores acréscimos nas digestibilidades enzimáticas das amostras de bagaço por culminar simultaneamente no aumento da estrutura capilar pela intensa fibrilação interna, e da área superficial externa tanto pela formação de elementos finos quanto pela redução das dimensões das fibras por corte. Já o refinador de discos Bauer levou a uma melhoria menos pronunciada na hidrolisabilidade dos materiais por resultar no aumento expressivo no volume de poros internos da parede celular, porém com evidências de fibrilação externa das fibras gradativa e apenas quando da aplicação de altas energias específicas e sem o seu expressivo corte. Diferentemente, a moagem criogênica promoveu apenas a drástica e heterogênea redução das 
dimensões das fibras pela quebra destas quando no estado congelado, enquanto não permitiu mudanças significativas na área de poros acessíveis enzimaticamente.

Os resultados da análise de PCA permitiram discriminar que os principais parâmetros que influenciam na digestibilidade das amostras de bagaço são: 1) a área superficial externa, calculada a partir do comprimento médio, da largura média e do volume total de poros das fibras; 2) a área cumulativa de poros com diâmetros maiores ou iguais a 3,96 nm; e 3) a dimensão lateral do cristalito de celulose na direção do plano $(200)_{\mathrm{m}}$.

Com relação ao modelo empírico de predição do rendimento de glicose proposto para as amostras de bagaço, este pôde explicar $87,4 \%$ da variabilidade da resposta. Por fim, a correlação exponencial entre os parâmetros estruturais e o rendimento de açúcares obtidos por hidrólise forneceu a possibilidade de utilizar métodos de análise para prever a conversão enzimática de uma determinada amostra de bagaço. 


\section{CAPÍTULO 7. REFERÊNCIAS BIBLIOGRÁFICAS}

ABDUL KHALIL, H. P. S.; DAVOUDPOUR, Y.; ISLAM, M. N.; MUSTAPHA, A.; SUDESH, K.; DUNGANI, R.; JAWAID, M. Production and modification of nanofibrillated cellulose using various mechanical process: a review. Carbohydrate Polymers, v. 99, p. 649-665, 2014.

ADNEY, B.; BAKER, J. Measurement of cellulase activities: laboratory analytical procedure (LAP). Technical Report, NREL/TP-510-42628, National Renewable Energy

Laboratory, 1996.

ADSUL, M. G.; SINGHVI, M. S.; GAIKAIWARI, S. A.; GOKHALE, D. V. Development of biocatalysts for production of commodity chemicals from lignocellulosic biomass.

Bioresource technology, v. 102, p. 4304-4312, 2011.

AGNIHOTRI, S.; JOHNSEN, I. A.; BØE, M. S.; ØYAAS, K.; MOE, S. Ethanol organosolv pretreatment of softwood (Picea abies) and sugarcane bagasse for biofuel and biorefinery applications. Wood Science and Technology, v. 49, p. 881-896, 2015.

ALVES, M.; PONCE, G. H. S. F.; SILVA, M. A.; ENSINAS, A. V. Surplus electricity production in sugarcane mills using residual bagasse and straw as fuel. Energy, v. 91, p. 751$757,2015$.

ALVIRA, P.; TOMÁS-PEJÓ, E.; BALLESTEROS, M.; NEGRO, M. J. Pretreatment technologies for an efficient bioethanol production process based on enzymatic hydrolysis: a review. Bioresource Technology, v. 101, p. 4851-4861, 2010.

AMORE, A.; CIESIELSKI, P. N.; LIN, C. Y.; SALVACHÚA, D.; NOGUÉ, V. S. Development of lignocellulosic biorefinery technologies: recent advances and current challenges. Australian Journal of Chemistry, v. 69, p. 1201-1218, 2016.

ANDERSEN, N. Enzymatic hydrolysis of cellulose: experimental and modeling studies. 2007. 162f. Tese (Doutorado) - BioCentrum - DTU, Technical University of Denmark, Copenhagen, 2007.

ANDRIC', P.; MEYER, A. S.; JENSEN, P. A.; DAM-JOHANSEN, K. Reactor design for minimizing product inhibition during enzymatic lignocellulose hydrolysis: I. Significance and mechanism of cellobiose and glucose inhibition on cellulolytic enzymes. Biotechnology Advances, v. 28, p. 308-324, 2010a.

ANDRIC', P.; MEYER, A. S.; JENSEN, P. A.; DAM-JOHANSEN, K. Reactor design for minimizing product inhibition during enzymatic lignocellulose hydrolysis: II. Quantification of inhibition and suitability of membrane reactors. Biotechnology Advances, v. 28, p. 407$425,2010 b$.

ARANTES, V.; GOURLAY, K.; SADDLER, J. The enzymatic hydrolysis of pretreated pulp fibers predominantly involves "peeling/erosion" modes of action. Biotechnology for Biofuels, v. 7, p. 87, 2014. 
ARANTES, V.; SADDLER, J. N. Access to cellulose limits the efficiency of enzymatic hydrolysis: the role of amorphogenesis. Biotechnology for Biofuels, v. 3, n. 4, 11 p. 2010.

ARANTES, V.; SADDLER, J. N. Cellulose accessibility limits the effectiveness of minimum cellulase loading on the efficient hydrolysis of pretreated lignocellulosic substrates.

Biotechnology for Biofuels, v. 4, n. 3, 17 p. 2011.

ARJA, M. O. Cellulases in the textile industry. In: POLAINA, J.; MACCABE, A. P. Industrial enzymes: structure, function and applications. Dordrecht: Springer, 2007. Cap. 4, p. 51-63.

ASSOCIAÇÃO NACIONAL DOS FABRICANTES DE VEÍCULOS AUTOMOTORES (ANFAVEA). Estatísticas. 2016. Disponível em:

<http://www.anfavea.com.br/estatisticas-2016.html>. Acesso em: 04 mar. 2016.

ATALLA, R. H.; VANDERHART, D. L. The role of solid state 13C NMR spectroscopy in studies of the nature of native celluloses. Solid State Nuclear Magnetic Resonance, v. 15, p. $1-19,1999$.

AUHORN, W. J. Papermaking chemistry \& technology. Pulp production processes. 2015. Disponível em: <http://chempatec-auhorn.com/stockprep/index.html> Acesso em: 09 mar. 2017.

BANAVATH, H. N.; BHARDWAJ, N. K.; RAY, A. K. A comparative study of the effect of refining on charge of various pulps. Bioresource Technology, v. 102, p. 4544-4551, 2011.

BANCO NACIONAL DE DESENVOLVIMENTO ECONÔMICO E SOCIAL (BNDES) e CENTRO DE GESTÃO E ESTUDOS ESTRATÉGICOS (CGEE). Bioetanol de cana-deaçúcar: energia para o desenvolvimento sustentável. Rio de Janeiro: BNDES, 2008. 316p. Disponível em: <http://www.iea.sp.gov.br/out/bioenergia/textos/bio_06_2008.pdf>. Acesso em: 20 fev. 2012.

BANSAL, P.; HALL, M.; REALFF, M. J.; LEE, J. H.; BOMMARIUS, A. S. Multivariate statistical analysis of X-ray data from cellulose: a new method to determine degree of crystallinity and predict hydrolysis rate. Bioresource Technology, v. 101, p. 4461-4471, 2010.

BANSAL, P.; VOWELL, B. J.; HALL, M.; REALFF, M. J.; LEE, J. H.; BOMMARIUS, A. S. Elucidation of cellulose accessibility, hydrolysability and reactivity as the major limitation in the enzymatic hydrolysis of cellulose. Bioresource Technology, v. 107, p. 243-250, 2012.

BARAKAT, A.; DE VRIES, H.; ROUAU, X. Dry fractionation process as an important step in current and future lignocellulose biorefineries: a review. Bioresource Technology, v. 134, p. 362-373, 2013.

BAUM, A.; AGGER, J.; MEYER, A. S.; EGEBO, M.; MIKKELSEN, J. D. Rapid near infrared spectroscopy for prediction of enzymatic hydrolysis of corn bran after various pretreatments. New Biotechnology, v. 29, n. 3, p. 293-301, 2010. 
BATALHA, L. A. R.; HAN, Q.; JAMEEL, H.; CHANG, H. M.; COLODETTE, J. L.; GOMES, F. J. B. Production of fermentable sugars from sugarcane bagasse by enzymatic hydrolysis after autohydrolysis and mechanical refining. Bioresource Technology, v. 180, p. 97-105, 2015.

BAYER, E. A.; CHANZY, H.; LAMED, R.; SHOHAM, Y. Cellulose, cellulases and cellulosomes. Current Opinion in Structural Biology, v. 8, p. 548-557, 1998.

BERNARDEZ, T. D.; LYFORD, K.; HOGSETT, D. A.; LYND, L. R. Adsorption of Clostridium thermocellum cellulase onto pretreated mixed hardwood, avicel and lignin. Biotechnology and Bioengineering, v. 43, p. 899-907, 1993.

BERTRAN, M. S.; DALE, B. E. Enzymatic hydrolysis and recrystallization behavior of initially amorphous cellulose. Biotechnology and Bioengineering, v. 27, p. 177-181, 1985.

BETINI, M. A.; GALATTI, P. E. Curso de pasta mecânica. In: CURSO DE PASTA MECÂNICA, 1995, Monte Alegre. Anais... Monte Alegre: Associação Brasileira Técnica de Celulose e Papel, 1995. 95p.

BHARDWAJ, N. K.; HOANG, V.; NGUYEN, K. L. A comparative study of the effect of refining on physical and electrokinetic properties of various cellulosic fibres. Bioresource Technology, v. 98, p. 1647-1654, 2007.

BHAUMIK, P.; DHEPE, P. L. Conversion of biomass into sugars. In: MURZIN, D.; SIMAKOVA, O. Biomass sugars for non-fuel applications. Cambridge: Royal Society of Chemistry, 2016. Cap. 1, p. 1-53.

BOUSSARSAR, H.; ROGÉ, B.; MATHLOUTHI, M. Optimization of sugarcane bagasse conversion by hydrothermal treatment for the recovery of xylose. Bioresource Technology, v. 100, p. 6537-6542, 2009.

BOZELL, J. J.; HOLLADAY, J. E.; JOHNSON, D.; WHITE, J. F. Top value added chemicals from biomass: results of screening for potential candidates from biorefinery lignin. U.S. Department of Energy (DOE), National Renewable Energy Laboratory (NREL), Pacific Northwest National Laboratory (PNNL), 2007. v. 2. Disponível em: <http://www.pnl.gov/main/publications/external/technical_reports/PNNL-16983.pdf>. Acesso em: 30 maio 2017.

BROWN, R. F.; HOLTZAPPLE, M. T. A comparison of the Michaelis-Menten and HCH-1 models. Biotechnology and Bioengineering, v. 36, p. 1151-1154, 1990.

BURGUER; P. Charles Fenerty and his paper invention. Toronto: PB Publishing, 2007. 226p. Disponível em: <http://www.charlesfenerty.ca/book_folder/BURGER\%20\%20Charles\%20Fenerty\%209780978331818.pdf>. Acesso em: 20 jan. 2017.

BURNS, D. S.; OOSHIMA, H.; CONVERSE, A. O. Surface area of pretreated lignocellulosics as a function of the extent of enzymatic hydrolysis. Applied Biochemistry and Biotechnology, v. 20, p. 79-94, 1989. 
CAMPOS, A.; CORREA, A. C.; CANNELLA, D.; TEIXEIRA, E. M.; MARCONCINI, J. M.; DUFRESNE, A.; MATTOSO, L. H. C.; CASSLAND, P.; SANADI, A. R. Obtaining nanofibers from curauá and sugarcane bagasse fibers using enzymatic hydrolysis followed by sonication. Cellulose, v. 20, p. 1491-1500, 2013.

CAMPOS, E. S. Curso básico de fabricação de papel. Apostila revisão 07. In: CURSO BÁSICO DE FABRICAÇÃO DE PAPEL, 2009, São Paulo. Anais... São Paulo: Associação Brasileira Técnica de Celulose e Papel (ABTCP); Universidade Setorial de Celulose e Papel (UNISCEPA), 2009. 347p.

CAMPOS, E. S. Refino da pasta celulósica. In: CURSO SOBRE REFINO DA PASTA CELULÓSICA, 1999, Guaíba. Anais... Guaíba: Associação Brasileira Técnica de Celulose e Papel, 1999.

CANILHA, L.; CHANDEL, A. K.; MILESSI, T. S. S.; ANTUNES, F. A. F.; FREITAS, W. L. C.; FELIPE, M. G. A.; SILVA, S. S. Bioconversion of sugarcane biomass into ethanol: an overview about composition, pretreatment methods, detoxification of hydrolysates, enzymatic saccharification, and ethanol fermentation. Journal of Biomedicine and Biotechnology, v. 2012, 15 p., 2012.

CARBOHYDRATE-ACTIVE ENZYMES DATABASE (CAZY). Glycoside hydrolase family classification. 2017. Disponível em: <http://www.cazy.org/>. Acesso em: 27 jul. 2017.

CARDONA, C. A.; QUINTERO, J. A.; PAZ, I. C. Production of bioethanol from Sugarcane bagasse: status and perspectives. Bioresource Technology, v. 101, p. 4754-4766, 2010.

CENTRO DE GESTÃO E ESTUDOS ESTRATÉGICOS. Sustainability of sugarcane bioenergy. Brasília: Ministério da Ciência, Tecnologia e Inovação, CGEE, 2012. 336p.

CHANDRA, R. P.; BURA, R.; MABEE, W. E.; BERLIN, A.; PAN, X.; SADDLER, J. N. Substrate pretreatment: the key to effective enzymatic hydrolysis of lignocellulosics?

Advances in Biochemical Engineering / Biotechnology, v. 108, p. 67-93, 2007.

CHANG, V. S.; HOLTZAPPLE, M. T. Fundamental factors affecting biomass enzymatic reactivity. Applied Biochemistry and Biotechnology, v. 84-86, p. 5-37, 2000.

CHANZY, H.; HENRISSAT, B.; VUONG, R. Colloidal gold labelling of 1,4- $\beta$-D-glucan cellobiohydrolase adsorbed on cellulose substrates. FEBS Letters, v. 172, p. 193-197, 1984.

CHANZY, H.; HENRISSAT, B. Unidirectional degradation of valonia cellulose microcrystals subjected to cellulase action FEBS Letters, v. 184, p. 285-288, 1985.

CHEN, R.; DOU, J. Biofuels and bio-based chemicals from lignocellulose: metabolic engineering strategies in strain development. Biotechnology Letters, v. 38, p. 213-221, 2016.

CHEN, H.; LIU, J.; CHANG, X.; CHEN, D.; XUE, Y.; LIU, P.; LIN, H.; HAN, S. A review on the pretreatment of lignocellulose for high-value chemicals. Fuel Processing Technology, v. 160, p. 196-206, 2017. 
CHEN, X.; KUHN, E.; WANG, W.; PARK, S.; FLANEGAN, K.; TRASS, O.; TENLEP, L.; TAO, L.; TUCKER. M. Comparison of different mechanical refining technologies on the enzymatic digestibility of low severity acid pretreated corn stover. Bioresource Technology, v. 147, p. 401-408, 2013.

CHEN, X.; SHEKIRO, J.; PSCHORN, T.; SABOURIN, M.; TAO, L.; ELANDER, R.; PARK, S.; JENNINGS, E.; NELSON, R.; TRASS, O.; FLANEGAN, K.; WANG, W.; HIMMEL, M. E.; JOHNSON, D.; TUCKER. M. A highly efficient dilute alkali deacetylation and mechanical (disc) refining process for the conversion of renewable biomass to lower cost sugars. Biotechnology for Biofuels, v. 7, p. 98, 2014.

CHEN, X.; TAO, L.; SHEKIRO, J.; MOHAGHAGHI, A.; DECKER, S.; WANG, W.; SMITH, H.; PARK, S.; HIMMEL, M. E.; TUCKER. M. Improved ethanol yield and reduced Minimum Ethanol Selling Price (MESP) by modifying low severity dilute acid pretreatment with deacetylation and mechanical refining: 1) Experimental. Biotechnology for Biofuels, $v$. 5, p. 60, 2012.

CHEN, X.; WANG, W.; CIESIELSKI, P.; TRASS, O.; PARK, S.; TAO, L.; TUCKER. M. Improving sugar yields and reducing enzyme loadings in the deacetylation and mechanical refining (DMR) process through multistage disk and szego refining and corresponding techno-economic analysis. ACS Sustainable Chemistry \& Engineering, v. 4, p. 324-333, 2016.

CHEN, Y.; WAN, J.; ZHANG, X.; MA, Y.; WANG, Y. Effect of beating on recycled properties of unbleached eucalyptus cellulose fiber. Carbohydrate Polymers, v. 87, p. 730$736,2012 b$.

CHERUBINI, F. The biorefinery concept: using biomass instead of oil for producing energy and chemicals. Energy Conversion and Management, v. 51, p. 1412-1421, 2010.

CHERUBINI, F.; JUNGMEIER, G. LCA of a biorefinery concept producing bioethanol, bioenergy, and chemical from switchgrass. The International Journal of Life Cycle Assessment, v. 15, p. 53-66, 2010.

CHERUBINI, F.; STRØMANN, A. H. Chemicals from lignocellulosic biomass: opportunities, perspectives and potential of biorefinery systems. Biofuels, Bioproducts and Biorefining: Modeling and Analysis, v. 5, p. 548-561, 2011.

CHOI, C. H.; MATHEWS, A. P. Two-step acid hydrolysis process kinetics in the saccharification of low-grade biomass: 1. Experimental studies on the formation and degradation of sugars. Bioresource Technology, v. 58, p. 101-106, 1996.

CIESIELSKI, P. N.; WANG, W.; CHEN, X.; VIZANT, T. B.; TUCKER, M. P.; DECKER, S. R.; HIMMEL, M. E.; JOHNSON, D. K.; DONOHOE, B. S. Effect of mechanical disruption on the effectiveness of three reactor used for dilute acid pretreatment of corn stover Part 2: morphological and structural substrate analysis. Biotechnology for Biofuels, v. 7, p. 47, 2014. 
COMPANHIA NACIONAL DE ABASTECIMENTO (CONAB). Levantamentos de safra. 2015. Disponível em:

<http://www.conab.gov.br/conteudos.php?a=1253\&ordem=criterioSafra1> . Acesso em: 03 mar. 2016.

COMPANHIA NACIONAL DE ABASTECIMENTO (CONAB). Acompanhamento da safra brasileira: cana-de-açúcar. Brasília, 2017. v. 3, safra 2016/2017, n. 4. Disponível em: <www.conab.gov.br/OlalaCMS/uploads/arquivos/17_04_19_11_27_36_boletim_cana_portug ues_-_4o_lev_-_16-17.pdf>. Acesso em: 20 maio 2016.

CONVERSE, A. O.; MATSUNO, R.; TANAKA, M.; TANIGUCHI, M. A model of enzyme adsorption and hydrolysis of microcrystalline cellulose with slow deactivation of the adsorbed enzyme. Biotechnology and Bioengineering, v. 32, p. 38-45, 1988.

CONVERSE, A. O.; OOSHIMA, H.; BURNS, D. S. Kinetics of enzymatic hydrolysis of lignocellulosic materials based on surface area of cellulose accessible to enzyme and enzyme adsorption on lignin and cellulose. Applied Biochemistry and Biotechnology, v. 24, p. 67$73,1990$.

CORTEZ, L. A. B.; LORA, E. S.; GÓMEZ, E. O. Biomassa para energia. Campinas: Editora Unicamp, 2008. 734p.

COUGHLAN, M. P. The properties of fungal and bacterial cellulases with comment on their production and application. Biotechnology and Genetic Engineering Reviews, v. 3, p. 39$110,1985$.

COUGHLAN, M. P. Enzymic hydrolysis of cellulose: an overview. Bioresource Technology, v. 39, p. 107-115, 1992.

COWLING, E. B.; KIRK, T. K. Properties of cellulose and lignocellulosic materials as substrates for enzymatic conversion processes. Biotechnology and Bioengineering Symposium, v. 6, p. 95-123, 1976.

D’ALMEIDA, M. L. O. Celulose e papel: tecnologia de fabricação do papel. $2^{a}$ ed. São Paulo: Escola SENAI “Theobaldo de Nigris", Instituto de Pesquisas Tecnológicas do Estado de São Paulo (IPT), 1988. v. 2, p. 560-964.

DA CRUZ, S. H.; DIEN, B. S.; NICHOLS, N. N.; SAHA, B. C.; COTTA, M. A. Hydrothermal pretreatment of sugarcane bagasse using response surface methodology improves digestibility and ethanol production by SSF. Journal of Industrial Microbiology \& Biotechnology, v. 39, p. 439-447, 2012.

DA SILVA, A. P. Os processos de refinação dentro das novas técnicas. In: CONVENÇÃO ANUAL DA ASSOCIAÇÃO BRASILEIRA TÉCNICA DE CELULOSE E PAPEL “SEMANA DO PAPEL”, 1., 1968, São Paulo. Anais... São Paulo: Associação Brasileira Técnica de Celulose e Papel, 1968. 
DA SILVA, A. S.; INOUE, H.; ENDO, T.; YANO, S.; BON, E. P. S. Milling pretreatment of sugarcane bagasse and straw for enzymatic hydrolysis and ethanol fermentation. Bioresource Technology, v. 101, p. 7402-7409, 2010.

DASARI, R. K.; BERSON, R. E. The effect of particle size on hydrolysis reaction rates and rheological properties in cellulosic slurries. Applied Biochemistry and Biotechnology, v. 137, p. 289-299, 2007.

DAVIES, G; HENRISSAT, B. Structures and mechanisms of glycosyl hydrolases. Structure, v. 3, p. 853-859, 1995.

DE ANGELO, J. C. Utilização de enzimas nas rações melhora o desempenho nutricional. São Paulo, 2013. Disponível em:

$<$ https://www.aviculturaindustrial.com.br/imprensa/utilizacao-de-enzimas-nas-racoesmelhora-o-desempenho-nutricional/20130401-135815-q101>. Acesso em: 30 abr. 2017.

DE BARROS, R. R. O.; PAREDES, R. S.; ENDO, T.; BON, E. P. S.; LEE, S. H. Association of wet disk milling and ozonolysis as pretreatment for enzymatic saccharification of sugarcane bagasse and straw. Bioresource Technology, v. 136, p. 288-294, 2013.

DE CASTRO, A. M.; PEREIRA JUNIOR, N. Produção, propriedades e aplicação de celulases na hidrólise de resíduos agroindustriais. Química Nova, v. 33, n. 1, p. 181-188, 2010.

DE SOUZA, A. P.; LEITE, D. C. C.; PATTATHIL, S.; HAHN, M. G.; BUCKERIDGE, M. S. Composition and structure of sugarcane cell wall polysaccharide: implications for secondgeneration bioethanol production. Bioenergy Research, v. 6, p. 564-579, 2013.

DEL RÍO, J. C.; PRINSEN, P.; RENCORET, J.; NIETO, L.; JIMÉNEZ-BARBERO, J.; RALPH, J.; MARTÍNEZ, Á. T.; GUTIÉRREZ, A. Structural characterization of the lignin in the cortex and pith of elephant grass (Pennisetum purpureum) stems. Journal of Agricultural and Food Chemistry, v. 60, p. 3619-3634, 2012.

DEL RIO, L. F.; CHANDRA, R. P.; SADDLER, J. N. The effects of increasing swelling and anionic charges on the enzymatic hydrolysis of organosolv-pretreated softwoods at low enzyme loadings. Biotechnology and Bioengineering, v. 108, p. 1549-1558, 2011.

DEMUNER, B. J. Refino. In: CURSO SOBRE REFINO DA PASTA CELULÓSICA, 2001, São Paulo. Anais... São Paulo: Associação Brasileira Técnica de Celulose e Papel, 2001. 29p.

DIAS, M. O. S.; JUNQUEIRA, T. L.; JESUS, C. D. F.; ROSSELL, C. E. V.; MACIEL FILHO, R.; BONOMI, A. Improving second generation ethanol production through optimization of first generation production process from sugarcane. Energy, v. 43, p. 246$252,2012$.

DINARDO-MIRANDA, L. L.; VASCONCELOS, A. C. M.; LANDELL, M. G. A. Cana-deaçúcar. Campinas: Instituto Agronômico, 2008. 882p. 
DIVNE, C.; STÅHLBERG, J.; REINIKAINEN, T.; RUOHONEN, L.; PETTERSSON, G.; KNOWLES, J. K.; TEERI, T. T.; JONES, T. A. The three-dimensional crystal structure of the catalytic core of cellobiohydrolase I from Trichoderma reesei. Science, v. 265, p. 524-528, 1994.

DOGARIS, I.; KARAPATI, S.; MAMMA, D.; KALOGERIS, E.; KEKOS, D. Hydrothermal processing and enzymatic hydrolysis of sorghum bagasse for fermentable carbohydrates production. Bioresource Technology, v. 100, p. 6543-6549, 2009.

DONOHOE, B. S.; DECKER, S. R., TUCKER, M. P.; HIMMEL, M. E.; VINZANT, T. B. Visualizing lignin coalescence and migration through maize cell walls following thermochemical pretreatment. Biotechnology and Bioengineering, v. 101, p. 913-925, 2008.

DRIEMEIER, C. Nanostructure of lignocellulose and its importance for biomass conversion into chemicals and biofuels. In: BUCKERIDGE, M. S.; DE SOUZA, A. P. Advances of basic science for second generation bioethanol from sugarcane. New York: Springer, 2017. Cap. 3, p. 21-38.

DRIEMEIER, C. Two-dimensional Rietveld analysis of celluloses from higher plants. Cellulose, v. 21, p. 1065-1073, 2014.

DRIEMEIER, C.; BRAGATTO, J. Crystallite width determines monolayer hydration across a wide spectrum of celluloses isolated from plants. The Journal of Physical Chemistry B, v. 117, p. 415-421, 2013.

DRIEMEIER, C.; CALLIGARIS, G. A. Theoretical and experimental developments for accurate determination of crystallinity of cellulose I materials. Journal of Applied Crystallography, v. 44, p. 184-192, 2011.

DRIEMEIER, C.; MENDES, F. M.; OLIVEIRA, M. M. Dynamic vapor sorption and thermoporometry to probe water in celluloses. Cellulose, v. 19, p. 1051-1063, 2012.

DRIEMEIER, C.; MENDES, F. M.; SANTUCCI, B. S.; PIMENTA, M. T. B. Cellulose cocrystallization and related phenomena occurring in hydrothermal treatment of sugarcane bagasse. Cellulose, v. 22, p. 2183-2195, 2015.

DRIEMEIER, C.; PIMENTA, M. T. B.; ROCHA, G. J. M.; OLIVEIRA, M. M.; MELLO, D. B.; MAZIERO, P.; GONÇALVEZ, A. R. Evolution of cellulose crystals during prehydrolysis and soda delignification of sugarcane lignocellulose. Cellulose, v. 18, p. 1509-1519, 2011.

DRIEMEIER, C.; SANTOS, W. D.; BUCKERIDGE, M. S. Cellulose crystals in fibrovascular bundles of sugarcane culms: orientation, size, distortion, and variability. Cellulose, v. 19, p. 1507-1515, 2012.

ELSHAFEI, A. M.; VEGA, J. L.; KLASSON, K. T.; CLAUSEN, E. C.; GADDY, J. L. The saccharification of corn stover by cellulase from Penicillium funiculosum. Bioresource Technology, v. 35, p. 73-80, 1991. 
ERIKSSON, K. E. L. Biotechnology in the pulp and paper industry. Wood Science and Technology, v. 24, p. 79-101, 1990.

ERTAS, M.; HAN, Q.; JAMEEL, H.; CHANG, H. M. Enzymatic hydrolysis of autohydrolyzed wheat straw followed by refining to produce fermentable sugars. Bioresource Technology, v. 152, p. 259-266, 2014.

FAN, L. T.; LEE, Y. H.; BEARDMORE, D. H. Mechanism of the enzymatic hydrolysis of cellulose: effects of major structural features of cellulose on enzymatic hydrolysis.

Biotechnology and Bioengineering, v. 22, p. 177-199, 1980.

FAN, L. T.; LEE, Y. H.; BEARDMORE, D. H. The influence of major structural features of cellulose on rate of enzymatic hydrolysis. Biotechnology and Bioengineering, v. 23, p. 419424, 1981.

FAN, S.; ZHANG, P.; LI, F.; JIN, S.; WANG, S.; ZHOU, S. A review of lignocellulose change during hydrothermal pretreatment for bioenergy production. Current Organic Chemistry, v. 20, p. 1-11, 2016.

FANG, H.; DENG, J.; ZHANG, X. Continuous steam explosion of wheat straw by high pressure mechanical refining system to produce sugars for bioconversion. BioResources, v. 6 , p. 4468-4480, 2011.

FARDIM, P.; DURÁN, N. Modification of fibre surfaces during pulping and refining as analysed by SEM, XPS and ToF-SIMS. Colloids and Surfaces A: Physicochemical and Engineering Aspects, v. 223, p. 263-276, 2003.

FENGEL, D.; WEGENER, G. Wood: chemistry, ultrastructure, reactions. Berlin: Walter de Gruyter, 1989. 611p.

FERNANDO, S.; ADHIKARI, S.; CHANDRAPAL, C.; MURALI, N. Biorefineries: current status, challenges, and future direction. Energy \& Fuels, v. 20, p. 1727-1737, 2006.

FERREIRA-LEITÃO, V.; GOTTSCHALK, L. M. F.; FERRARA, M. A.; NEPOMUCENO, A. L.; MOLINARI, H. B. C.; BON, E. P. S. Biomass residues in Brazil: availability and potential uses. Waste and Biomass Valorization, v. 1, p. 65-76, 2010.

FERREIRA, P. Estudos de pastas kraft Eucalyptus globulus: características estruturais e aptidão papeleira. 2000. 366f. Tese (Doutorado) - Faculdade de Ciências e Tecnologia, Universidade de Coimbra, Coimbra, 2000.

FIEROBE, H. P.; BAYER, E. A.; TARDIF, C.; CZJZEK, M.; MECHALY, A.; BÉLAÏCH, A.; LAMED, R.; SHOHAM, Y.; BÉLAÏCH, J. P. Degradation of cellulose substrates by cellulosome chimeras. Substrate targeting versus proximity of enzyme components. The Journal of Biological Chemistry, v. 277, p. 49621-49630, 2002.

FOOD AND AGRICULTURE ORGANIZATION (FAO). FAOSTAT Database: Production - Crops, 2015. Disponível em:

<http://www.fao.org/faostat/en/\#data/QC>. Acesso em: 05 mar. 2016. 
FOOD AND AGRICULTURE ORGANIZATION (FAO). FAOSTAT Database: Forestry production and trade, 2015. Disponível em:

<http://www.fao.org/faostat/en/\#data/FO>. Acesso em: 08 mar. 2017.

FRANCO, H.; FERRAZ, A.; MILAGRES, A. M. F.; CARVALHO, W.; FREER, J.; BAEZA, J.; MENDONÇA, R. T. Alkaline sulfite/anthraquinone pretreatment followed by disk refining of Pinus radiata and Pinus caribaea wood chips for biochemical ethanol production. Journal of Chemical Technology and Biotechnology, v. 87, p. 651-657, 2012.

GALBE, M.; ZACCHI, G. Pretreatment of lignocellulosic materials for efficient bioethanol production. Advances in Biochemical Engineering / Biotechnology, v. 108, p. 41-65, 2007.

GAO, M. T.; YANO, S.; INOUE, H.; SAKANISHI, K. Combination of wet disk milling and hydrogen peroxide treatments for enhancing saccharification of sugarcane bagasse.

Biochemical Engineering Journal, v. 68, p. 152-158, 2012.

GAO, Y.; XU, J.; ZHANG, Y.; YU, Q.; YUAN, Z.; LIU, Y. Effects of different pretreatment methods on chemical composition of sugarcane bagasse and enzymatic hydrolysis.

Bioresource Technology, v. 144, p. 396-400, 2013.

GARCÍA, A.; ALRIOLS, M. G.; LABIDI, J. Evaluation of different lignocellulosic raw materials as potential alternative feedstocks in biorefinery processes. Industrial Crops and Products, v. 53, p. 102-110, 2014.

GCE PAPÉIS. EcoQuality. Preservação do meio ambiente. 2012. Disponível em: <http://www.gcepapeis.com.br/index.php/sustentabilidade/porque-o-papel-de-cana-de-acucare-um-produto-sustentavel.html>. Acesso em: 30 maio 2017.

GENOVESE, A. L.; UDAETA, M. E. M.; GALVAO, L. C. R. Aspectos energéticos da biomassa como recurso no Brasil e no mundo. In: ENCONTRO DE ENERGIA NO MEIO RURAL, 6., 2006, Campinas. Anais eletrônicos... Disponível em:

$<$ http://www.proceedings.scielo.br/scielo.php?pid=MSC0000000022006000100021\&script=s ci_arttext>. Acesso em: 06 mar. 2016.

GHAFFAR, S. H.; FAN, M. Lignin in straw and its application as an adhesive. International Journal of Adhesion \& Adhesives, v. 48, p. 92-101, 2014.

GHAREHKHANI, S.; SADEGHINEZHAD, E.; KAZI, S. N.; YARMAND, H.; BADARUDIN, A.; SAFAEI, M. R.; ZUBIR, M. N. M. Basic effects of pulp refining on fiber properties - a review. Carbohydrate Polymers, v. 115, p. 785-803, 2015.

GHARPURAY, M. M.; LEE, Y. H.; FAN, L. T. Structural modification of lignocellulosics by pretreatments to enhance enzymatic hydrolysis. Biotechnology and Bioengineering, v. 25, p. 157-172, 1983.

GHOSE, T. K. Measurement of cellulase activities. Pure and Applied Chemistry, v. 59, p. 257-268, 1987. 
GLOBAL BIOENERGY PARTNERSHIP (GBEP). Working together for sustainable development since 2006. 2006. Disponível em: <http://www.globalbioenergy.org/>. Acesso em: 19 maio 2017.

GLOSTER, T. M.; DAVIES, G. J. Glycosidase inhibition: assessing mimicry of the transition state. Organic \& Biomolecular Chemistry, v. 8, p. 305-320, 2010.

GONZALEZ, R.; JAMEEL, H.; CHANG, H. M.; TREASURE, T.; PIRRAGLIA, A.; SALONI, D. Thermo-mechanical pulping as a pretreatment for agricultural biomass for biochemical conversion. BioResources, v. 6, p. 1599-1614, 2011.

GOURLAY, K.; ARANTES, V.; SADDLER, J. N. Use of substructure-specific carbohydrate binding modules to track changes in cellulose accessibility and surface morphology during the amorphogenesis step of enzymatic hydrolysis. Biotechnology for Biofuels, v. 5, 14p. 2012.

GOURLAY, K.; HU, J.; ARANTES, V.; PENTTILÄ, M.; SADDLER, J. N. The use of carbohydrate binding modules (CBMs) to monitor changes in fragmentation and cellulose fiber surface morphology during cellulase- and swollenin-induced deconstruction of lignocellulosic substrates. The Journal of Biological Chemistry, v. 290, p. 2938-2945, 2015.

GOUVEIA, E. R.; NASCIMENTO, R. T.; MAIOR, A. M. S.; ROCHA, G. J. M. Validação de metodologia para a caracterização química de bagaço de cana-de-açúcar. Química Nova, v. 32, p. 1500-1503, 2009.

GRETHLEIN, H. E. The effect of pore size distribution on the rate of enzymatic hydrolysis of cellulosic substrates. Nature Biotechnology, p. 155-160, 1985.

GROHMANN, K.; MITCHELL, D. J.; HIMMEL, M. E.; DALE, B. E.; SCHROEDER, H. A. The role of ester groups in resistance of plant cell wall polysaccharides to enzymatic hydrolysis. Applied Biochemistry and Biotechnology, v. 20, p. 45-61, 1989.

GRUNO, M.; VÄLJAMÄE, P.; PETTERSSON, G.; JOHANSSON, G. Inhibition of the Trichoderma reesei cellulases by cellobiose is strongly dependent on the nature of the substrate. Biotechnology and Bioengineering, v. 86, p. 503-512, 2004.

GURGEL, L. V. A. Hidrólise ácida de bagaço de cana-de-açúcar: estudo cinético de sacarificação de celulose para a produção de etanol. 2010. 315f. Tese (Doutorado) Universidade de São Paulo, Instituto de Química de São Carlos, São Carlos, 2010.

HABIBI, Y.; LUCIA, L. A.; ROJAS, O. J. Cellulose nanocrystals: chemistry, self-assembly, and applications. Chemical Reviews, v. 110, p. 3479-3500, 2010.

HAHN-HÄGERDAL, B.; GALBE, M.; GORWA-GRAUSLUND, M. F.; LIDÉN, G.; ZACCHI, G. Bio-ethanol - the fuel of tomorrow from the residues of today. Trends in Biotechnology, v. 24, p. 549-556, 2006.

HALLAC, B. B.; SANNIGRAHI, P.; PU, Y.; RAY, M.; MURPHY, R. J.; RAGAUSKAS, A. $\mathrm{J}$. Effect of ethanol organosolv pretreatment on enzymatic hydrolysis of Buddleja davidii stem Biomass. Industrial \& Engineering Chemical Research, v. 49, p. 1467-1472, 2010. 
HAN, Q.; JIN, Y.; JAMEEL, H.; CHANG, H. M.; PHILLIPS, R.; PARK, S. Autohydrolysis pretreatment of waste wheat straw for cellulosic ethanol production in a co-located straw pulp mill. Applied Biochemistry and Biotechnology, v. 175, p. 1193-1210, 2015.

HANSEN, M. A.; KRISTENSEN, J. B.; FELBY, C. J $\square$ RGENSEN, H. Pretreatment and enzymatic hydrolysis of wheat straw (Triticum aestivum L.) - the impact of lignin relocation and plant tissues on enzymatic accessibility. Bioresource Technology, v. 102, p. 2804-2811, 2011.

HASSAN, M. L.; BRAS, J.; HASSAN, E. A.; SILARD, C.; MAURET, E. Enzyme-assisted isolation of microfibrillated cellulose from date palm fruit stalks. Industrial Crops and Products, v. 55, p. 102-108, 2014.

HENDRIKS, A. T. W. M.; ZEEMAN, G. Pretreatments to enhance the digestibility of lignocellulosic biomass. Bioresource Technology, v. 100, p. 10-18, 2009.

HENRIKSSON, M.; HENRIKSSON, G.; BERGLUND, L. A.; LINDSTRÖM, T. An environmentally friendly method for enzyme-assisted preparation of Microfibrillated cellulose (MFC) nanofibers. European Polymer Journal, v. 43, p. 3434-3441, 2007.

HENRISSAT, B.; DRIGUEZ, H.; VIET, C.; SCHÜLEIN, M. Synergism of cellulases from Trichoderma reesei in the degradation of cellulose. Nature Biotechnology, v. 3, p. 722-726, 1985.

HERGEN. Refinadores. 2017. Disponível em:

<http://www.hergen.com.br/produtos/preparacao-de-massa/refinadores/>. Acesso em: 16 mar. 2017.

HIDENO, A.; INOUE, H.; TSUKAHARA, K.; FUJIMOTO, S.; MINOWA, T.; INOUE, S.; ENDO, T.; SAWAYAMA, S. Wet disk milling pretreatment without sulfuric acid for enzymatic hydrolysis of rice straw. Bioresource Technology, v. 100, p. 2706-2711, 2009.

HIDENO, A.; INOUE, H.; YANAGIDA, T.; TSUKAHARA, K.; ENDO, T.; SAWAYAMA, S. Combination of hot compressed water treatment and wet disk milling for high sugar recovery yield in enzymatic hydrolysis of rice straw. Bioresource Technology, v. 104, p.743$748,2012$.

HOEGER, I. C.; NAIR, S. S.; RAGAUSKAS, A. J.; DENG, Y.; ROJAS, O. J.; ZHU, J. Y. Mechanical deconstruction of lignocellulose cell walls and their enzymatic saccharification. Cellulose, v. 20, p. 807-818, 2013.

HOFFMANN, P.; JONES, M. A. Structure and degradation process for waterlogged archeological wood. In: ROWELL, R. M.; BARBOUR, R. J. Archaeological wood: properties, chemistry and preservation. Washington: ACS, 1989. p.35-65.

HOLTZAPPLE, M.; COGNATA, M.; SHU, Y.; HENDRICKSON, C. Inhibition of Trichoderma reesei cellulase by sugars and solvents. Biotechnology and Bioengineering, $\mathrm{v}$. 36, p. 275-287, 1990. 
HORN, S. J.; VAAJE-KOLSTAD, G.; WESTERENG, B.; EIJSINK, V. G. H. Novel enzymes for the degradation of cellulose. Biotechnology for Biofuels, v. 5, n. 45, 12 p., 2012.

HU, J.; ARANTES, V.; PRIBOWO, A.; SADDLER, J. N. The synergistic action of accessory enzymes enhances the hydrolytic potential of a "cellulase mixture" but is highly substrate specific. Biotechnology for Biofuels, v. 6, p. 112-123, 2013.

HU, J.; CHANDRA, R.; ARANTES, V.; GOURLAY, K.; VAN DYK, J. S.; SADDLER, J. N. The addition of accessory enzymes enhances the hydrolytic performance of cellulase enzymes at high solid loadings. Bioresource Technology, v. 186, p. 149-153, $2015 \mathrm{a}$.

HU, J.; GOURLAY, K.; ARANTES, V.; VAN DYK, J. S.; PRIBOWO, A.; SADDLER, J. N. The accessible cellulose surface influences cellulase synergism during the hydrolysis of lignocellulosic substrates. ChemSusChem, v. 8, p. 901-907, 2015 b.

HU, Z.; FOSTON, M.; RAGAUSKAS, A. J. Comparative studies on hydrothermal pretreatment and enzymatic saccharification of leaves and internodes of Alamo switchgrass.

Bioresource Technology, v. 102, p. 7224-7228, 2011.

HU, Z.; RAGAUSKAS, A. J. Hydrothermal pretreatment of switchgrass. Industrial \& Engineering Chemistry Research, v. 50, p. 4225-4230, 2011.

HUANG, R.; SU, R.; QI, W.; HE, Z. Understanding the key factors for enzymatic conversion of pretreated lignocellulose by partial least square analysis. Biotechnology Progress, v. 26, n. 2, p. 384-392, 2010.

HUIJGEN, W. J. J.; SMIT, A. T.; DE WILD, P. J.; DEN UIL, H. Fractionation of wheat straw by prehydrolysis, organosolv delignification and enzymatic hydrolysis for production of sugars and lignin. Bioresource Technology, v. 114, p. 389-398, 2012.

HUO, D.; FANG, G.; YANG, Q.; HAN, S.; DENG, Y.; SHEN, K.; LIN, Y. Enhancement of eucalypt chips' enzymolysis efficiency by a combination method of alkali impregnation and refining pretreatment. Bioresource Technology, v. 150, p. 73-78, 2013.

IDM TEST. Molino de refino jokro PTA. 2017a. Disponível em: <http://www.idmtest.com/productos/molino-de-refino-jokro-pta>. Acesso em: 24 mar. 2017.

IDM TEST. Refinador carga automática PFI IDM. 2017b. Disponível em: $<$ http://www.idmtest.com/productos/refinador-carga-automatica-pfi-idm>. Acesso em: 24 mar. 2017.

IEA BIOENERGY. Large industrial users of energy biomass. 2013. 75p. (Task 40: Sustainable International Bioenergy Trade). Disponível em: $<$ http://task40.ieabioenergy.com/wp-content/uploads/2013/09/t40-large-industrial-biomassusers.pdf>. Acesso em: 06 mar. 2016. 
INTERNATIONAL ENERGY AGENCY (IEA). Sustainable production of secondgeneration biofuels: potential and perspectives in major economies and developing countries. International Energy Agency: Information paper, 2010. 221p. Disponível em: $<$ https://www.iea.org/publications/freepublications/publication/second_generation_biofuels.p df>. Acesso em: 05 mar. 2016.

INTERNATIONAL ENERGY AGENCY (IEA). Global energy \& $\mathbf{C O}_{\mathbf{2}}$ status report: the latest trends in energy ans emissions in 2017. Disponível em:

<https://www.iea.org/geco/renewables/>. Acesso em: 27 set. 2018.

JÄGER, G.; BÜCHS, J. Biocatalytic conversion of lignocellulose to platform chemicals. Biotechnology Journal, v. 7, p. 1122-1136, 2012.

JALAK, J.; VÄLJAMÄE, P. Mechanism of initial rapid rate retardation in cellobiohydrolase catalyzed cellulose hydrolysis. Biotechnology and Bioengineering, v. 106, p. 871-883, 2010.

JEOH, T.; ISHIZAWA, C. I.; DAVIS, M. F.; HIMMEL, M. E.; ADNEY, W. S.; JOHNSON, D. K. Cellulase digestibility of pretreated biomass is limited by cellulose accessibility.

Biotechnology and Bioengineering, v. 98, p. 112-122, 2007.

JIANG, J.; WANG, J.; ZHANG, X.; WOLCOTT, M. Evaluation of physical structural features on influencing enzymatic hydrolysis efficiency of micronized wood. RSC Advances, v. 6, p. 103026-103034, 2016.

JONES, B. W.; VENDITTI, R.; PARK, S.; JAMEEL, H. Comparison of lab, pilot, and industrial scale low consistency mechanical refining for improvements in enzymatic digestibility of pretreated hardwood. Bioresource Technology, v. 167, p. 514-520, 2014.

JONES, B. W.; VENDITTI, R.; PARK, S.; JAMEEL, H.; KOO, B. Enhancement in enzymatic hydrolysis by mechanical refining for pretreated hardwood lignocellulosics.

Bioresource Technology, v. 147, p. 353-360, 2013.

JÖNSSON, L. J.; ALRIKSSON, B.; NILVEBRANT, N. O. Bioconversion of lignocellulose: inhibitors and detoxification. Biotechnology for Biofuels, v. 6, p. 16-25, 2013.

KAJASTE, R. Chemicals from biomass - managing greenhouse gas emissions in biorefinery production chains - a review. Journal of Cleaner Production, v. 75, p. 1-10, 2014.

KARLSSON, J.; SIIKA-AHO, M.; TENKANEN, M.; TJERNELD, F. Enzymatic properties of the low molecular mass endoglucanases Cel12A (EG III) and Cel45A (EG V) of Trichoderma reesei. Journal of Biotechnology, v. 99, p. 63-78, 2002.

KARTHA MÁQUINAS E EQUIPAMENTOS. Discos e cones para refinadores, deflakers e dispersores. 2017a. Disponível em: <http://www.kartha-br.com/parason---discos-e-conesrefinadores.html>. Acesso em: 16 mar. 2017.

KARTHA MÁQUINAS E EQUIPAMENTOS. Equipamentos de preparação de massa. 2017b. Disponível em: <http://www.kartha-br.com/parason---equipamentos-de-preparacaode-massa.html>. Acesso em: 16 mar. 2017. 
KARTHA MÁQUINAS E EQUIPAMENTOS. Refinador de celulose duplo disco. 2017c. Disponível em: <http://www.kartha-br.com/refinador-de-celulose-a-disco.html>. Acesso em: 16 mar. 2017.

KEREKES, R. J. Characterizing refining action in PFI mills. TAPPI Journal, v. 4, n.3, p. 9$14,2005$.

KHULLAR, E.; DIEN, B. S.; RAUSCH, K. D.; TUMBLESON, M. E.; SINGH, V. Effect of particle size on enzymatic hydrolysis of pretreated Miscanthus. Industrial Crops and Products, v. 44, p. 11-17, 2013.

KIM, J. S.; LEE, Y. Y.; TORGET, R. W. Cellulose hydrolysis under extremely low sulfuric acid and high-temperature conditions. Applied Biochemistry and Biotechnology, v. 91-93, p. 331-340, 2001.

KIM, T. H.; KIM, J. S.; SUNWOO, C.; LEE, Y. Y. Pretreatment of corn stover by aqueous ammonia. Bioresource Technology, v. 90, p. 39-47, 2003.

KLEMM, D.; HEUBLEIN, B.; FINK, H. P.; BOHN, A. Cellulose: fascinating biopolymer and sustainable raw material. Angewandte Chemie - International Edition, v. 44, n. 22, p. 3358-3393, 2005.

KLOCK, U.; DE ANDRADE, A. S.; HERnANDEZ, J. A. Polpa e papel - manual didático. $3^{\text {a }}$ ed. Curitiba: Universidade Federal do Paraná, Setor de Ciências Agrárias, Departamento de Engenharia e Tecnologia Florestal, 2013. Disponível em:

<http://www.madeira.ufpr.br/disciplinasklock/polpaepapel/manualpolpa2013.pdf >. Acesso em: 20 jan. 2017.

KNAPPERT, D.; GRETHLEIN, H.; CONVERSE, A. Partial acid hydrolysis of cellulosic materials as a pretreatment for enzymatic hydrolysis. Biotechnology and Bioengineering, $v$. 22, p. 1449-1463, 1980.

KO, J. K.; KIM, Y.; XIMENES, E.; LADISCH, M. R. Effect of liquid hot water pretreatment severity on properties of hardwood lignin and enzymatic hydrolysis of cellulose.

Biotechnology and Bioengineering, v. 112, p. 252-262, $2015 \mathrm{a}$.

KO, J. K.; UM, Y.; PARK, Y. C.; SEO, J. H.; KIM, K. H. Compounds inhibiting the bioconversion of hydrothermally pretreated lignocellulose. Applied Microbiology and Biotechnology, v. 99, p. 4201-4212, 2015b.

KO, J. K.; XIMENES, E.; KIM, Y.; LADISCH, M. R. Adsorption of enzyme onto lignins of liquid hot water pretreated hardwoods. Biotechnology and Bioengineering, v. 112, p. 447$456,2015 \mathrm{c}$.

KOBAYASHI, H.; FUKUOKA, A. Synthesis and utilisation of sugar compounds derived from lignocellulosic biomass. Green Chemistry, v. 15, p. 1740-1763, 2013. 
KOO, B. W.; TREASURE, T. H.; JAMEEL, H.; PHILLIPS, R. B.; CHANG, H. M.; PARK, S. Reduction of enzyme dosage by oxygen delignification and mechanical refining for enzymatic hydrolysis of green liquor-pretreated hardwood. Applied Biochemistry and Biotechnology, v. 165, p. 832-844, 2011.

KOSHLAND JUNIOR, D. E. Stereochemistry and the mechanism of enzymatic reactions. Biological Reviews, v. 28, p. 416-436, 1953.

KRÄSSING, H. A. Cellulose: structure, accessibility and reactivity. Pennsylvania: Gordon and Breach Science Publishers, 1993. Cap. 5, p. 167-324.

KUMAR, L.; ARANTES, V.; CHANDRA, R.; SADDLER, J. The lignin present in steam pretreated softwood binds enzymes and limits cellulose accessibility. Bioresource Technology, v. 103, p. 201-208, 2012.

KUMAR, R.; WYMAN, C. E. Effect of xylanase supplementation of cellulase on digestion of corn stover solids prepared by leading pretreatment technologies. Bioresource Technology, v. 100, p. 4203-4213, 2009a.

KUMAR, R.; WYMAN, C. E. Effect of enzyme supplementation at moderate cellulase loadings on initial glucose and xylose release from corn stover solids pretreated by leading technologies. Biotechnology and Bioengineering, v. 102, p. 457-467, $2009 \mathrm{~b}$.

LAI, C.; TU, M.; LI, M.; YU, S. Remarkable solvent and extractable lignin effects on enzymatic digestibility of organosolv pretreated hardwood. Bioresource Technology, v. 156, p. 92-99, 2014.

LAMSAL, B. P.; MADL, R.; TSAKPUNIDIS, K. Comparison of feedstock pretreatment performance and its effect on soluble sugar availability. Bioenergy Research, v. 4, p. 193200, 2011.

LANGFORD, J. I.; WILSON, A. J. C. Scherrer after sixty years: a survey and some new results in the determination of crystallite size. Journal of Applied Crystallography, v. 11, p. 102-113, 1978.

LASER, M.; LARSON, E.; DALE, B.; WANG, M.; GREENE, N.; LYND, L. R. Comparative analysis of efficiency, environmental impact, and process economics for mature biomass refining scenarios. Biofuels, Bioproducts and Biorefining, v. 3, p. 247-270, 2009.

LAUREANO-PEREZ, L.; DALE, B. E.; O’DWYER, J. P.; HOLTZAPPEL, M. Statistical correlation of spectroscopic analysis and enzymatic hydrolysis of poplar samples.

Biotechnology Progress, v. 22, p. 835-841, 2006.

LAVOINE, N.; DESLOGES, I.; DUFRESNE, A.; BRAS, J. Microfibrillated cellulose - its barrier properties and applications in cellulosic materials: a review. Carbohydrate Polymers, v. 90, p. 735-764, 2012. 
LEE, S. H.; CHANG, F.; INOUE, S.; ENDO, T. Increase in enzyme accessibility by generation of nanospace in cell wall supramolecular structure. Bioresource Technology, v. 101, p. 7218-7223, 2010.

LEE, Y. H.; FAN, L. T. Kinetic studies of enzymatic hydrolysis of insoluble cellulose: analysis of the initial rates. Biotechnology and Bioengineering, v. 24, p. 2383-2406, 1982. LESCHINSKY, M.; ZUCKERSTÄTTER, G.; WEBER, H. K.; PATT, R.; SIXTA, H. Effect of autohydrolysis of Eucalyptus globulus wood on lignin structure. Part 1: comparison of different lignin fractions formed during water prehydrolysis. Holzforschung, v. 62, p. 645652,2008 a.

LESCHINSKY, M.; ZUCKERSTÄTTER, G.; WEBER, H. K.; PATT, R.; SIXTA, H. Effect of autohydrolysis of Eucalyptus globulus wood on lignin structure. Part 2: influence of autohydrolysis intensity. Holzforschung, v. 62, p. 653-658, 2008 b.

LEU, S. Y.; ZHU, J. Y. Substrate-related factors affecting enzymatic saccharification of lignocelluloses: our recent understanding. Bioenergy Research, v. 6, p. 405-415, 2013.

LI, H.; YE, C.; LIU, K.; GU, H.; DU, W.; BAO, J. Analysis of particle size reduction on overall surface area and enzymatic hydrolysis yield of corn stover. Bioprocess and Biosystems Engineering, v. 38, p. 149-154, 2015.

LI, J.; HENRIKSSON, G.; GELLERSTEDT, G. Lignin depolymerization/ repolymerization and its critical role for delignification of aspen wood by steam explosion. Bioresource Technology, v. 98, p. 3061-3068, 2007.

LIGUORI, R.; FARACO, V. Biological processes for advancing lignocellulosic waste biorefinery by advocating circular economy. Bioresource Technology, v. 215, p. 13-20, 2016.

LIN, L.; YAN, R.; LIU, Y.; JIANG, W. In-depth investigation of enzymatic hydrolysis of biomass wastes based on three major components: cellulose, hemicellulose and lignin.

Bioresource Technology, v. 101, p. 8217-8223, 2010.

LUO, X.; ZHU, J. Y. Effects of drying-induced fiber hornification on enzymatic saccharification of lignocelluloses. Enzyme and Microbial Technology, v. 48, p. 92-99, 2011.

LUO, X.; ZHU, J. Y.; GLEISNER, R.; ZHAN, H. Y. Effect of wet pressing-induced fiber hornification on enzymatic saccharification of lignocelluloses. Cellulose, v. 18, p. 1339-1344. 2011.

LYND, L. R.; WEIMER, P. J.; VAN ZYL, W. H.; PRETORIUS, I. S. 2002. Microbial cellulose utilization: fundamentals and biotechnology. Microbiology and Molecular Biology Reviews, v. 66, p. 506-577, 2002.

MANSFIELD, S. D.; MOONEY, C.; SADDLER, J. N. Substrate and enzyme characteristics that limit cellulose hydrolysis. Biotechnology Progress, v. 15, p. 804-816, 1999. 
MARABEZI, K. Deslignificação de bagaço de cana-de-açúcar: reações, isolamento e utilização de ligninas. 2014. 240f. Tese (Doutorado) - Universidade de São Paulo, Instituto de Química de São Carlos, São Carlos, 2014.

MARABEZI, K. Estudo sistemático das reações envolvidas na determinação dos teores de lignina e holocelulose em amostras de bagaço e palha de cana-de-açúcar. 2009. 158f.

Dissertação (Mestrado) - Universidade de São Paulo, Instituto de Química de São Carlos, São Carlos, 2009.

MARIANO, J. Futuro brilhante do etanol celulósico está ameaçado. 2016. Disponível em: <https://www.novacana.com/n/etanol/2-geracao-celulose/futuro-brilhante-etanol-celulosicoameacado-010316/>. Acesso em: 30 maio 2017.

MARIANO, M.; EL KISSI, N.; DUFRESNE, A. Cellulose nanocrystals and related nanocomposites: review of some properties and challenges. Journal of Polymer Science, Part B: Polymer Physics, v. 52, p. 791-806, 2014.

MAZIERO, P. Estudos topoquímicos durante obtenção de etanol a partir de celulose de bagaço e palha de cana-de-açúcar. 2013. 180f. Tese (Doutorado) - Universidade de São Paulo, Escola de Engenharia de Lorena, Lorena, 2013.

MAZIERO, P.; JONG, J.; MENDES, F. M.; GONÇALVES, A. R.; EDER, M.; DRIEMEIER, C. Tissue-specific cell wall hydration in sugarcane stalks. Journal of Agricultural and Food Chemistry, v. 61, p. 5841-5847, 2013.

MENG, X.; FOSTON, M.; LEISEN, J.; DE MARTINI, J.; WYMAN, C. E.; RAGAUSKAS, A. J. Determination of porosity of lignocellulosic biomass before and after pretreatment by using Simons' stain and NMR techniques. Bioresource Technology, v. 144, p. 467-476, 2013.

MENON, V.; RAO, M. Trends in bioconversion of lignocellulose: biofuels, platform chemicals \& biorefinery concept. Progress in Energy and Combustion Science, v. 38, p. 522-550, 2012.

MERALI, Z.; HO, J. D.; COLLINS, S. R. A.; LE GALL, G.; ELLISTON, A.; KÄSPER, A.; WALDRON, K. W. Characterization of cell wall components of wheat straw following hydrothermal pretreatment and fractionation. Bioresource Technology, v. 131, p. 226-234, 2013.

MESA, L.; GONZÁLEZ, E.; CARA, C.; GONZÁLEZ, M.; CASTRO, E.; MUSSATTO, S. I. The effect of organosolv pretreatment variables on enzymatic hydrolysis of sugarcane bagasse. Chemical Engineering Journal, v. 168, p. 1157-1162, 2011.

MESA, L.; GONZÁLEZ, E.; RUIZ, E.; ROMERO, I.; CARA, C.; FELISSIA, F.; CASTRO, E. Preliminary evaluation of organosolv pre-treatment of sugar cane bagasse for glucose production: application of $2^{3}$ experimental design. Applied Energy, v. 87, p. 109-114, 2010.

MICHALOWICZ, G.; TOUSSAINT, B.; VIGNON, M. R. Ultrastructural changes in poplar cell wall during steam explosion treatment. Holzforschung, v. 45, p. 175-179, 1991. 
MILLER, G. L. Use of dinitrosalicylic acid reagent for determination of reducing sugar. Analytical Chemistry, v. 31, p. 426-428, 1959.

\section{MINISTÉRIO DE MINAS E ENERGIA (MME). Balanço energético nacional 2015.} Brasília, 2015. 155 p. Disponível em:

<https://ben.epe.gov.br/downloads/Relatorio_Final_BEN_2015.pdf>. Acesso em: 08 mar. 2016.

MINISTÉRIO DO MEIO AMBIENTE (MMA). Acordo de Paris. 2016. Disponível em: <http://www.mma.gov.br/clima/convencao-das-nacoes-unidas/acordo-de-paris>. Acesso em: 19 maio 2017.

MITTAL, A.; CHATTERJEE, S. G.; SCOTT, G. M.; AMIDON, T. E. Modeling xylan solubilization during autohydrolysis of sugar maple and aspen wood chips: reaction kinetics and mass transfer. Chemical Engineering Science, v. 64, p. 3031-3041, 2009.

MIURA, T.; LEE, S. H.; INOUE, S.; ENDO, T. Improvement of enzymatic saccharification of sugarcane bagasse by dilute-alkali-catalyzed hydrothermal treatment and subsequent disk milling. Bioresource Technology, v. 105, p. 95-99, 2012a.

MIURA, T.; LEE, S. H.; INOUE, S.; ENDO, T. Combined pretreatment using ozonolysis and wet-disk milling to improve enzymatic saccharification of Japanese cedar. Bioresource Technology, v. 126, p. 182-186, 2012 b.

MOON, R. J.; MARTINI, A.; NAIRN, J.; SIMONSEN, J.; YOUNGBLOOD, J. Cellulose nanomaterials review: structure, properties and nanocomposites. Critical review. Chemical Society Reviews, v. 40, p. 3941-3994, 2011.

MOONEY, C. A.; MANSFIELD, S. D.; TOUHY, M. G.; SADDLER, J. N. The effect of initial pore volume and lignin content on the enzymatic hydrolysis of softwoods. Bioresource Technology, v. 64, p. 113-119, 1998.

MOORE, P. H.; BOTHA, F. C. Sugarcane: physiology, biochemistry \& functional biology. Oxford: Wiley Blackwell, 2014. 716p.

MOU, H.; IAMAZAKI, E.; ZHAN, H.; ORBLIN, E.; FARDIM, P. Advanced studies on the topochemistry of softwood fibres in low-consistency refining as analyzed by FE-SEM, XPS, and ToF-SIMS. BioResources, v. 8, p. 2325-2336, 2013.

MOU, H.; LI, B.; FARDIM, P. Pretreatment of corn stover with the modified hydrotropic method to enhance enzymatic hydrolysis. Energy \& Fuels, v. 28, p. 4288-4293, 2014.

MOXLEY, G.; GASPAR, A. R.; HIGGINS, D.; XU, H. Structural changes of corn stover lignin during acid pretreatment. Journal of Industrial Microbiology \& Biotechnology, v. 39, p. 1289-1299, 2012.

MURAD, H. A.; AZZAZ, H. H. Cellulase and dairy animal feeding. Biotechnology, v. 9, n. 3, p. 238-256, 2010. 
NATIONAL RENEWABLE ENERGY LABORATORY (NREL). Gregg Beckham. 2017. Disponível em: <https://www.nrel.gov/research/gregg-beckham.html>. Acesso em: 27 jul. 2017.

NAKAGAME, S.; CHANDRA, R. P.; SADDLER, J. N. The effect of isolated lignins, obtained from a range of pretreated lignocellulosic substrates, on enzymatic hydrolysis. Biotechnology and Bioengineering, v. 105, p. 871-879, 2010.

NAKAGAME, S.; CHANDRA, R. P.; KADLA, J. F.; SADDLER, J. N. The isolation, characterization and effect of lignin isolated from steam pretreated Douglas-fir on the enzymatic hydrolysis of cellulose. Bioresource Technology, v. 102, p. 4507-4517, 2011 a.

NAKAGAME, S.; CHANDRA, R. P.; KADLA, J. F.; SADDLER, J. N. Enhancing the enzymatic hydrolysis of lignocellulosic biomass by increasing the carboxylic acid content of the associated lignin. Biotechnology and Bioengineering, v. 108, p. 538-548, $2011 \mathrm{~b}$.

NAKATANI, T.; ISHIMARU, Y.; IIDA, I.; FURUTA, Y. Micropore structure of wood: Change in micropore structure accompanied by delignification. Journal of Wood Science, v. 54, p. 252-255, 2008.

NEGRO, M. J.; MANZANARES, P.; BALLESTEROS, I.; OLIVA, J. M.; CABAÑAS, A.; BALLESTEROS, M. Hydrothermal pretreatment conditions to enhance ethanol production from poplar biomass. Applied Biochemistry and Biotechnology, v. 105-108, p, 87-100, 2003.

NISHIYAMA, Y.; KIM, U. J.; KIM, D. Y.; KATSUMATA, K. S.; MAY, R. P.; LANGAN, P. Periodic disorder along ramie cellulose microfibrils. Biomacromolecules, v. 4, p. 10131017, 2003.

NITSOS, C. K.; MATIS, K. A.; TRIANTAFYLLIDIS, K. S. Optimization of hydrothermal pretreatment of lignocellulosic biomass in the bioethanol production process.

ChemSusChem, v. 6, p. 110-122, 2013.

NOVO, L. P. Determinação da relação dos parâmetros de solubilidade de Hansen de solventes orgânicos com a deslignificação organossolve de bagaço de cana-de-açúcar. 2012. 139f. Dissertação (Mestrado) - Instituto de Química de São Carlos, Universidade de São Paulo, São Carlos, 2012.

NOVO, L. P. Novas perspectivas para uma biorrefinaria de cana-de-açúcar no Brasil. 2016. 193f. Tese (Doutorado) - Universidade de São Paulo, Instituto de Química de São Carlos, São Carlos, 2016.

OBAMA, P.; RICOCHON, G.; MUNIGLIA, L.; BROSSE, N. Combination of enzymatic hydrolysis and ethanol organosolv pretreatments: effect on lignin structures, delignification yields and cellulose-to-glucose conversion. Bioresource Technology, v. 112, p. 156-163, 2012.

OLIVEIRA, R. P.; DRIEMEIER, C. CRAFS: a model to analyze two-dimensional X-ray diffraction patterns of plant cellulose. Journal of Applied Crystallography, v. 46, p. 1196$1210,2013$. 
PAPER DISCOVERY CENTER. Friedrich Gottlob Keller. 2017. Disponível em: <http://www.paperhall.org/friedrichgottlobkeller/>. Acesso em: 15 mar. 2017.

OOSHIMA, H.; BURNS, D. S.; CONVERSE, A. O. Adsorption of cellulase from Trichoderma reesei on cellulose and lignacious residue in wood pretreated by dilute sulfuric acid with explosive decompression. Biotechnology and Bioengineering, v. 36, p. 446-452, 1990.

PÄÄKKÖ, M.; ANKERFORS, M.; KOSONEN, H.; NYKÄNEN, A.; AHOLA, S.; ÖSTERBERG, M.; RUOKOLAINEN, J.; LAINE, J.; LARSSON, P. T.; IKKALA, O.; LINDSTRÖM, T. Enzymatic hydrolysis combined with mechanical shearing and highpressure homogenization for nanoscale cellulose fibrils and strong gels. Biomacromolecules, v. 8, p. 1934-1941, 2007.

PALONEN, H.; TJERNELD, F.; ZACCHI, G.; TENKANEN, M. Adsorption of Trichoderma reesei $\mathrm{CBH}$ I and EG II and their catalytic domains on steam pretreated softwood and isolated lignin. Journal of Biotechnology, v. 107, 'p. 65-72, 2004.

PARAMESWARAN, N.; LIESE, W. On the fine structure of bamboo fibres. Wood Science and Technology, v. 10, p. 231-246, 1976.

PARK, J.; JONES, B.; KOO, B.; CHEN, X.; TUCKER, M.; YU, J. H.; PSCHORN, T.; VENDITTI, R.; PARK, S. Use of mechanical refining to improve the production of low-cost sugars from lignocellulosic biomass. Bioresource Technology, v. 199, p. 59-67, 2016.

PARK, S.; VENDITTI, R. A.; JAMEEL, H.; PAWLAK, J. J. Changes in pore size distribution during the drying of cellulose fibers as measured by differential scanning calorimetry. Carbohydrate Polymers, v. 66, p. 97-103, 2006.

PATURAU, J. M. By-products of the cane sugar industry: an introduction to their industrial utilization. $3^{\mathrm{a}}$ ed. Amsterdam: Elsevier, 1989. 435p.

PECIULYTE, A.; KARLSTRÖM, K.; LARSSON, P. T.; OLSSON, L. Impact of the supramolecular structure of cellulose on the efficiency of enzymatic hydrolysis.

Biotechnology for Biofuels, v. 8, p. 56, 2015.

PEDERSEN, M.; MEYER, A. S. Influence of substrate particle size and wet oxidation on physical surface structures and enzymatic hydrolysis of wheat straw. Biotechnology Progress, v. 25, p. 399-408, 2009.

PENG, H.; LI, H.; LUO, H.; XU, J. A novel combined pretreatment of ball milling and microwave irradiation for enhancing enzymatic hydrolysis of microcrystalline cellulose. Bioresource Technology, v. 130, p. 81-87, 2013.

PIHLAJANIEMI, V.; SIPPONEN, M. H.; LIIMATAINEN, H.; SIRVIÖ, J. A.; NYYSSÖLÄ, A.; LAAKSO, S. Weighing the factors behind enzymatic hydrolyzability of pretreated lignocellulose. Green Chemistry, v. 18, p. 1295-1305, 2016. 
PIMENTA, M. T. B. Utilização de fluidos no estado supercrítico na polpação de Eucalyptus grandis e Pinus taeda. 2005. 215f. Tese (Doutorado) - Instituto de Química de São Carlos, Universidade de São Paulo, São Carlos, 2005.

POLETTO, M.; PISTOR, V.; ZATTERA, A. Structural characteristics and thermal properties of native cellulose. In: VAN DE VEN, T.; GODBOUT, L. Cellulose: fundamental aspects. London: InTech, 2013. Cap. 2, p. 45-68.

PRASAD, S.; SINGH, A.; JOSHI, H. C. Ethanol as an alternative fuel from agricultural, industrial and urban residues. Resources, Conservation and Recycling, v. 50, p. 1-39, 2007.

PURI, V. P. Effect of crystallinity and degree of polymerization of cellulose on enzymatic saccharification. Biotechnology and Bioengineering, v. 26, p. 1219-1222, 1984.

PUTRO, J. N.; SOETAREDJO, F. E.; LIN, S. Y.; JU, Y. H.; ISMADJI, S. Pretreatment and conversion of lignocellulose biomass into valuable chemical. RSC Advances, v. 6, p. 4683446852, 2016.

QING, Q.; YANG, B.; WYMAN, C. E. Xylooligomers are strong inhibitors of cellulose hydrolysis by enzymes. Bioresource Technology, v. 101, p. 9624-9630, 2010.

QING, Y.; SABO, R.; ZHU, J. Y.; AGARWAL, U.; CAI, Z.; WU, Y. A comparative study of cellulose nanofibrils disintegrated via multiple processing approaches. Carbohydrate Polymers, v. 97, p. 226-234, 2013.

RABELO, S. C. Avaliação e otimização de pré-tratamentos e hidrólise enzimática do bagaço de cana-de-açúcar para a produção de etanol de segunda geração. 2010. 447f. Tese (Doutorado) - Faculdade de Engenharia Química, Universidade Estadual de Campinas, Campinas, 2010.

RABELO, S. C.; CARRERE, H.; MACIEL FILHO, R.; COSTA, A. C. Production of bioethanol, methane and heat from sugarcane bagasse in a biorefinery concept. Bioresource Technology, v. 102, p. 7887-7895, 2011.

RABEMANOLONTSOA, H.; SAKA, A. Various pretreatments of lignocellulosics. Bioresource Technology, v. 199, p. 83-91, 2016.

RABINOVICH, M. L.; MELNICK, M. S.; BOLOBOVA, A. V. The structure and mechanism of action of cellulolytic enzymes. Biochemistry (Moscow), v. 67, p. 850-871, 2002.

RAHIKAINEN, J. L.; MARTIN-SAMPEDRO, R.; HEIKKINEN, H.; ROVIO, S.; MARJAMAA, K.; TAMMINEN, T.; ROJAS, O. J.; KRUUS, K. Inhibitory effect of lignin during cellulose bioconversion: the effect of lignin chemistry on non-productive enzyme adsorption. Bioresource Technology, v. 133, p. 270-278, 2013.

RAINEY, T. J.; COVEY, G. Pulp and paper production from sugarcane bagasse. In:

O'HARA, I. M.; MUNDREE, S. G. Sugarcane-based biofuels and bioproducts. New York: John Wiley, 2016. Cap. 10, p. 259-280. 
REESE, E. T. A microbiological process report: enzymatic hydrolysis of cellulose. Applied and Environmental Microbiology, v. 4, p. 39-45, 1956.

REESE, E. T.; SIU, R. G. H.; LEVINSON, H. S. The biological degradation of soluble cellulose derivatives and its relationship to the mechanism of cellulose hydrolysis. Journal of Bacteriology, v. 59, p. 485-497, 1950.

REISINGER, M.; TIRPANALAN, Ö.; HUBER, F.; KNEIFEL, W.; NOVALIN, S. Investigations on a wheat bran biorefinery involving organosolv fractionation and enzymatic treatment. Bioresource Technology, v. 170, p. 53-61, 2014.

RINALDI, R.; SCHÜTH, F. Acid hydrolysis of cellulose as the entry point into biorefinery schemes. ChemsSusChem, v. 2, p. 1096-1107, 2009.

RIVERS, D. B.; EMERT, G. H. Factors affecting the enzymatic hydrolysis of bagasse and rice straw. Biological Wastes, v. 26, p. 85-95, 1988.

ROCHA, G. J. M.; GONÇALVES, A. R.; OLIVEIRA, B. R.; OLIVARES, E. G.; ROSSEL, C. E. V. Steam explosion pretreatment reproduction and alkaline delignification reactions performed on a pilot scale with sugarcane bagasse for bioethanol production. Industrial Crops and Products, v. 35, p. 274-279, 2012.

ROBUSTI, C.; VIANA, E. F.; FERREIRA JÚNIOR, F.; GOMES, I.; TOGNETTA, L.; DOS SANTOS, O.; DRAGONI, P. Papel. São Paulo: SENAI-SP, 2014. 436p.

ROCHA, G. J. M.; MARTIN, C.; SOARES, I. B.; MAIOR, A. M. S.; BAUDEL, H. M.; ABREU, C. A. M. Dilute mixed-acid pretreatment sugarcane bagasse for ethanol production. Biomass and Bioenergy, v. 35, p. 663-670, 2011.

SAHA, B. C.; YOSHIDA, T.; COTTA, M. A.; SONOMOTO, K. Hydrothermal pretreatment and enzymatic saccharification of corn stover for efficient ethanol production. Industrial Crops and Products, v. 44, p. 367-372, 2013.

SAHARAY, M.; GUO, H.; SMITH, J. C. Catalytic mechanism of cellulose degradation by a cellobiohydrolase, CelS. PLoS One, v. 5, n. 10, e12947, 2010.

SANDHU, H. S.; SINGH, M. P.; GILBERT, R. A.; ODERO, D. C. Sugarcane Botany: a brief review. Florida: University of Florida, Agronomy Department, IFAS Extension. SS AGR-234. 2016. Disponível em: <http://edis.ifas.ufl.edu/pdffiles/SC/SC03400.pdf>. Acesso em: 25 maio 2017.

SANNIGRAHI, P.; RAGAUSKAS, A. J.; MILLER, S. J. Lignin structural modifications resulting from ethanol organosolv treatment of loblolly pine. Energy Fuels, v. 24, p. 683-689, 2010.

SANT'ANNA, C.; COSTA, L. T.; ABUD, Y.; BIANCATTO, L.; MIGUENS, F. C.; DE SOUZA, W. Sugarcane cell wall structure and lignin distribution investigated by confocal and electron microscopy. Microscopy Research and Technique, v. 76, p. 829-834, 2013. 
SANTOS, V. E. N.; ELY, R. N.; SZKLO, A. S.; MAGRINI, A. Chemicals, electricity and fuels from biorefineries processing Brazil's sugarcane bagasse: production recipes and minimum selling princes. Renewable and Sustainable Energy Reviews, v. 53, p. 1443$1458,2016$.

SANTUCCI, B. S.; MAZIERO, P.; RABELO, S. C.; CURVELO, A. A. S.; PIMENTA, M. T. B. Autohydrolysis of hemicelluloses from sugarcane bagasse during hydrothermal pretreatment: a kinetic assessment. Bioenergy Research, v. 8, p. 1778-1787, 2015.

SCANDINAVIAN PULP, PAPER AND BOARD TESTING COMMITTEE. SCAN-C19:65: Drainability of pulp by the Schopper-Riegler method. Stockholm, 1964. 4 p.

SCHÜTT, F.; WESTERENG, B.; HORN, S. J.; PULS, J.; SAAKE, B. Steam refining as an alternative to steam explosion. Bioresource Technology, v. 111, p. 476-481, 2012.

SEGAL, L.; CREELY, J. J.; MARTIN, A. E.; CONRAD Jr, C. M. An empirical method for estimating the degree of crystallinity of native cellulose using the X-ray diffractometer.

Textile Research Journal, v. 29, n. 10, p. 786-794, 1959.

SELIG, M. J.; VIAMAJALA, S.; DECKER, S. R.; TUCKER, M. P.; HIMMEL, M. E.; VINZANT, T. B. Deposition of lignin droplets produced during dilute acid pretreatment of maize stems retards enzymatic hydrolysis of cellulose. Biotechnology Progress, v. 23, p. 1333-1339, 2007.

SERVIÇO NACIONAL DE APRENDIZAGEM INDUSTRIAL (SENAI). Refinação. In: SEMINÁRIO DE PAPEL E CELULOSE, 3., 2011, São Paulo. Apresentação... São Paulo: Sistema FIEP, 2011. Disponível em:

<http://www.pr.senai.br/uploadAddress/Refinacao\%5B28911\%5D.pdf>. Acesso em: 30 out. 2012.

SILVA, G. G. D.; COUTURIER, M.; BERRIN, J. G.; BULÉON, A.; ROUAU, X. Effects of grinding processes on enzymatic degradation of wheat straw. Bioresource Technology, v. 103, p. 192-200, 2012.

SILVA, R. N.; MONTEIRO, V. N.; ALCANFOR, J. D. X.; ASSIS, E. M.; ASQUIERI, E. R. Comparação de métodos para a determinação de açúcares redutores e totais em mel. Food Science and Technology, v. 23, n. 3, p. 337-341, 2003. Disponível em: <http://www.scielo.br/scielo.php?script=sci_arttext\&pid=S0101-20612003000300007>. Acesso em: 20 mar. 2017.

SILVA, V. F. N.; ARRUDA, P. V.; FELIPE, M. G. A.; GONÇALVES, A. R.; ROCHA, G. J. M. Fermentation of cellulosic hydrolysates obtained by enzymatic saccharification of sugarcane bagasse pretreated by hydrothermal processing. Journal of Industrial Microbiology \& Biotechnology, v. 38, p. 809-817, 2011. 
SINDICATO NACIONAL DA INDÚSTRIA DE COMPONENTES PARA VEÍCULOS AUTOMOTORES (SINDIPEÇAS). Relatório da frota circulante de 2015. 2015.

Disponível em:

<http://www.sindipecas.org.br/sindinews/Economia/R_Frota_Circulante_2015_vf.pdf >. Acesso em: 06 mar. 2016.

SINITSYN, A. P.; GUSAKOV, A. V.; VLASENKO, E. Y. Effect of structural and physicochemical features of cellulosic substrates on the efficiency of enzymatic hydrolysis. Applied Biochemistry and Biotechnology, v. 30, p. 43-59, 1991.

SIRÓ, I.; PLACKETT, D. Microfibrillated cellulose and new nanocomposite materials: a review. Cellulose, v. 17, p. 459-494, 2010.

SINOSTAR. Refiner plate. 2017. Disponível em:

<http://www.sinostarparts.com/supplier-137958-refiner-plate>. Acesso em: 10 mar. 2017.

SIQUEIRA, G.; MILAGRES, A. M. F.; CARVALHO, W.; KOCH, G.; FERRAZ, A. Topochemical distribution of lignin and hydroxycinnamic acids in sugar-cane cell walls and its correlation with the enzymatic hydrolysis of polysaccharides. Biotechnology for Biofuels, v. 4, p. 7-15, 2011.

SLUITER, A.; HAMES, B.; RUIZ, R.; SCARLATA, C.; SLUITER, J.; TEMPLETON, D. Determination of ash in biomass. Golden: National Renewable Energy Laboratory, 2005. 8p. (Technical Report, NREL/TP-510-42622). Disponível em:

<https://www.nrel.gov/docs/gen/fy08/42622.pdf>. Acesso em: 01 mar. 2012.

SLUITER, A.; HAMES, B.; RUIZ, R.; SCARLATA, C.; SLUITER, J.; TEMPLETON, D.; Crocker, D. Determination of structural carbohydrates and lignin in biomass. Golden: National Renewable Energy Laboratory, 2008. 18p. (Technical Report, NREL/TP-51042618). Disponível em: < https://www.nrel.gov/docs/gen/fy13/42618.pdf>. Acesso em: 01 mar. 2012.

SLUITER, J. B.; CHUM, H.; GOMES, A. C.; TAVARES, R. P. A.; AZEVEDO, V.; PIMENTA, M. T. B.; RABELO, S. C.; MARABEZI, K.; CURVELO, A. A. S.; ALVES, A. R.; GARCIA, W. T.; CARVALHO, W.; ESTEVES, P. J.; MENDONÇA, S.; OLIVEIRA, P. A.; RIBEIRO, J. A. A.; MENDES, T. D.; VICENTIN, M. P.; DUARTE, C. L.; MORI, M. N. Evaluation of brazilian sugarcane bagasse characterization: an interlaboratory comparison study. Journal of AOAC International, v. 99, n. 3, p. 579-585, 2016.

SOARES, I.; TÁVORA, Z.; BARCELOS, R. P.; BARONI, S. Microorganism-produced enzymes in the food industry. In: VALDEZ, B. Scientific, health and social aspects of the food industry. London: InTech, 2012. Cap. 5, p. 83-94.

SPEX® SAMPLEPREP. 6970EFM Enclosed Freezer/Mill (Model 6970D): Operating Manual. New Jersey, 2011. 34 p.

STAHLBERG, J.; JOHANSSON, G.; PETTERSSON, G. Trichoderma reesei has no true exo-cellulase: all intact and truncated cellulases produce new reducing end groups on cellulose. Biochimica et Biophysica Acta, v. 1157, p. 107-13, 1993. 
STONE, J. E.; SCALLAN, A. M. A structural model for the cell wall of water-swollen wood pulp fibres based on their accessibility to macromolecules. Cellulose Chemistry and

Technology, v. 2, p. 343-358, 1968.

STONE, J. E.; SCALLAN, A. M.; DONEFER, E.; AHLGREN, E. Digestibility as a simple function of a molecule of similar size to a cellulase enzyme. Advances in Chemistry, v. 95, p. 219-241, 1969.

SUN, Q.; FOSTON, M.; MENG, X.; SAWADA, D.; PINGALI, S. V.; O’NEILL, H. M.; LI, H.; WYMAN, C. E.; LANGAN, P.; RAGAUSKAS, A. J.; RAJEEV KUMAR, R. Effect of lignin content on changes occurring in poplar cellulose ultrastructure during dilute acid pretreatment. Biotechnology for Biofuels, v. 7, p. 150-163, 2014.

SUN, S.; SUN, S.; CAO, X.; SUN, R. The role of pretreatment in improving the enzymatic hydrolysis of lignocellulosic materials. Bioresource Technology, v. 199, p. 49-58, 2016.

TAGUCHI, V. Bagaço de cana produz papel biodegradável. Revista globo rural, Rio de Janeiro, 2011. Disponível em:

<http://revistagloborural.globo.com/Revista/Common/0,,EMI281184-18080,00-

BAGACO+DE+CANA+PRODUZ+PAPEL+BIODEGRADAVEL.html>. Acesso em: 30 maio 2017.

TAHERZADEH, M. J.;KARIMI, K. Pretreatment of lignocellulosic wastes to improve ethanol and biogas production: a review. International Journal of Molecular Science, v. 9, p. 1621-1651, 2008.

TAO, L.; CHEN, X.; ADEN, A.; KUHN, E.; HIMMEL, M. E.; TUCKER. M.; FRANDEN, M. A. A.; ZHANG, M.; JOHNSON, D. K.; DOWE, N.; ELANDER, R. T. Improved ethanol yield and reduced minimum ethanol selling price (MESP) by modifying low severity dilute acid pretreatment with deacetylation and mechanical refining: 2) techno-economic analysis. Biotechnology for Biofuels, v. 5, p. 69, 2012.

TECHMELT. A consistência. 2013. Disponível em:

<http://www.techmelt.com/pt/a_consistencia.html>. Acesso em: 16 mar. 2017.

TECHNICAL ASSOCIATION OF THE PULP AND PAPER INDUSTRY (TAPPI). T204 cm-97: Solvent extractives of wood and pulp. Atlanta, 2007. v. 2.

THOMPSON, D. N.; CHEN, H. C.; GRETHLEIN, H. E. Comparison of pretreatment methods on the basis of available surface area. Bioresource Technology, v. 39, p. 155-163, 1992.

THYGESEN, L. G.; HIDAYAT, B. J.; JOHANSEN, K. S.; FELBY, C. Role of supramolecular cellulose structures in enzymatic hydrolysis of plant cell walls. Journal of Industrial Microbiology \& Biotechnology, v. 38, p. 975-983, 2011.

TORRES, C. E.; NEGRO, C.; FUENTE, E.; BLANCO, A. Enzymatic approaches in paper industry for pulp refining and biofilm control. Applied Microbiology and Biotechnology, v. 96, p. 327-344, 2012. 
TRAJANO, H. L.; ENGLE, N. L.; FOSTON, M.; RAGAUSKAS, A. J.; TSCHAPLINSKI, T. J.; WYMAN, C. E. The fate of lignin during hydrothermal pretreatment. Biotechnology for Biofuels, v. 6, p. 110-125, 2013.

\section{U.S. DEPARTMENT OF ENERGY (US DOE). Breaking the biological barriers to} cellulosic ethanol: a joint research agenda. 2006. 216p. Disponível em:

<http://genomicsgtl.energy.gov/biofuels/2005workshop/b2blowres63006.pdf>. Acesso em: 29 jul. 2017.

VÄLJAMÄE, P.; SILD, V.; PETTERSSON, G.; JOHANSSON, G. The initial kinetics of hydrolysis by cellobiohydrolases I and II is consistent with a cellulose surface - erosion model. European Journal of Biochemistry, v. 253, p. 469-475, 1998.

VALLEJOS, M. E.; ZAMBON, M. D.; AREA, M. C.; CURVELO, A. A. S. Low liquid-solid ratio fractionation of sugarcane bagasse by hot water autohydrolysis and organosolv delignification. Industrial Crops and Products, v. 65, p. 349-353, 2015.

VALLEJOS, M. E.; ZAMBON, M. D.; AREA, M. C.; CURVELO, A. A. S. Low liquid-solid ratio (LSR) hot water pretreatment of sugarcane bagasse. Green Chemistry, v. 14, p. 9821989, 2012.

VAN ZYL, W. H.; CHIMPHANGO, A. F. A.; DEN HAAN, R.; GÖRGENS, J. F.; CHIRWA, P. W. C. Next-generation cellulosic ethanol technologies and their contribution to a sustainable Africa. Interface Focus, v. 1, n. 2, p. 196-211, 2011.

VÁRNAI, A.; SIIKA-AHO, M.; VIIKARI, L. Restriction of the enzymatic hydrolysis of steam-pretreated spruce by lignin and hemicellulose. Enzyme and Microbial Technology, v. 46, p. 185-193, 2010.

VERMAAS, J. V.; PETRIDIS, L.; QI, X.; SCHULZ, R.; LINDNER, B.; SMITH, J. C. Mechanism of lignin inhibition of enzymatic biomass deconstruction. Biotechnology for Biofuels, v. 8, p. 217-232, 2015.

VIËTOR, R. J.; NEWMAN, R. H.; HA, M. A.; APPERLEY, D. C.; JARVIS, M. C. Conformational features of crystal-surface cellulose from higher plants. The Plant Journal, v. 30, p. 721-731, 2002.

VIRTANEN, T.; PENTTILÄ, P. A.; MALONEY, T. C.; GRÖNQVIST, S.; KAMPPURI, T.; VEHVILÄINEN. M.; SERIMAA, R.; MAUNU, S. L. Impact of mechanical and enzymatic pretreatments on softwood pulp fiber wall structure studied with NMR spectroscopy and Xray scattering. Cellulose, v. 22, p. 1565-1576, 2015.

VOCADLO, D. J.; DAVIES, G. J. Mechanistic insights into glucosidase chemistry. Current Opinion in Chemical Biology, v. 12, p. 539-555, 2008.

WALKER, L. P.; WILSON, D. B. Enzymatic hydrolysis of cellulose: an overview.

Bioresource Technology, v. 36, p. 3-14, 1991. 
WALTER, A.; DOLZAN, P.; PIACENTE, E. Biomass energy and bio-energy trade: historic developments in Brazil and current opportunities. 2006. (Country Report: Brazil - Task 40 - Sustainable bio-energy trade, securing supply and demand). Disponível em <http://www.globalbioenergy.org/uploads/media/0604_Biomass_Energy_and_Bioenergy_Trade_Historic_Developments_in_Brazil_and_Current_Opportunities_IEA_T40.pdf $>$ . Acesso em: 05 mar. 2016.

WANG, L.; ZHANG, Y.; GAO, P.; SHI, D.; LIU, H.; GAO, H. Changes in the structural properties and rate of hydrolysis of cotton fibers during extended enzymatic hydrolysis. Biotechnology and Bioengineering, v. 93, p. 443-456, 2006.

WANG, Q. Q.; HE, Z.; ZHU, Z.; ZHANG, Y. H.; NI, Y.; LUO, X. L.; ZHU, J. Y. Evaluations of cellulose accessibilities of lignocelluloses by solute exclusion and protein adsorption techniques. Biotechnology and Bioengineering, v. 109, p. 381-389, 2012a.

WANG, W.; CHEN, X.; DONOHOE, B. S; CIESIELSKI, P. N.; KATAHIRA, R.; KUHN, E. M.; KAFLE, K.; LEE, C. M.; PARK, S.; KIM, S. H.; TUCKER, M. P.; HIMMEL, M. E.; JOHNSON, D. K. Effect of mechanical disruption on the effectiveness of three reactor used for dilute acid pretreatment of corn stover Part 1: chemical and physical substrate analysis. Biotechnology for Biofuels, v. 7, p. 57, 2014.

WANG, Z. J.; ZHU, J. Y.; GLEISNER, R.; CHEN, K. F. Ethanol production from poplar wood through enzymatic saccharification and fermentation by dilute acid and SPORL pretreatments. Fuel, v. 95, p. 606-614, 2012 b.

WEIMER, P. J.; WESTON, W. M. Relationship between the fine structure of native cellulose and cellulose degradability by the cellulase complexes of Trichoderma reesei and Clostridium thermocellum. Biotechnology and Bioengineering, v. 27, p. 1540-1547, 1985.

WEIQI, W.; SHUBIN, W.; LIGUO, L. Combination of liquid hot water pretreatment and wet disk milling to improve the efficiency of the enzymatic hydrolysis of eucalyptus. Bioresource Technology, v. 128, p. 725-730, 2013.

WERPY, T.; PETERSEN, G. Top value added chemicals from biomass: results of screening for potential candidates from sugar and synthesis gas. U.S. Department of Energy, National Renewable Energy Laboratory, Pacific Northwest National Laboratory, 2004. v. 1. Disponível em: <http://www.nrel.gov/docs/fy04osti/35523.pdf〉. Acesso em: 30 maio 2017.

WEUSTHUIS, R. A.; AARTS, J. M. M. J. G.; SANDERS, J. P. M. From biofuel to bioproduct: is bioethanol a suitable fermentation feedstock for synthesis of bulk chemicals?

Biofuels, Bioproducts and Biorefining, v. 5, p. 486-494, 2011.

WILDSCHUT, J.; SMIT, A. T.; REITH, J. H.; HUIJGEN, W. J. J. Ethanol-based organosolv fractionation of wheat straw for the production of lignin and enzymatically digestible cellulose. Bioresource Technology, v. 135, p. 58-66, 2013.

WIKIPEDIA. Aparat Schoppera-Rieglera.svg. 2013. Disponível em: <https://commons.wikimedia.org/wiki/File:Aparat_Schoppera-Rieglera.svg>. Acesso em: 13 mar. 2017. 
WIKIPEDIA. Hollander beater. 2008. Disponível em:

<https://en.wikipedia.org/wiki/File:Hollander_beater.jpg\#filehistory>. Acesso em: 13 mar. 2017.

WIMAN, M.; DIENES, D.; HANSEN, M. A. T.; VAN DER MEULEN, T.; ZACCHI, G.; LIDÉN, G. Cellulose accessibility determines the rate of enzymatic hydrolysis of steampretreated spruce. Bioresource Technology, v. 126, p. 208-215, 2012.

WITHERS, S.; WILLIAMS, S. Glycoside hydrolases. CAZypedia. 2017. Disponível em: <https://www.cazypedia.org/index.php/Glycoside_hydrolases>. Acesso em: 27 jul. 2017.

WONG, K. K.; DEVERELL, K. F.; MACKIE, K. L.; CLARK, T. A.; DONALDSON, L. A. The relationship between fiber-porosity and cellulose digestibility in steam-exploded Pinus radiata. Biotechnology and Bioengineering, v. 31, p. 447-456, 1988.

WOOD, T. M.; BHAT, K. M. Methods for measuring cellulase activities. Methods in Enzymology, v. 160, p. 87-112, 1988.

WOODWARD, J.; HAYES, M. K.; LEE, N. E. Hydrolysis of cellulose by saturating and nonsaturating concentrations of cellulase: implications for synergism. Nature Biotechnology, v. 6, p. 301-304, 1988.

WORLD BIOENERGY ASSOCIATION. WBA global bioenergy statistics 2014. World Bioenergy Association, 2014. 40p. Disponível em:

<http://www.worldbioenergy.org/uploads/WBA\%20Global\%20Bioenergy\%20Statistics\%202 014.pdf>. Acesso em: 05 mar. 2016.

WYMAN, C. E.; BALAN, V.; DALE, B. E.; ELANDER, R. T.; FALLS, M.; HAMES, B.; HOLTZAPPLE, M. T.; LADISCH, M. R.; LEE, Y. Y.; MOSIER, N.; PALLAPOLU, V. R.; SHI, J.; THOMAS, S. R.; WARNER, R. E. Comparative data on effects of leading pretreatments and enzyme loadings and formulations on sugar yields from different switchgrass sources. Bioresource Technology, v. 102, p. 11052-11062, 2011.

XIAO, L. P.; SHI, Z. J.; XU, F.; SUN, R. C. Hydrothermal treatment and enzymatic hydrolysis of Tamarix ramosissima: evaluation of the process as a conversion method in a biorefinery concept. Bioresource Technology, v. 135, p. 73-81, 2013.

XU, H.; LI, B.; MU, X.; YU, G.; LIU, C.; ZHANG, Y.; WANG, H. Quantitative characterization of the impact of pulp refining on enzymatic saccharification of the alkaline pretreated corn stover. Bioresource Technology, v. 169, p. 19-26, 2014.

XU, J.; ZONG, M. H.; FU, S.; LI, N. Correlation between physicochemical properties and enzymatic digestibility of rice straw pretreated with cholinium ionic liquids. ACS

Sustainable Chemistry \& Engineering, v. 4, n. 8, p. 4340-4345, 2016.

YANG, B.; DAI, Z.; DING, S. Y.; WYMAN, C. E. Enzymatic hydrolysis of cellulosic biomass. Biofuels, v. 4, p. 421-450, 2011. 
YASUMURA, P. K.; D'ALMEIDA, M. L. O.; PARK, S. W. Ações de refino em moinho PFI e em refinador industrial de disco. O PAPEL, v. 69, p. 63-72, 2008.

YU, Q.; ZHUANG, X.; LV, S.; HE, M.; ZHANG, Y.; YUAN, Z.; QI, W.; WANG, Q.;

WANG, W.; TAN, X. Liquid hot water pretreatment of sugarcane bagasse and its comparison with chemical pretreatment methods for the sugar recovery and structural changes.

Bioresource Technology, v. 129, p. 592-598, $2013 \mathrm{a}$.

YU, Q.; ZHUANG, X.; YUAN, Z.; QI, W.; WANG, W.; WANG, Q.; TAN, X. Pretreatment of sugarcane bagasse with liquid hot water and aqueous ammonia. Bioresource Technology, v. 144, p. 210-215, 2013 b.

ZAKARIA, M. R.; HIRATA, S.; FUJIMOTO, S.; HASSAN, M. A. Combined pretreatment with hot compressed water and wet disk milling opened up oil palm biomass structure resulting in enhanced enzymatic digestibility. Bioresource Technology, v. 193, p. 128-134, 2015.

ZECHEL, D. L.; WITHERS, S. G. Glycosidase mechanisms: anatomy of a finely tuned catalyst. Accounts of Chemical Research, v. 33, n.1, p. 11-18, 2000.

ZENG, M.; MOSIER, N. S.; HUANG, C. P.; SHERMAN, D. M.; LADISCH, M. R. Microscopic examination of changes of plant cell structure in corn stover due to hot water pretreatment and enzymatic hydrolysis. Biotechnology and Bioengineering, v. 97, p. 265$278,2007$.

ZHANG, Y.; MU, X.; WANG, H.; LI, B.; PENG, H. Combined deacetylation and PFI refining pretreatment of corn cob for the improvement of a two-stage enzymatic hydrolysis. Journal of Agricultural and Food Chemistry, v. 62, p. 4661-4667, 2014.

ZHANG, Y. H. P.; LYND, L. R. Toward an aggregated understanding of enzymatic hydrolysis of cellulose: noncomplexed cellulase systems. Biotechnology and

Bioengineering, v. 88, n. 7, p. 797-824, 2004.

ZHANG, Y. H. P.; LYND, L. R. Determination of the number-average degree of polymerization of cellodextrins and cellulose with application to enzymatic hydrolysis.

Biomacromolecules, v. 6, p. 1510-1515, 2005.

ZHANG, Y. H. P.; LYND, L. R. A functionally based model for hydrolysis of cellulose by fungal cellulase. Biotechnology and Bioengineering, v. 94, p. 888-898, 2006.

ZHANG, X. Z.; ZHANG, Y. H. P. Cellulases: characteristics, sources, production, and applications. In: YANG, S. T.; EL-ENSHASY, H. A.; THONGCHUL, N. Bioprocessing technologies in biorefinery for sustainable production of fuels, chemicals, and polymers. New York: John Wiley, 2013. Cap. 8, p. 131-146.

ZHAO, X.; CHENG, K.; LIU, D. Organosolv pretreatment of lignocellulosic biomass for enzymatic hydrolysis. Applied Microbiology and Biotechnology, v. 82, p. 815-827, 2009. 
ZHAO, X.; ZHANG, L.; LIU, D. Biomass recalcitrance. Part II: fundamentals of different pre-treatments to increase the enzymatic digestibility of lignocellulose. Biofuels, Bioproducts and Biorefining, v. 6, p. 561-579, 2012.

ZHAO, X.; ZHOU, Y.; LIU, D. Kinetic model for glycan hydrolysis and formation of monosaccharides during dilute acid hydrolysis of sugarcane bagasse. Bioresource Technology, v. 105, p. 160-168, 2012.

ZHU, J. Y.; PAN, X. J. Woody biomass pretreatment for cellulosic ethanol production: technology and energy consumption evaluation. Bioresource Technology, v.101, p.49925002, 2010.

ZHU, J. Y.; WANG, G. S.; PAN, X. J.; GLEISNER, R. Specific surface to evaluate the efficiencies of milling and pretreatment of wood for enzymatic saccharification. Chemical Engineering Science, v. 64, p. 474-485, 2009.

ZHU, J. Y.; ZHU, W.; OBRYAN, P.; DIEN, B. S.; TIAN, S.; GLEISNER, R.; PAN, X. J. Ethanol production from SPORL-pretreated lodgepole pine: preliminary evaluation of mass balance and process energy efficiency. Applied Microbiology and Biotechnology, v. 86, p. 1355-1365, 2010.

ZHU, L.; O’DWYER, J. P.; CHANG, V. S.; GRANDA, C. B.; HOLTZAPPLE, M. T. Structural features affecting biomass enzymatic digestibility. Bioresource Technology, v. 99, p. 3817-3828, 2008.

ZHU, W.; HOUTMAN, C. J.; ZHU, J. Y.; GLEISNER, R.; CHEN, K. F. Quantitative predictions of bioconversion of aspen by dilute acid and SPORL pretreatments using a unified combined hydrolysis factor (CHF). Process Biochemistry, v. 47, p. 785-791, 2012.

ZHU, W.; ZHU, J. Y.; GLEISNER, R.; PAN, X. J. On energy consumption for size-reduction and yields from subsequent enzymatic saccharification of pretreated lodgepole pine.

Bioresource Technology, v. 101, p. 2782-2792, 2010. 
Anexo A. Variação do diâmetro médio $(\mu \mathrm{m})$ das partículas analisadas com (A) o tempo de refino em moinho Jokro, (B) o tempo de refino em refinador Bauer e (C) a moagem criogênica, para os cinco materiais em estudo: $F(\rightarrow-), H(\rightarrow \mathbf{\Delta} \cdot), H O_{180}(-\rightarrow-), O_{190}(\rightarrow-)$ e $O_{200}(\cdot \bullet \times \cdot \bullet)$.

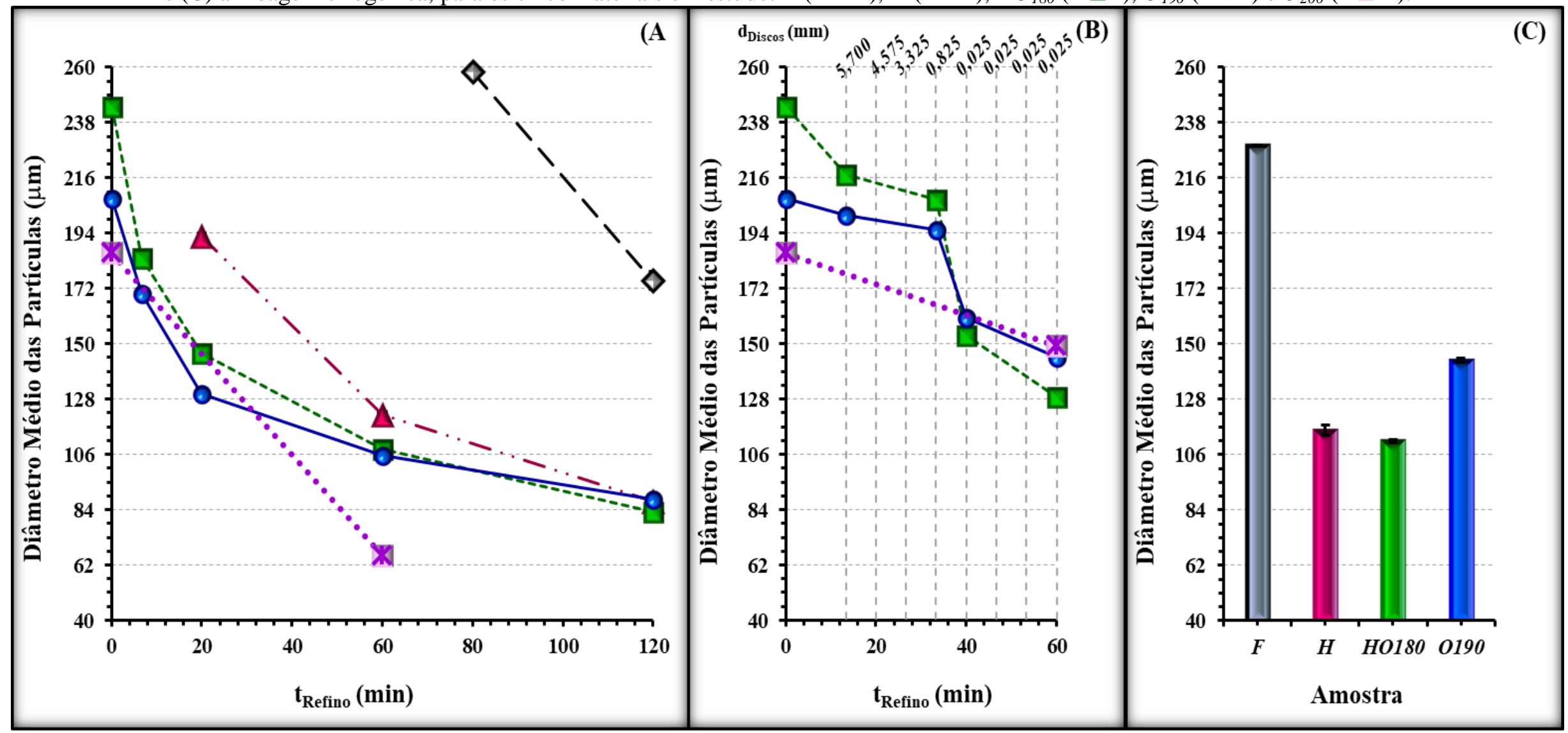

Legenda: $\mathrm{t}_{\text {Refino }}=$ tempo de refino; $\mathrm{d}_{\text {Discos }}=$ distância entre os discos. 
Anexo B. Variação do diâmetro mais frequente (moda) $(\mu \mathrm{m})$ das partículas analisadas com (A) o tempo de refino em moinho Jokro, $(\mathrm{B})$ o tempo

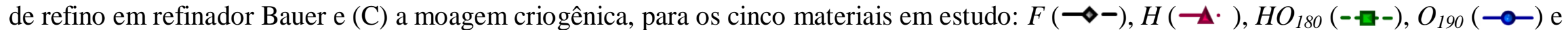

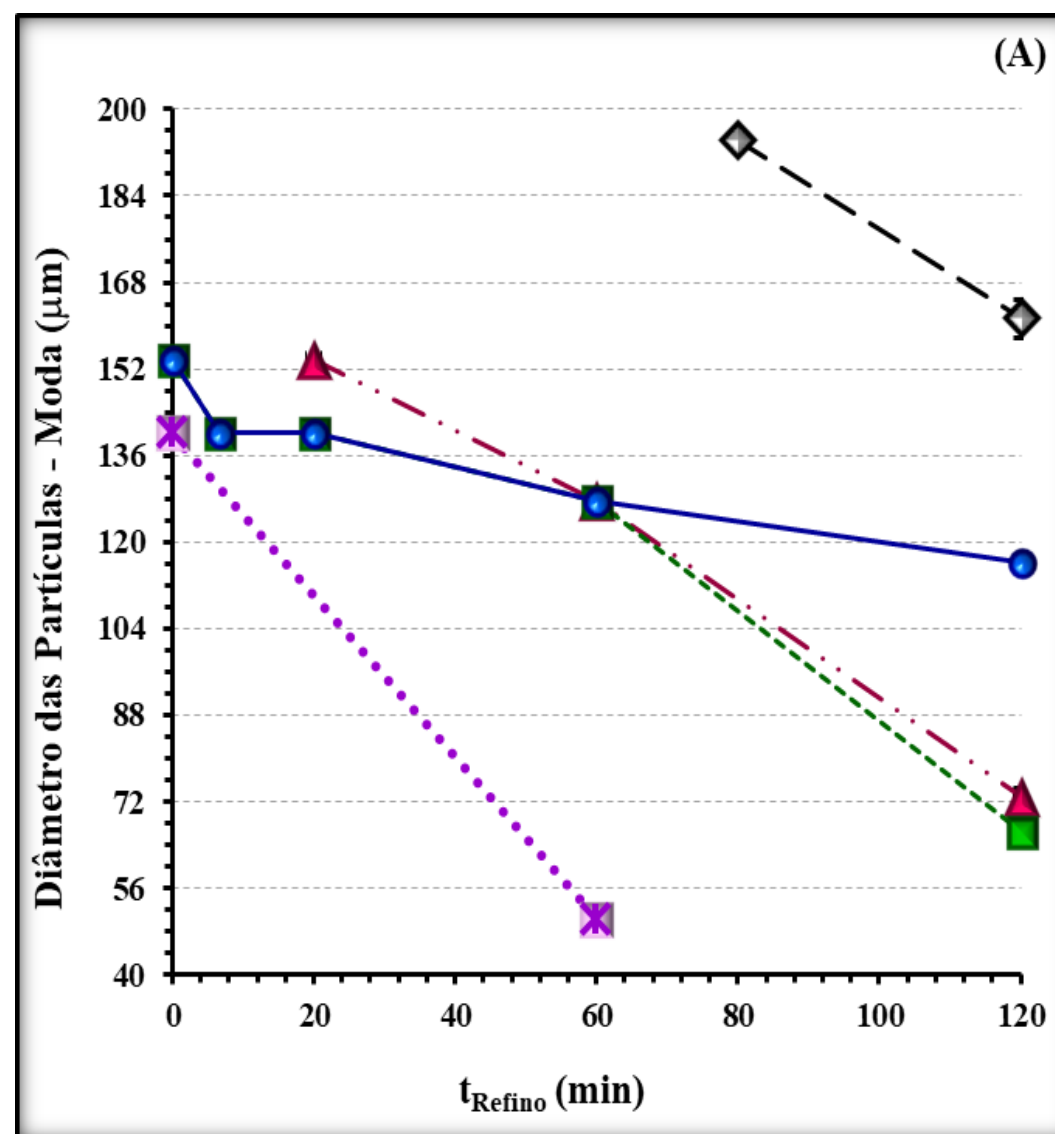

$\mathrm{O}_{200}\left(\cdot \bullet \cdot \mathrm{m}_{\bullet} \cdot\right)$

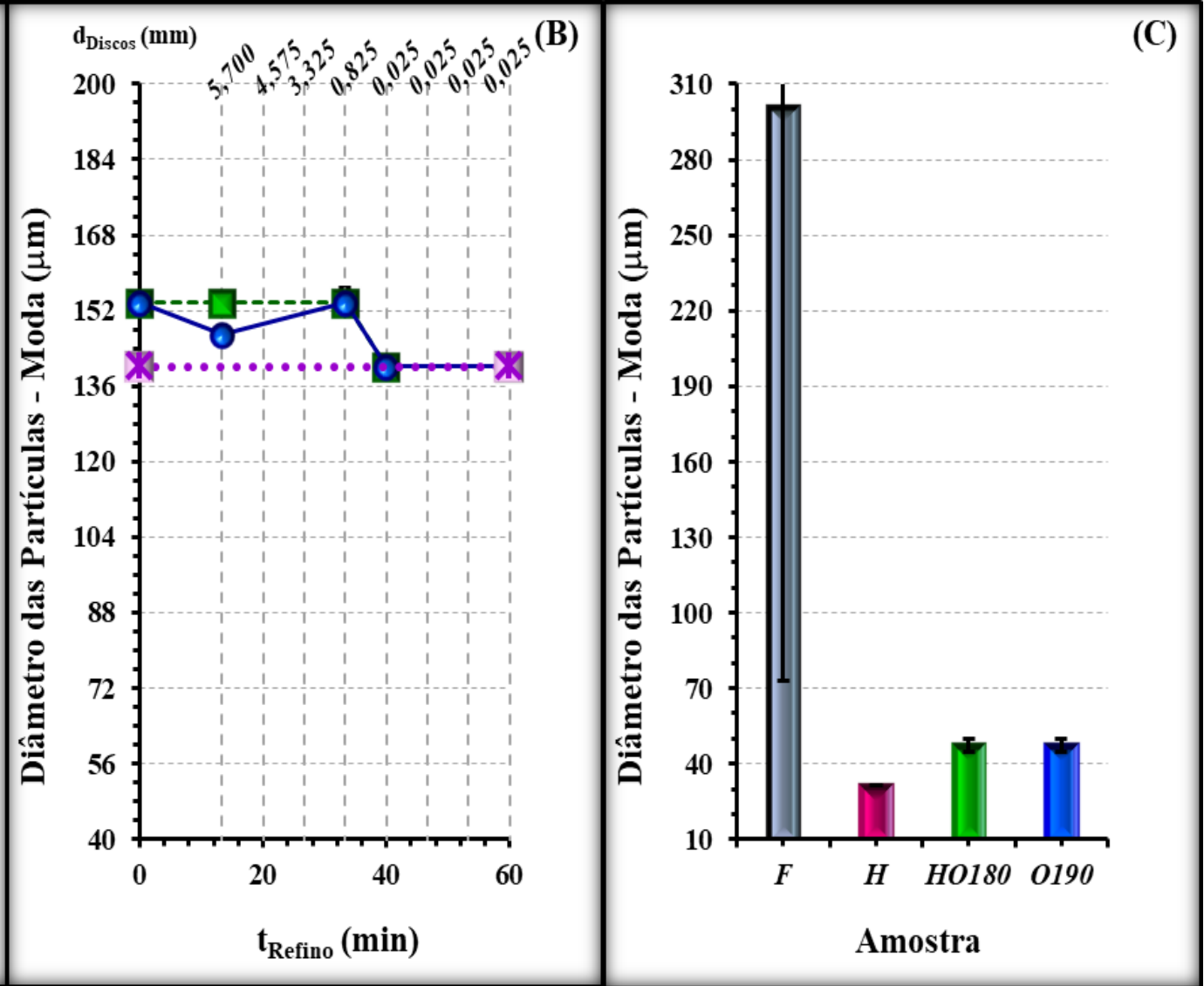

Legenda: $\mathrm{t}_{\text {Refino }}=$ tempo de refino; $\mathrm{d}_{\text {Discos }}=$ distância entre os discos. 
Figura C. Variação da dispersão dos valores de diâmetro $(\mu \mathrm{m})$ em torno da média calculada para as partículas analisadas com (A) o tempo de refino em moinho Jokro, (B) o tempo de refino em refinador Bauer e (C) a moagem criogênica, para os cinco materiais em estudo: $F(\rightarrow-), H$

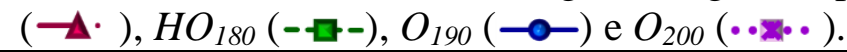

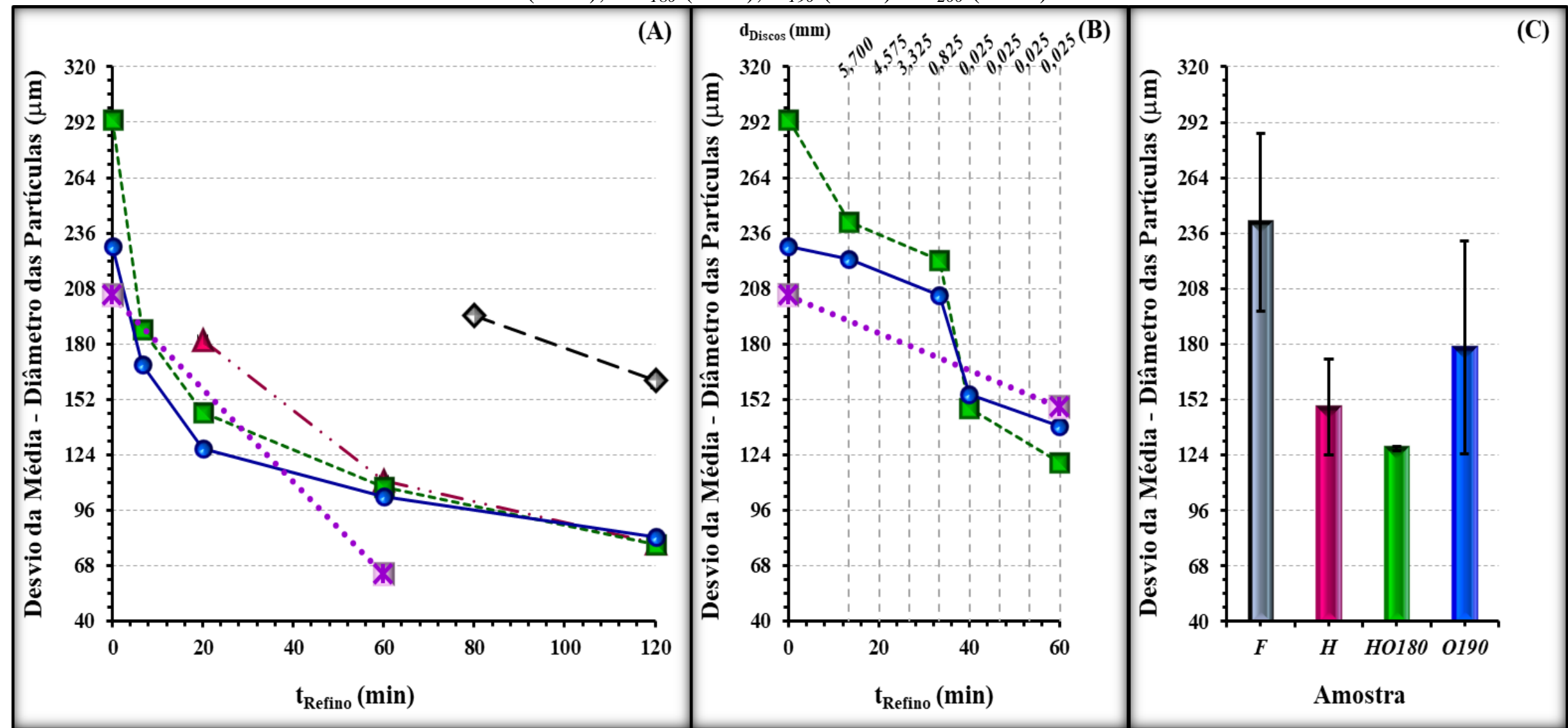

Legenda: $\mathrm{t}_{\text {Refino }}=$ tempo de refino; $\mathrm{d}_{\text {Discos }}=$ distância entre os discos. 
Anexo D. Variação do volume cumulativo de partículas analisadas (\%) com diâmetros de até $100 \mu \mathrm{m}$ com (A) o tempo de refino em moinho Jokro, (B) o tempo de refino em refinador Bauer e (C) a moagem criogênica, para os cinco materiais em estudo: $F(\rightarrow-), H\left(\rightarrow \mathbf{\Delta}^{\cdot}\right), H O_{180}$

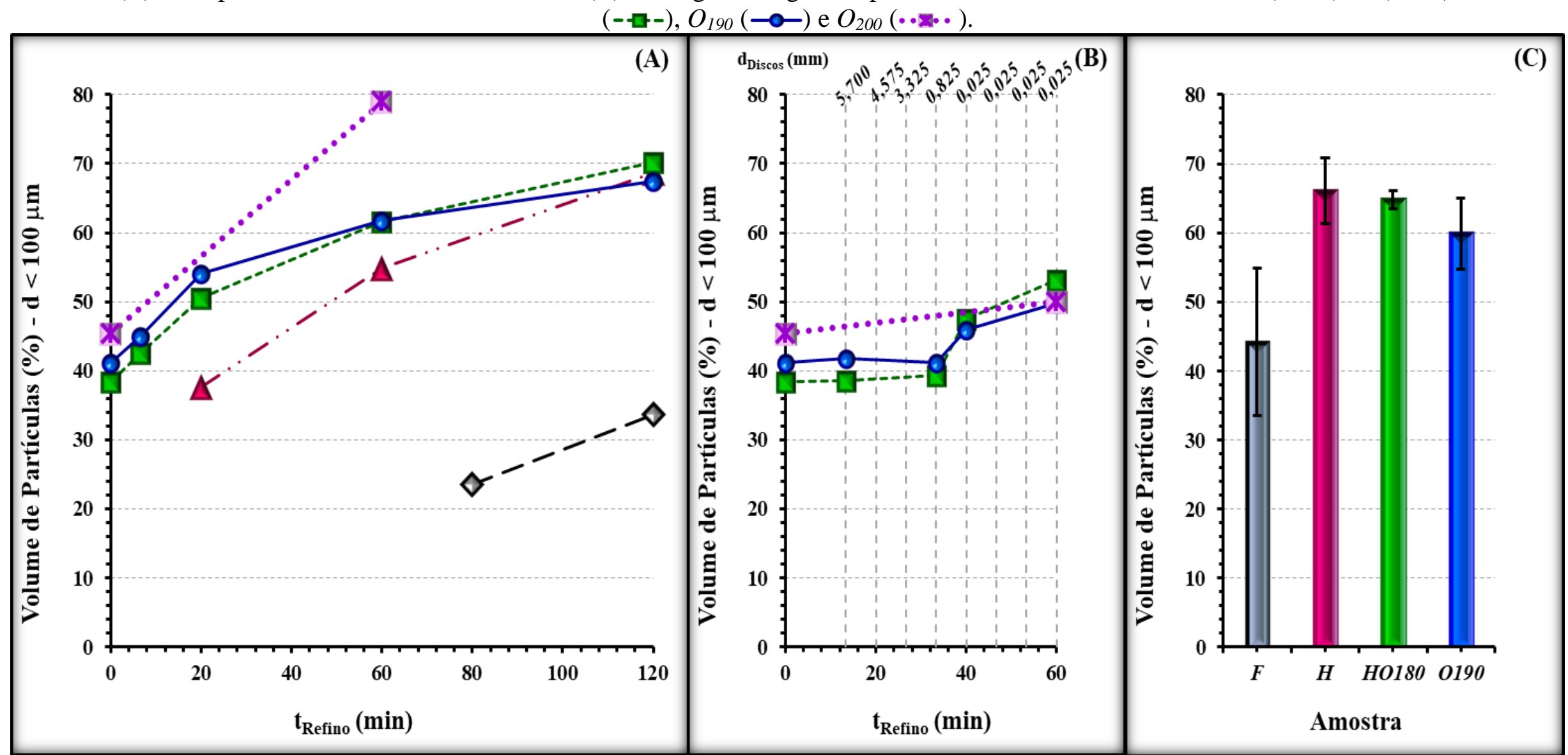

Legenda: $\mathrm{t}_{\text {Refino }}=$ tempo de refino; $\mathrm{d}_{\text {Discos }}=$ distância entre os discos; $\mathrm{d}=$ diâmetro da partícula. 
Anexo E. Variação do volume cumulativo de partículas analisadas (\%) com diâmetros de até $30 \mu \mathrm{m}$ com (A) o tempo de refino em moinho Jokro, (B) o tempo de refino em refinador Bauer e (C) a moagem criogênica, para os cinco materiais em estudo: $F(\longrightarrow-), H(\rightarrow \mathbf{\Delta} \cdot), H O_{180}$ $(-\rightarrow-), O_{190}(-\circ)$ e $O_{200}(\cdot \cdot$.

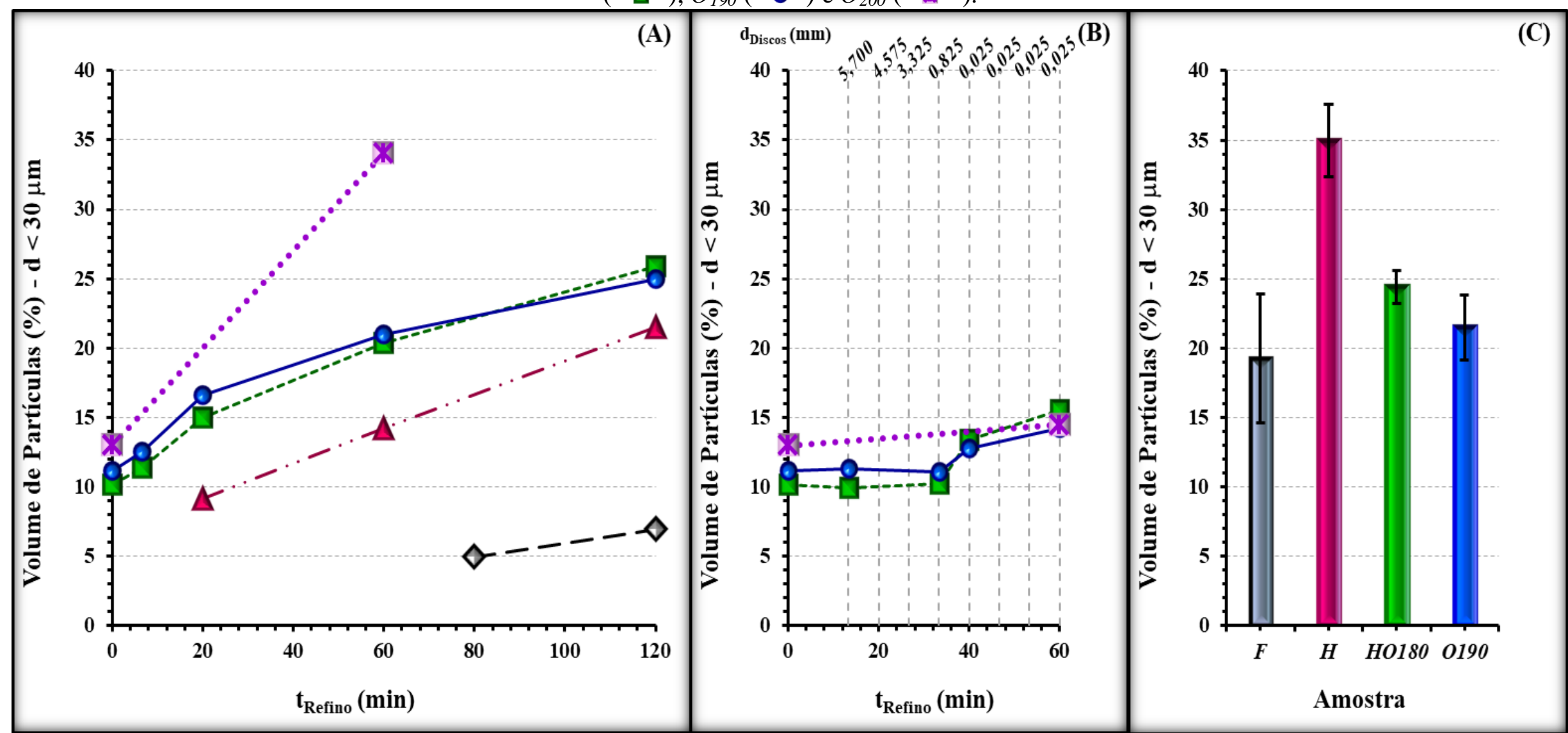

Legenda: $t_{\text {Refino }}=$ tempo de refino; $d_{\text {Discos }}=$ distância entre os discos; $d=$ diâmetro da partícula. 
Anexo F. Variação da área de poros $\left(\mathrm{m}^{2} / \mathrm{g}\right)$ com diâmetros maiores ou iguais a 6,60 nm com (A) o tempo de refino em moinho Jokro, (B) o tempo de refino em refinador Bauer e (C) a moagem criogênica, para os cinco materiais em estudo: $F(\multimap-), H(\rightarrow \mathbf{\Delta} \cdot), H O_{180}\left(-\nabla^{-}-\right), O_{190}$

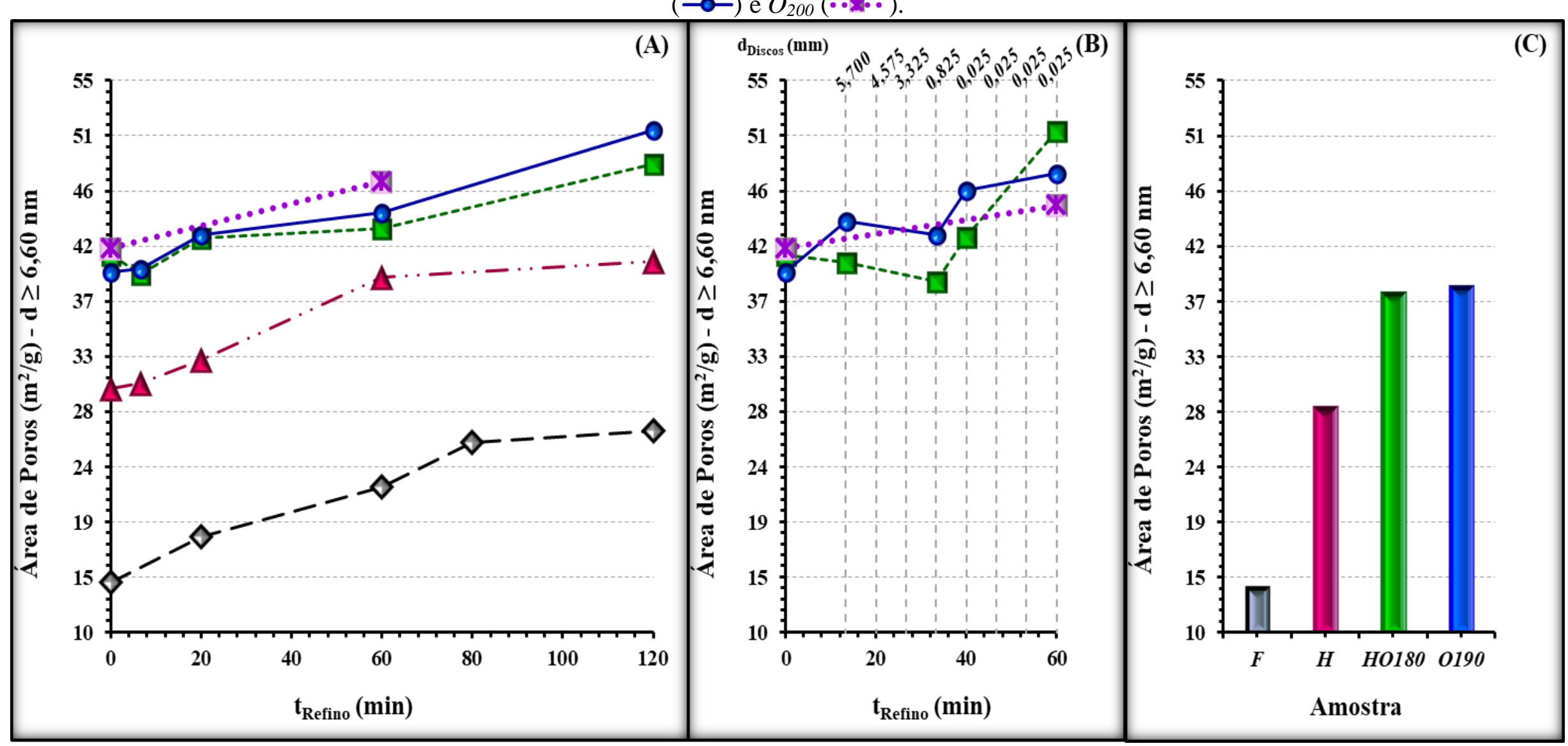

Legenda: $\mathrm{t}_{\text {Refino }}=$ tempo de refino; $\mathrm{d}_{\text {Discos }}=$ distância entre os discos; $\mathrm{d}=$ diâmetro do poro. 
Anexo G. Variação da área de poros $\left(\mathrm{m}^{2} / \mathrm{g}\right)$ com diâmetros maiores ou iguais a 3,96 nm com (A) o tempo de refino em moinho Jokro, (B) o tempo de refino em refinador Bauer e $(\mathrm{C})$ a moagem criogênica, para os cinco materiais em estudo: $F(\longrightarrow-), H(\rightarrow \mathbf{\Delta} \cdot), H O_{180}\left(-\rightarrow-\mathbf{C}^{-}\right), O_{190}$

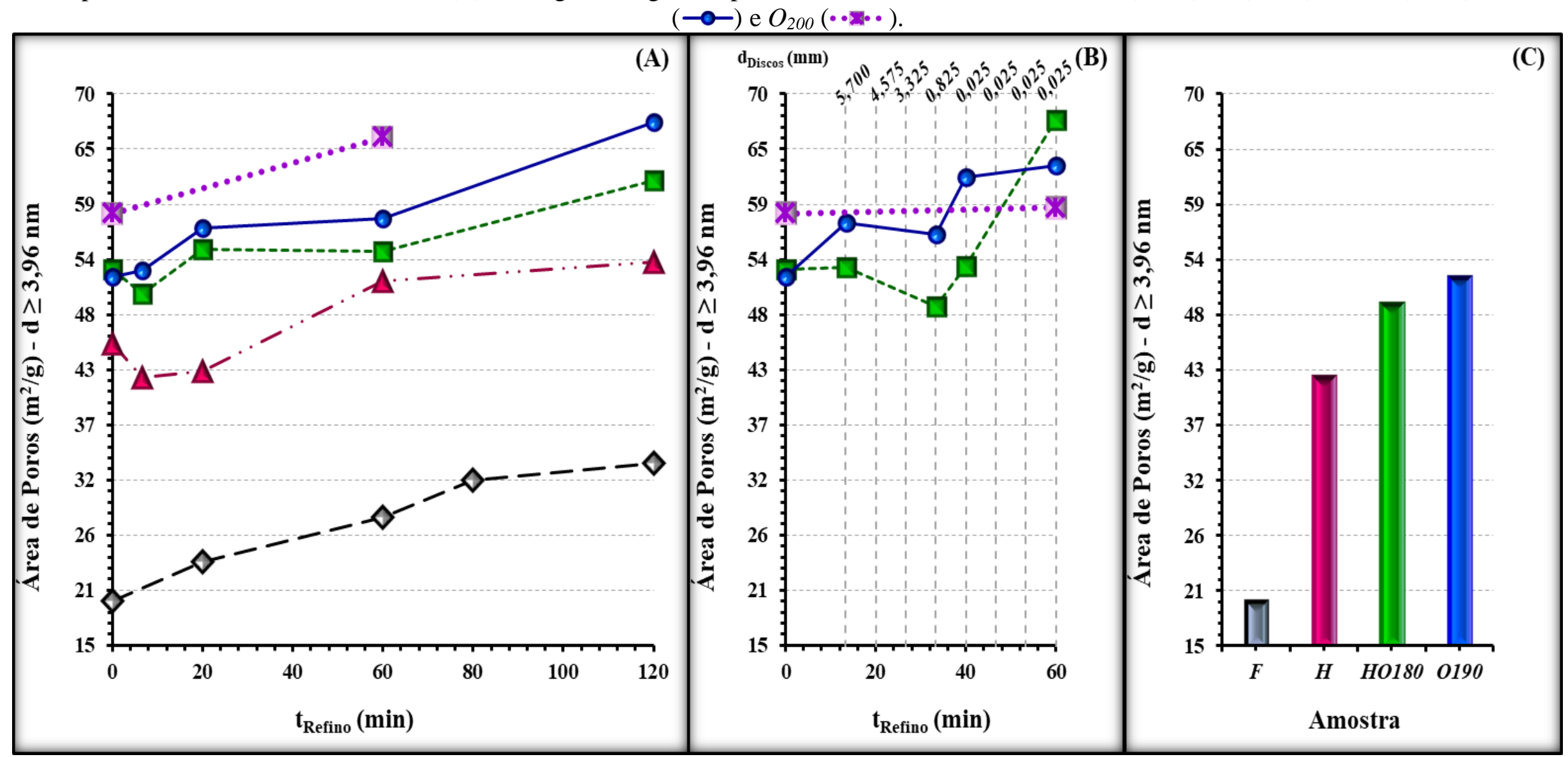

Legenda: $\mathrm{t}_{\text {Refino }}=$ tempo de refino; $\mathrm{d}_{\text {Discos }}=$ distância entre os discos; $\mathrm{d}=$ diâmetro do poro. 
Anexo H. Incrementos alcançados nos rendimentos dos açúcares redutores com o refino das amostras de bagaço em relação às amostras de mesma composição química não refinadas. Continua.

\begin{tabular}{|c|c|c|c|c|c|c|}
\hline \multirow{2}{*}{ Amostra } & \multirow{2}{*}{$\begin{array}{c}\text { Método Físico- } \\
\text { Mecânico }\end{array}$} & \multirow{2}{*}{$\begin{array}{l}t_{\text {Refino }} \\
(\min )\end{array}$} & \multicolumn{2}{|c|}{$\Delta \boldsymbol{R}$} & \multicolumn{2}{|c|}{$\Delta \boldsymbol{R}(\%)$} \\
\hline & & & Glicose - 72h & Xilose - 72h & Glicose $-72 h$ & Xilose - 72h \\
\hline \multirow{7}{*}{$F$} & \multirow{6}{*}{$M J$} & 20 & 1,9 & 2,5 & 24,8 & 79,3 \\
\hline & & 40 & 1,9 & 2,9 & 24,1 & 92,7 \\
\hline & & 60 & 3,2 & 3,9 & 40,5 & 123,8 \\
\hline & & 80 & 6,8 & 6,8 & 86,6 & 217,0 \\
\hline & & 100 & 8,6 & 8,2 & 109,0 & 262,6 \\
\hline & & 120 & 7,9 & 7,2 & 100,5 & 229,3 \\
\hline & $M C$ & 12 & $-3,6$ & $-0,8$ & $-45,4$ & $-25,4$ \\
\hline \multirow{9}{*}{$\boldsymbol{H}$} & \multirow{8}{*}{ MJ } & 6,7 & 10,7 & 12,6 & 62,3 & 52,7 \\
\hline & & 13,3 & 14,1 & 14,0 & 82,4 & 58,6 \\
\hline & & 20 & 14,1 & 14,0 & 81,9 & 58,5 \\
\hline & & 26,7 & 17,4 & 17,2 & 101,2 & 72,1 \\
\hline & & 33,3 & 18,2 & 17,5 & 106,3 & 73,1 \\
\hline & & 40 & 21,4 & 21,6 & 124,6 & 90,4 \\
\hline & & 60 & 23,2 & 19,6 & 134,9 & 82,0 \\
\hline & & 120 & 34,0 & 29,9 & 197,9 & 125,1 \\
\hline & $M C$ & 12 & 4,8 & 2,9 & 28,1 & 12,0 \\
\hline \multirow{17}{*}{$\mathrm{HO}_{180}$} & \multirow{8}{*}{ MJ } & 6,7 & 14,5 & 10,8 & 45,8 & 28,5 \\
\hline & & 13,3 & 16,6 & 13,0 & 52,4 & 34,4 \\
\hline & & 20 & 21,8 & 21,3 & 68,8 & 56,5 \\
\hline & & 26,7 & 21,2 & 19,1 & 67,0 & 50,6 \\
\hline & & 33,3 & 24,9 & 24,1 & 78,6 & 63,8 \\
\hline & & 40 & 30,9 & 30,4 & 97,5 & 80,5 \\
\hline & & 60 & 33,0 & 32,1 & 104,1 & 85,1 \\
\hline & & 120 & 38,3 & 36,2 & 120,6 & 96,0 \\
\hline & \multirow{8}{*}{$R D$} & 13,3 & 17,7 & 21,1 & 55,9 & 55,9 \\
\hline & & 20 & 15,9 & 18,7 & 50,1 & 49,5 \\
\hline & & 26,7 & 13,5 & 16,7 & 42,5 & 44,4 \\
\hline & & 33,3 & 9,9 & 12,5 & 31,1 & 33,1 \\
\hline & & 40 & 23,5 & 23,4 & 74,2 & 61,9 \\
\hline & & 46,7 & 27,9 & 21,4 & 87,9 & 56,8 \\
\hline & & 53,3 & 32,9 & 26,8 & 103,9 & 71,0 \\
\hline & & 60 & 13,6 & $-16,2$ & 43,0 & $-42,8$ \\
\hline & $M C$ & 12 & 2,4 & 1,3 & 7,5 & 3,4 \\
\hline
\end{tabular}

Legenda: $\Delta R=\left(R_{\text {pós-refino }}-R_{\text {não refinado }}\right) ; R(\%)=\left[\left(R_{\text {pós-refino }}-R_{\text {não refinado }}\right) \times 100\right] / R_{\text {não refinado }}$ 
Anexo H. Conclusão.

\begin{tabular}{|c|c|c|c|c|c|c|}
\hline \multirow{2}{*}{ Amostra } & \multirow{2}{*}{$\begin{array}{c}\text { Método Físico- } \\
\text { Mecânico }\end{array}$} & \multirow{2}{*}{$\begin{array}{l}\mathbf{t}_{\text {Refino }} \\
(\min )\end{array}$} & \multicolumn{2}{|c|}{$\Delta R$} & \multicolumn{2}{|c|}{$\Delta \boldsymbol{R}(\%)$} \\
\hline & & & Glicose - 72h & Xilose $-72 h$ & Glicose $-72 h$ & Xilose $-72 h$ \\
\hline \multirow{17}{*}{$O_{190}$} & \multirow{8}{*}{$M J$} & 6,7 & 20,7 & 17,2 & 45,9 & 34,9 \\
\hline & & 13,3 & 21,6 & 18,1 & 47,9 & 36,7 \\
\hline & & 20 & 24,2 & 22,5 & 53,7 & 45,7 \\
\hline & & 26,7 & 23,2 & 19,1 & 51,5 & 38,8 \\
\hline & & 33,3 & 23,2 & 19,4 & 51,4 & 39,2 \\
\hline & & 40 & 25,7 & 20,7 & 56,8 & 42,0 \\
\hline & & 60 & 27,4 & 22,8 & 60,7 & 46,3 \\
\hline & & 120 & 18,6 & 12,1 & 41,1 & 24,5 \\
\hline & \multirow{8}{*}{$R D$} & 13,3 & 12,4 & 10,6 & 27,4 & 21,5 \\
\hline & & 20 & 10,6 & 8,9 & 23,4 & 18,0 \\
\hline & & 26,7 & 11,8 & 10,6 & 26,2 & 21,5 \\
\hline & & 33,3 & 8,5 & 8,1 & 18,8 & 16,3 \\
\hline & & 40 & 19,5 & 17,3 & 43,1 & 35,2 \\
\hline & & 46,7 & 19,0 & 16,8 & 42,2 & 34,0 \\
\hline & & 53,3 & 20,5 & 17,5 & 45,4 & 35,5 \\
\hline & & 60 & 15,5 & 10,6 & 34,3 & 21,6 \\
\hline & $M C$ & 12 & 3,7 & 2,4 & 8,2 & 4,9 \\
\hline \multirow{2}{*}{$O_{200}$} & $M J$ & 60 & 12,9 & 0 & 16,8 & 0 \\
\hline & $R D$ & 60 & $-0,6$ & 0 & $-0,8$ & 0 \\
\hline
\end{tabular}

Legenda: $\Delta R=\left(R_{\text {pós-refino }}-R_{\text {não refinado }}\right) ; R(\%)=\left[\left(R_{\text {pós-refino }}-R_{\text {não refinado }}\right) \times 100\right] / R_{\text {não refinado }}$ 
Anexo I. Variação do rendimento de glicose (\%) obtido após $72 \mathrm{~h}$ de hidrólise enzimática com o diâmetro médio das partículas $(\mu \mathrm{m})$ para os diferentes materiais em estudo.

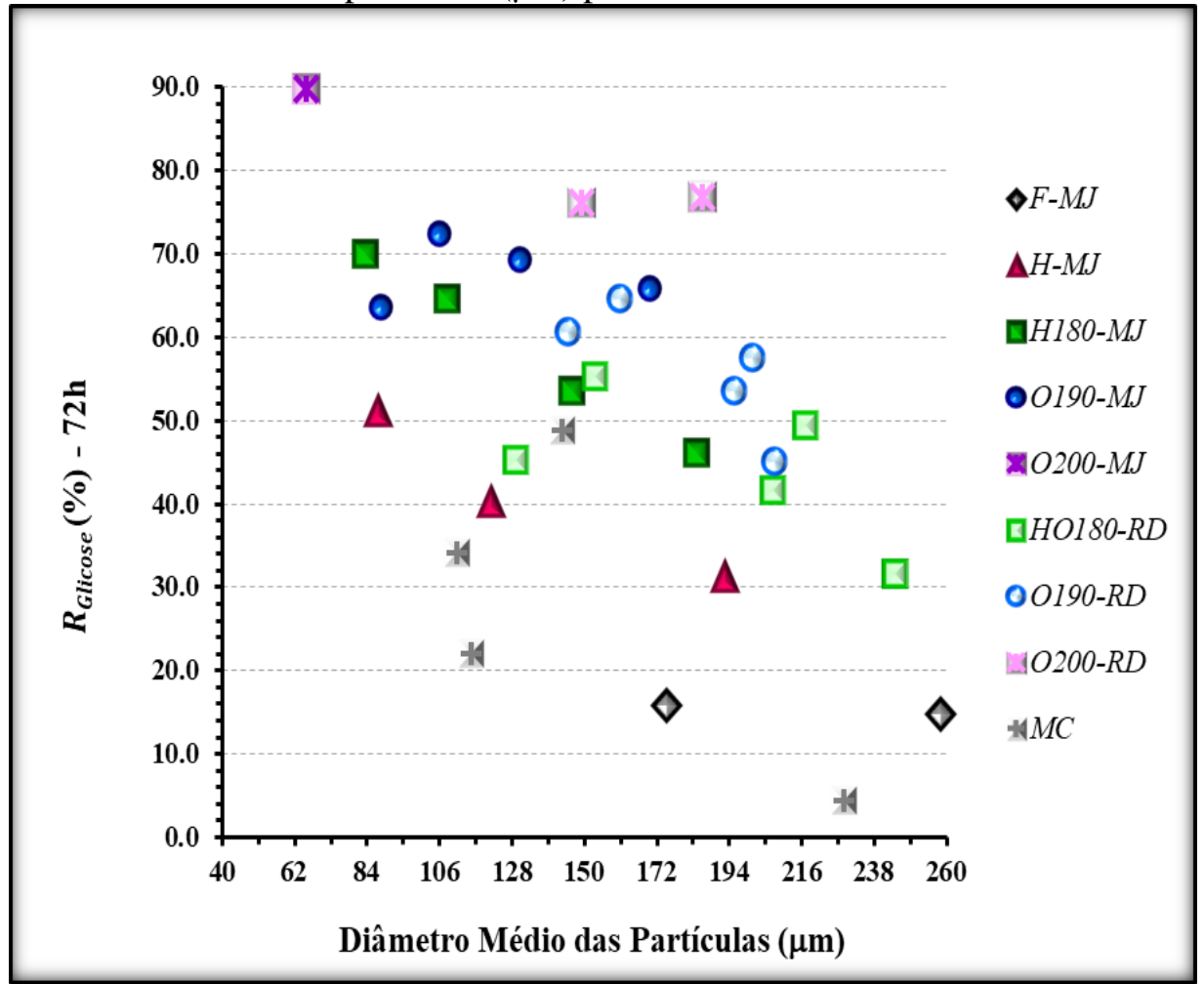

Anexo J. Variação do rendimento de glicose (\%) obtido após $72 \mathrm{~h}$ de hidrólise enzimática com o volume cumulativo de partículas analisadas (\%) com diâmetros de até $30 \mu \mathrm{m}$ para os diferentes materiais em estudo.

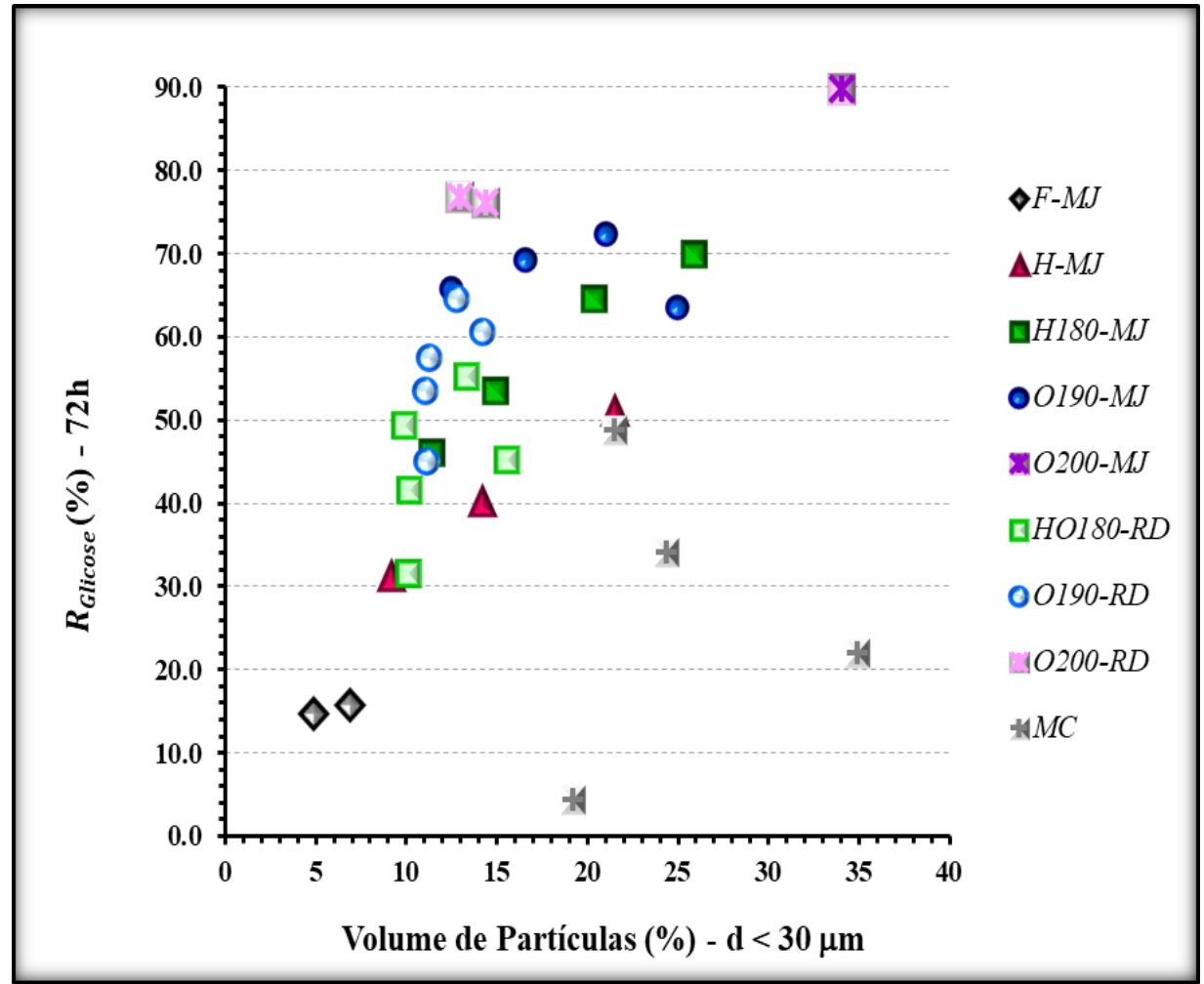


Anexo K. Variação do rendimento de glicose (\%) obtido após $72 \mathrm{~h}$ de hidrólise enzimática com o volume cumulativo de partículas analisadas (\%) com diâmetros de até $100 \mu \mathrm{m}$ para os diferentes materiais em estudo.

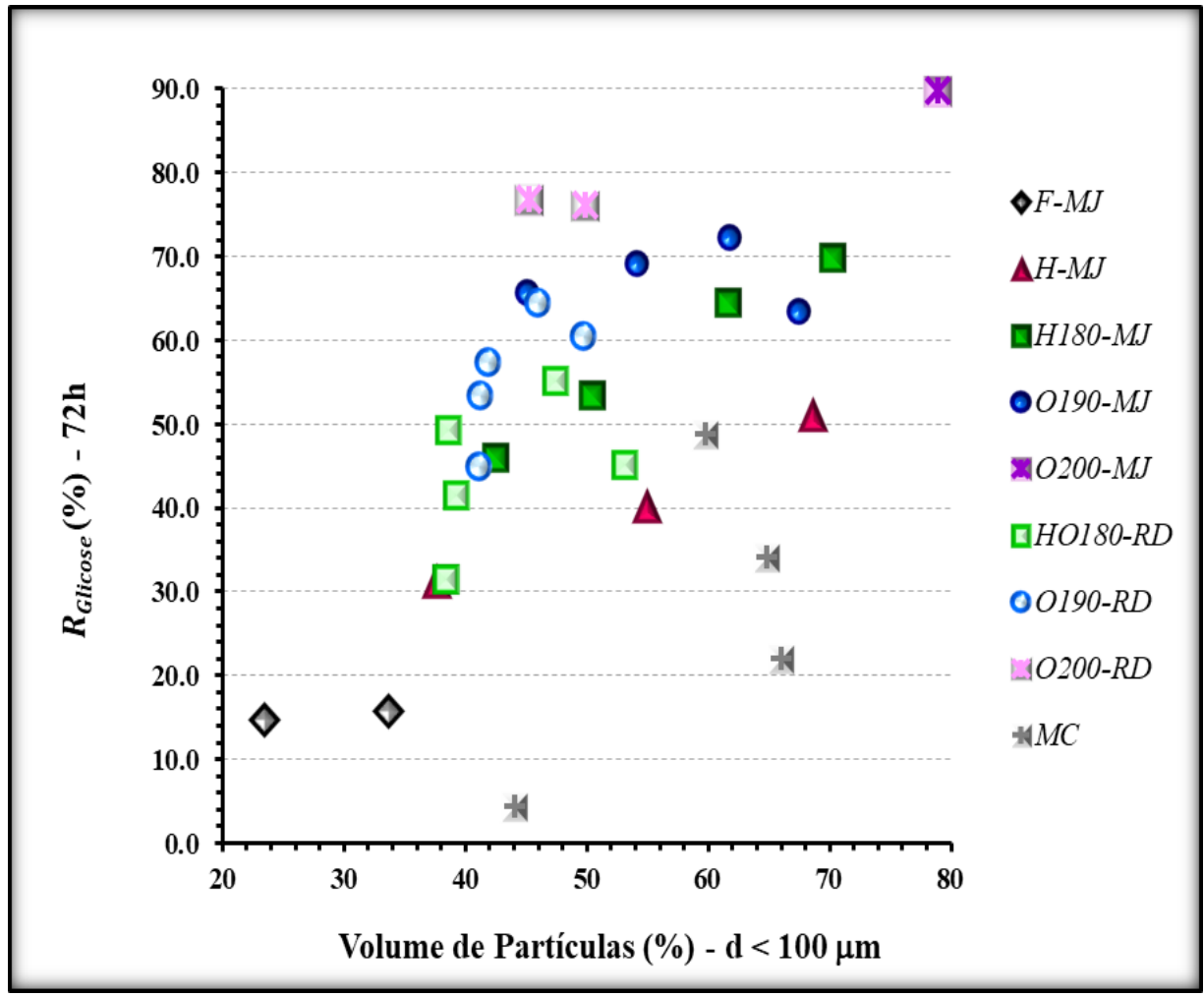

Anexo L. Variação do rendimento de glicose (\%) obtido após 72h de hidrólise enzimática com o comprimento médio das fibras $(\mathrm{mm})$ para os diferentes materiais em estudo.

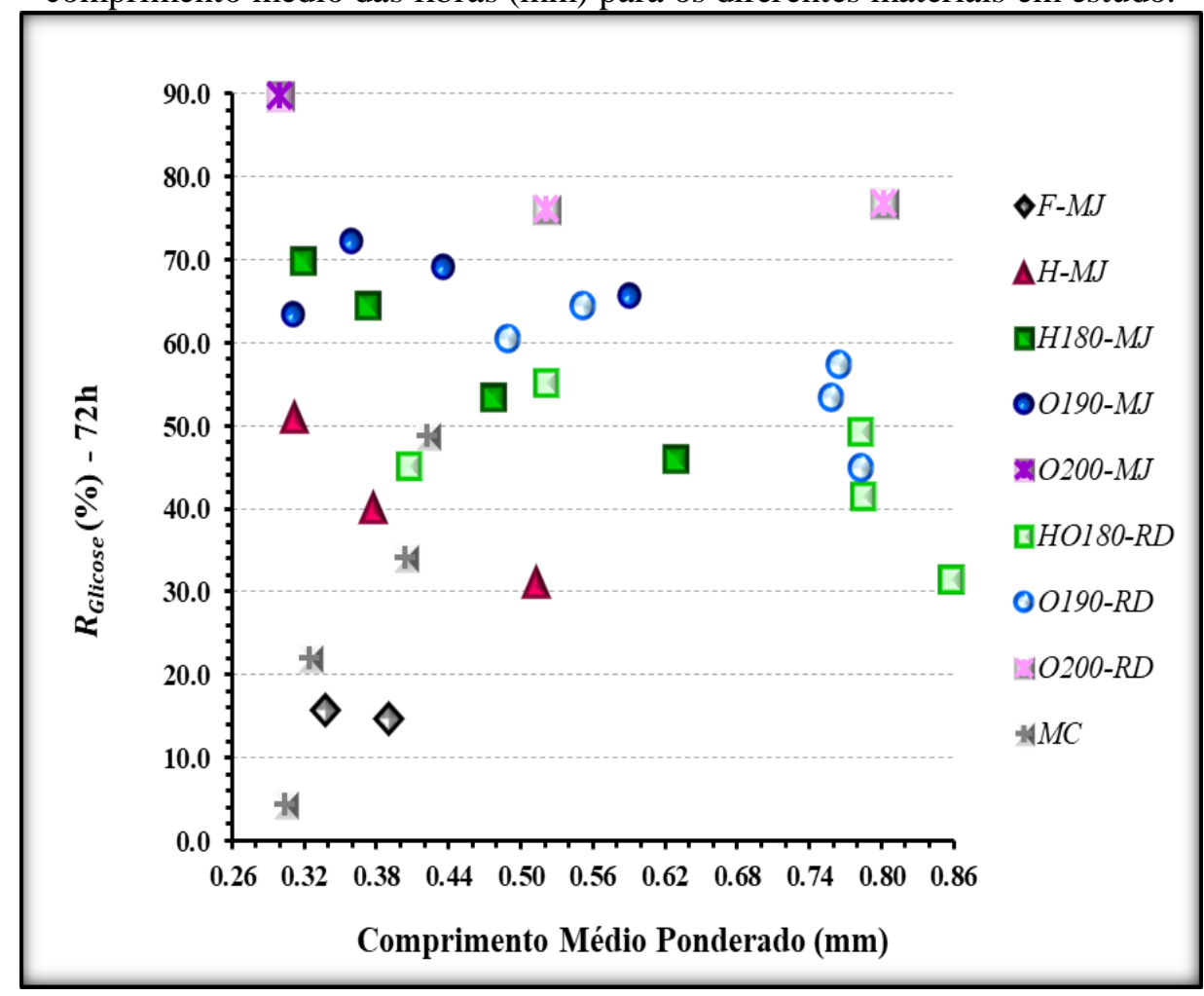


Anexo M. Variação do rendimento de glicose (\%) obtido após $72 \mathrm{~h}$ de hidrólise enzimática com a largura média das fibras $(\mu \mathrm{m})$ para os diferentes materiais em estudo.

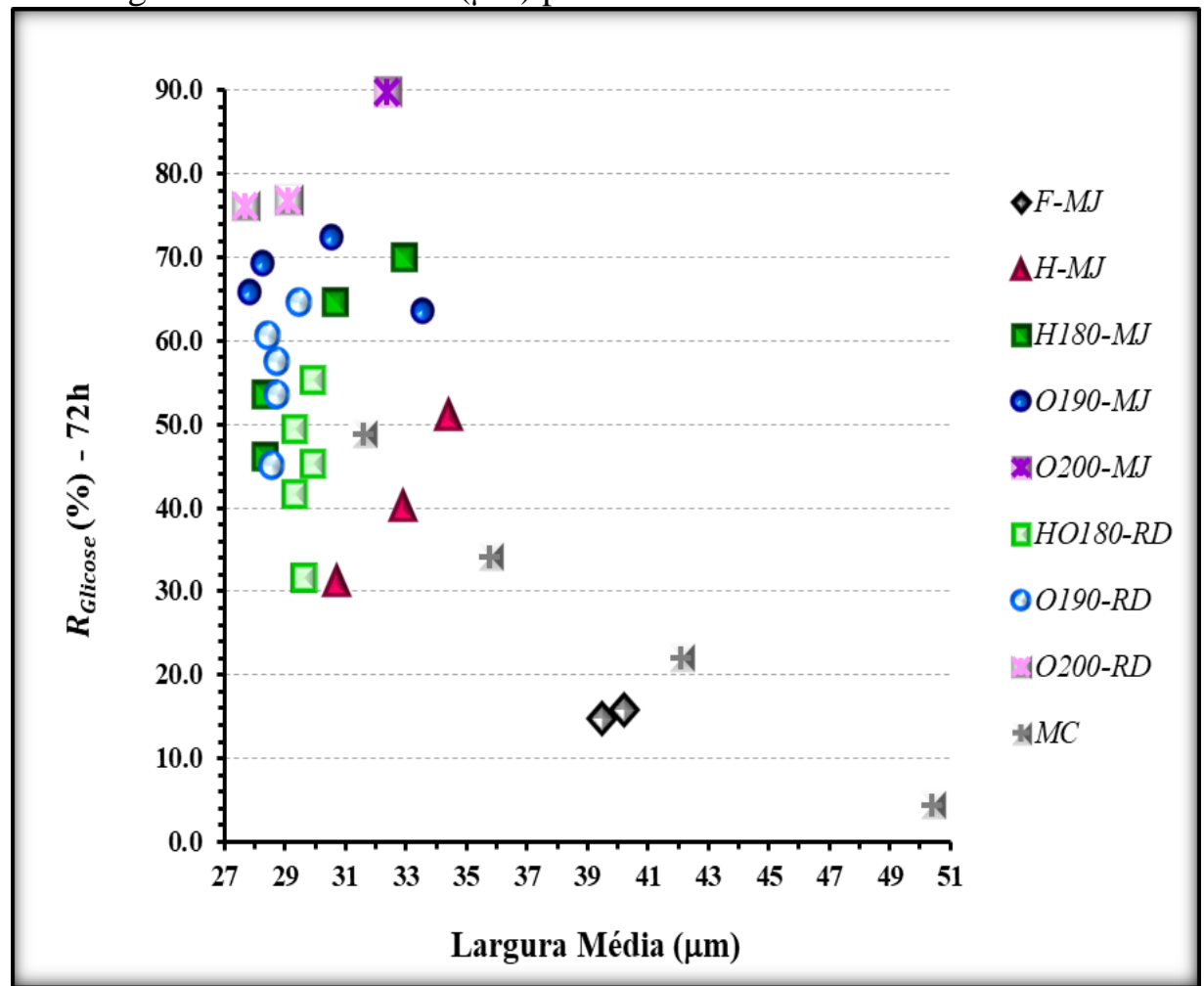

Anexo N. Variação do rendimento de glicose (\%) obtido após 72h de hidrólise enzimática com o teor de finos (\%) para os diferentes materiais em estudo.

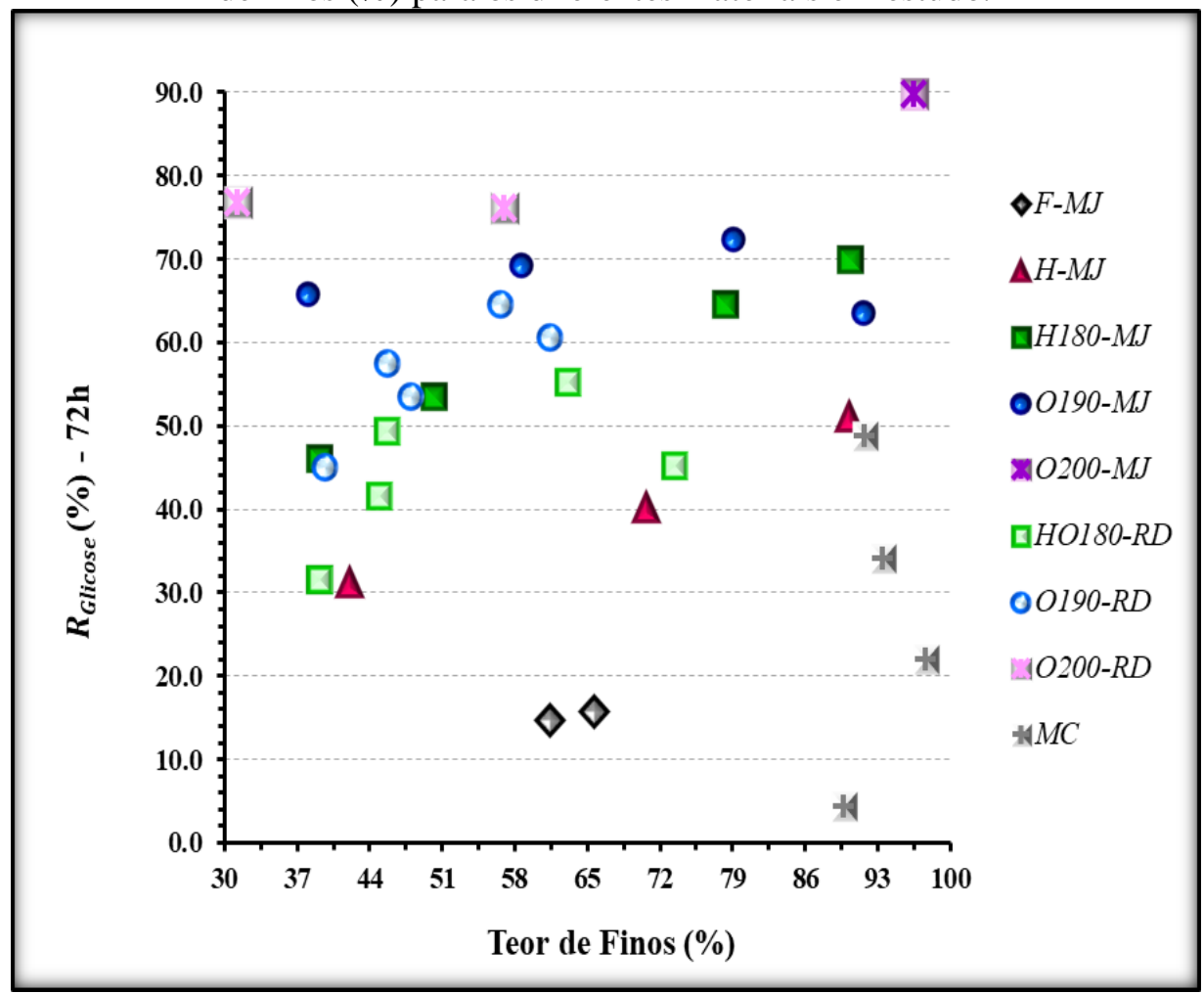


Anexo O. Variação do rendimento de glicose (\%) obtido após $72 \mathrm{~h}$ de hidrólise enzimática com a área total de poros $\left(\mathrm{m}^{2} / \mathrm{g}\right)$ para os diferentes materiais em estudo.

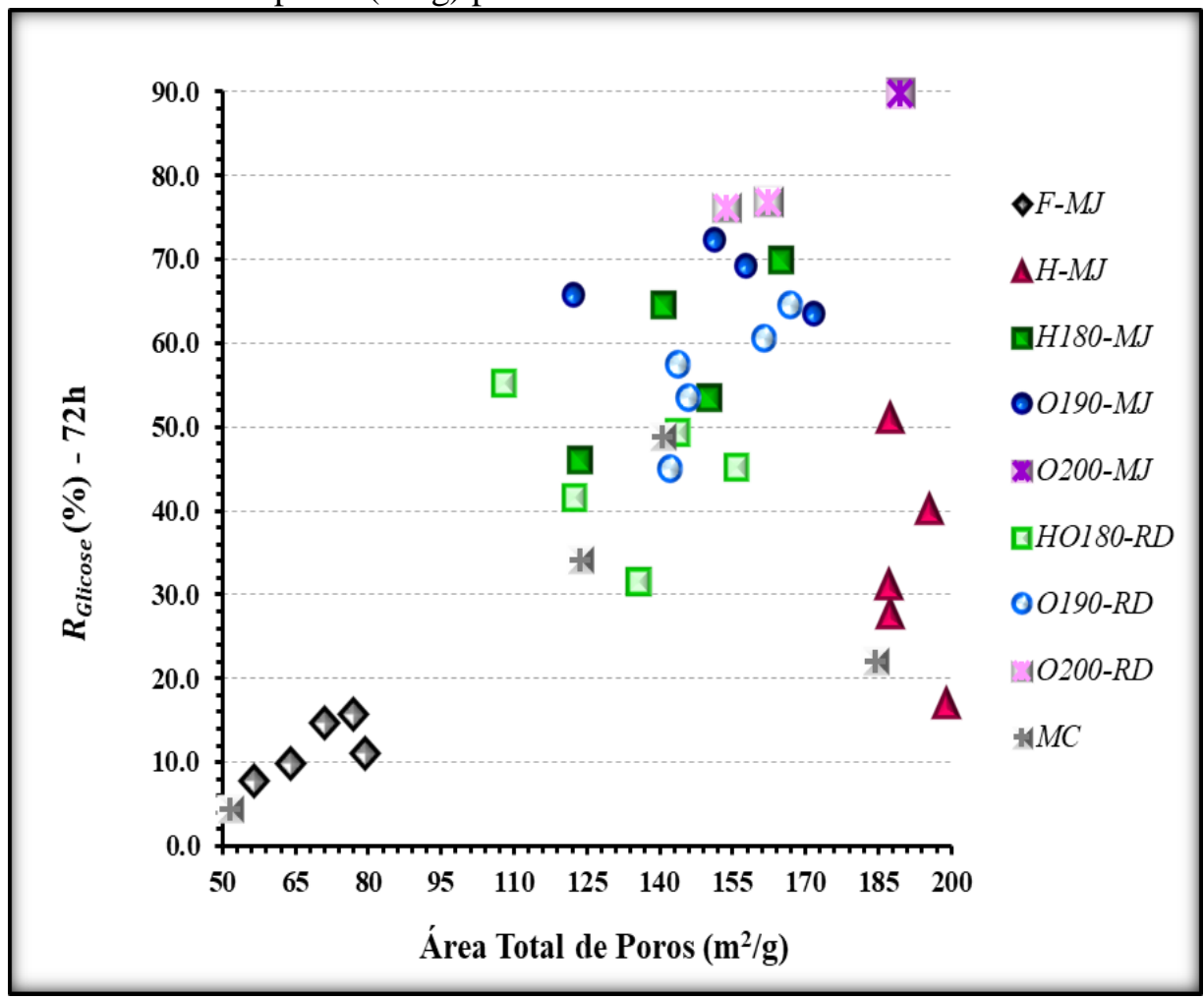

Anexo P. Variação do rendimento de glicose (\%) obtido após $72 \mathrm{~h}$ de hidrólise enzimática com a área de poros $\left(\mathrm{m}^{2} / \mathrm{g}\right)$ com diâmetros maiores ou iguais a $6,60 \mathrm{~nm}$ para os diferentes materiais em estudo.

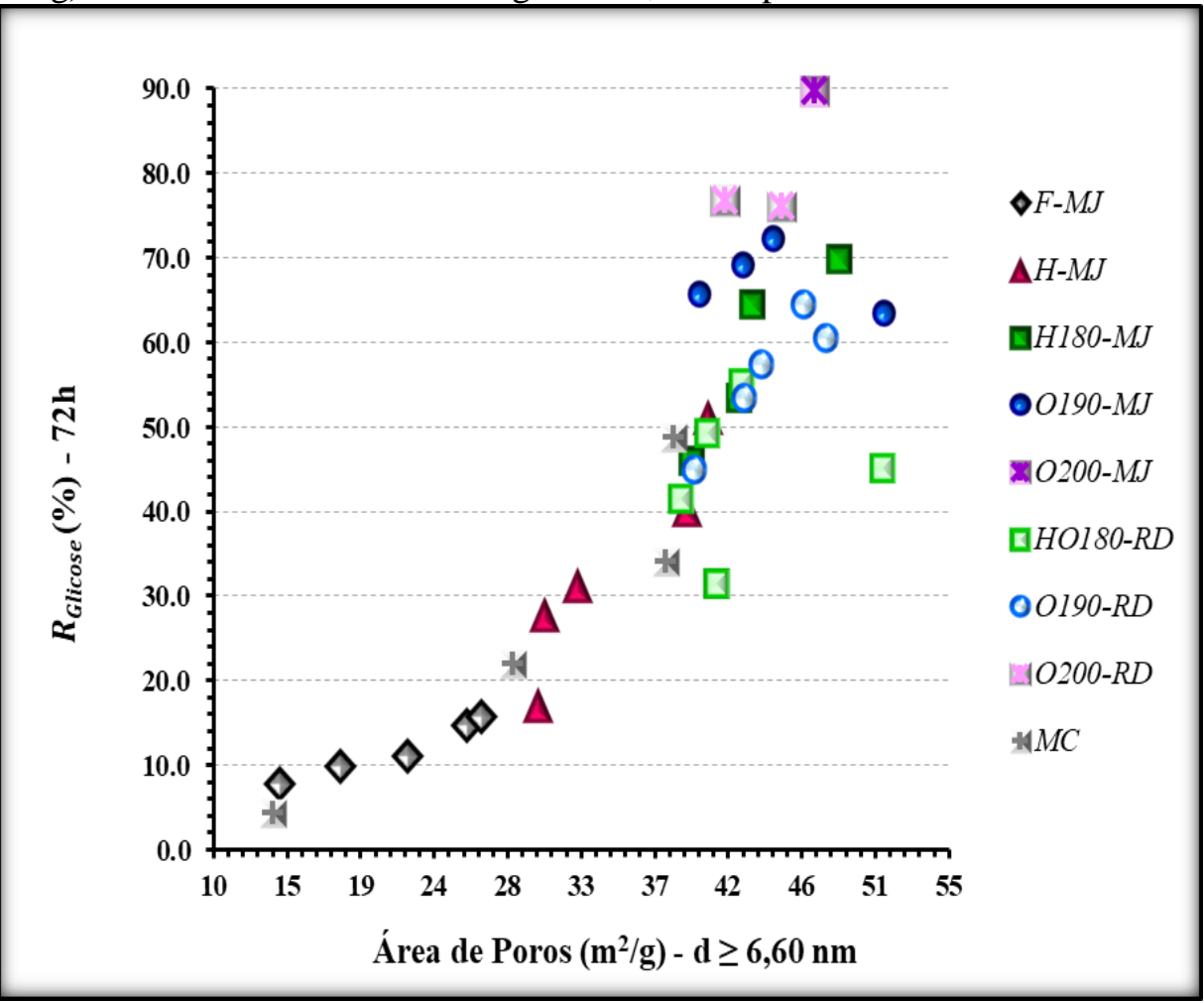


Anexo Q. Variação do rendimento de glicose (\%) obtido após 72h de hidrólise enzimática com a área de poros $\left(\mathrm{m}^{2} / \mathrm{g}\right)$ com diâmetros maiores ou iguais a 3,96 nm para os diferentes materiais em estudo.

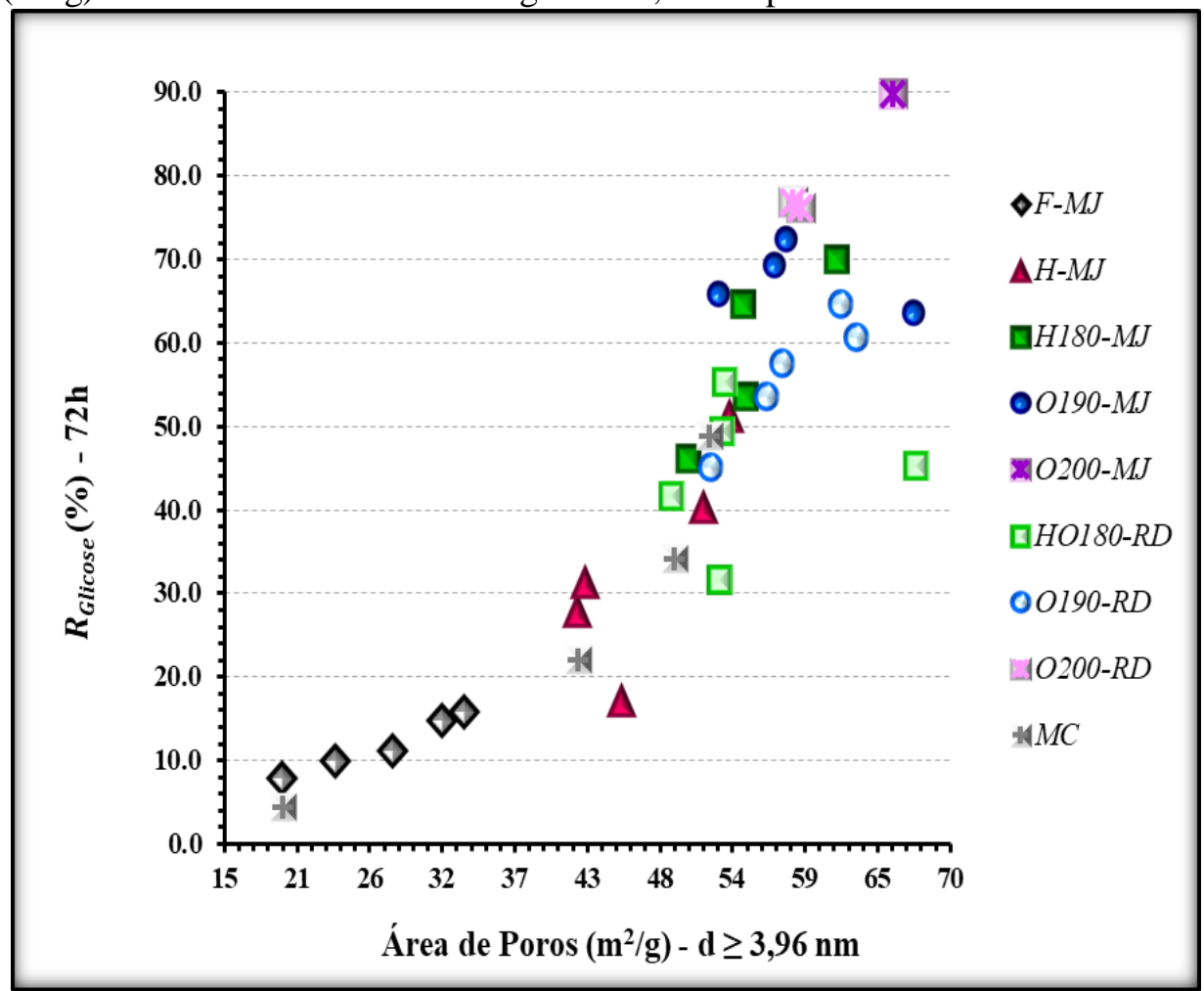

Anexo R. Variação do rendimento de glicose (\%) obtido após $72 \mathrm{~h}$ de hidrólise enzimática com a dimensão lateral do cristalito de celulose $(\AA)$ na direção dos planos $(110)_{\mathrm{m}}$ e $(1-10)_{\mathrm{m}}$ para os diferentes materiais em estudo.

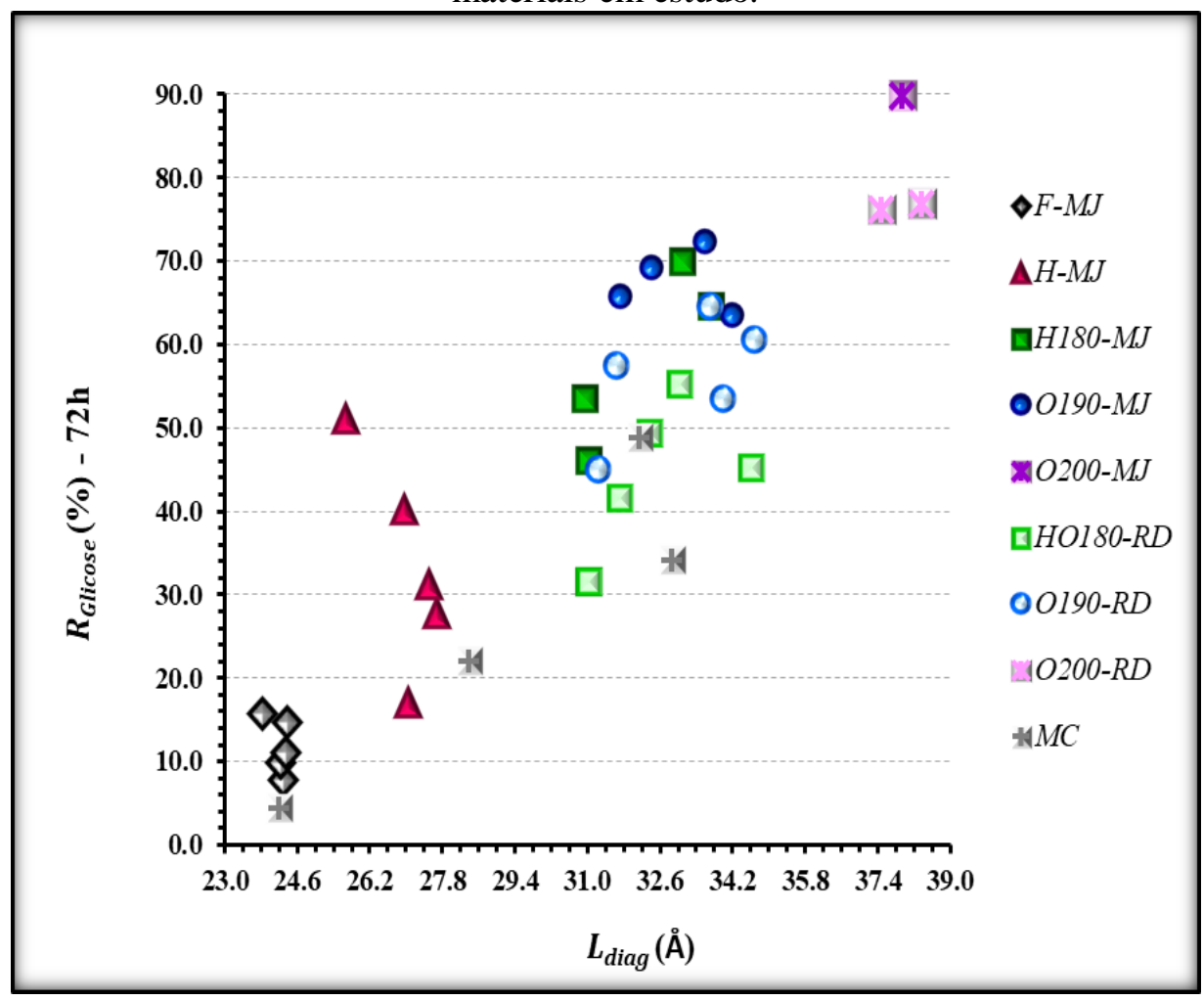


Anexo S. Variação do rendimento de glicose (\%) obtido após $72 \mathrm{~h}$ de hidrólise enzimática com o índice de cristalinidade para os diferentes materiais em estudo.

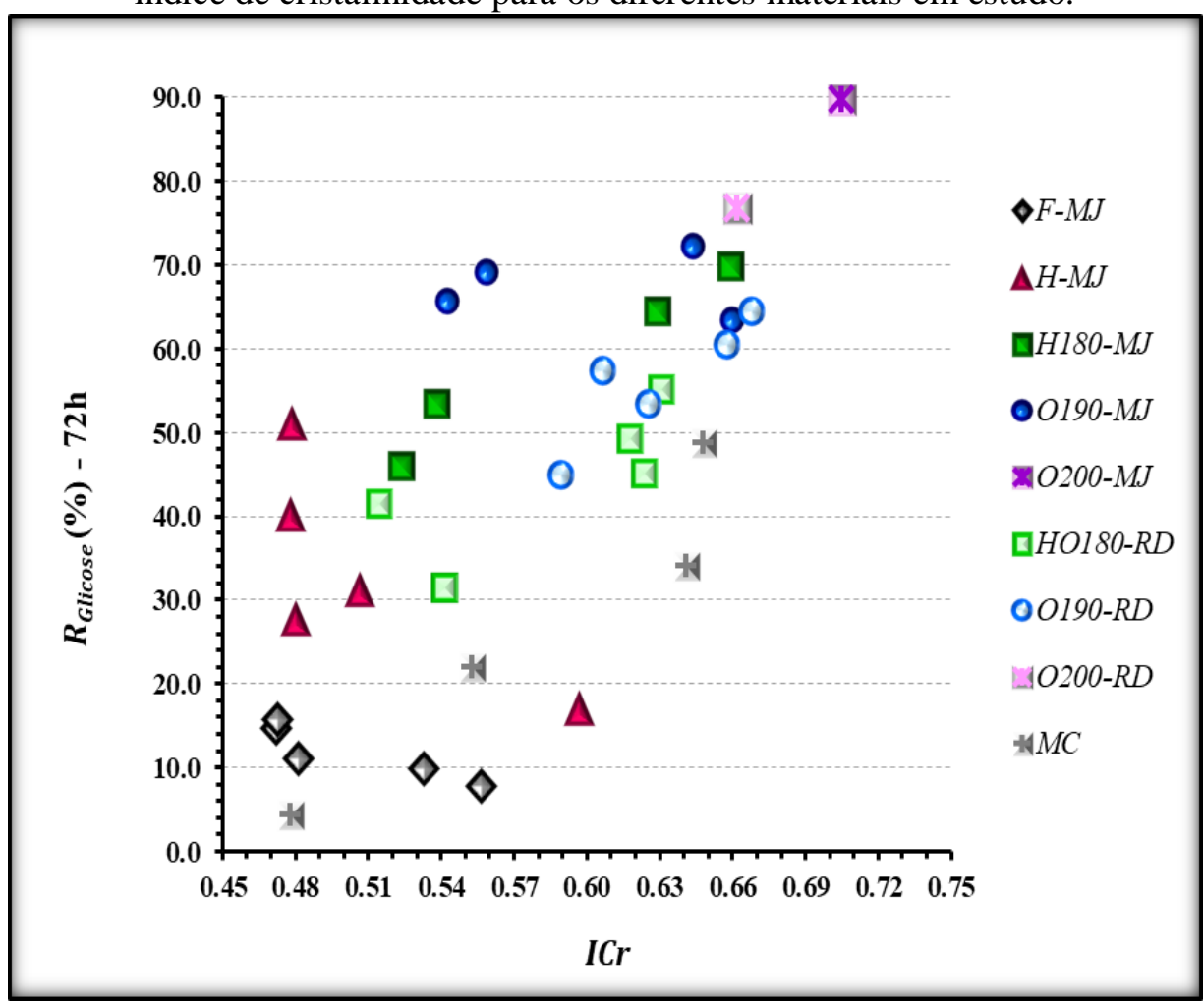

Anexo T. Variação do rendimento de glicose (\%) obtido após 72h de hidrólise enzimática com o decréscimo da cristalinidade da celulose (\%) para os diferentes materiais em estudo.

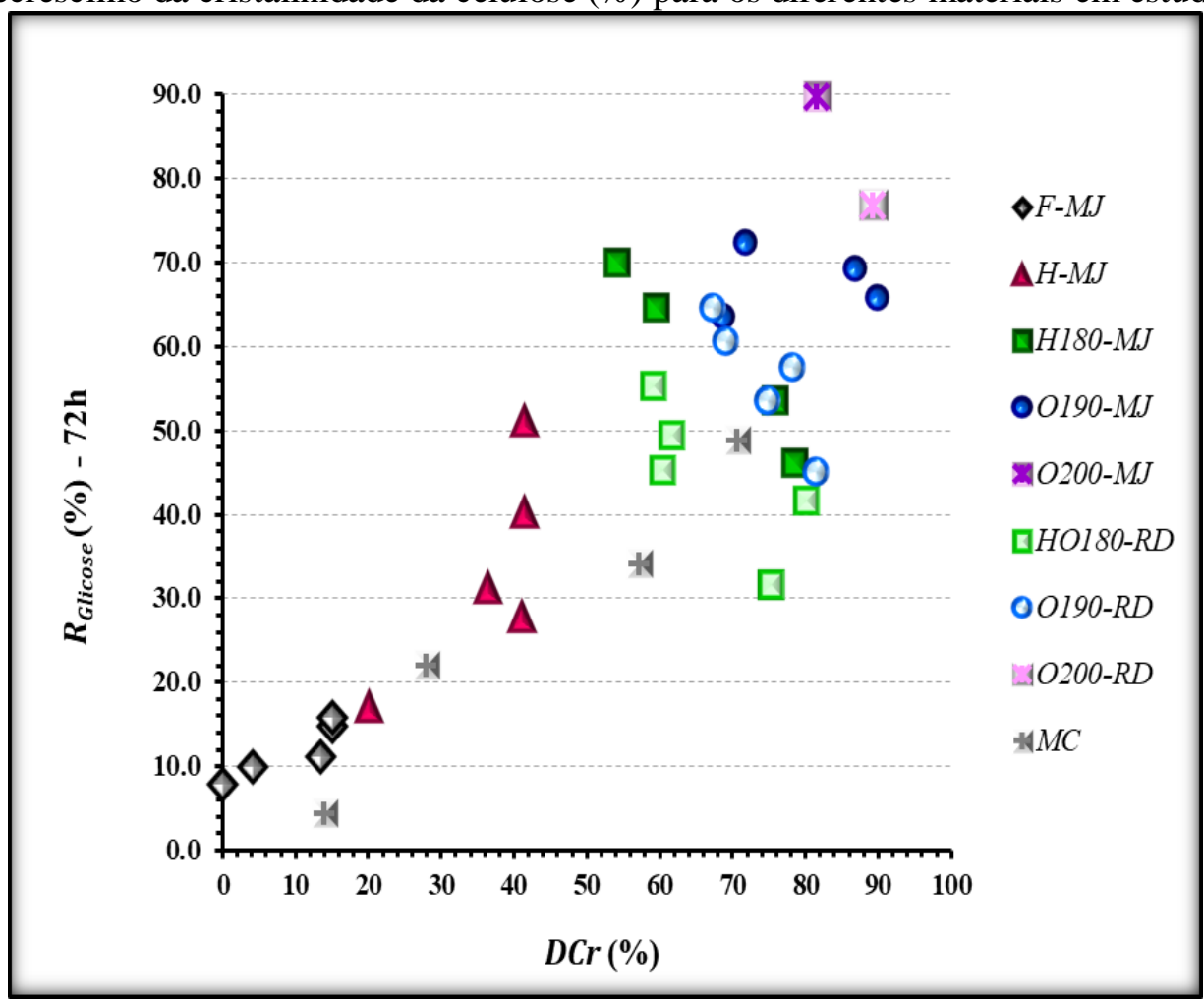


Anexo U. Parâmetros de correlação linear entre o rendimento de glicose (72h) obtido para os diferentes materiais em estudo e alguns dos parâmetros estruturais avaliados.

\begin{tabular}{|c|c|}
\hline Parâmetro Estrutural & Correlação Linear $\left(\mathbf{R}^{2}\right)$ com o $\mathbf{R}_{\text {Glicose }}(72 \mathrm{~h})$ \\
\hline Diâmetro Médio das Partículas ( $\mu m)$ & 0,2784 \\
\hline Volume de Partículas $(\%)-d<30 \mu m$ & 0,0721 \\
\hline Volume de Partículas (\%) $-d<100 \mu m$ & 0,2307 \\
\hline$A S E\left(m^{2} / g\right)-D L S$ & 0,3796 \\
\hline Comprimento Médio Ponderado $(\mathrm{mm})$ & 0,0059 \\
\hline Largura Média $(\mu \mathrm{m})$ & 0,4751 \\
\hline Teor de Finos (\%) & 0,0027 \\
\hline $\operatorname{ASE}\left(\mathrm{m}^{2} / \mathrm{g}\right)-\operatorname{MorFI}$ & 0,6871 \\
\hline Área Total de Poros $\left(\mathrm{m}^{2} / \mathrm{g}\right)$ & 0,2954 \\
\hline Área de Poros $\left(\mathrm{m}^{2} / \mathrm{g}\right)-d \geq 9,90 \mathrm{~nm}$ & 0,7621 \\
\hline Área de Poros $\left(\mathrm{m}^{2} / \mathrm{g}\right)-d \geq 6,60 \mathrm{~nm}$ & 0,7613 \\
\hline Área de Poros $\left(\mathrm{m}^{2} / \mathrm{g}\right)-d \geq 3,96 \mathrm{~nm}$ & 0,7706 \\
\hline$L_{200}(\AA)$ & 0,8403 \\
\hline$L_{\text {Diag }}(\AA)$ & 0,7783 \\
\hline$I C r$ & 0,4775 \\
\hline $\operatorname{DCr}(\%)$ & 0,7097 \\
\hline
\end{tabular}

Legenda: $d=$ diâmetro; $A S E$ = área superficial específica externa; $D L S=$ análise de distribuição de tamanhos de partículas por difração a laser; $M o r F I=$ análise morfológica das fibras; $L_{200}=$ dimensão lateral do cristalito de celulose na direção do plano $(200)_{m}$; $L_{\text {diag }}=$ dimensão lateral do cristalito de celulose na direção dos planos $(110)_{\mathrm{m}} \mathrm{e}(110)_{\mathrm{m}} ; I C r=$ índice de cristalinidade da celulose; $D C r=$ decréscimo da cristalinidade da celulose. 